\title{
Idaho National Laboratory PCB Annual Document Log and Annual Records for Calendar Year 2004
}

August 2005

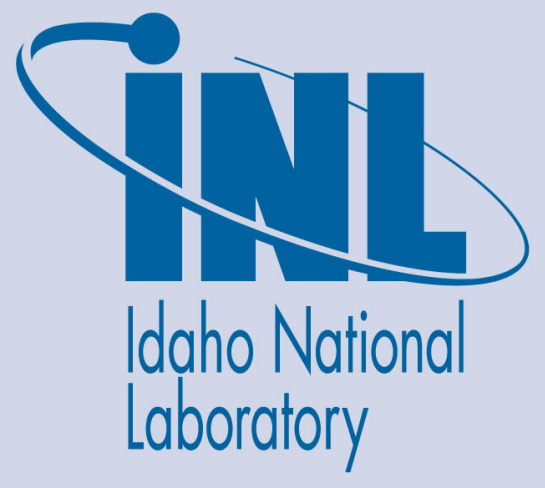

The INL is a U.S. Department of Energy National Laboratory operated by Battelle Energy Alliance 
INL/EXT-05-00353

\title{
Idaho National Laboratory PCB Annual Document Log and Annual Records for Calendar Year 2004
}

August 2005

\author{
Idaho National Laboratory \\ Idaho Falls, Idaho 83415
}

http://www.inl.gov

\author{
Prepared for the \\ U.S. Department of Energy \\ Assistant Secretary for Environmental Management \\ Under DOE Idaho Operations Office \\ Contract DE-AC07-05ID14517
}



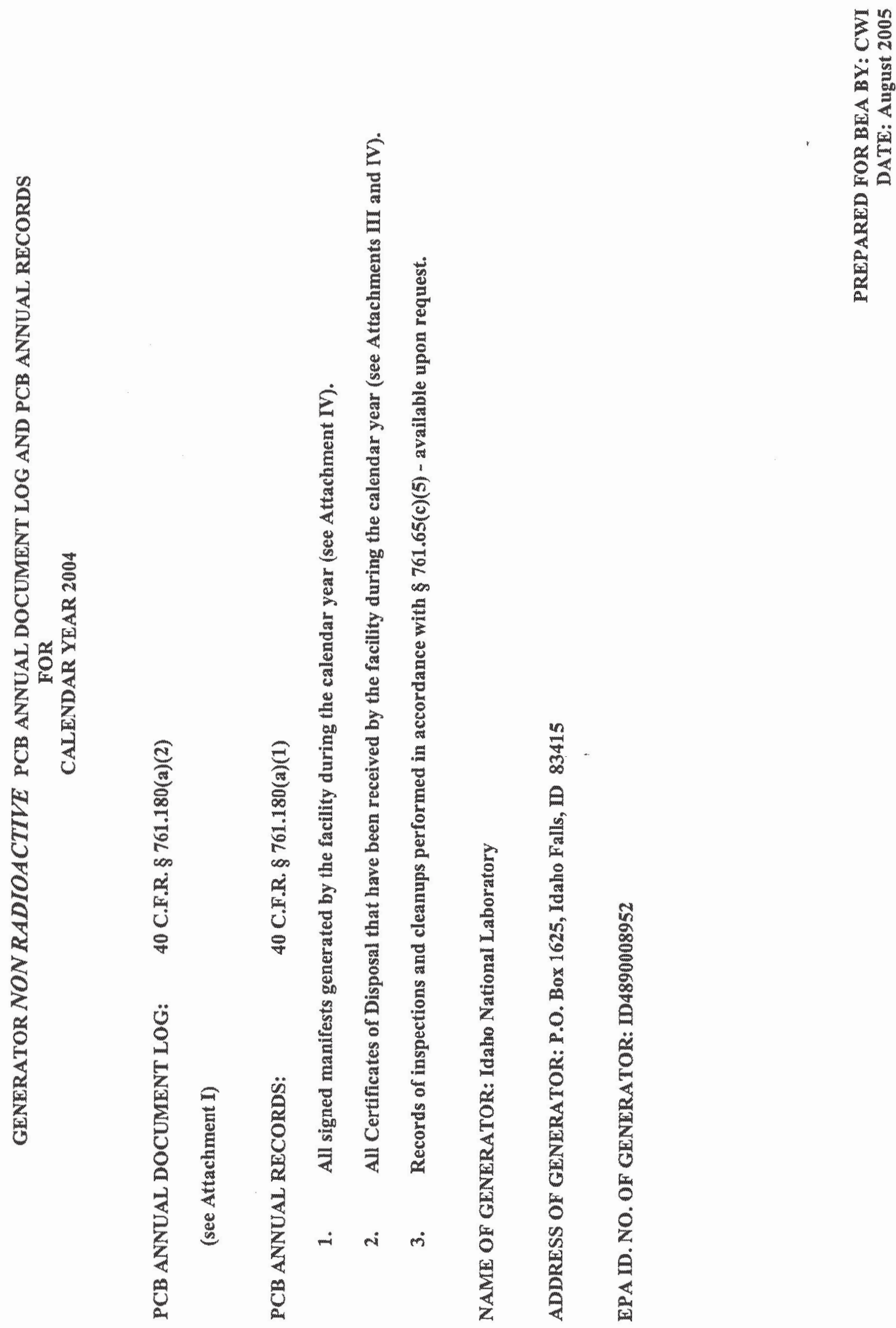

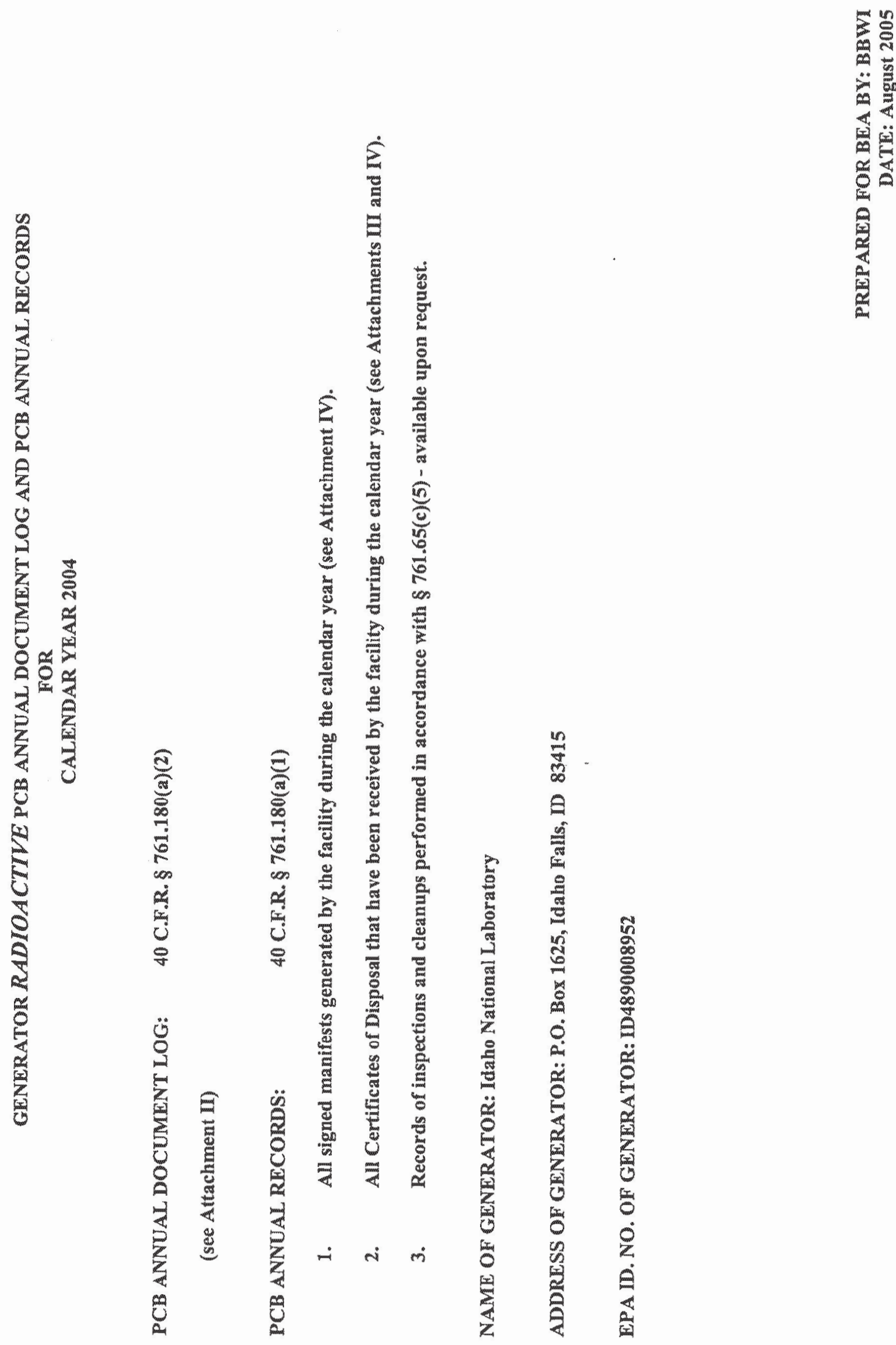


\section{ATTACHMENT I: \\ GENERATOR NON RADIOACTIVE PCB ANNUAL DOCUMENT LOG FOR CALENDAR YEAR 2004}

\section{Following Pages:}

Table 1 - PCB ARTICLES Removed from Service during Calendar Year 2004

Table 2 - PCB ARTICLE CONTAINERS Removed from Service during Calendar Year 2004

Table 3 - PCB CONTAINERS Removed from Service during Calendar Year 2004

Table 4 - BULK PCB Shipped and Disposed During Calendar Year 2004

Table 5 - PCB ARTICLES Shipped and Disposed during Calendar Year 2004

Table 6 - PCB ARTICLE CONTAINERS Shipped and Disposed during Calendar Year 2004

Table 7 - PCB CONTANERS Shipped and Disposed during Calendar Year 2004

Table 8 - PCBs Remaining in Service at End of Calendar Year 2004 


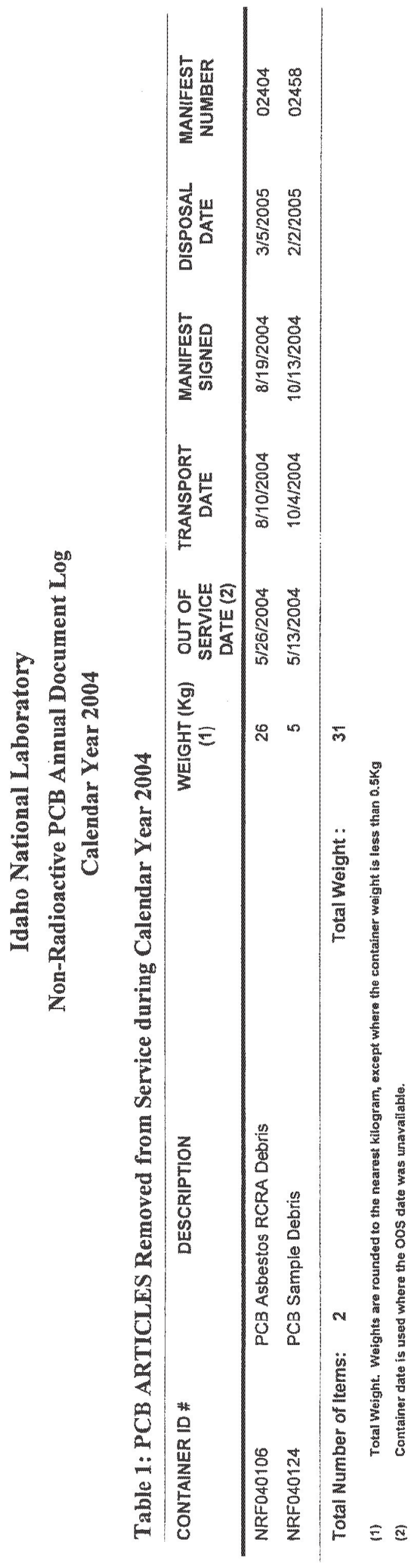

$\frac{\overrightarrow{5}}{3}$ 


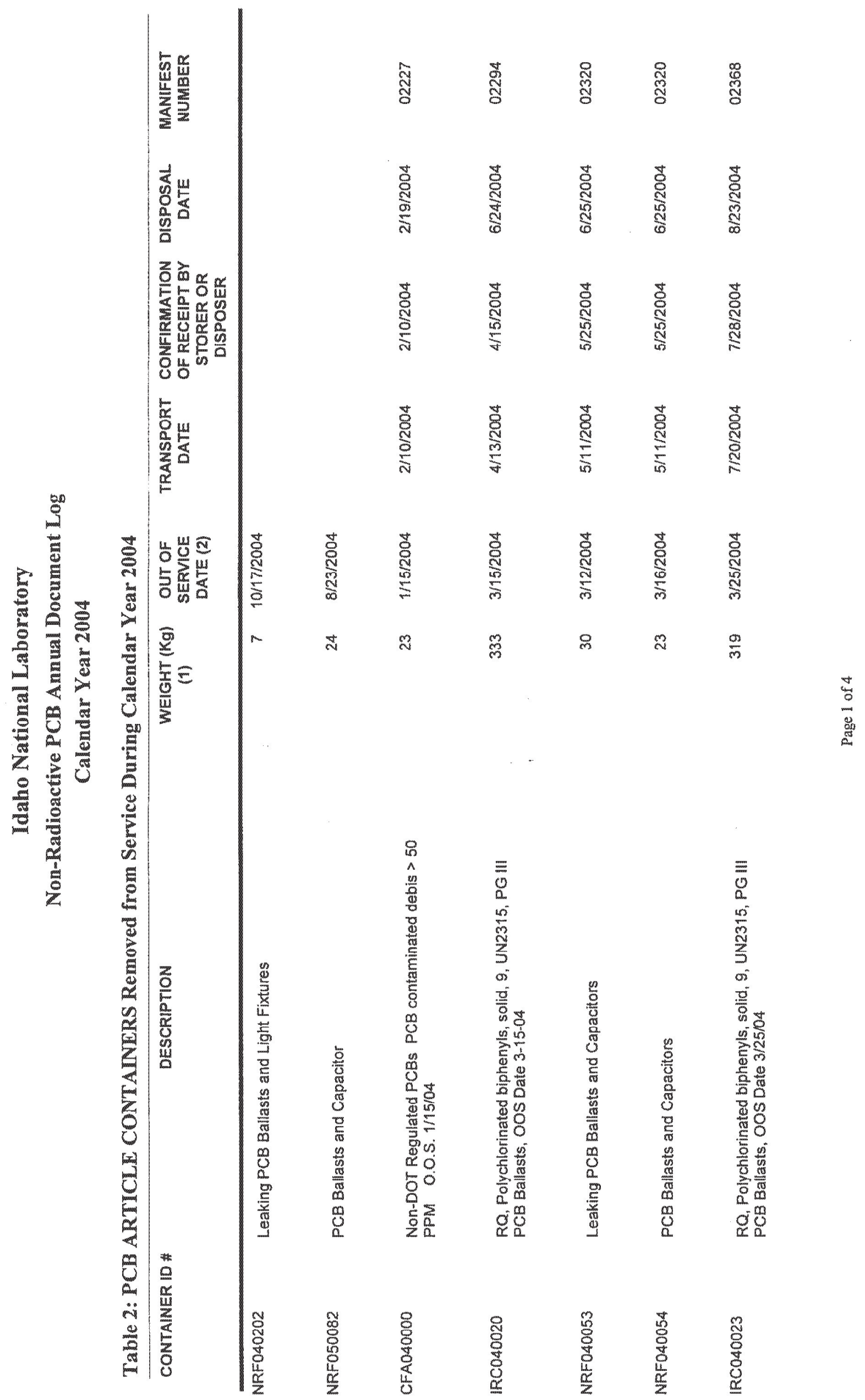




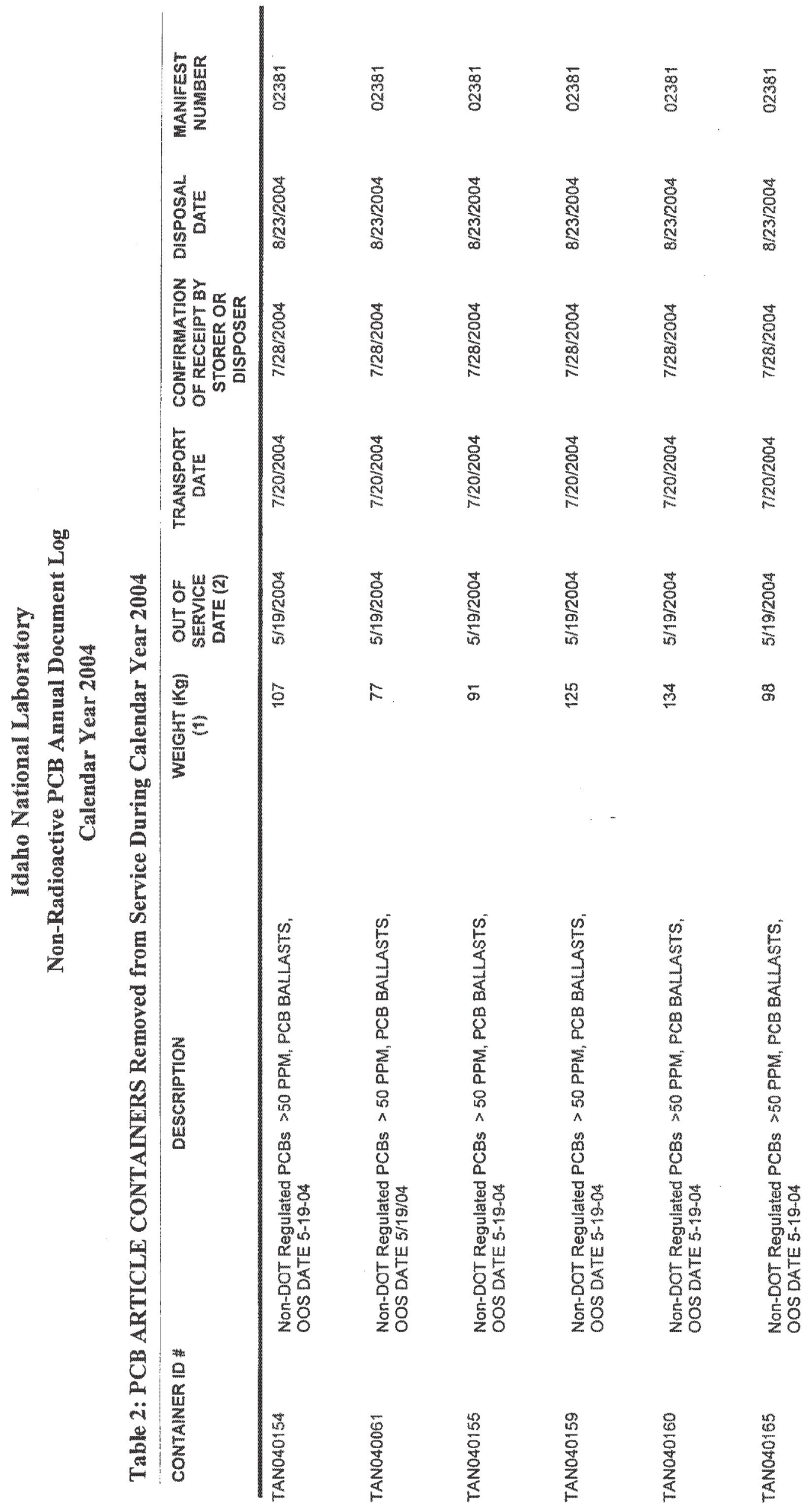




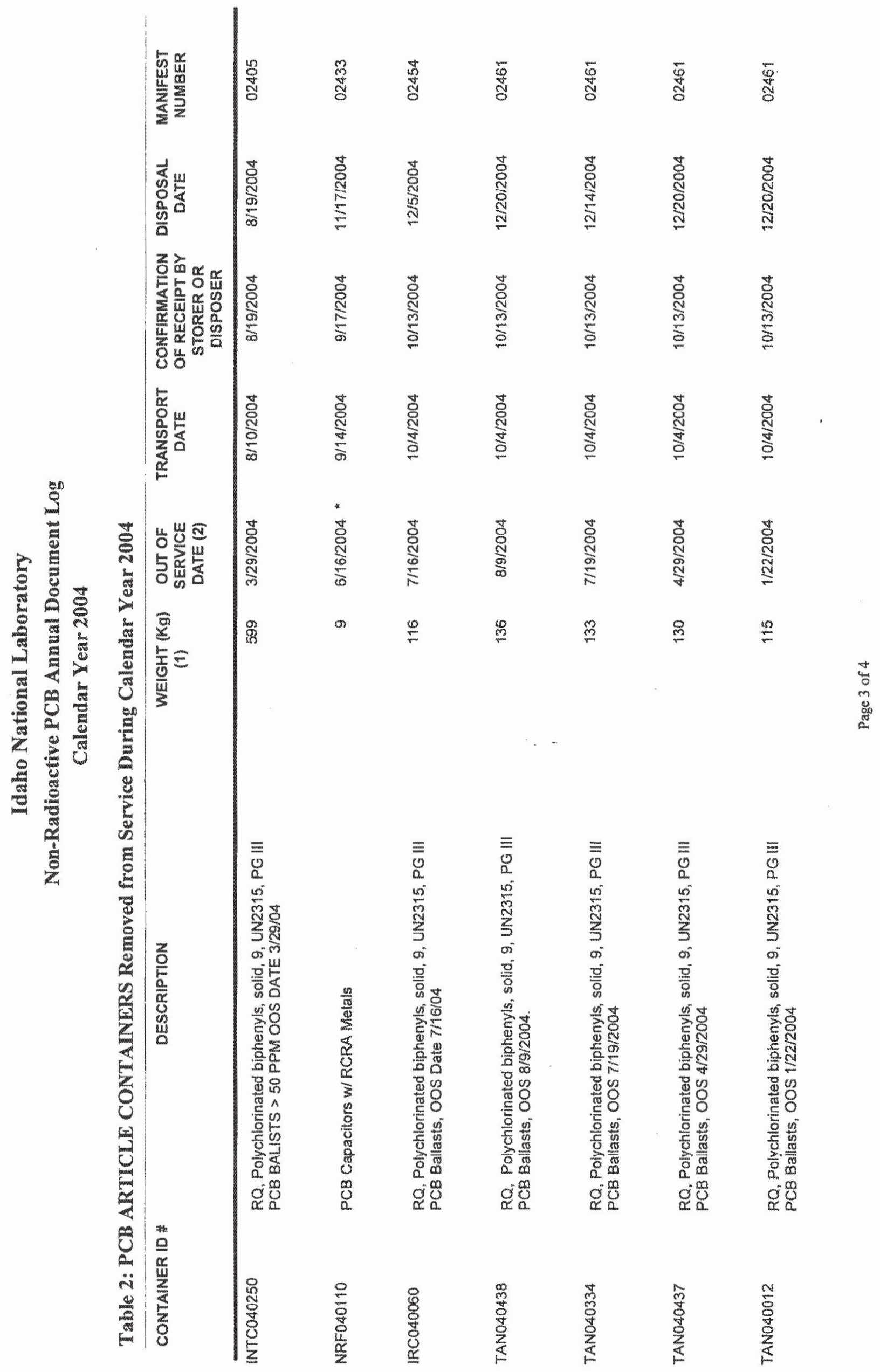




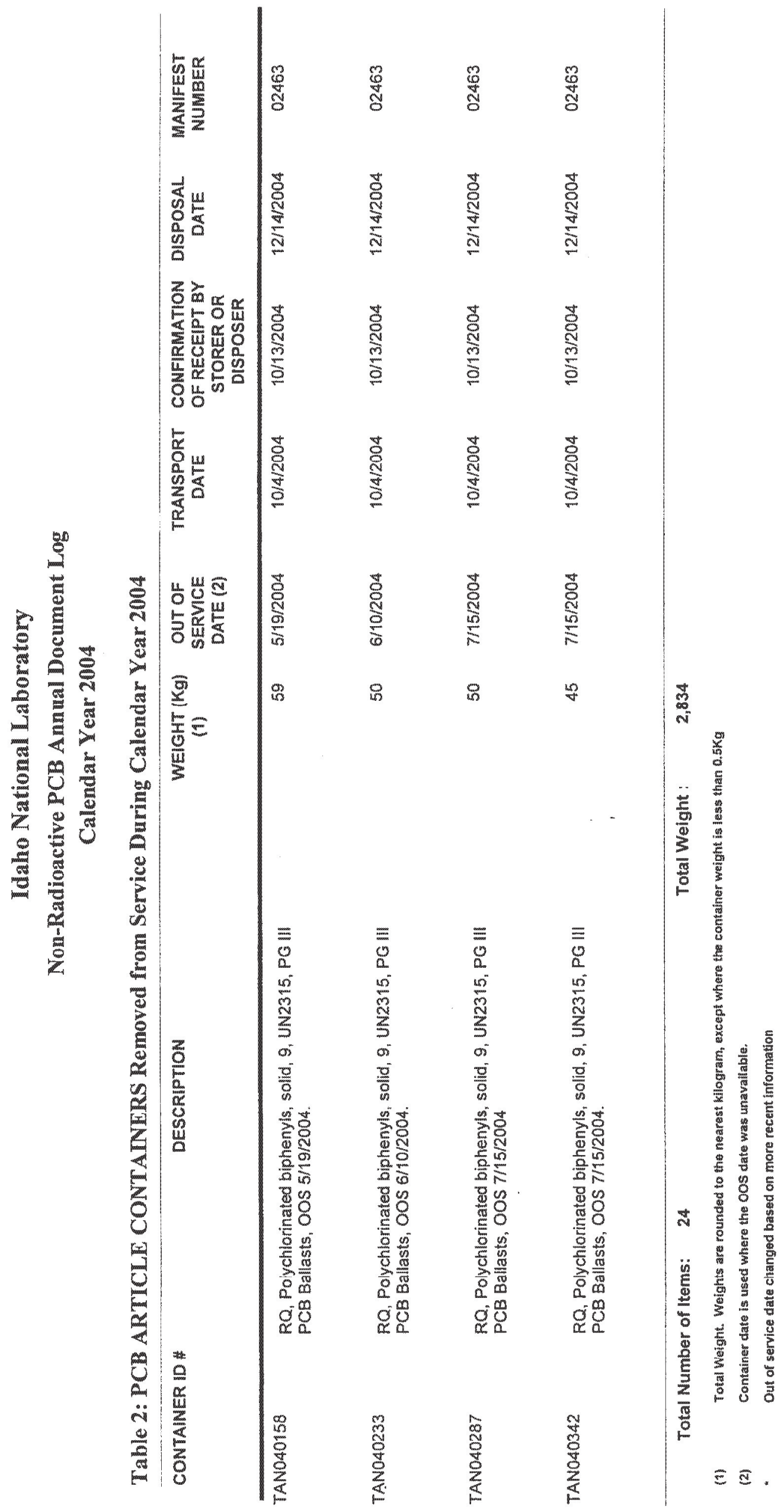




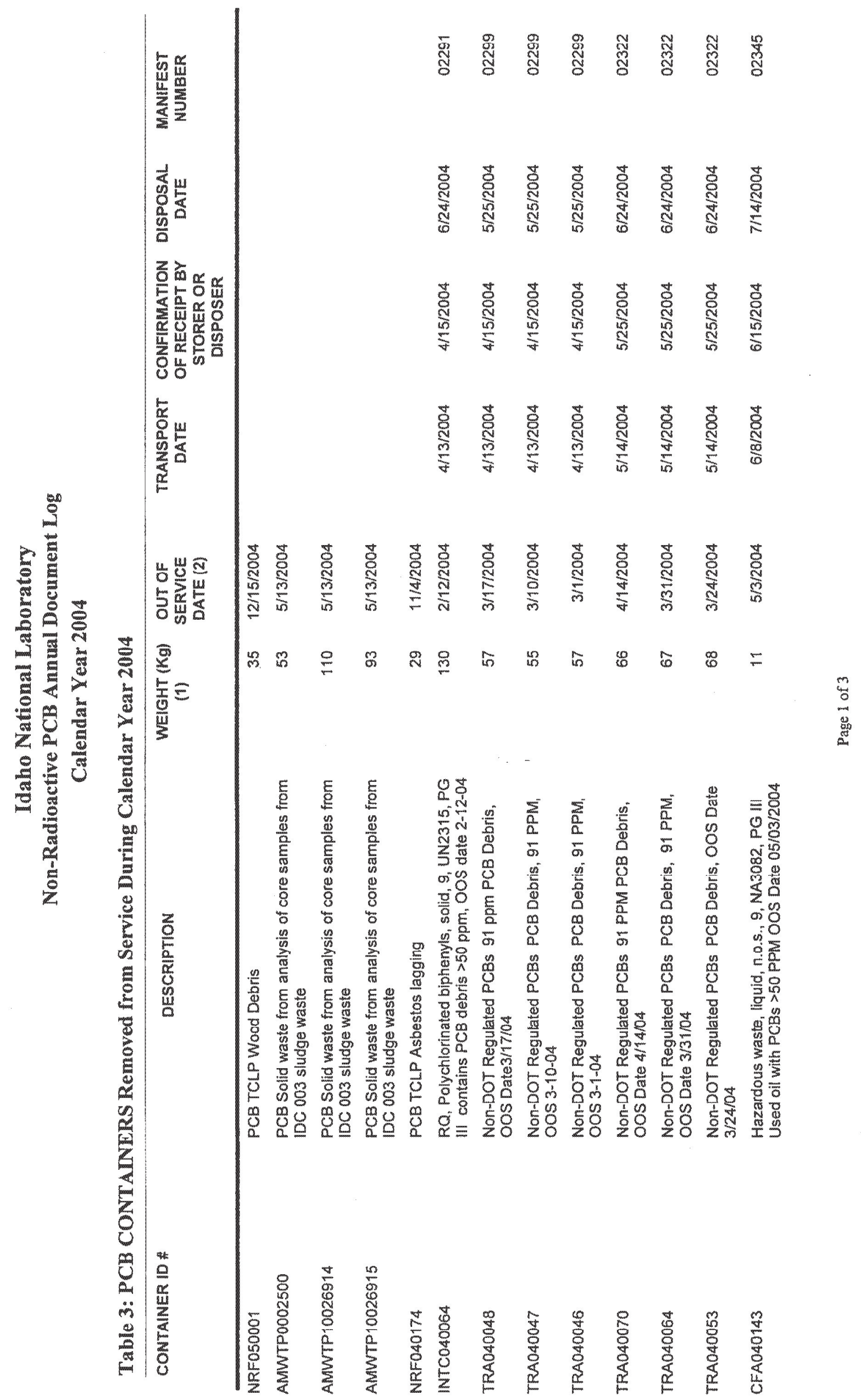




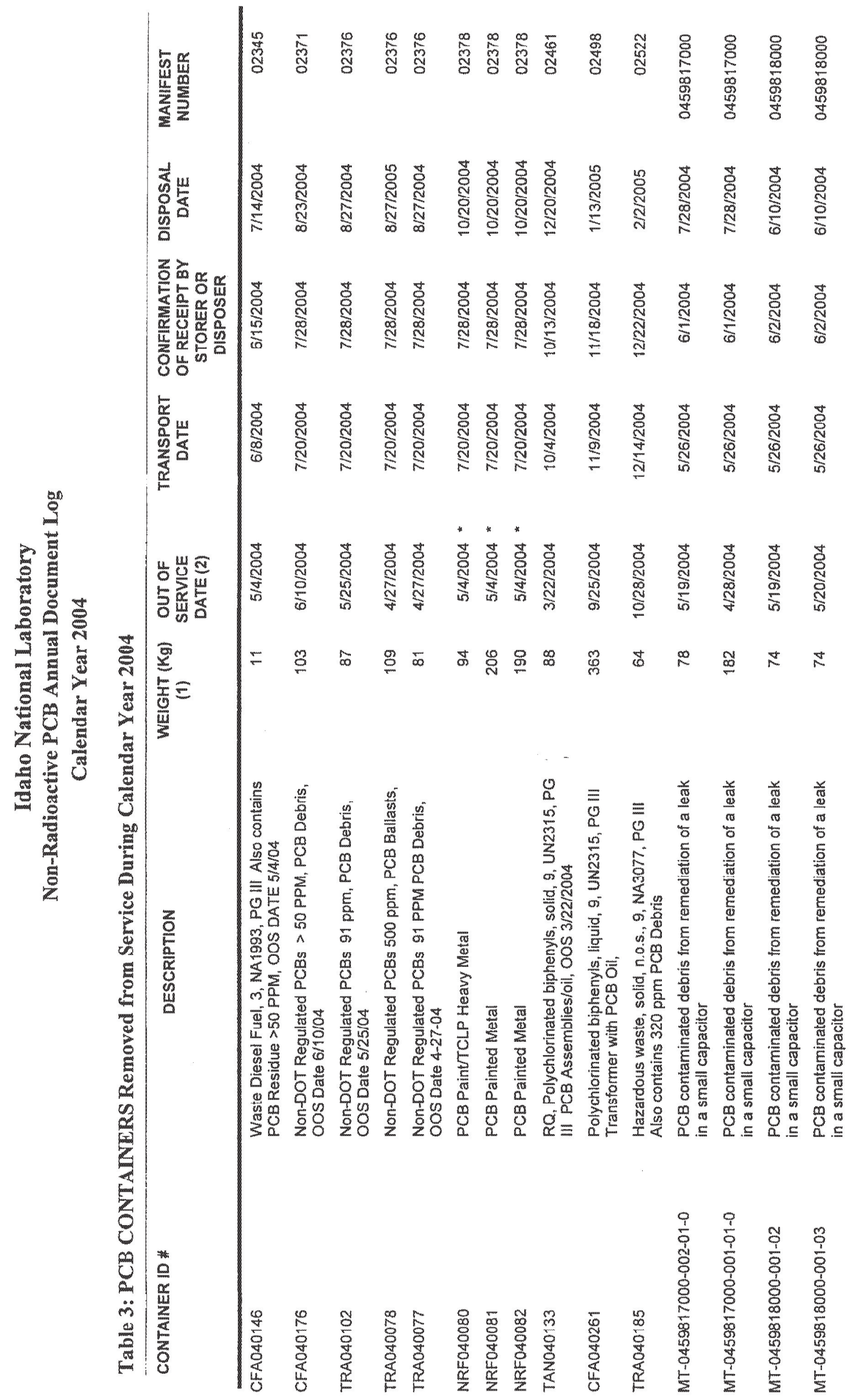




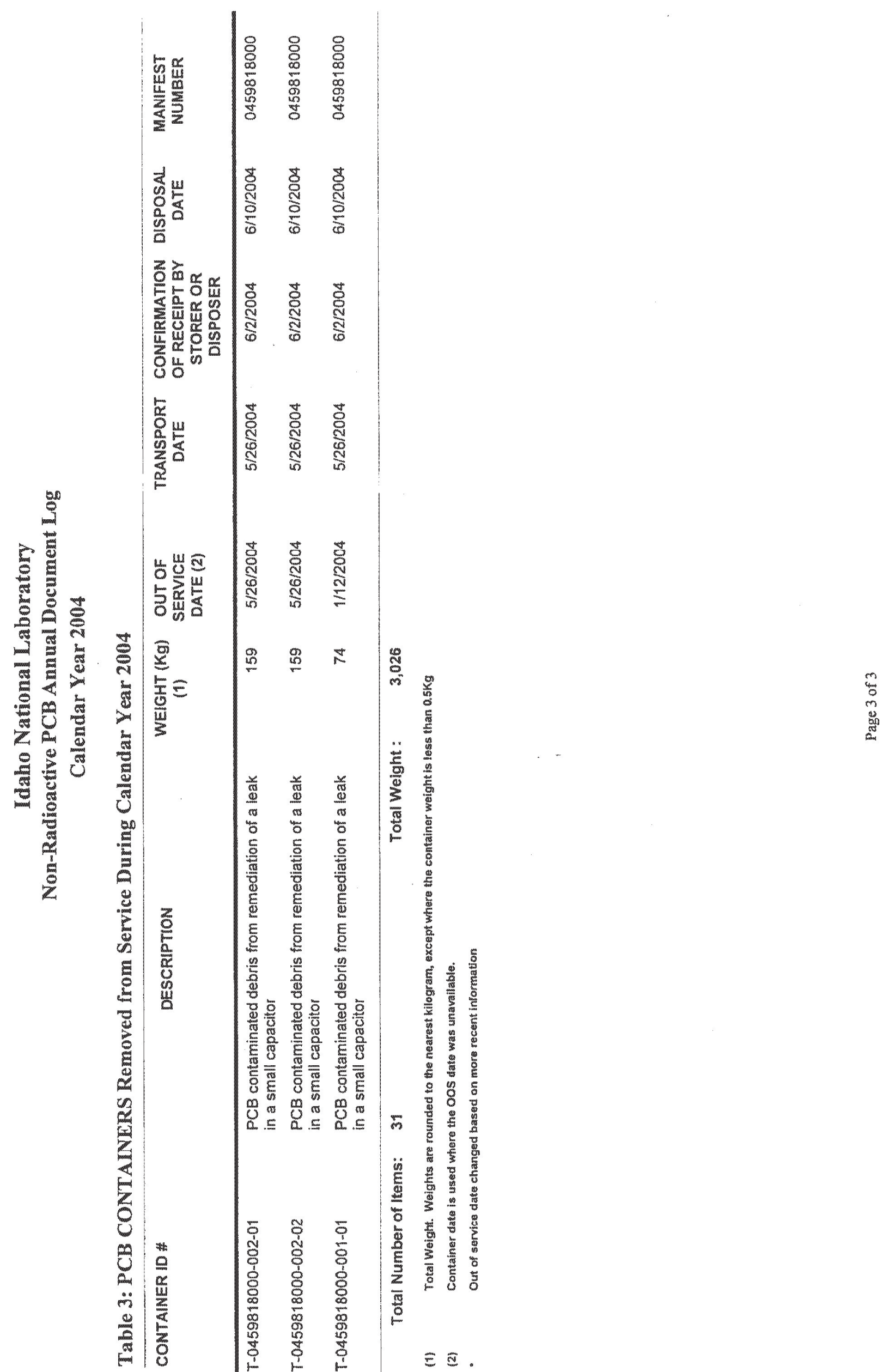




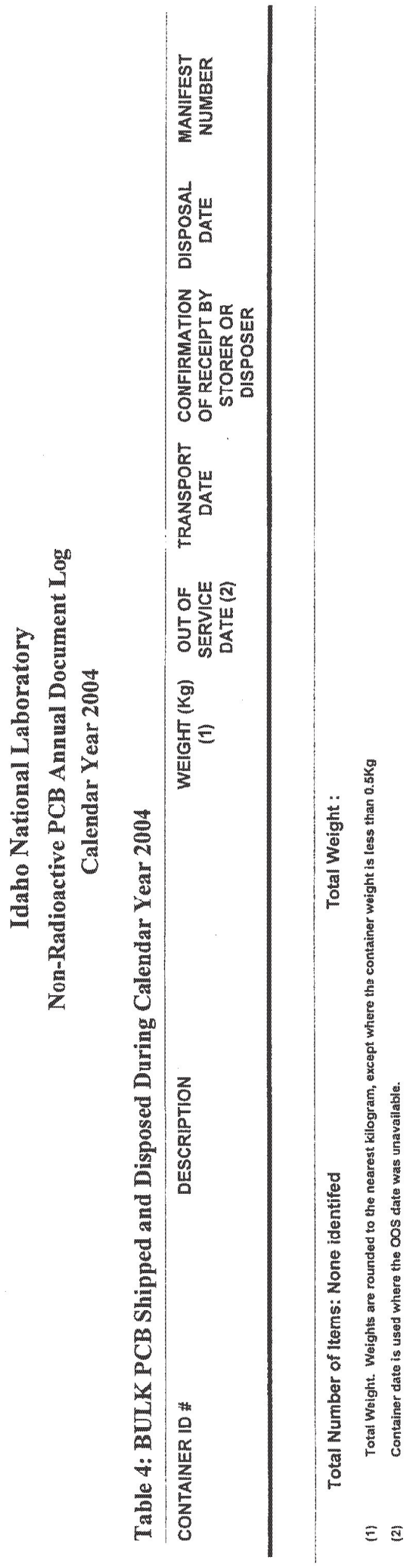

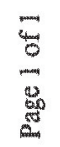




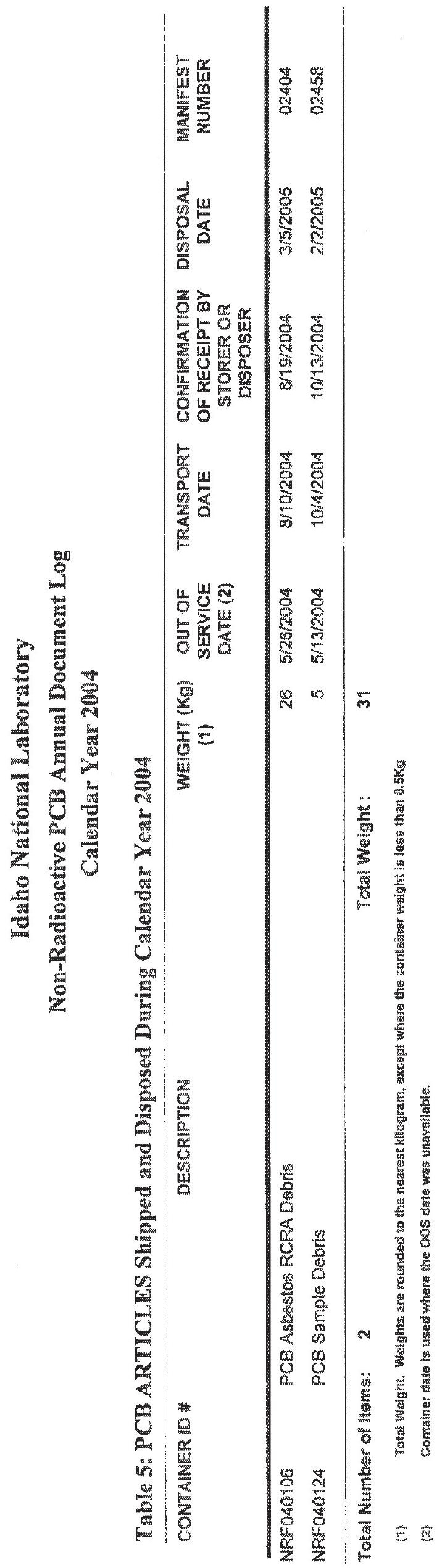

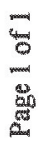




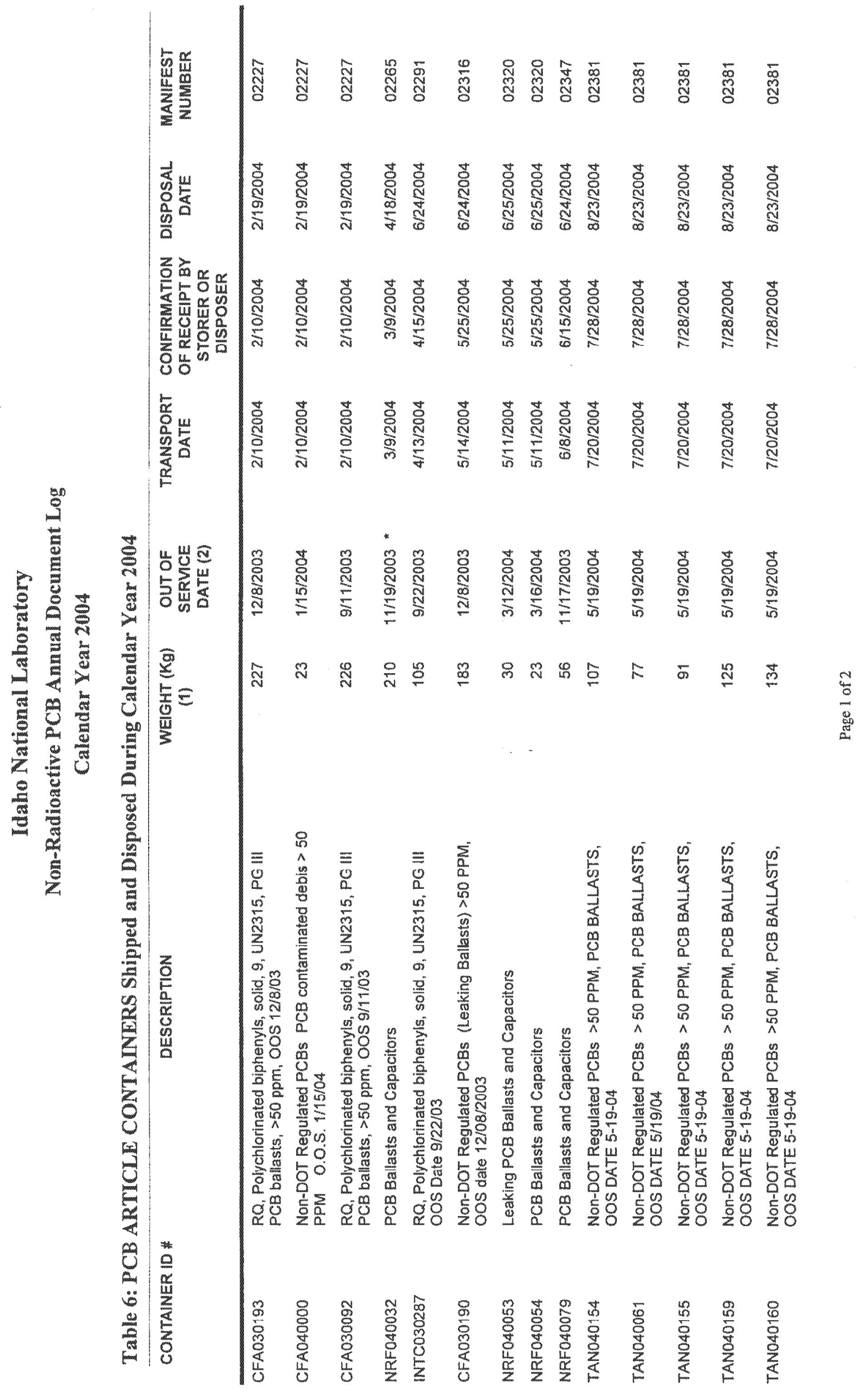




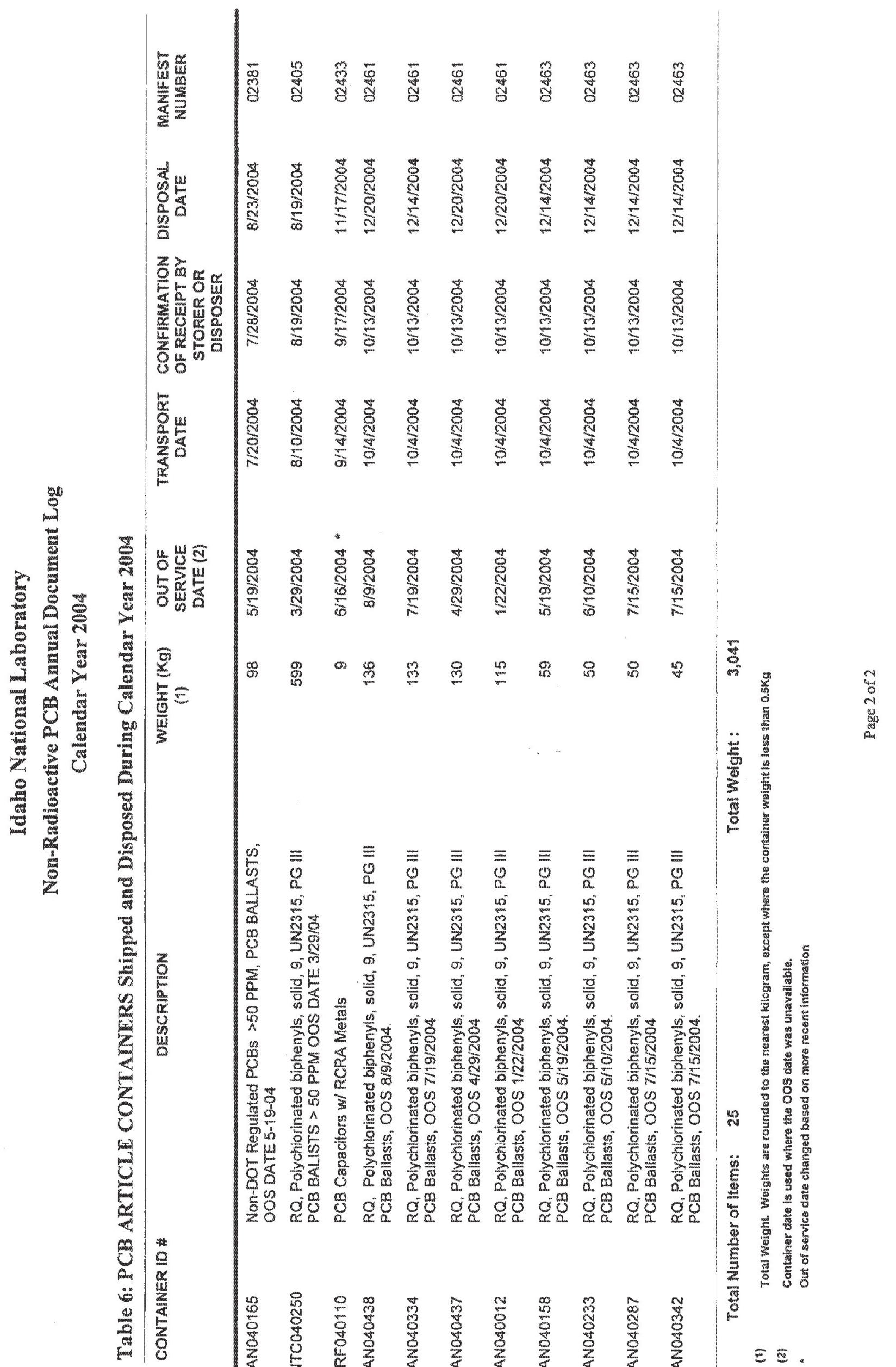




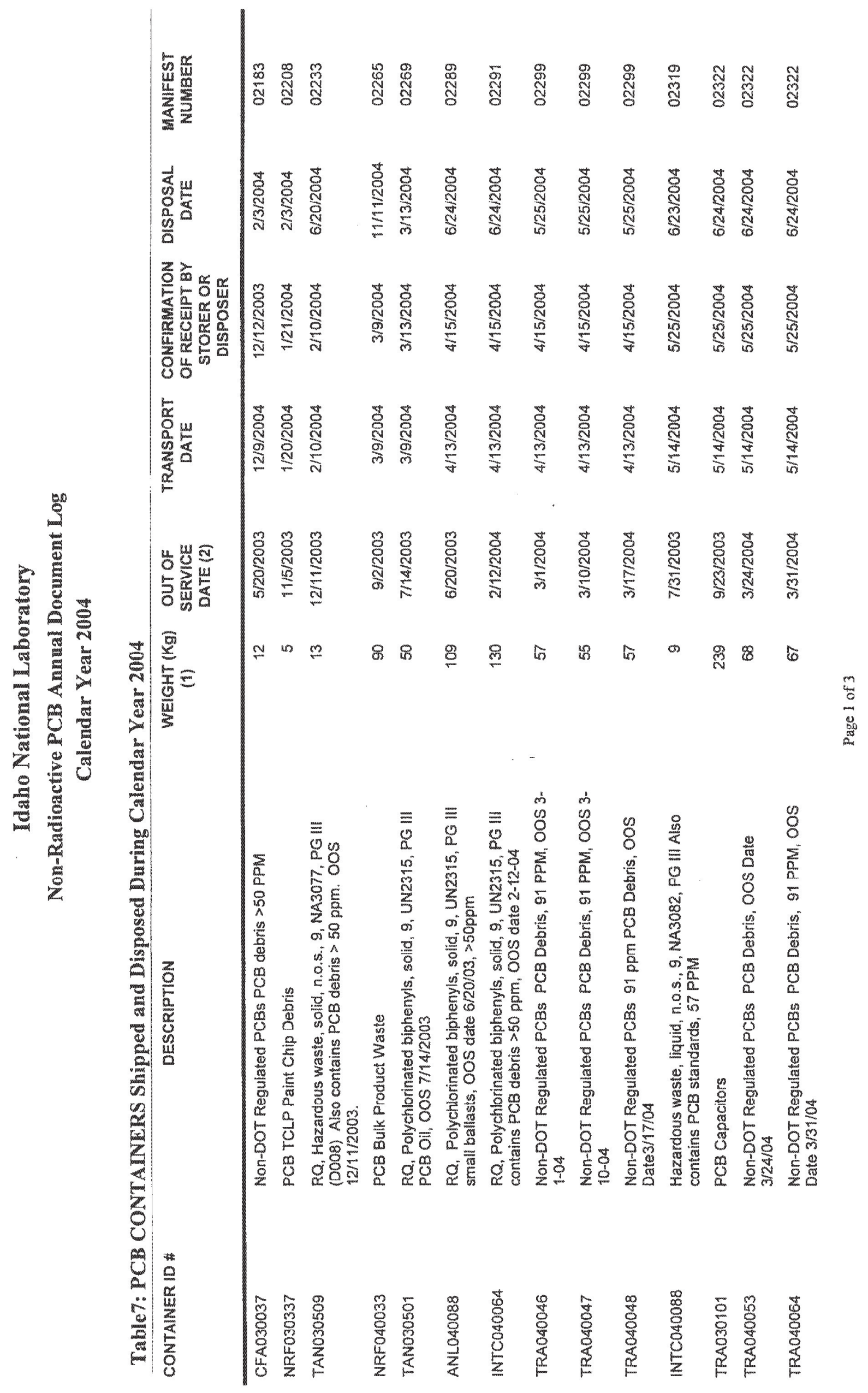




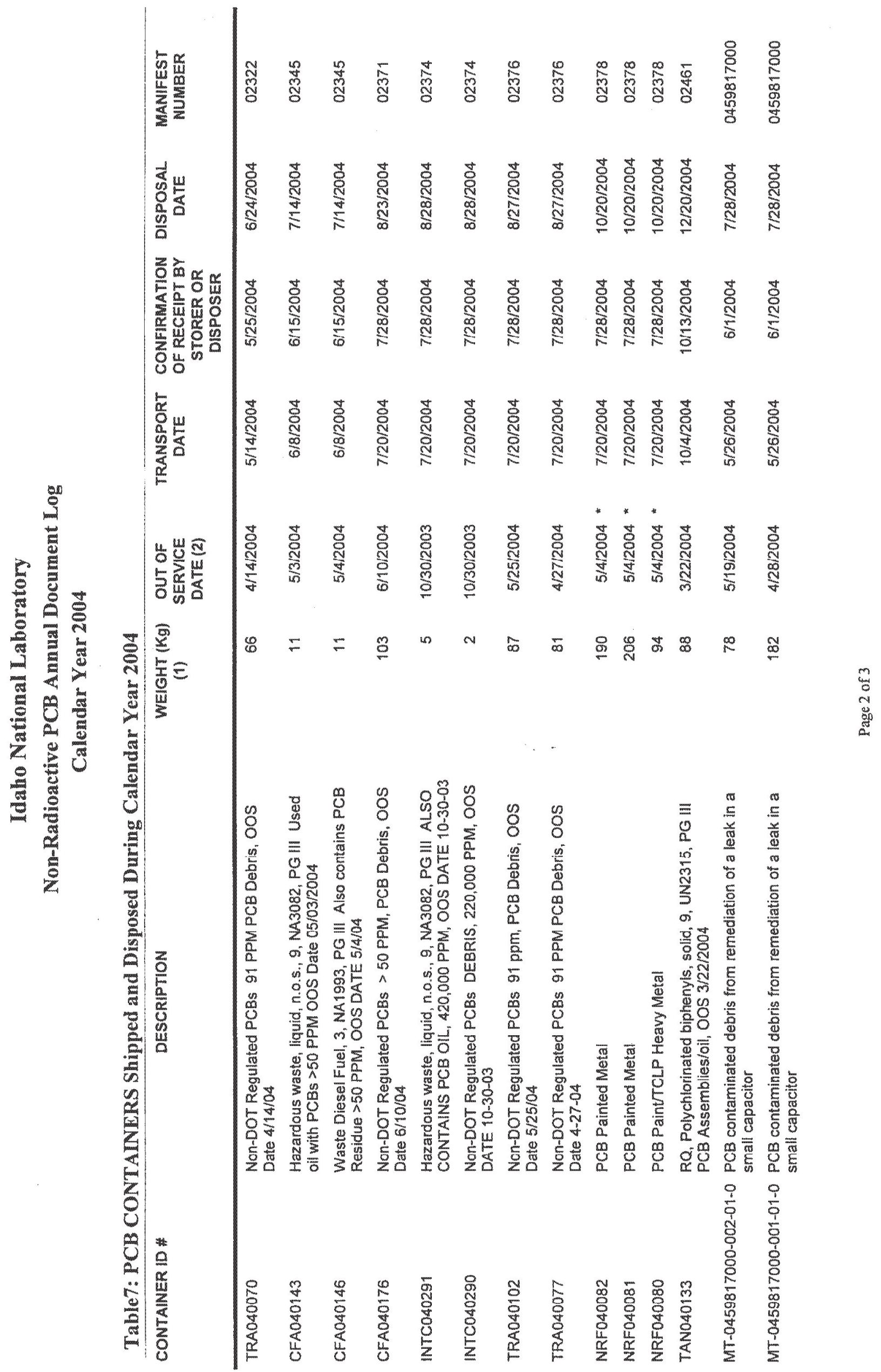




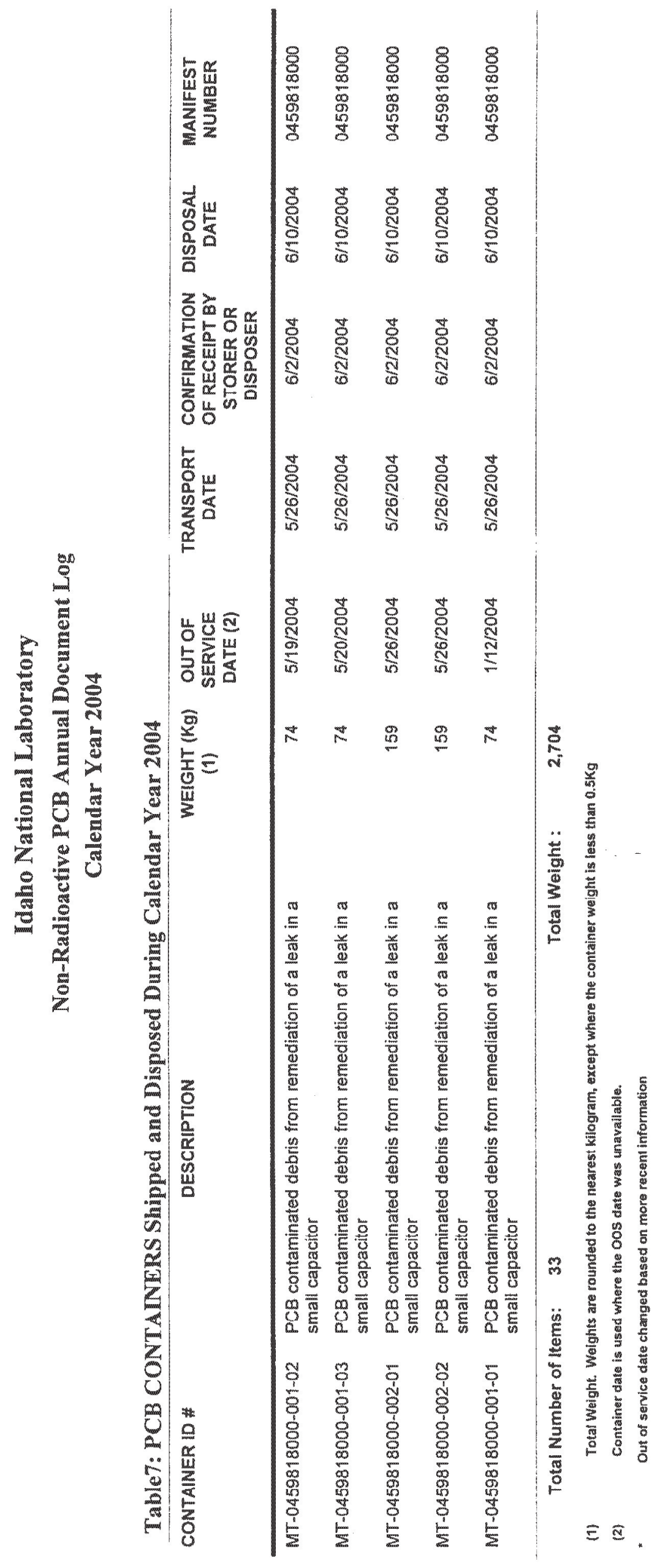



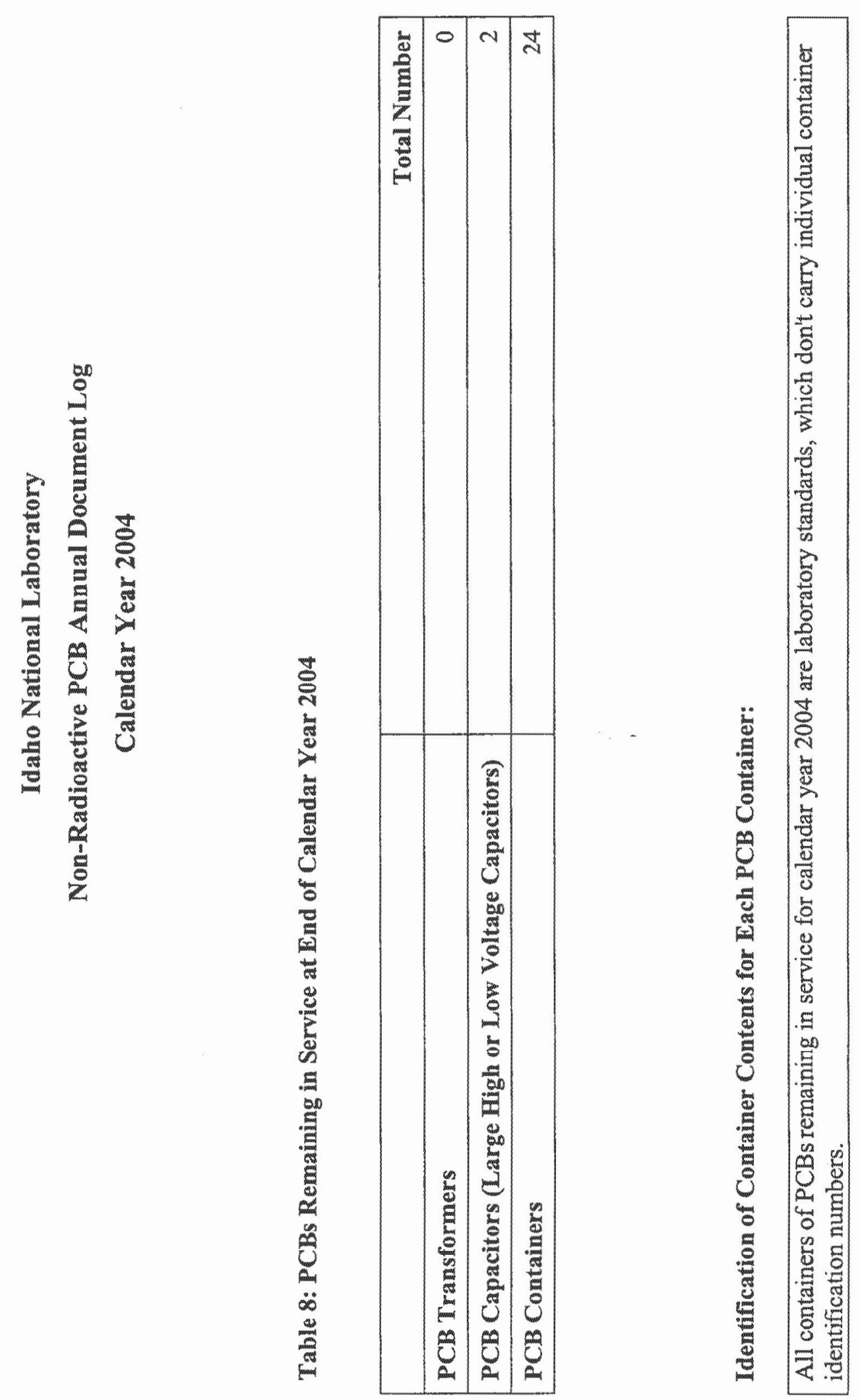
La.

L.

.

8

a

ent

nit

.

E

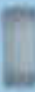

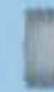

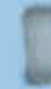

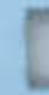

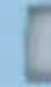

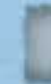

L

D

.

p 


\section{ATTACHMENT II: \\ GENERATOR RADIOACTIVE PCB ANNUAL DOCUMENT LOG FOR CALENDAR YEAR 2004}

\section{Following Pages:}

Table 1 - PCB/Radioactive ARTICLES Removed from Service during Calendar Year 2004

Table 2 - PCB/Radioactive ARTICLE CONTAINERS Removed from Service during Calendar Year 2004

Table 3 - PCB/Radioactive CONTAINERS Removed from Service during Calendar Year 2004

Table 4 - PCB/Radioactive ARTICLES Shipped and Disposed during Calendar Year 2004

Table 5 - PCB/Radioactive ARTICLE CONTAINERS Shipped and Disposed during Calendar Year 2004

Table 6 - PCB/Radioactive CONTAINERS Shipped and Disposed during Calendar Year 2004 


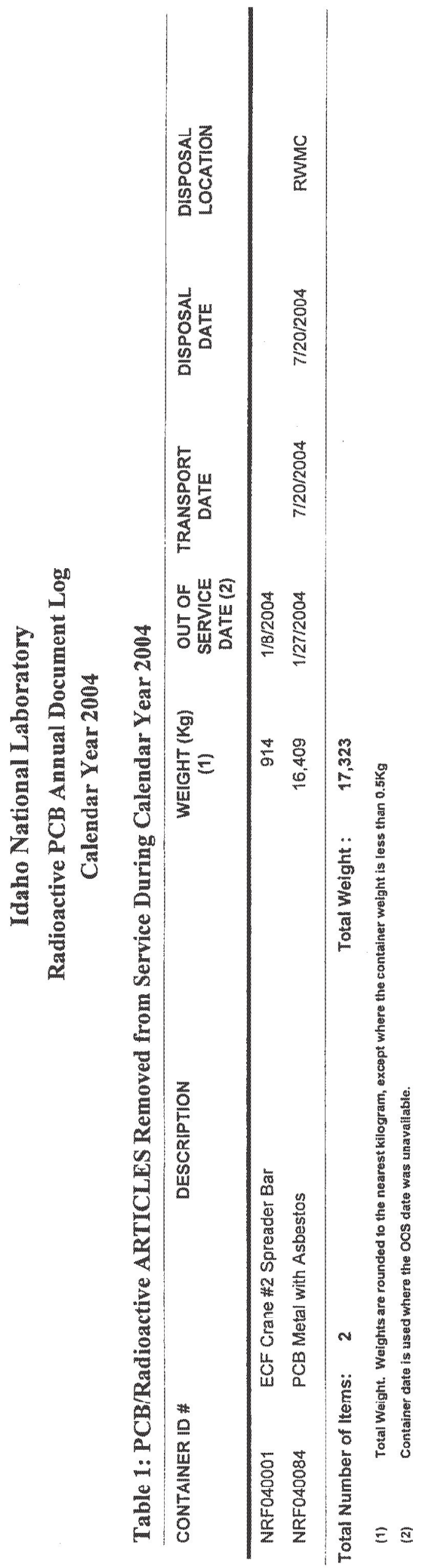

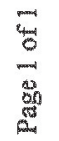




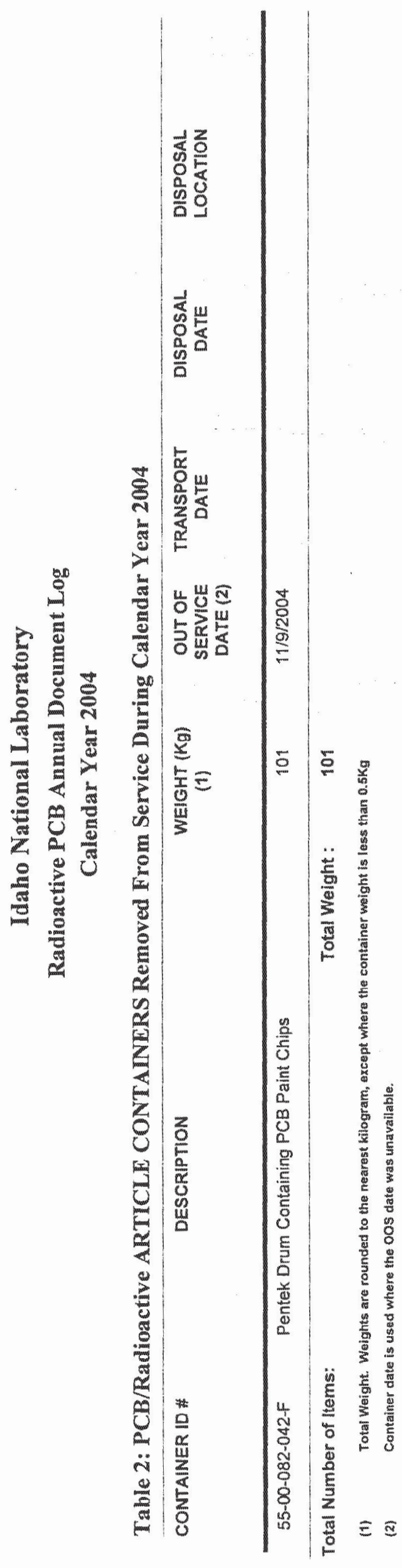




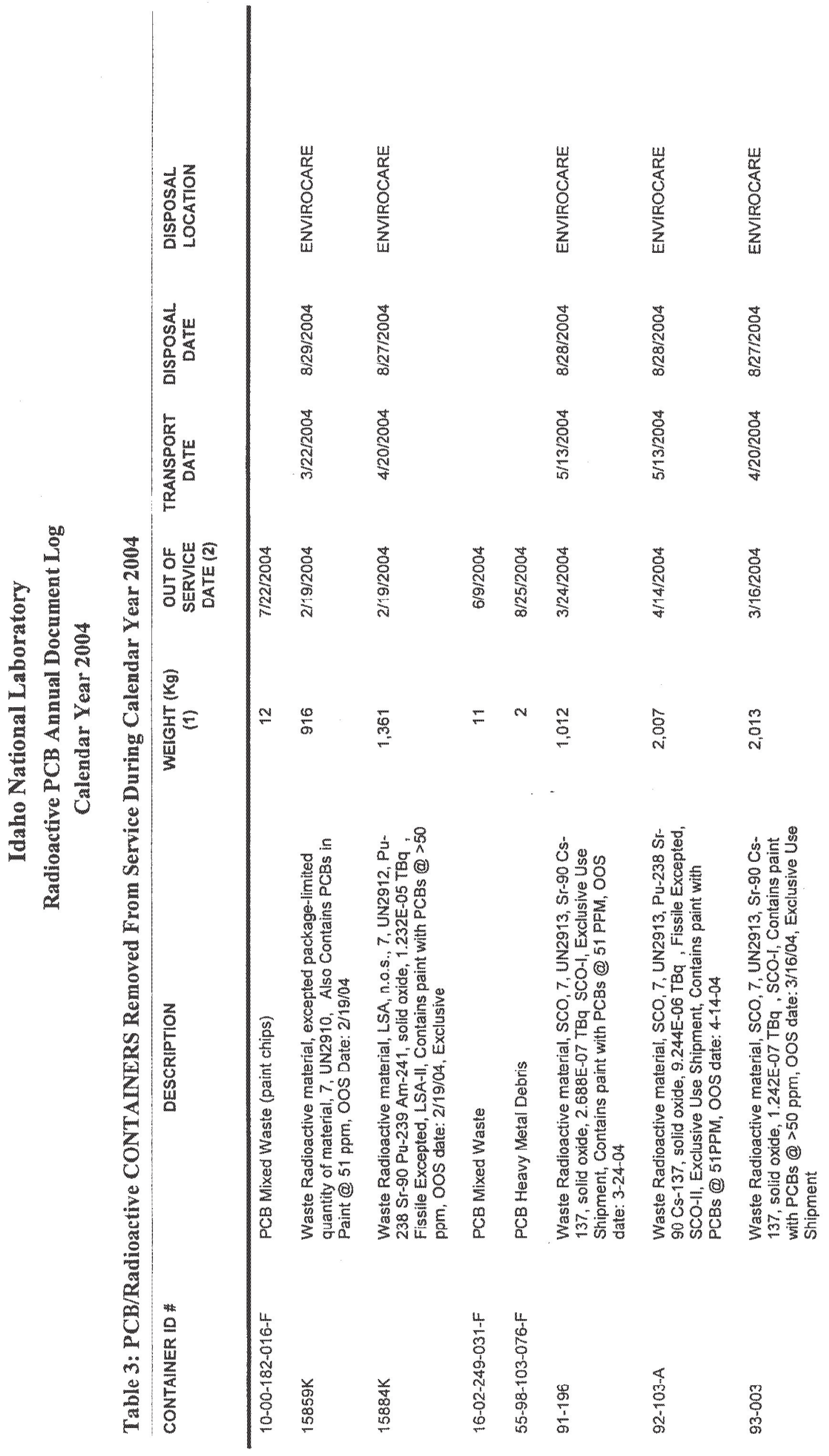




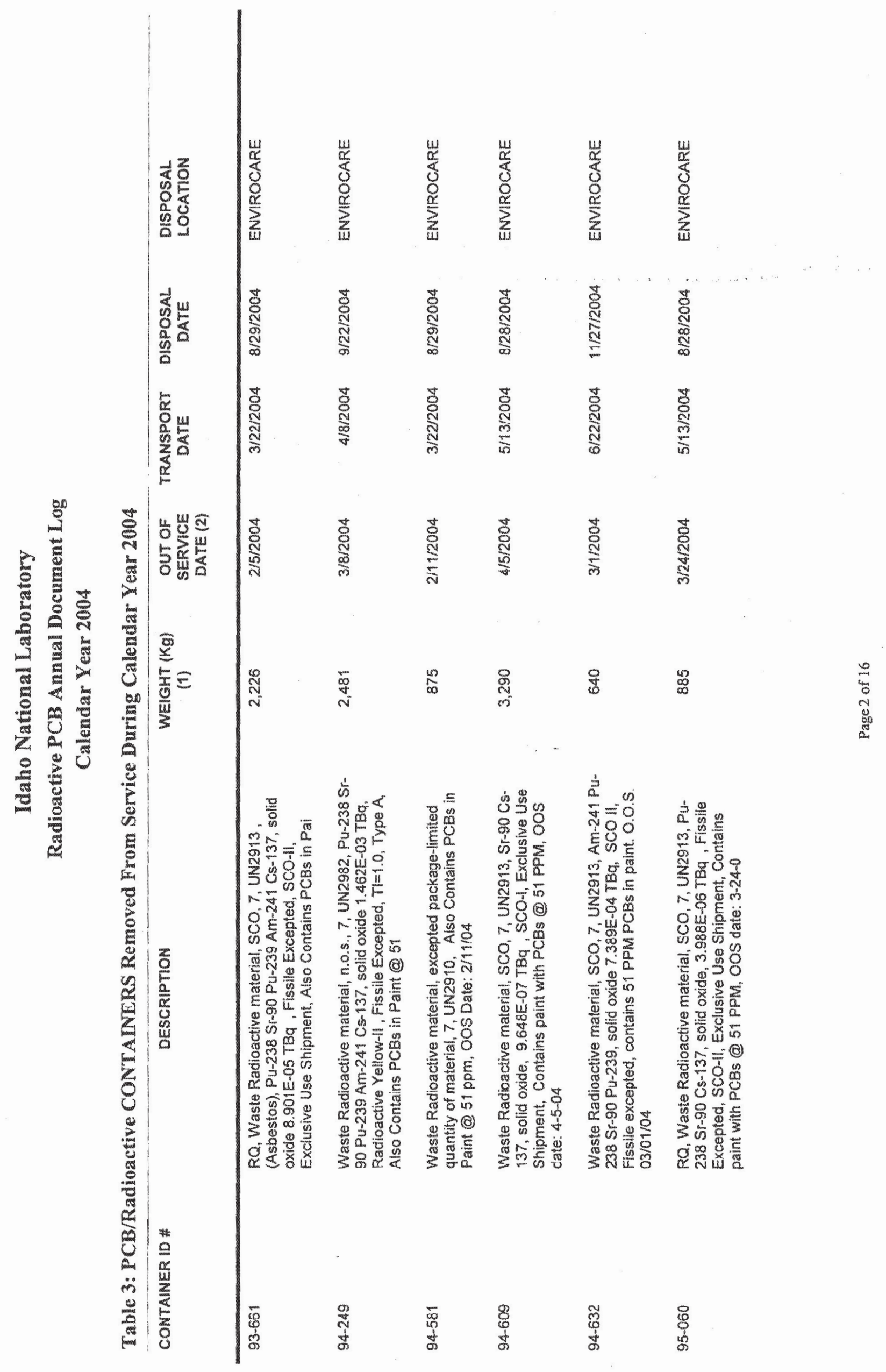




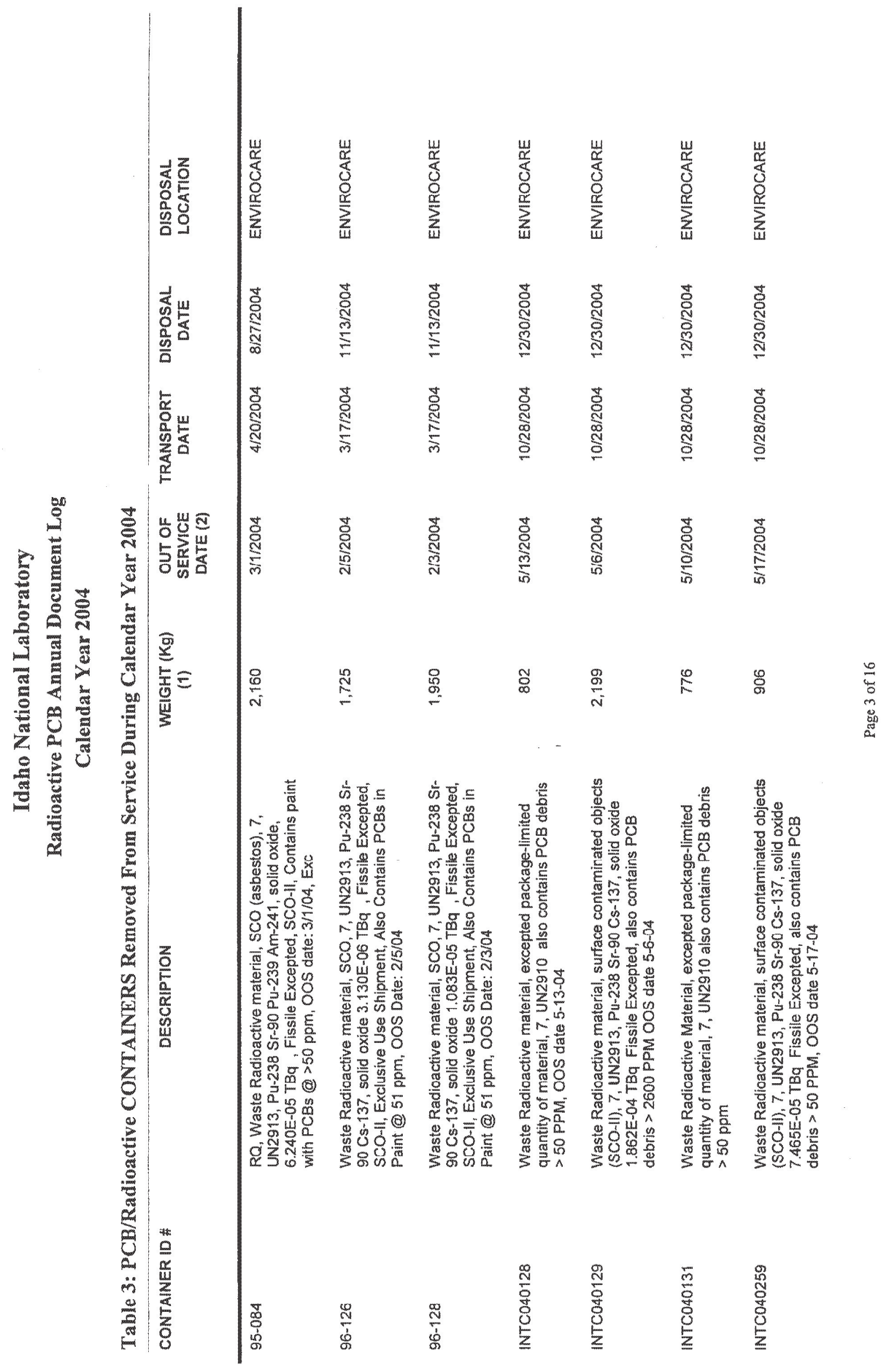




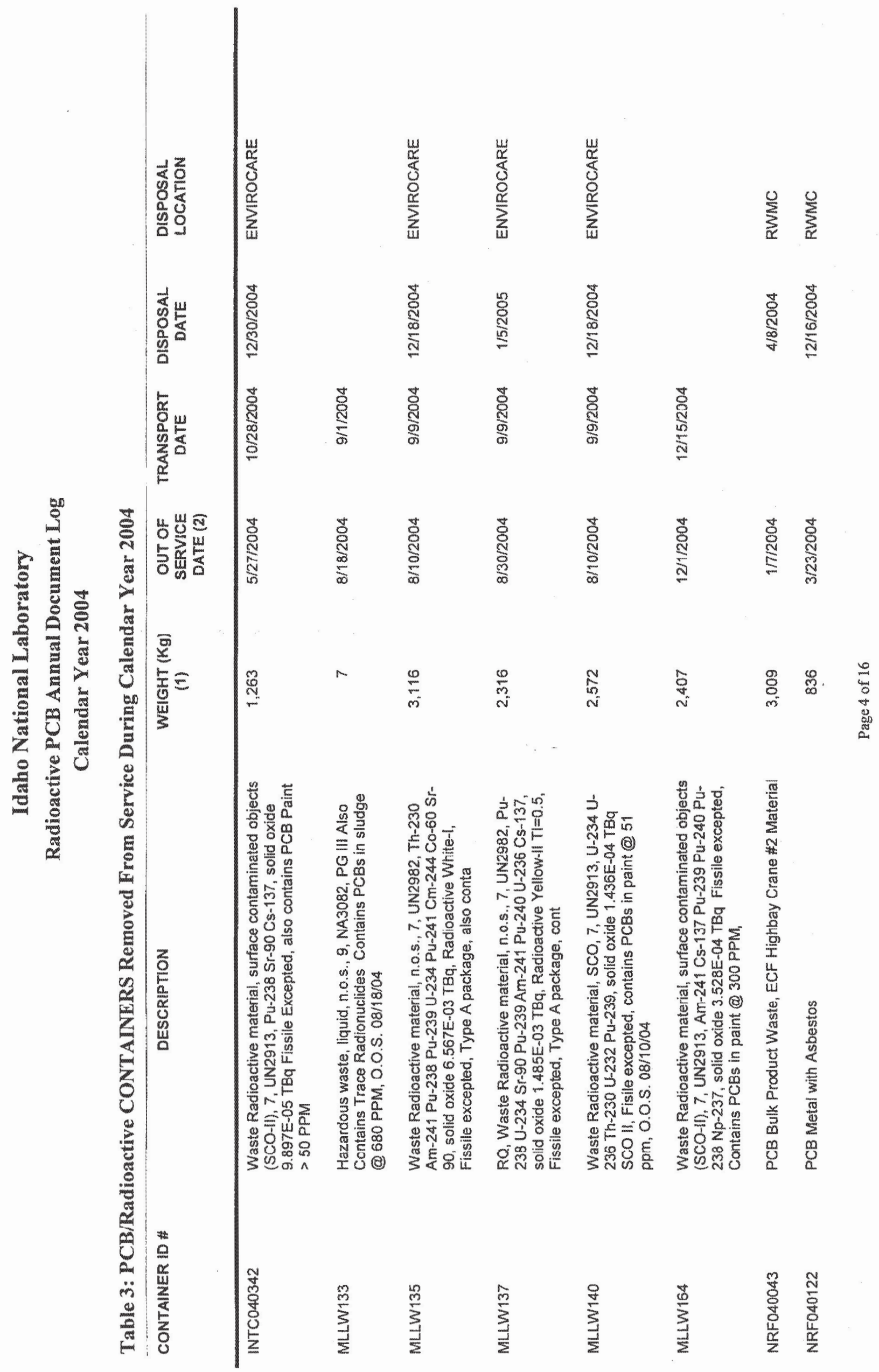




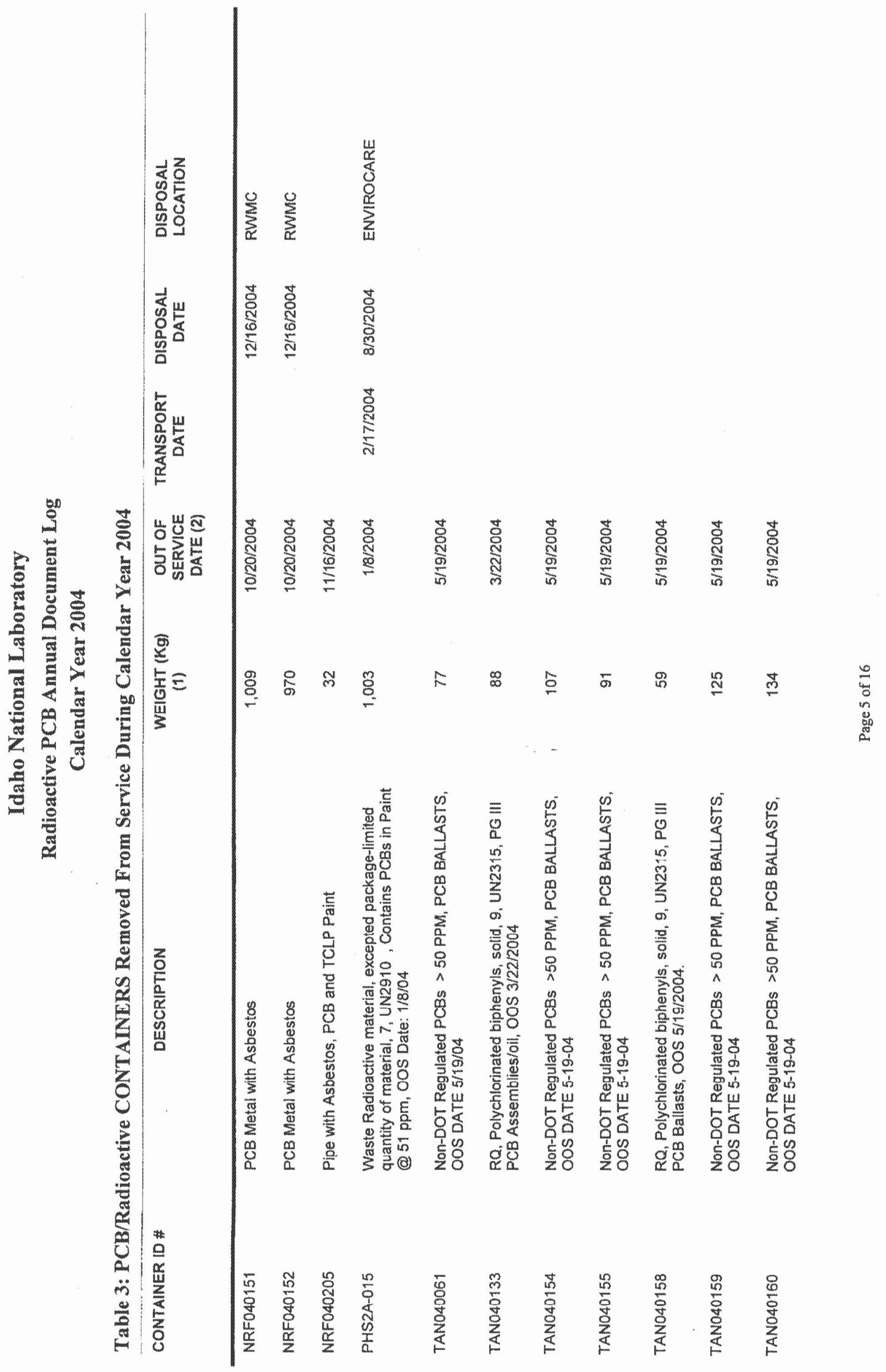




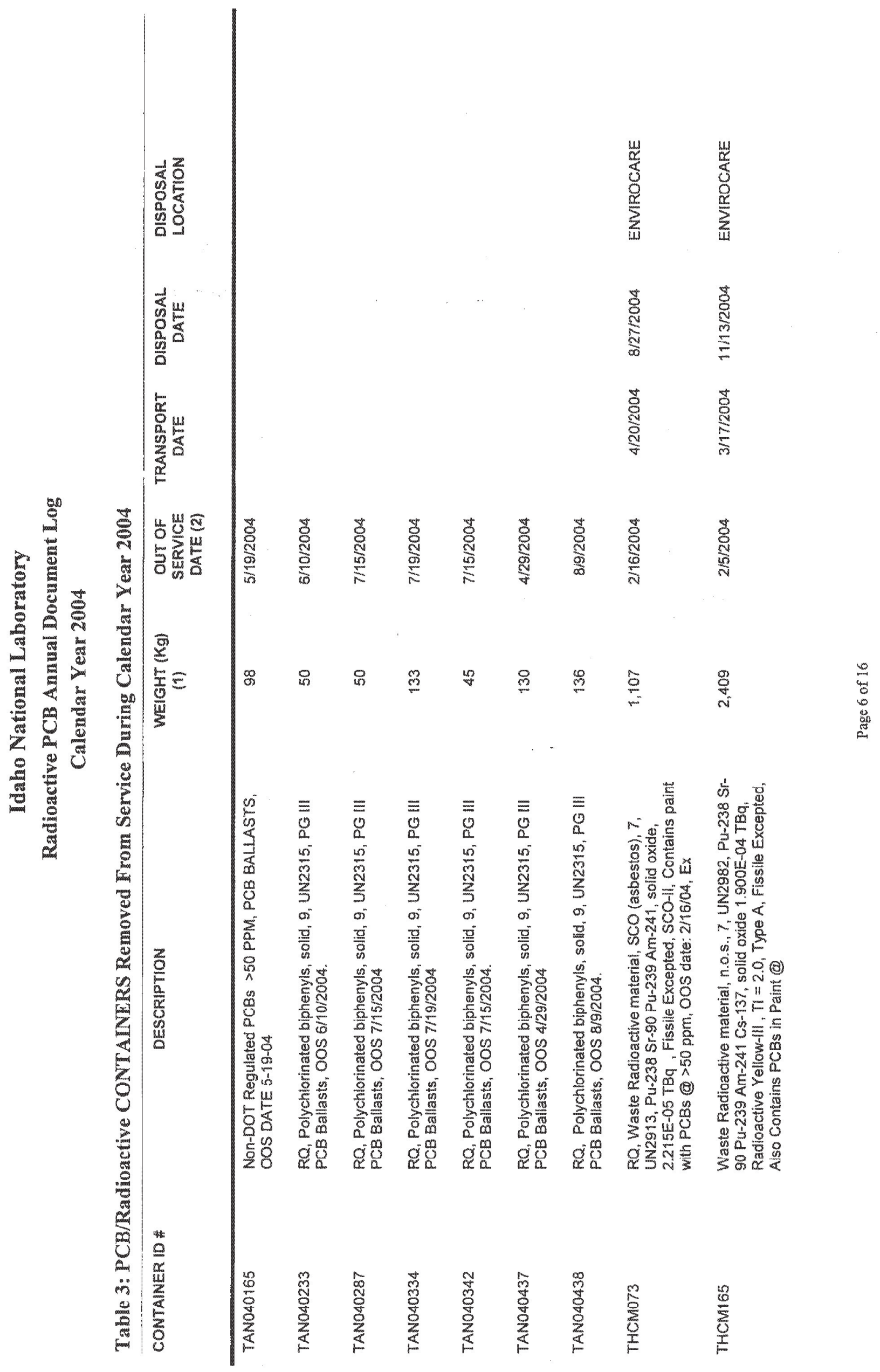




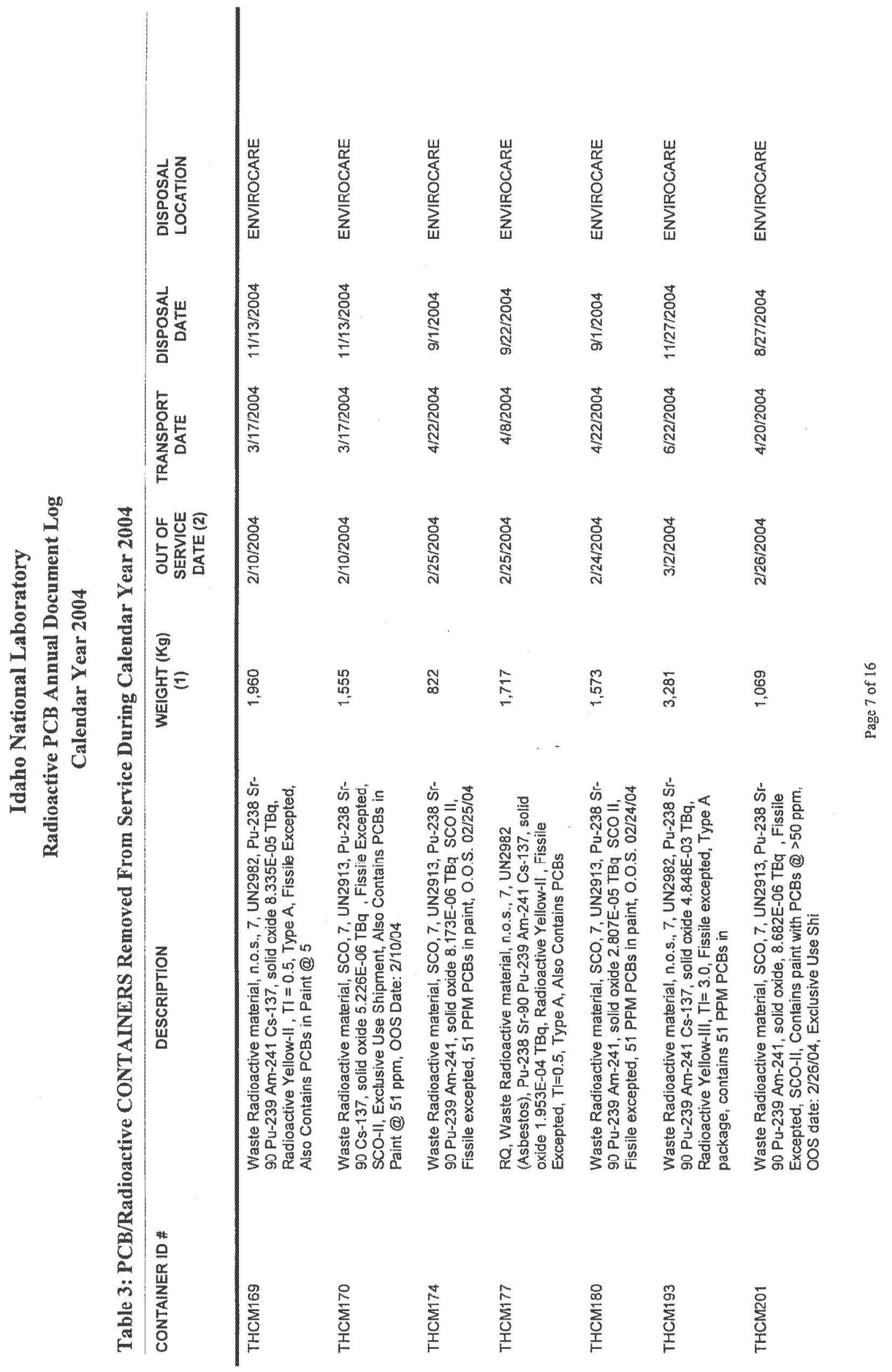




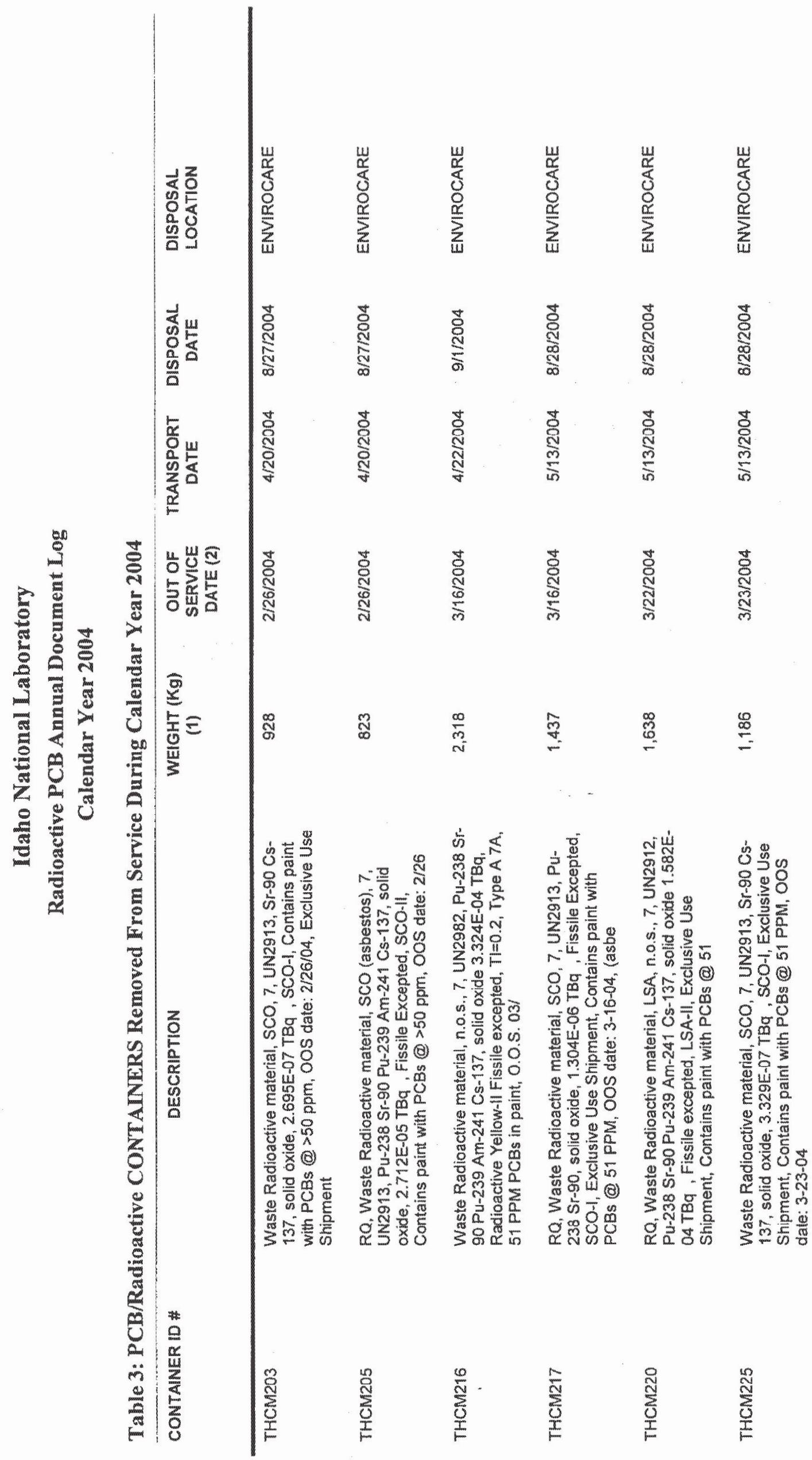




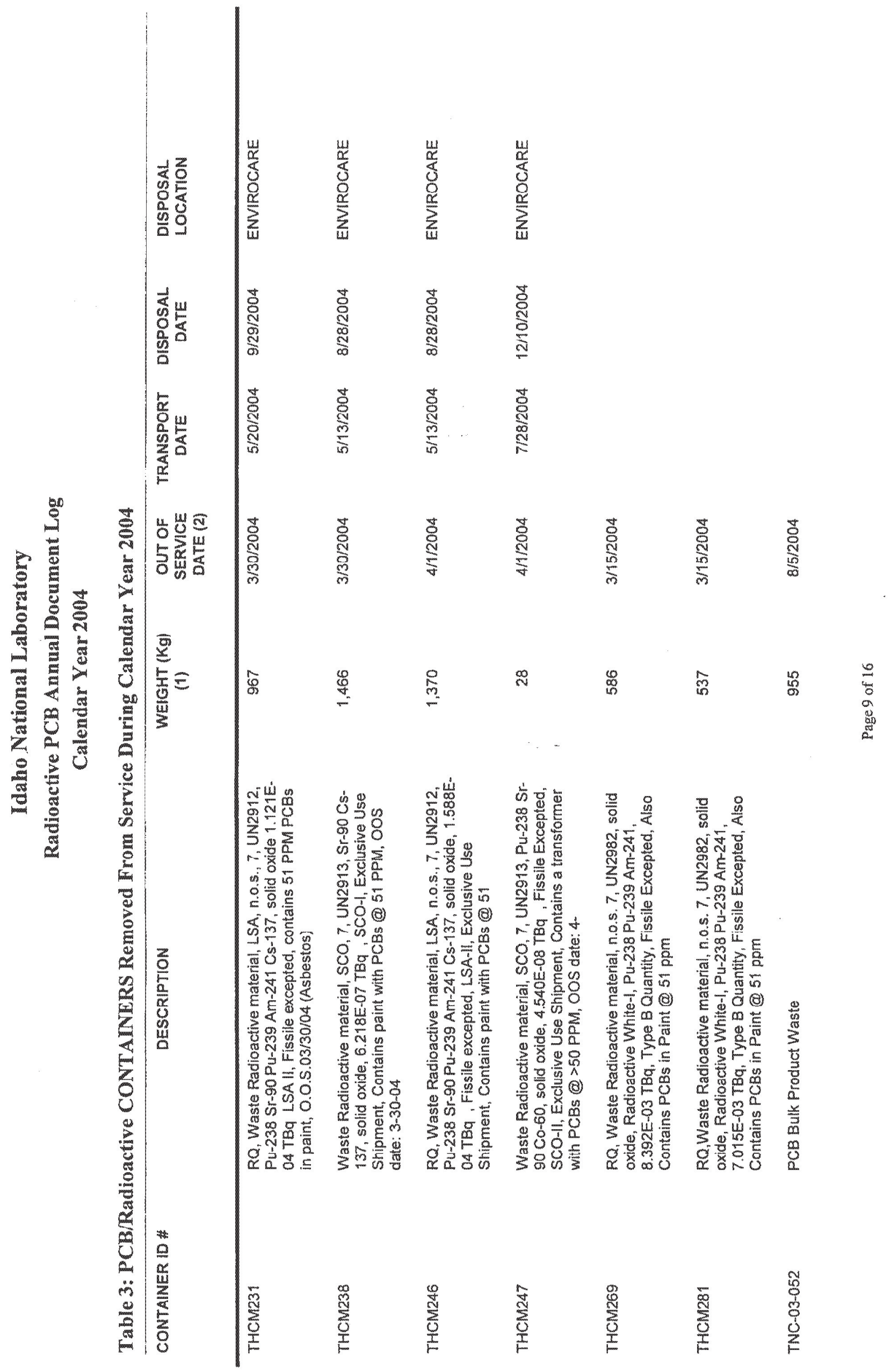




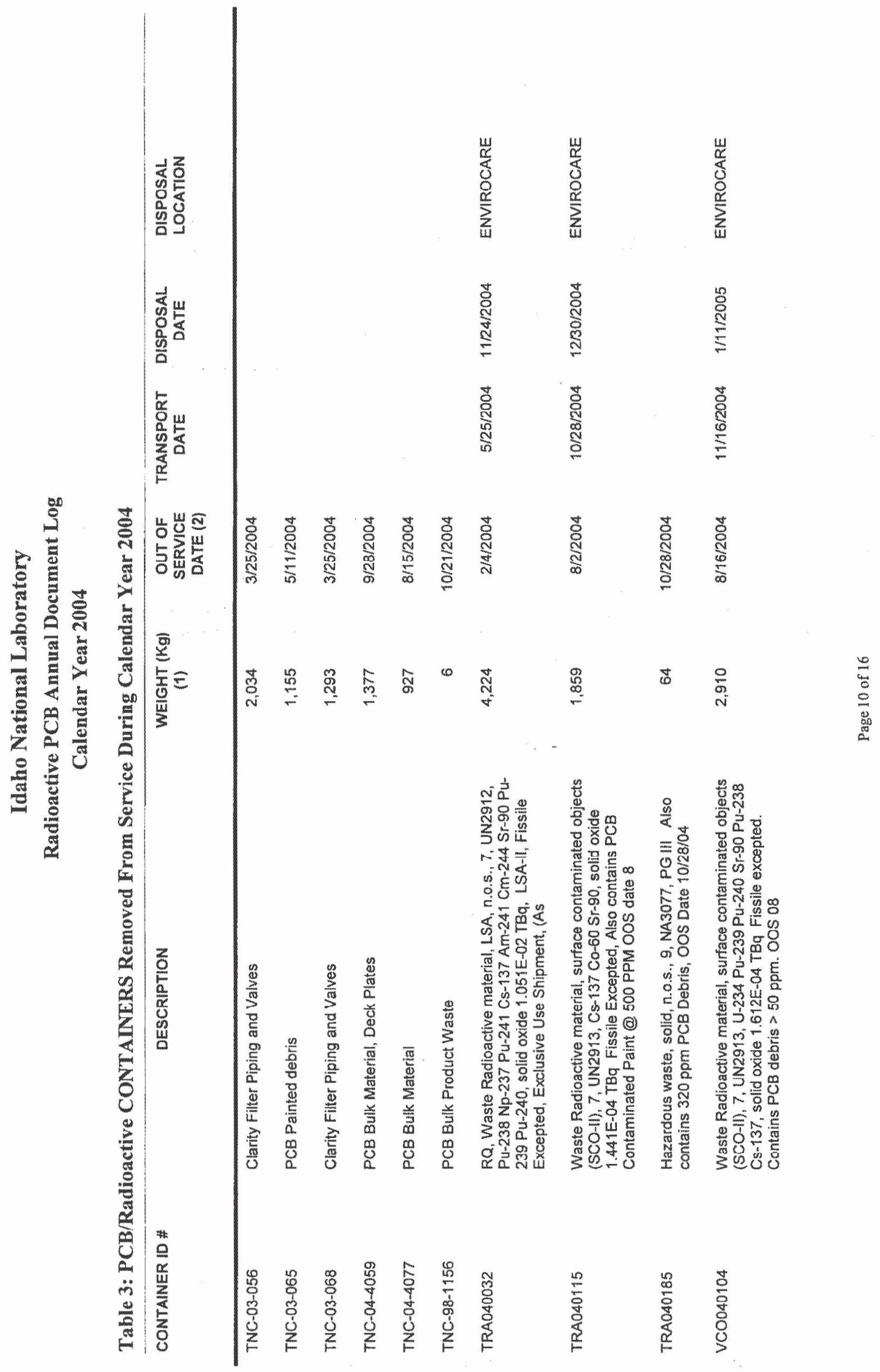




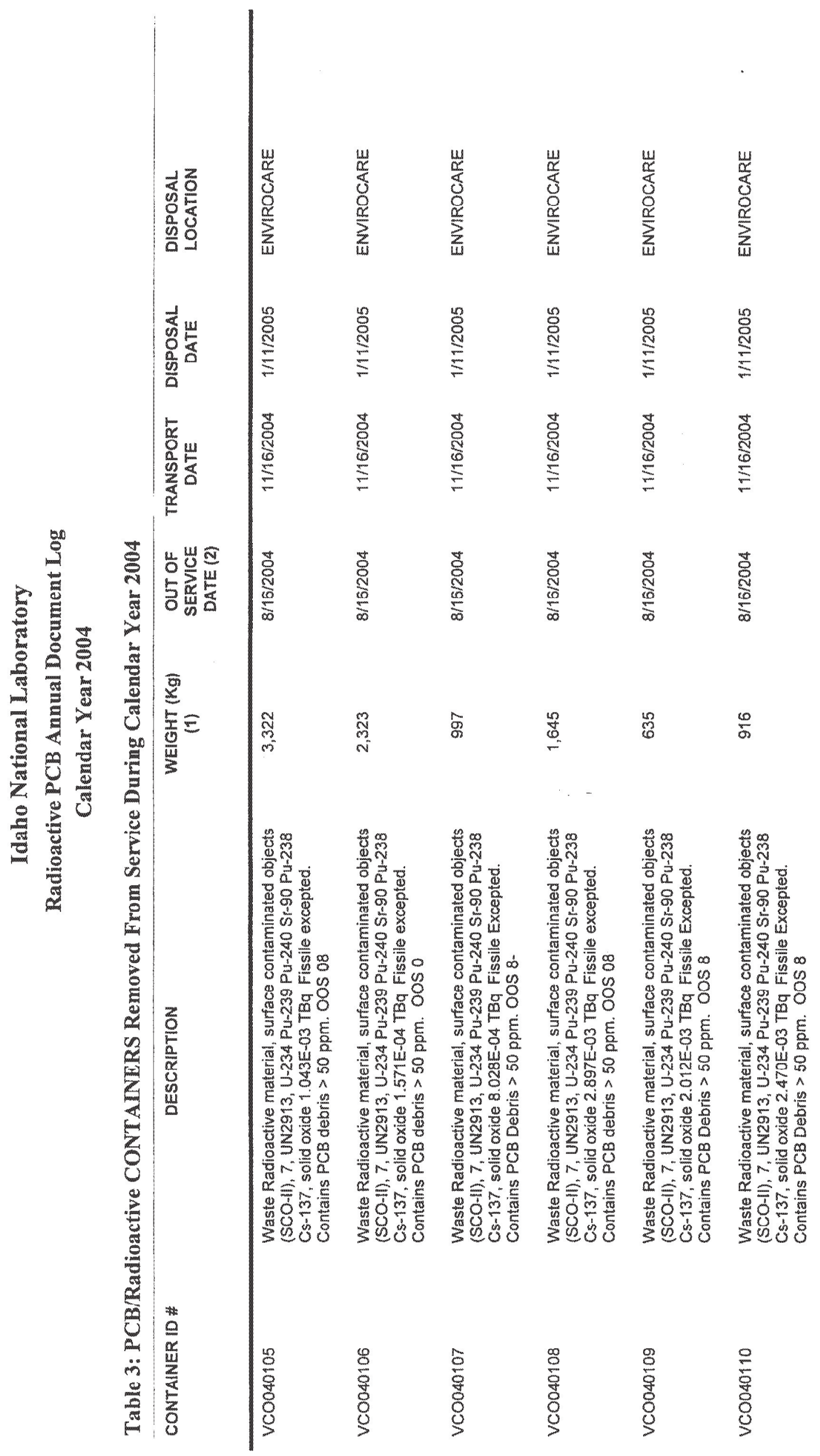




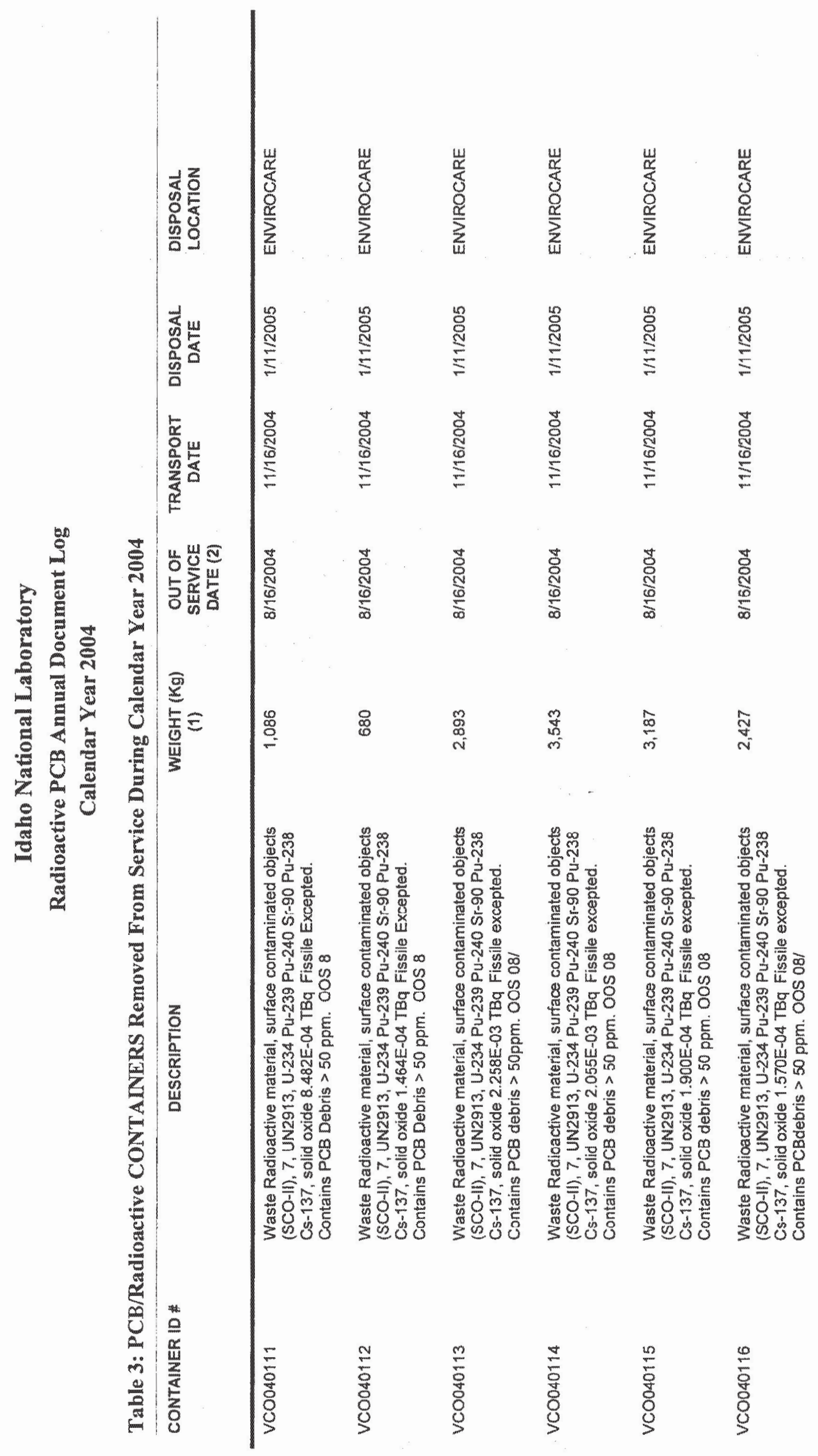




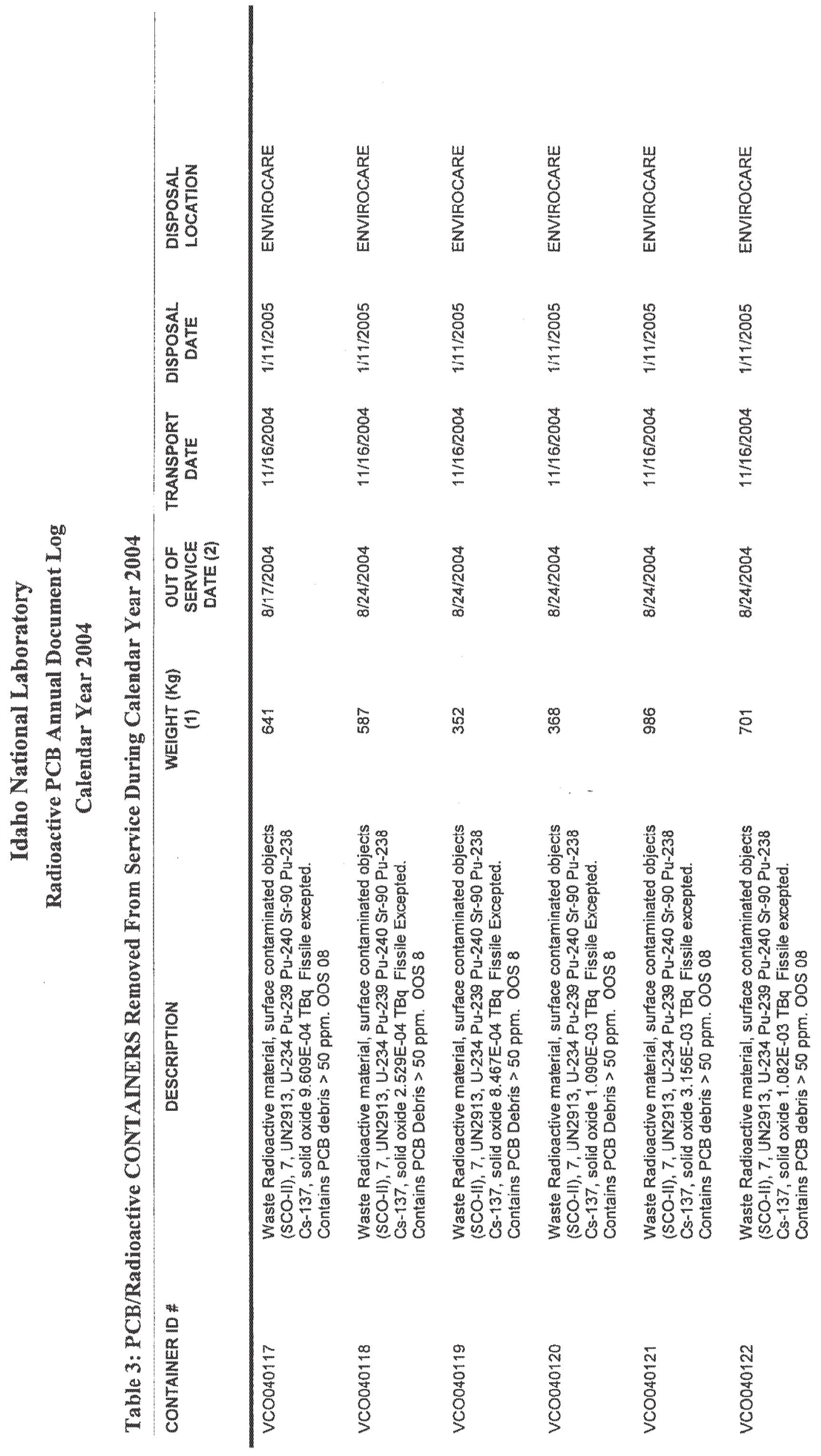




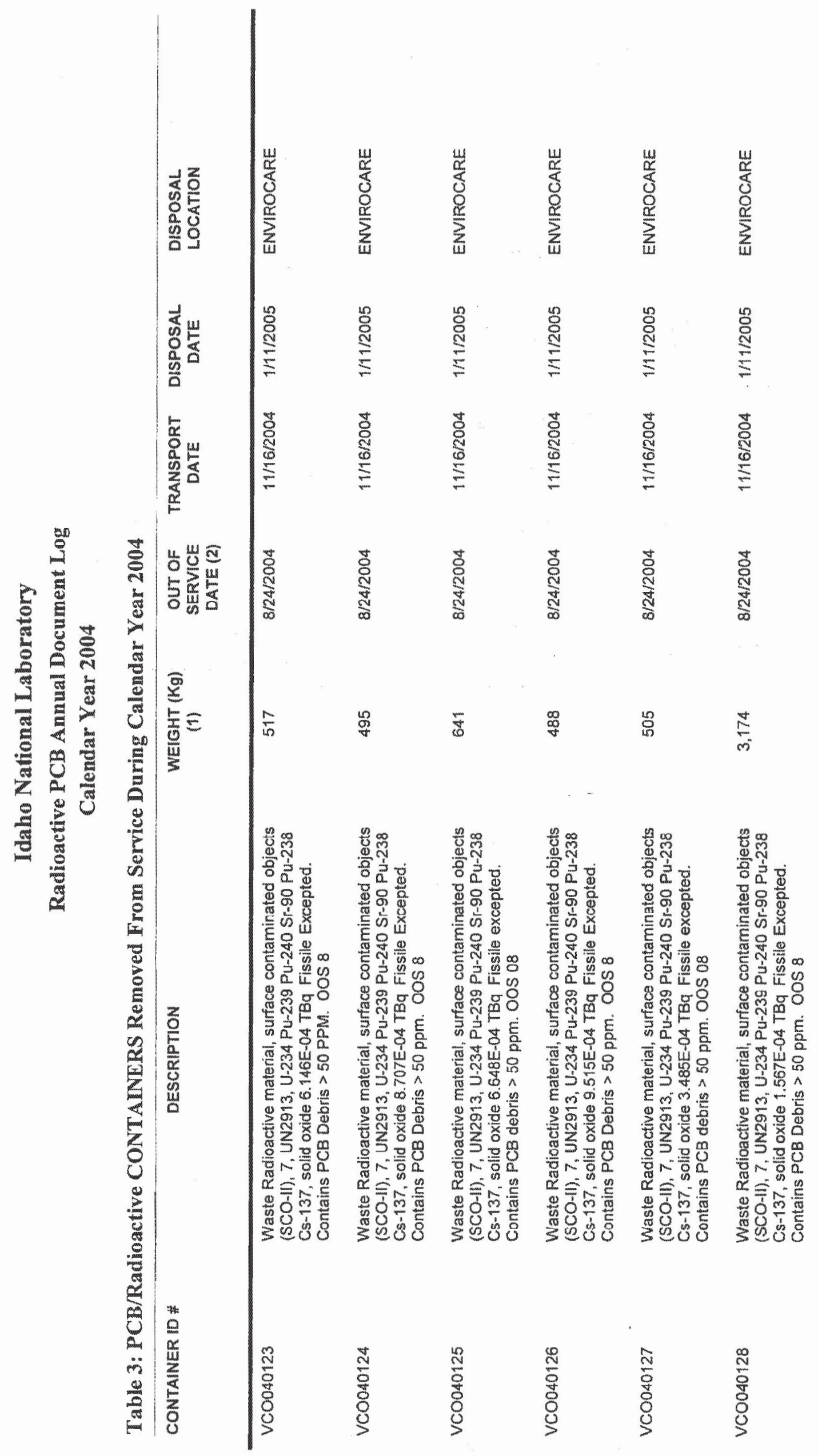




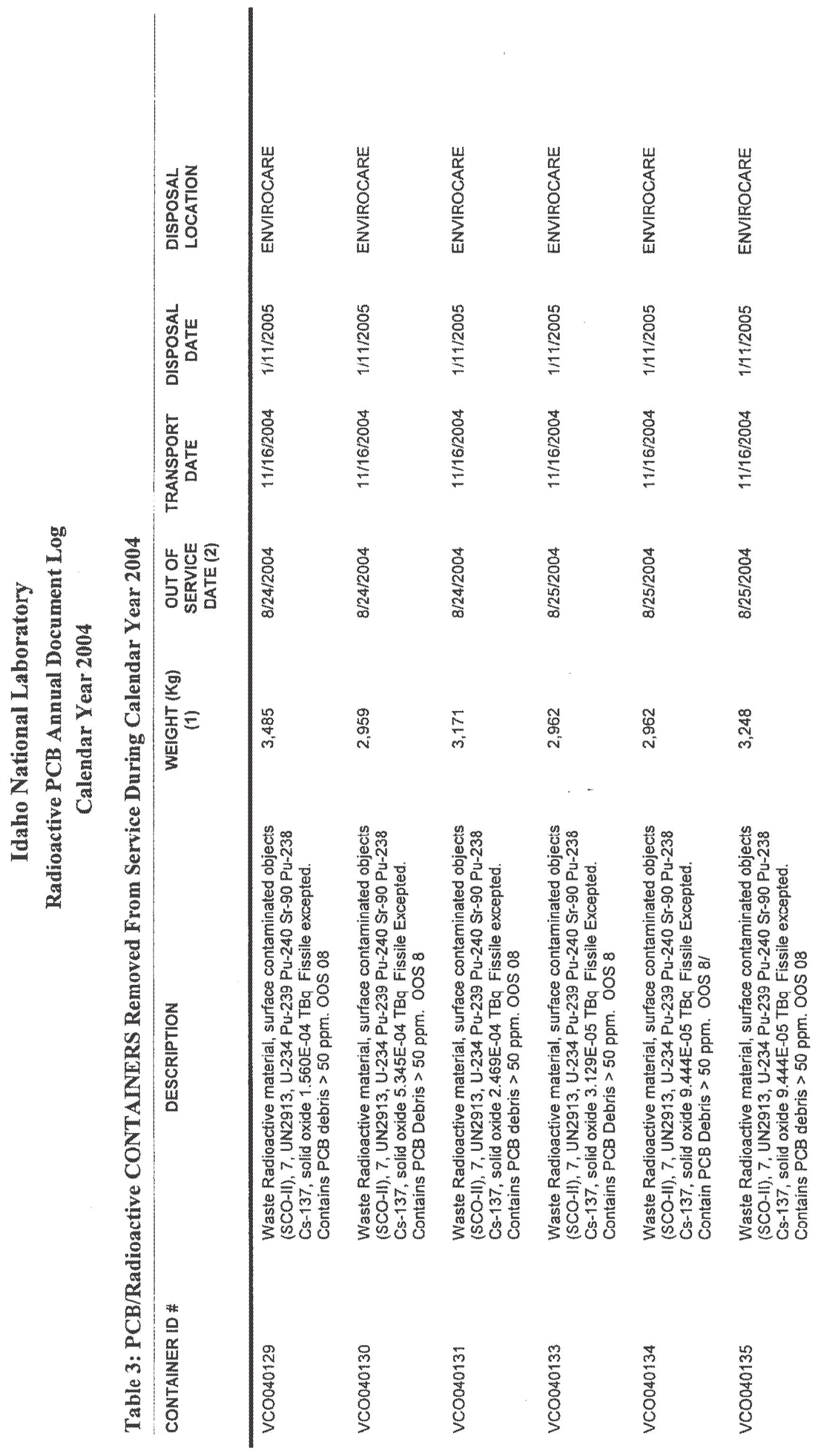




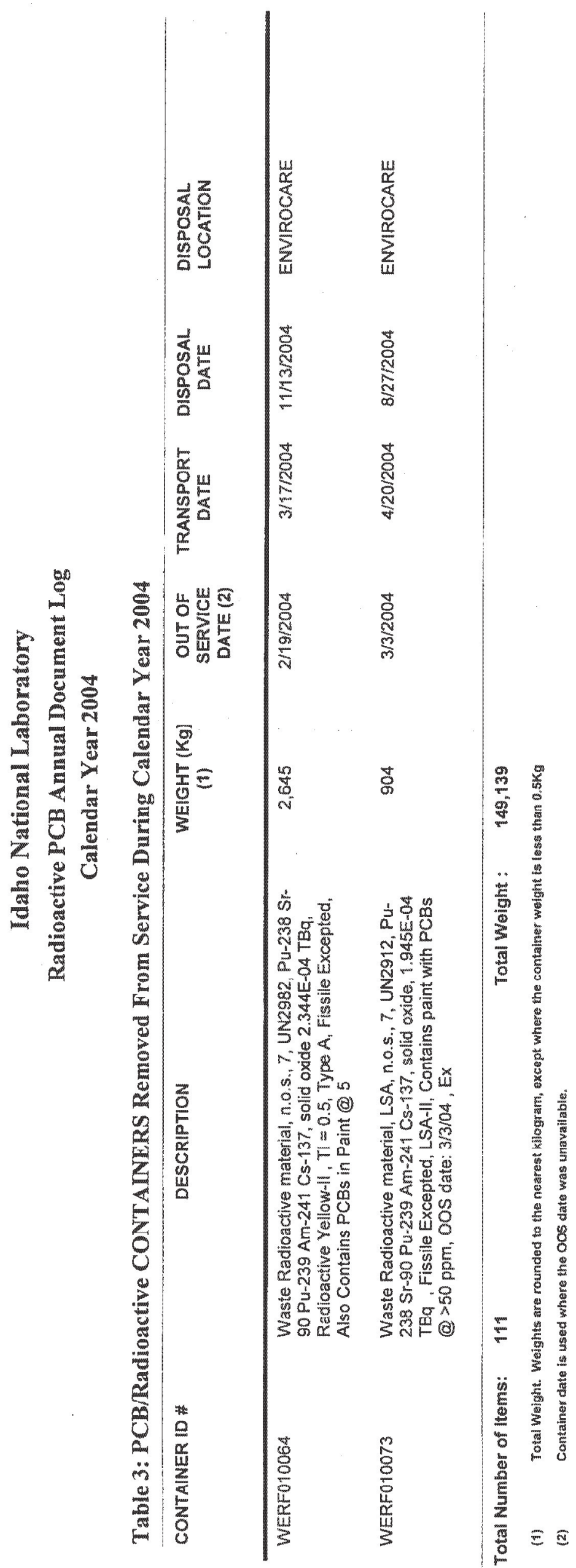

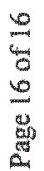




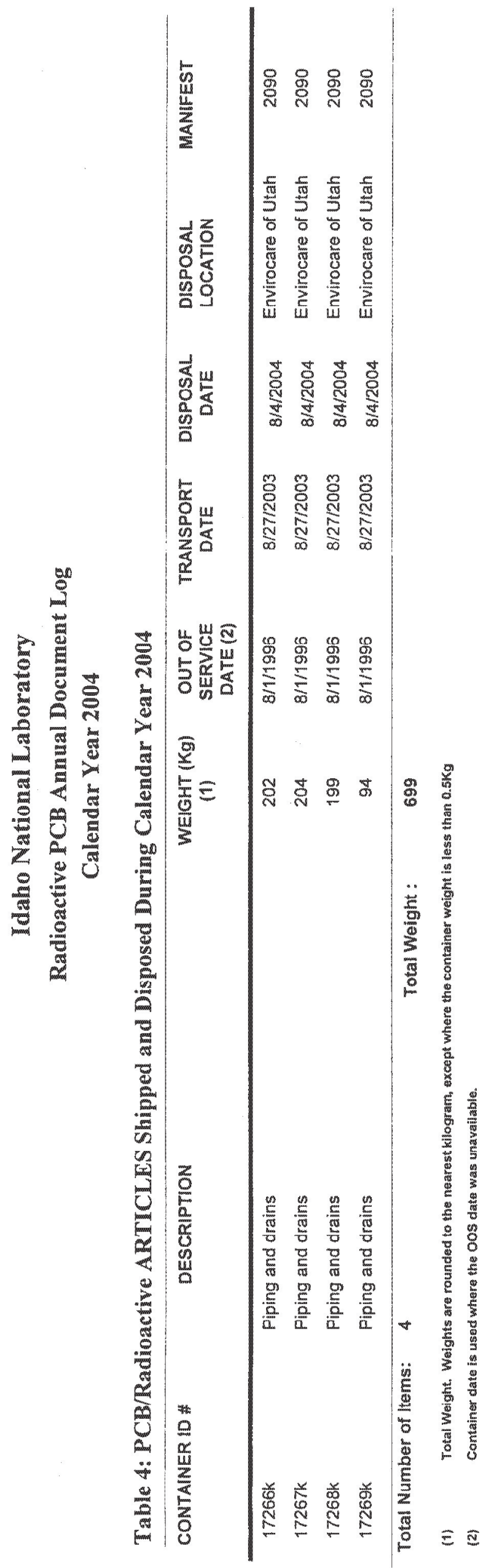

$\frac{5}{5}$ 


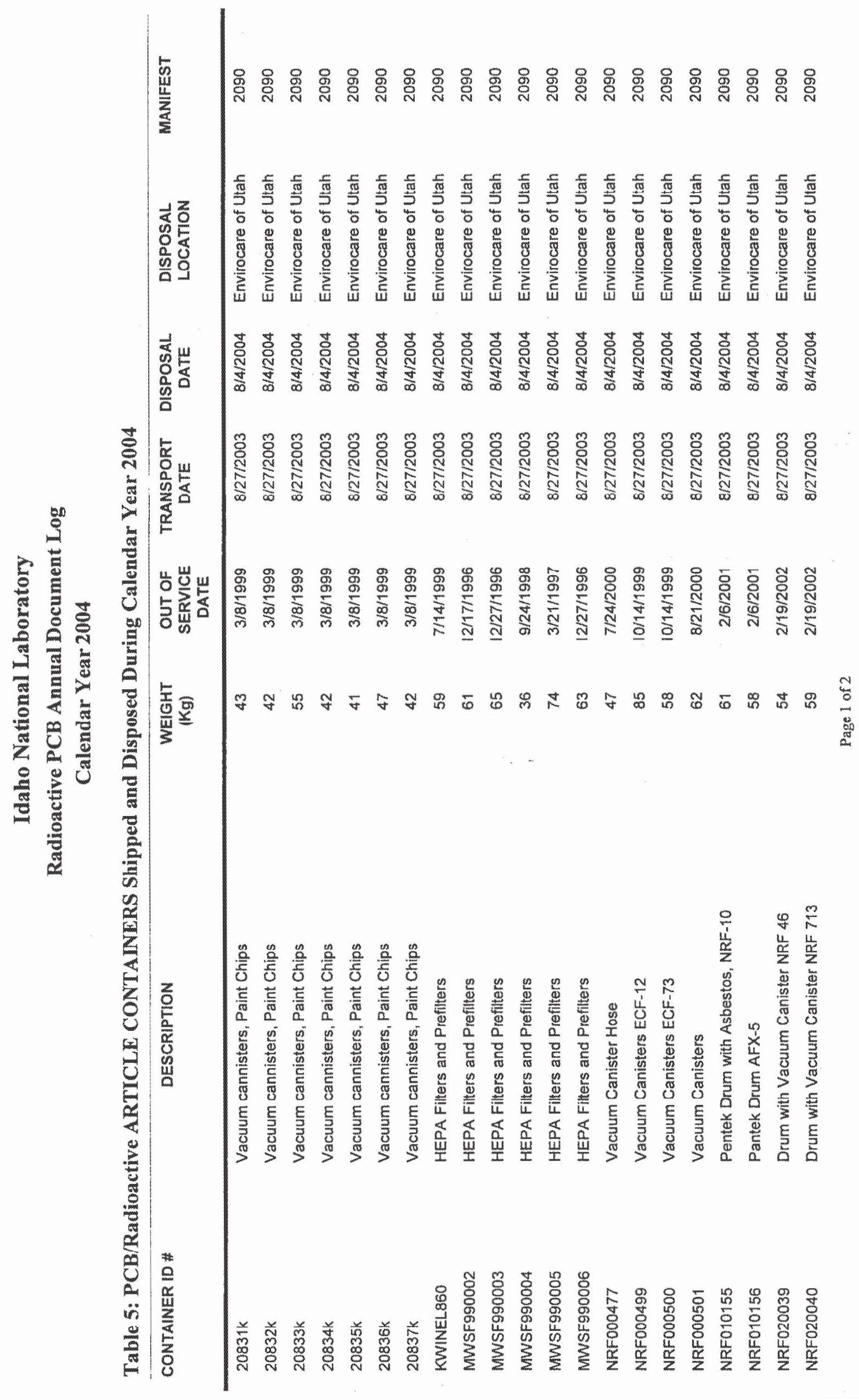




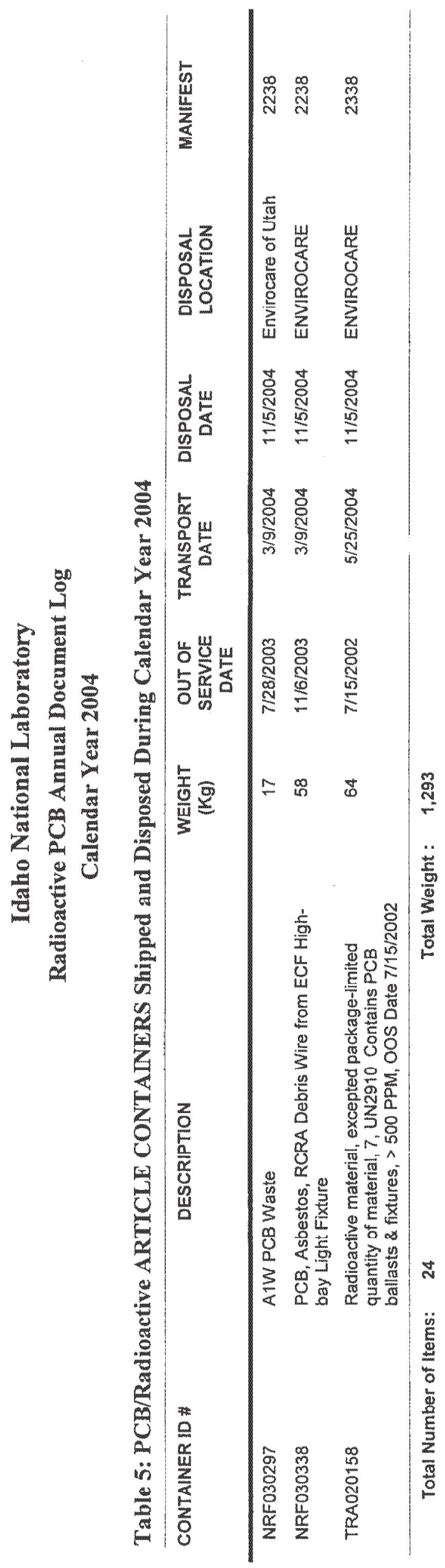




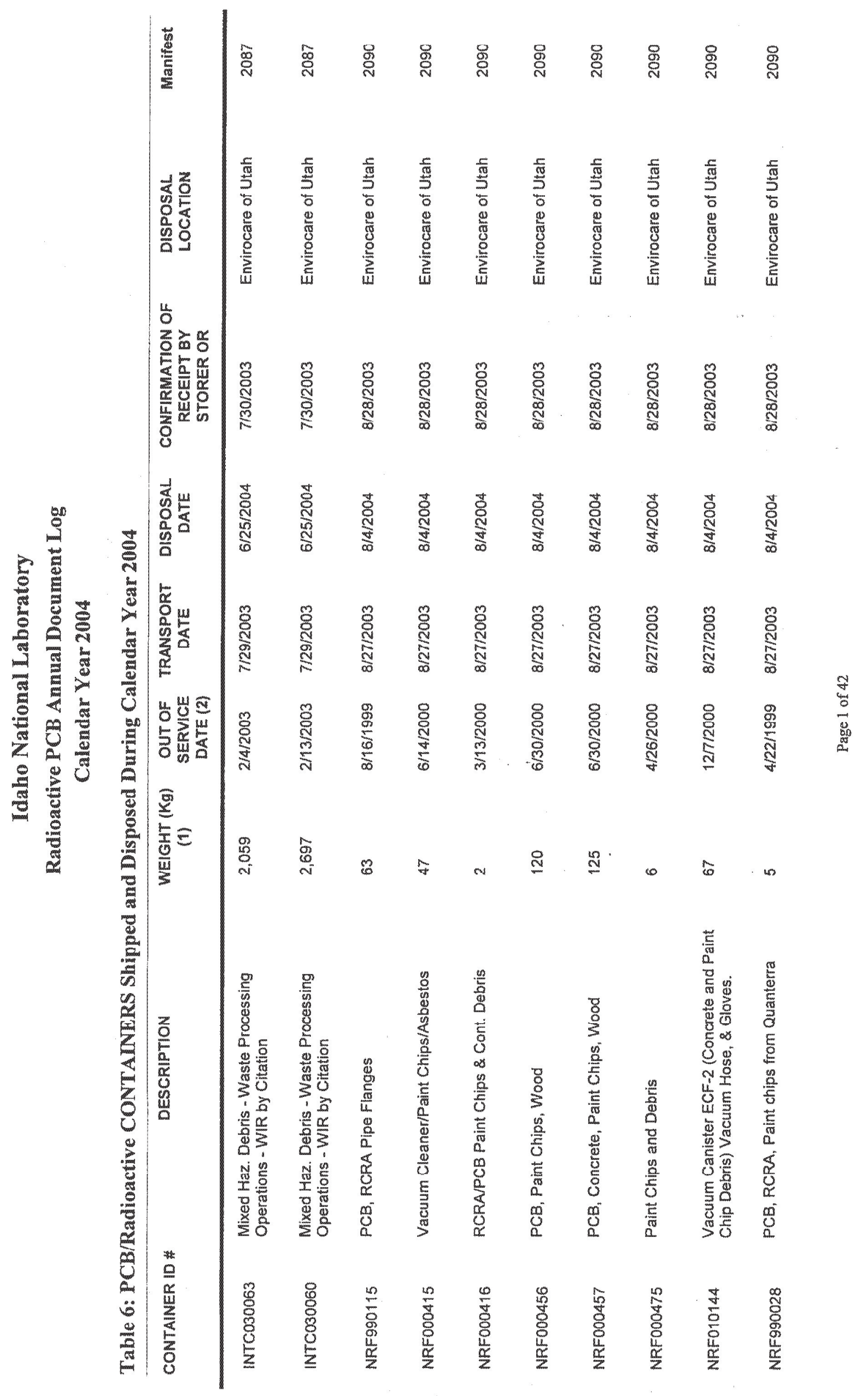




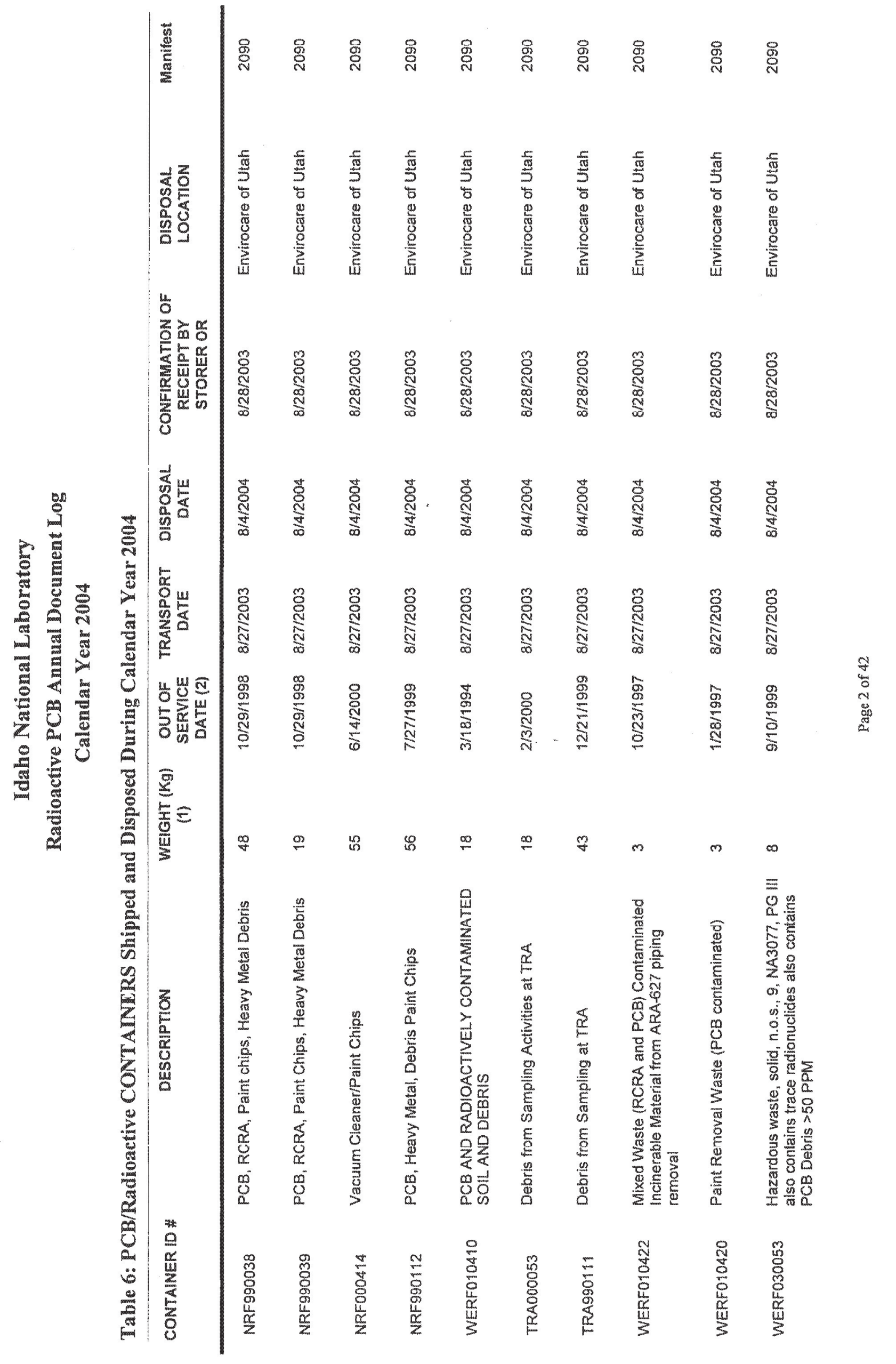




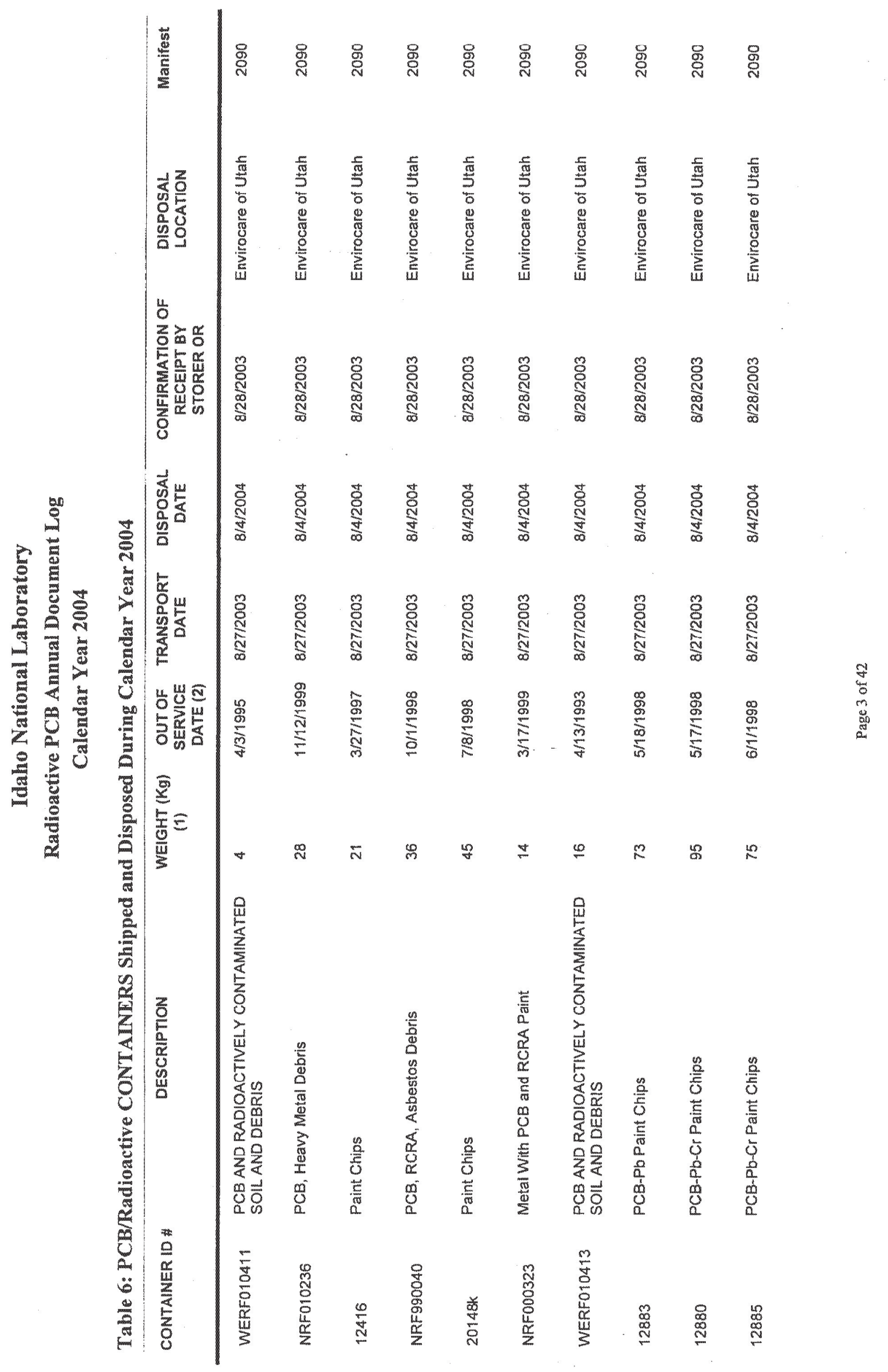




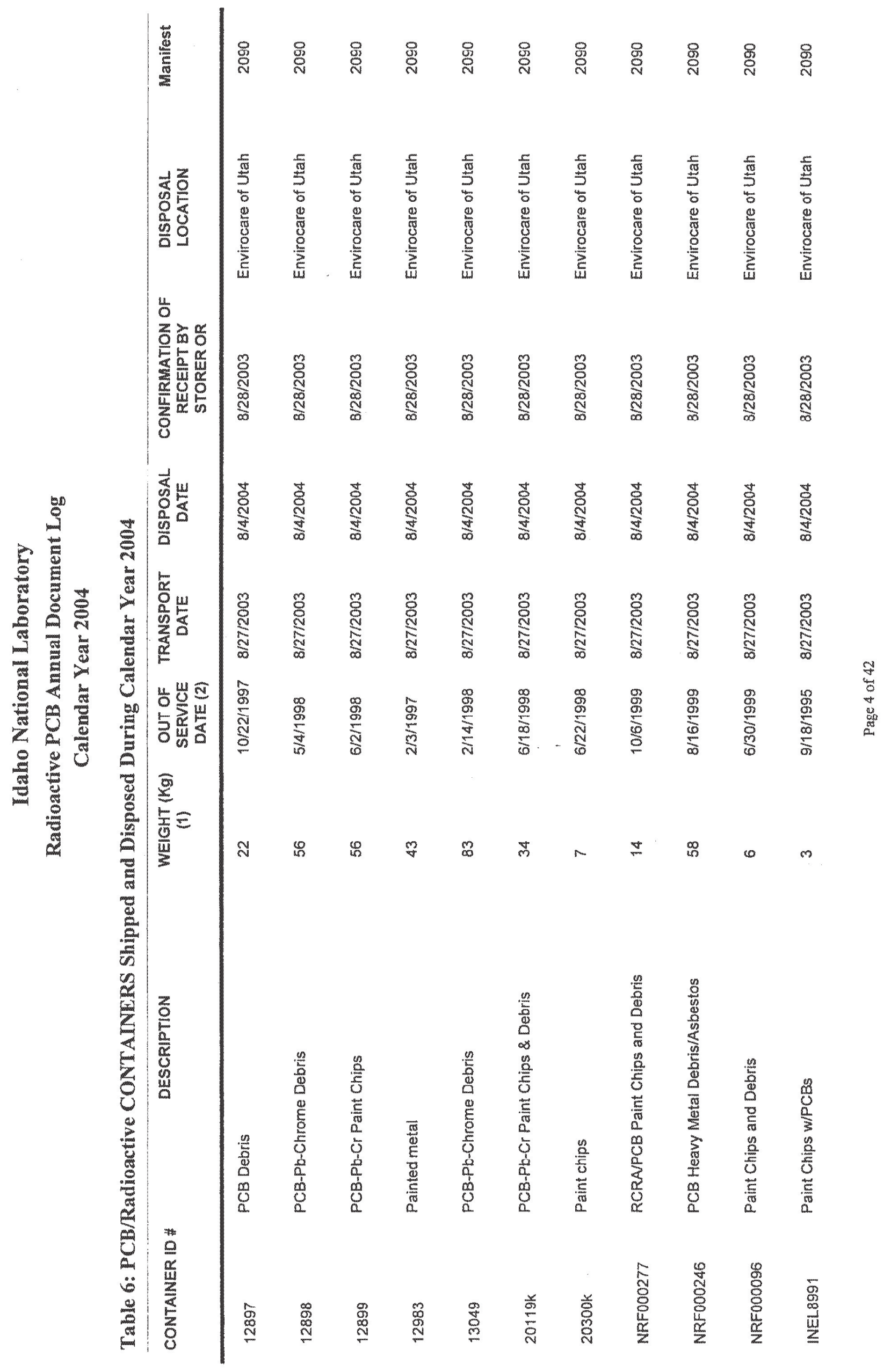




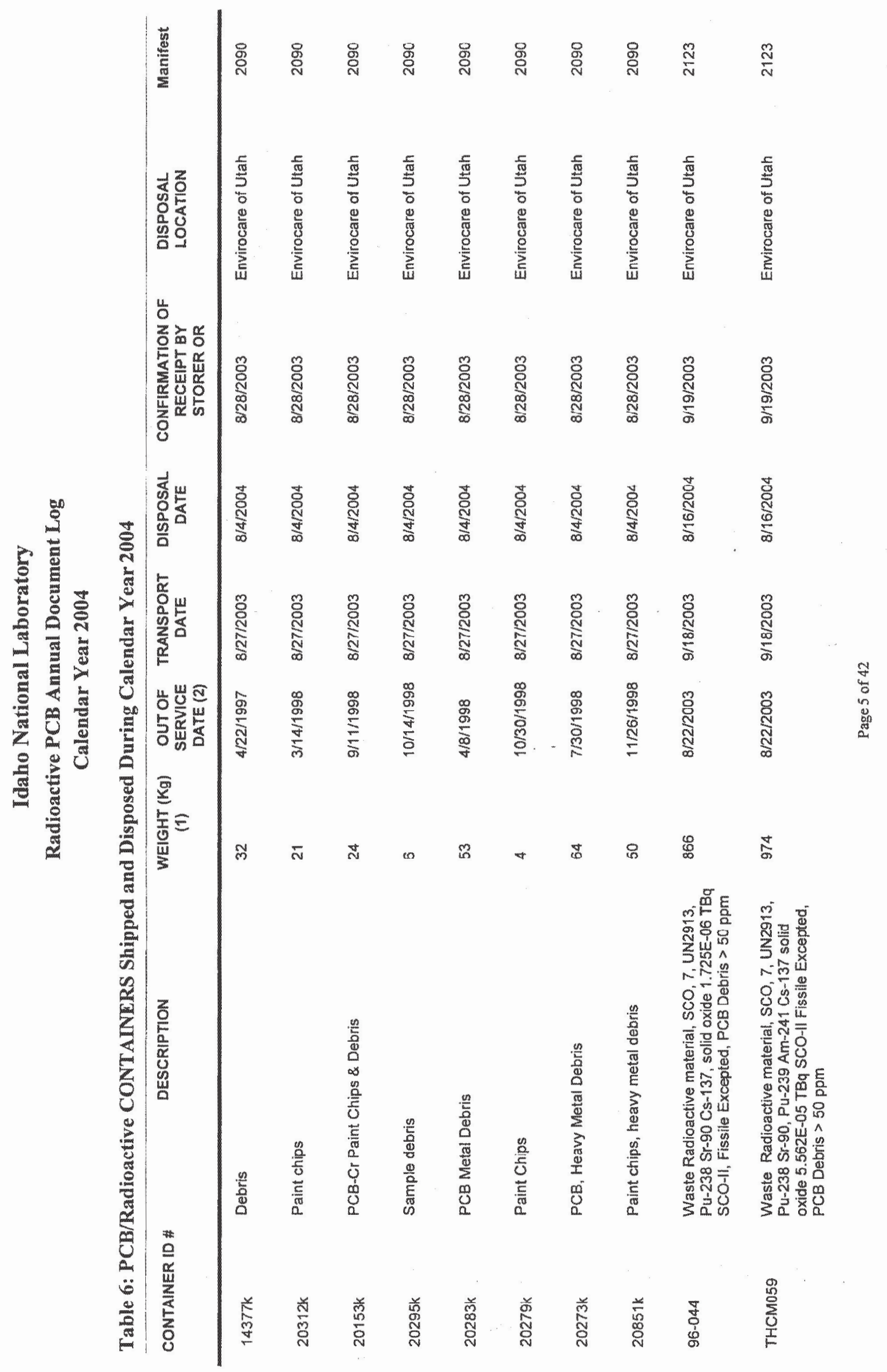




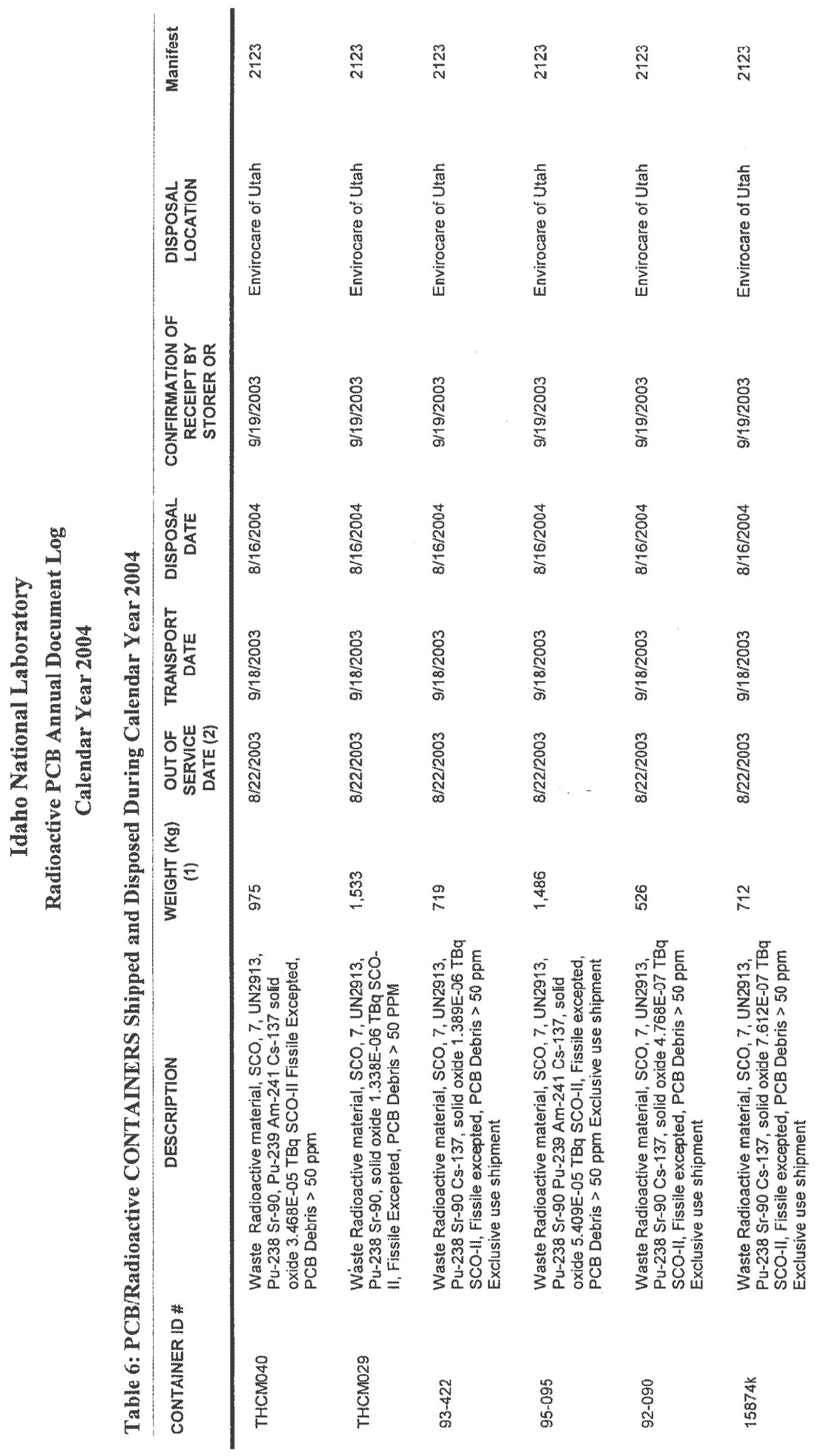




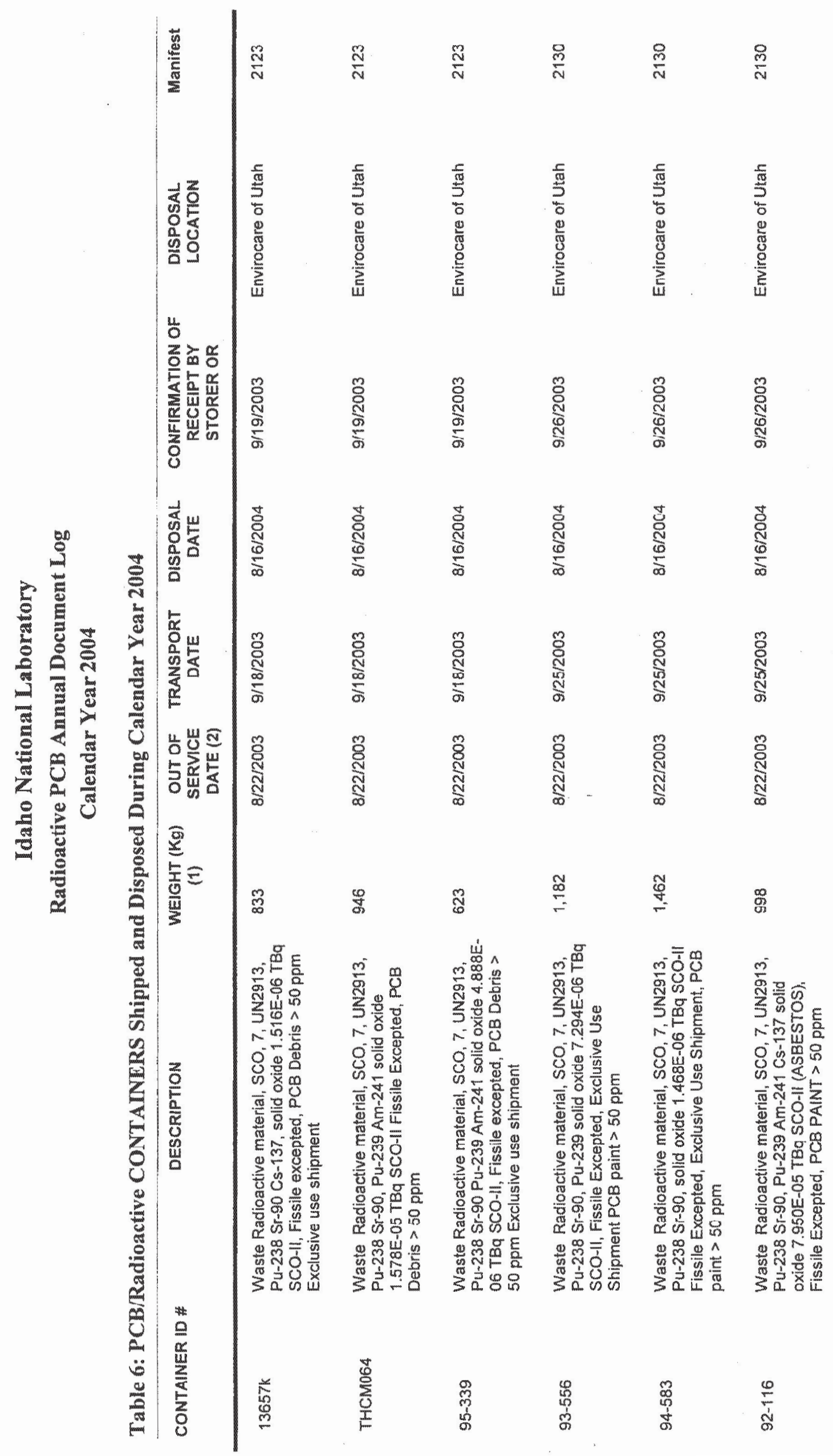




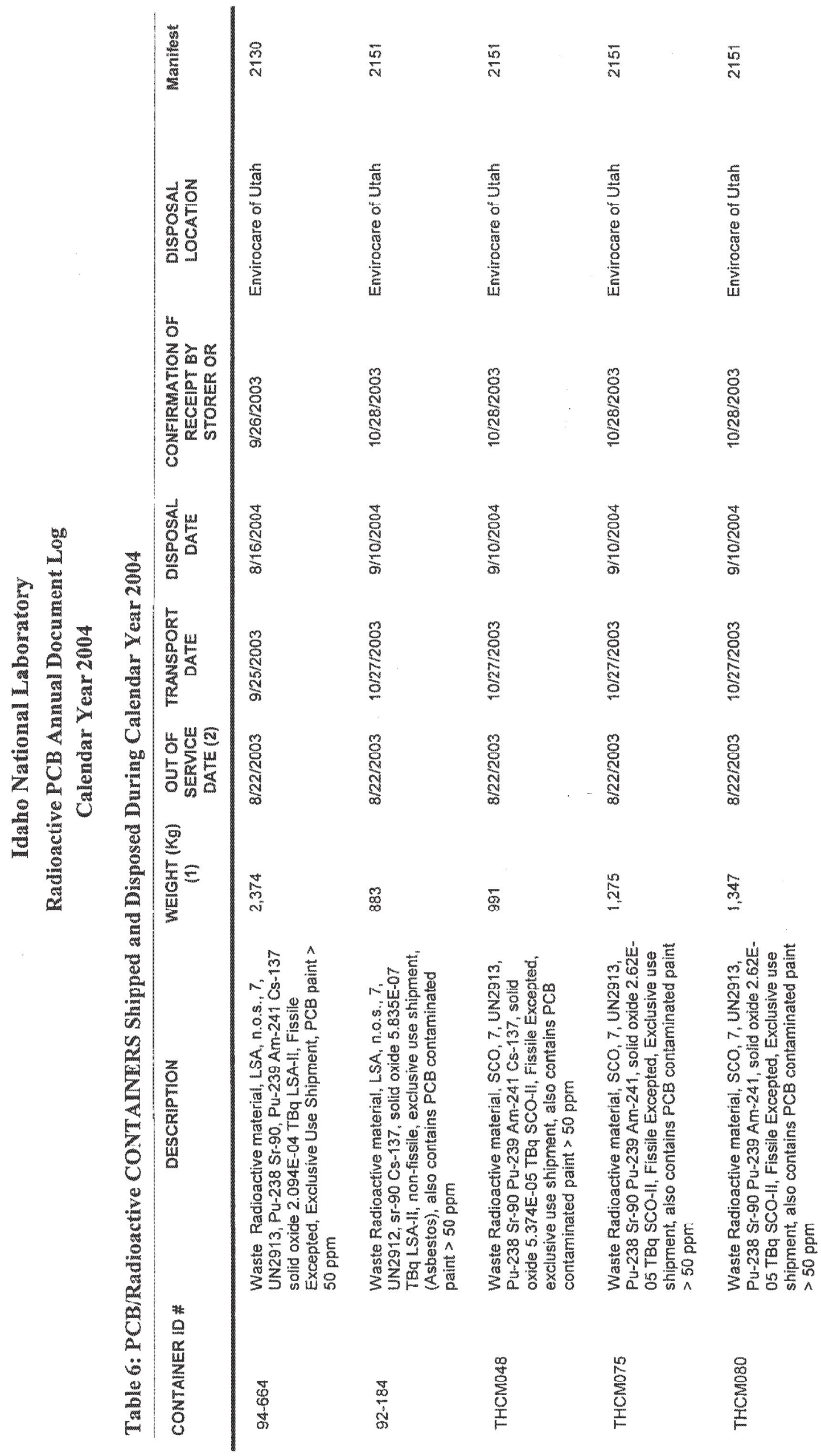




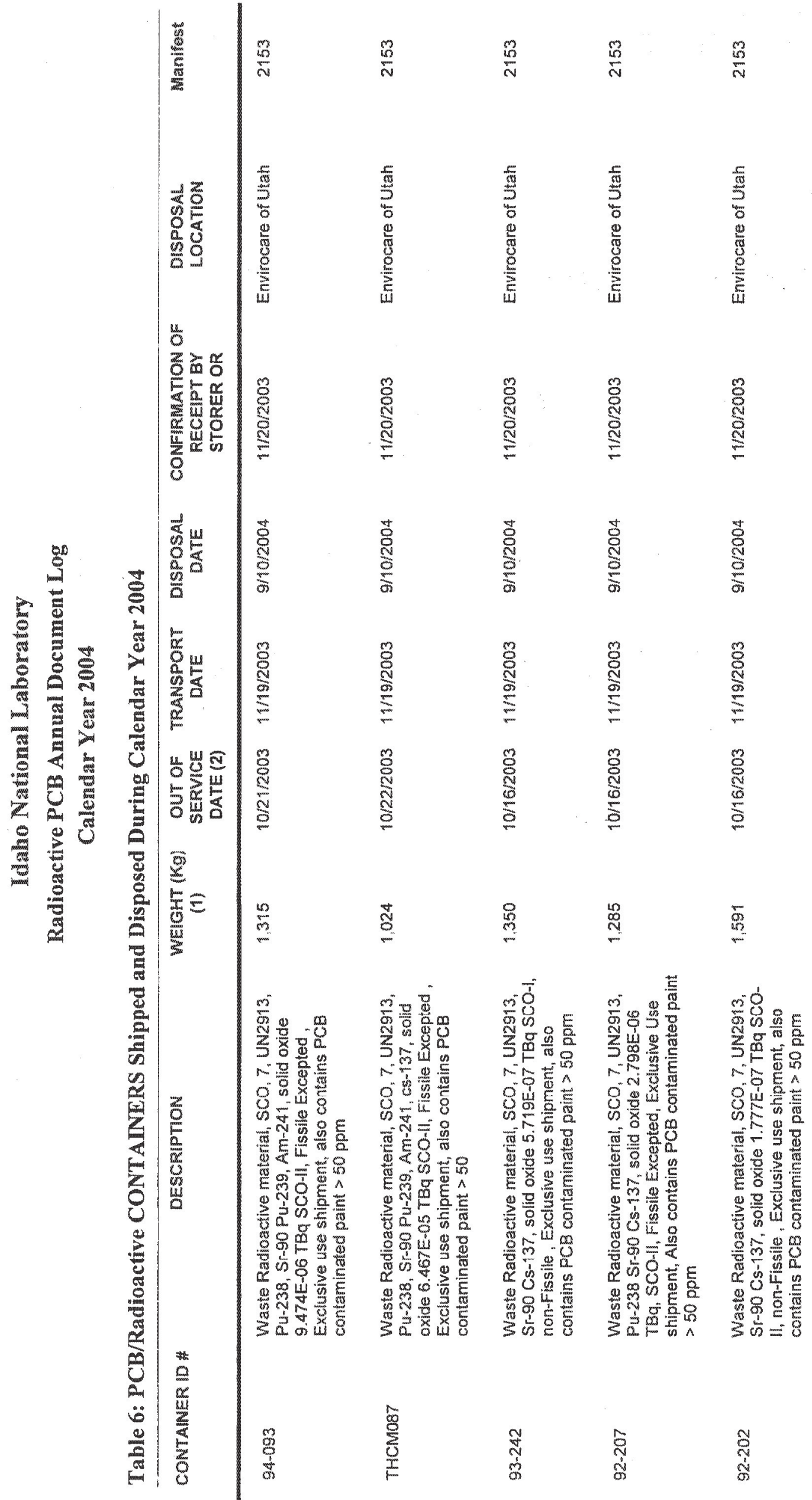




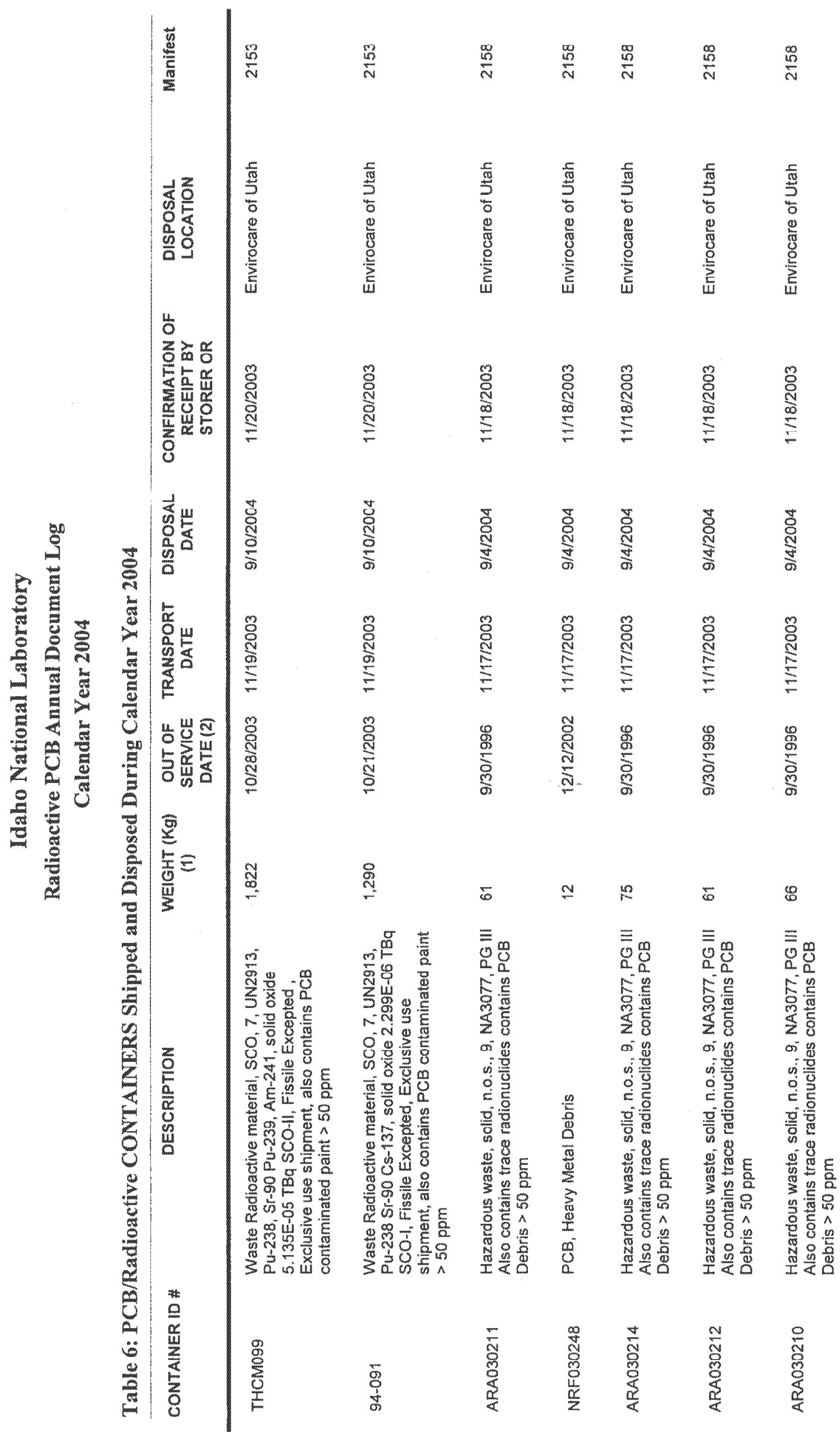




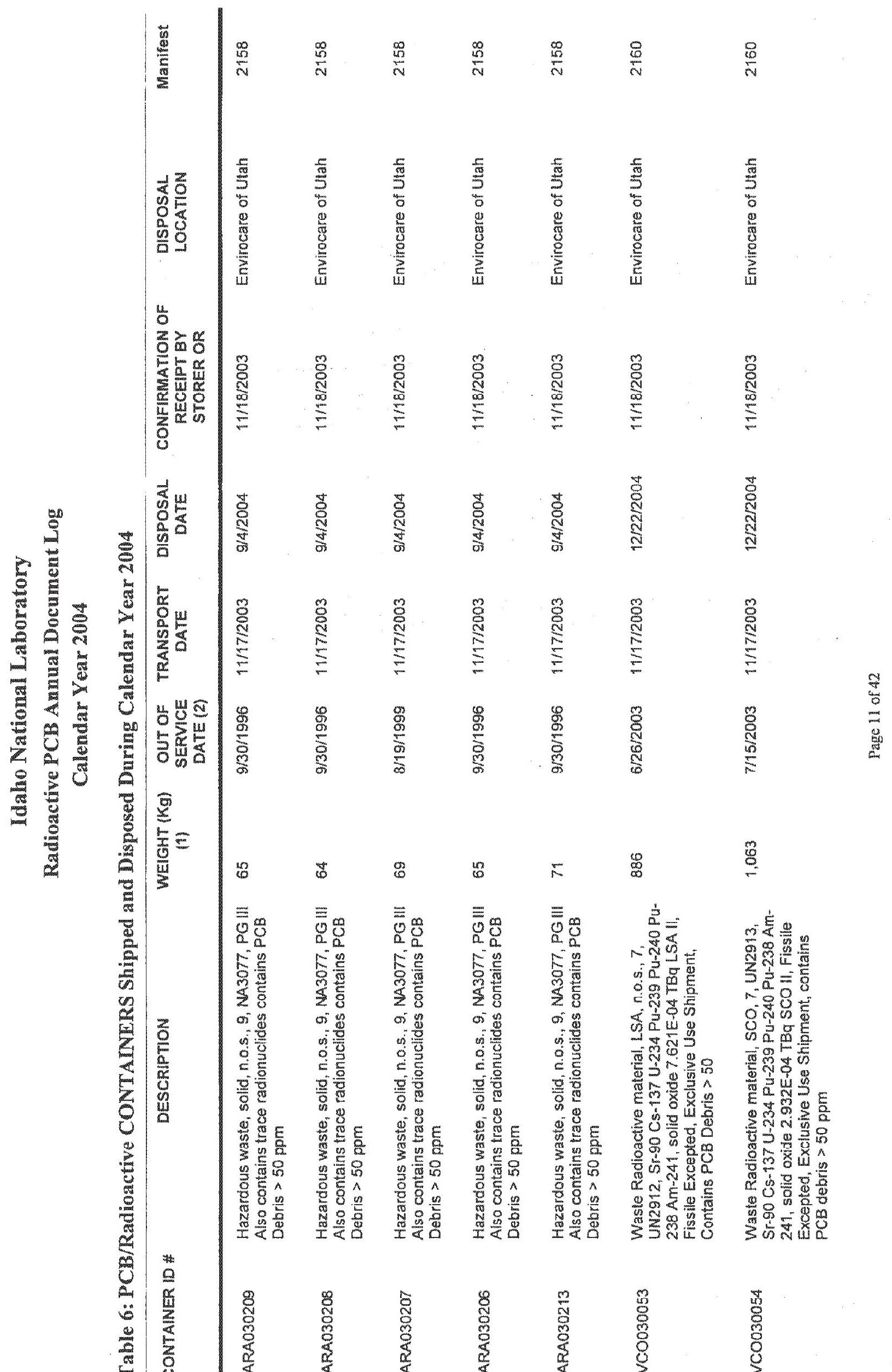




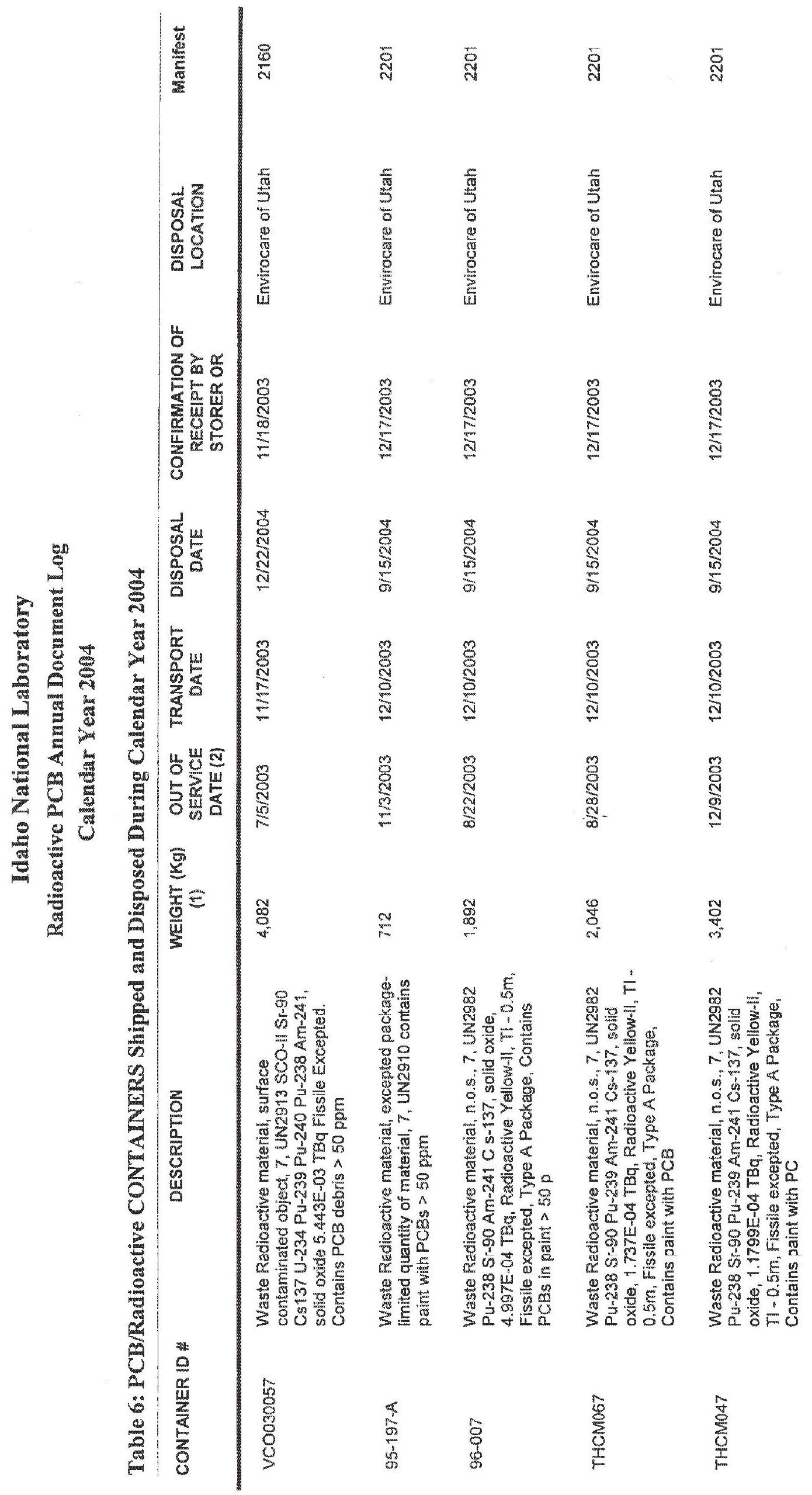




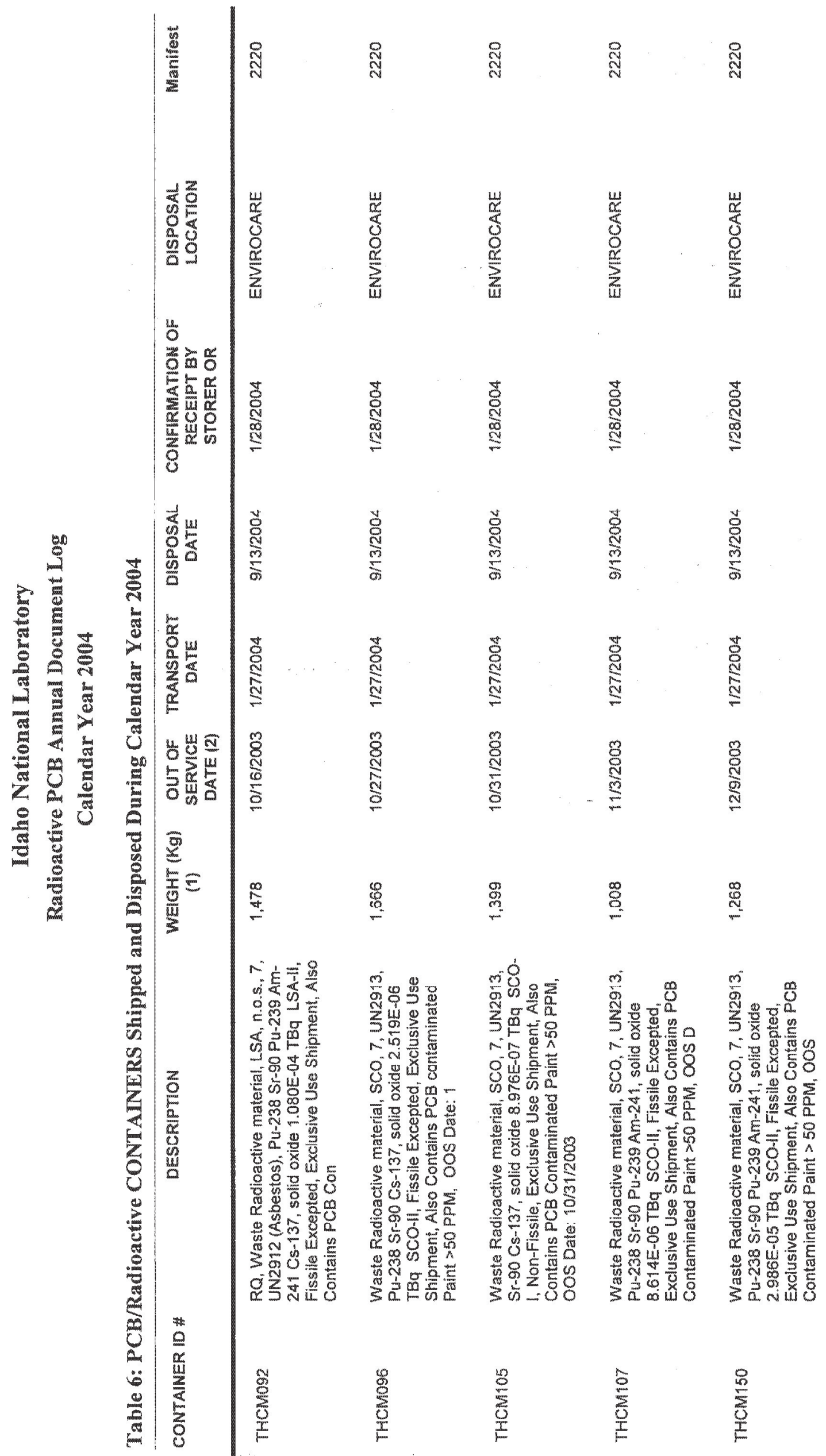




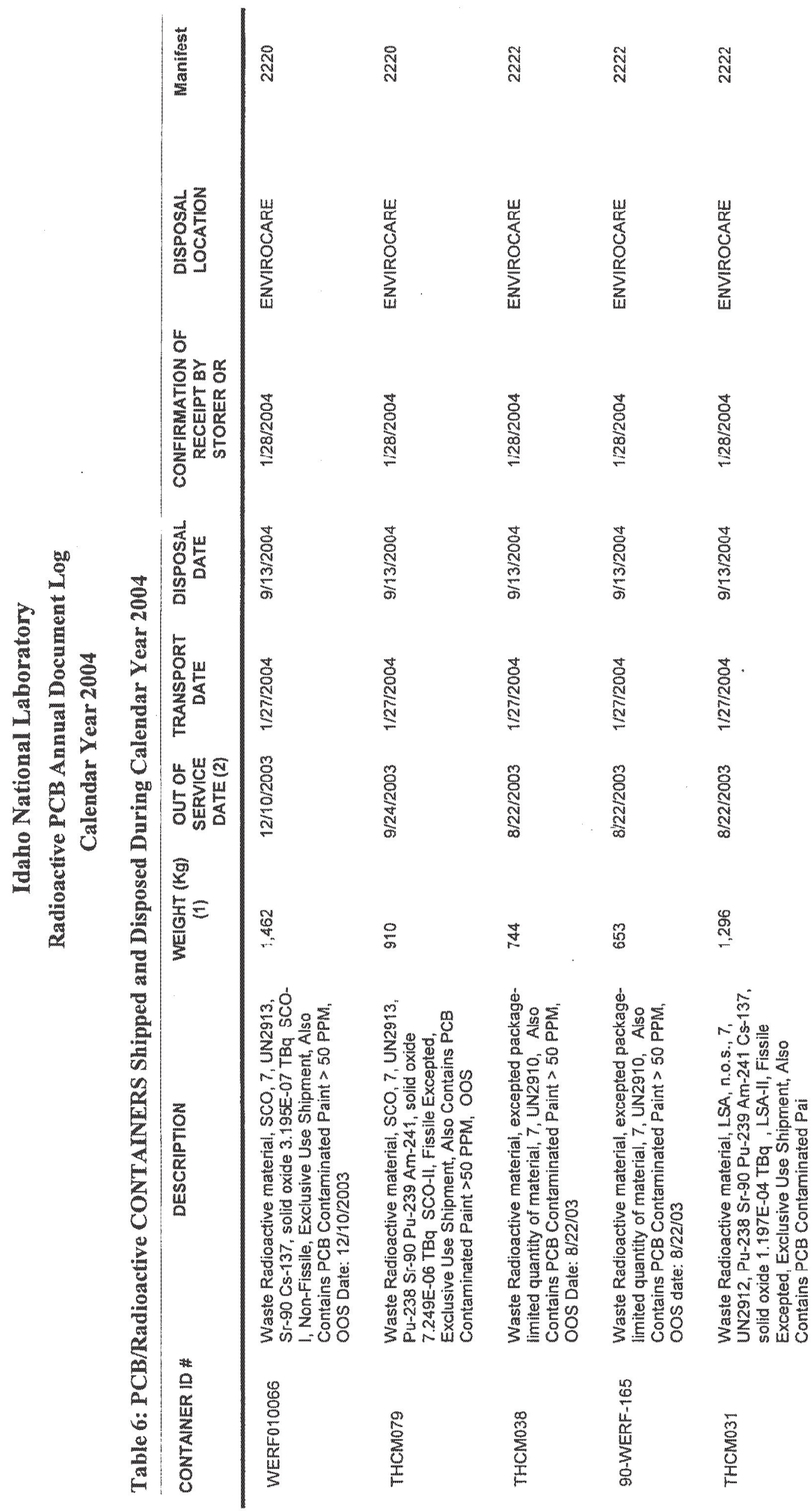




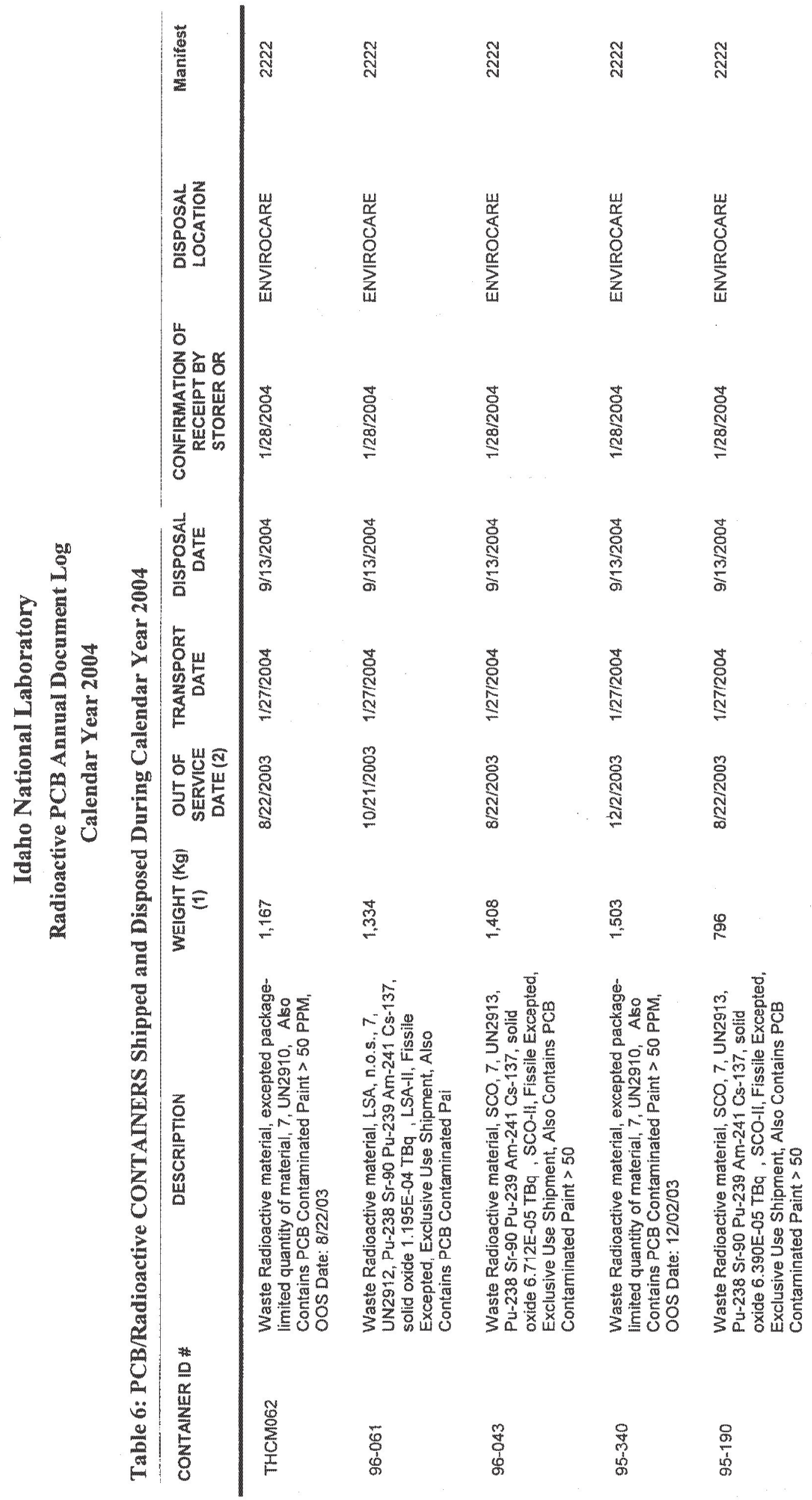




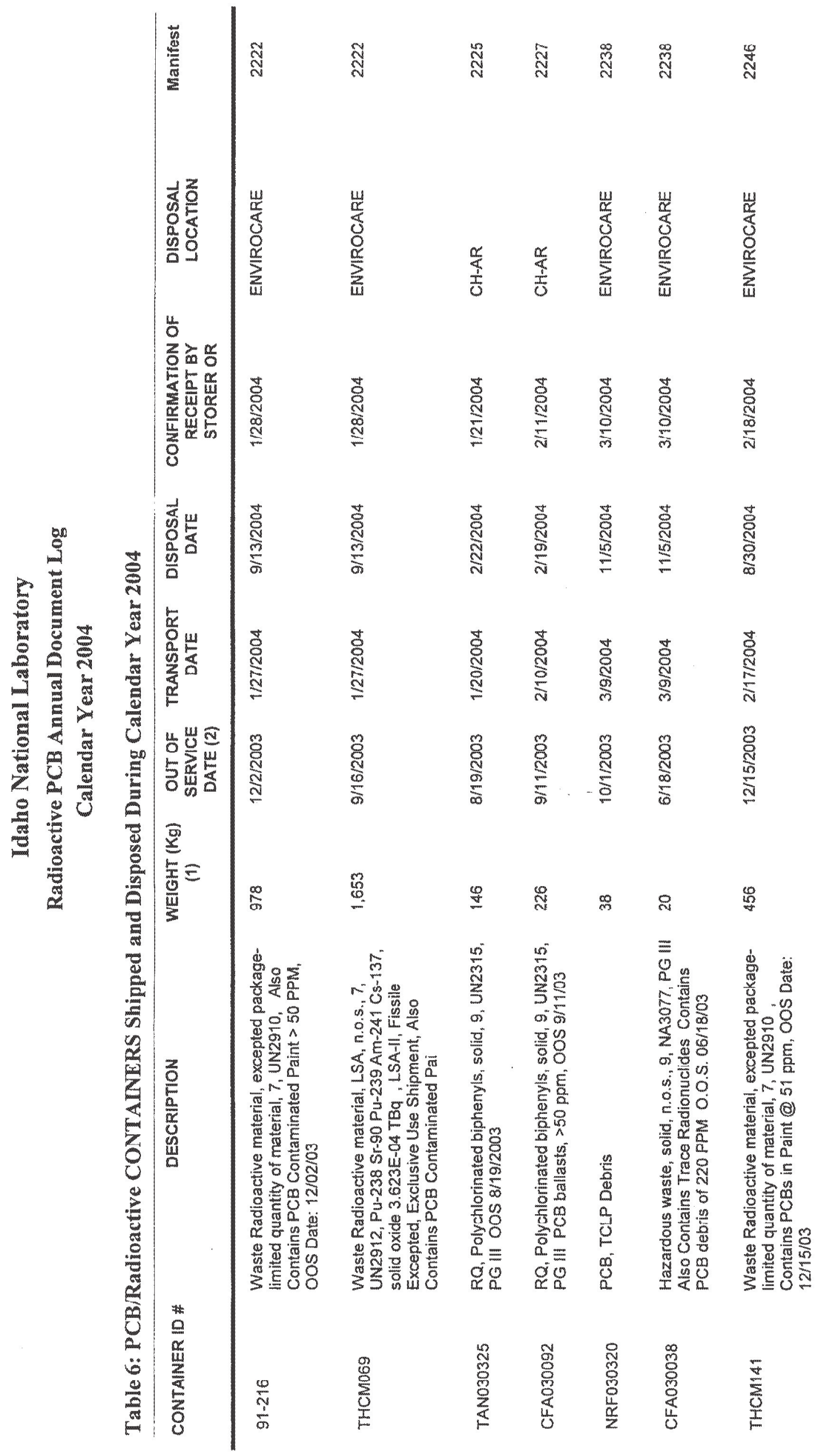




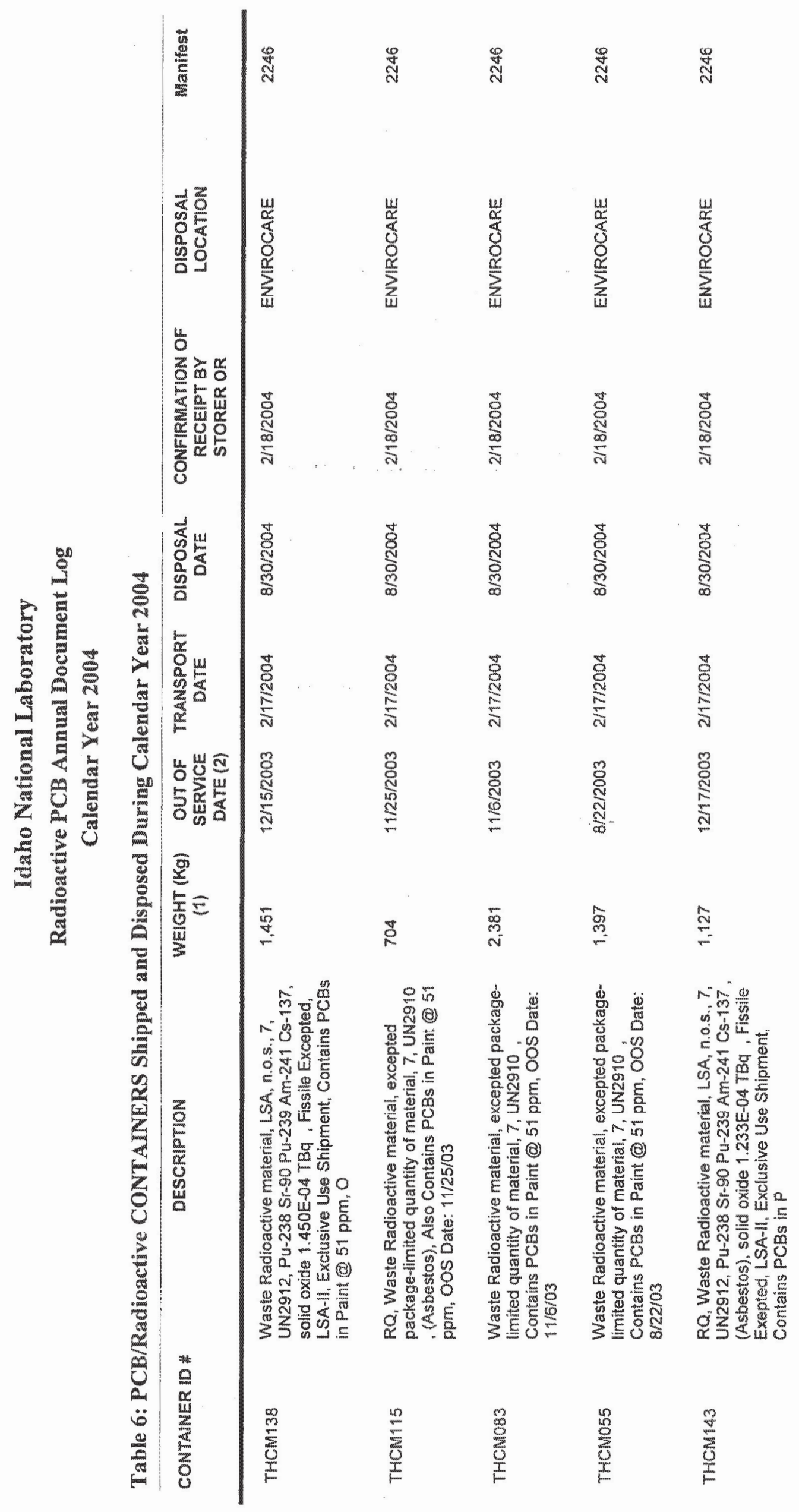




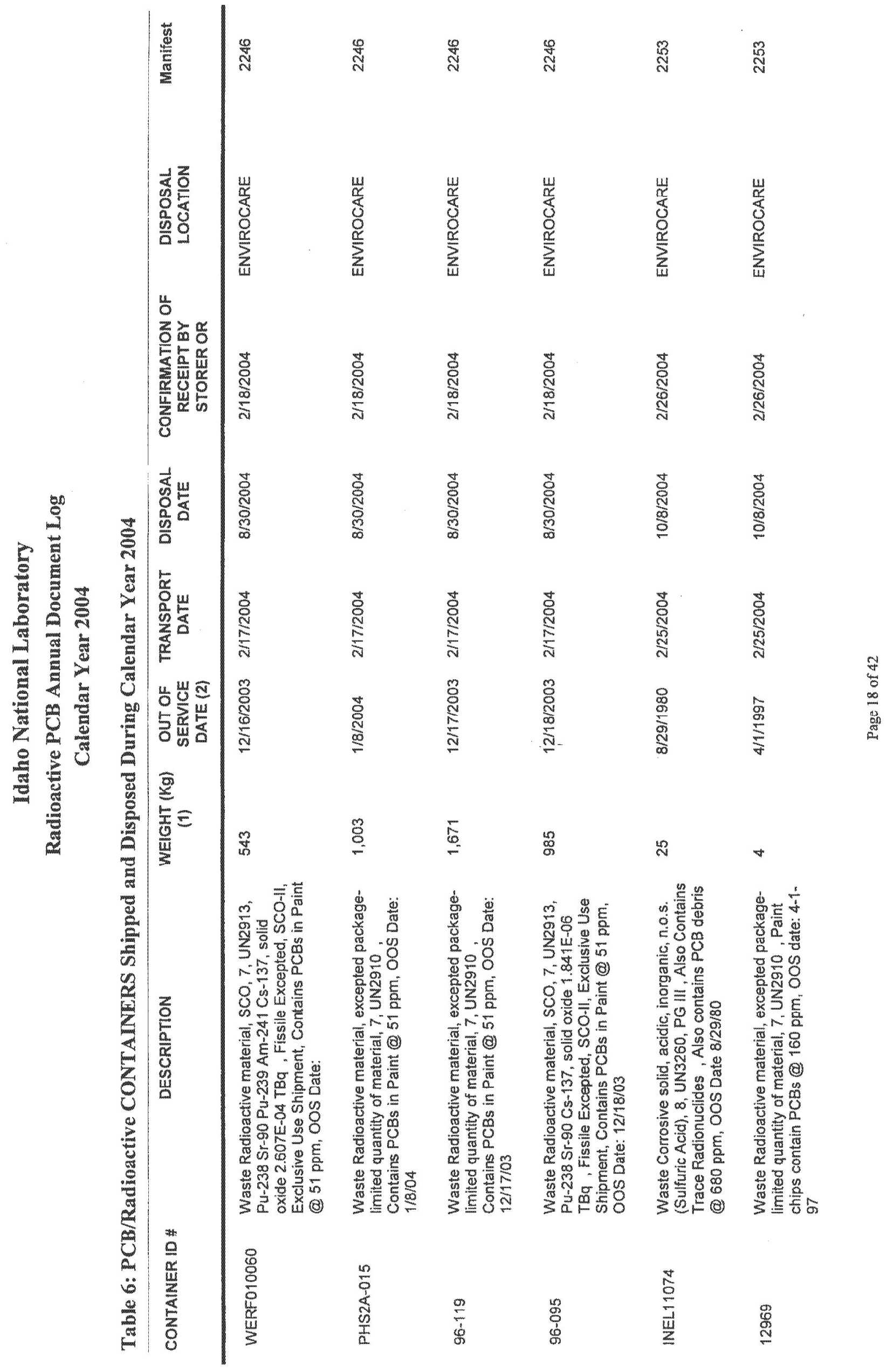




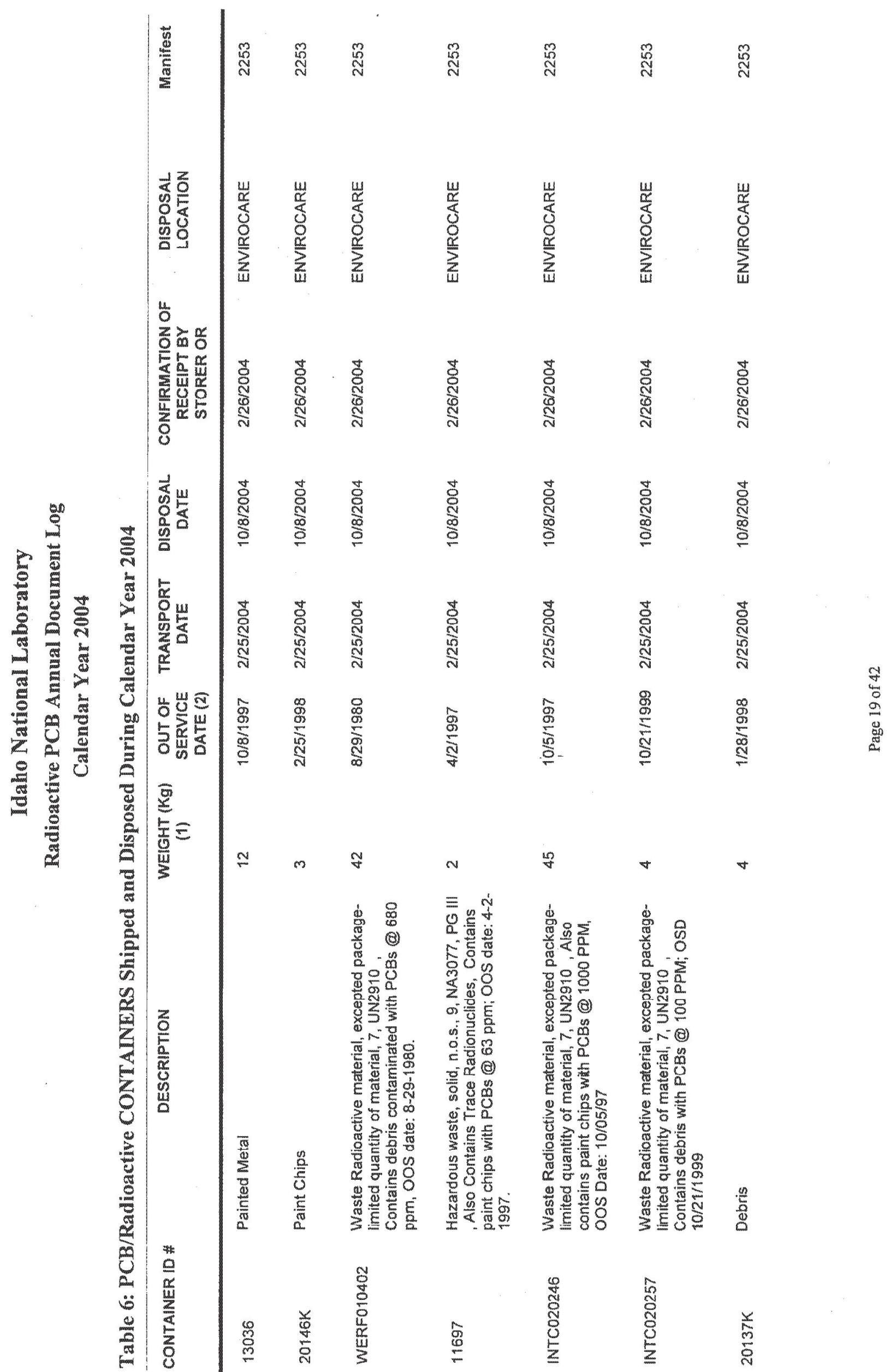




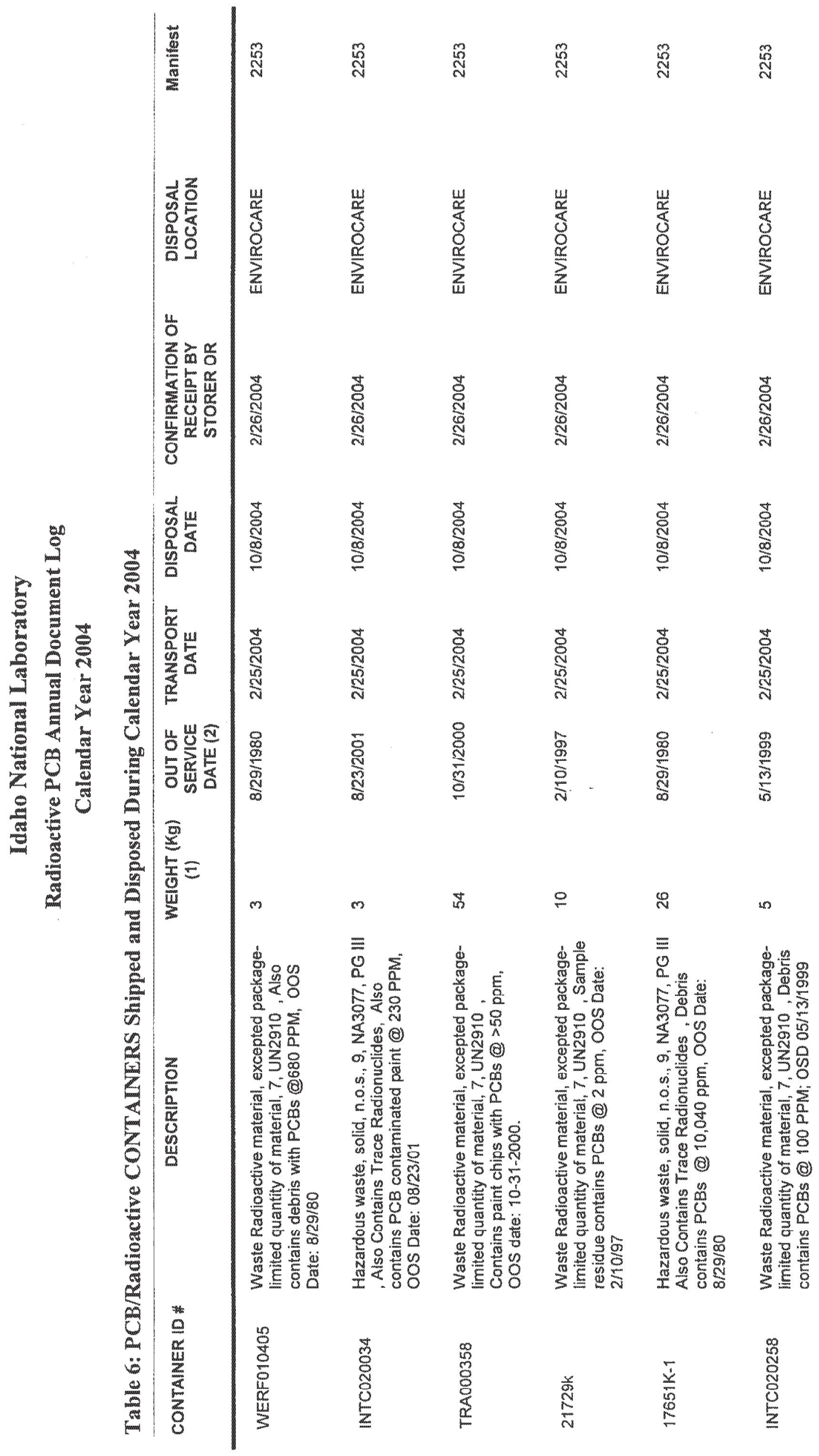

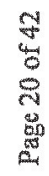




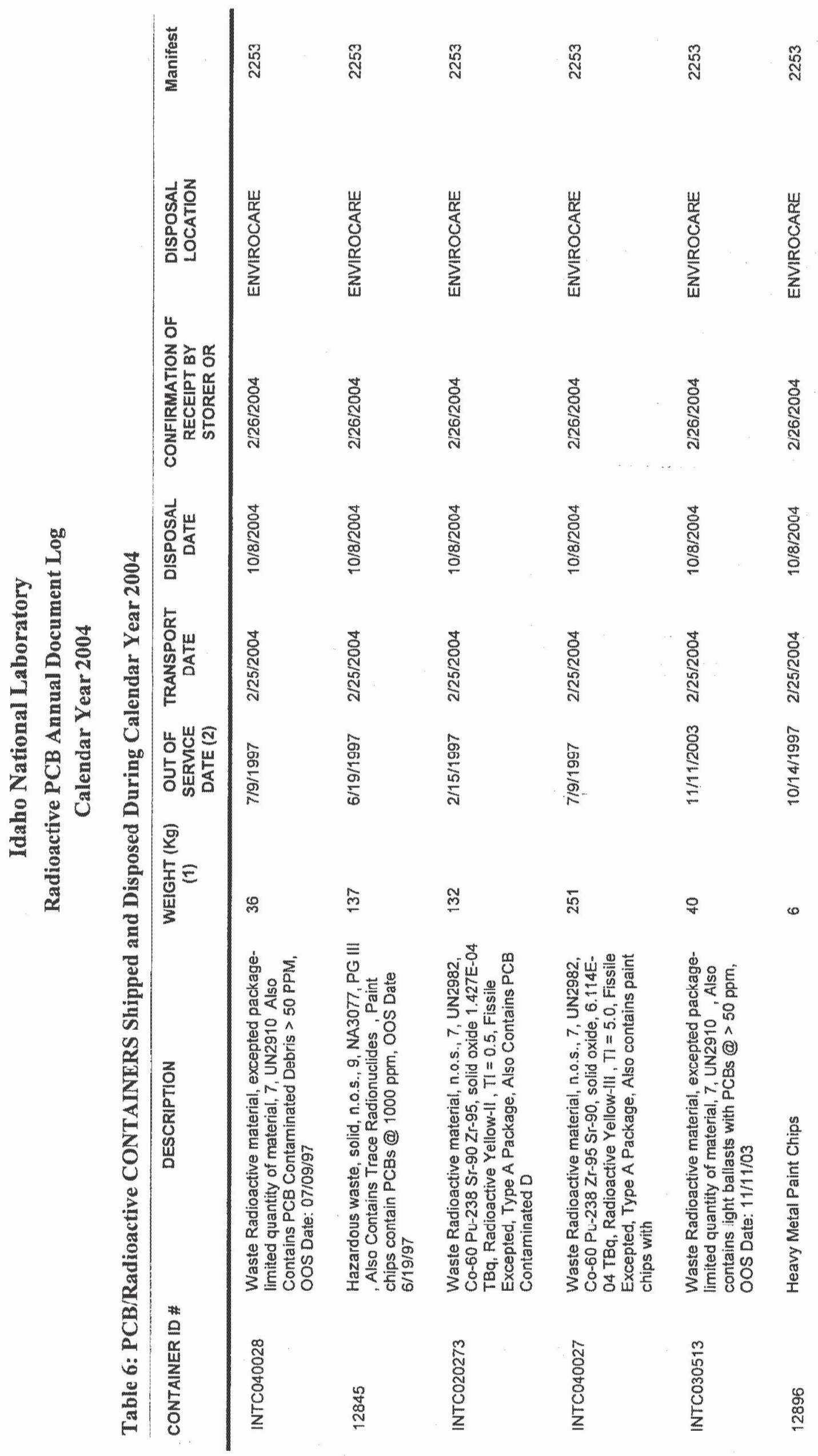




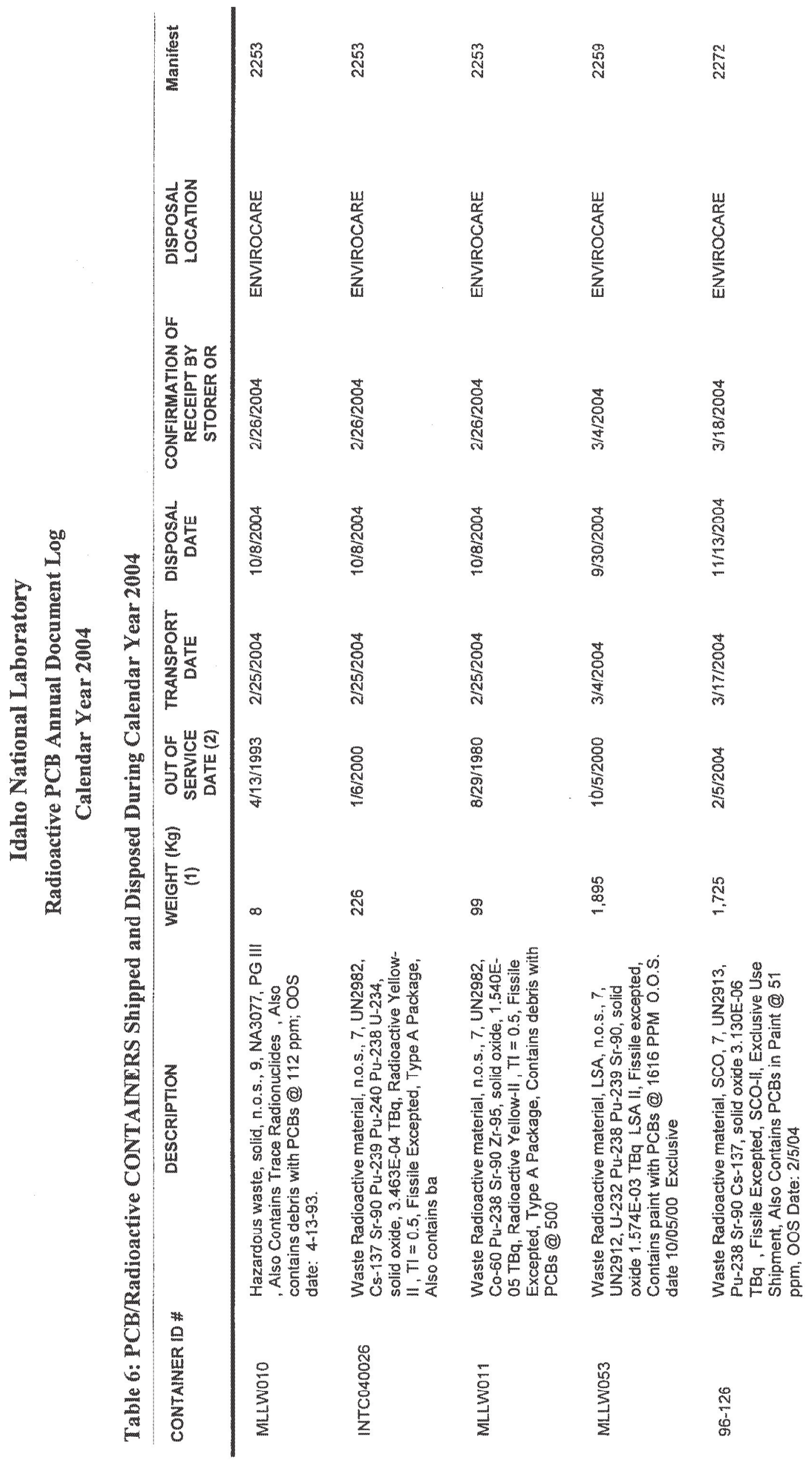




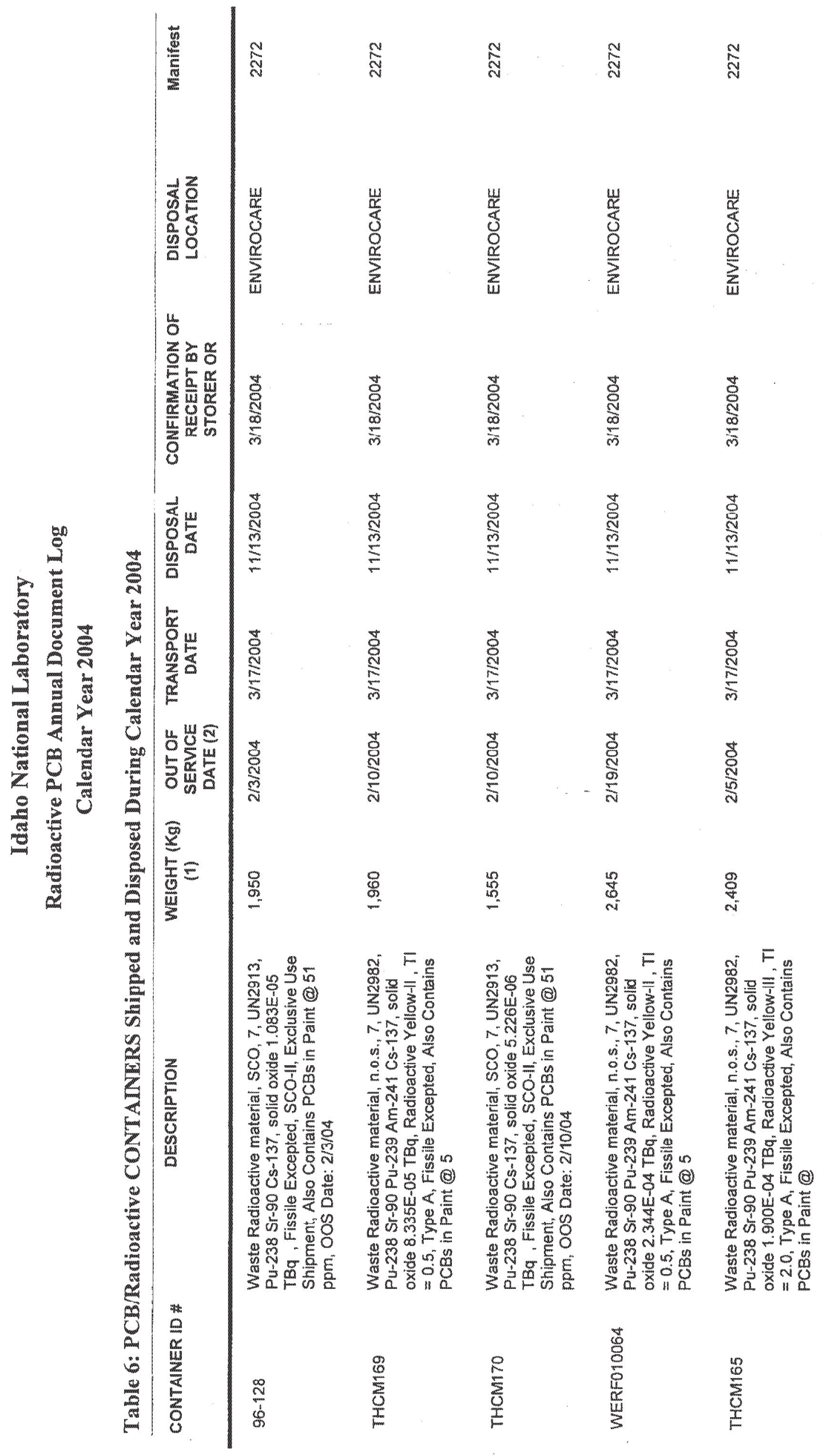




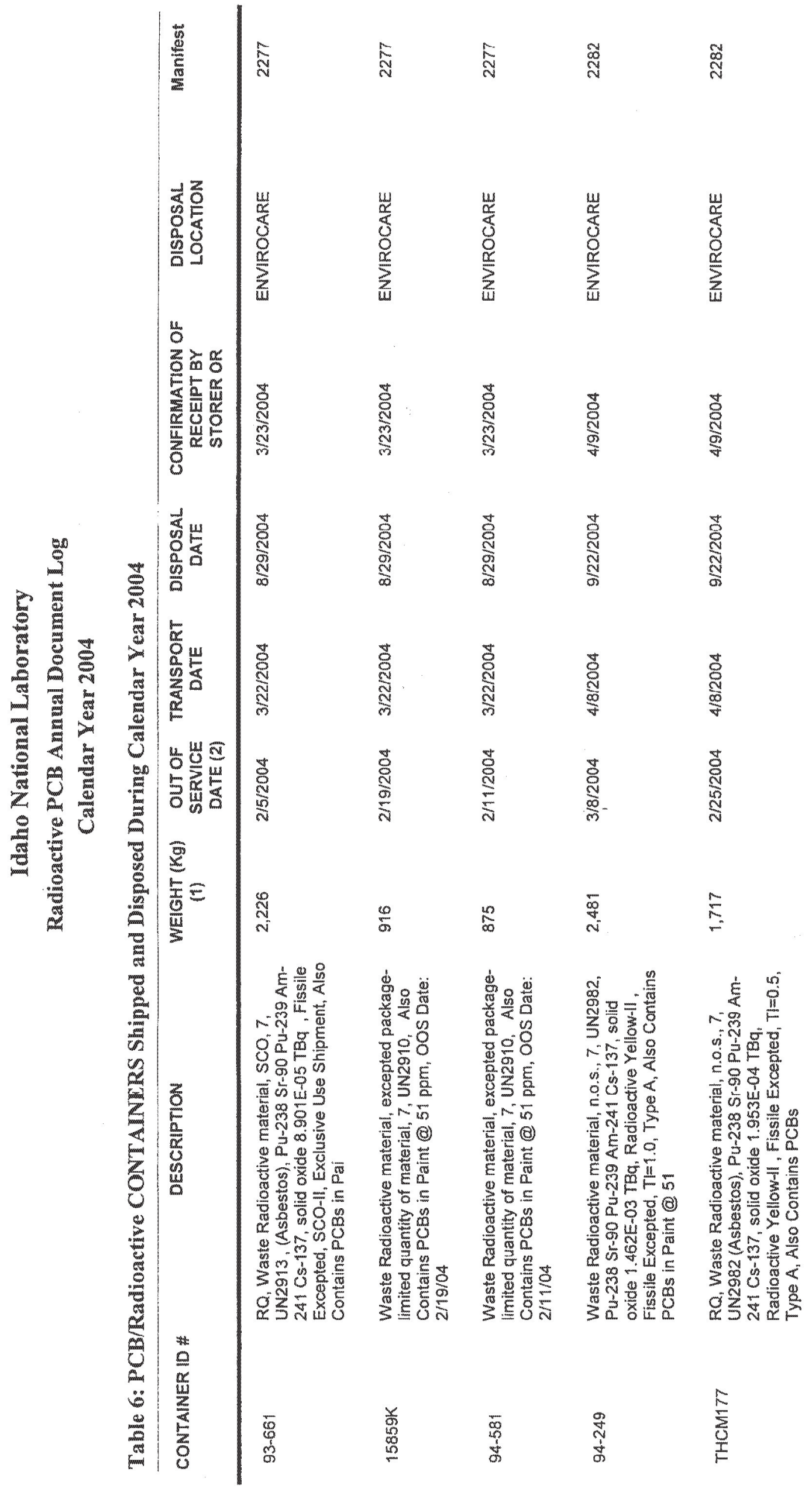




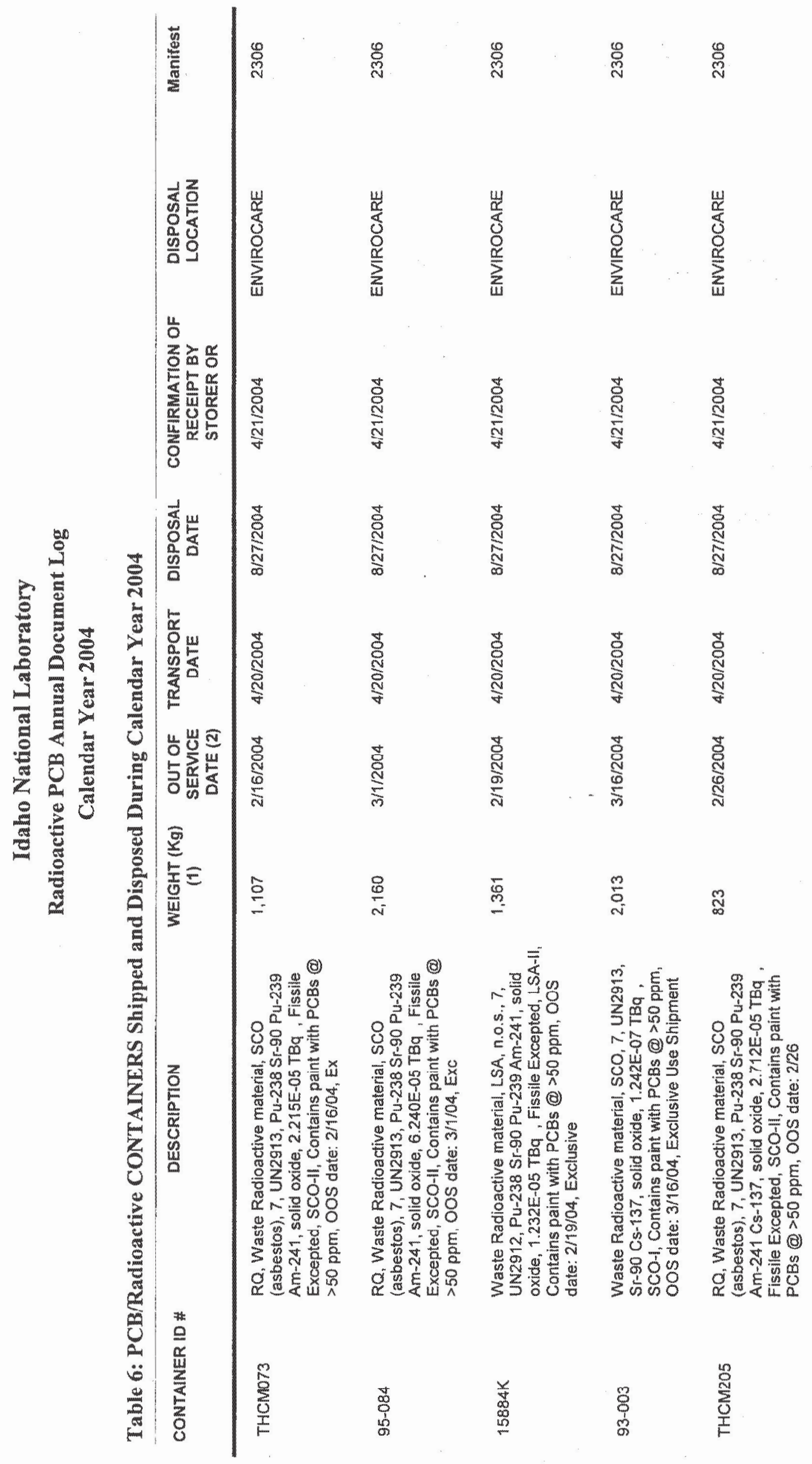




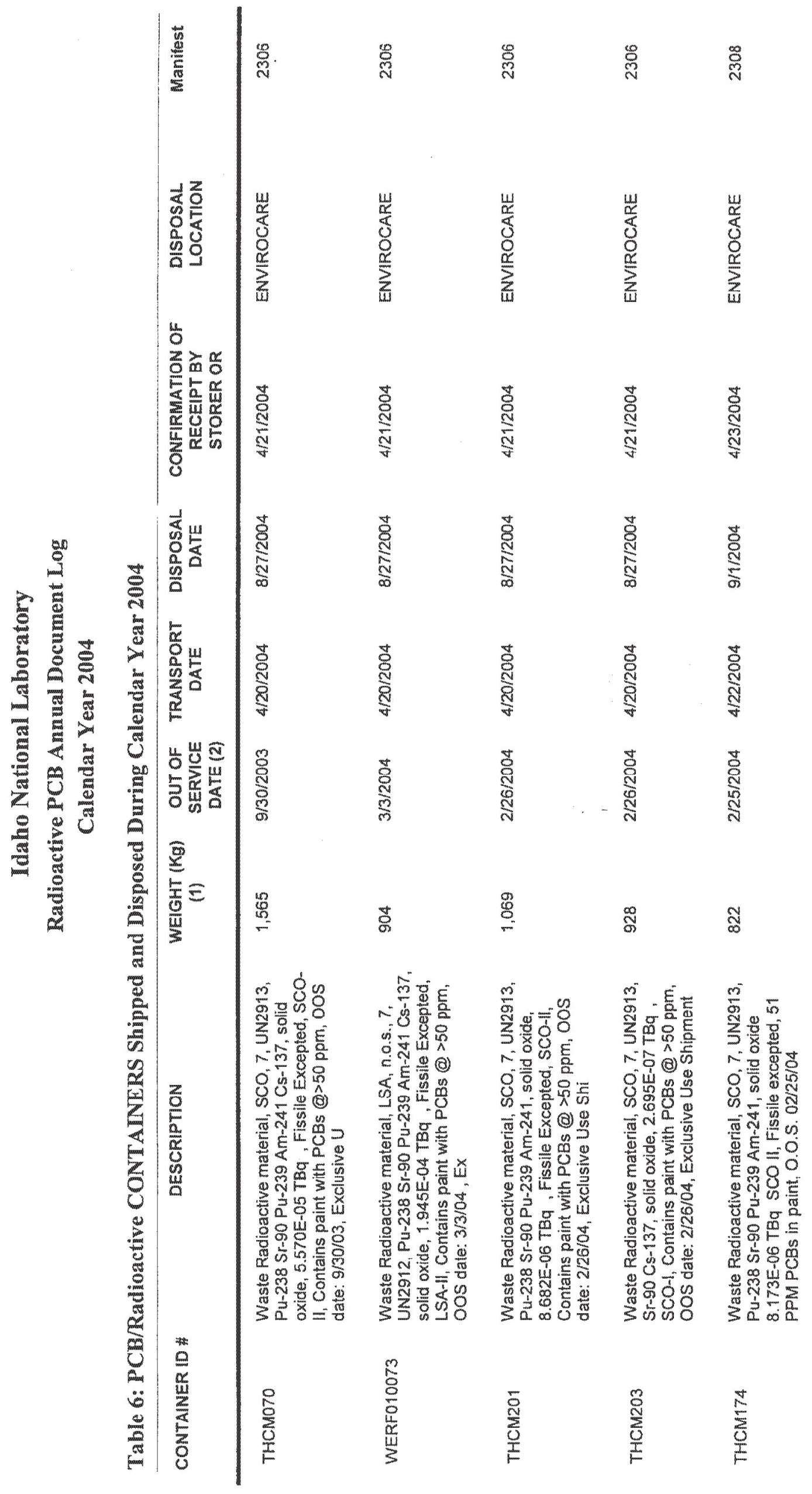




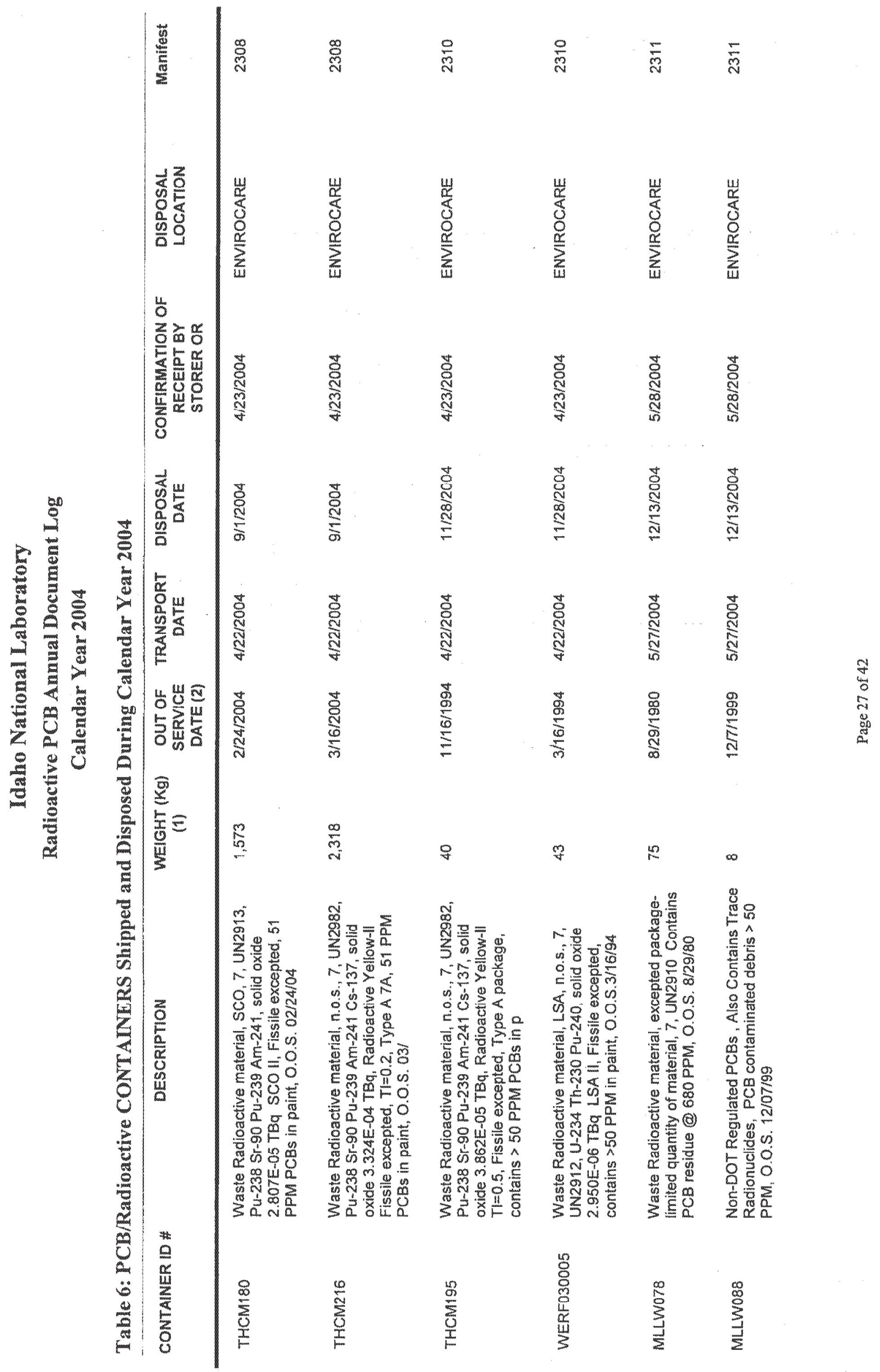




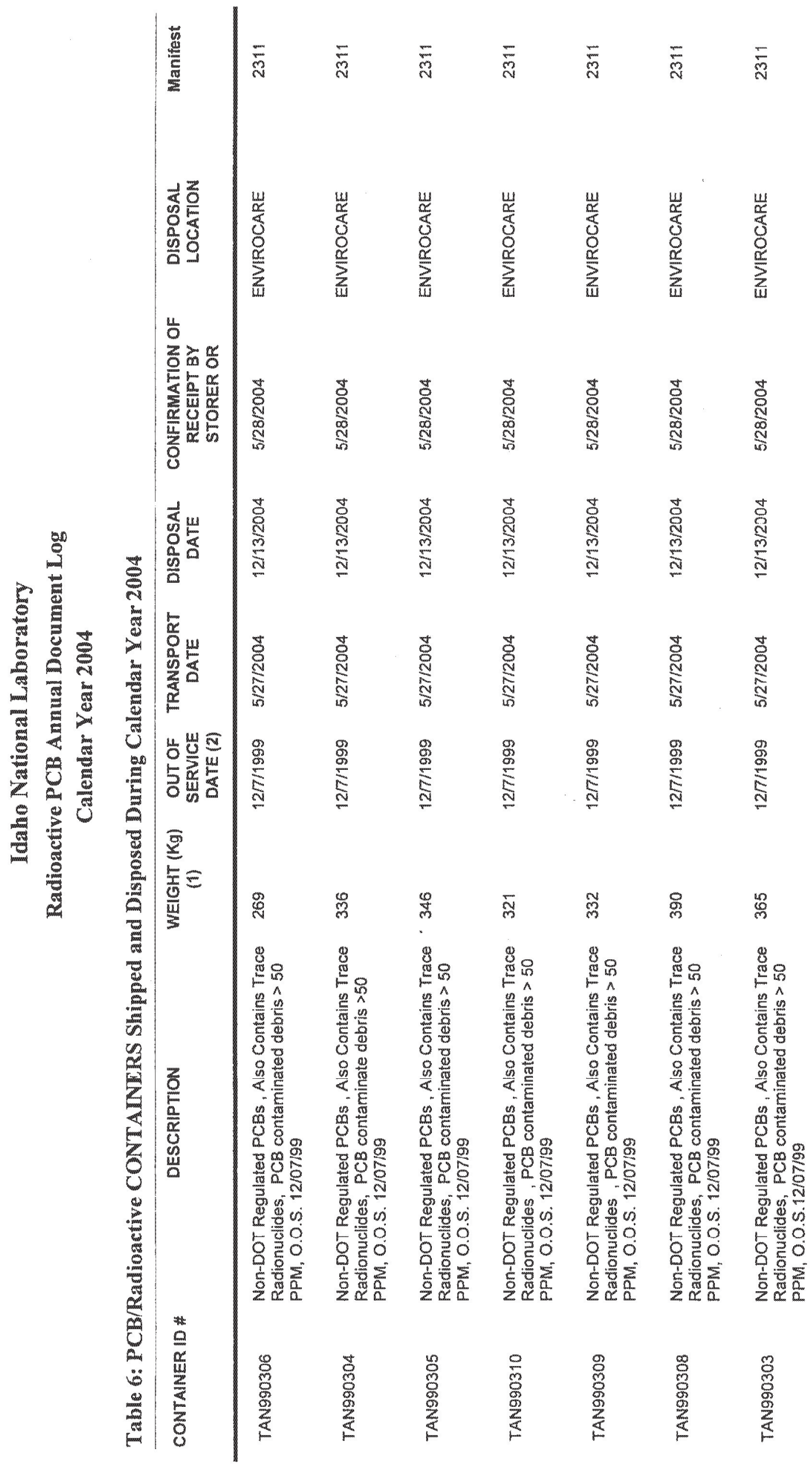




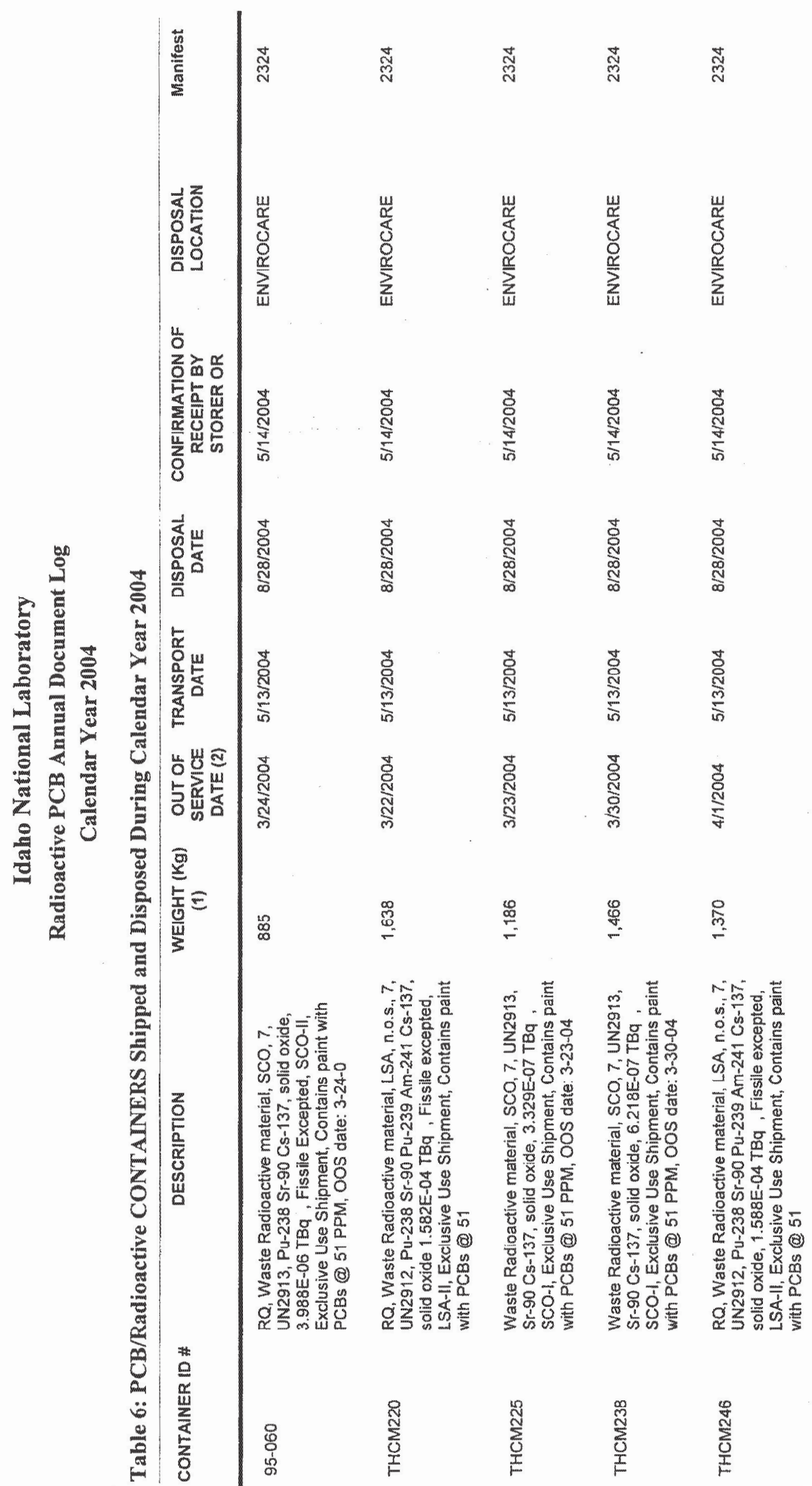




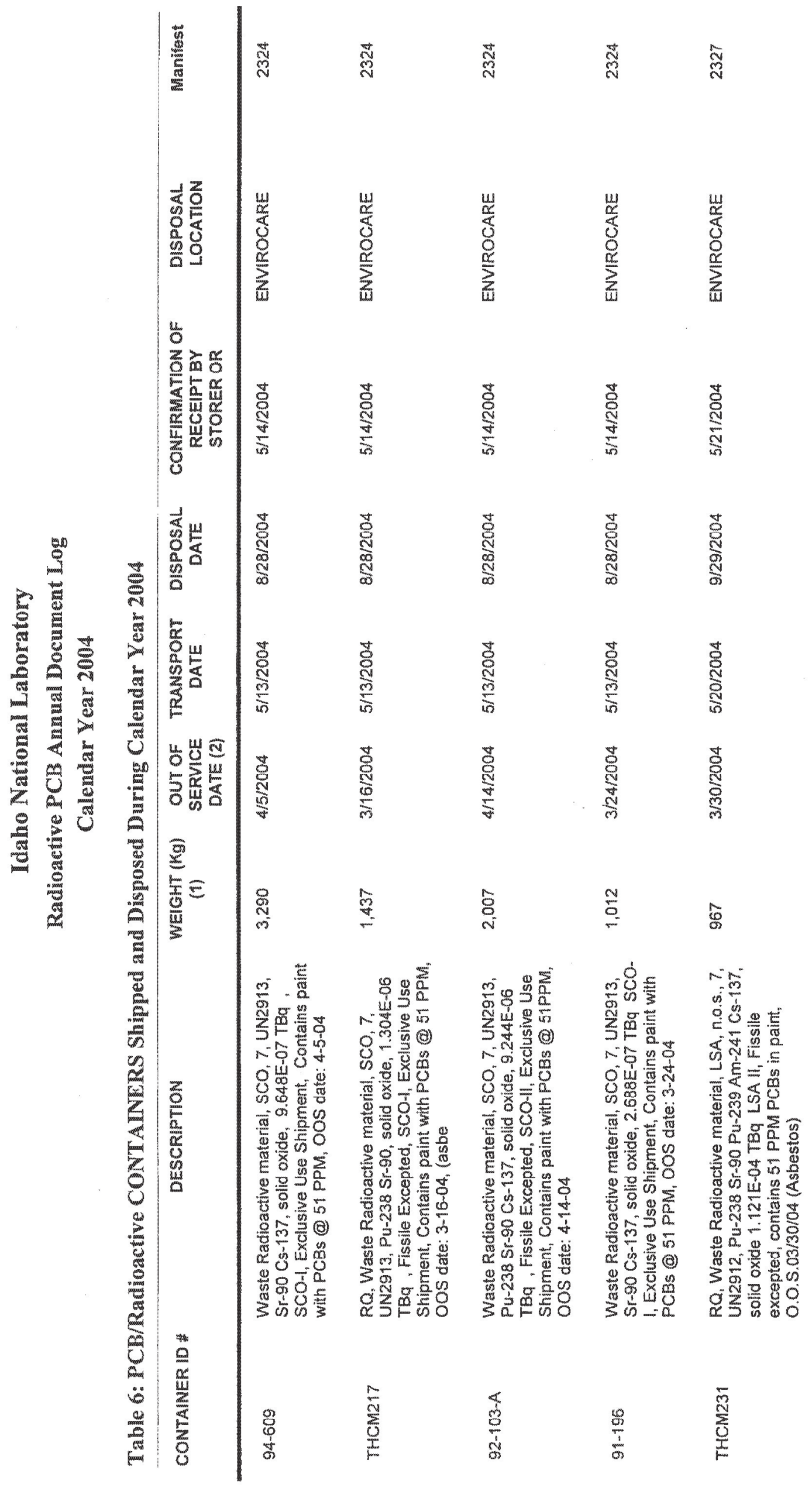




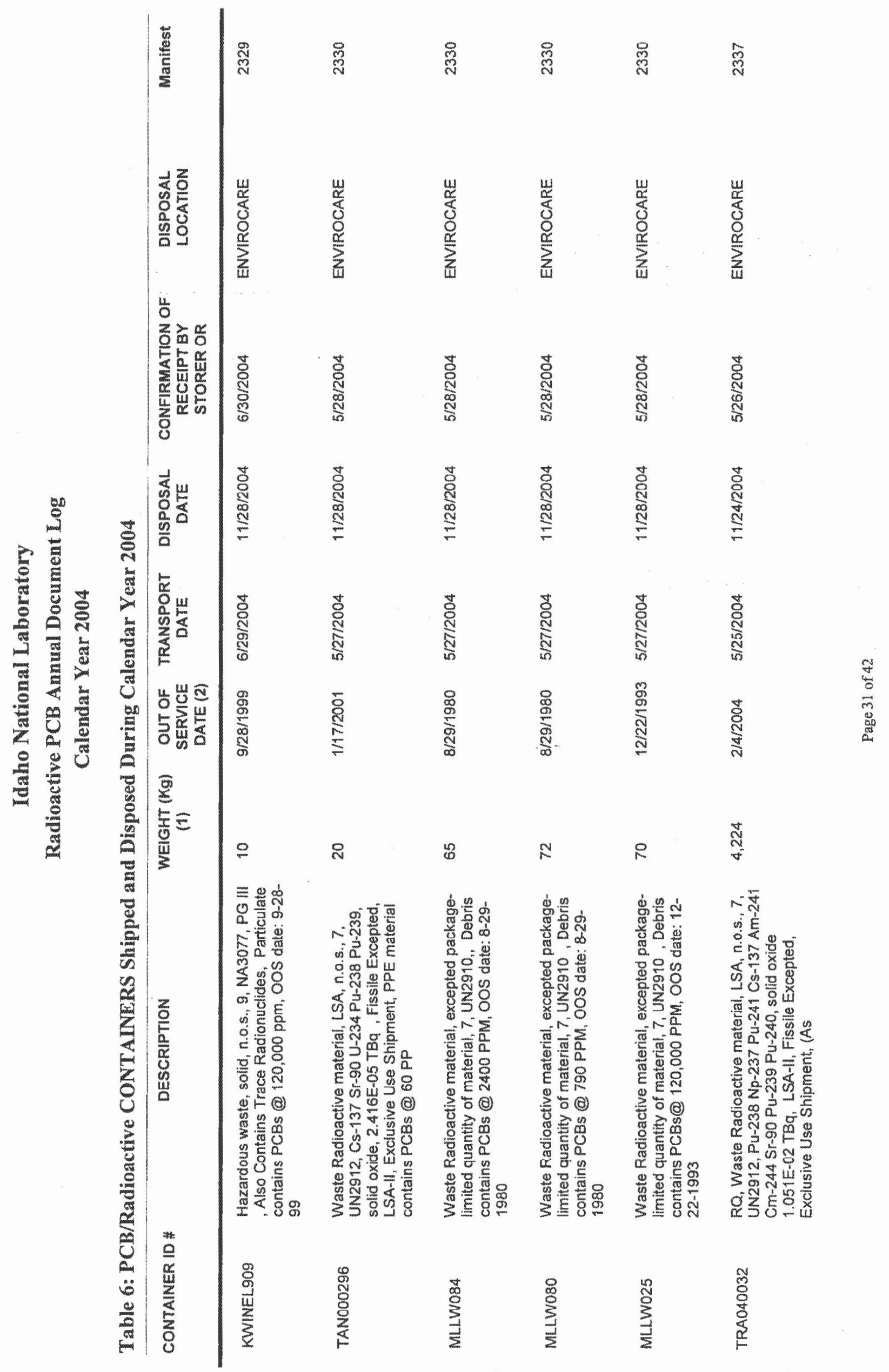




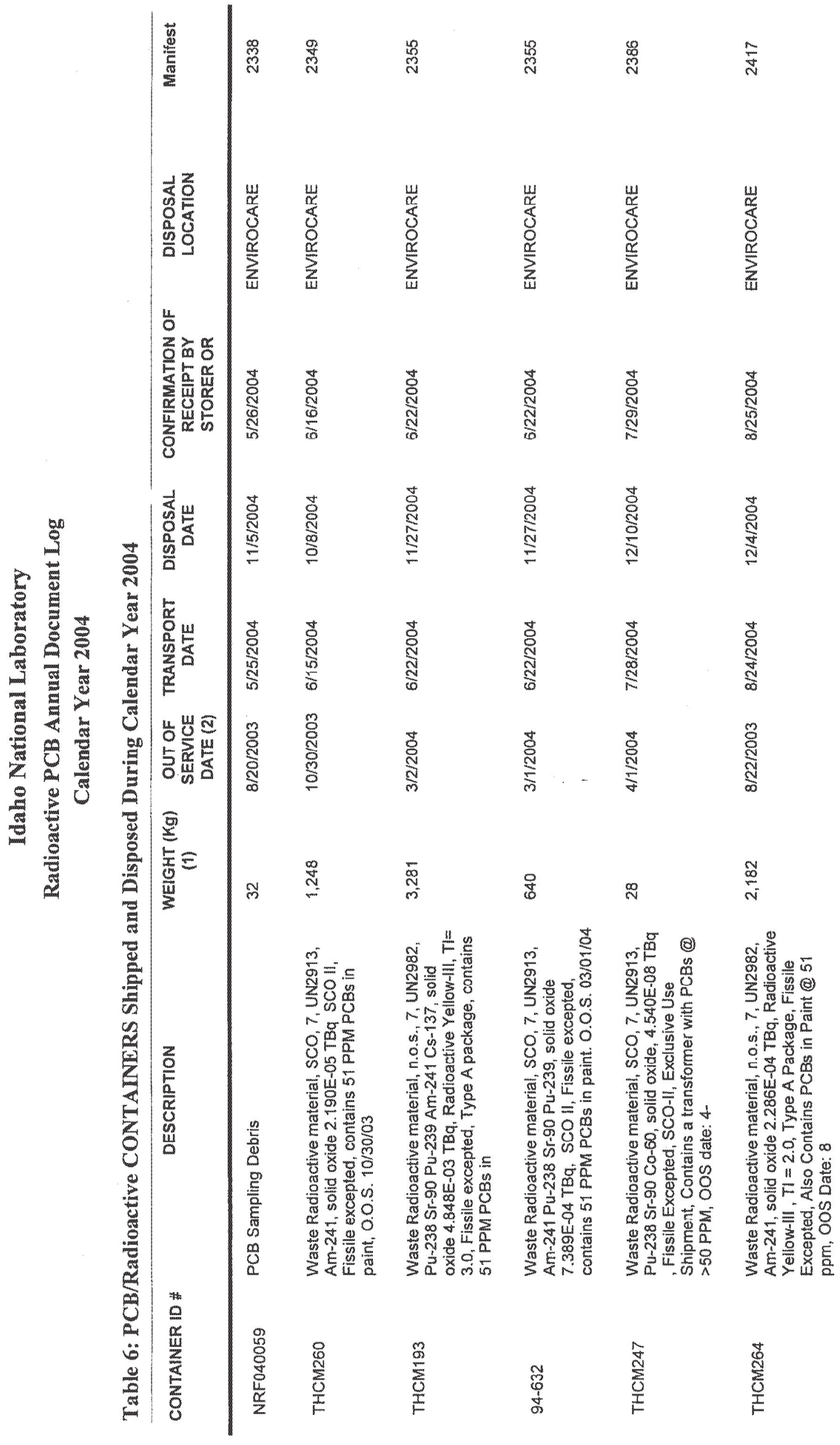




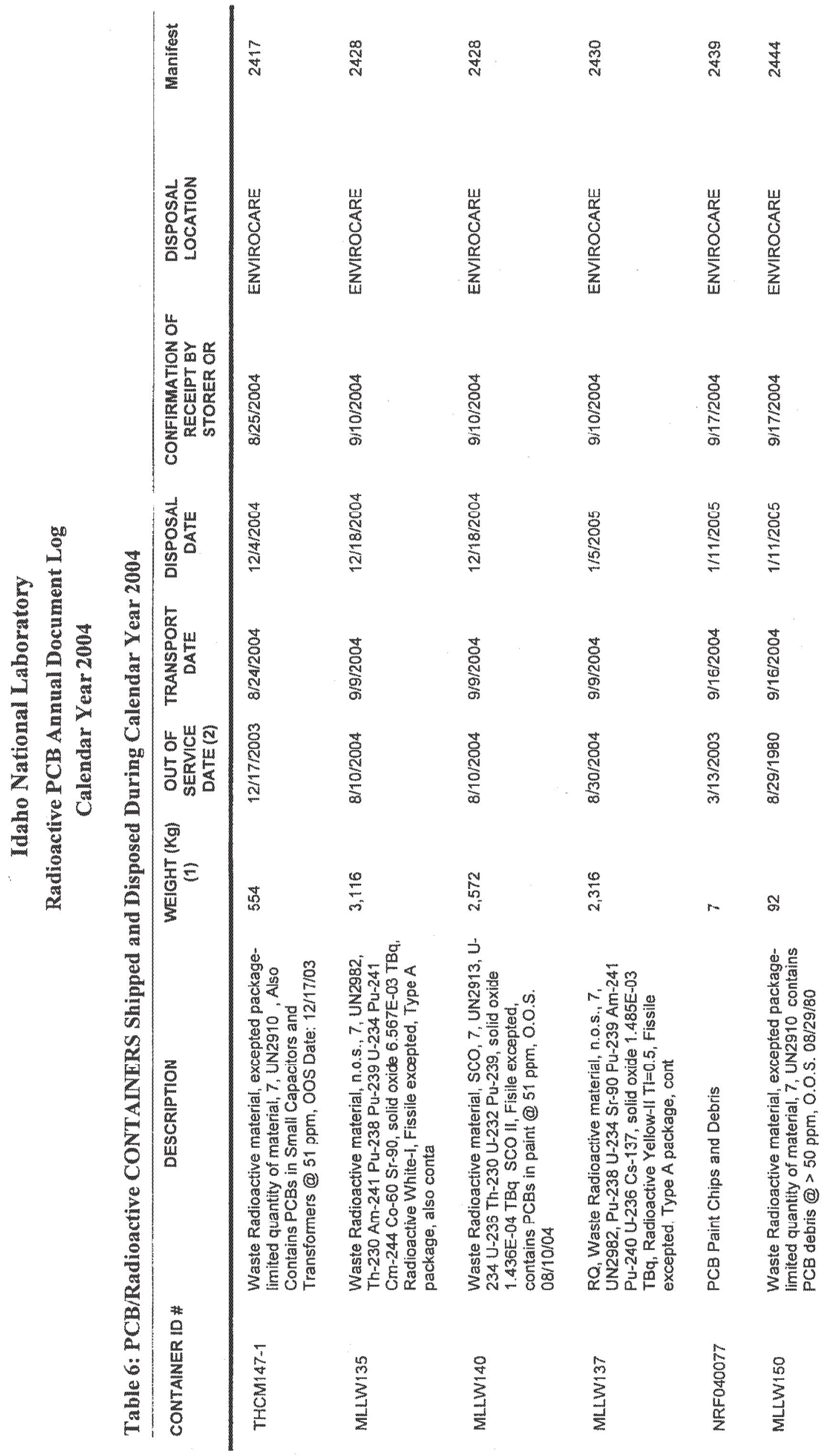




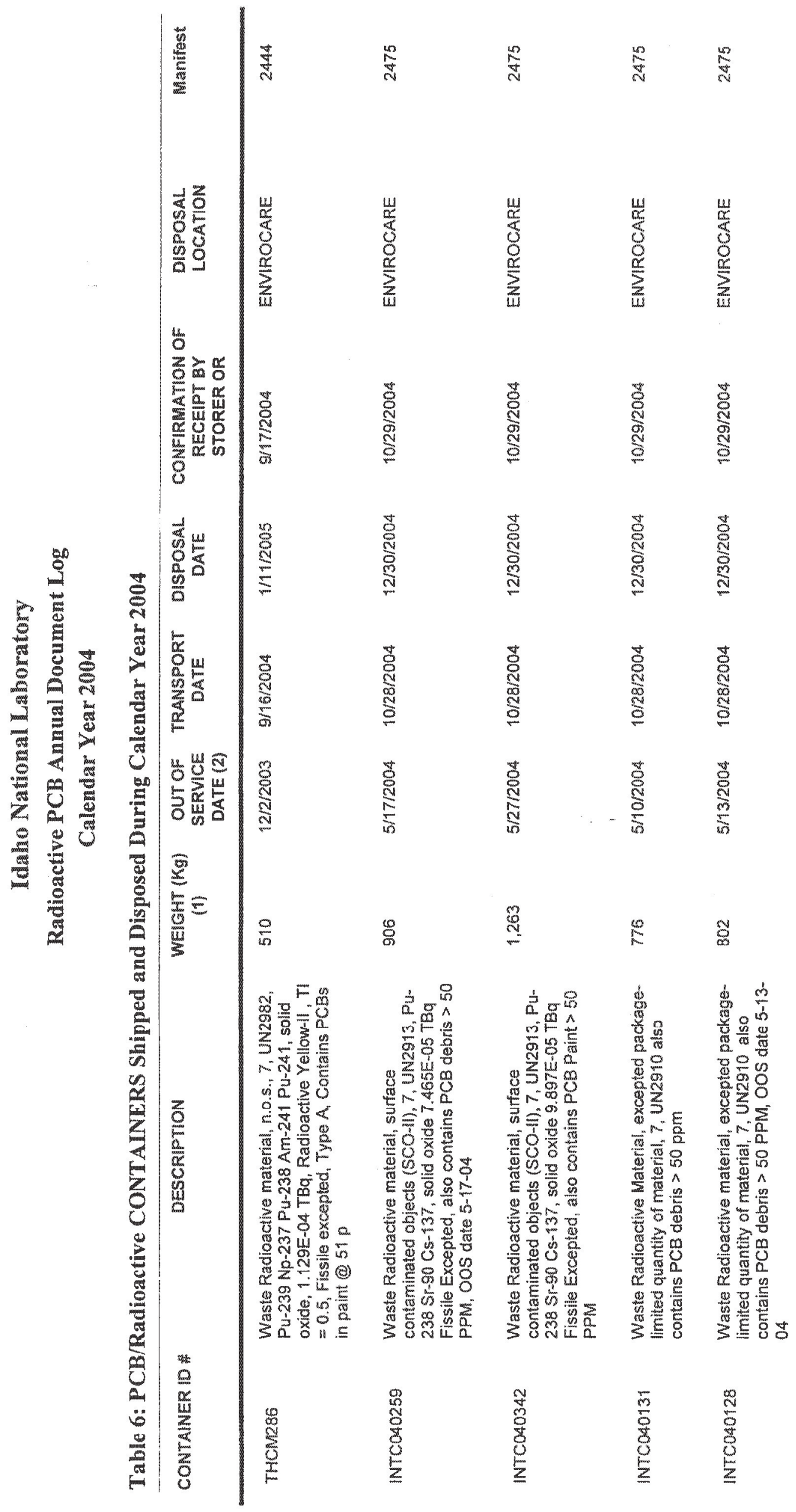




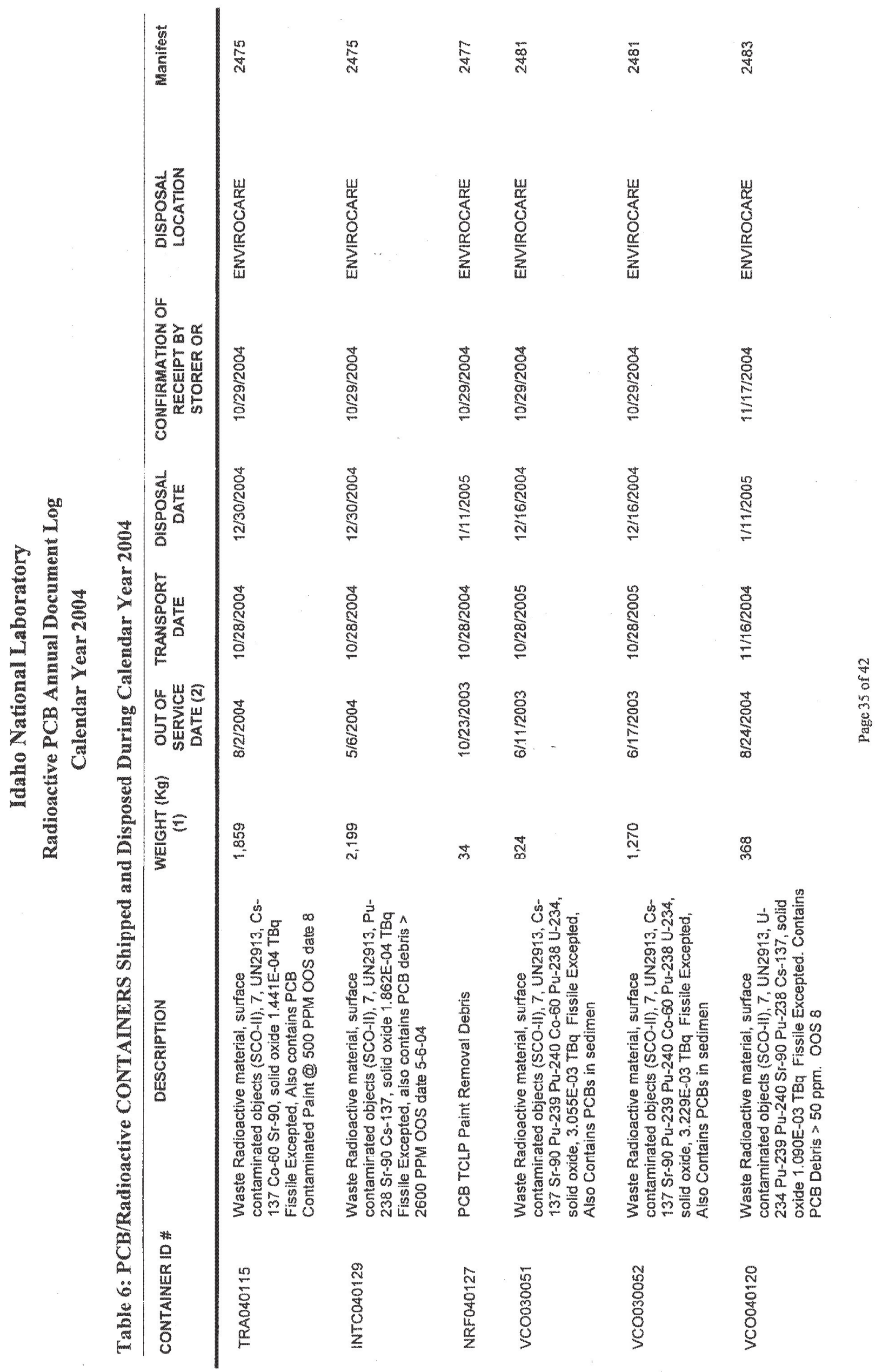




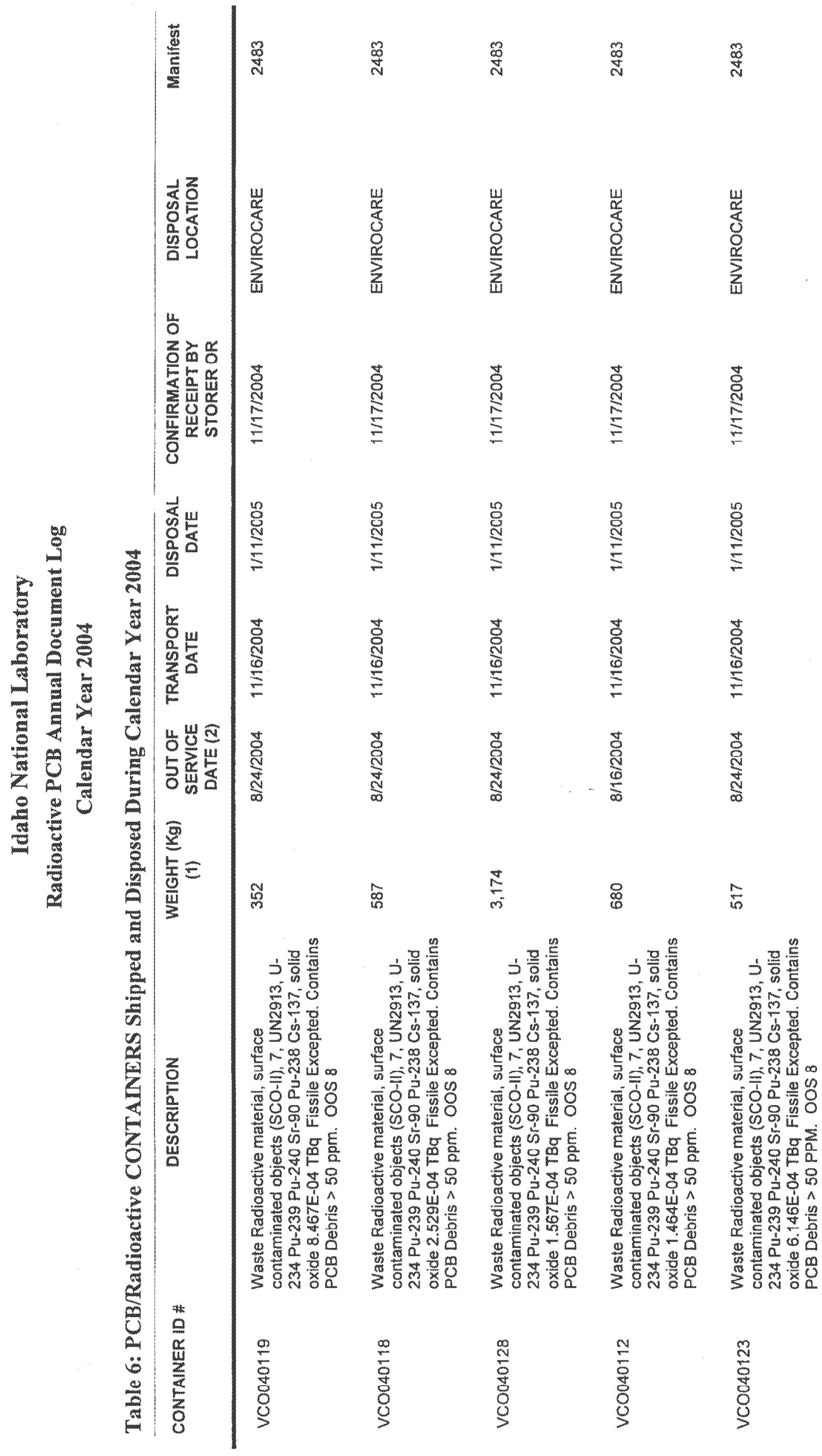




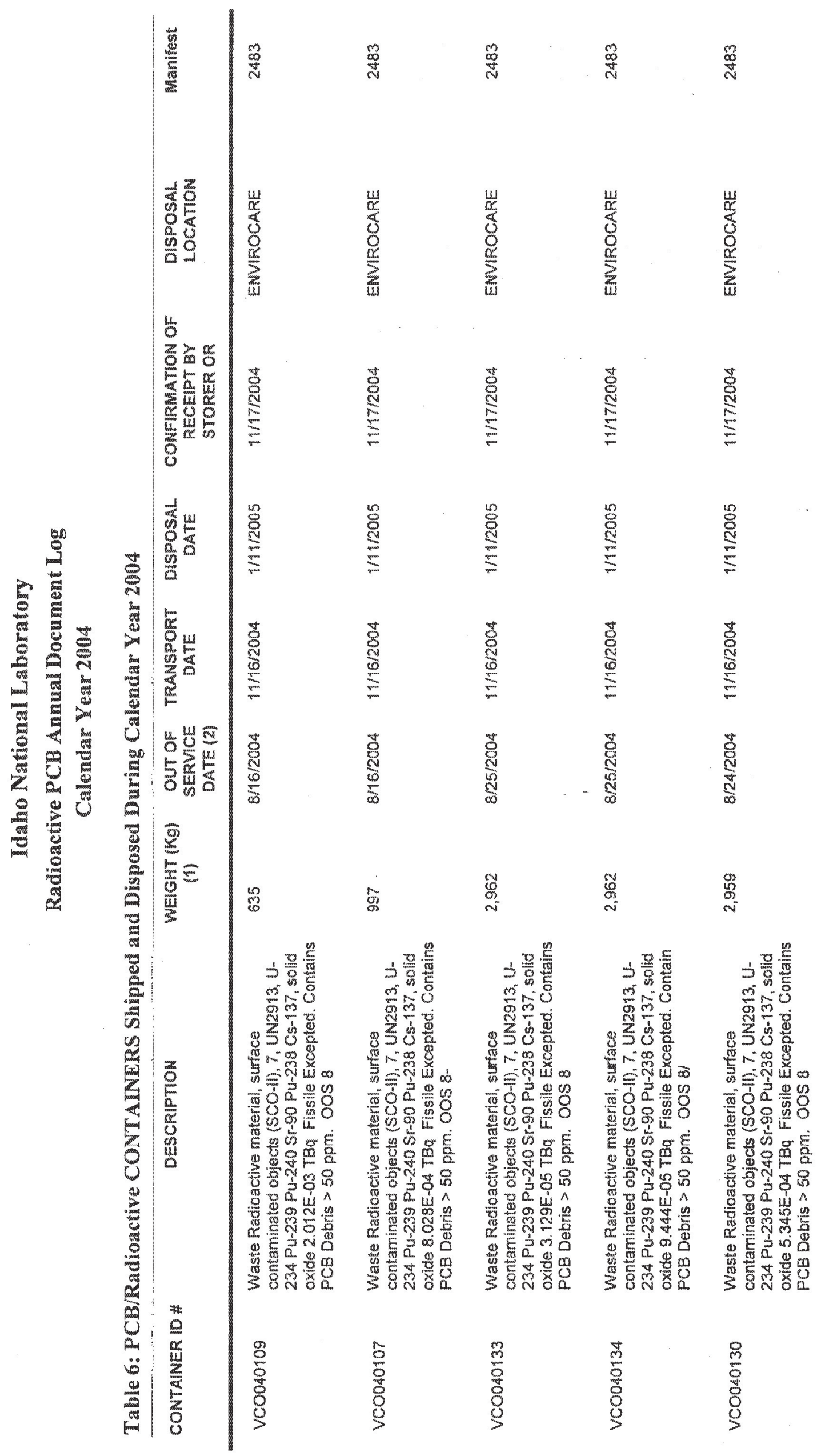




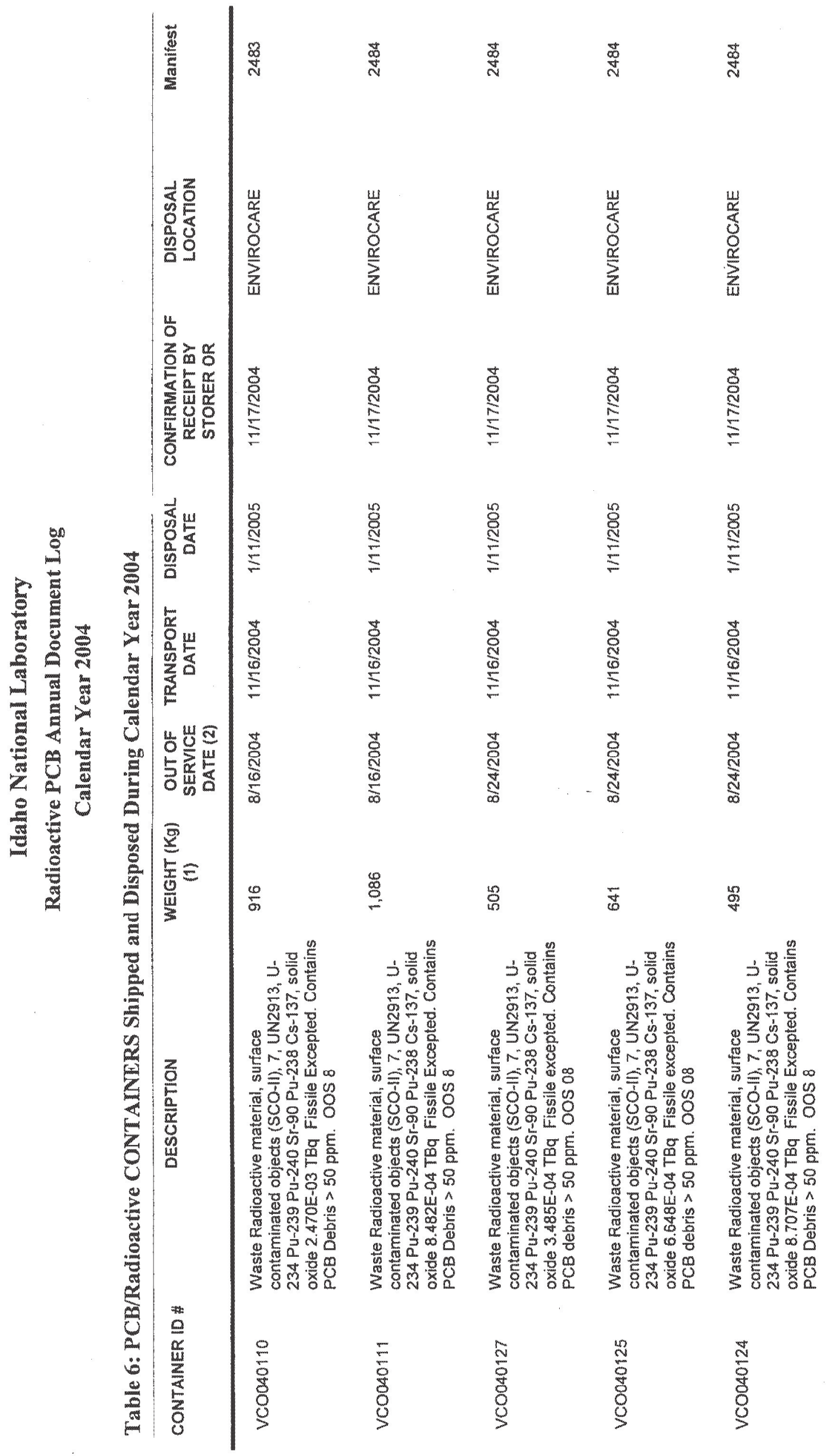




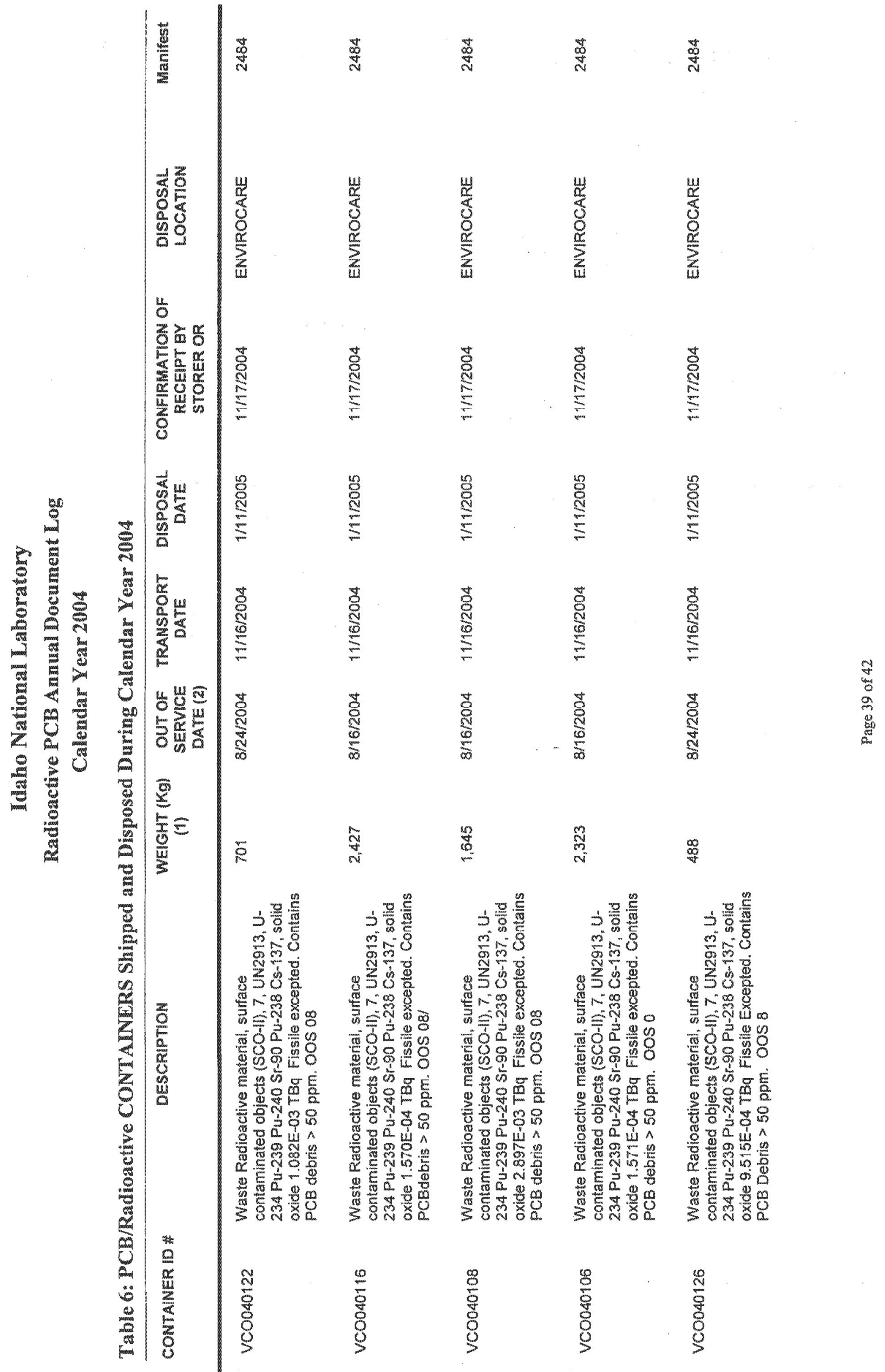




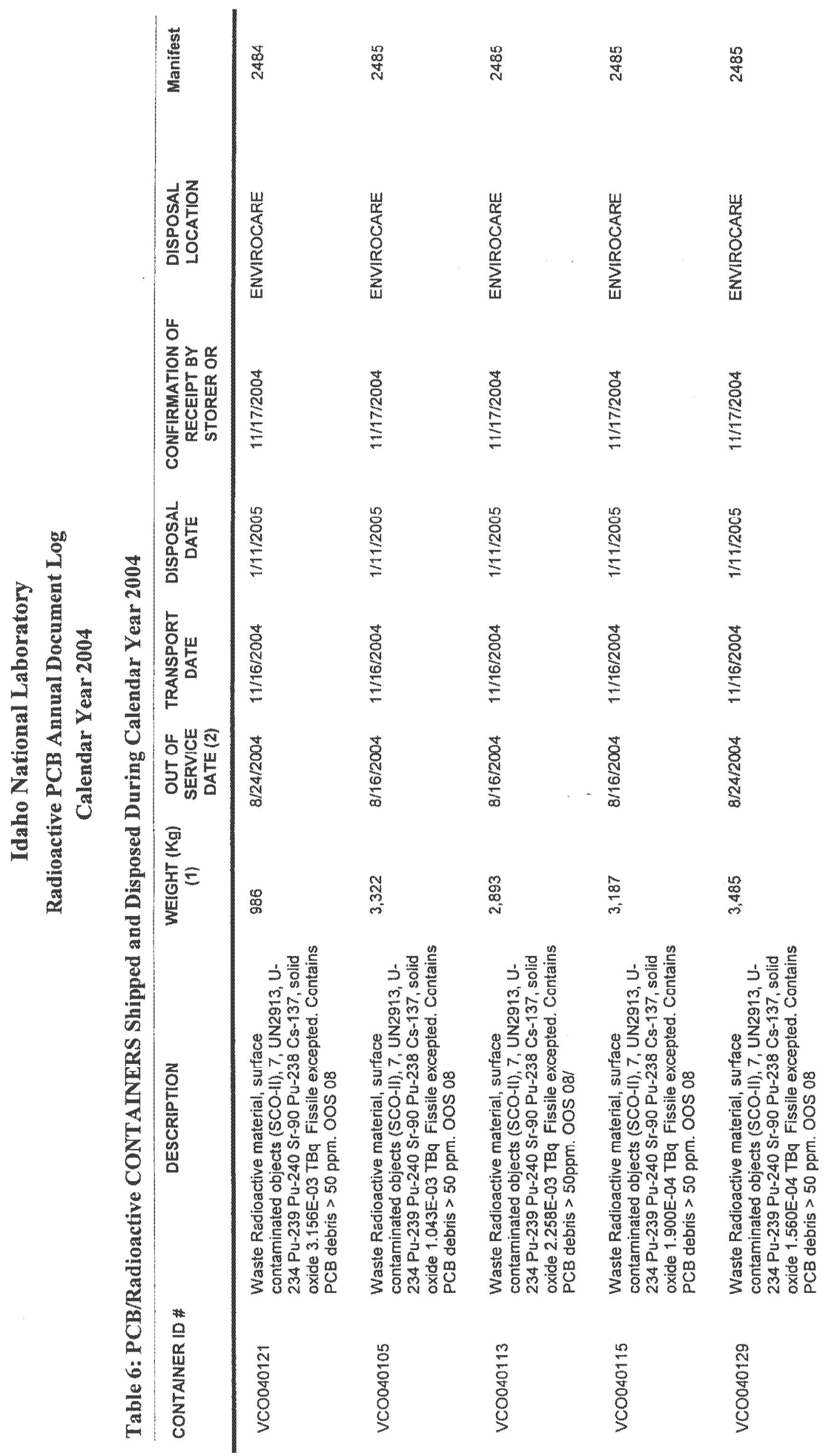

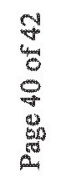




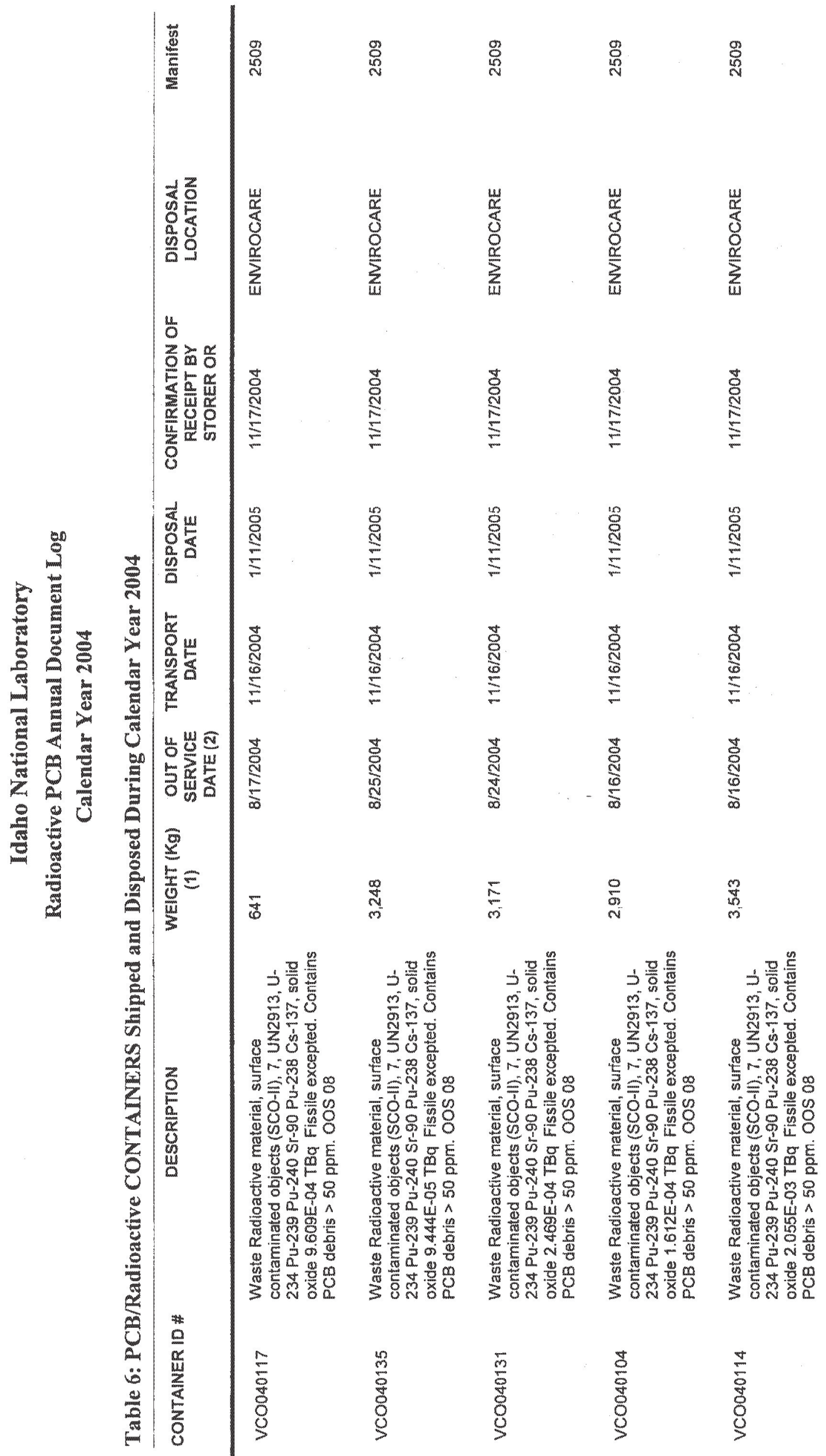



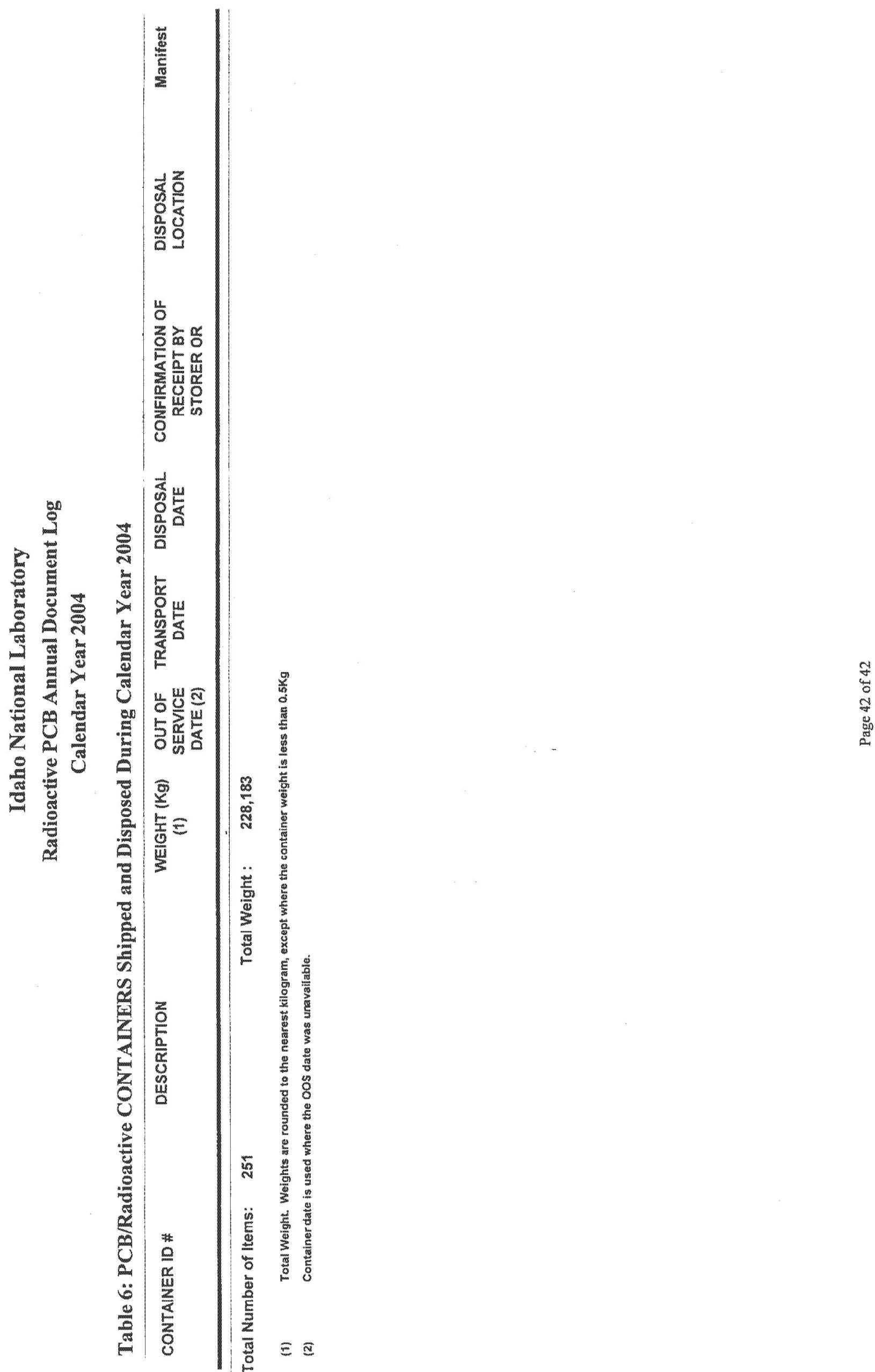
tras

an

$x_{0}$

Ind

태

in

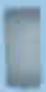

exs

In:

둔.

t.7.

te

L

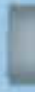

단.

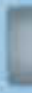

e.

I.

2 


\section{ATTACHMENT III: Certificates of Disposal/Destruction}

\section{Received during Calendar Year 2004}

For Wastes Manifested during Calendar Year 2003 (following pages)

\begin{tabular}{|c|c|}
\hline Item No. & Manifest No. \\
\hline 1 & 02086 \\
\hline 2 & 02087 \\
\hline 3 & 02090 \\
\hline 4 & 02123 \\
\hline 5 & 02130 \\
\hline 6 & 02151 \\
\hline 7 & 02153 \\
\hline 8 & 02158 \\
\hline 9 & 02160 \\
\hline 10 & 02175 \\
\hline 11 & 02186 \\
\hline 12 & 02190 \\
\hline 13 & 02201 \\
\hline
\end{tabular}





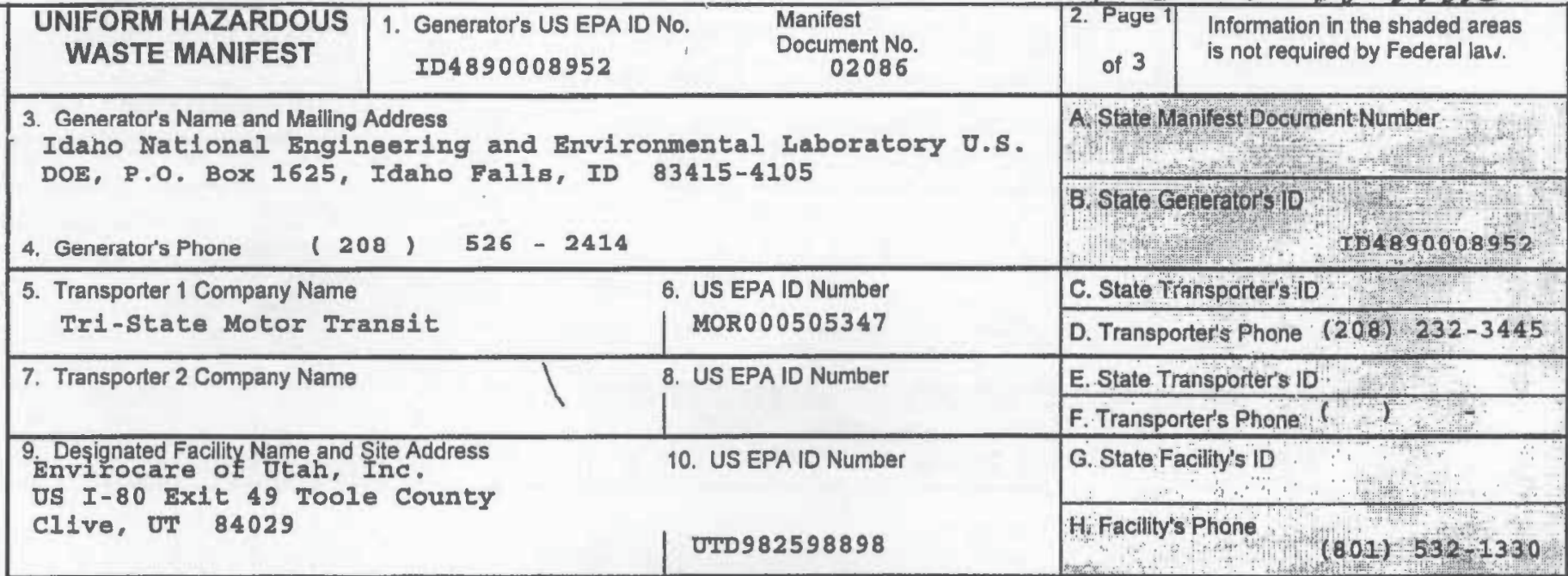

11. US DOT Description (Including Proper Shipping Name, Hazand Class and ID Number) \begin{tabular}{ll|l|l|}
\cline { 2 - 3 } & & HM & \\
\hline E. & RQ & Hazardous waste, solid, n.0.s., 9, NA3077, PG
\end{tabular} $\mathrm{E}$
$\mathrm{N}$ E (D08) Contains Paint Chips with PCBs $>50$ ppm 005

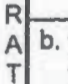
Oे c. RQ Hazardous waste, solid, n.0.8., 9, NA3077, PG III Also Contains Trace Radionuclides 10007 D008) Contains paint chips with $\mathrm{PCBs}>50 \mathrm{ppm}$ d. $\frac{x}{x}$ $005-9-23=02$ $8-15-02$ $\mathrm{x}$

J. Additional Descripting for Materials isted Aboys $1,16-\mathrm{GAI}$

1.C WSID $-2223 \mathrm{~A}, \mathrm{BC}-\mathrm{NRE} 020246,171,55-\mathrm{GAL}$ stom

15. Special Handling Instructions and Additional Information 7.3007

\begin{tabular}{|c|c|c|c|}
\hline 12. Containers & $\begin{array}{c}\text { Total } \\
\text { Tuantity }\end{array}$ & $\begin{array}{c}14 \\
\text { Unit } \\
\text { Wivol }\end{array}$ & 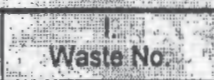 \\
\hline & & & 0007.0008 \\
\hline 1) DM & & $\mathbf{K}$ & \\
\hline
\end{tabular}
Return signed original to: S.M. IInts Idaho National Engineering \& Environmental Laboratory/US DOE, P.O. Box 1625, Idaho Falls, ID 83415-5117. Prepared under contract \#DEAC07 99ID 13727. USDOE 24-Hr. Emergency Phone: $208526-1515$. proper shipping name and are classified, packed declare that the contents of this consignment are fully and accurateily described above by according to applicable international and national govemment regulations.

If I am a large quantily generator, I certify that I have a program in place to reduce the volume and toxicity of waste generated to the degree I have determined to be economically practicable and that I have selected the practicable method of treatment. storage, or disposal currently avallable to me which minimizes the present and future threat to human health and the environment; OR, II I am a small quantily generator, I have made a good faith effort to minimize my waste generation and select the best waste management method that is available to me and that I can afford. Printed/Typed Name Sheila Lints

17. Transporter 1 Agknowledgement of Receipt of Materials

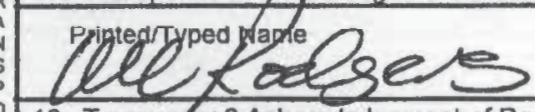

18. Transporter 2 Acknowledgement of Receipt of Materials

Printed/Typed Name

R
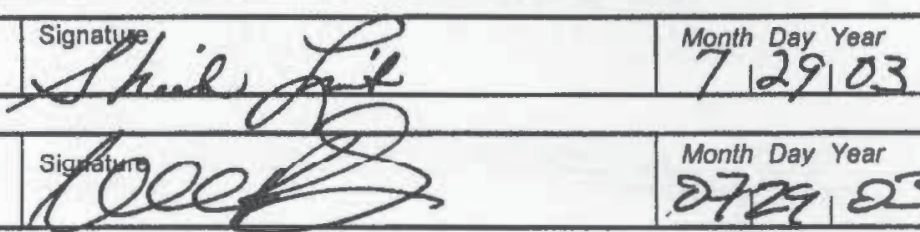

Month Day Year 2725,23

F 19. Discrepancy Indication Space

A

1

20. Facility Owner or Operator: Certification of receipt of hazardous materials covered by this manifest except as noted in ltem 19

y Printed/Typed Name

Justin Les

Integrated Waste Tracking System.

Signature

Month Day Year 


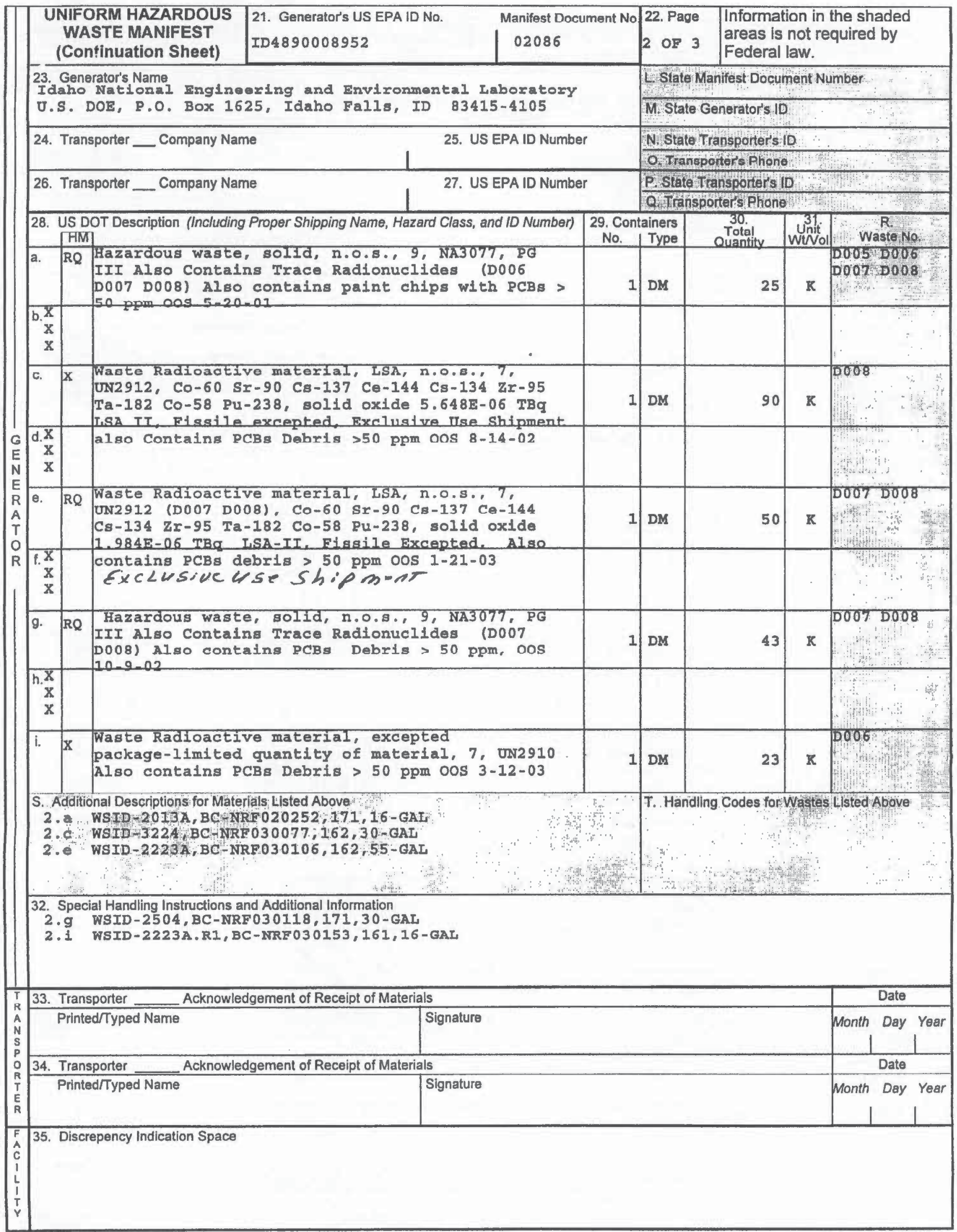




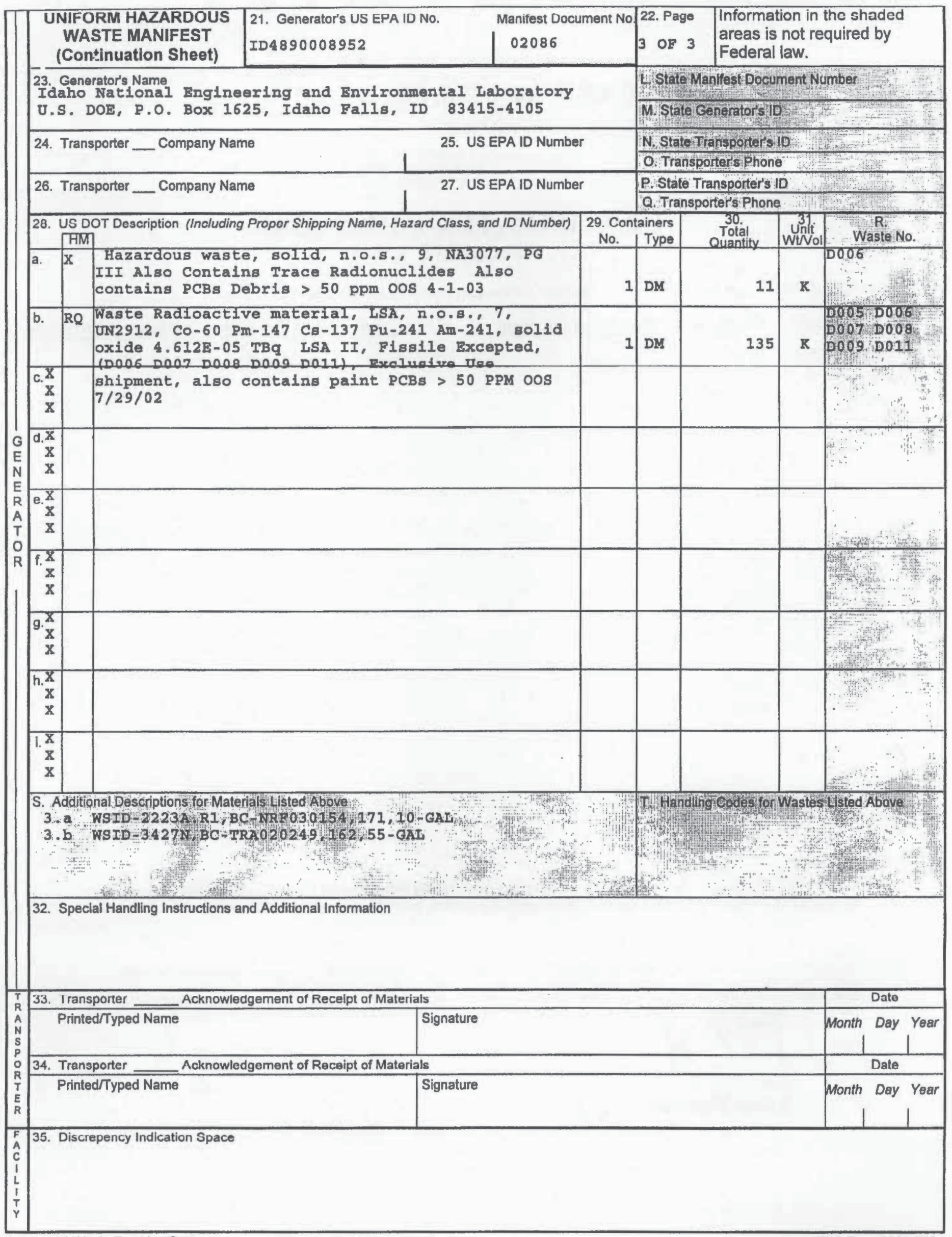




\section{ENVIROCARE OF UTAH, INC.}

THE SAFE ALTERNATIVE

3 mi. S. Ext. $49,1-80$

Clive, Utah 84029 EPA

ID: UT982598898

\section{CERTIFICATE OF DISPOSAL DOE, INEEL (BBWI), Idaho Falls}

This Certificate acknowledges that the following manifested shipments:

$\frac{\text { Shipment }}{9016-07-0001} \frac{\text { Manifest }}{02086} \quad \frac{\text { Date(s) of Disposal }}{12 / 09 / 2003} \quad \frac{\text { Cu/Ft }}{37.83} \quad \frac{\text { Process }}{\text { Landfill }} \quad \frac{\text { Disposal Location }}{\text { Mixed Wasto }}$

Representing 37.83 Cubic feet of waste disposed of at Envirocare's above listed Disposal Facility landfifl. Disposal is subject to Iinvirocarc's Radioactive Material License, all other applicable licenses, permits and regulations, and the Disposal Agreement.

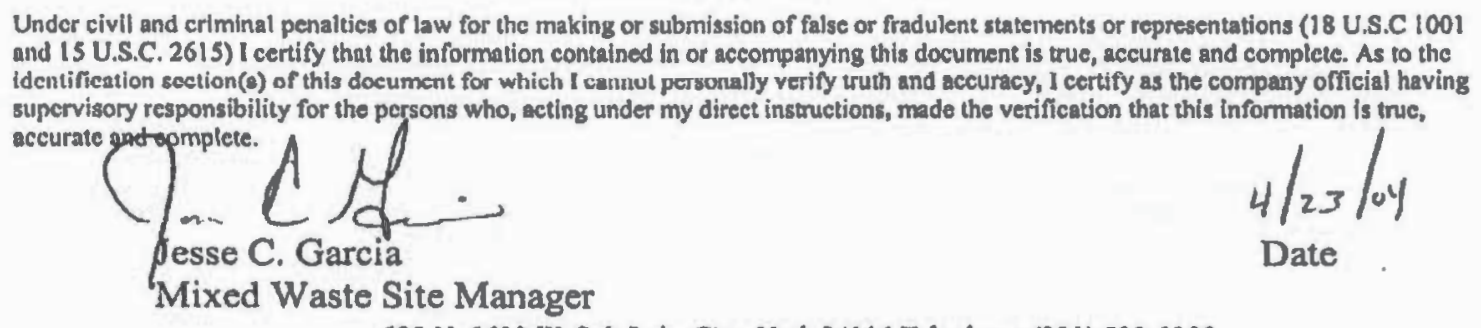

605 N. 5600 W, Salt Lake City, Utah 84116 Telephone (801) 532-1330

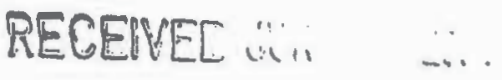



$59530 \quad 848017$

\begin{tabular}{|c|c|c|}
\hline $\begin{array}{l}\text { UNIFORM HAZARDOUS } \\
\text { WASTE MANIFEST }\end{array}$ & $\begin{array}{l}\text { 1. Generator's LS EPA ID No. } \\
\text { ID4890008952 }\end{array}$ & $\begin{array}{l}\text { Manifest } \\
\text { Document No. } \\
02087\end{array}$ \\
\hline
\end{tabular}

4. Generator's Phone ( 208$) 526-2414$

\begin{tabular}{|c|c|c|}
\hline \multirow{2}{*}{$\begin{array}{l}\text { 5. Transporter } 1 \text { Company Name } \\
\text { Tri-State Motor Transit }\end{array}$} & \multirow{2}{*}{$\begin{array}{l}\text { 6. US EPA ID Number } \\
\text { MOR000505347 }\end{array}$} & C. State Transpoiters ID \\
\hline & & D. Transporter's Phone $(208) \quad 232-3445$ \\
\hline 7. Transporter 2 Company Name & 8. US EPA ID Number & E State Transporters ID \\
\hline $\begin{array}{l}\text { 9. Dessignated Facility Name and Site Address } \\
\text { invirocare ot Utah. Inc. } \\
\text { US I-80 Exit } 49 \text { Toole County }\end{array}$ & 10. US EPA ID Number & Q. State: Facility's:D \\
\hline Clive, UT 84029 & UTD982598898 & H. Faclitys phone: $\quad(801) \quad 532-1330$ \\
\hline
\end{tabular}

11. US DOT Description (Including Proper Shipping Name, Hazand Class and ID Number)

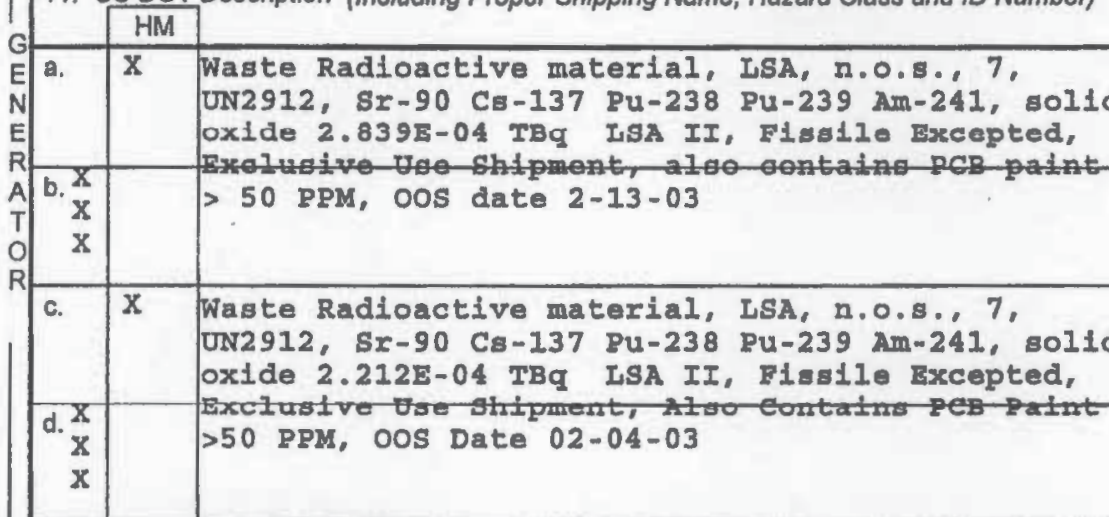

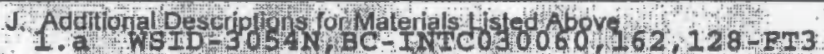

1.C. HSTP-3054 M BC-INTC030063, $162,128-\mathrm{FT} 3$

aris

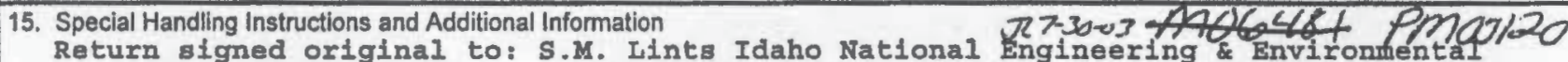
Laboratory/US DOE, P.O. Box 1625, Idaho Fal1s, ID 83415-5117. Preparad under contract \#DEAC07 99ID 13727. USDOE 24-Hx. Emergency Phone: 208 526-1515.

\begin{tabular}{|c|c|c|c|}
\hline 12. Containers & $\begin{array}{c}13 \\
\text { Total } \\
\text { Quantity }\end{array}$ & $\begin{array}{c}\text { Unit } \\
\text { Wivol }\end{array}$ & Waste No \\
\hline$C M$ & & & $\begin{array}{l}00050006 \\
0007 \text { D00 }\end{array}$ \\
\hline
\end{tabular}

1 is not required by Federal law.

A Stale Manifost Doctument Number

B. State Generator's $1 \mathrm{D}$

ID 489000895

\begin{tabular}{|l|l|l|l|}
\hline & & & \\
\hline
\end{tabular}

\begin{tabular}{|l|l|l|}
1 & $\mathrm{CM}$ & \\
\hline & & 2059 \\
\hline
\end{tabular}

D005 D006

$\mathrm{k}$

D.007 D008

K Handling Codes for Wastés Listed Above

TNMEC IO ENVIROCARE:

$90 / 6-07-1002$

16. GENERATOR'S CERTIFICATION: I hereby declare that the contents of this consignment are fully and accurately described above by proper shipping name and are classilied, packed, marked, and labeled, and are in all respects in proper condition for transport by highway according to applicable international and nalional government regulations.

If I am a large quantity generator, I certify that I have a program in place to reduce the volume and toxicliy of waste generated to the degree I have determined to be economically practicable and that I have selected the practicable method of treatment, slorage, or disposal currently available to me which minimizes the present and future threat to human health and the environment; $O R$, if l am a small quanfity generator, I have made a good falth effort to minimize my waste generation and select the best waste management method that is available to me and that I can afford.

Printed yped Name

$\times 41, \%+5$

17. Transporter 1 Acknowledgement of Receipl of Materials

A Printed/Typed Name

S STevw Doyce

18. Transporter 2 Acknowledgement of Receipt of Materials

\begin{tabular}{|l|l|l|} 
Printed/Typed Name & Signature
\end{tabular}

Signature 1 Month Day Year 712963

$E$
$R$

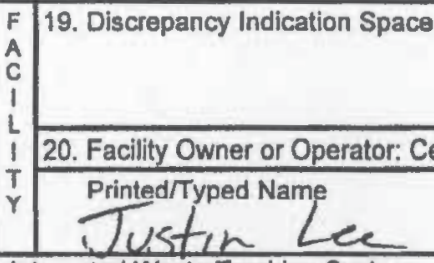

Integrated Waste Tracking System.

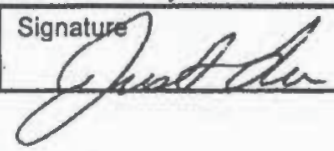

Month Day Year

07130103 


\title{
ENVTROCARE OF UTAH, INC.
}

THE SAFE ALTERNATIVE

\author{
- 3 mi. S. Ext 49, I-80 \\ Clive, Utah 84029 EPA \\ ID: UT982598898

\section{CERTIFICATE OF DISPOSAL}

This Certiflcate acknowledges that the following manifested shipments:
Shipment
Manifest
Date(s) of Disposal
$\mathrm{Cu} / \mathrm{Ft}$
Process
Disposal Location
9016-07-0002 02087
$6 / 23 / 04,6 / 25 / 04$
LandFill
Mixed Waste

Representing 256 Cubic feet of waste of at listed Disposal Facility landfill. Disposal is subject to Envirocare's Radioactive Material License, all other applicable licenses, perraits and regulations, and the Disposal Agreement.

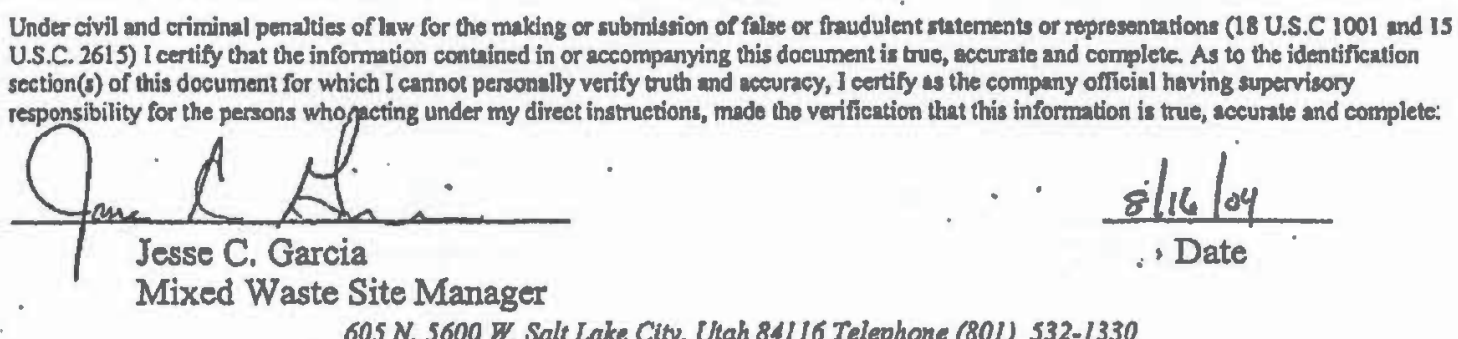

605 N. 5600 W. Salt Lake City, Ulah 81/16 Telephone (80I) 532-J330 



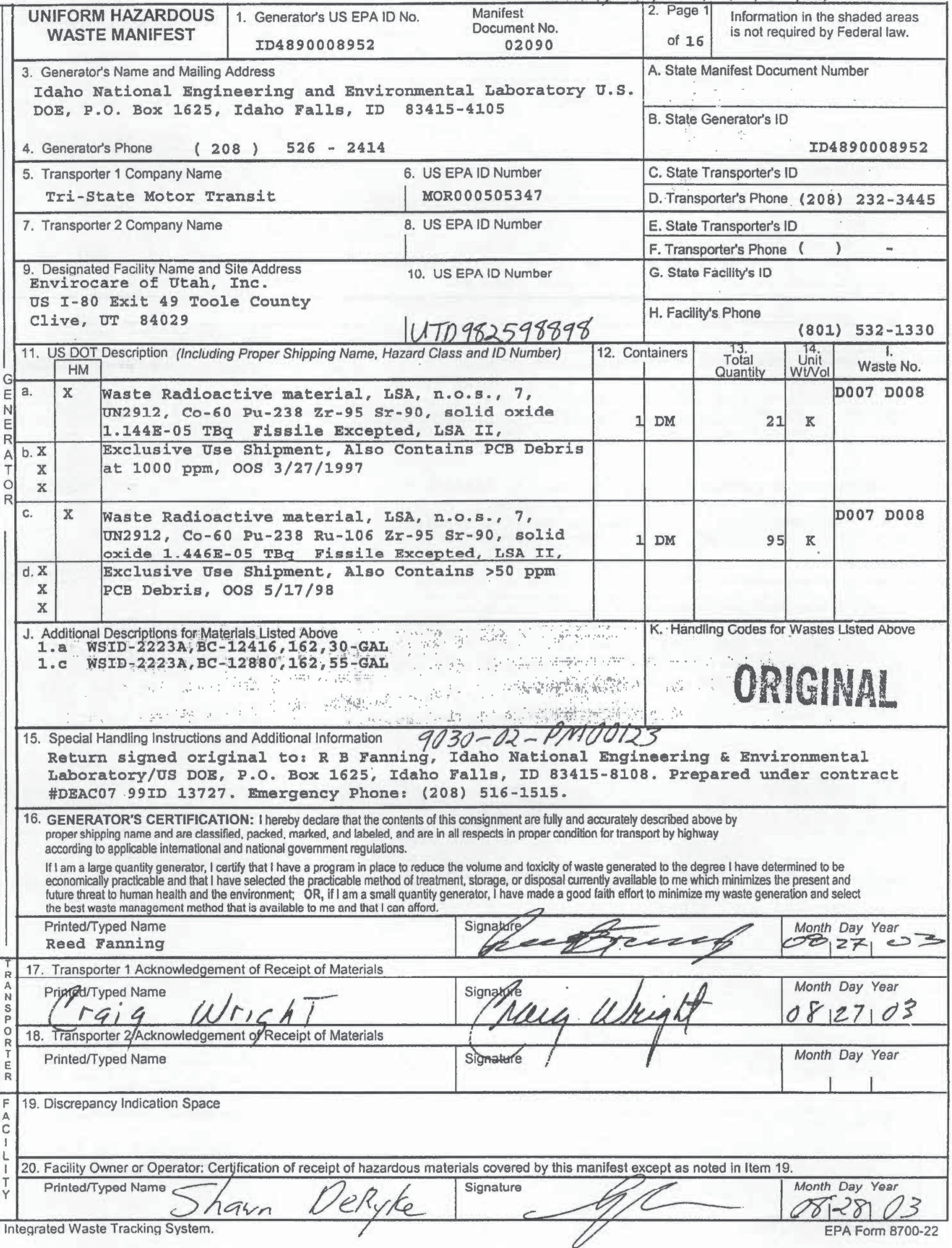




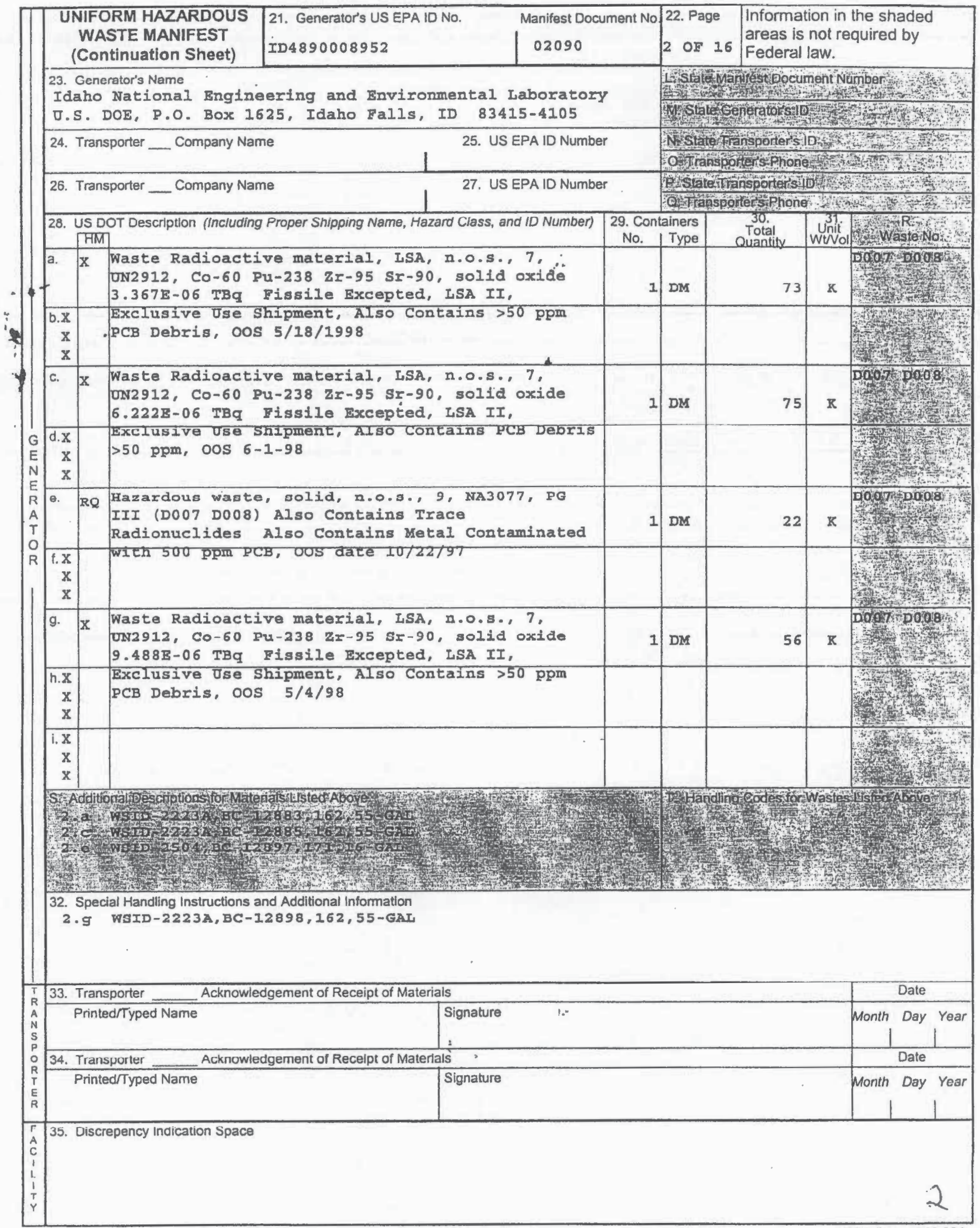




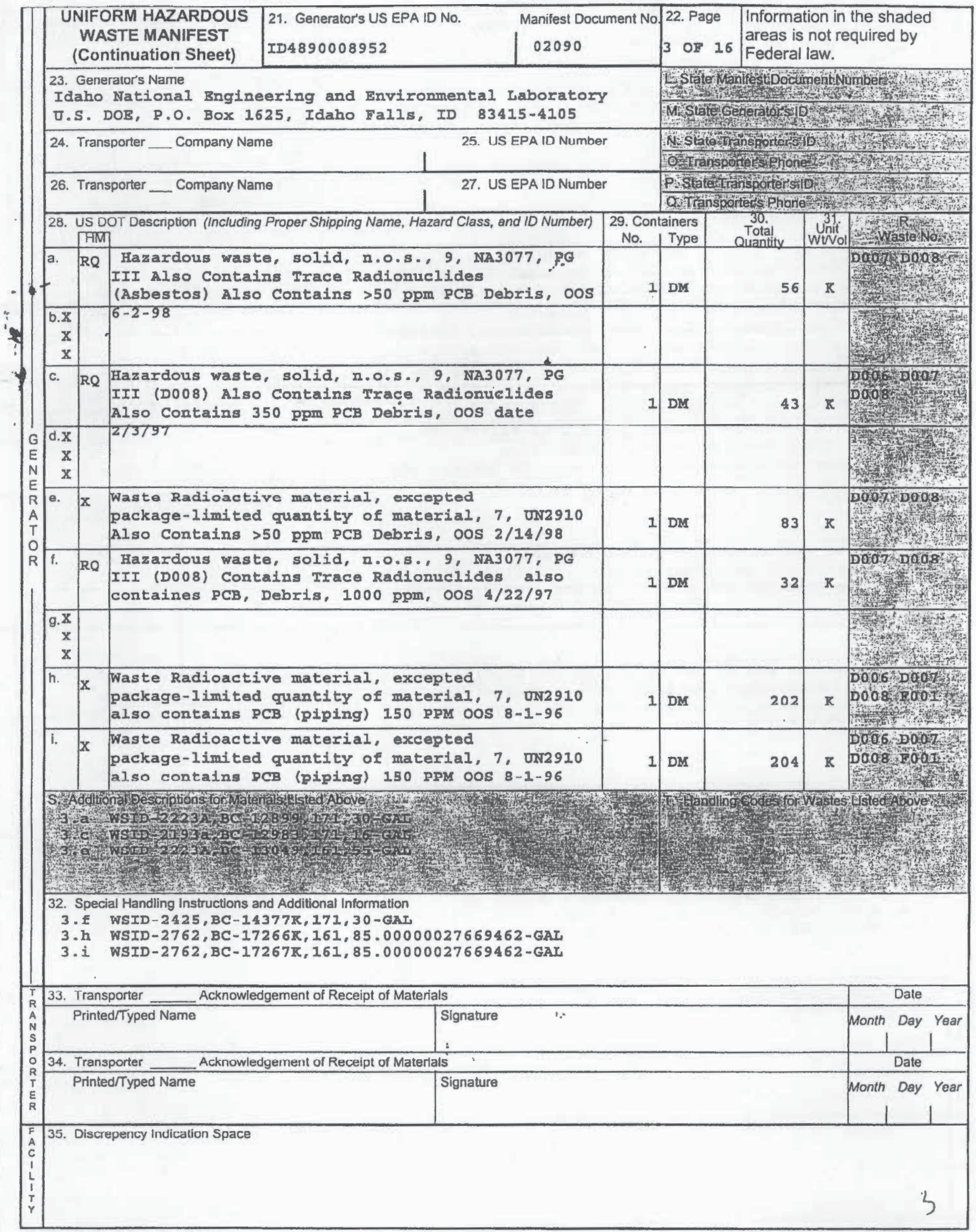




\begin{tabular}{|c|c|c|c|c|c|c|c|}
\hline & \multicolumn{2}{|r|}{$\begin{array}{l}\text { UNIFORM HAZARDOUS } \\
\text { WASTE MANIFEST } \\
\text { (Continuation Sheet) }\end{array}$} & \multicolumn{2}{|l|}{$\begin{array}{l}\text { 21. Generator's US EPA ID No. } \\
\text { ID4890008952 }\end{array}$} & \multicolumn{3}{|c|}{\begin{tabular}{l|l} 
22. Page & $\begin{array}{l}\text { Information in the shaded } \\
\text { areas is not required by }\end{array}$ \\
4 of 16 & Federal law.
\end{tabular}} \\
\hline & \multicolumn{4}{|c|}{$\begin{array}{l}\text { 23. Generators Name } \\
\text { Idaho National Engineering and Enviromental Laboratory } \\
\text { O.S. DOE, P.O. Box 1625, Idaho Falls, ID } 83415-4105\end{array}$} & \multicolumn{3}{|c|}{ 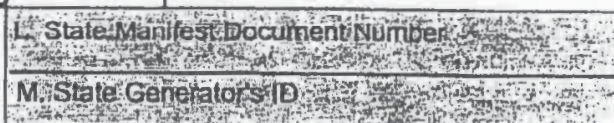 } \\
\hline & \multicolumn{4}{|c|}{ 24. Transporter _ Company Name } & \multicolumn{3}{|c|}{ 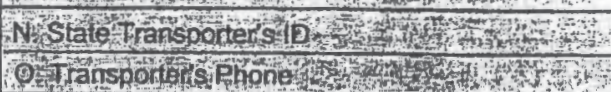 } \\
\hline & \multicolumn{4}{|c|}{ 26. Transporter___Company Name } & \multicolumn{3}{|c|}{ 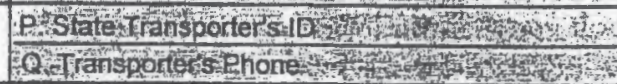 } \\
\hline & \multicolumn{3}{|c|}{$\begin{array}{l}\text { 28. US DOT Description (Including Proper Shipping Name, Mazard Class, and IO Number) } \\
\text { [HM] }\end{array}$} & \multicolumn{2}{|c|}{$\begin{array}{l}\text { 29. Containers } \\
\text { No. Type }\end{array}$} & 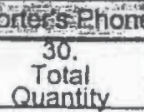 & $\frac{1}{\text { Whit }}$ \\
\hline & a. & \begin{tabular}{l|l}
$\mathrm{X}$ & Waste Radioact \\
package-limited \\
also contains
\end{tabular} & $\begin{array}{l}\text { ve material, excepted } \\
\text { quantity of material, } 7, \text { oN2910 } \\
\text { CB DEBRIS, } 150 \text { PPM OOS } 8 / 1 / 96\end{array}$ & 1 & DM & 199 & 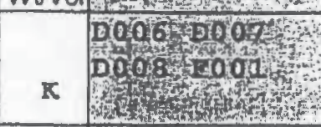 \\
\hline & b. & $\begin{array}{l}\text { Waste Radioacti } \\
\text { package-limitec } \\
\text { also contains }\end{array}$ & $\begin{array}{l}\text { ve material, excepted } \\
\text { quantity of material, } 7 \text {, UN2910 } \\
\text { CB debris, } 150 \text { PPM, oOs } 8 / 1 / 96\end{array}$ & 1 & DM & 94 & 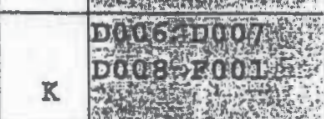 \\
\hline & c. & $\begin{array}{l}\text { Xazardous waste } \\
\text { III Also Conta: } \\
\text { Contains }>50 \mathrm{PE}\end{array}$ & $\begin{array}{l}\text { solid, n.0.s., 9, NA3077, PG } \\
\text { ns Trace Radionuclides Also } \\
\text { PCB Debris, oos } 6-18-98\end{array}$ & 1 & DM & 34 & Pogr \\
\hline \multirow{8}{*}{$\begin{array}{l}T \\
G \\
E \\
N \\
E \\
R \\
A \\
T \\
O \\
R\end{array}$} & d. & 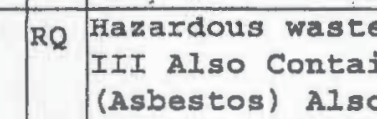 & $\begin{array}{l}\text { : solid, n.0.s., 9, NA3077, PG } \\
\text { ns Trace Radionuclides } \\
\text { Contains }>50 \text { ppm PCB Debris, oos }\end{array}$ & 1 & DM & 45 & 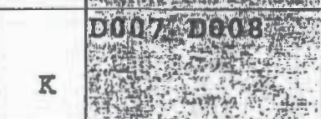 \\
\hline & $\begin{array}{l}e . x \\
x \\
x\end{array}$ & $7-8-98$ & . & & & & 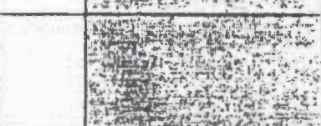 \\
\hline & f. & $\begin{array}{l}\text { X Waste Radioacti } \\
\text { package-limited } \\
\text { Also Contains }\end{array}$ & $\begin{array}{l}\text { ve material, excepted } \\
\text { quantity of material, } 7 \text {, ON2910 } \\
\text { CB Debris >50 PPM, OOS } 9 / 11 / 1998\end{array}$ & 1 & DM & 24 & $\mathrm{x}$ \\
\hline & $\frac{x}{x}$ & & & & & & thot \\
\hline & h. & \begin{tabular}{|l|l} 
RQ & $\begin{array}{l}\text { Hazardous waste } \\
\text { III (D006) Alsc } \\
\text { (Asbestos) Alsc }\end{array}$
\end{tabular} & $\begin{array}{l}\text { solid, n.o.s., 9, NA.3077, PG } \\
\text { Contains Trace Radionuclides } \\
\text { Contalns PCB Debris >50 PPM, oos }\end{array}$ & 1 & DM & 64 & 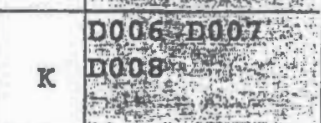 \\
\hline & $\begin{array}{l}\text { i. } x \\
x \\
x\end{array}$ & $7 / 30 / 1998$ & & & & & in. \\
\hline & \multicolumn{7}{|c|}{ 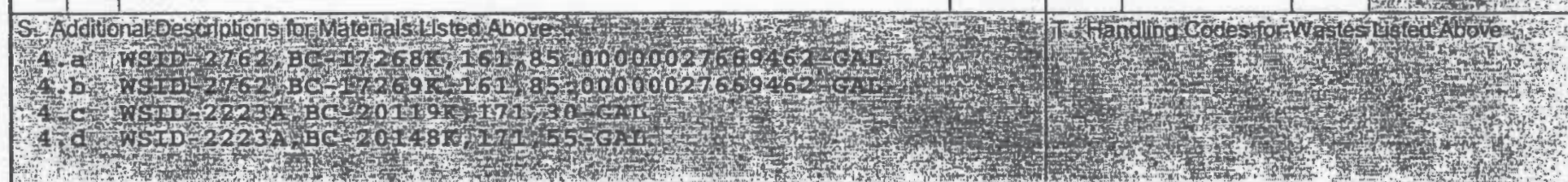 } \\
\hline & \multicolumn{7}{|c|}{ 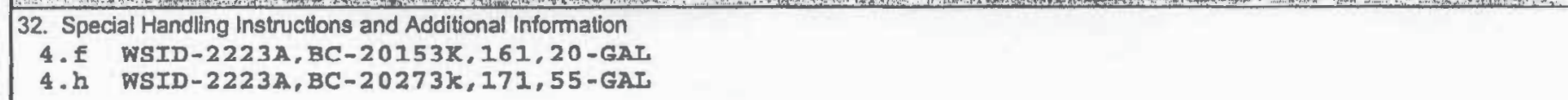 } \\
\hline & \multicolumn{4}{|c|}{ 33. Transporter __ Acknowledgement of Recelpt of Materlals } & \multicolumn{3}{|r|}{ Date } \\
\hline & \multirow{3}{*}{ 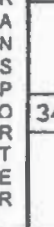 } & \multirow{2}{*}{\multicolumn{3}{|c|}{ Acknowledgement of Receipt of Materials }} & \multicolumn{3}{|c|}{ Month Day Year } \\
\hline & & & & & \multicolumn{3}{|r|}{ Date } \\
\hline & & \multicolumn{3}{|l|}{ Printed/Typed Name } & & & Month Day Year \\
\hline 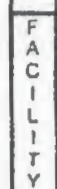 & \multicolumn{7}{|c|}{ 35. Discrcpency Indicalion Space } \\
\hline
\end{tabular}

Integrated Waste Tracking System. 


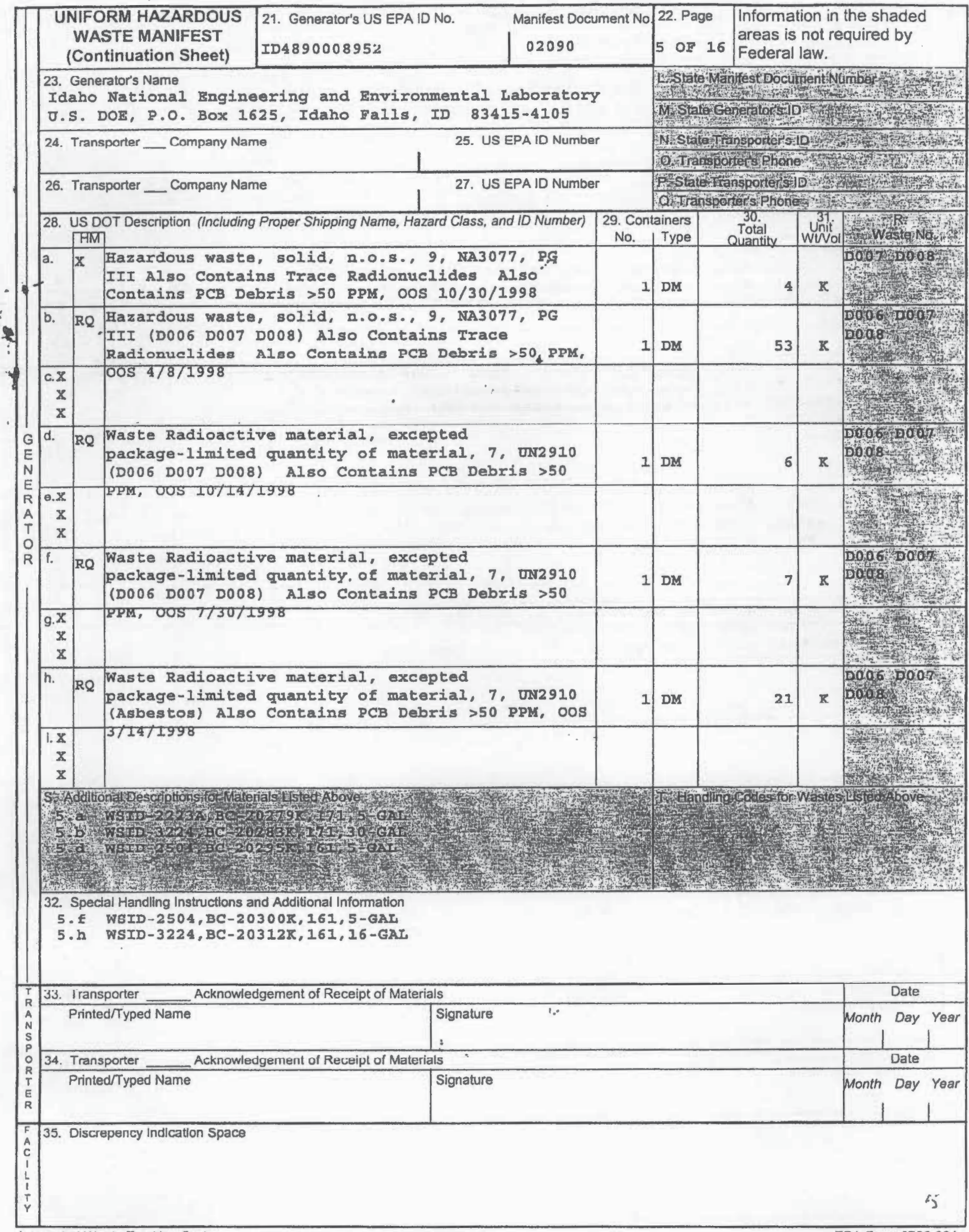




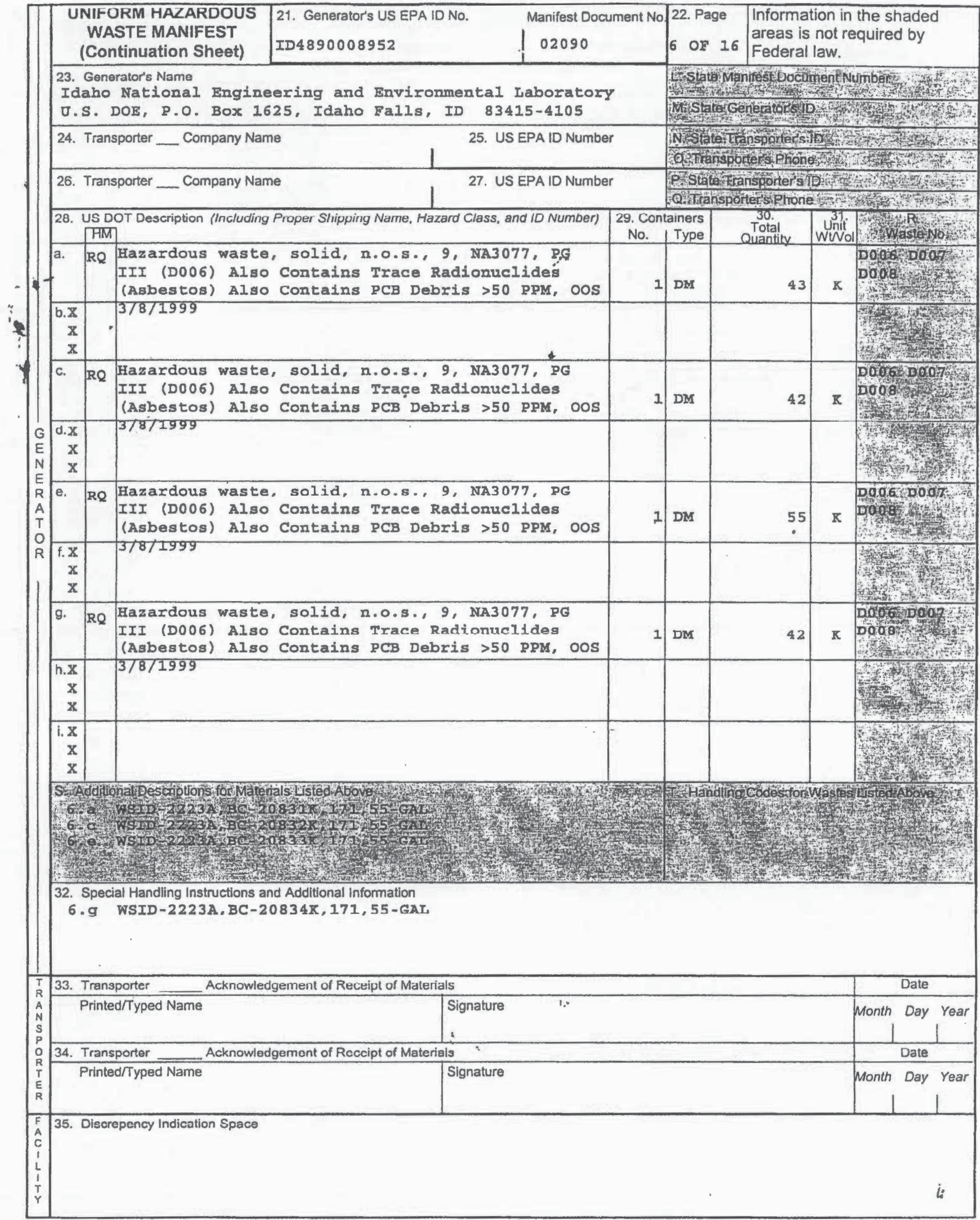




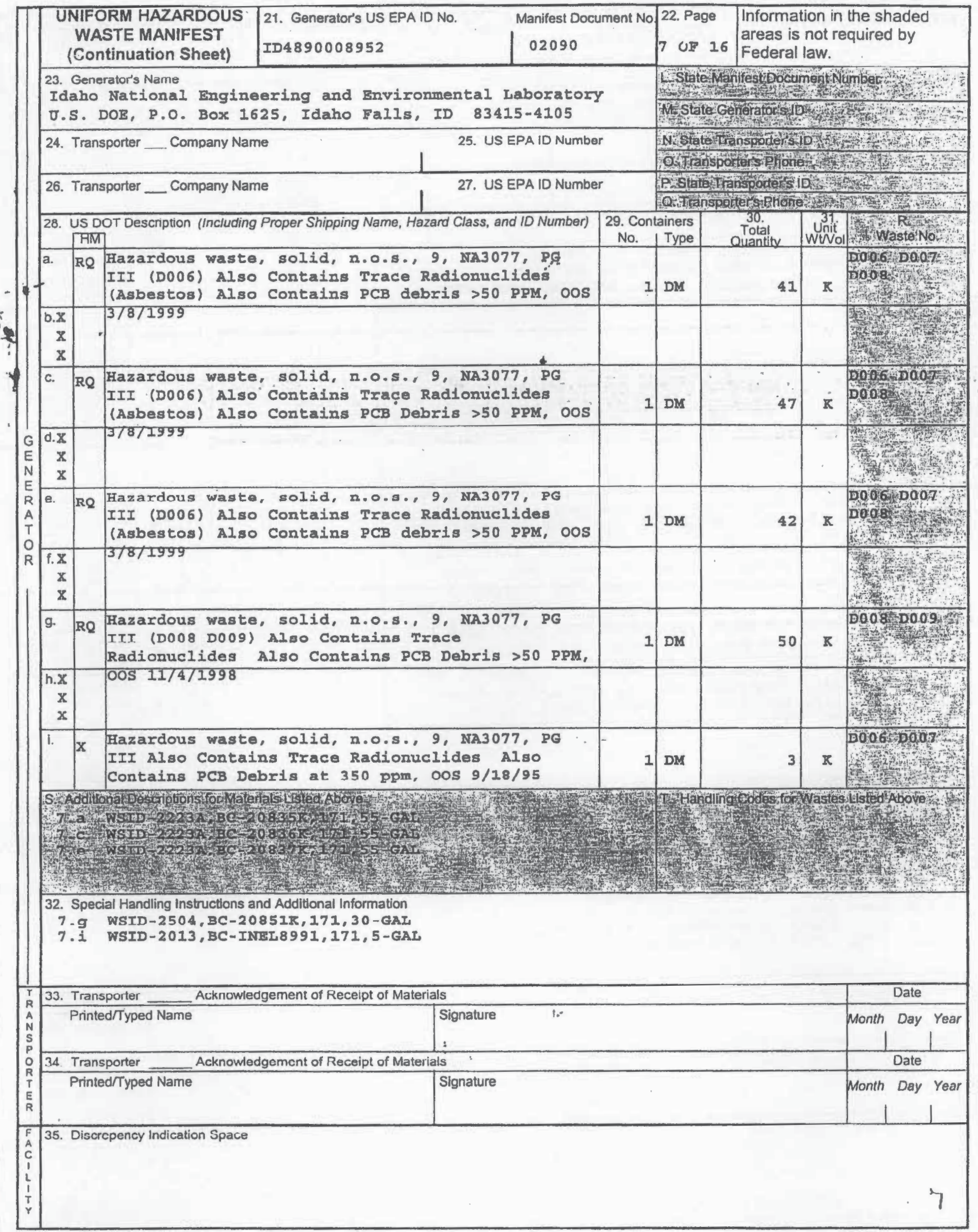




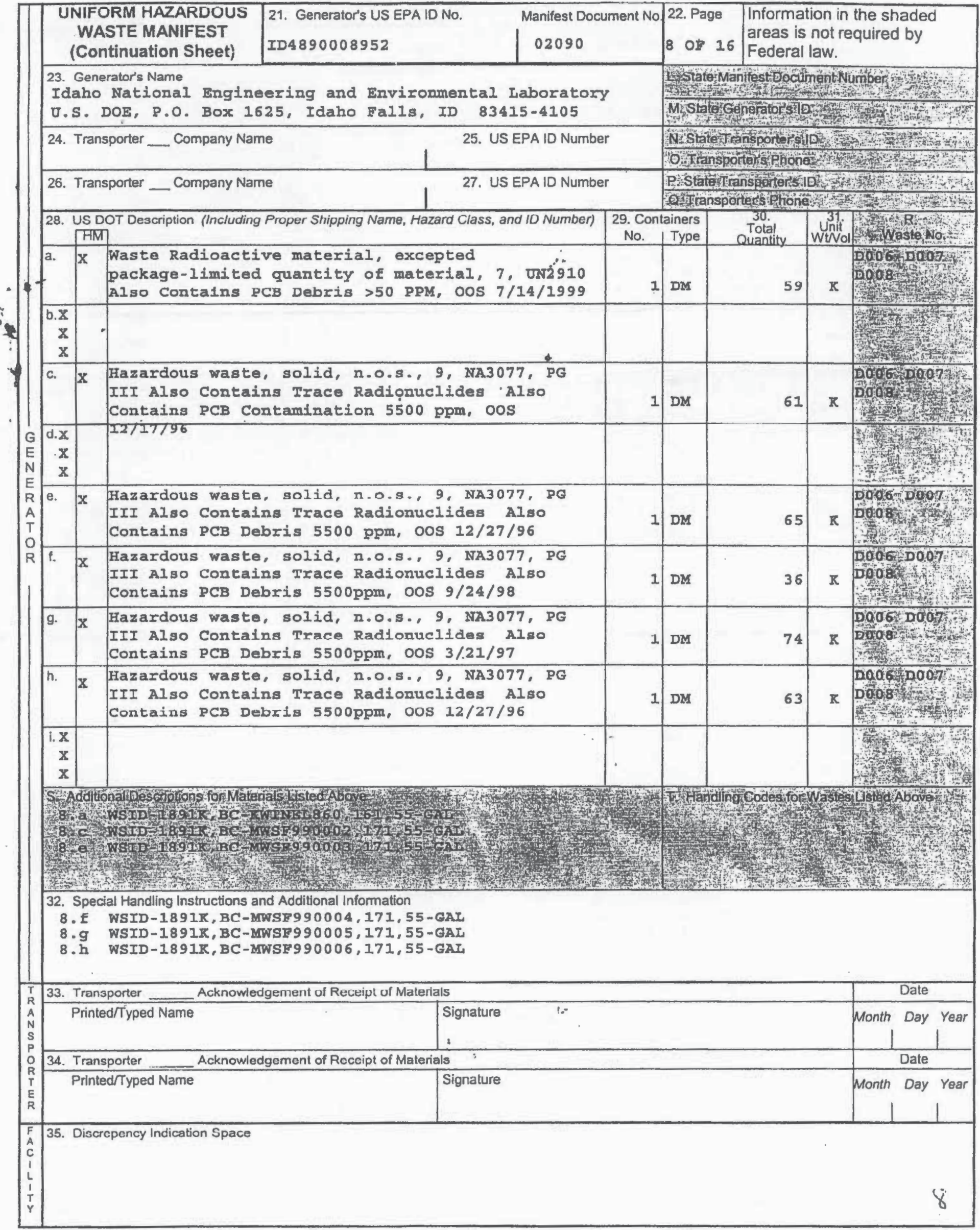




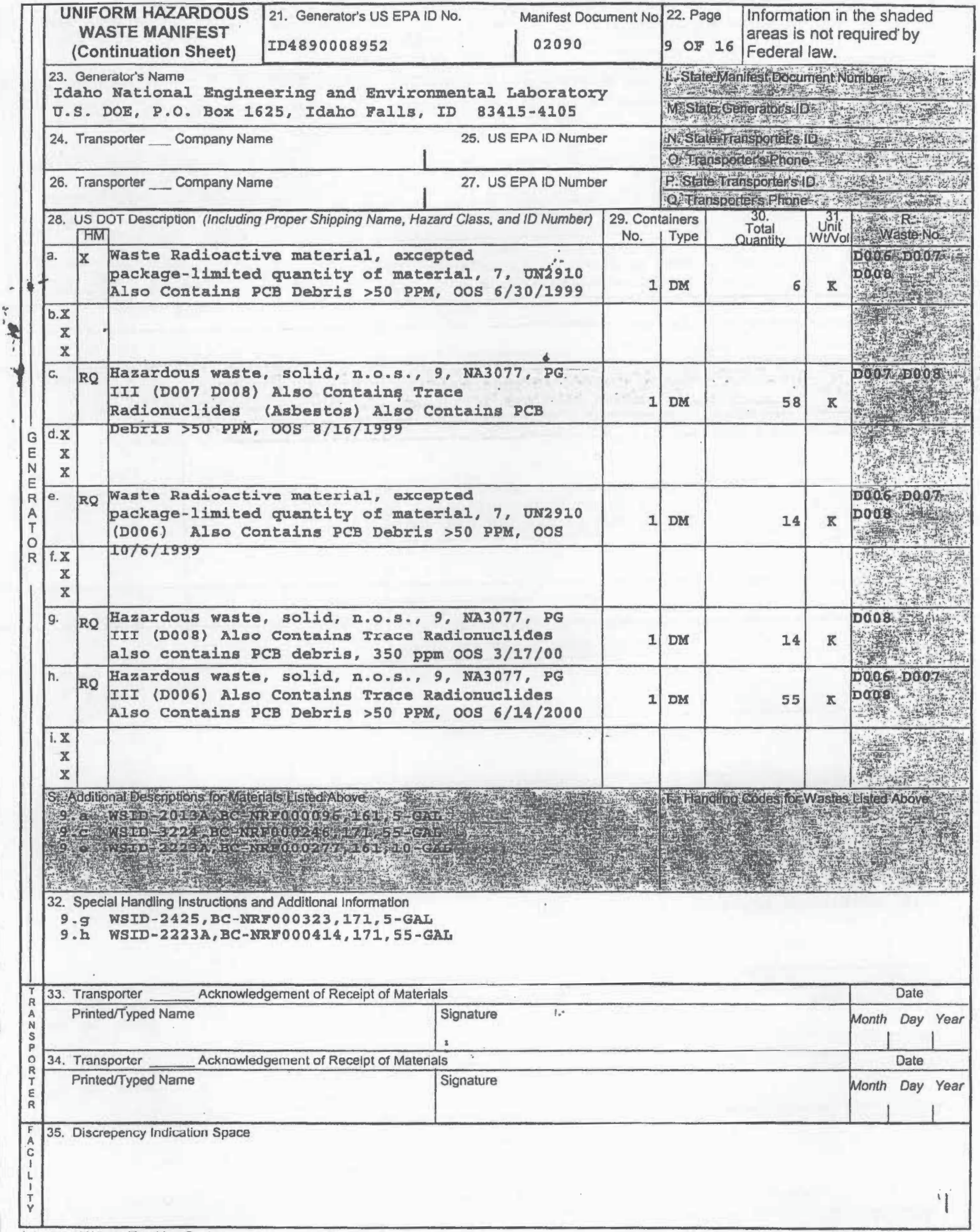




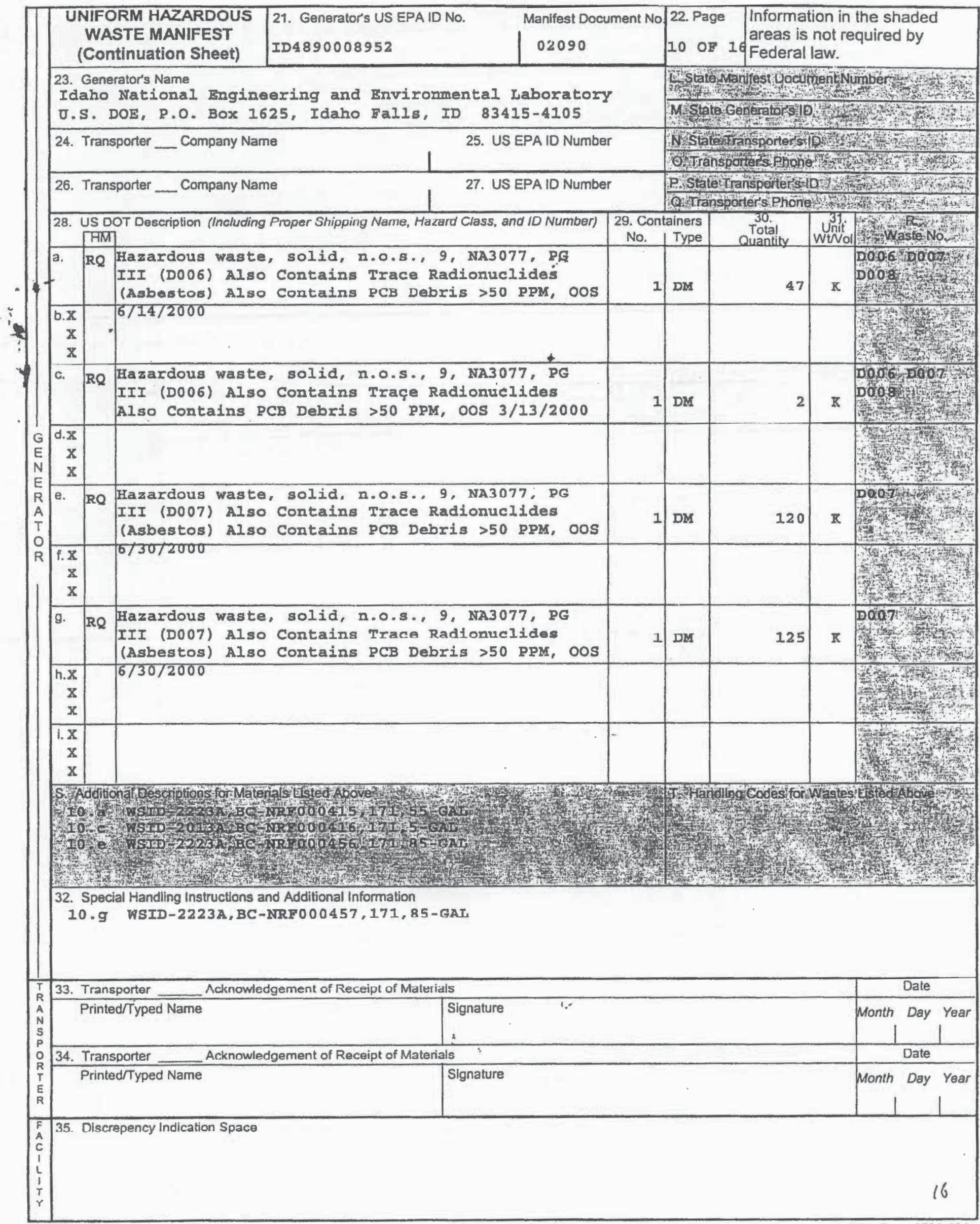

Integrated Waste Tracking System. 


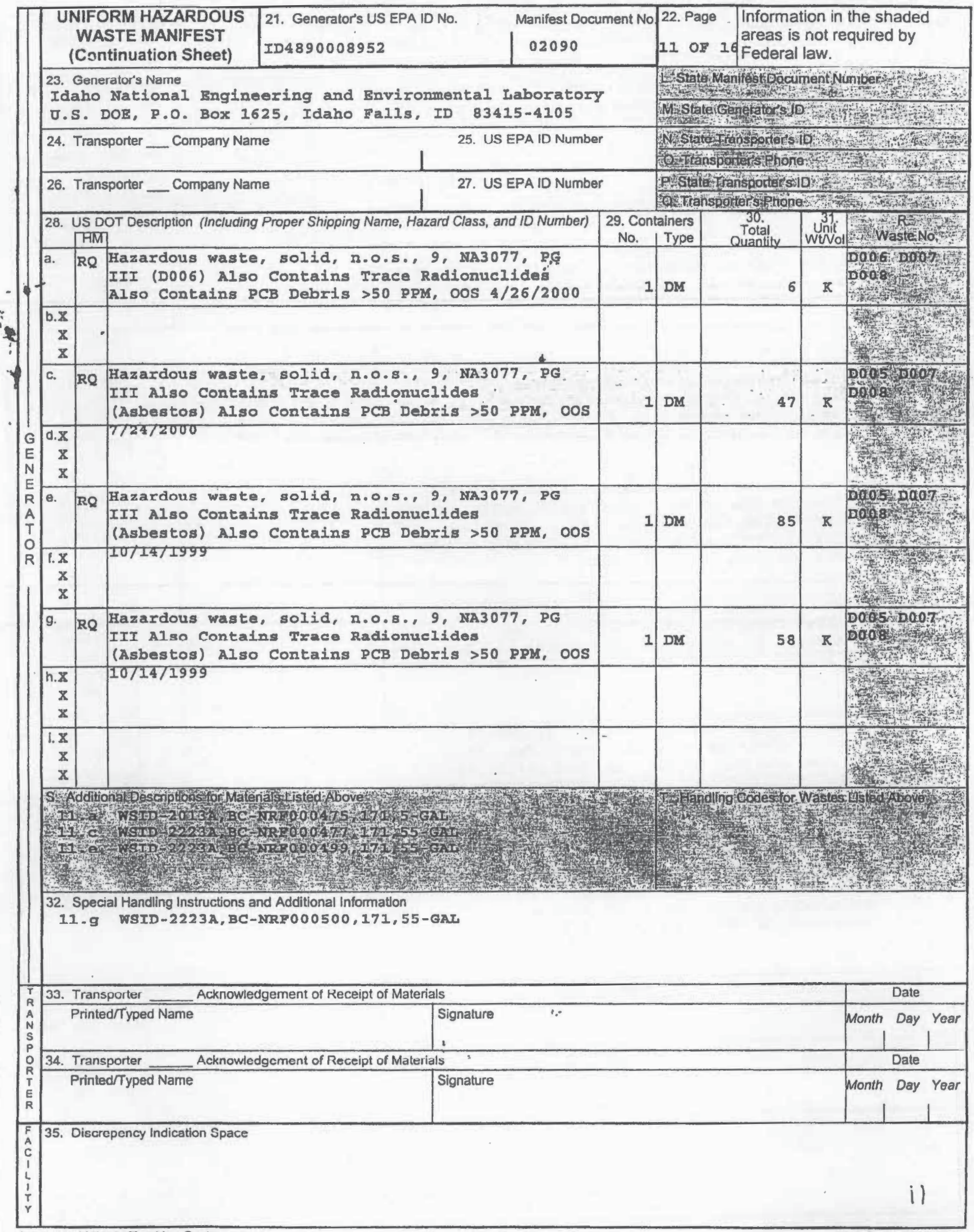




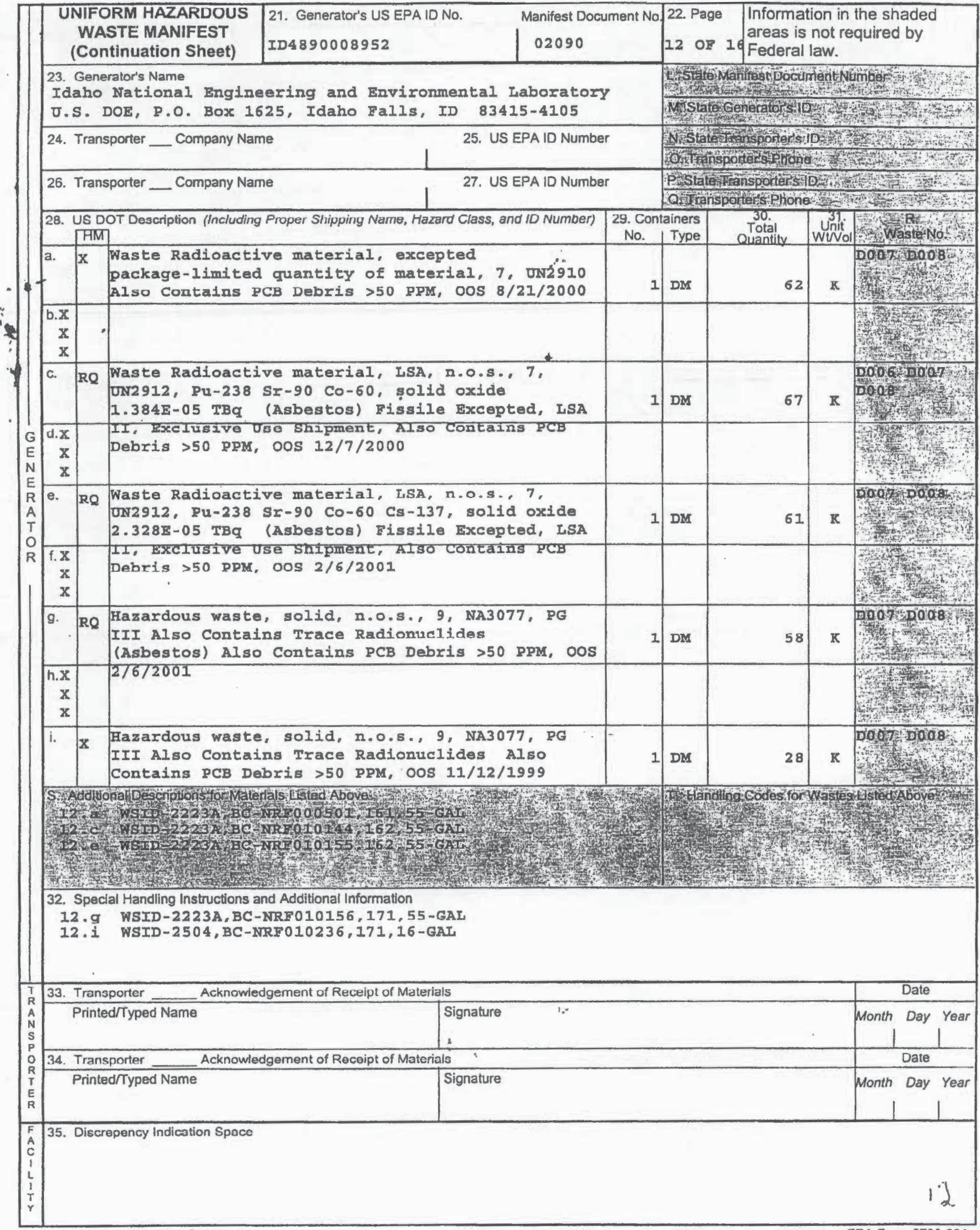




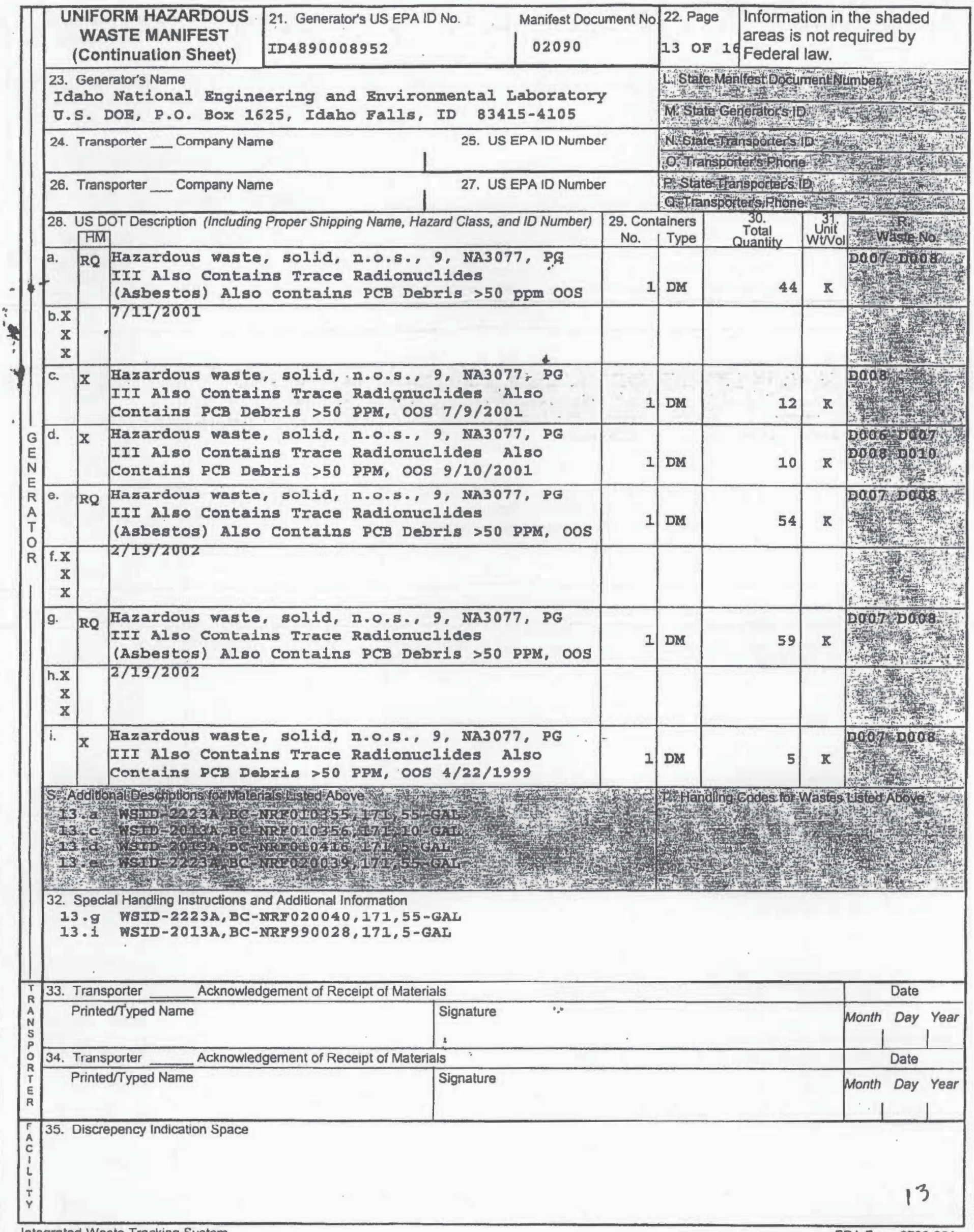

Integrated Waste Tracking System. 


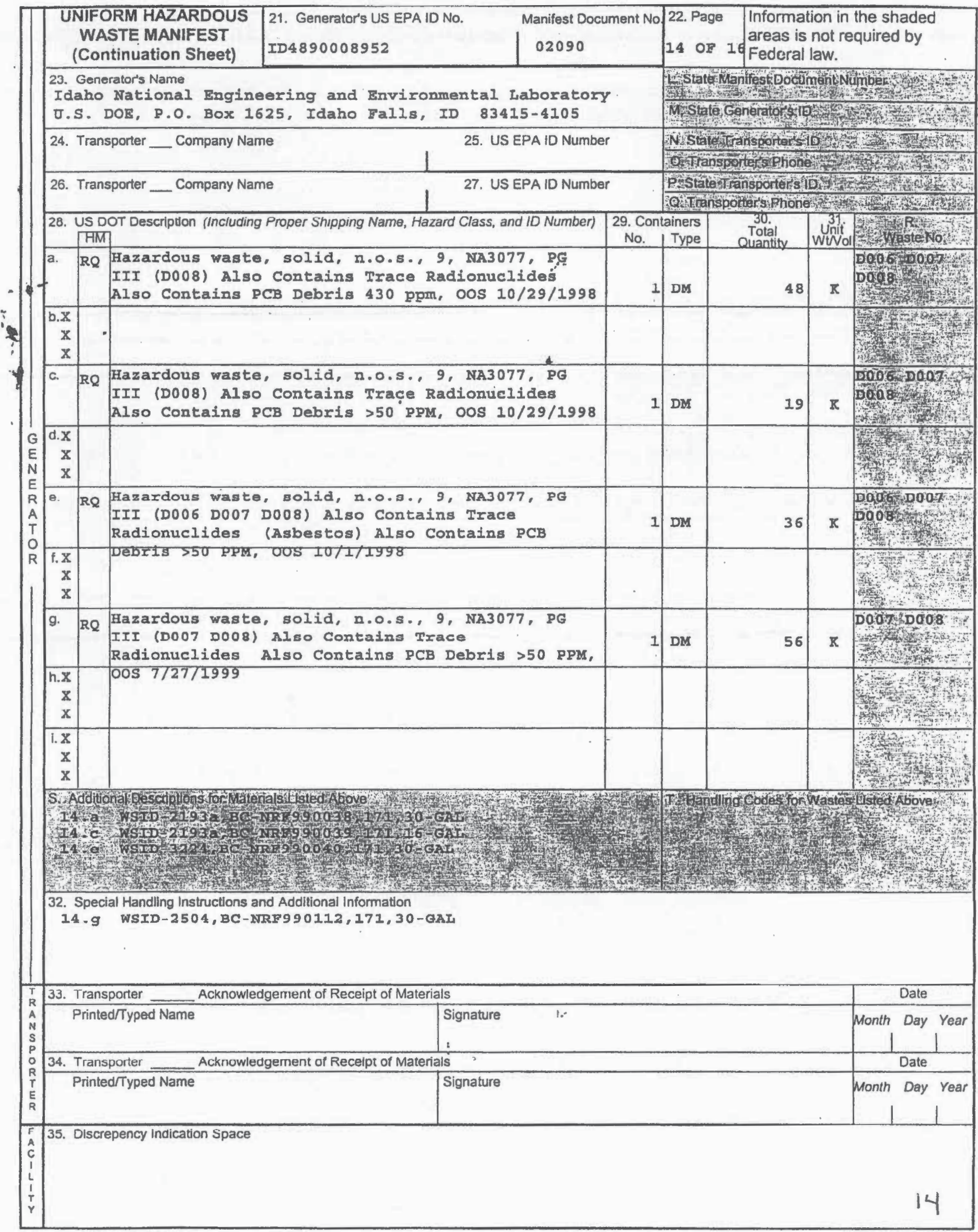




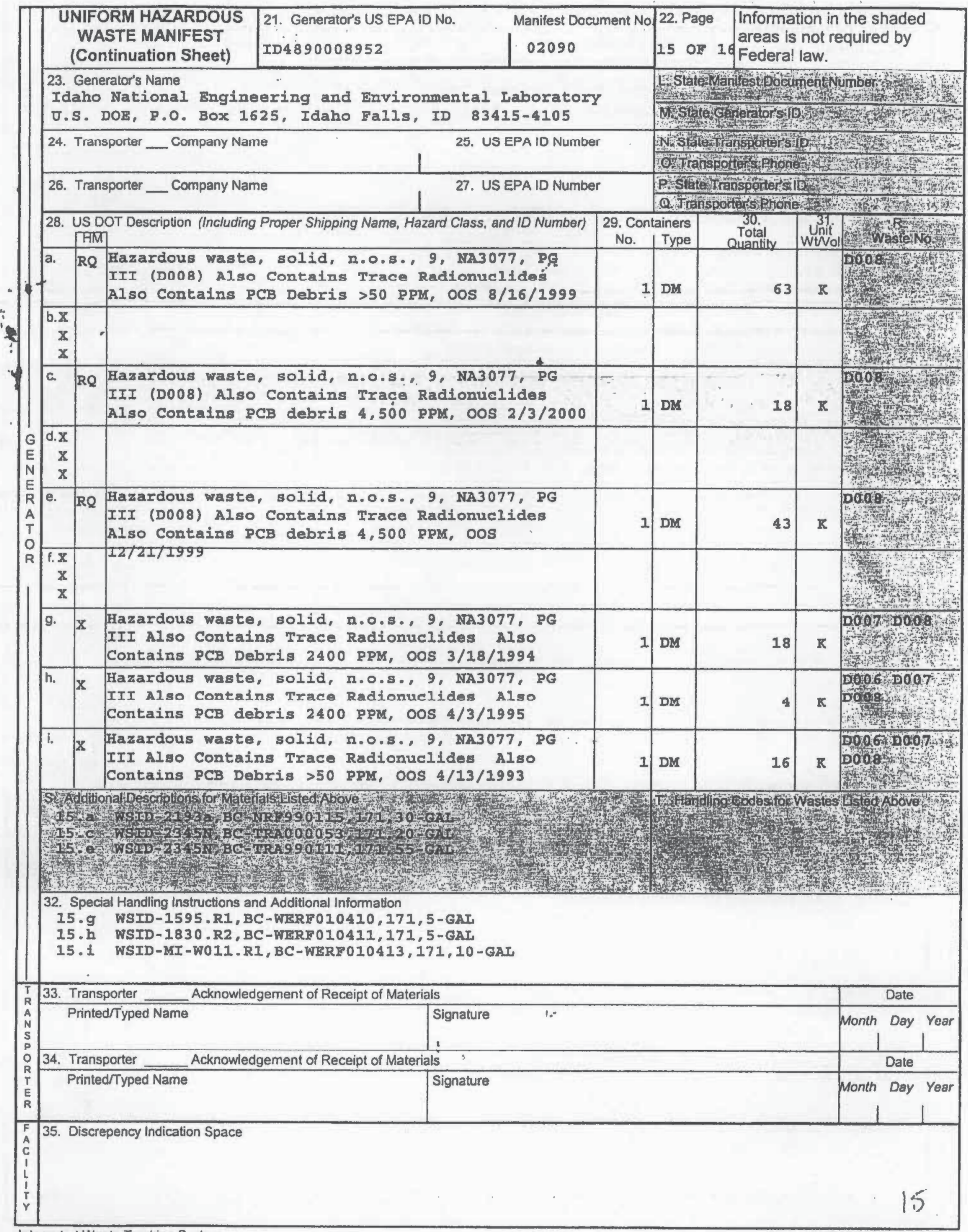




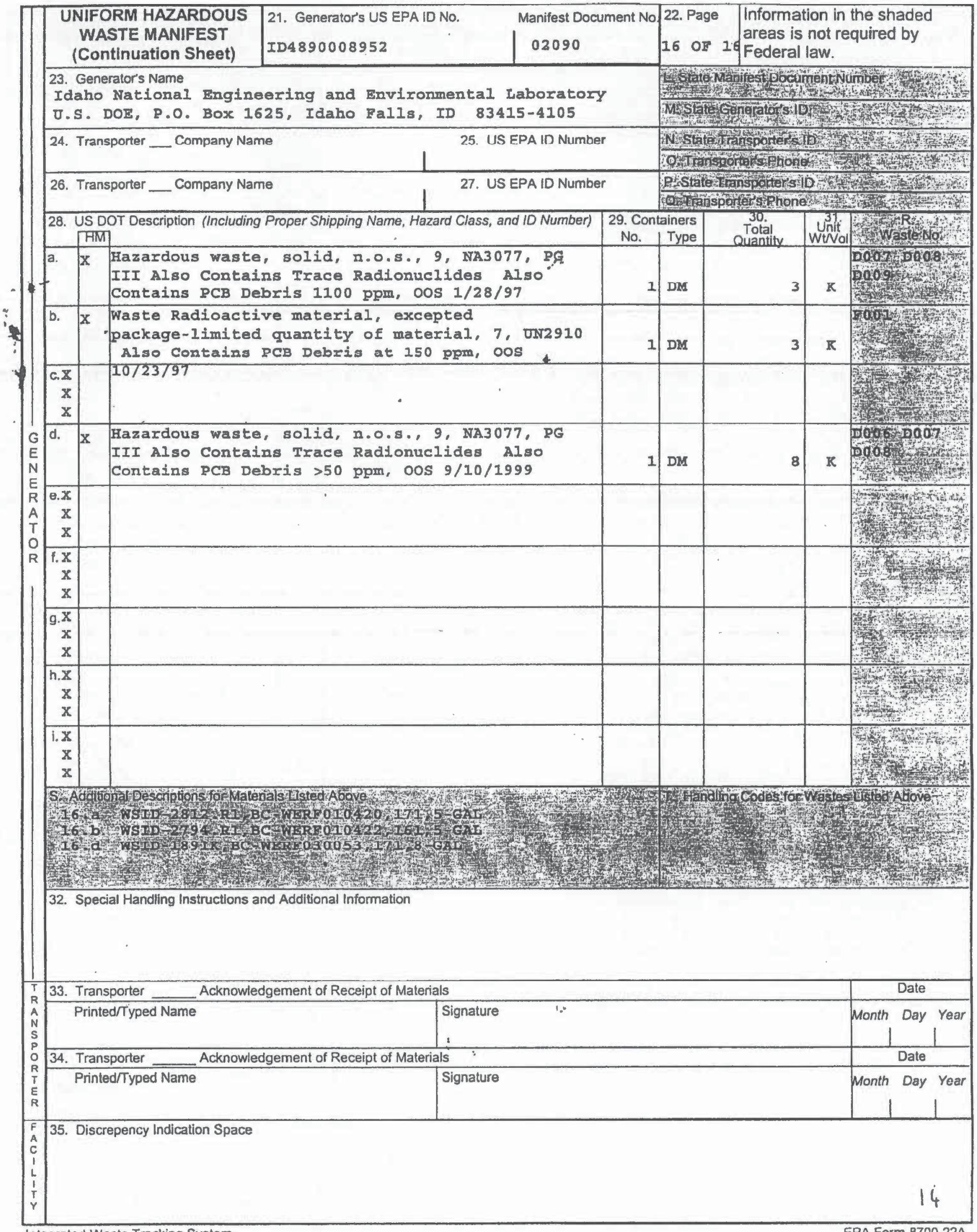




\section{ENVIROCARE OF UTAH, INC.}

THE SAFE ALTERNATIVE

3 mi S. I.x. 40,1-80

Clive, Utah s4029 EBn

IV: UT8ห2548898

\section{CERTIFICATE OF DISPOSAL}

This Certificate acknowledges that the following manifested shipments:

\begin{tabular}{|c|c|c|c|c|c|}
\hline Shipment & Manifest & Date(s) of Disposal & $\mathrm{Cu} / \mathrm{Ft}$ & Process & Disposal Location \\
\hline 9030-02-0001 & 02090 & 08/04/2004 & 388.74 & LandFIII & Mixed Waste \\
\hline
\end{tabular}

Representing 388.74 Cubic feet of waste of at Listed Disposal Facility landfill. Disposal is subjcct 10

Envirocare's Radioactive Material Lisense, all other applicable liccnses, pemms and regulations, and the Disposul Agrecment.

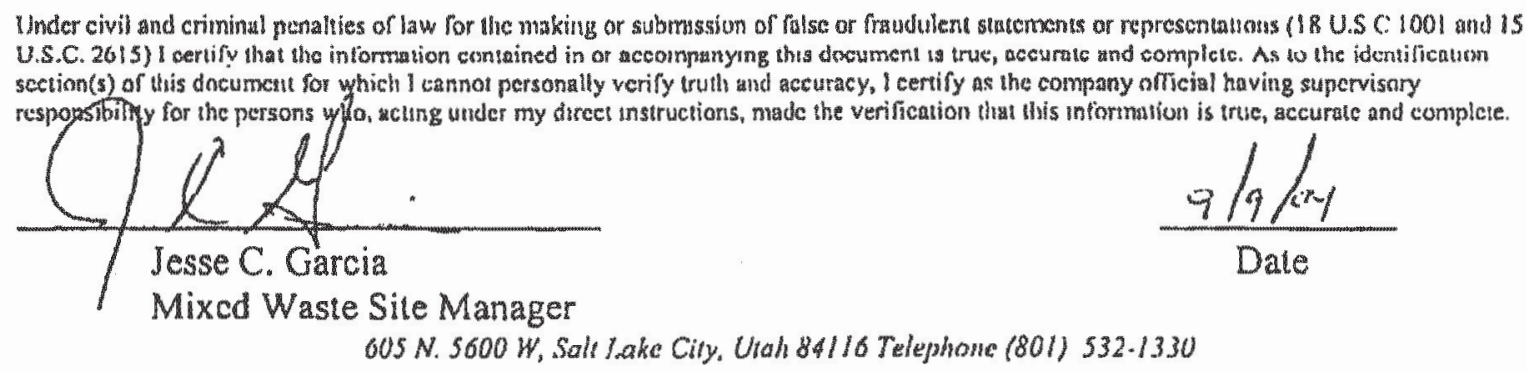


. 


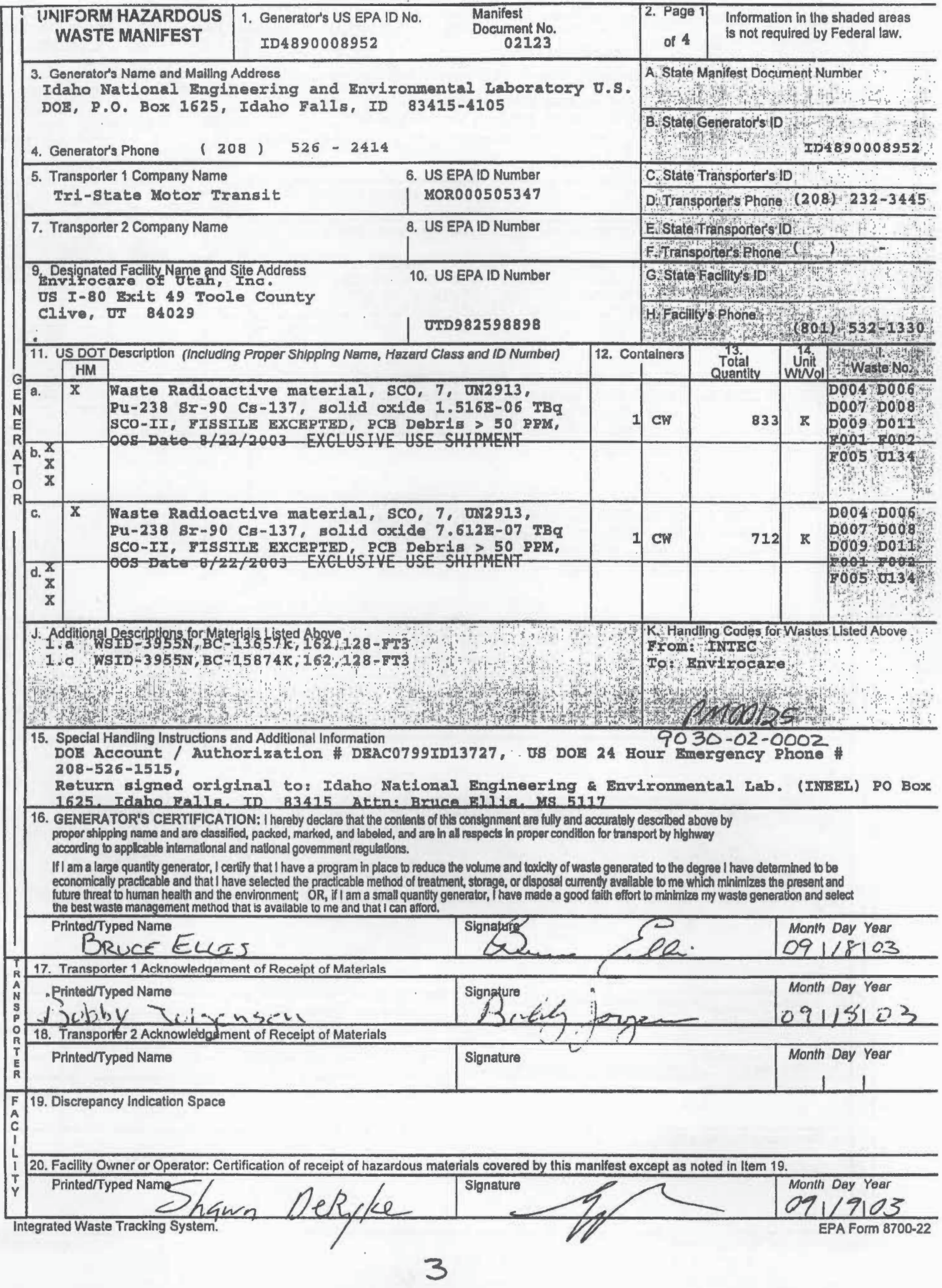




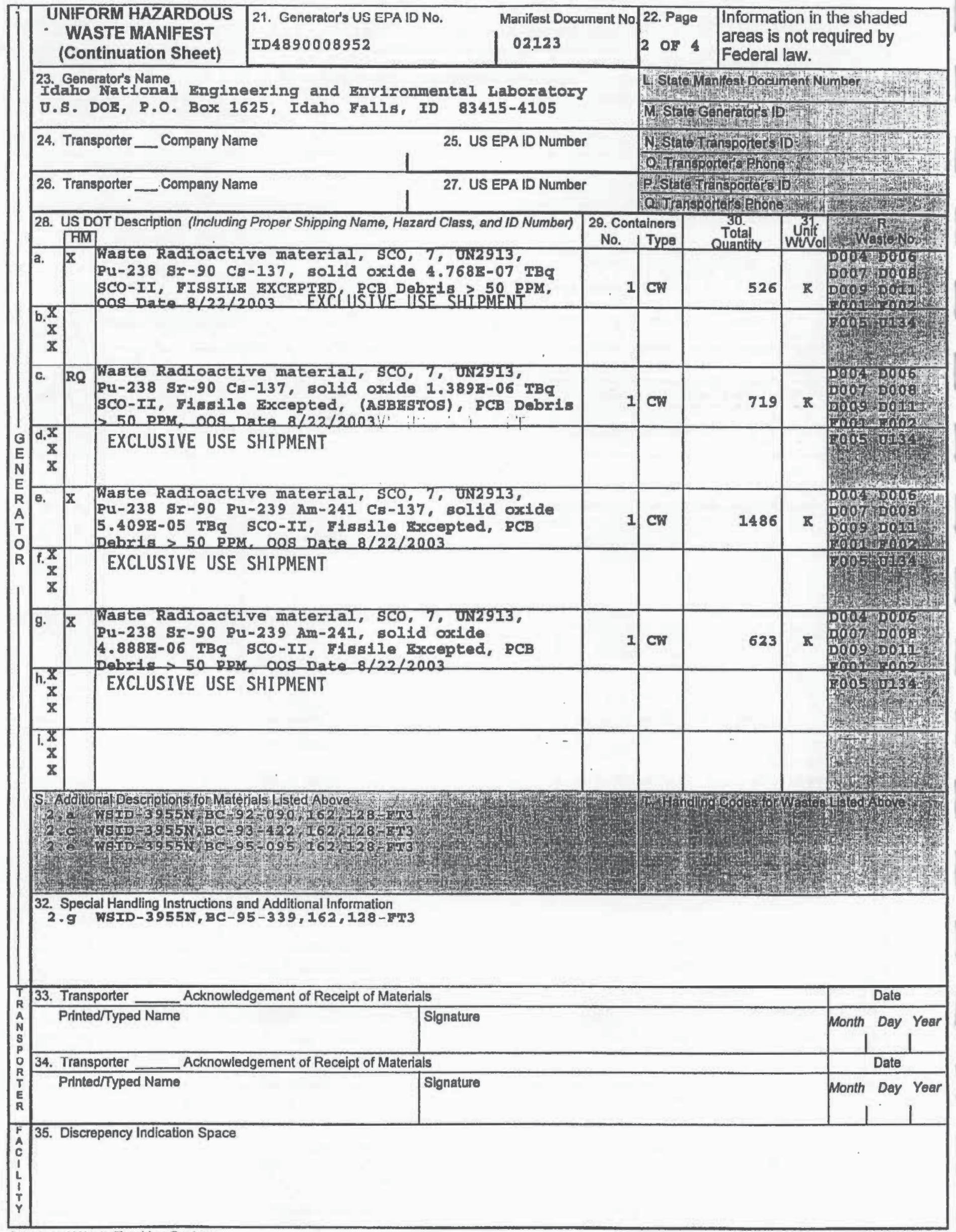




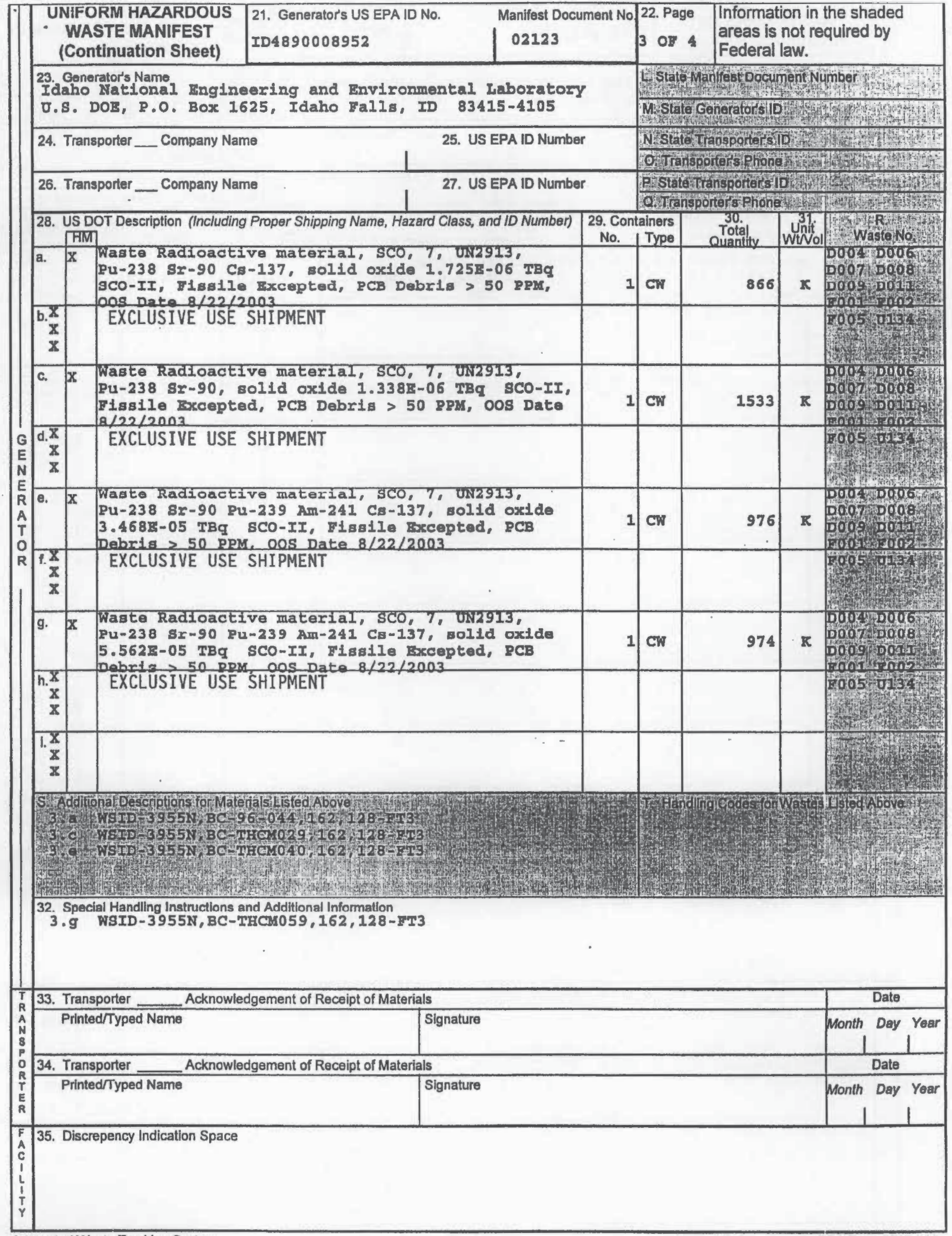




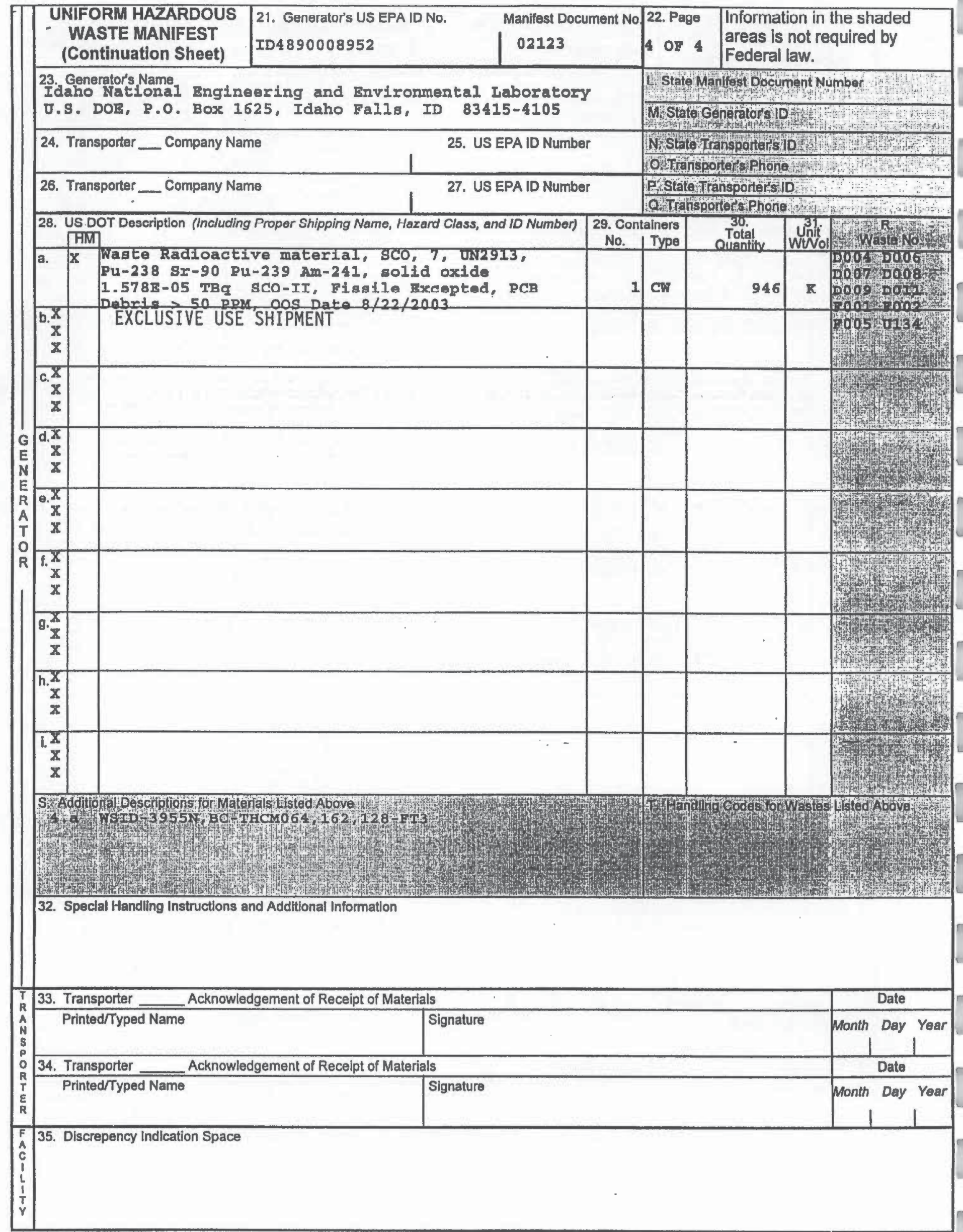




\section{ENVIROCARE OF UTAH, INC.}

THE SAFE ALTERNATIVE

3 mi. 5. Ext. $49,1.80$

Clive, Utah $84029 \mathrm{EPA}$

D: UT982598898

\section{CERTIFICATE OF DISPOSAL}

This Certificate acknowledges that the following manifested shipments:

$\underset{9030-02-0002}{\text { Shipment }} \frac{\text { Mawifest }}{02123} \quad \frac{\text { Date(s) of Disposal }}{8 / 12,8 / 16,2004} \quad \frac{\text { Cu/Ft }}{1408} \quad \frac{\text { Process }}{\text { LandFill Mixposal Location }}$

MLL

Representing 1408 Cubic feet of waste of at listed Disposal Facility landifl. Disposal is subject to Envirocare's Raditoactive Material License, all other applicable licenses, permits and regulations, and the Disposal Agreement.

Under civil and criminial penalties of law for the making or submission of false or frudulent statements or representations (18 U.S.C 1001 and 15 U.S.C. 2615 ) ? certify that the information contuined in or accompanying this docursent is true, aceurate and convplete. Aa to the identification section(s) of this document for which I cannot personally verify trath and aceuracy, I certify as the comporny offectab having supervisory

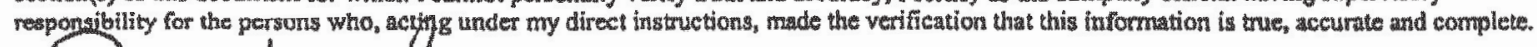
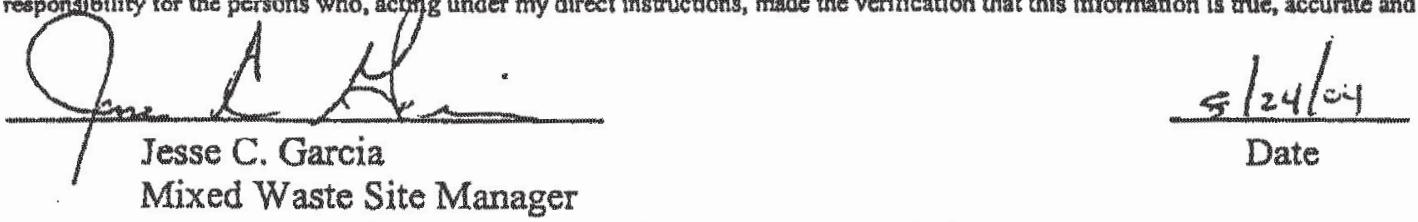

605 N. 3600 W. Sall Lake City, Uhah 84116 Telephone (801) 532.1330 



\begin{tabular}{|c|c|c|c|c|}
\hline $\begin{array}{l}\text { UNIFORM HAZARDOUS } \\
\text { WAETE MANIFEST }\end{array}$ & $\begin{array}{l}\text { 1. Generator's US EPA ID No. } \\
\text { ID4890008952 }\end{array}$ & $\begin{array}{l}\text { Manifest } \\
\text { Document No. } \\
02130\end{array}$ & $\begin{array}{c}\text { 2. Page } 1 \\
\text { of } 2\end{array}$ & $\begin{array}{l}\text { Information in the shaded areas } \\
\text { Is not required by Federal law. }\end{array}$ \\
\hline \multirow{2}{*}{\multicolumn{3}{|c|}{$\begin{array}{l}\text { 3. Generator's Name and Mailing Address } \\
\text { Idaho National Englneering and Environmental Laboratory U.S. } \\
\text { DOE, P.O. Box 1625, Idaho Falls, ID 83415-4105 }\end{array}$}} & \multicolumn{2}{|c|}{ A. State Manifest Document Number } \\
\hline & & & \multicolumn{2}{|c|}{ 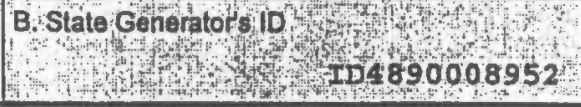 } \\
\hline \multirow{2}{*}{\multicolumn{2}{|c|}{$\begin{array}{l}\text { 5. Transporter } 1 \text { Company Name } \\
\text { Iri-state Motor Transit }\end{array}$}} & \multirow{2}{*}{$\begin{array}{l}\text { 6. US EPA ID Number } \\
\text { MOR000505347 }\end{array}$} & \multirow{2}{*}{\multicolumn{2}{|c|}{ C. State Transporterslb }} \\
\hline & & & & \\
\hline \multirow{2}{*}{\multicolumn{2}{|c|}{ 7. Transporter 2 Company Name }} & \multirow[t]{2}{*}{ 8. US EPA ID Number } & \multirow{2}{*}{\multicolumn{2}{|c|}{$\begin{array}{l}\text { E Statetransporters do } \\
\text { F Transporter's Phone ( }\end{array}$}} \\
\hline & & & & \\
\hline \multirow{2}{*}{\multicolumn{2}{|c|}{$\begin{array}{l}\text { 9. Designated Facility Name and Site Address } \\
\text { Envirocare of Utah, Inc. } \\
\text { US I-80 Exit } 49 \text { Toole County } \\
\text { Clive, UT } 84029 \\
\end{array}$}} & ID Number & \multicolumn{2}{|c|}{ G Stale Facilfy's iD } \\
\hline & & 98898 & \multicolumn{2}{|c|}{ 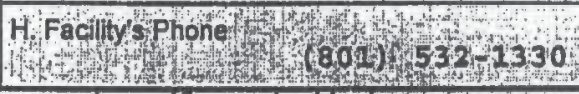 } \\
\hline
\end{tabular}

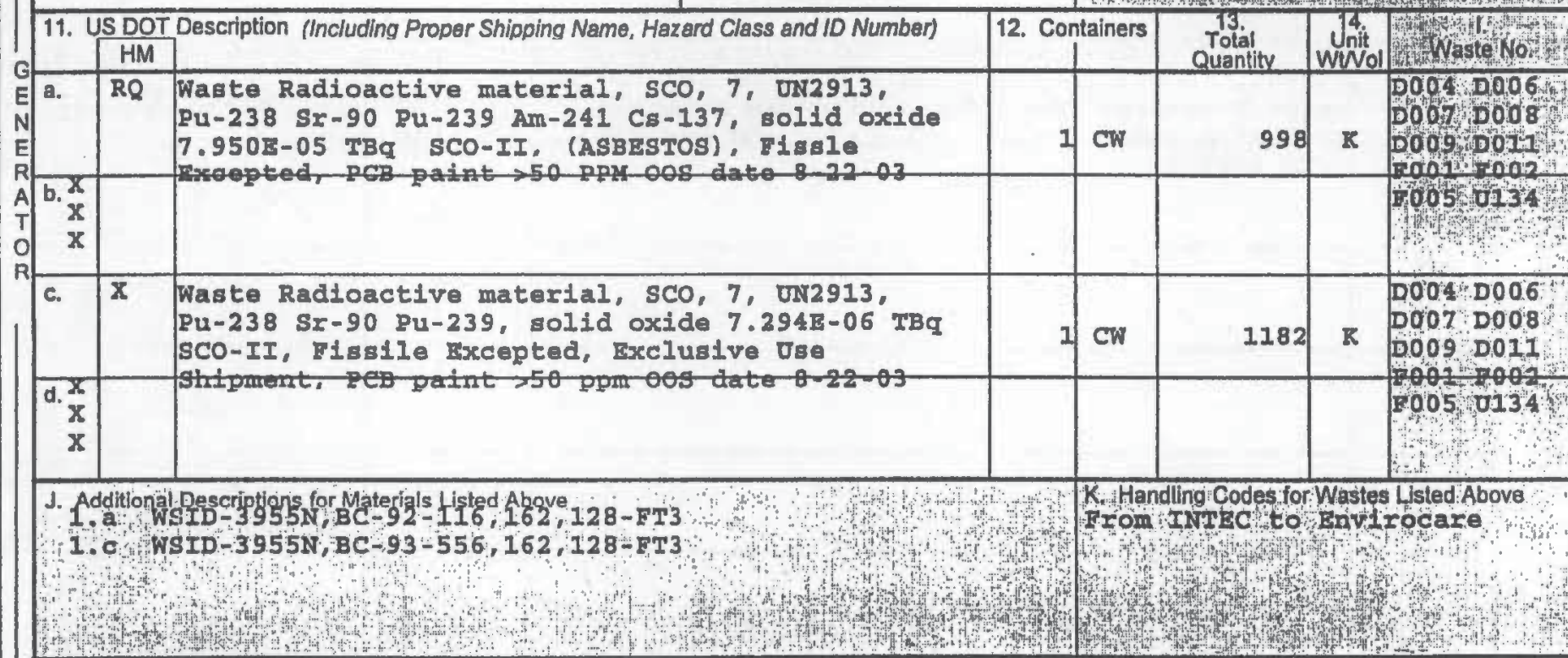

15. Special Handling Instructions and Additional Information

Return algned original to: S.M. Linta Idaho Nationäl Engineering Environmental

Laboratory/US DOE, P.O. Box 1625. Idaho Falls, ID 83415-5117. Prepared under contract \#DEAC07 99ID 13727. USDOE 24-Fr. Emergency Phone: 208 526-1515. Exclusive Ose Shipment

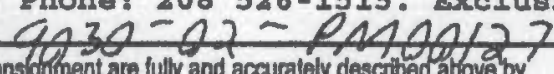

16. GENERATOR'S CERTIFICATION: I hereby declare that the contents of this consighimant are fully and accuralely descrited above by proper shipping name and are classified, packed, marked, and labeled, and are in all respects in proper condlition for transport by highway according ic applicable international and national govemment regulations.

III am a large quantity generator, I certify that I have a program in place to reduce the volume and toxicily of waste generated to the degree I have delernined to be economically practlcable and that I have selected the practicable method of treatment, storage, or disposal currenty avallable to me which minimizes the present and future threat to human health and the environment: OR, III am a small quantity generator, I have made a good failh effort lo minimize my waste generalon and select the best waste management method that is available to me and that I can afford.

Printed/Typed Yame

$\sqrt{22}<275$

17. Transporter 1 Acknowledgement of Receipt of Materials

Printed/Typed Name

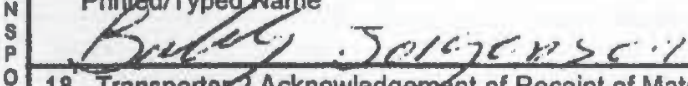

18. Transportar 2 Acknowledgement of Receipt of Materials

Printed/Typed Name
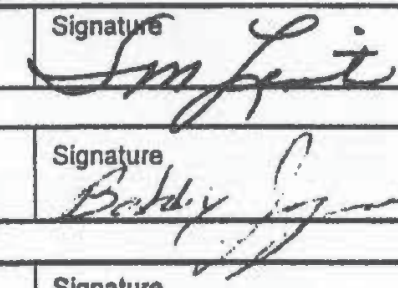

?
Signature

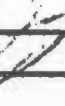

$1-2$

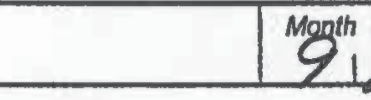

gith Day Year 2503

F 19. Discrepancy Indication Space

C

20. Facility Owner or Operator: Certification of receipt of hazardous materials covered by this manifest except as noted in Item 19.

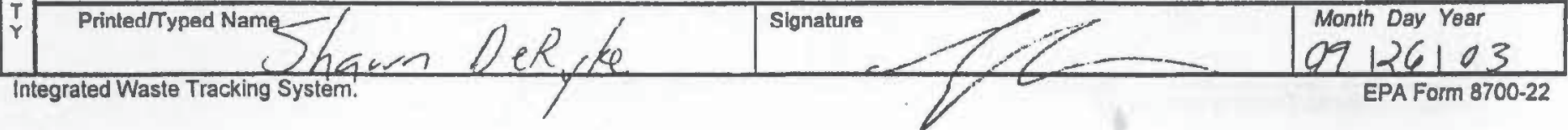




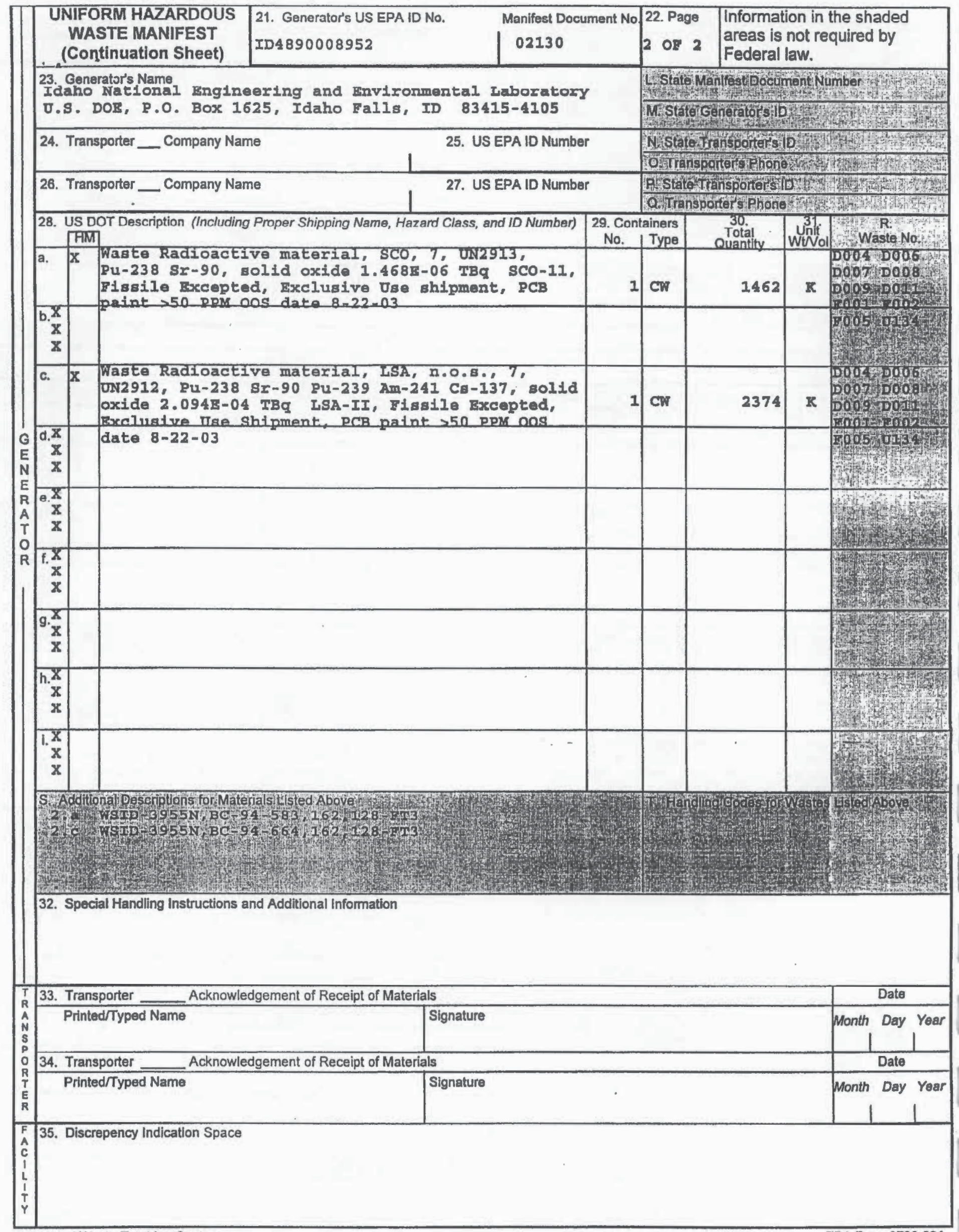




\section{ENVTROCARE OF UTAH, INC.}

THE SAFE ALTERNATIVE

3 mi, S. I.xL 49.1.80

Clive, Uiaht 404022 rtrs

ID: 67982588898

\section{CERTIFICATE OF DISPOSAL}

This Certificato acknowledges that the following manifested shipments:

\begin{tabular}{|c|c|c|c|c|c|}
\hline Shipment & Manifest & Date(s) of Disposal & $\mathrm{Cu} / \mathrm{Ft}$ & Process & Disposal Location \\
\hline $9030-02 m 0003$ & & $8 / 17,23,2004$ & 512 & Land FIII & Mixed Waste \\
\hline 9030-02-0004 & 02151 & $8 / 28 / 2004$ & 512 & LandFill & Mixed Waste \\
\hline
\end{tabular}

Representing 1024 Cubic feet of waste of al listed Disnosal Facility land Ru. Disposal is subject to Enviroeures Radioactive Material License, all other applicable licenses, permits and regulations, and the Disposal Agreement

Under civil and criminal pernalthes of law for the making car submäsion of false or frauduem statements or representations (18 U.S.C. 1001 and 15 U.S.C. 2615) ! cerify that the intomation contained in or accompanying this ducument is tue, wecurste and complete. As to the identificatinn section(s) of this document for which I canno gersnnally verify truth and accuracy, I ererify as the company official having supervisory

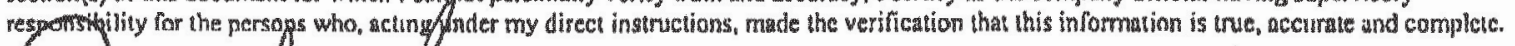
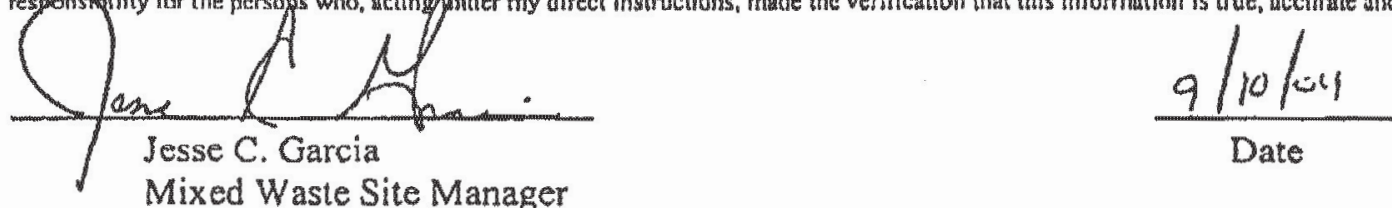

605 N. 5600 W, sals lake City, Whah 84116 Telephone (801) 532.1330 



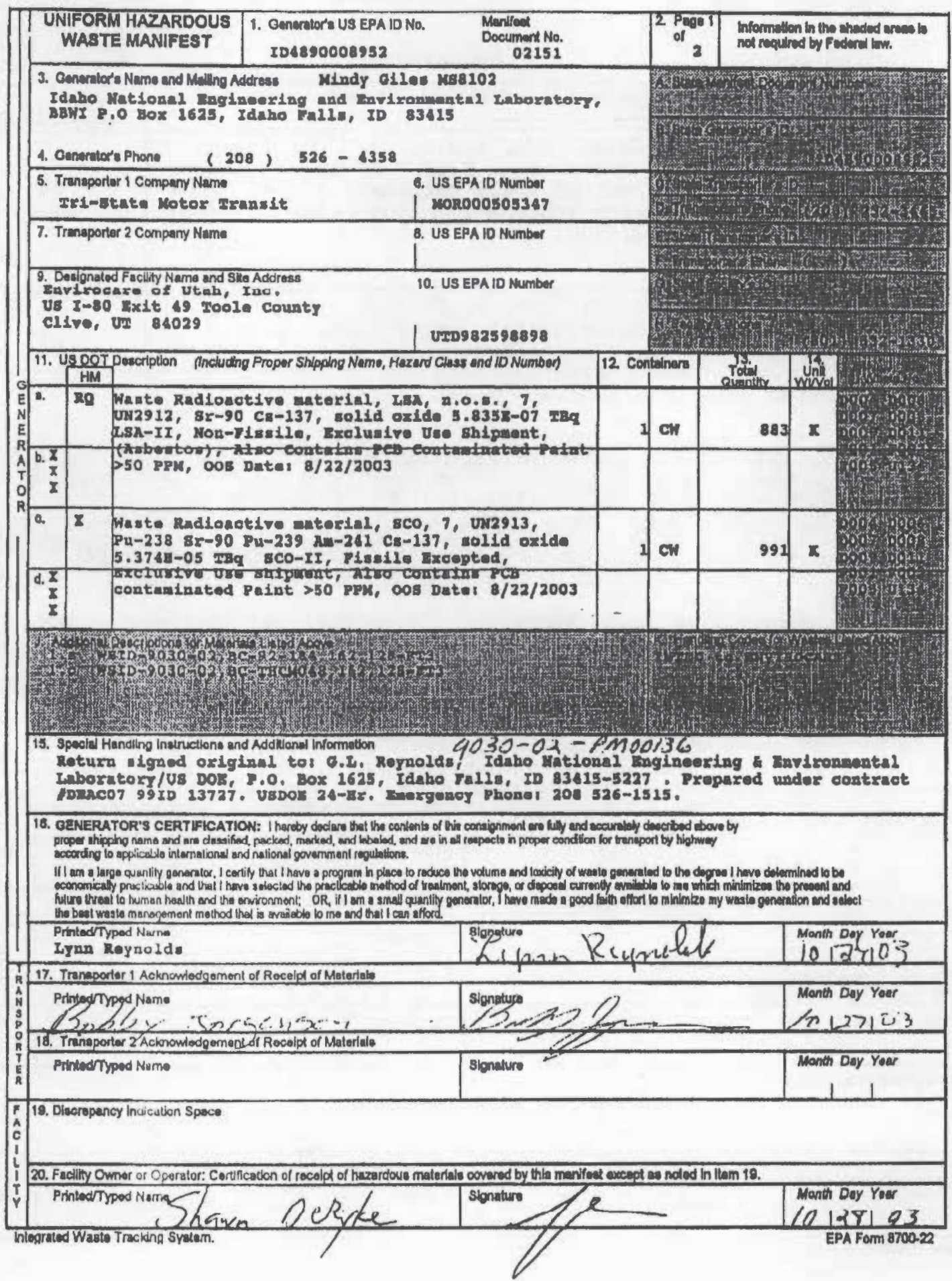




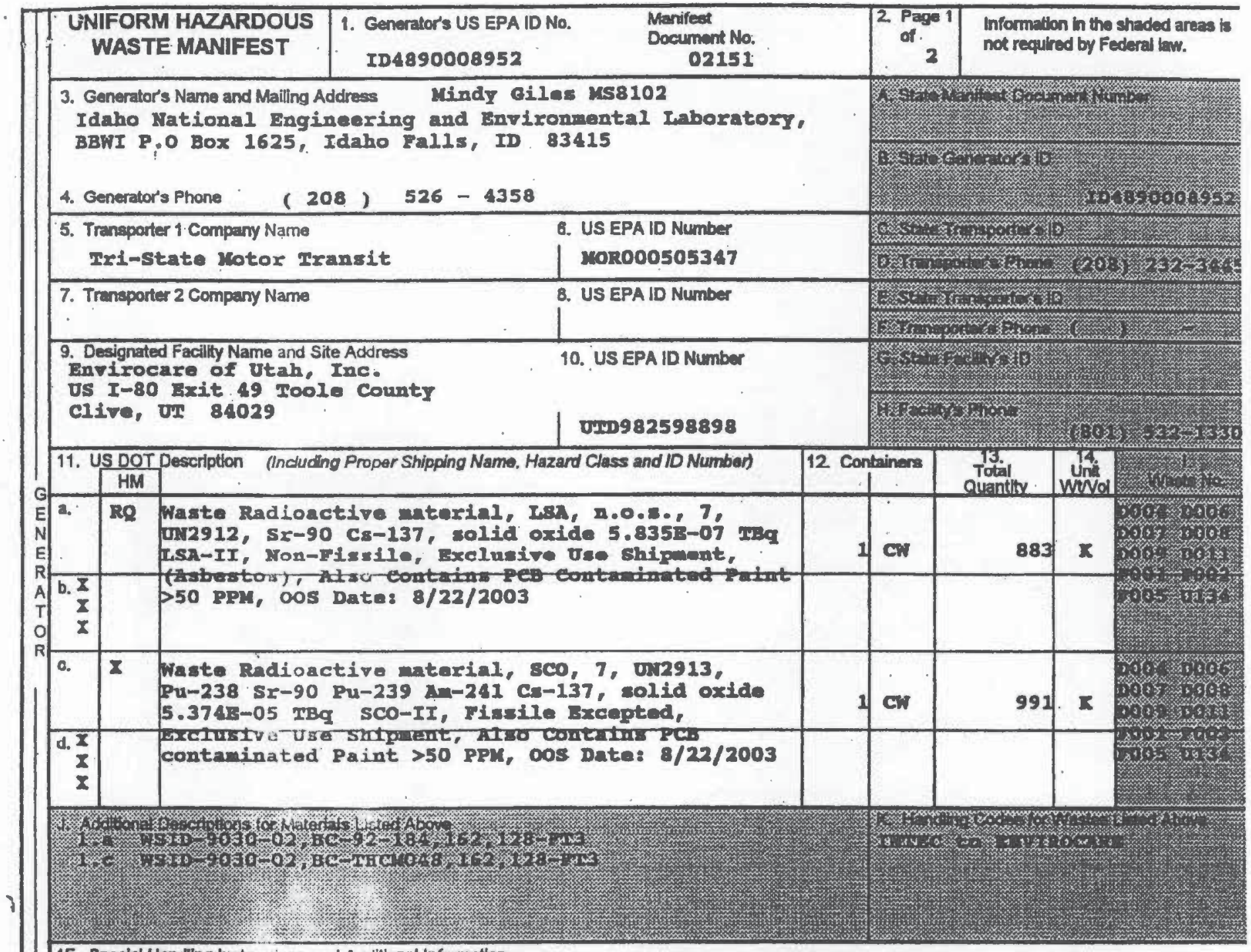

15. Spectel Handiling Instru iuns and Auditional Information

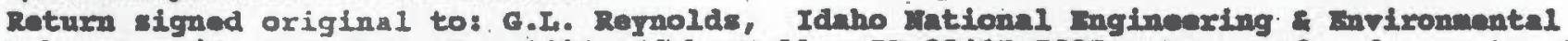
Laboratory/US DOE, P.O. Box 1625, Idiho Falls, ID 83415-5227. Propared under contract

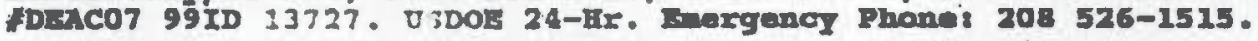

16. CENERATOR'S CERTIFICATION: I hereby dectare that the contents of this consignment are lully and accurately described above by proper shipping name and are classified, pecked, marked, and abeled, and are in all reapects in proper condition for transport by highway

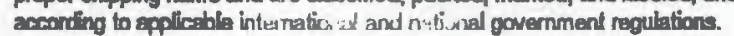

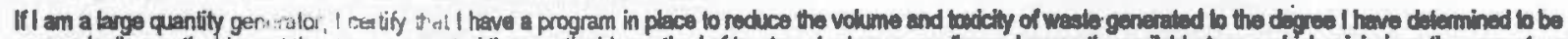
economicaly practicable ar. future threal to human heai. I and 8 res err. the best waste managemes inis:th, $n 1$ that is avaikable to me and that $I$ can afford.

Printed/yped Name

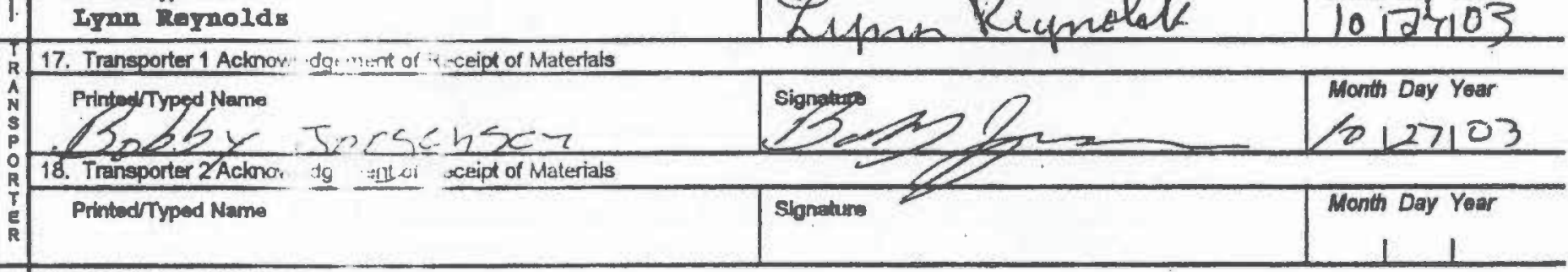

19. Discrepancy Indication Space

20. Facilly Owner or Oper or. Certification of receipt of hazandous materials covered by this manifest except as noted in ltem 19. \begin{tabular}{l|l|l}
$r$ & Printed/Typed Name & Signature
\end{tabular}

Integrated Waste Tracking $S$, em. 


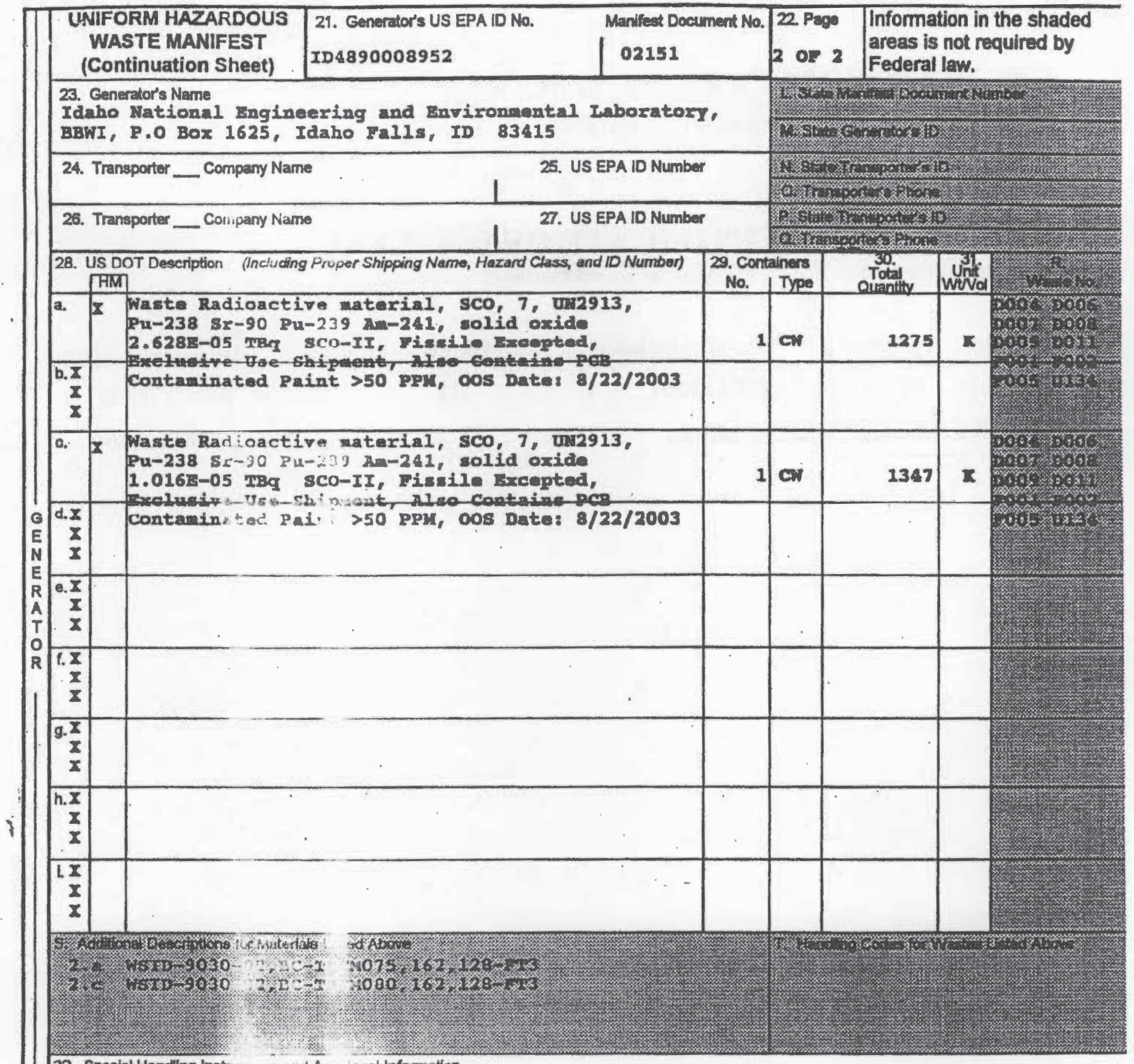

32. Special Handing Inetruci $x$ is and A....cival Information

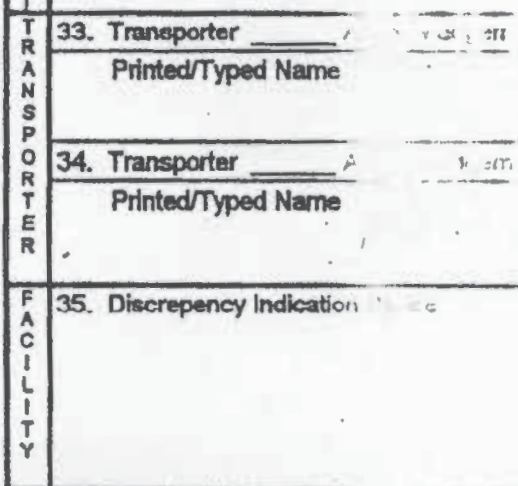

\begin{tabular}{|l|l|c|}
\hline Sicuceipt of Naterlals & Date \\
\hline & Signature & Month Day Yoar \\
\hline sceipt or Materials & Signature & Date \\
\hline & & Month Day Year \\
\hline
\end{tabular}




\section{ENVIROCARE OF UTAH. INC. \\ THE SAFE ALTERNATIVE \\ 3 mi. S. fixt. 49, 1.80 \\ Clive, Utah 84020 RTA \\ ID: U'' 282598898}

\section{CERTIFICATE OF DISPOSAL}

This Certificate acknowledges that the following manifested shipments:

\begin{tabular}{|c|c|c|c|c|c|}
\hline Shipment & Manifest & Date(s) of Disposal & $\mathrm{Cu} / \mathrm{Ft}$ & Process & Disposal Location \\
\hline $9030-02-0003$ & & $8 / 17,23,2004$ & 512 & Land Fill & Mixed Waste \\
\hline 9030-02-0004 & 02151 & $8 / 28 / 2004$ & 512 & LandFill & Mixed Waste \\
\hline
\end{tabular}

Representing 1024 Cubic feet of waste of at listed Disposal Facility landfill. Disposal is subjecl to Envirocure's Radioactive Material Licensc, all other applicable licenses, permits and regulations, and the Disqosal Agreement.

Under civil and crimiual penaltues of law for the making or submission of lalse or fraudulent statements or representations (18 U.S.C. 1001 and IS U.S.C. 2615) I certify that the information contuined in of accompanying this ducument is true, aceurate and complete. As to the identificalion section(s) of this document for which I carnot personally verify truth and accuracy, I cervify as the compasiy oflicial having supervisory responsithility for the persogs who, actung (nder my direct inatructions, made the verification that this information is true, accurate and complete.

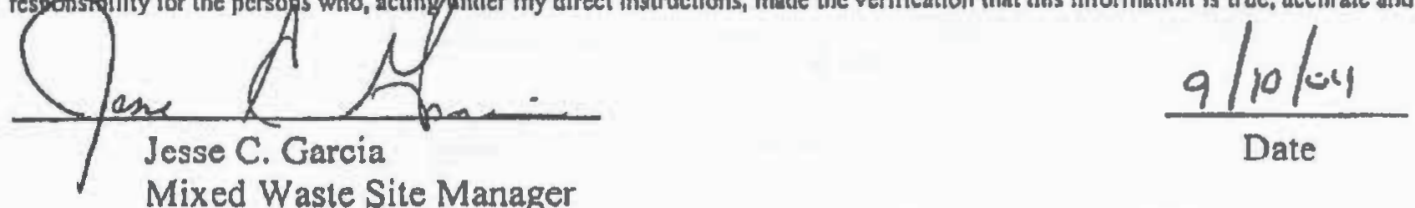

Mixed Waste Site Manager

605 N. 5600 W, Sali Lake City, Uiah 84II6 Telephone (80I) 532.1330 



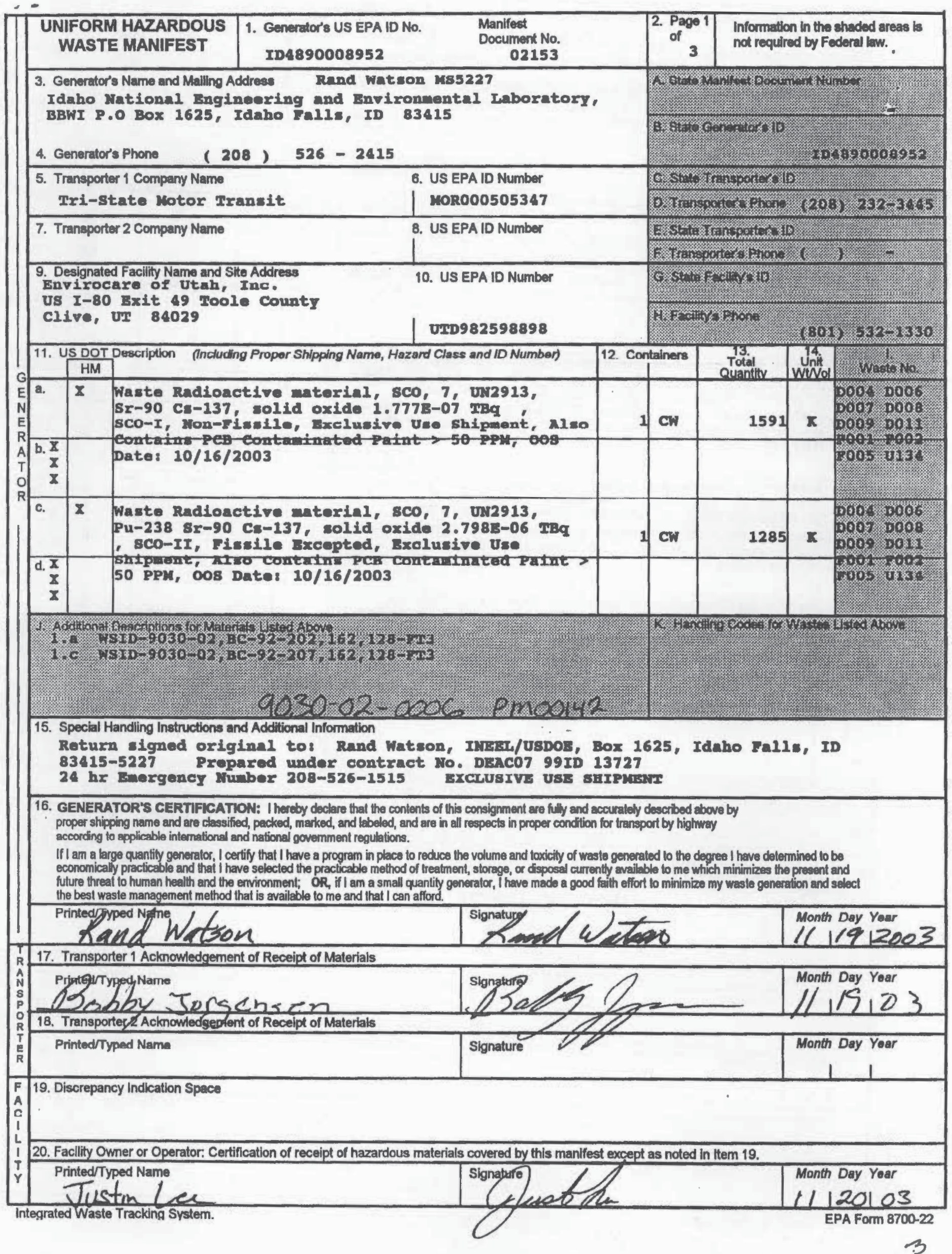




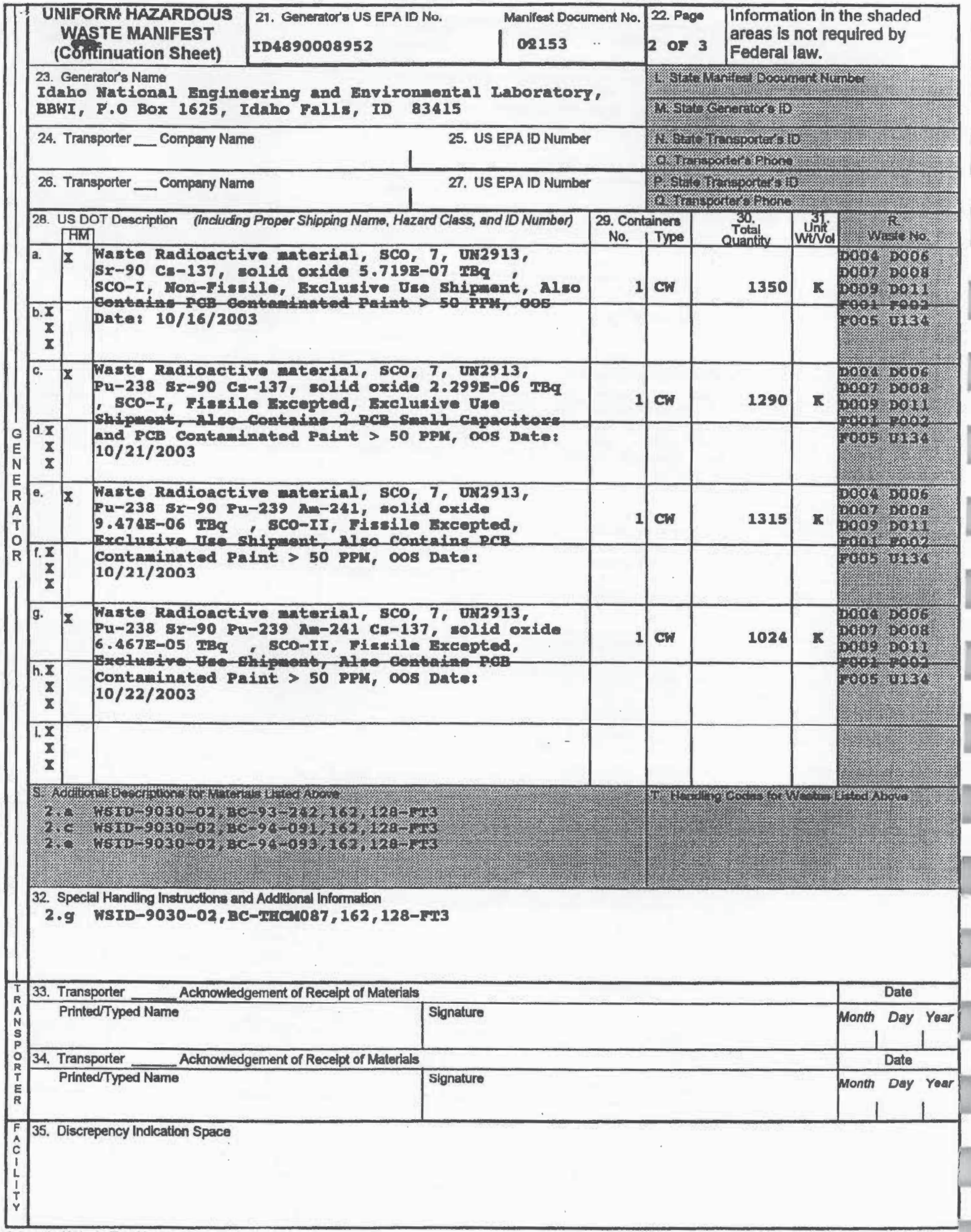




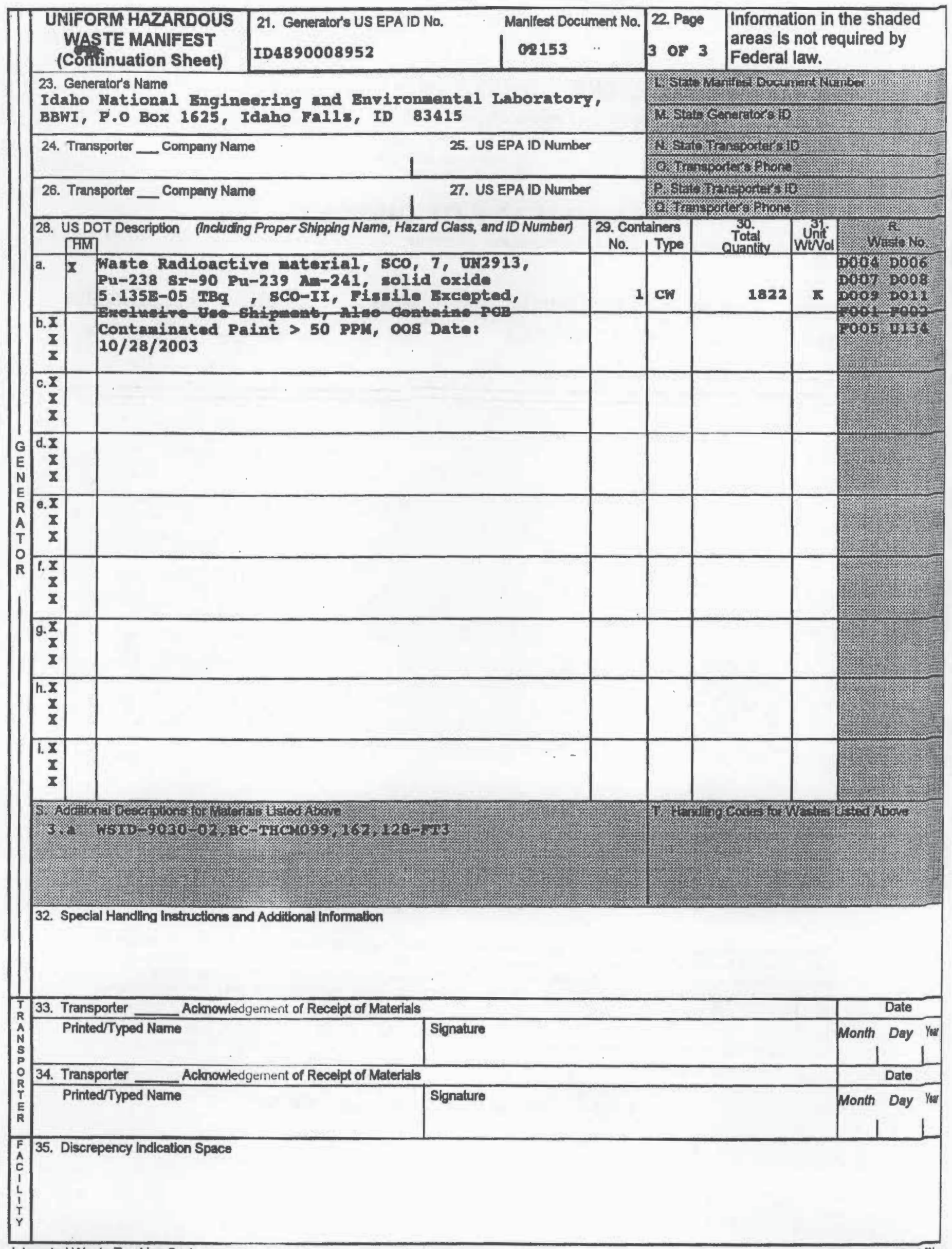




\title{
ENVIROCARE OF UTAH, INC.
}

THE SAFE ALTERNATTVE

\author{
3 mi. S. Ext. 49, 1-80 \\ Clive, Utah 84029 EPA \\ ID: UT982598898
}

\section{CERTIFICATE OF DISPOSAL}

This Certificate acknowledges that the following manlfested shipments:

\begin{tabular}{|c|c|c|c|c|c|}
\hline Shipment & Manifest & Date(s) of Disposal & $\mathrm{Cu} / \mathrm{Ft}$ & Process & Disposal Location \\
\hline $9030-02-0006$ & 02153 & $09 / 10, \quad 09 / 11 / 2004$ & 896 & LandFill & Mixed Waste \\
\hline
\end{tabular}

Representing 896 Cubic feet of waste of at listed Disposal Facility landfill. Disposal is subject to

Envirocare's Radioactive Material License, all other applicable licenses, permits and regulations, and the Disposal Agreement.

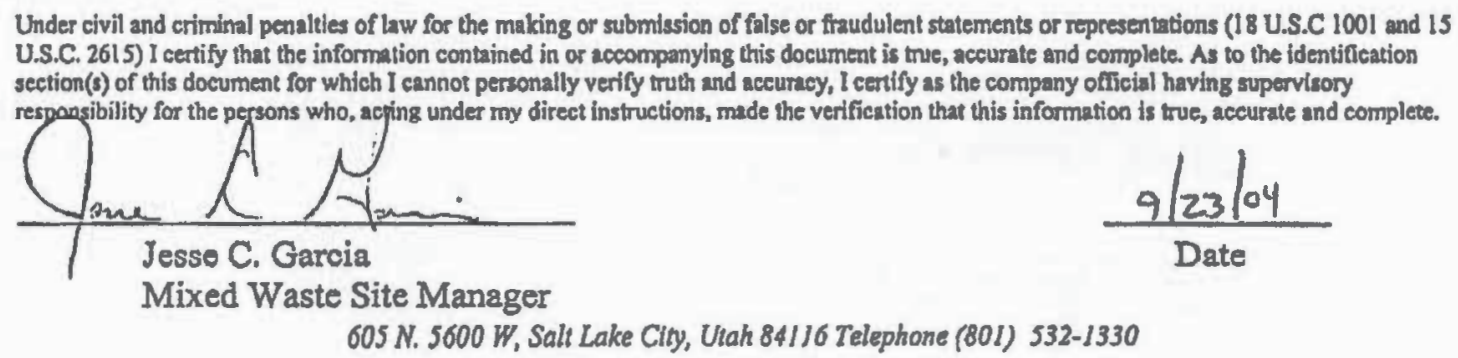





\begin{tabular}{c|cc} 
UNIFORAI HAZARDOUS & 1. Genaralor's US EPA ID No. & Manifest \\
WASTE MANIFEST & IDA690008952 & 0.02158
\end{tabular}

$\left|\begin{array}{c}2 \text { Page } \\ \text { of } 2\end{array}\right|$

Information in the shaded areas is not required by Federal isw.

3. Generutor Name and Mailing Address

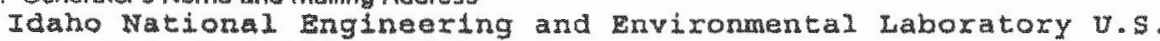

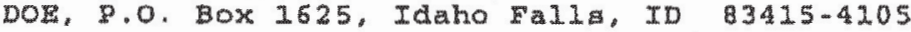

A. State Marifest Oocumen: Number

Generators phone $\quad(208) 526-2414$

B. Slate Generator's ID

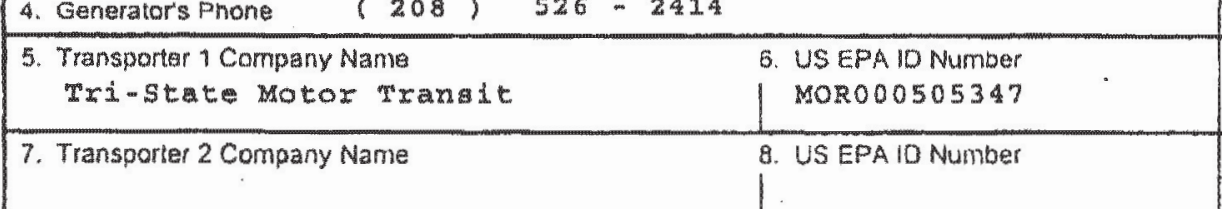

9 Dasignaled Facility Narre and Silu Address

10. US EPA ID Number

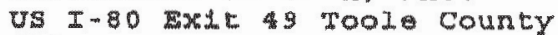

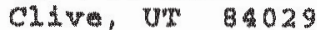

UTD982598898

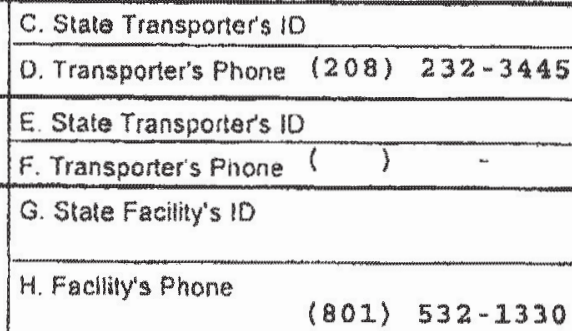

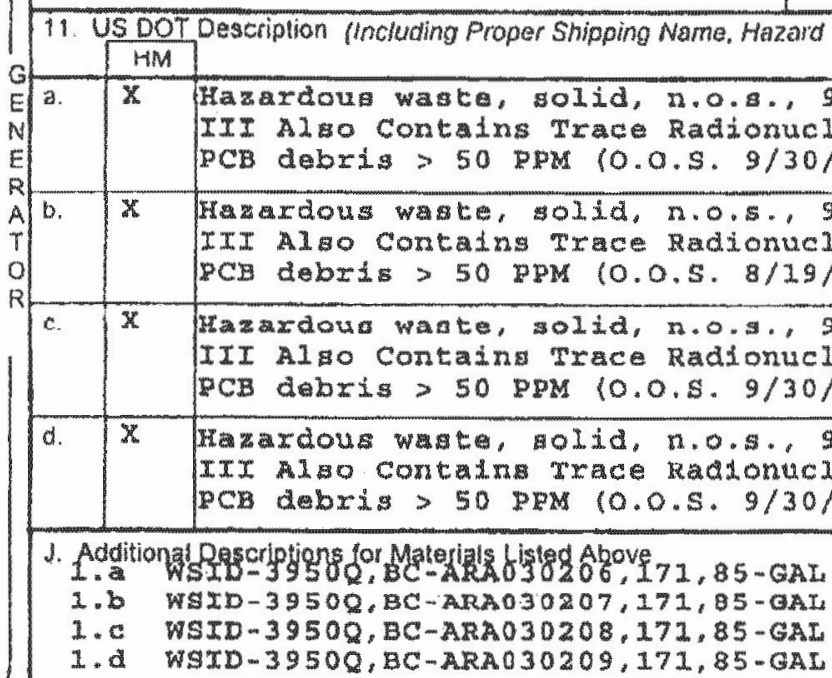

15. Special Handling instructions and Additional Infortration

DOE Account / ALthor

$208-526-2525$

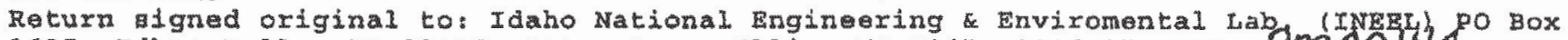

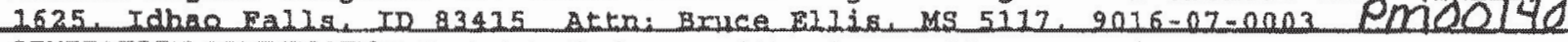

\begin{tabular}{|c|c|c|c|c|}
\hline 12. Con & tainers & $\begin{array}{l}\text { Total } \\
\text { ounguty }\end{array}$ & $\begin{array}{l}\text { Unik } \\
\text { Wuvol }\end{array}$ & $\begin{array}{c}\text { l. } \\
\text { Wasta No. }\end{array}$ \\
\hline 1$)$ & DM & 65 & K & 7001 \\
\hline 1 & $D M$ & 69 & $K$ & 5001 \\
\hline 4 & $D M$ & 64 & $K$ & 5001 \\
\hline 1. & $\mathrm{DM}$ & 65 & $\mathbb{K}$ & 8001 \\
\hline
\end{tabular}

K. Handing Codes for Wastes Listed Above

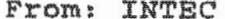

To: Envirocare of Utah

16. GENERATOR'S CERTHFICATION: I hereby dectare that the contents of this consignment are fully and accurately described above by

proper shipping name and aro classified, packed, marked, and laboled, and aro in all respocts in proper condition lor transpon by highway

accorobing to apylicable intemalional and national governmont regulations.

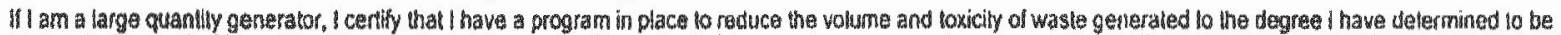

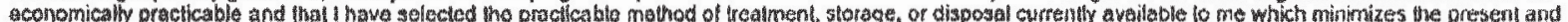

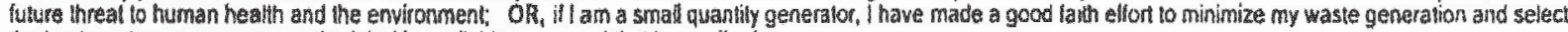

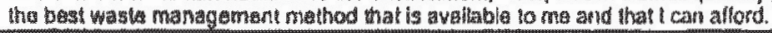

PristodTyped Namp

$\int 21-225$

11. Thansporter 1 Acknowiedgenent of Receipl of Malenals

Prinulf Typed Name

$\left.2 L^{2}\right)^{2}$
2

Wricht

18. Kansporter z Rckncwiadgement of Receipt of Materials Printedryped Mame

19. Discrepancy Indication Space

A

20. Facilly Owner or Operalor: Certilicalion of racelpt of hazardous materbals covered by this manifest except as noted in ltem 19 .

PrintedTyped Name

$\operatorname{Lith} L$

integrated Waste Tracking System.

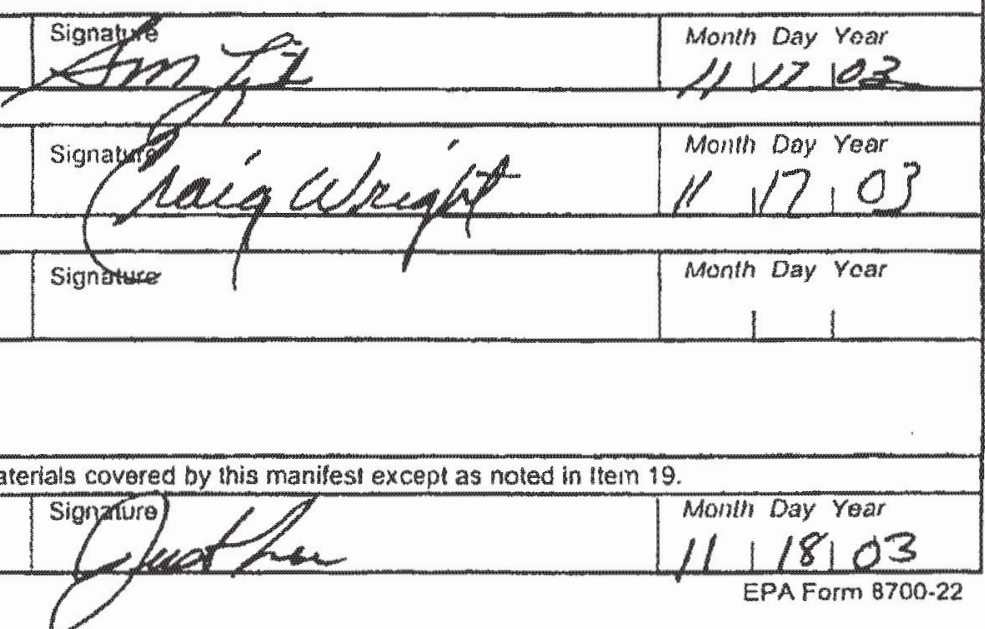




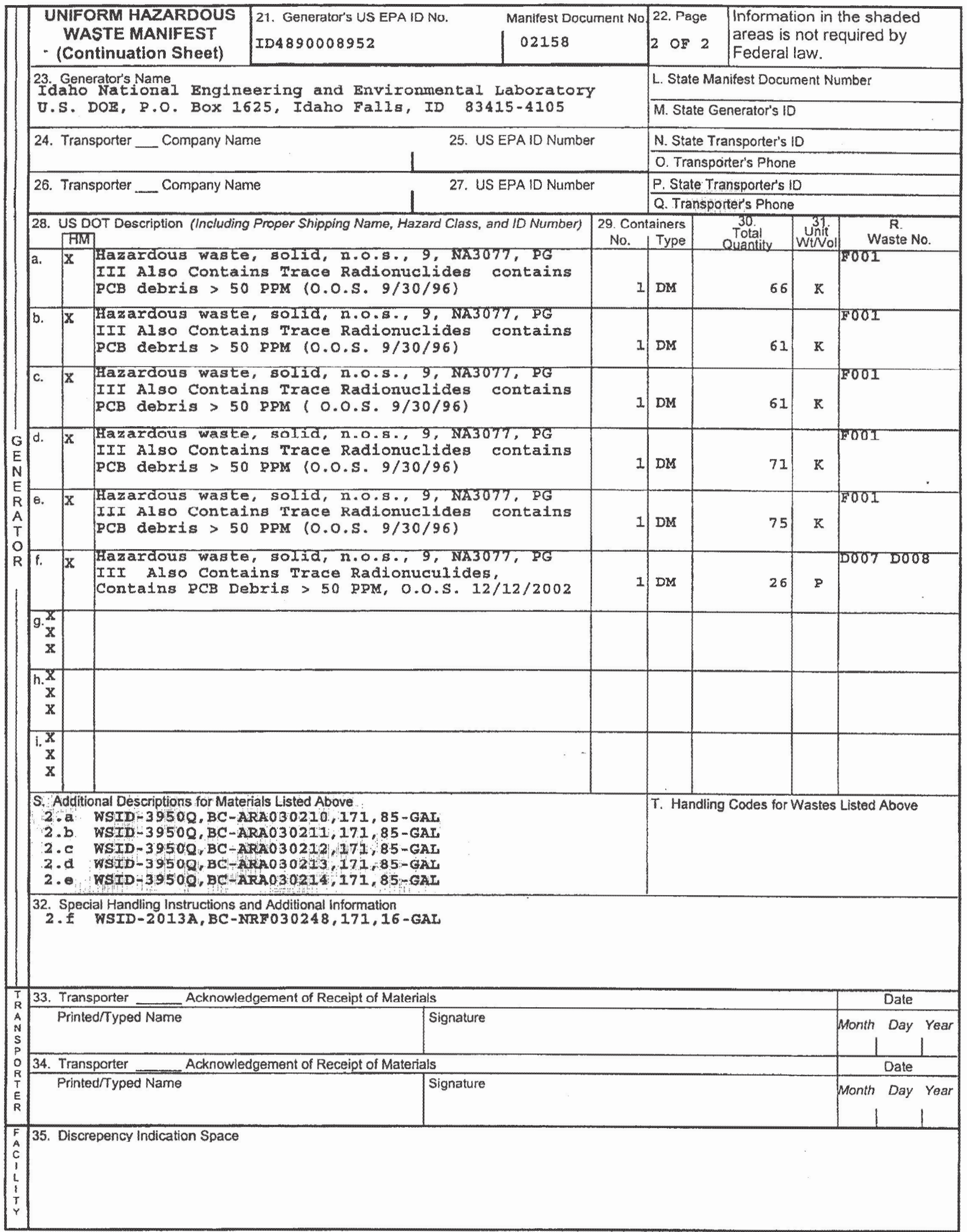




\section{ENVIROCARE}

OF UTAH. INC:

THE SAFE ALTERNATTVE

$3 \mathrm{mi.}$ S. Ext 49, 1.80

Clive, Utah $84029 \mathrm{EPA}$

1D: UTYG 2598898

\section{CERTIFICATE OF DISPOSAL}

This Certificate acknowledges that the followng manifested shipments:

$\frac{\text { Shipment }}{9016-07-0003} \frac{\text { Manifest }}{02158} \quad \frac{\text { Date(s) of Disposal }}{09 / 04 / 2004} \quad \frac{\text { Cu/Ft }}{104.4} \quad \frac{\text { Process }}{\text { Landrill }} \quad \frac{\text { Disposal Location }}{\text { Mixed Waste }}$

Representing 104.4 Cubic feet of waste of at listed Disposal Facility landfill. Disposal is subject to

Envirocaress Redioscrive Marcrial License, all other applicable licknses, permits and regulations, and the Disposal Agreernernt.

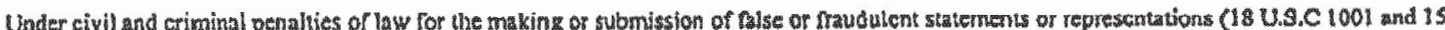

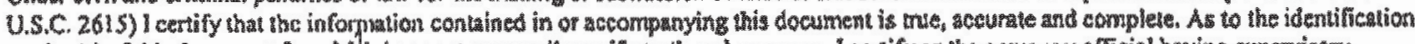

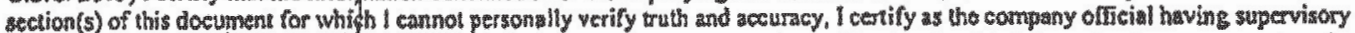

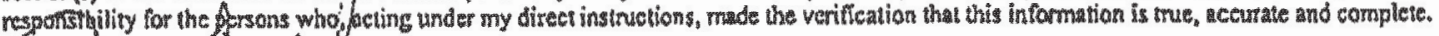
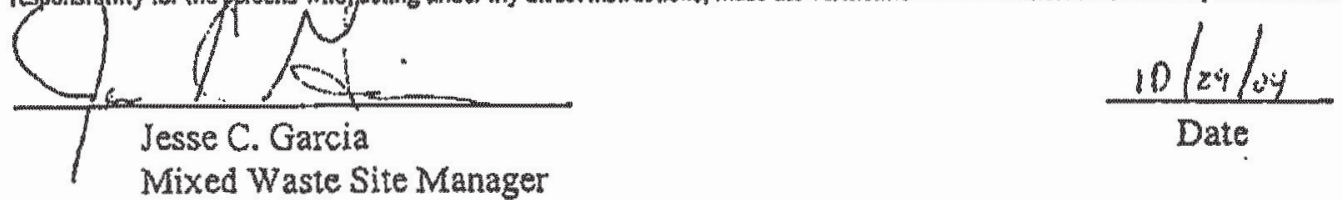

605 N. 5600 W. Sall Lake Cly, Wah 84116 Telephone (801) $\$ 32-1330$ 



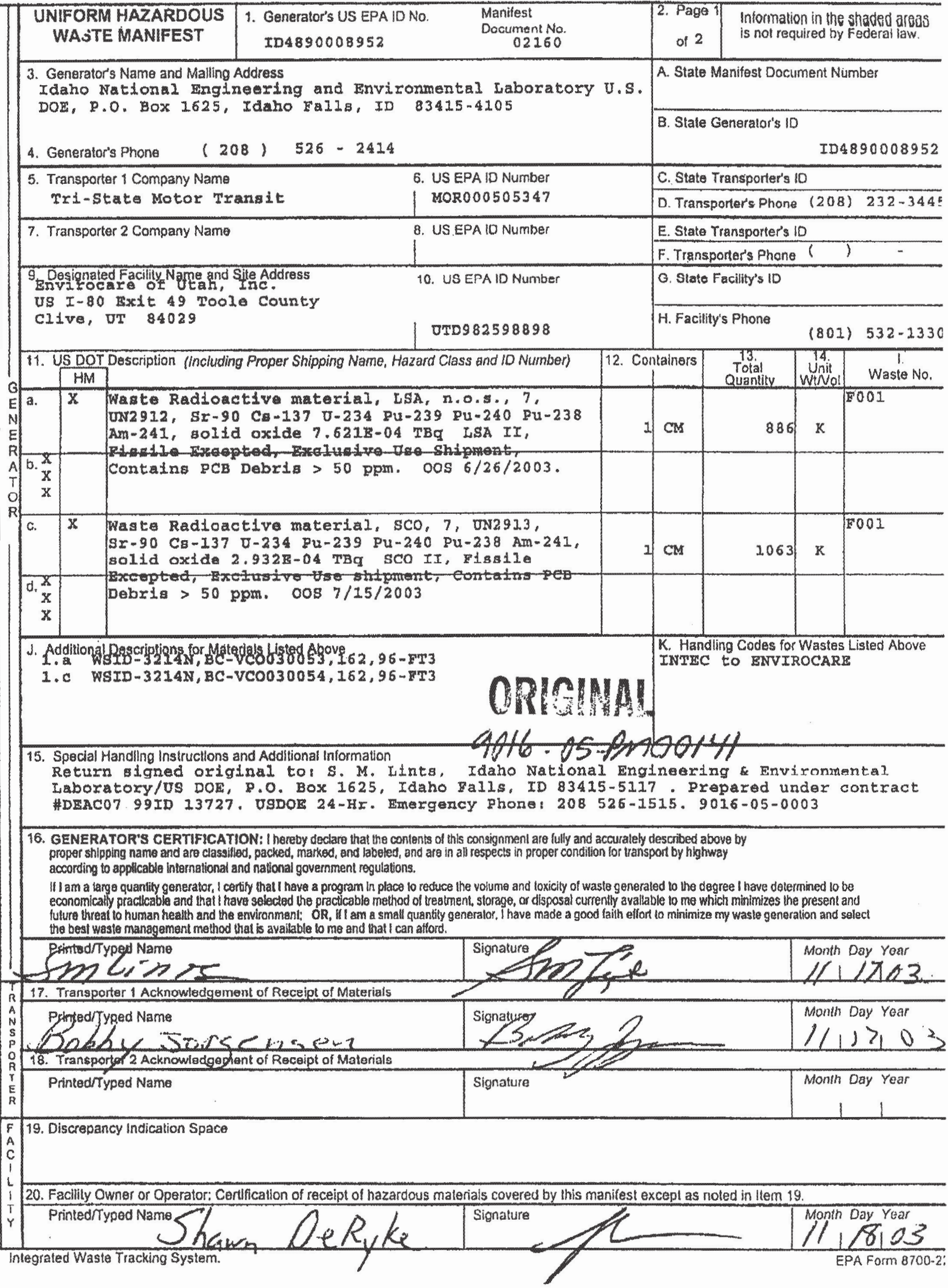




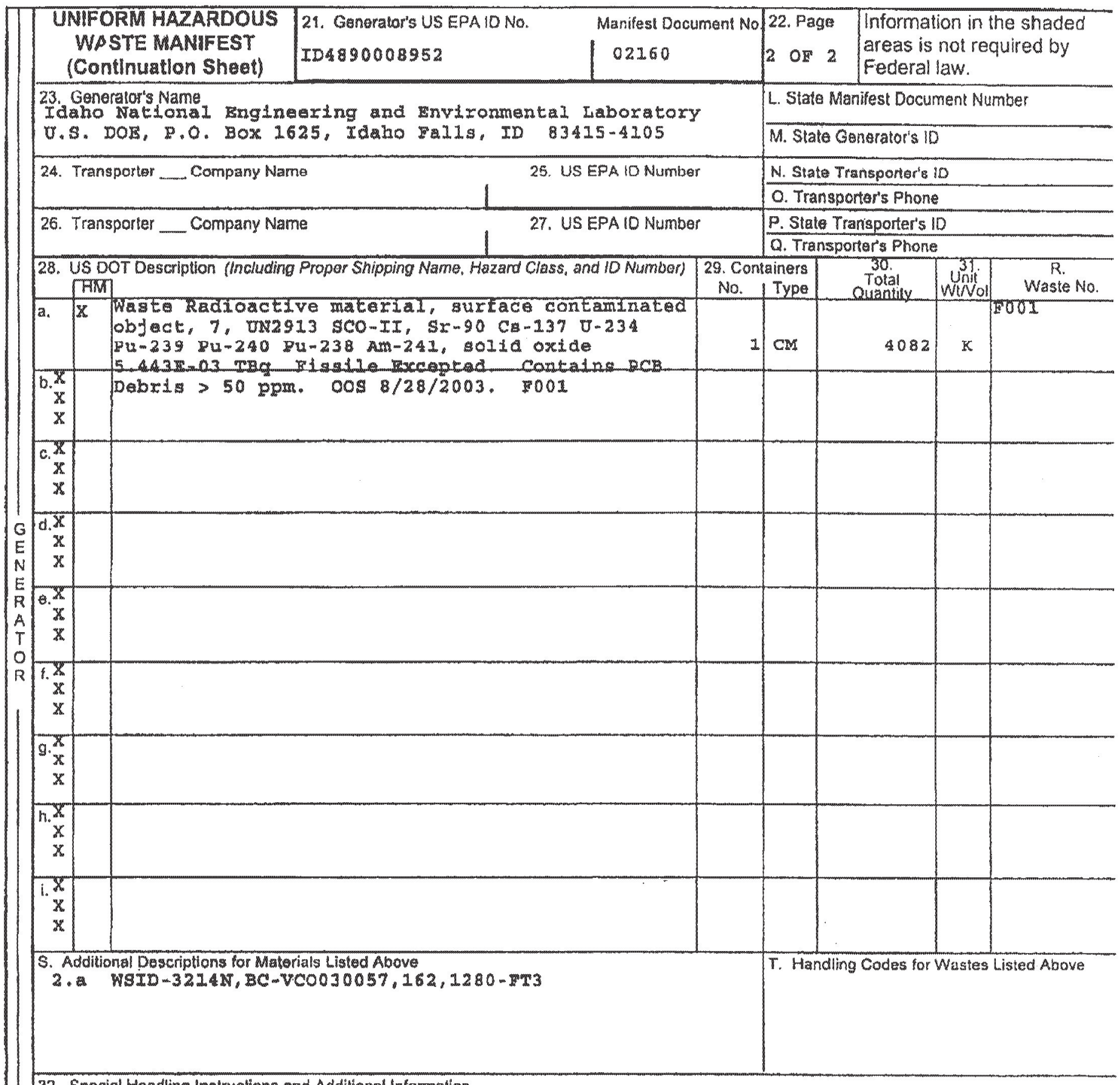

32. Spacial Handling Instructions and Additional Information

\begin{tabular}{|c|c|c|}
\hline \multicolumn{2}{|c|}{ 33. Transporter ____Acknowladgoment of Receipl of Materials } & Date \\
\hline \multicolumn{2}{|c|}{ Acknowedgoment of Recelpt of Materials } & Dalo \\
\hline
\end{tabular}

\section{Discrepency indicallon Space}




\section{ENVIROCARE}

ON UTAH. NC.

THE SAFE ALTERNATTVE

3 m. s. Ext. $49,11.80$

Clives, Wtat 4009

ID: UTY82358ggg

\section{CERTIFICATE OF DISPOSAL}

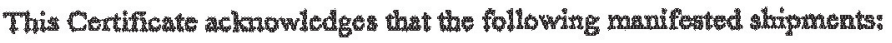

$\frac{\text { Shipment }}{001605-0003} \frac{\text { Manifest }}{02180} \quad \frac{\text { Date(s) of Disposal }}{11 / 48 / 2004} \quad \frac{\text { Cw/ft }}{1472} \quad \frac{\text { Process }}{\text { Landth }} \quad \frac{\text { Disposal Location }}{\text { Mixed Wasto }}$

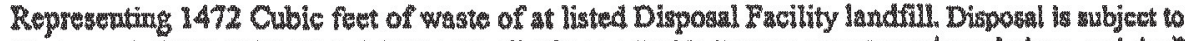

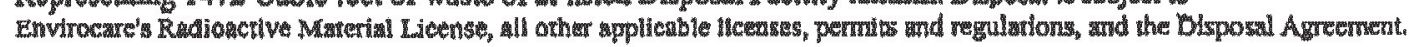

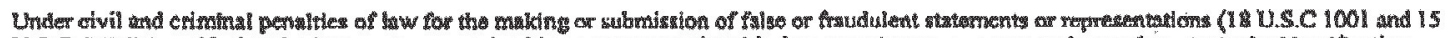

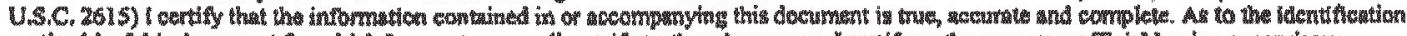

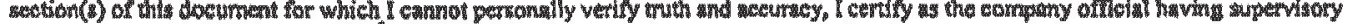

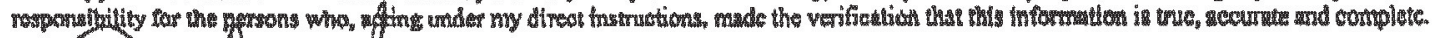

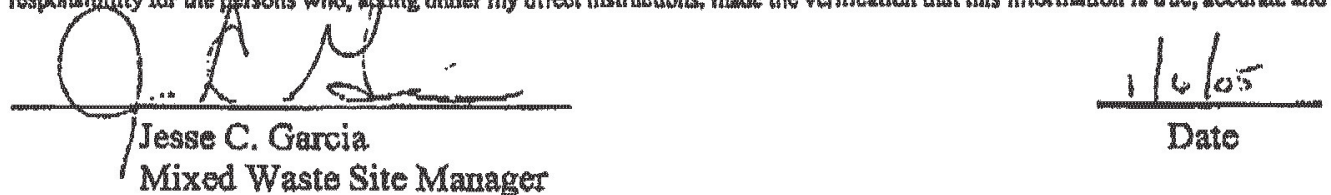

605 N. 5600 W. Sall Lake City, Wroh 84116 Thighone (801) \$32-1330 


\section{$"$}




\begin{tabular}{|c|c|c|c|c|}
\hline $\begin{array}{c}\text { UNIFORN: HAZARDOUS } \\
\text { WASTE: MANIFEST }\end{array}$ & $\begin{array}{c}\text { 1. Generator's US EPA ID No. } \\
\text { ID4890008952 }\end{array}$ & $\begin{array}{c}\text { Manifest } \\
\text { Document No. } \\
02175\end{array}$ & $\begin{array}{c}\text { Page 1 } \\
\text { of } 4\end{array}$ & $\begin{array}{c}\text { Information in the shaded.areas } \\
\text { is not required by Federal law. }\end{array}$ \\
\hline
\end{tabular}

3. Generator's Name and Mailing Address

Idaho National Engineering and Environmental Iaboratory, BBWI P:O BOx 1625, Idaho Falls, ID 83415

A. State Manifest Document Number *

B. State Generator's ID

4. Generator's Phone (208) $526-8505$

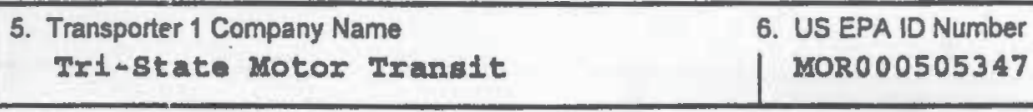

In 4890008952

7. Transporter 2 Company Name 8. US EPA ID Number

9. Designated Facility Name and Site Address

invirocare of Utah, Inc.

10. US EPA ID Number

US I-80 ExIt 49 Toole County

Clive, UI 84029

UYD 982598898

C. State Transporter's ID

D. Transporter's Phone (208) 232-3445

11. US DOT Description (Including Proper Shipping Name, Hazard Class and ID Number) 11. US DOT Des

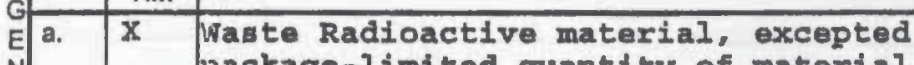

N package-limited guantity of material, 7, oN2910

E $\quad$, contains PCBs $220 \mathrm{ppm}$, COs date: 6-11-2001

A b. $\mathrm{X}$ Hazaxdous waste, solid, n.0.8., 9, NA3077, PG

T) III, Also Contains Trace Radionuclides,

o wontains plastic and cloth contaminated with

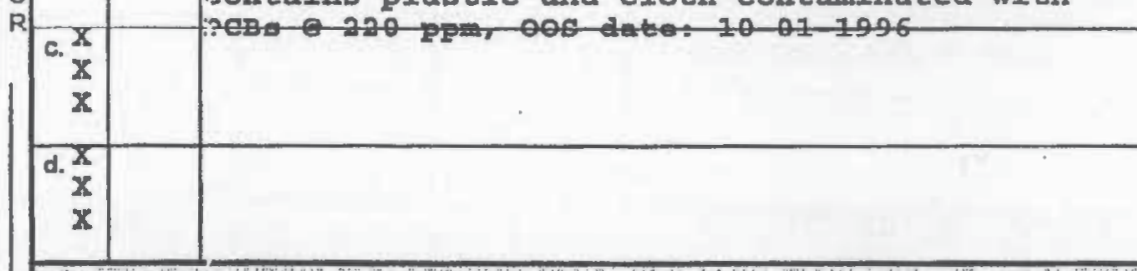

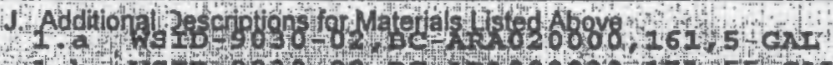

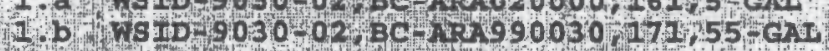

$+3$

inting

15. Special Handling Instructions and Additional Information

Return sIgned orIginel to: $R$ T Kendrick, INEE/0SDos, Box 1625 - MS5227, Idaho Falls, Id 83415-5227. Prepaxed under contract: DEACO7 99ID 13727. Inergency phone: 208-526-1515. EXCLUSIVR USE SHIPMEMT $4030-02-10120144$

16. GENERA'TOR'S CERTIFICATION: I hereby dectare that the contents of this consignment are fully and accurately described above by proper shlpping name and are ctassitied, packed, marked, and labeled, and are in all respects in proper condlition for transport by highway according to applicable intemational and national govemment regulations.

If I am a larg s quantity generator, I certify that I have a program in place to reduce the volume and toxicty of waste generated to the degree I have determined to be economically practicable and that I have selected the practicable method of treatment, storage, or disposal currenty avallable to me which minimizes the present and future threat to human health and the environment: $\mathrm{OR}$, III am a small quantily generator, I have made a good faili effort to mininize my waste generation and select the best waste management method that is avallable to me and that I can afford.
Printed/Ty sed Name
R. T. Kendrick
Signature.

17. Transporjer 1 Acknowledgement of Receipt of Materials

\begin{tabular}{|c|c|c|}
\hline Printegfy sed Name & Sign & $\begin{array}{l}\text { Monts Day Yoar } \\
1 / \quad 12410\end{array}$ \\
\hline \multicolumn{3}{|c|}{ 18. Traksporrer 2 Acknowledgement of Receipt of Materials } \\
\hline Printed/Typed Name & Signaty & Month Day Year \\
\hline
\end{tabular}

\begin{tabular}{l|l}
\hline F & 19. Discrepanisy Indication Space \\
C & \\
i & \\
L & \\
1 & 20. Facilly Owner or Operator: Centification \\
Y Printed/Typed Name &
\end{tabular}

Integrated Waste Tracking System.

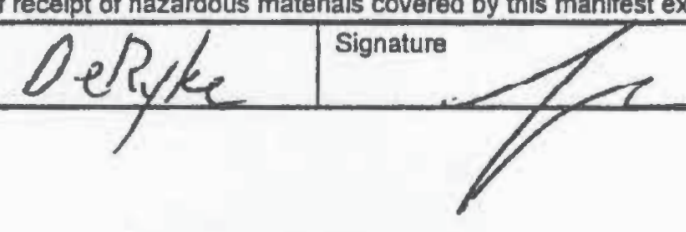

Month Day Year

$11 \times 5103$

EPA Form $8700-22$ 


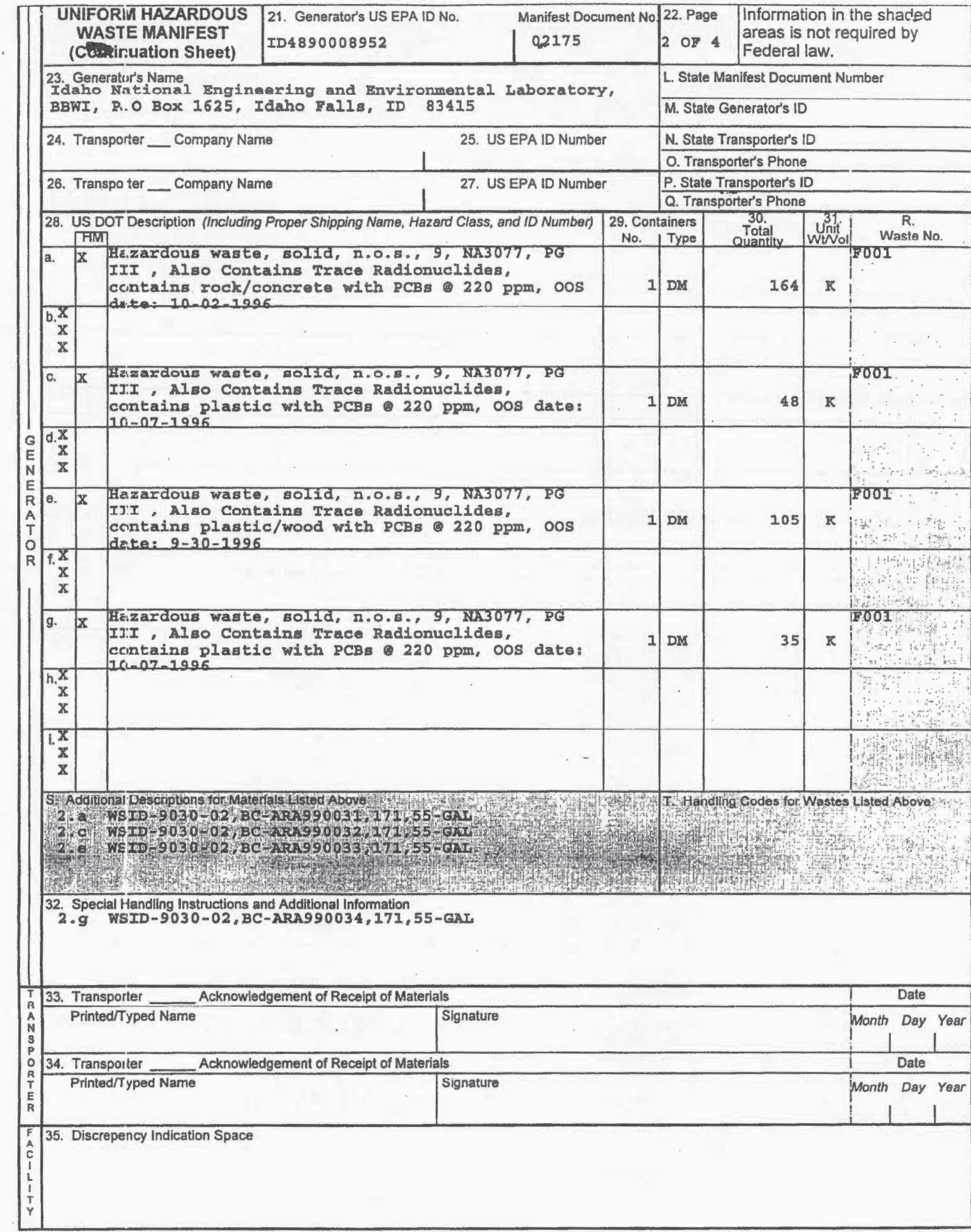




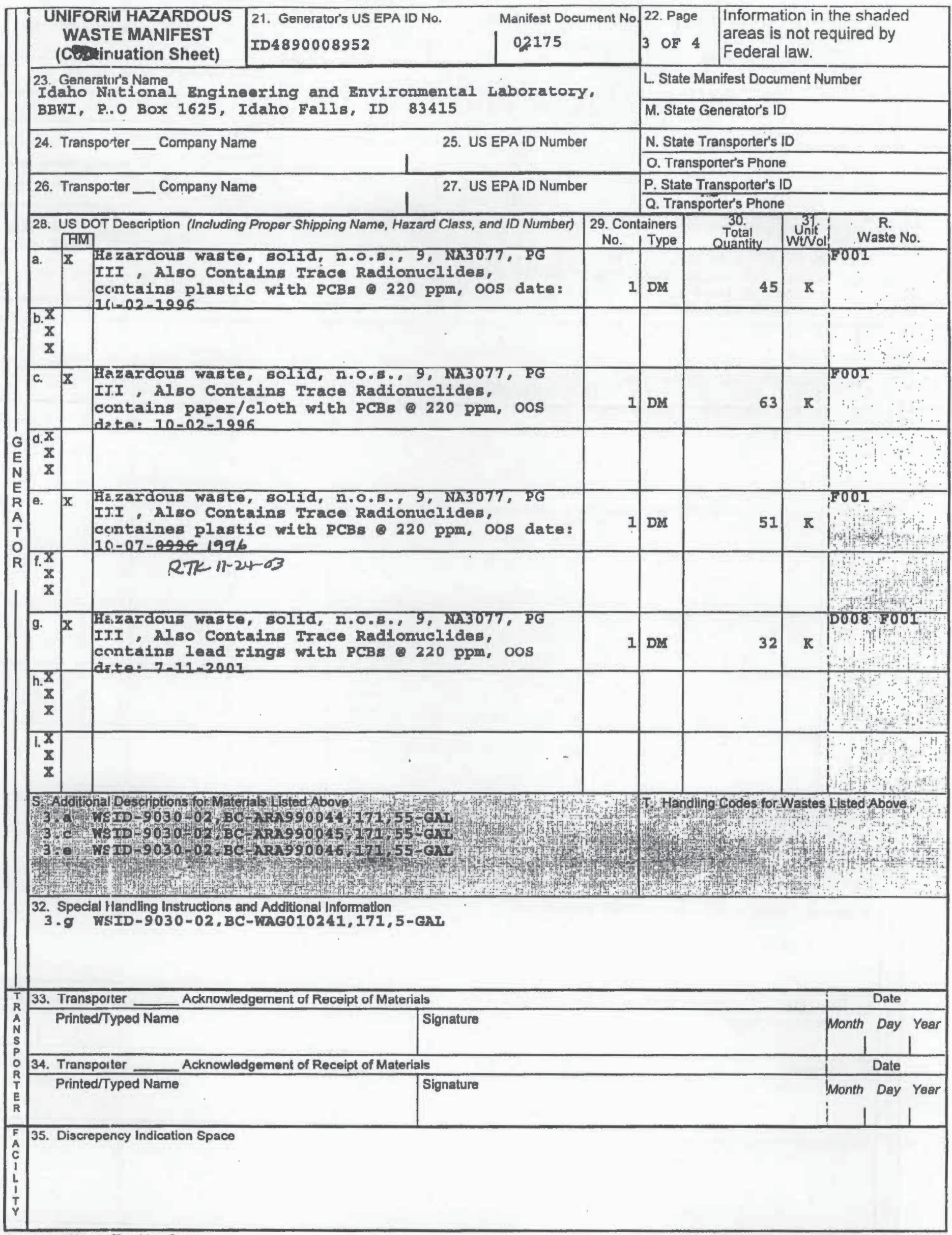




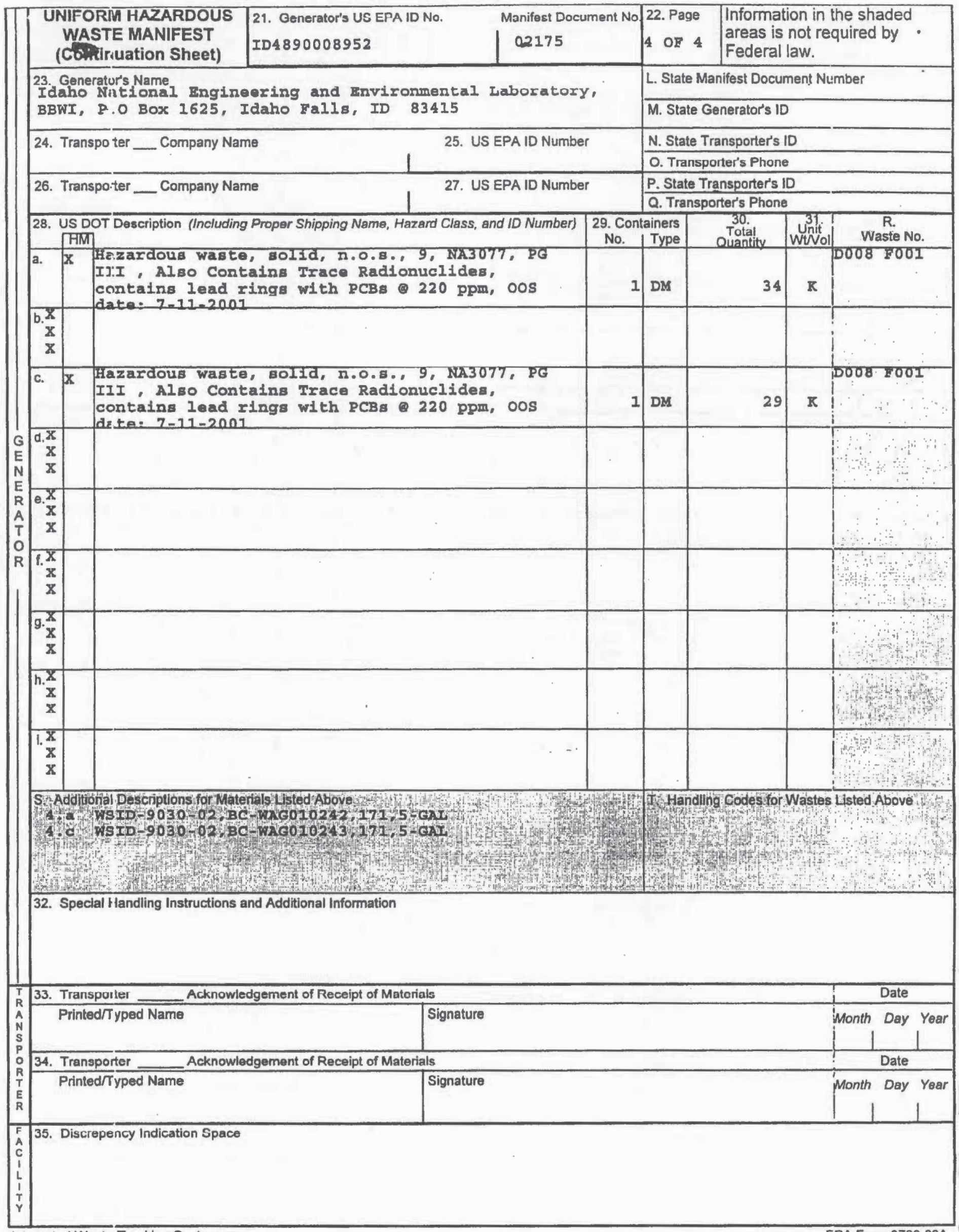




\section{ENVTROCARE}

OF UTAH, INC.

THE SAFE ALTERNATIVE

3 mi. S. Ext. 49,1280

Clive. Utah 8SOX EPA

10: UT982598898

\section{CERTIFICATE OF DISPOSAC}

This Certificate acknowledges that the following manifested shipments:

$\frac{\text { Shipment }}{9030-02-0005} \frac{\text { Manifest }}{02175} \quad \frac{\text { Date(s) of Disposal }}{10 / 08 / 2004} \quad \frac{\text { Cu/Et }}{61.49} \quad \frac{\text { Process }}{\text { Landfin }} \quad \frac{\text { Disposal Location }}{\text { Mixed Waste }}$

Representing 61.49 Cubic fect of waste of at listed Disposal Facility land fill. Disposal is subject to

Envirocare's Radioactive Matcrial License, all other applicable licenses, pernits and regulations, and the Disposal Agrement.

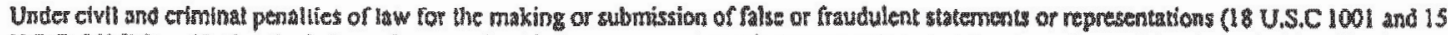

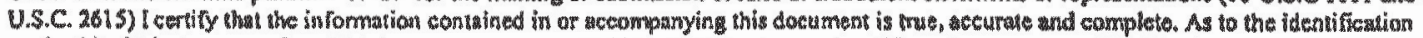

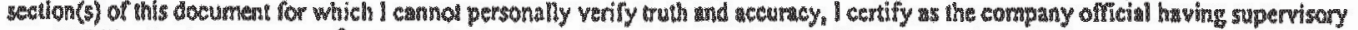

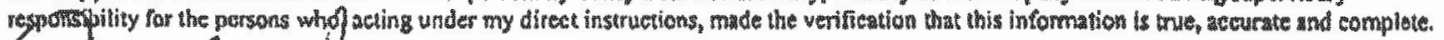
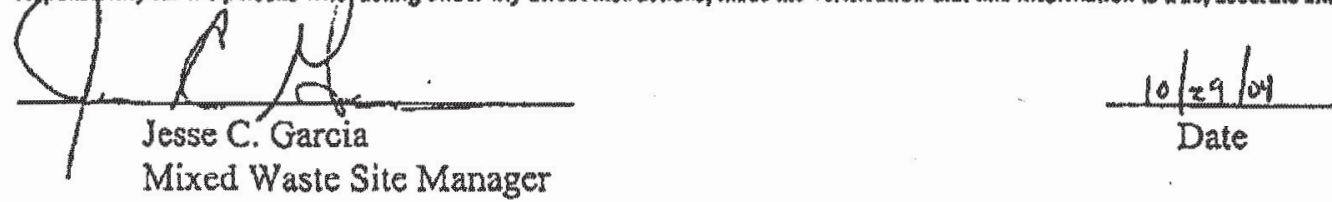

605 N. 5000 Wall Lake City. Uhah 84116 rehaphone (801) $532 \times 1330$ 



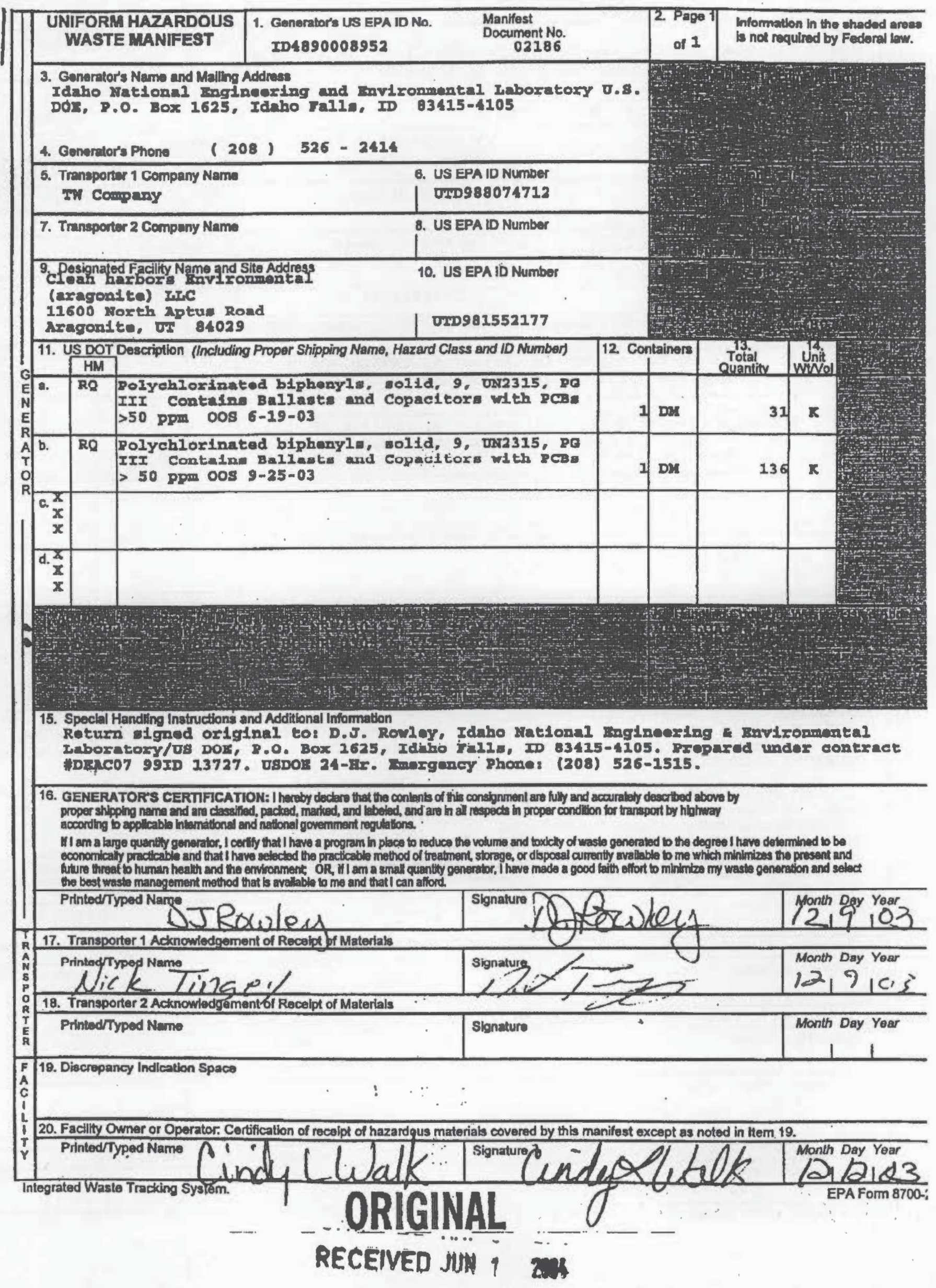




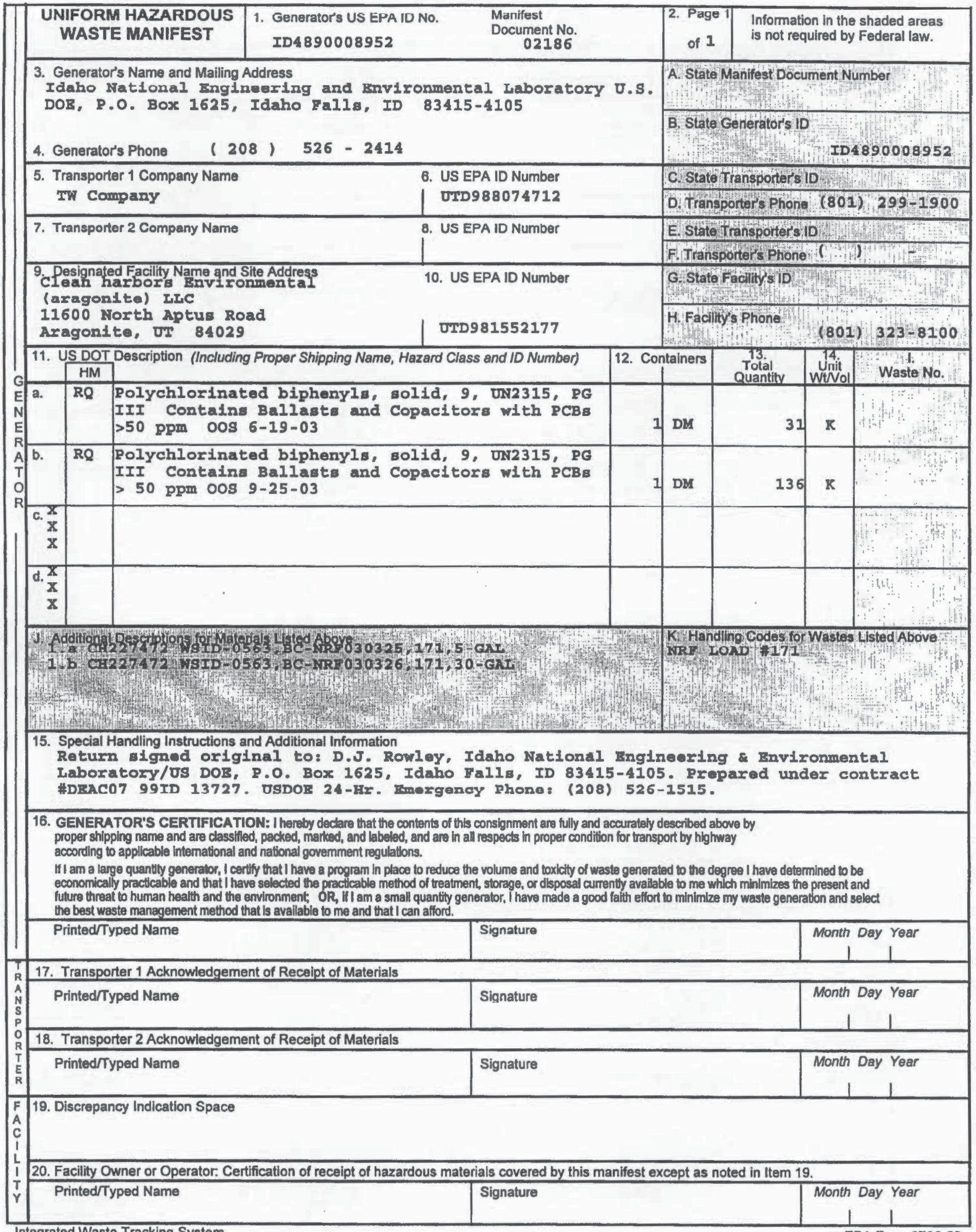




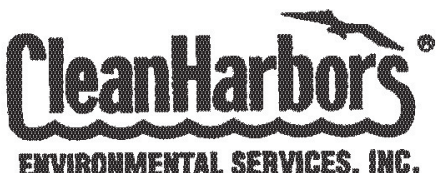

11600 North Aptus Road Aragonite, UT 84029

801.323 .8877

www.cleanharbors.com

JUNE 04, 2004

US DOE @ INEEL AMWTP

HIGHWAY 20 \& VAN BUREN

IDAHO FALLS, IDAHO 83415

EPA ID: ID4 890008952

Certificate of Disposal

No. 205862 $m$

- This is to certify that the hazardous material manifested to Clean Harbors on the above clean Harbors Aragonite Document Number was disposed of by incineration in accordance with 40 CFR 761 (and 40 CFR 264 if applicable) as of the above certification date.

Attached is a detailed report which identifies the date(s) of disposal. Residue from this waste has been disposed of at an approved and permitted Hazardous Waste Landfili.

Under civil and criminal penalties of law for the making or submission of false or fraudulent statements or representations (18 U.S.C. 1001 and 15

U.S.C. 2615), I certify that the information contained in or accompanying this document is true, accurate, and complete. As to the identified section(s) of this document for which I cannot personally verify truth and . accuracy, I certify as the company official having supervisory responsibility For the persons who, acting under my direct instructions, made the verification that this information is true, accurate, and complete.

Clean Harbors, Aragonite UT

EPA ID \# UTD 981552177

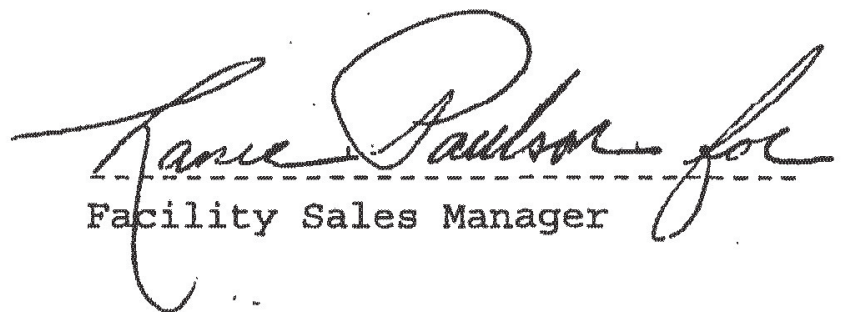

RECEIVEO JUN 152004 


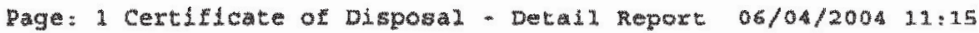

Genexter: 705603 US DOE INEEL AMWT"

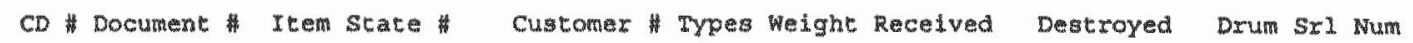

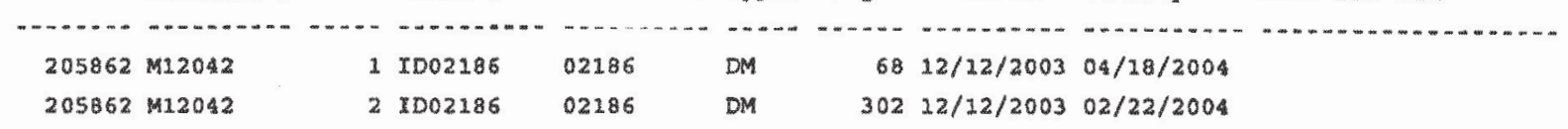


11600 North Apcus Road Aragonite, UT 84029

801.323 .8877

www.cleanhabors.com

JUNE 04, 2004

Environmental Manager

US DOE INEEL AMWTP

HIGHWAY 20 \& VAN BUREN

IDAHO FALIS, IDAHO 83415

RE: Certificates of Disposal

Dear Environmental Manager:

Enclosed please find your Certificate(s) of Disposal and accompanying detailed report(s) for the waste that was shipped to our facility for treatment. Your original manifest number is referenced on both of these documents along with a Clean Harbors Aragonite document number.

- Your waste has been properly treated and the residue from this waste has been disposed of at an approved and permitted hazardous waste landfil1.

Clean Haxbors appreciates you as a valued customer. If you should have any questions or concerns please do not hesitate to contact one of our customer/facility representatives at (801) 323-8100.

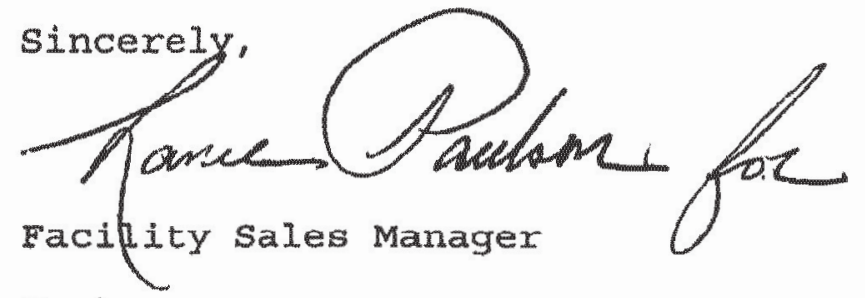

Enclosures 
Clean Harbors Aragonite LLC

11600 North Aptus Road

Aragonite UT 84029

EPA ID UTD 981552177

November 11, 2004

DJ ROWLEY

Ineel US DOE

47 miles West of Idaho Falls on US Hwy 20

Scoville ID, 83415

Re: Certificates of Disposal

Dear DJ ROWLEY

This letter and the attached CD Log constitute your Certificate(s) of Disposal for the waste that was shipped to our facility for disposal.

This is to certify that the waste referenced on the attached CD Log and manifested to the above referenced Clean Harbors facllity was processed and disposed of in accordance with 40 CFR 761 (and 40 CFR 264 If applicable). Your waste has been properly treated and any residue from this waste has been disposed of at an approved and permitted Facillty.

Under civll and criminal penalties of law for the making or submission of false or fraudulent statements or representations (18 U.S.C. 1001 and U.S.C. 2615). I certify that the information contained in or accompanying this document is true, accurate and complete. As to the identified section(s) of this document for which I cannot personally verify truth and accuracy, I certify as the company official having supervisory responsibility for the persons who, acting under my direct instructions, made the verification that this information is true accurate, and complete.

Clean Harbors appreciates you as a valued customer. If you should have any questions or concerns please do not hesitate to contact one of our customer/facility representatives.

Sincerely,

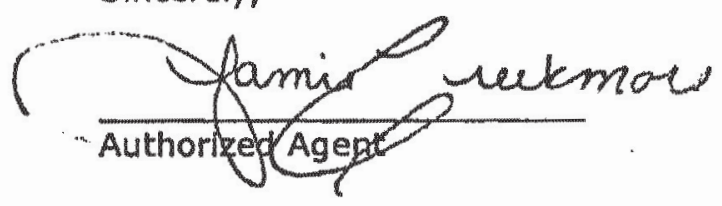

Enclosures 
Generator:

$\mathrm{CONbr}$

$11137423-83$

Tracking Nor

4802202

CD Nbr

$11137423-84$

Tracking Nor

5007934
Ineel US DOE 47 miles West of Idaho Falls on US Hwy 20 Scoville, ID 83415

\begin{tabular}{|c|c|c|c|c|c|}
\hline & & Order Nor & Manifest Nor & Recei & ed Date \\
\hline & & C9705412 & 054 & 1 & 103 \\
\hline & & Container & & & sposal \\
\hline Serial Nor & Iroe & Contents & Procd shoto & Method & Date \\
\hline & DM & Solid without free liquid & CHSI & INCN & $04 / 18 / 2004$ \\
\hline & & Order Nbr & Manifest Nbr & Recel & ed Date \\
\hline & & c9744467 & $002265-C 974446$ & $1103 / 10$ & 2004 \\
\hline & & Container : & & & sposal \\
\hline Serial Nor & Troe & Contents & Sho To & Metbod & D. \\
\hline & $D M$ & Solid without fre & CHSI & INCN & $4 / 18 / 2004$ \\
\hline
\end{tabular}


Generator:

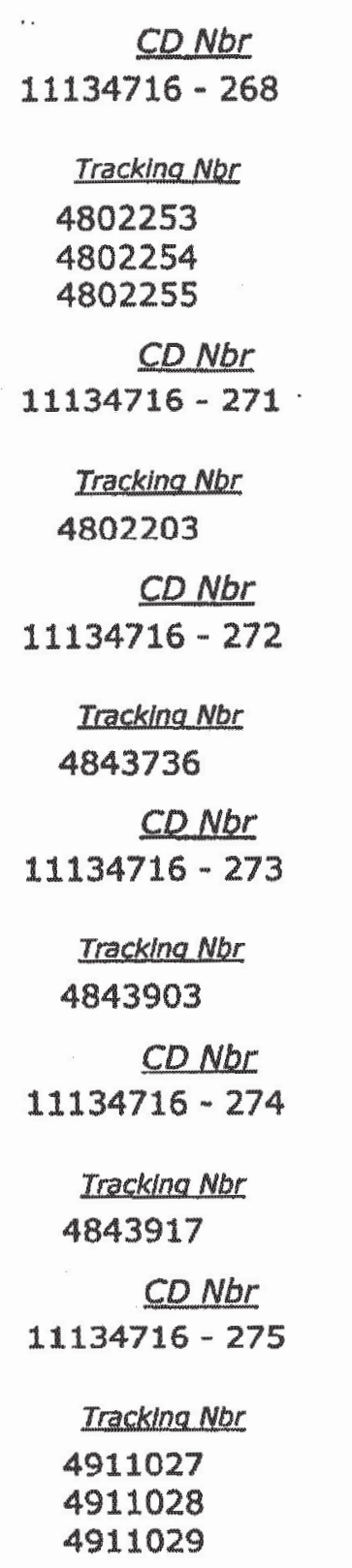

Ineel US DOE 47 miles West of Idaho Falls on US HWy 20 Scoville, ID 83415

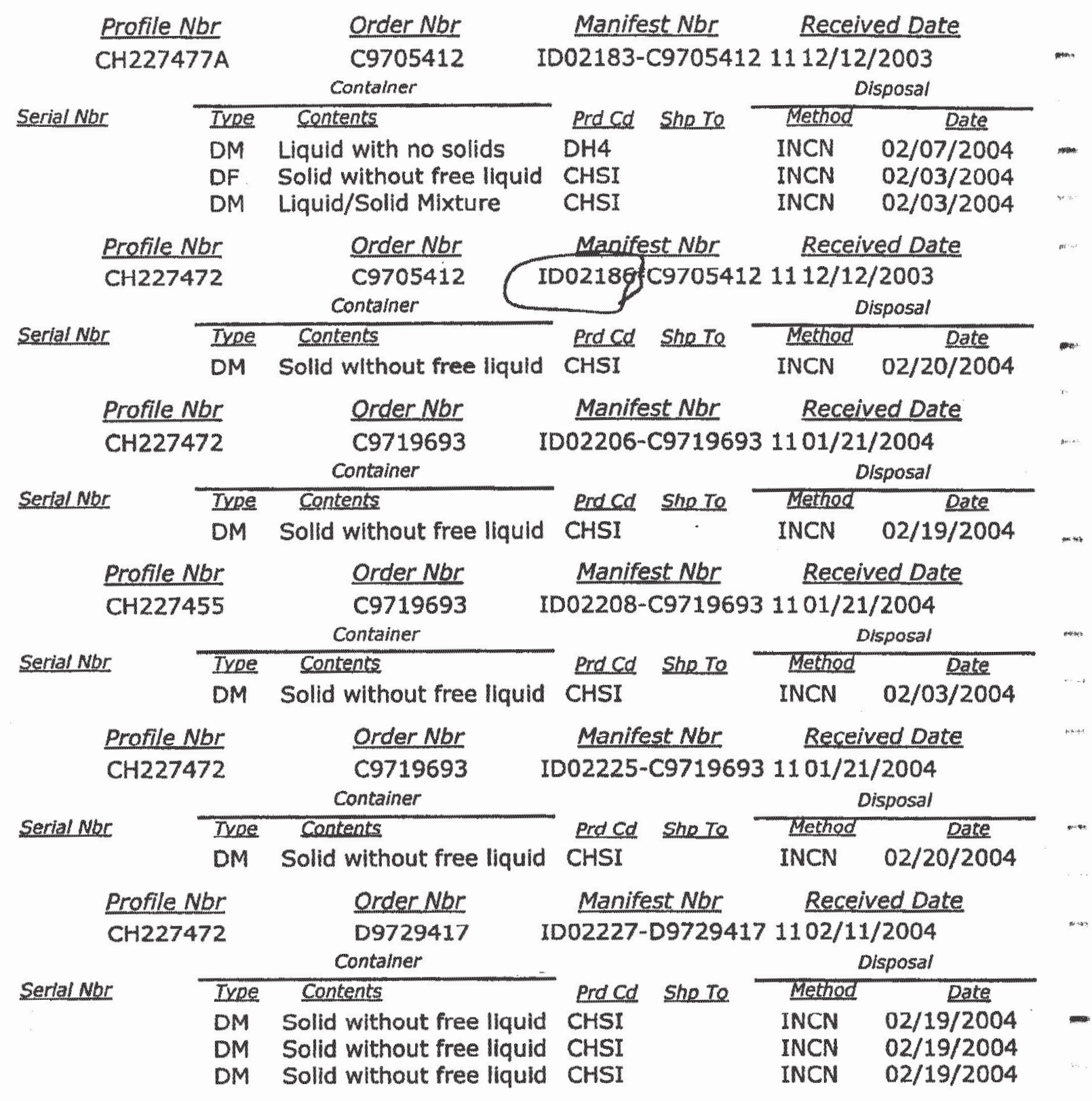




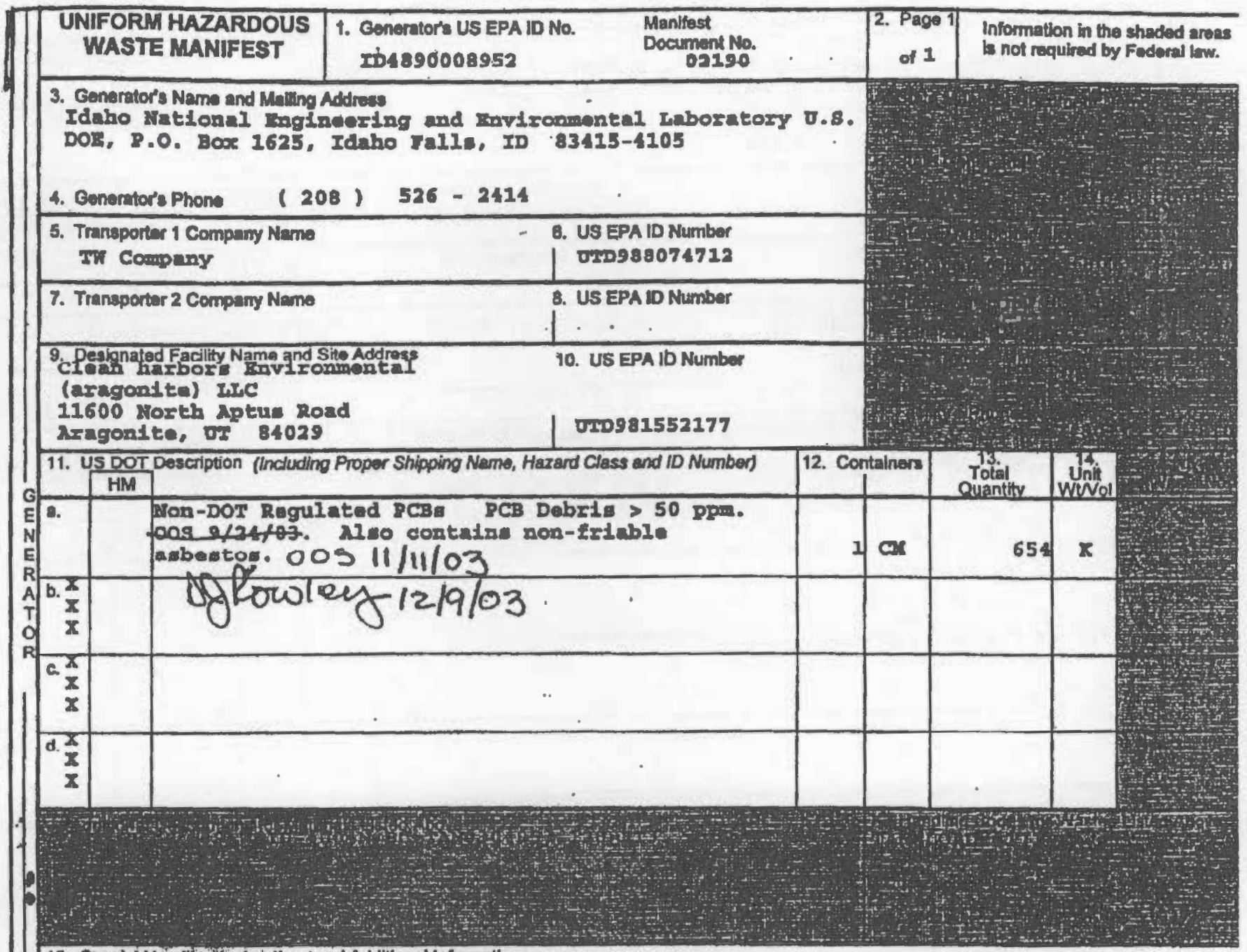

18. Spectal Hendlin instrictions and Additional Intormation

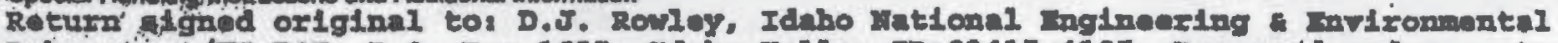

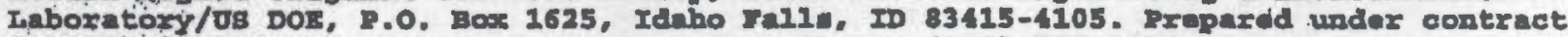

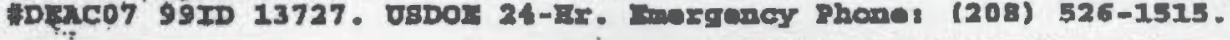

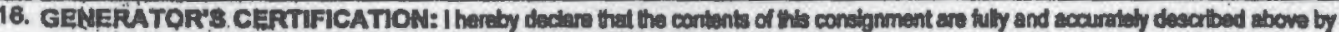

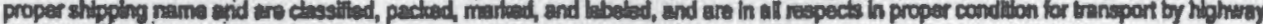

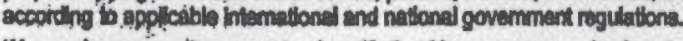

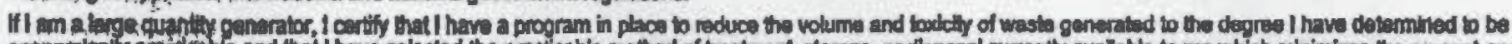

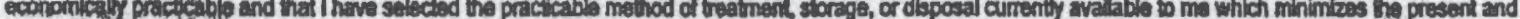

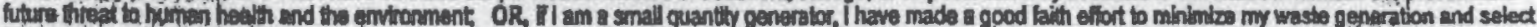

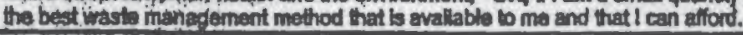

Printedryped Name

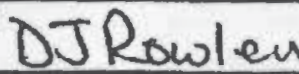

17. Trangpoter 1. Acknowtedgément of Receipl of Miaterials Printedtyped Name Hick Tin wo.

18. Transporter 2 Actunowled gement of Recelpt of Materlals Printed/Typod Name

19. Diserepengy Indicalión Space

20. Eacilify Omnor or Operator: Certification of neceipl of hazandous matorlals covered by thismanifest except as noted in item 19.

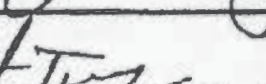
12,9103 


\begin{tabular}{|c|c|c|}
\hline $\begin{array}{l}\text { UNIFORM HAZARDOUS } \\
\text { WASTE MANIFEST }\end{array}$ & $\begin{array}{l}\text { 1. Generator's US EPA ID No. } \\
\text { ID4890008952 }\end{array}$ & $\begin{array}{l}\text { Manifest } \\
\text { Document No. } \\
02190\end{array}$ \\
\hline
\end{tabular}

4. Generator's Phone (208) $526-2414$

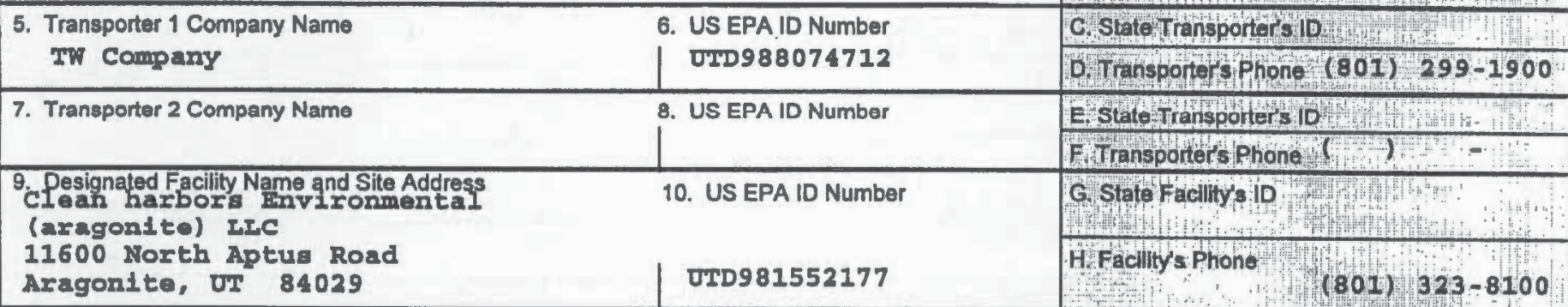

\begin{tabular}{|c|c|c|c|c|c|c|c|}
\hline $11 . \mathrm{L}$ & $\frac{\mathrm{SDOT}}{\mathrm{HM}}$ & Description (Including Proper Shipping Name, Hazard Class and ID Number) & 12. Cont & tainers & $\begin{array}{c}\text { Total } \\
\text { Tuantity }\end{array}$ & $\begin{array}{l}\text { Un } \\
\text { unit } \\
\text { Wol }\end{array}$ & Waste No. \\
\hline a. & & $\begin{array}{l}\text { Non-DOT Regulated PCBs PCB Debris }>50 \text { ppm. } \\
\text { oos } 9 / 24 / 03 \text {. Also contalns non-friable } \\
\text { asbestos. }\end{array}$ & 1) & $C M$ & 654 & wored & 19 \\
\hline b. $\frac{x}{x} \frac{x}{x}$ & & & & & & & $\begin{array}{l}\square ! \\
\because \quad\end{array}$ \\
\hline c. $\frac{x}{x}$ & & & & & & & and \\
\hline d. $\begin{array}{l}x \\
x \\
x\end{array}$ & & & & & & & \\
\hline \multicolumn{6}{|c|}{ 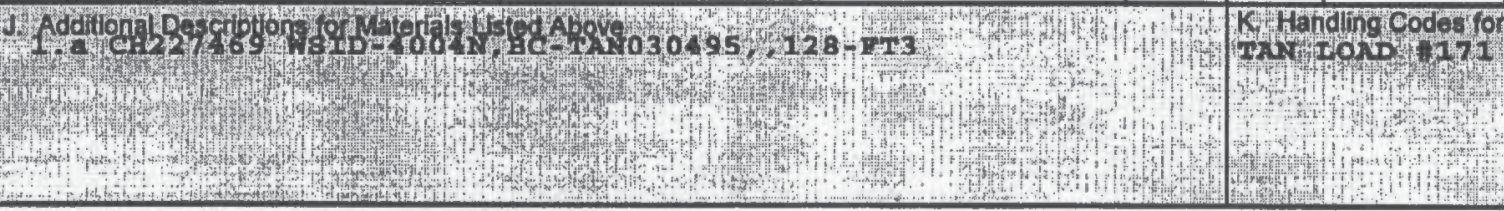 } & Vaste: & Clisted Abov \\
\hline
\end{tabular}

15. Special Handling Instructions and Additional Information

Return aigned original to: D.J. Rowloy, Idaho National Ingineering f Invironmental Laboratory/US DOE, P.O. Box 1625, Idaho Falls, ID 83415-4105. Prepared under contract \#DEAC07 99ID 13727. USDOE 24-Hr. Emergency Phone: (208) 526-1515.

16. GENERATOR'S CERTIFICATION: I hereby declare that the contents of this consignment are fully and accurately described above by proper shipping name and are classified, packed, manked, and labeled, and are in all respects in proper condition for transport by highway according to applicable international and national govemment regulations.

III am a large quantty generator, I certity that I have a program in place to reduce the volume and toxicity of waste generated to the degree I have determined to be economically practicable and that I have selected the practicable method of treatment, storage, or disposal currently avallable to me which minimizes the present and future threat to human health and the environment: $\mathrm{OR}$, 11 I am a small quantily generator, I have made a good faith effort to minimize my waste generation and select the best waste management method that is available to me and that I can afford.

Trinted

\begin{tabular}{|c|c|c|}
\hline Printed/Typed Name & Signature & \begin{tabular}{c|c|} 
Month Day Year & \\
\end{tabular} \\
\hline \multicolumn{3}{|l|}{ 17. Transporter 1 Acknowledgement of Receipt of Materials } \\
\hline Printed/Typed Name & Signature & Month Day Yoar \\
\hline \multicolumn{3}{|l|}{ 18. Transporter 2 Acknowledgement of Receipt of Materials } \\
\hline Printed/Typed Name & Signature & Month Day Year \\
\hline \multicolumn{3}{|l|}{ 19. Discrepancy Indication Space } \\
\hline \multicolumn{3}{|c|}{ 20. Facility Owner or Operator: Certification of receipt of hazardous materials covered by this manifest except as noted in Item 19.} \\
\hline Printed/Typed Name & Signature & $\begin{array}{c}\text { Month Day Year } \\
\mid\end{array}$ \\
\hline
\end{tabular}




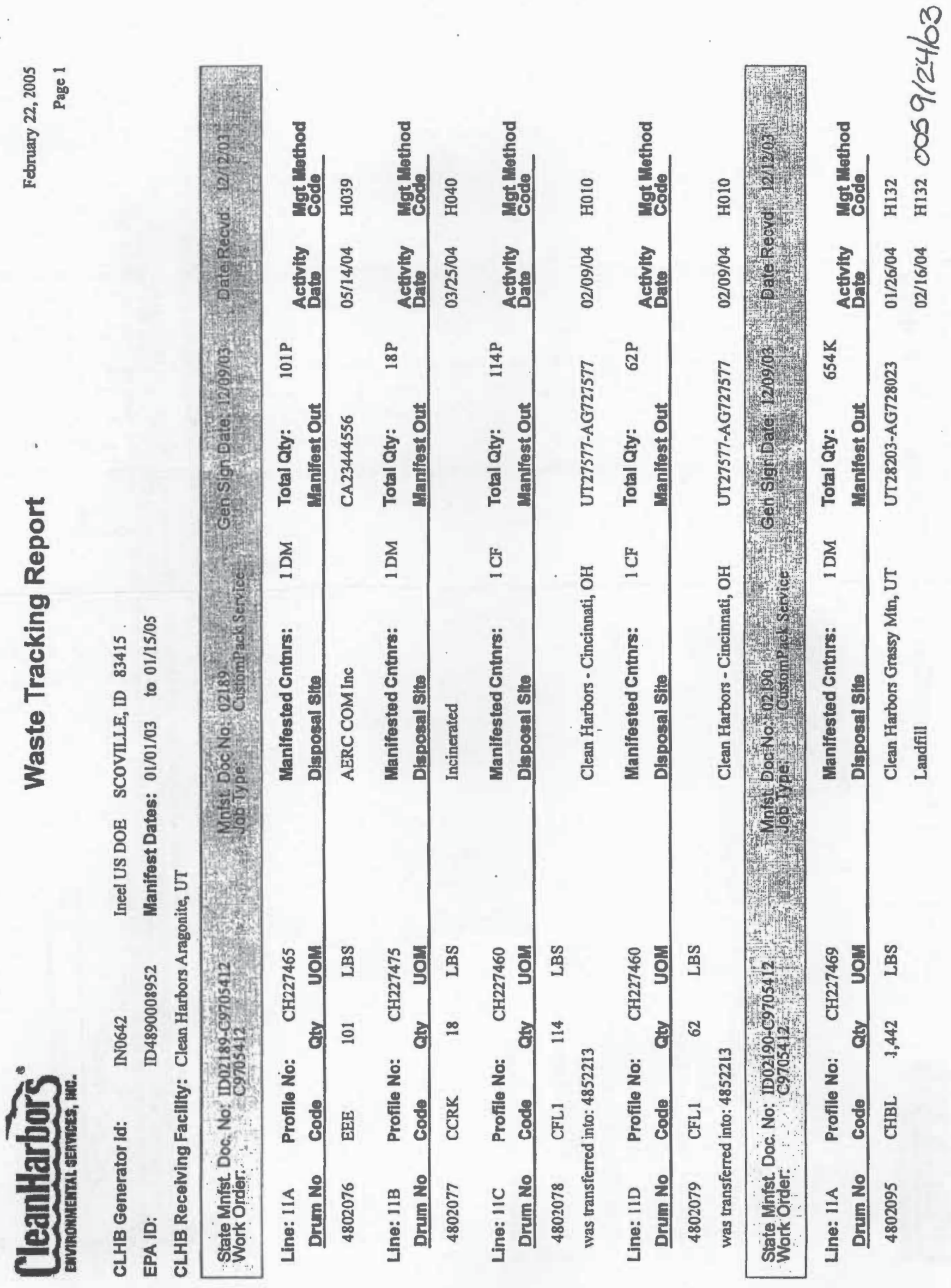



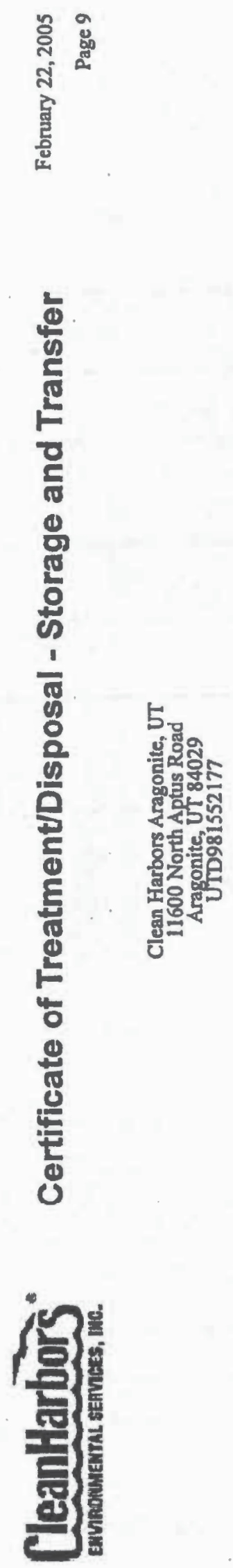

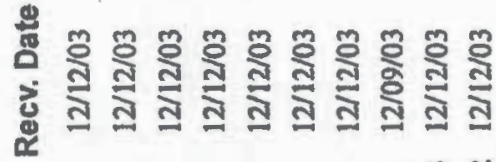

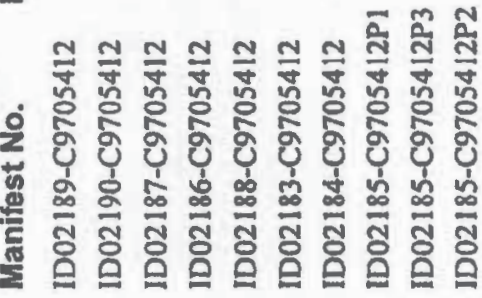

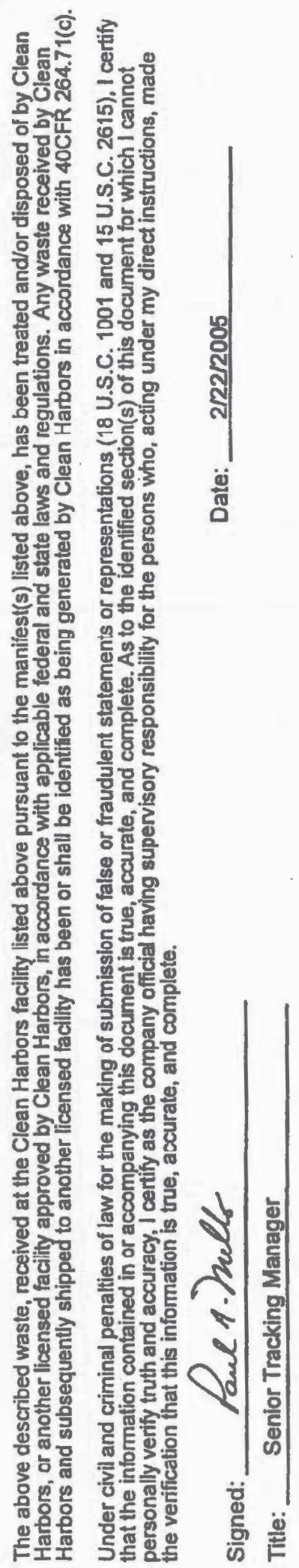


ENVIROCARE OFUTAH,INC.

THE SAFE ALTERNATIVE

3 mil. 3.

Clive, Uth 84029 EPA

D: Ur9R2598898

\section{CERTIFICATE OF DISPOSAL}

This Certicate acknowledges that the foliowing manifested shipments:

$\underset{\text { Shipment }}{30-02-0007} \frac{\text { Manifest }}{02201} \quad \frac{\text { Date(s) of Disposal }}{9 / 10,11,15 / 2004} \quad \frac{\text { Curft }}{794} \quad \frac{\text { Process }}{\text { LandFill }} \frac{\text { Disposal Location }}{\text { Mired Waste }}$

9030-02-0007 02201

$9 / 10,11,15 / 2004$

794

LandFill Mixed Waste

Representing 794 Cubic feet of waste of at listed Disposal Fucility landfill. Disposal is subject to

trvirocare's Radionctive Material License, all other applicuble licenses, perrnits and regulations, and the Disposal Agreement.

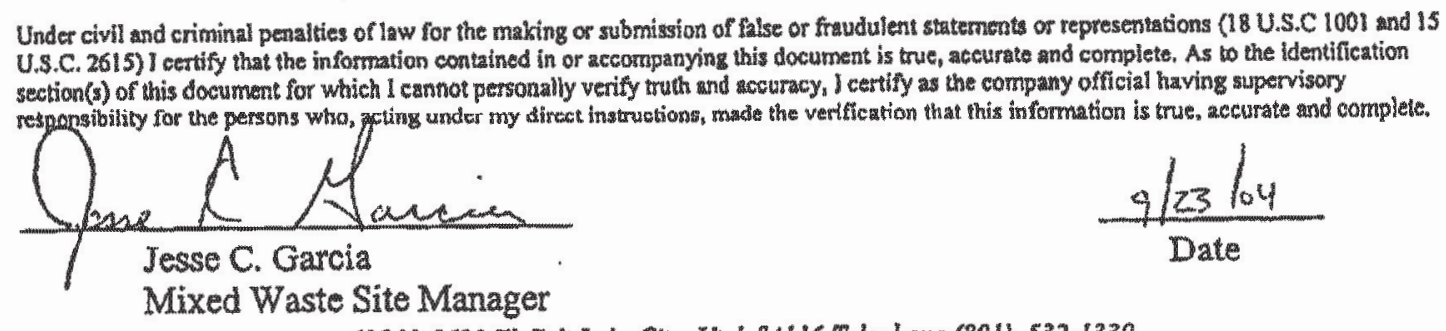

605 N. 5600 W, Salt Lake City, Utah 84116 Telephone (801) $532-1330$ 


\section{Inspection Records}

(Available on request) 


\begin{tabular}{|c|c|c|}
\hline $\begin{array}{l}\text { UNIFORM HAZARDOUS } \\
\text { WASTE MANIFEST }\end{array}$ & $\begin{array}{l}\text { 1. Generator's US EPA ID No. } \\
\text { ID4890008952 }\end{array}$ & $\begin{array}{l}\text { Manifest } \\
\text { Document No. } \\
02208\end{array}$ \\
\hline
\end{tabular}

4. Generator's Phone (208) $526-2414$

5. Transporter 1 Company Name TW Company

7. Transporter 2 Company Name
6. US EPA ID Number UTD988074712

8. US EPA ID Number of 1

Information in the shaded areas is not required by Federal law.

A. State Manifest Document Number

B. State Generator's ID

ID4890008952

C. State Transporter's ID

D. Transporter's Phone (801) 299-1900

E. State Transporter's ID

F. Transporter's Phone () ) -

G. State Facility's ID

10. US EPA ID Number

UTD981552177
H. Facillty's Phone

(801) $323-8100$

11600 North Aptus Road

Aragonite, UT $\mathbf{8 4 0 2 9}$

11. US DOT Description (Including Proper Shipping Name, Hazard Class and ID Number) HM

E a. $\mathrm{X}$ Hazardous waste, sol1d, n.0.8., 9, NA3077, PG

N III Contains paint chips with $\mathrm{PCBs}>50 \mathrm{pm}$.

E oos 11-5-03

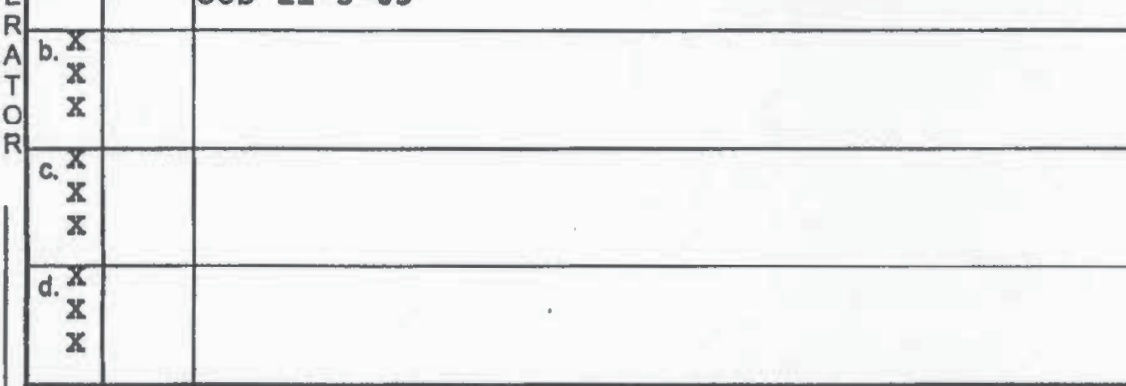

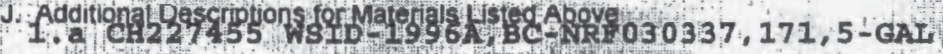

K. Hándling Codos for Wastos Listed Above $\mathrm{NRE}$ LOND $\$ 172$

SALES OROER \#C9719693

\begin{tabular}{|c|c|c|c|}
\hline 12. Containers & $\begin{array}{c}\text { Total } \\
\text { Quantity }\end{array}$ & $\begin{array}{l}\text { Unit } \\
\text { Unt } \\
\text { Whol }\end{array}$ & Waste No. \\
\hline$D M$ & & & $\begin{array}{l}D 006007 \\
0008\end{array}$ \\
\hline
\end{tabular}

15. Special Handling Instructions and Additional Information

Return Bigned original to: D.J. Rowley, Idaho National Engineering E Environmental

Iaboratory/OS Dor. P.O. Box 1625, Idaho Falla, ID 83415-4105. Prepared under contract \#DEAC07 99ID 13727. USDOF 24-Fr. Bmergency Phone: (208) 526-1515.

16. GENERATOR'S CERTIFICATION: I hereby declare that the contents of this consignment are fully and accurately described above by proper shipping name and are classified, packed, marked, and labelad, and are in all respects in proper condition for transport by highway according to applicable international and nalional govemment regulations.

If I am a lange quantity generator, I certlfy that I have a program in place to reduce the volume and loxicity of waste generated to the degree I have determined to be economically practicable and that I have selected the practicable method of treatment, storage, or disposal currently avallable to me which minimizes the present and future threal to human health and the environment. OR, III am a small quanlity generator, I have made a good faith effort to minimize my waste generabion and select the best waste management method that is avallable to me and that I can afford.

Printed/Typed Name

$$
\text { JJRucislec }
$$

T 17. Transporter 1 Acknowledgement of Receipt of Materials

A Printed/Typed Name Nic.\{L Tincs, $t^{\prime} / \mid$ Printed/Typed Name

19. Discrepancy Indication Space
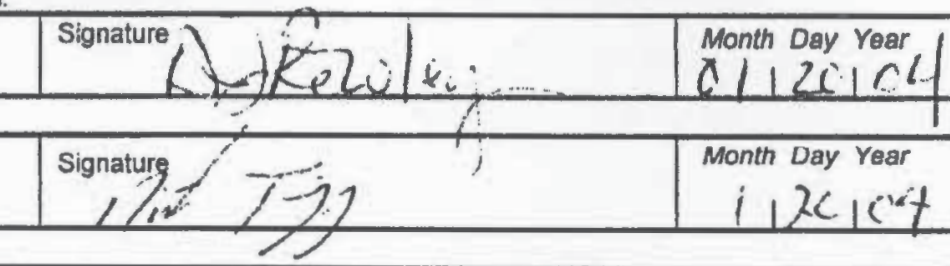

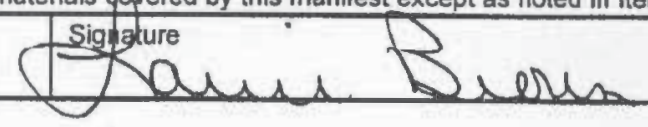

Signature
Month Day Year 



\title{
Cleantharbors
}

11600 North Aprus Road

Aragonite, UT 84029

801.323.8100

Fax 801.323.8877

when.clearharbors.com

MARCE 12, 2004

US DOE @ INEEL AMWTP

HIGHWAY 20 \& VAN BUREN

IDAHO FALLS, IDAHO 83415

EPA ID: ID4 890 008 952

\author{
PCB \\ Certiflcate of Disposal \\ No. 198943
}

Customer Manifest: Mazos Document: N0321 destroyed as of FEBRUARY 03, 2004

This is to certify that the hamardous material manifested to clean Harbors on the above clean Harbors Aragonite Document Number was disposed of by incineration in accordance with 40 CFR 761 (and 40 CFR 264 if applicable) as of the above certification date.

Attached is a detailed report which identifies the date(s) of disposal. Residue from this waste has been disposed of at an approved and permitred Hazardous Waste Landfill.

Under civil and criminal penalties of law for the making or submission of false or fraudulent statements or representations (18 U.S.C. 1001 and 15 U.S.C. 2615), I certify that the information contained in or accompamying this document is true, accurate, and complete. As to the identified saction(s) of this document for which I cannot personally verify truth and accuracy. I certify as the company official having supervisory responsibility for the persons who, acting under my direct instructions, made the verification that this information is true, accurate, and complete.

Clean Harbors, Aragonite UT

EPA ID \# UTD $981 \quad 552 \quad 177$

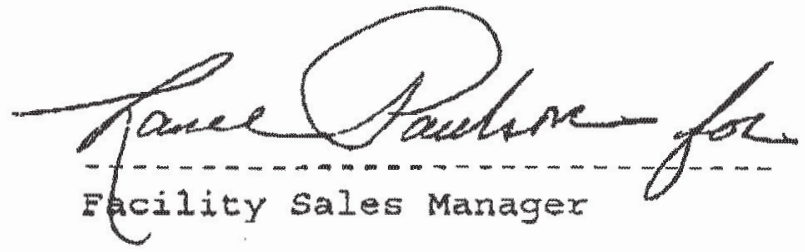

"Ponnle amd Terhnolaw Cruatino a Better Environment" 

03:15-2004 08:57 am FrOM-CLEAN HARBORS LAKEPOINT
8015087617
T-445 P. $010 \quad F-268$
MAR-15-2004 $08: 09$
$S K$ ARAGONITE
0013238877
P. $09 / 16$

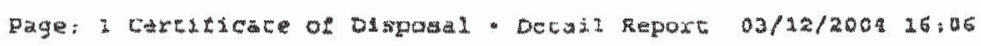

Generaco: 705603 US DOE INES AMHT

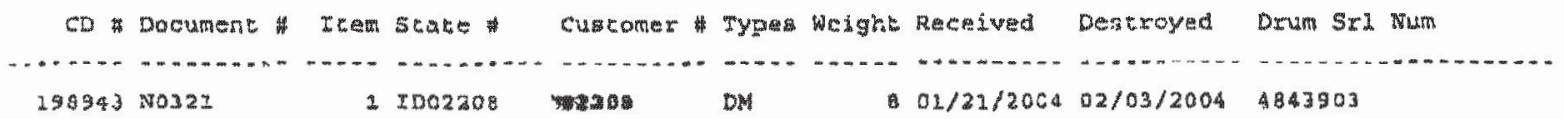

NRFO30337 IIA. 


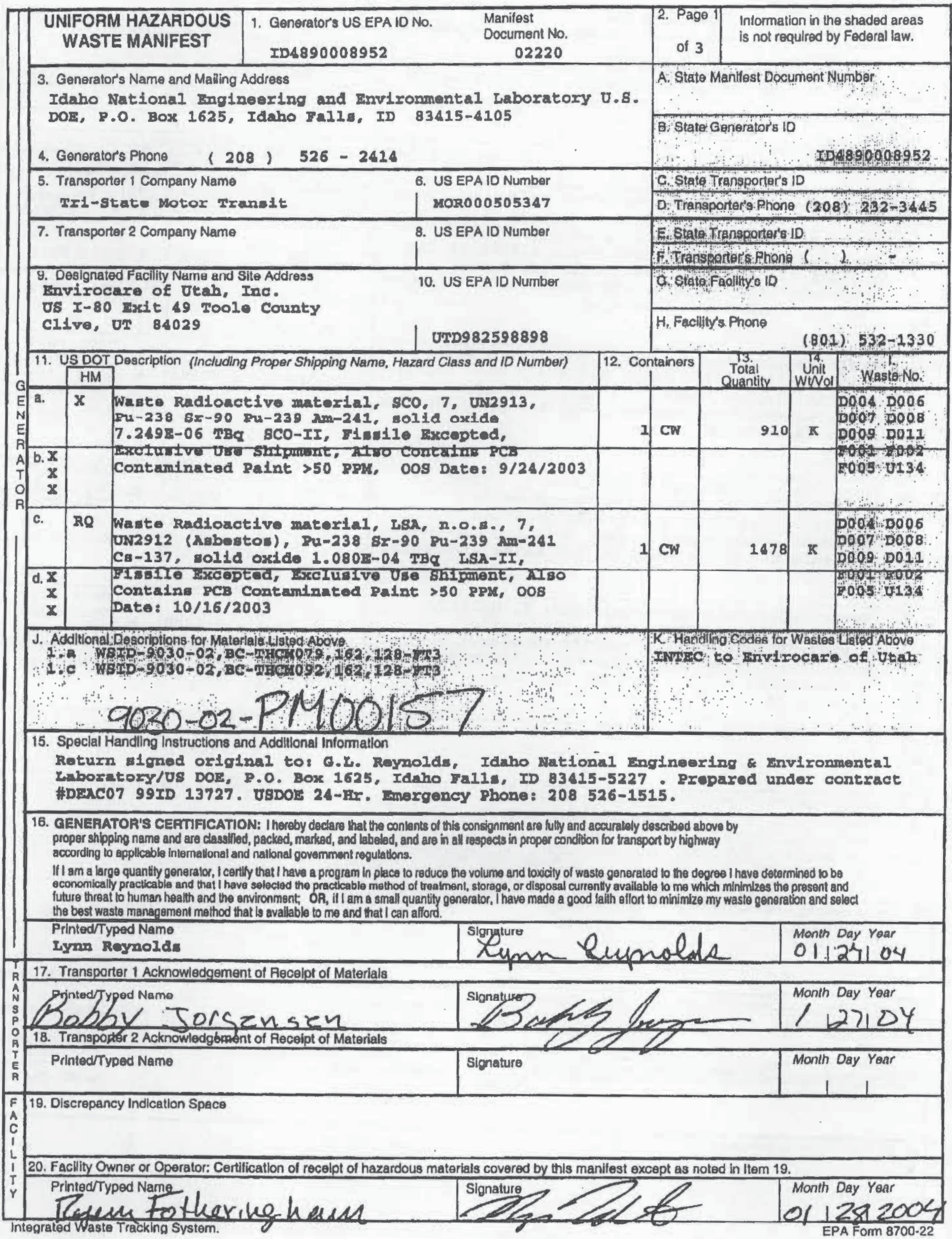




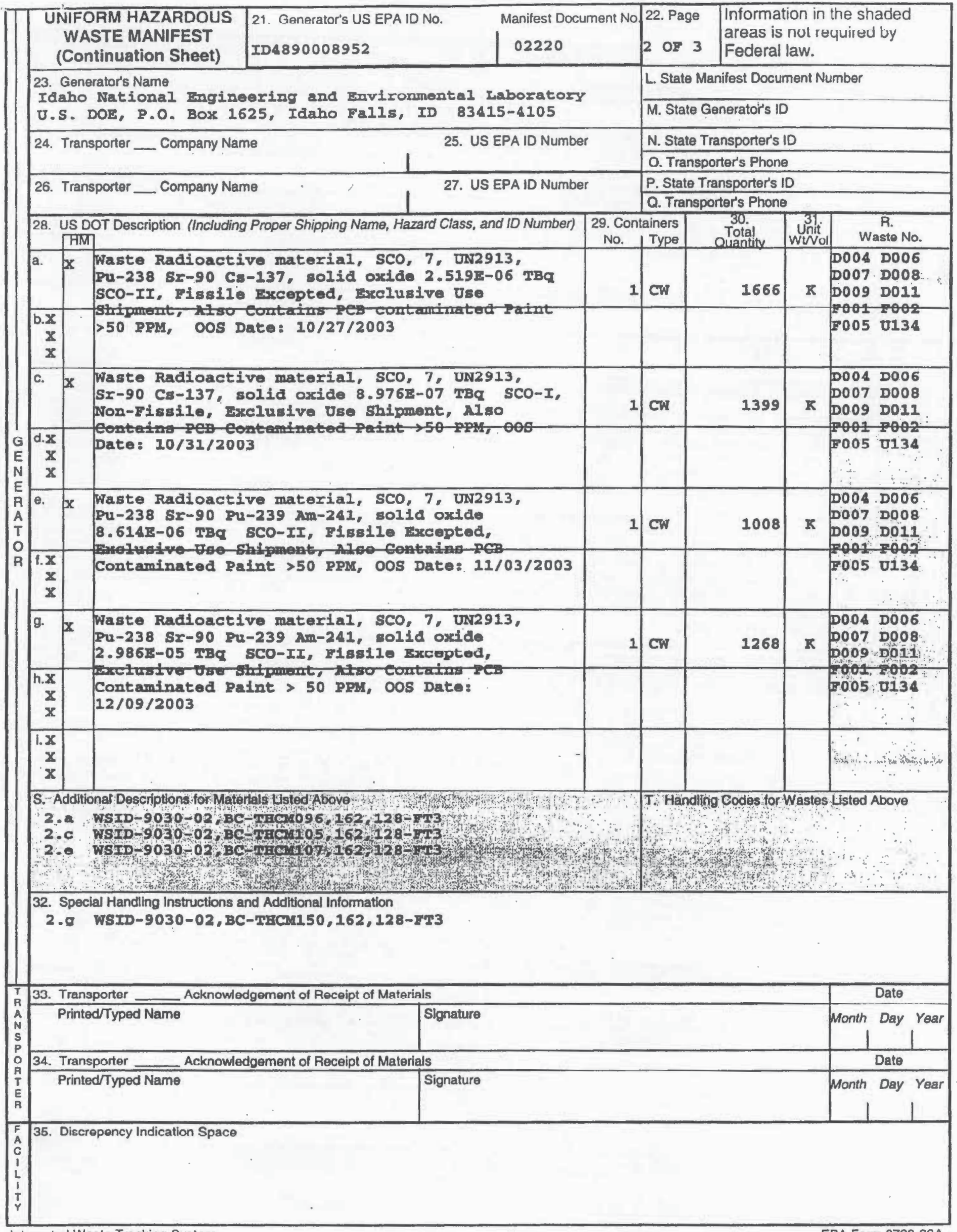




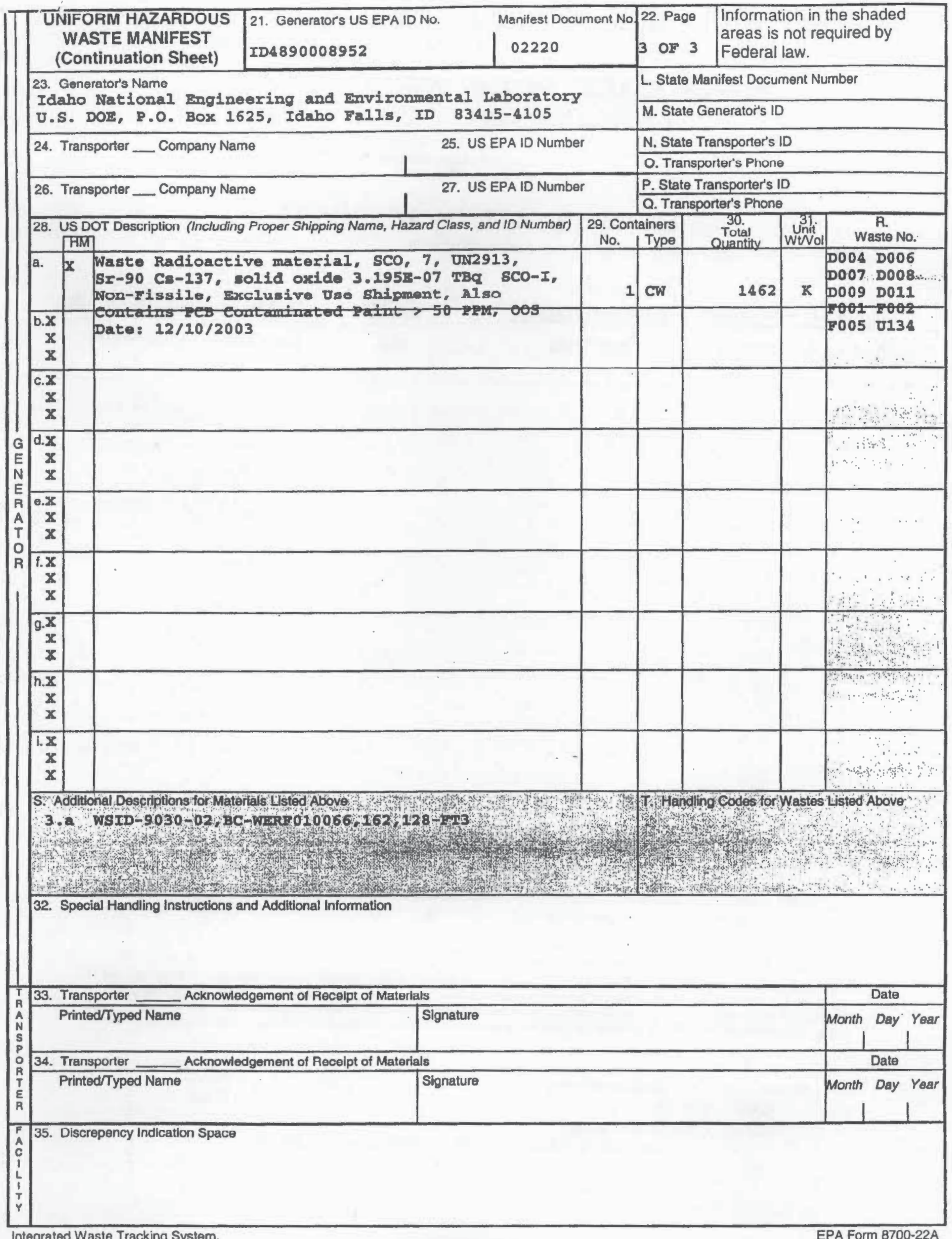




\section{ENVIROCARE OF UTAH, INC. \\ THE SAFE ALTERNATTVE}

3 mi. S. Ext. 49, 1-80

Clive, Uah 84029 EPA

D: UT982598898

\section{CERTIFICATE OF DISPOSAL}

This Certificate acknowledges that the following manifested shlpments:

\begin{tabular}{|c|c|c|c|c|c|}
\hline Shlpment & Manifest & Date(B) of Disposal & Culft & Prociess & Di:poral Location \\
\hline 9030-02-0009 & 02220 & $9 / 13 / 2004$ & 896 & LandFIII & Mixed Waste \\
\hline
\end{tabular}

Representing 896 Cubic feet of waste of at listed Disposal Fecility landfill. Disposal is wubject to Bavirocare's Redioactive Material License, all other applieable licenses, pemults and regulationa, and the Diaposal Agreement.

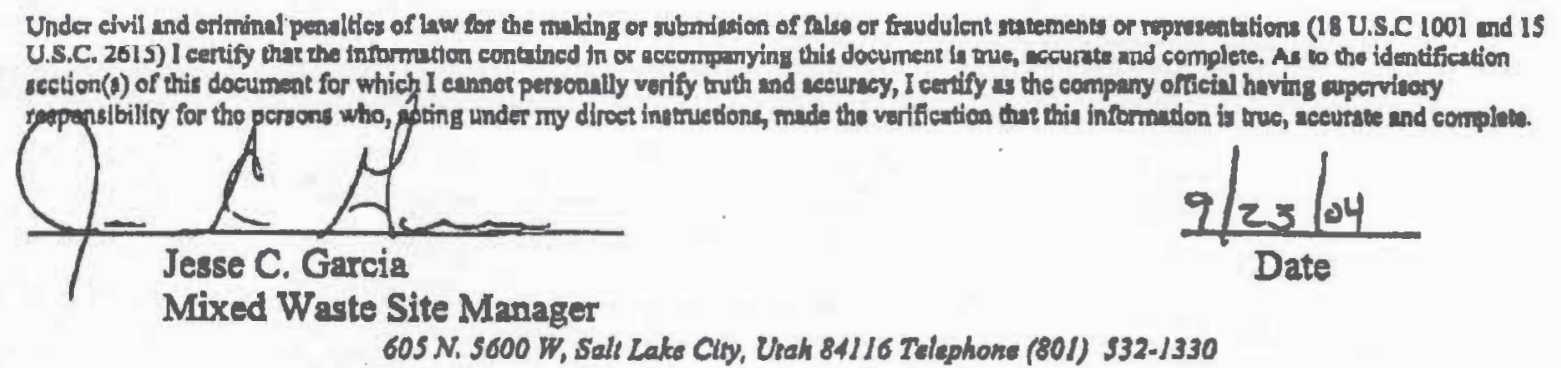




\section{ATTACHMENT IV: Manifests Generated during Calendar Year 2003 with Received Certificates of Disposal/Destruction (following pages)}

\begin{tabular}{|c|c|c|c|}
\hline Item No. & Manifest No. & Item No. & Manifest No. \\
\hline 1 & 02208 & 37 & 02347 \\
\hline 2 & 02220 & 38 & 02349 \\
\hline 3 & 02222 & 39 & 02355 \\
\hline 4 & 02225 & 40 & 02365 \\
\hline 5 & 02227 & 41 & 02368 \\
\hline 6 & 02233 & 42 & 02371 \\
\hline 7 & 02238 & 43 & 02374 \\
\hline 8 & 02246 & 44 & 02376 \\
\hline 9 & 02253 & 45 & 02378 \\
\hline 10 & 02259 & 46 & 02381 \\
\hline 11 & 02265 & 47 & 02383 \\
\hline 12 & 02269 & 48 & 02386 \\
\hline 13 & 02272 & 49 & 02404 \\
\hline 14 & 02277 & 50 & 02405 \\
\hline 15 & 02282 & 51 & 02417 \\
\hline 16 & 02287 & 52 & 02424 \\
\hline 17 & 02289 & 53 & 02428 \\
\hline 18 & 02291 & 54 & 02430 \\
\hline 19 & 02294 & 55 & 02433 \\
\hline 20 & 02299 & 56 & 02438 \\
\hline 21 & 02306 & 57 & 02439 \\
\hline 22 & 02308 & 58 & 02444 \\
\hline 23 & 02310 & 59 & 02454 \\
\hline 24 & 02311 & 60 & 02458 \\
\hline 25 & 02316 & 61 & 02461 \\
\hline 26 & 02319 & 62 & 02463 \\
\hline 27 & 02320 & 63 & 02475 \\
\hline 28 & 02322 & 64 & 02477 \\
\hline 29 & 02324 & 65 & 02481 \\
\hline 30 & 02327 & 66 & 02483 \\
\hline 31 & 02329 & 67 & 02484 \\
\hline 32 & 02330 & 68 & 02485 \\
\hline 33 & 02337 & 69 & 02498 \\
\hline 34 & 02338 & 70 & 02509 \\
\hline 35 & 02341 & 71 & 02522 \\
\hline 36 & 02345 & 72 & 02528 \\
\hline
\end{tabular}


. 
UNIFORM HAZARDOUS 1. Generalor's US EPA ID No. WASTE MANIFEST
Manifest

Document No.

02222

3. Generator's Name and Malling Address

Idaho National Ingineoring and Environnental Laboratory U.S.

DO2, P.O. Box 1625, Idnho Fa11s, ID 83415-4105

4. Generators Phone (208) $526-2414$

5. Transporter 1 Company Name 6. US EPA ID Number

Tri-stute Notor Trankit

7. Tranaporter 2 Company Name

Mo5000505347

8. US EPA ID Number

10. US EPA ID Number

8. Desconaled Fecility Name and Sine Addrose

Us I-80 Exit 49 roole county

clive, orl 84029

UL40982598898

11. US DOT Deweription anclucing Proper Shipging Name, Hazand Cless and ID Numbert

E. I Waste Radloactire material, exceptod

N package-1inited quantity of materini, 7, uv2910, E Aleo contains PCB contaninated Paint > 50 PPU

$\sqrt[R]{\text { b. } X}$ Aleo contalns

T)

c. I Waste Radionctive materill, excopted

package-linited quantity of enterind, 7, ur2910, Iso contain PCB Contalineted Paint > 50 PPX,

d. $x$ pos Deter? $12 / 02 / 03$

$\frac{1}{2}$

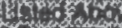

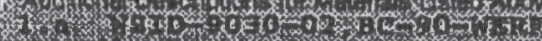

W.

15. Special Hendling instructione and Additional informedion

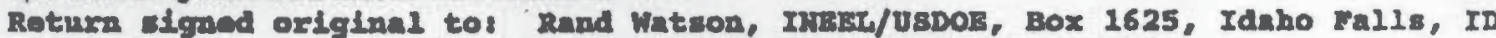

$83415-5227$

Prepared under contract No

24 hr zwaxgoncy Munber 208-526-1515

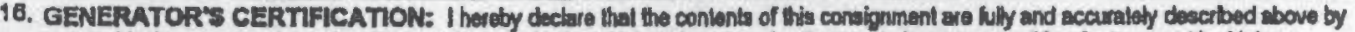

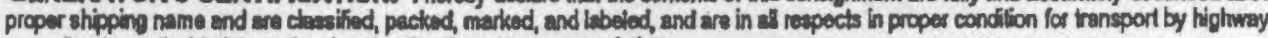
according to applicedolo inlemetionel and ralional govenment regulations.

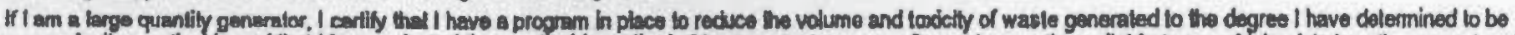

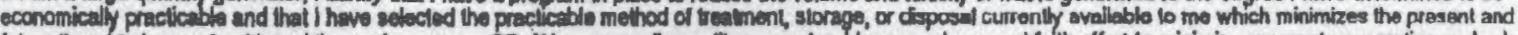

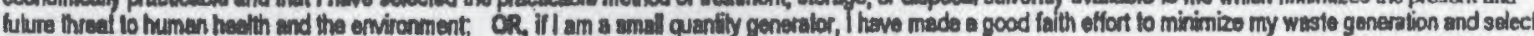
the best wasle managentent mothod that is evailable to $\mathrm{me}$ and trat I can afford.

Printed/Typed Name

Rand Hatson

17. Transporter 1 Acknowdedgemenl of Recoipt of Malerisls

Printed/Tyed/serne

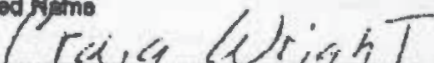

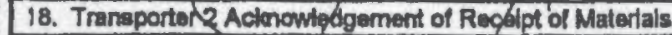
Prinled/Typed Namo

19. Discrepancy Indicalion Space

A

20. Faclity Owner or Operator. Certificalion of recalpt of hazardous materials covered by thla manifest except as noted in ftem 19

Y Priniod/Typed Name

Intesyaled Waste Tracking System.
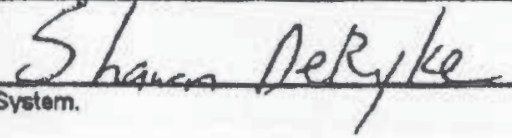

Signalure
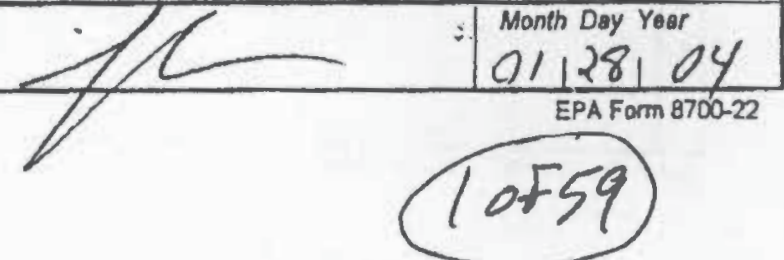


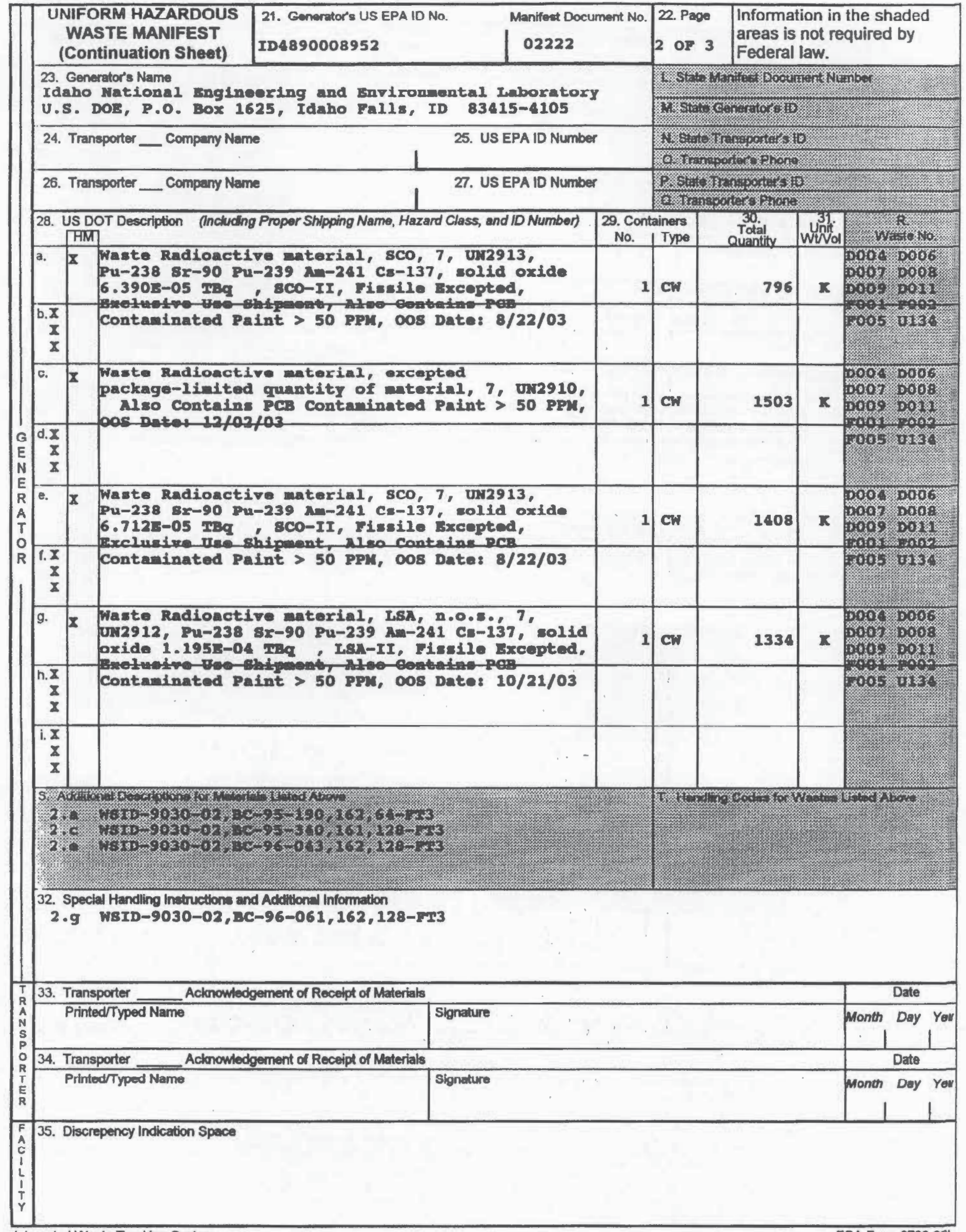




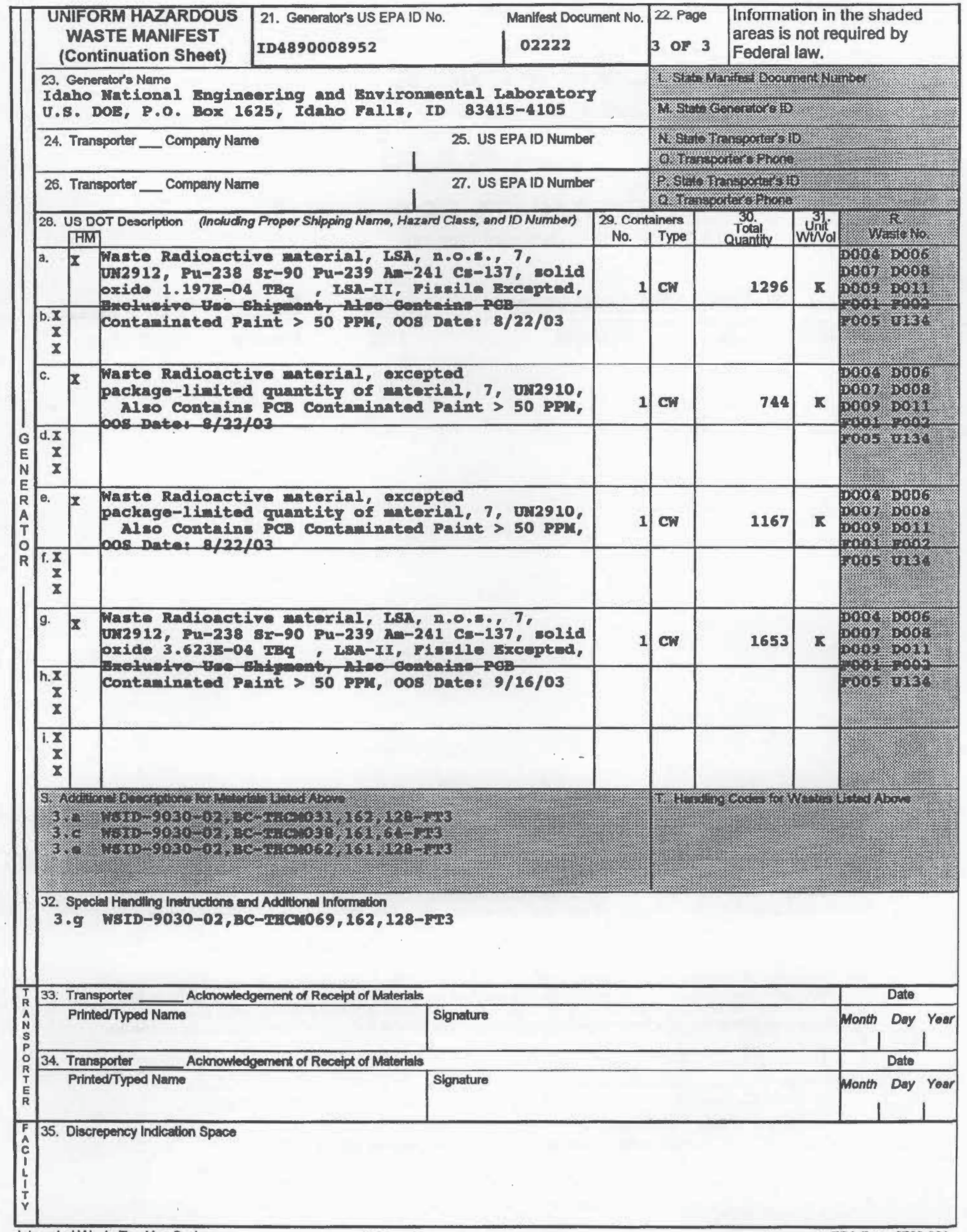


OCT. 25. 2004 7:47AM BECHTEL BWXT ID SAMPLE MANAGEMEN $\quad$ NO.8167 P. 11

ENVIROCARE OF UTAH, INC.

THE SAFE ALTERNATTVE

$3 \mathrm{mi}$. S. Exh. 49, 1.80

Clive, Utah 84029 BRA

D: UT982598898

\section{CERTIFICATE OF DISPOSAL}

This Certficate acknowledges that the following manifested shipmenta:

\begin{tabular}{|c|c|c|c|c|c|}
\hline Shipment & Manifest & Date(s) of Disposs & $\mathrm{Cn} / \mathrm{Ft}$ & Process & Dieposal Loction \\
\hline $9030-02-0008$ & 02222 & 9/13/2004 & 1152 & Landrill & Mix \\
\hline
\end{tabular}

Representing 1152 Cubic feet of waste of at listed Dinposal Facility landtill. Disposal is nubject to Bnvirocare's Redionetive Manerial License, all other applieable lieenses, permits and regulations, and the Disposal Agreement.

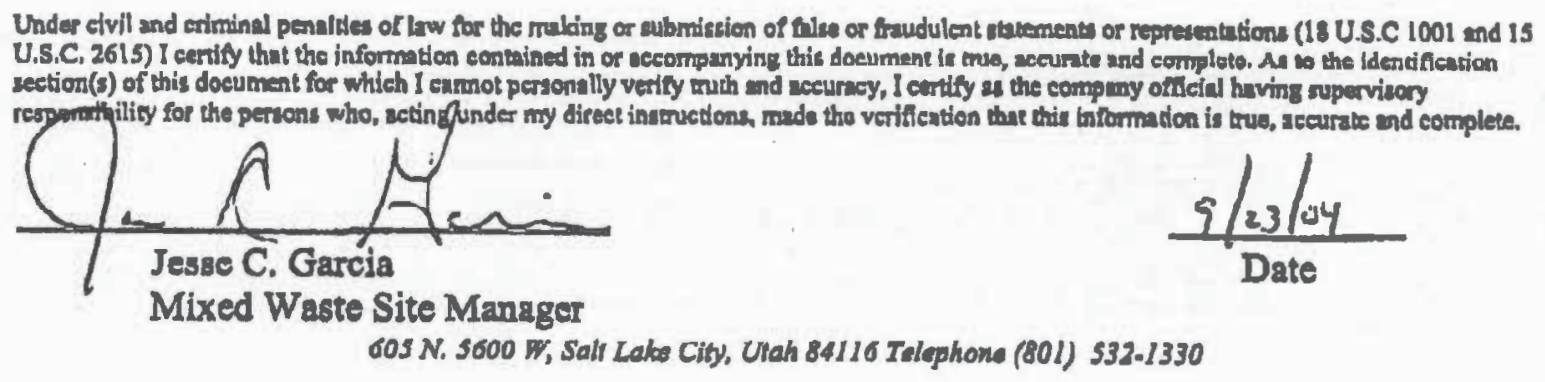




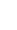


$\mathrm{NO} 323$

\begin{tabular}{|l|ll}
\hline $\begin{array}{l}\text { UNIFORM HAZARDOUS } \\
\text { WASTE MANIFEST }\end{array}$ & $\begin{array}{c}\text { 1. Generator's US EPA ID No. } \\
\text { ID48900008952 }\end{array}$ & $\begin{array}{l}\text { Manifest } \\
\text { Document No. } \\
02225\end{array}$
\end{tabular}

19150
Information in the shaded areas is not required by Federal law.
3. Generator's Name and Mailing Address

Idaho National Engineering and Environmental Laboratory U.S. DOE, P.O. Box 1625, Idaho Falls, ID 83415-4105

4. Generator's Phone (208) $526-2414$

5. Transporter 1 Company Name TW Company

7. Transporter 2 Company Name

9. Designated Facillty Name and Site Address

(aragonite) ILC

11600 North Aptus Road

Aragonite, UT 84029
6. US EPA ID Number UTD988074712

8. US EPA ID Number
10. US EPA ID Number

A. State Manifest Document Number

B. State Generator's ID

TD4890008952

C. State Transporter's ID

D. Transporter's Phone (801) 299-1900

E. State Transporters:D F. Transporter's Phone ( I) -

G. State Facility's ID H. Facility's Phone

(801) $323-8100$

11. US DOT Description (Including Proper Shipping Name, Hezard Class and IO Number) $\mathrm{HM}$

a. RQ Polychlorinated biphenyla, solid, 9, ON2315, PG

N

E

A b.

R.

Return signed original to: D.J. Rowley, Idaho National Engineering \& Environmental

Laboratory/OS DOE, P.O. Box 1625, Idaho Ralls, ID 83415-4105. Prepared under contract \#DEAC07 99ID 13727. USDOE 24-Ex. Enexgency Phone: (208) 526-1515.

16. GENERATOR'S CERTIFICATION: I hereby dectare that the contents of this consignment are fully and accurately described above by proper shipping name and are classified, packed, marked, and labeled, and are in all respects in proper condition for transport by highway according to applicable intemational and national govemment regulations.

If I am a large quantity generator, I certify that I have a program in place to reduce the volume and toxicity of waste generated to the degree I have determined to be economically practicable and that I have selected the practicable method of treatment, storege, or disposal currenty available to me which minimizes the present and future threat to human health and the environment; OR, If I am a small quantity generator, I have made a good faith effort to minimize my waste generation and seloct the best waste management method that is avaliable to me and that I can afiord.

Printed/Typed Name JoCL) Cu

17. Transporter 1 Acknowledgement of Receipt of Materials

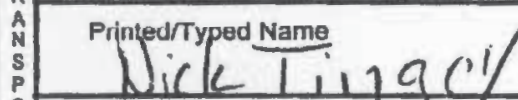

18. Transporter 2 Acknowledgenent of Receipt of Materials Printed/Typod Name

R

\begin{tabular}{l|l}
$\mathbf{F}$ \\
$\mathbf{C}$ \\
$\mathbf{C}$
\end{tabular}

19. Discrepancy Indication Space

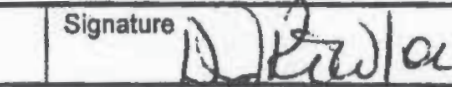

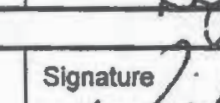

Ke Handling Codes for
TAN LOAD $=172$

SATES, ORDER C C9719693

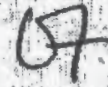

20. Facility Owner or Operator: Certification of receipt of hazardous materials coffered by this manifest except as noted in Item 19.

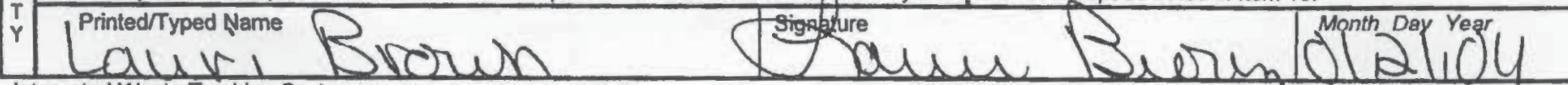


11600 North Aptus Road Asegonite, UT 84029

801.323 .8100

Fax 801.323.8877

wrw.deanharbors.com

MARCH 12, 2004

US DOE — INEEL AMWTP

HIGHWAY 20 \& VAN BUREN

IDAFO FALIS, IDAHO 83415

EPA ID: ID4 890 008952

Certificate of Disposal

No. 200876

Customer Manifegt: $\$ 2225$ a Document: No323 destroyed as of FEBRUARY 22,2004

This is to certify that the hazardous material manifested to Clean Harbors on. the above Clean Harbors Aragonite Document Number was disposed of by incineration in accordance with 40 CFR 761 (and 40 CFR 264 if applicable) as of the above cercification date.

Attached is a detailed report which identifies the date(s) of disposal. Residue from this waste has been disposed of at an approved and permitted Hazardous Waste LandEill.

Under civil and criminal penalties of law for the making or submission of false or fraudulent statements or representations (18 U.S.C. 1001 and 15 U.S.C. 2615). I cartify that the information contained In or accompanying this document 13 true, accurate, and complete. As to the identified section(s) of this document for which I cannot personally verify truth and accuracy, I certify as the company officlal having supervisory responsibility for the persons who, acting under my direct instructions, made the verification that this information is true, accurate, and complete.

Clean Harbors, Aragonite UT

EPA ID \# UTD $981552 \quad 177$

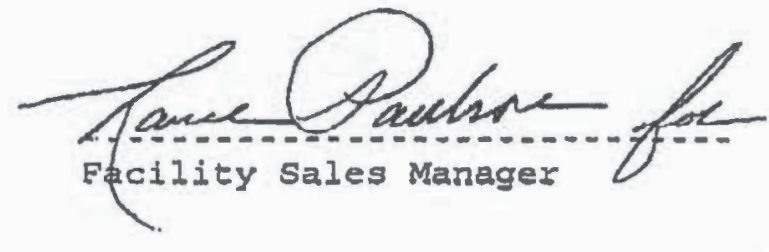

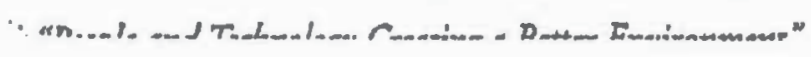


03-15-2004 08:54am From-CLEAM HARBORS LAKEPOIMT

8015087617

$T-445 \quad P .004 \quad F-268$

$M R-15-2004 \quad 08: 68$

$S K$ ARAGONITE

801323 897? $P .03 / 16$

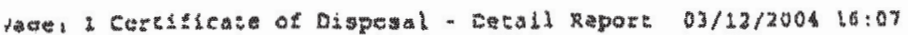

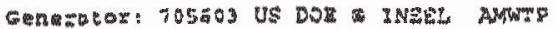

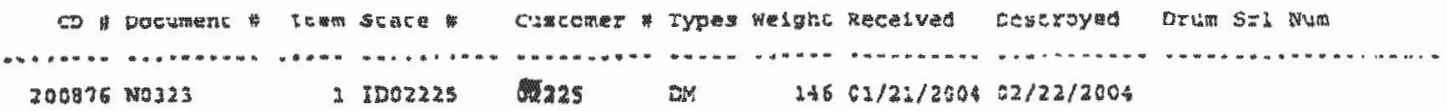

TANO30325 II.A 
03-15-2004 08:55am FrOI-CLEAN HARBORS LAKEPOINT

MAR-15-2004 08:09

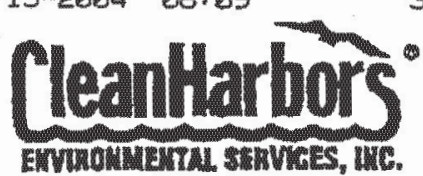

11600 North Aptur Road

Aragonite, UT B4029

801.323 .8100

Fix 801.323 .8877

Www.clenhabors.com

MARCH 12, 2004

Environmental Manager

US DOE INEEL AMWTE

HIGHWAY 20 \& VAN BUREN

IDAHO FALLS, IDAHO 83415

RE: Certificates of Disposal

Dear Environmental Manager:

Enclosed please find your certificate(s) of Disposal and accompanying detailed repore(s) for the waste that was shipped to our Eacility for treatment. Your original manifest number is referenced on both of these documents along with a Clean Harbors Aragonite document number.

Youx waste has been properly treated and the residue from this waste has been disposed of at an approved and perritted hazardous waste landf11.

Clean Harboxa appreciaces you as a valued customer. If you should have any questions or concerng please do not hesitare to contact one of our customer/facility representatives at (80I) 323-8100.

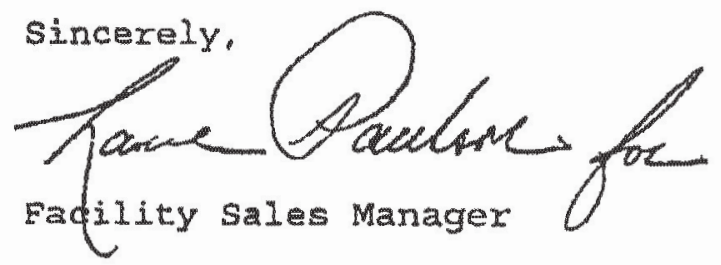

Enclosures 
Generator:

CONbr

$11134716-268$

Trackine Nbr

4802253

4802254

4802255

CDNbr

$11134716-271$

Iracking Nor

4802203

CO Nor

11134716 - 272

Tracking Nbr

4843736

CD Nbr

$11134716-273$

Trackina Nor

4843903

CD Nbr

$11134716-274$

Iracking Nbr

4843917

CO Nor

$11134716-275$

Trackina Nbr

4911027

4911028

4911029
Ineel US DOE 47 miles West of Idaho Falls on US Hwy 20 Scoville, ID 83415

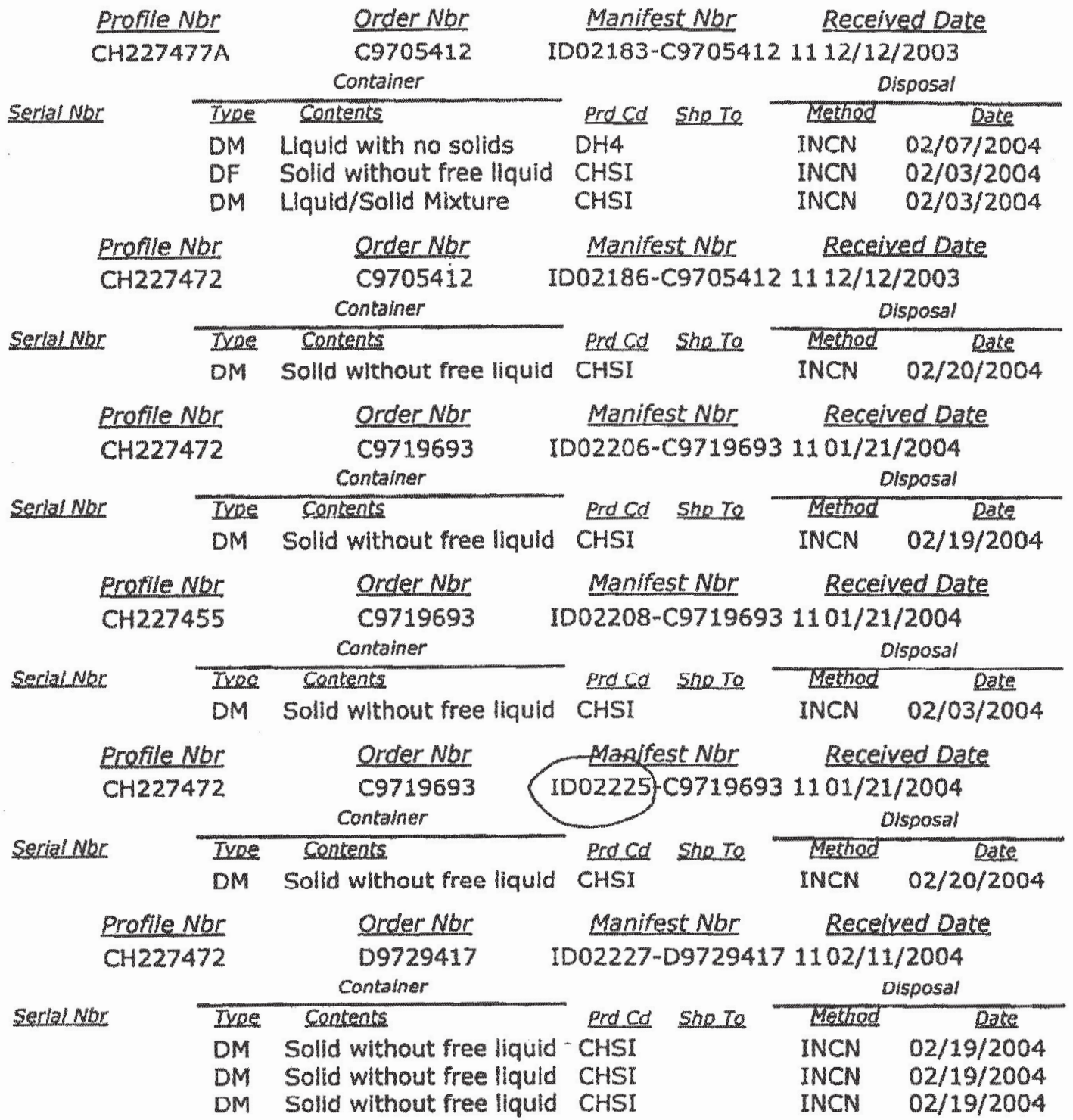


Clean Harbors Aragonite LLC

11600 North Aptus Road

Aragonite UT 84029

EPA ID UTD981552177

November 11,2004

DJ ROWLEY

Ineel US DOE

47 miles West of Idaho Falls on US Hwy 20

scovile ID, 83415

Re: Certificates of Disposal

Dear DJ ROWLEY

This letter and the attached CD Log constitute your Certificate(s) of Disposal for the waste that was shipped to our facility for disposal.

This is to certify that the waste referenced on the attached CD Log and manifested to the above referenced Clean Harbors facillty was processed and disposed of in accordance with 40 CFR 761 (and 40 CFR 264 if applicable). Your waste has been properly treated and any residue from this waste has been disposed of at an approved and permitted Facility.

Under civil and criminal penalties of law for the making or submission of faise or fraudulent statements of representations (18 U.S.C. 1001 and U.S.C. 2615). I certify that the Information contained in or accompanying this document is true, accurate and complete. As to the identified section(s) of this document for which I cannot personally verify truth and accuracy, I certify as the company official having supervisory responsibility for the persons who, acting under my direct instructions, made the verification that this information is true accurate, and complete.

Clean Harbors appreciates you as a valued customer. If you should have any questions or concerns please do not hesitate to contact one of our customer/facillty representatives.

Sincerely,

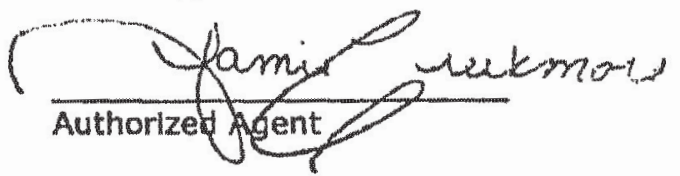

Enclosures 



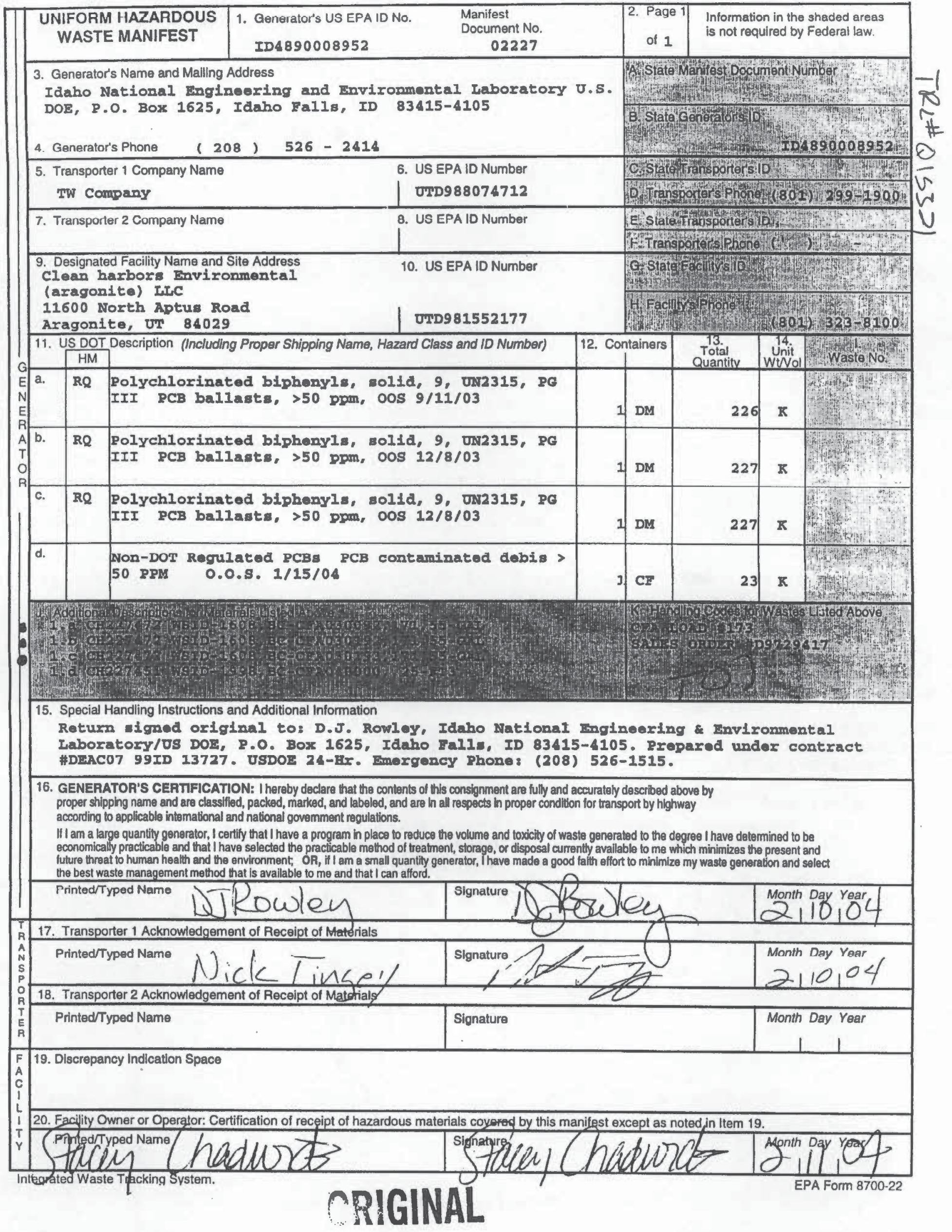


03-15-2004 08:56am FrOM-CLEAN HARBORS LAKEPOINT

\title{
Cleantharbors
}

11600 North Aprus Road

Argonite, UT 84029

$801.323 .8100^{\circ}$

F $2 \times 801.323 .8877$

mww.cleanharbors.com

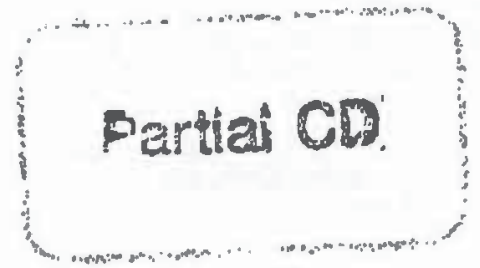

MARCH 12, 2004

US DOE @ INEEL AMWTP

HIGHWAY 20 \& VAN BUREN

IDAHO FALLS, IDAHO 83415

EPA ID: ID4 890008952

\author{
PCB \\ Certificate of Disposal
}

No. 200553

Customer Manifest: GP27 Document: N1222 destroyed as of FEBRUARY 19, 2004

This is to certify that the hazardous material manifested to clean Harbors on the above Clean Harbors Aragonite Document Number was disposed of by incineration in accordance with 40 CFR 761 (and 40 CFR 264 if applicable) as of the above certification date.

Attached is a detailed report which identifies the date(s) of disposal. Residue from this waste has been disposed of at an approved and permitted Hazardous Waste Landfill.

Under civil and criminal penalties of law for the making or submission of false or fraudulent statements or representations $118 \mathrm{U.S.C.} 1001$ and 15 U.S.C. 2615), I certify that the information contained in or accompanying this document is erue, accurate, and complete. As to the identified section(s) of this document for which I cannot personally verify truth and accuracy. I certify as the company official having supervisory responsibility for the persons who, acting under my direct instructions, made the verification that this information is true, accurate, and complete.

Clean Harbors, Aragonite UT

EPA ID \# UTD 981552177

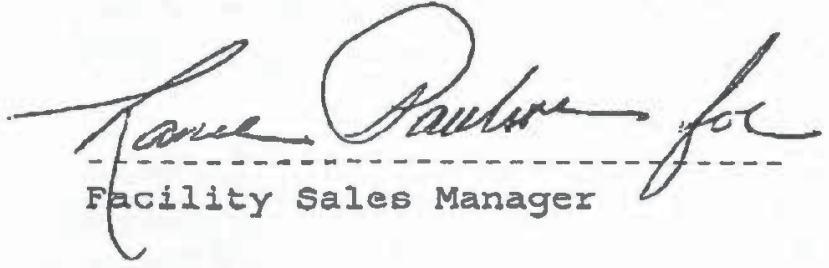

$\because$ "People and Technologv Creating a Betrer Environment" 


\section{Cleantlarbor's}

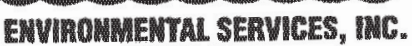

11600 North Aptus Rosd

Aragonite, UT' 84029

801.323 .8877

www.cleanharbors,com

JUNE 04,2004

Envixonmental Managex US DOE @ INEEL AMWTP HIGHWAX $20 \&$ VAN BUREN

IDAHO FALIS, IDAHO 83415

RE: Certificates of Disposal

Dear Environmental Manager:

Enclosed please find your Certificate(s) of Disposal and accompanying detailed report(s) for the waste that was shipped to our facility for treatment. Your original manifest number is referenced on both of these documents along with a Clean Harbors Aragonite document number.

Your waste has been properly treated and the residue from this waste - has been disposed of at an approved and permitted hazardous waste landfill.

Clean Harbors appreciates you as a valued customer. If you should have any questions or concerns please do not hesitate to contact one of our customer/facility representatives at (801) 323-8100.

sincerely,

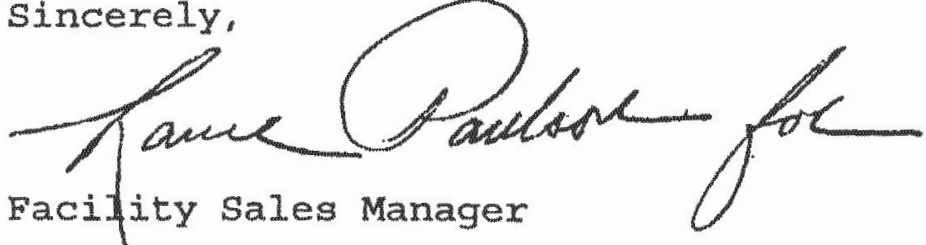

Enclosures 


\title{
Cleantharbors'

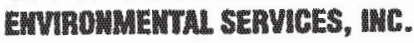

11600 North Aptus Road

Aragonice, UT 84029

801.323 .8877

www, deanharbors.com

JUNE 04, 2004

US DOE @ INEEL AMWTP

HIGHWAY 20 \& VAN BUREN

IDAHO FAILS, IDAHO 83415

EPA ID: ID4 $890 \quad 008952$

\author{
PCB \\ Certificate of Disposal \\ No. 200553
}

Customer Manifest: 02227 Dócument: $N 1222$ destroyed as of FEBRUARY 19, 2004

This is to cextify that the hazardous material manifested to clean Haxbors on the above Clean Harbors Aragonite Document Number was diaposed of by incineration in accordance with 40 CFR 761 (and 40 CFR 264 if applicable) as of the above certification date.

Attached is a detailed report which identifies the date(s) of disposal. Residue from this waste has been disposed of at an approved and permitted Hazardous Waste Landfil1.

Under civil and criminal penalties of law for the making or submission of false or fraudulent statements or representations (18 U.S.C. 1001 and 15 U.S.C. 2615), I certify that the information contained in ox accompanying this document is true, accurate, and complete. As to the identified section(s) of this document for which I cannot personally verify truth and accuracy, I certify as the company official having supervisory responsibility for the persons who, acting under my direct instructions, made the verification that this information is true, accurate, and complete.

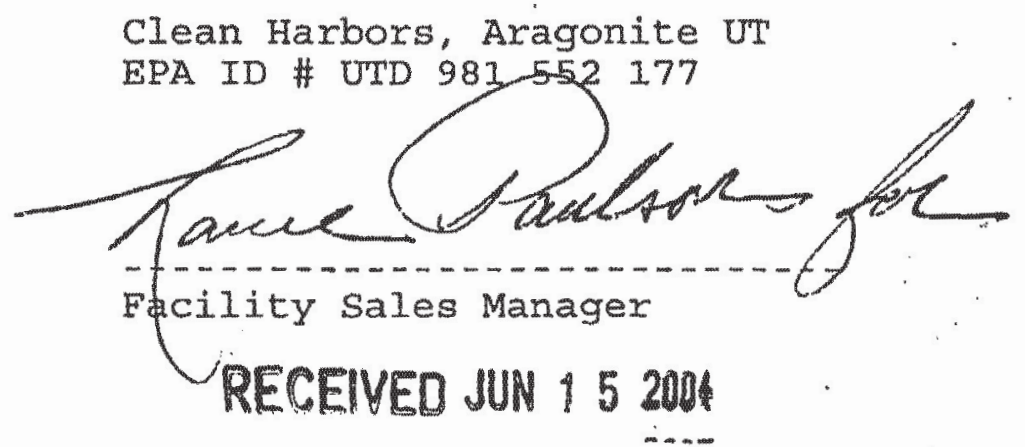

t." "People and Technology Creating a Better Environment" 
Rage: 1 Certificate of Disposal - Detal Report 06/04/2004 11:17

Gerer tox: 705603 US DOE INEEL AMWT:

\begin{tabular}{|c|c|c|c|c|c|c|c|c|c|}
\hline$C D$ & Document & Item & stace & cugcomer & rypes & Weight & Received & Destroyed & Dxum $S x 1$ Nพum \\
\hline$+\infty-\infty+\cdots$ & $\ldots \ldots \ldots \ldots$ & $m-m-\infty$ & $\ldots \ldots+\ldots+\cdots$ & $\ldots+\infty+\infty \ldots+\infty$ & $\ldots \ldots$ & $\ldots \ldots$ & $-+\cdots+\infty-\infty=$ & $m-m-\infty=-x-m=$ & 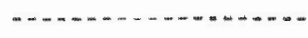 \\
\hline 200553 & N 1222 & 1 & 1002227 & 02227 & DN & 254 & $02 / 11 / 2004$ & $02 / 29 / 2004$ & \\
\hline 200553 & N1222 & 2 & 1002227 & 02227 & $\mathrm{DM}$ & 456 & $02 / 11 / 2004$ & $02 / 29 / 2004$ & \\
\hline 200553 & N1222 & 3 & I002227 & 02227 & Den & 456 & $02 / 11 / 2004$ & $02 / 19 / 2004$ & \\
\hline & N1222 & 4 & 1002227 & 02227 & $C F$ & 50 & $02 / 11 / 2004$ & & 1 \\
\hline
\end{tabular}


Clean Harbors Aragonite LIC

11600 North Aptus Road

Aragonite UT 84029

EPA ID UTD 981552177

November 11, 2004

DJ ROWLEY

Ineel US DOE

47 miles West of Idaho Falls on US Hwy 20

Scoville ID, 83415

Re: Certificates of Disposal

Dear DJ ROWLEY

This letter and the attached CD Log constitute your Certificate(s) of Disposal for the waste that was shipped to our facility for disposal.

This is to certify that the waste referenced on the attached $\mathrm{CD} \log$ and manifested to the above referenced Clean Harbors facility was processed and disposed of in accordance with 40 CFR 761 (and 40 CFR 264 if applicable). Your waste has been properly treated and any residue from this waste has been disposed of at an approved and permitted Facility.

Under clvil and criminal penalties of law for the making or submission of false or fraudulent statements or representations (18 U.S.C. 1001 and U.S.C. 2615). I certify that the information contained in or accompanying this document is true, accurate and complete. As to the identified section(s) of this document for which I cannot personally verify truth and accuracy, I certify as the company official having supervisory responsibility for the persons who, acting under my direct instructions, made the verification that this information is true accurate, and complete.

Clean Harbors appreciates you as a valued customer. If you should have any questions or concerns please do not hesitate to contact one of our customer/facillity representatives.

Sincerely,

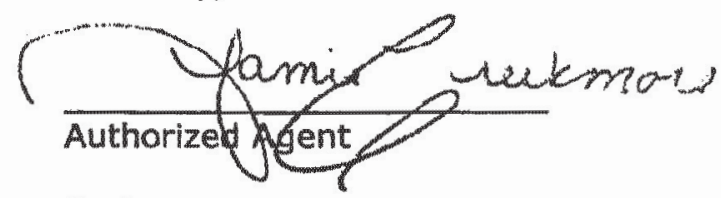

Enclosures 
Generator:

CD Nbr

$11134716-268$

Tracking Nor

4802253

4802254

4802255

CONbr

$11134716-271$

Trackino Nbr

4802203

$\mathrm{CDNbr}$

$11134716-272$

Trackina Nor

4843736

CD Nbr

$11134716-273$

Trackina $\mathrm{Nbr}$

4843903

CONbr

11134716 - 274

Tracking Nbr

4843917

CD Nbr

$11134716-275$

Trackino Nor

4911027

4911028

4911029
Ineel US DOE 47 miles West of Idaho Falls on US Hwy 20 Scoville, ID 83415

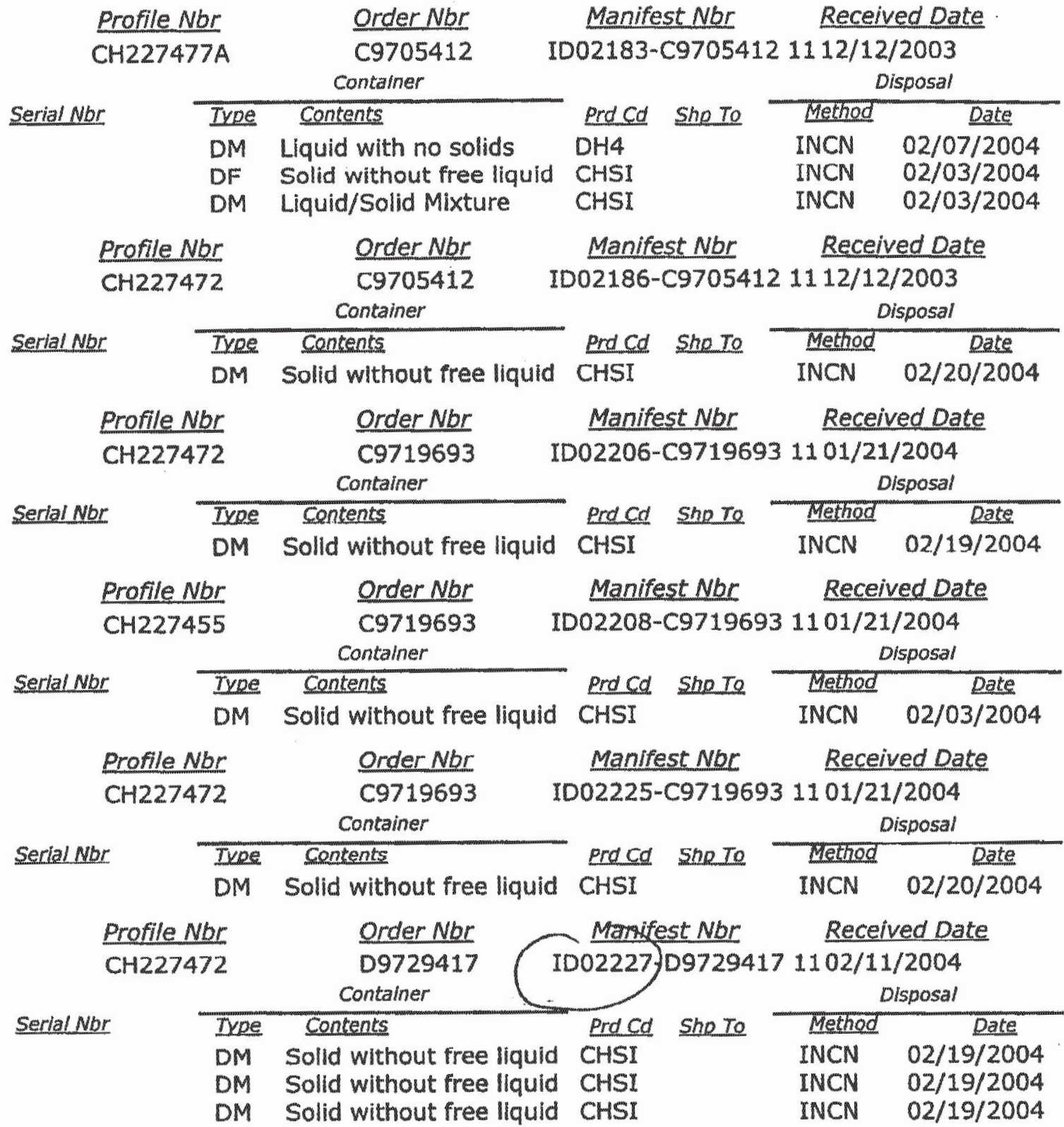





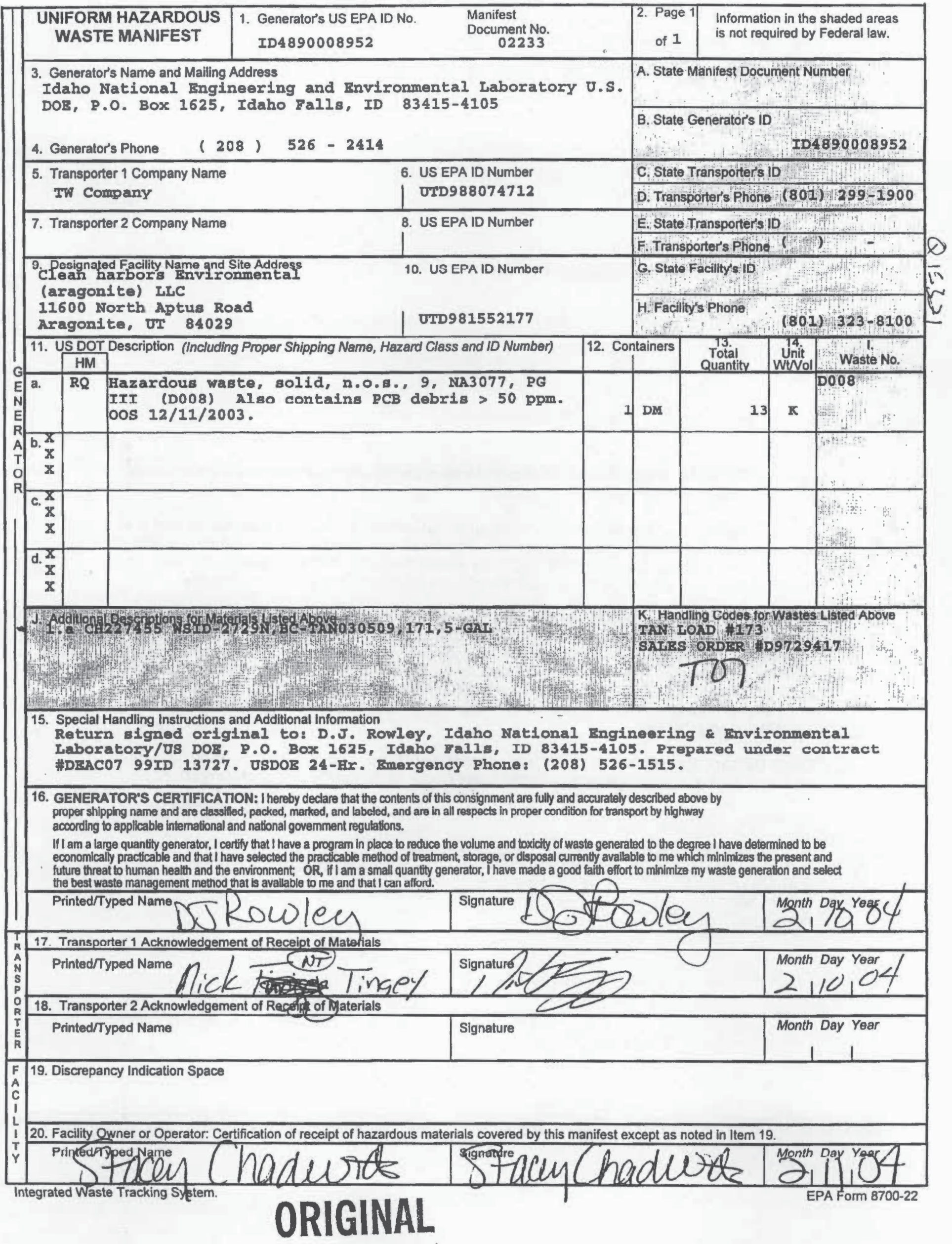


- Clean Harbors Aragonite LLC 11600 North Aptus Road

Aragonite UT 84029

EPA ID UTD981552177

November 11, 2004

DJ ROWLEY

Ineel US DOE

47 miles West of Idaho Falls on US Hwy 20

SCOVILLE ID, 83415

Re: Certificates of Disposal

Dear DJ ROWLEY

This letter and the attached CD Log constitute your Certificate(s) of Disposal for the waste that was shipped to our facility for disposal.

This is to certify that the waste referenced on the attached CD Log and manifested to the above referenced Clean Harbors facility was processed and dlsposed of in accordance with 40 CFR 761 (and 40 CFR 264 if applicable). Your waste has been properly treated and any residue from this waste has been disposed of at an approved and permitted Facility.

Under civil and criminal penalties of law for the making or submission of false or fraudulent statements or representations (18 U.S.C. 1001 and U.S.C. 2615). I certify that the information contained in or accompanying this document is true, accurate and complete. As to the identified section(s) of this document for which I cannot personally verify truth and accuracy, I certify as the company official having supervisory responsibility for the persons who, acting under my direct instructions, made the verification that this information is true accurate, and complete.

Clean Harbors appreciates you as a valued customer. If you should have any questions or concerns please do not hesitate to contact one of our customer/facillty representatives.

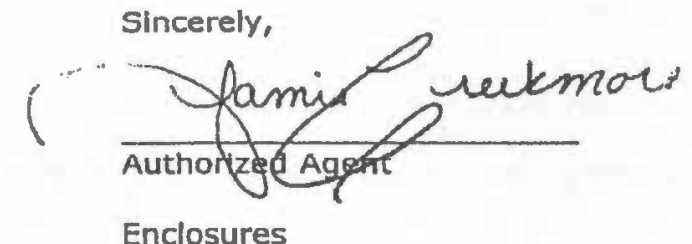

Enclosures 
Ineel US DOE 47 miles West of Idaho Falls on US Hwy 20 SCOVILLE, ID 83415

\begin{tabular}{|c|c|c|c|c|c|c|c|}
\hline \multirow{2}{*}{$\frac{C D N O F}{11137829-1}$} & \multicolumn{2}{|c|}{ Broflle Nor } & Order Nbr & \multicolumn{2}{|c|}{ Manifest Nor } & Recei & ed Date \\
\hline & \multicolumn{2}{|c|}{ CH227455 } & 09729417 & \multirow{2}{*}{\multicolumn{2}{|c|}{ ID02233-D972941 }} & \multirow{2}{*}{\multicolumn{2}{|c|}{$\begin{array}{r}1102 / 11 / 2004 \\
\text { Disposal }\end{array}$}} \\
\hline & & & Container & & & & \\
\hline Trecking Nor & Serial Nbr & Troe & Contents & PrdCd & Sho To & Method & Date \\
\hline 4911109 & & DF & ALL & CHSI & & INCN & $06 / 20 / 2004$ \\
\hline
\end{tabular}

THE ABOVE REFERENCED WASTE WAS PROCESSED AND DISPOSEO OF, IN ACCORDANCE WITH 40 CFR 761, AND THE FACILITY'S TSCA AUTHORIZATION 


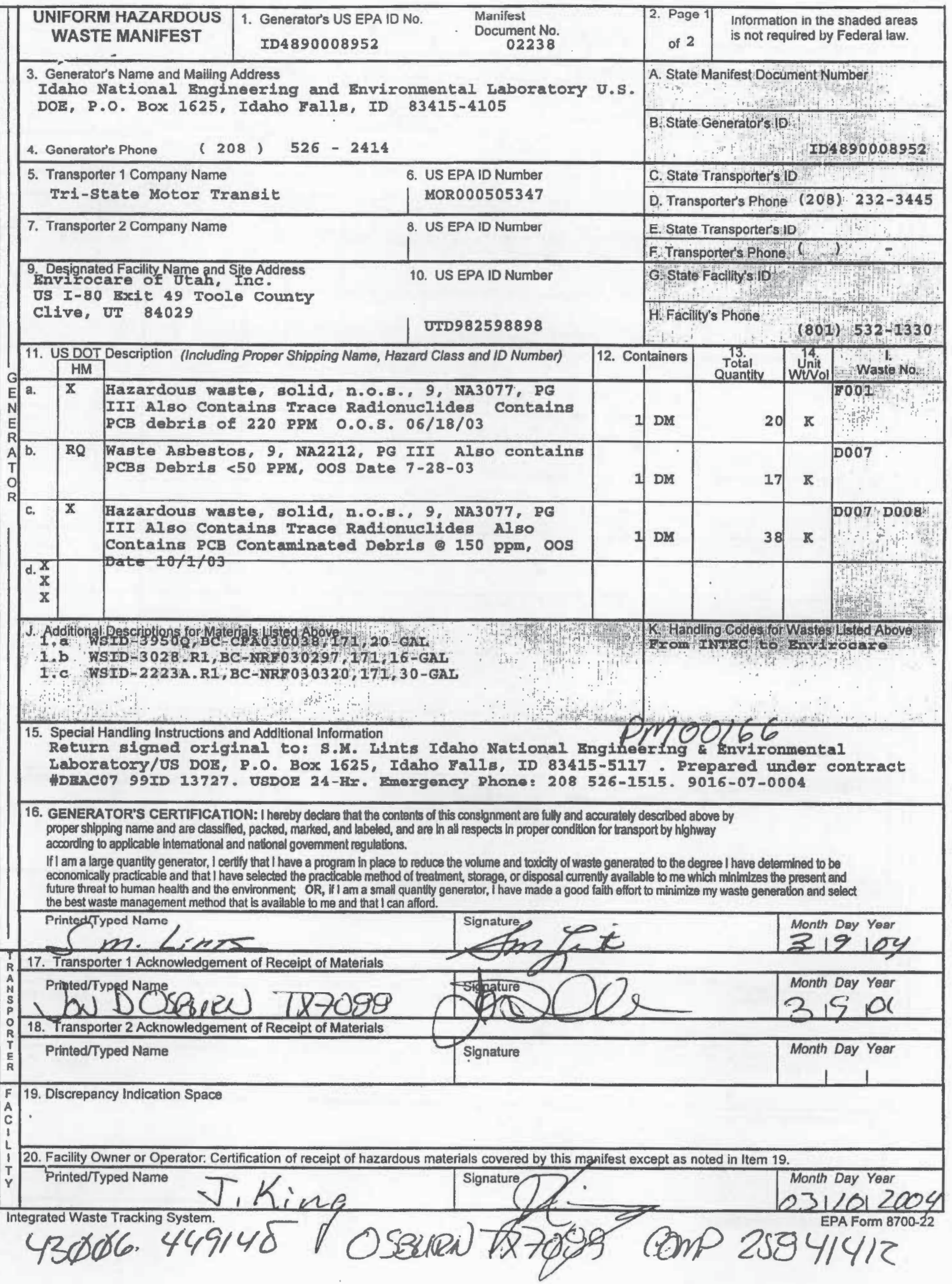




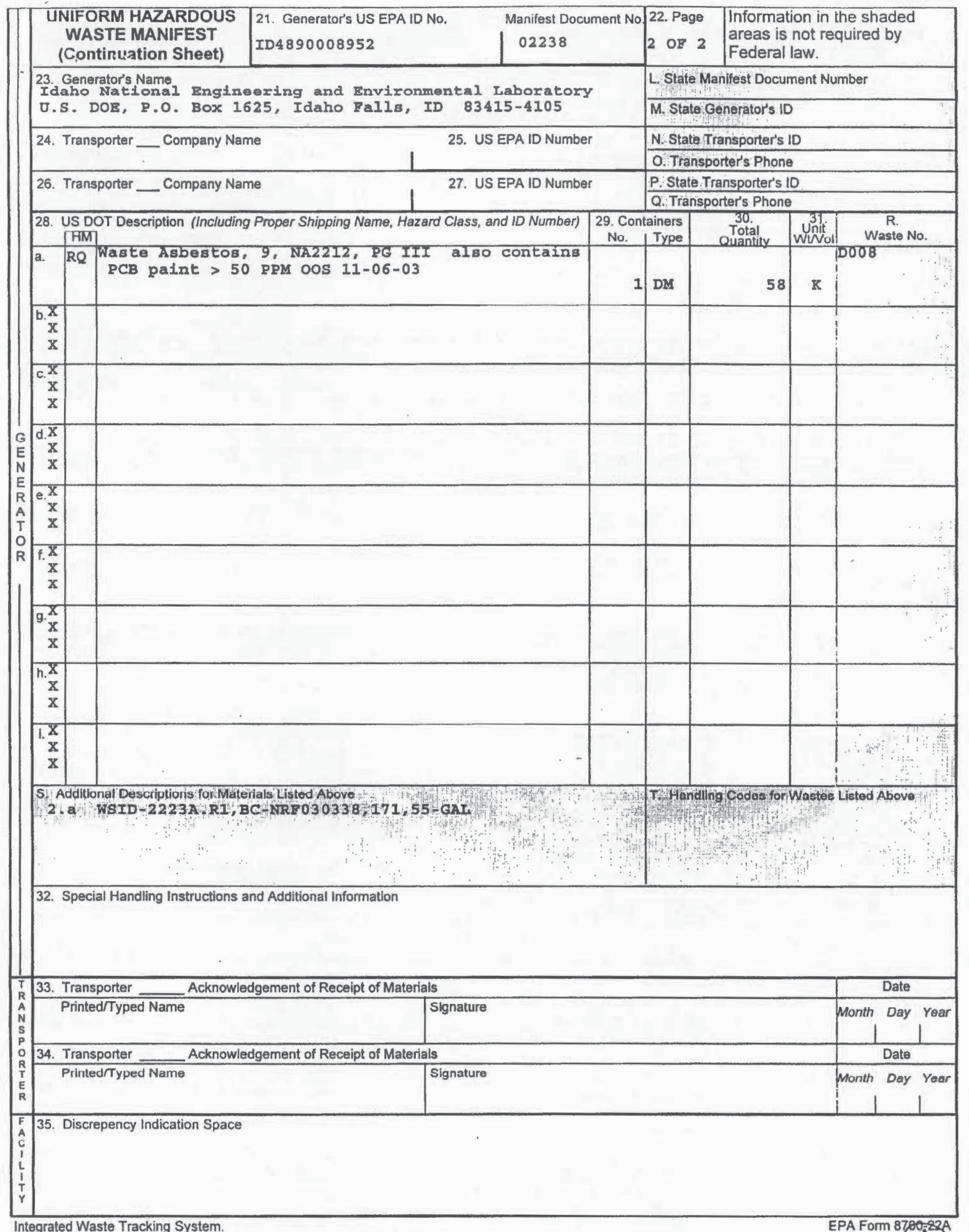




\section{ENVIROCARE}

OF UTAL, MNC.

THE SAFE ALTERNATTVE

3 mi. S. Ext 49, Ir80

Chye, Utah 84029 EPA

D: UT982598898

\section{CERTIFICATE OF DISPOSAL}

This Certificate acknowledges that the following manifested shipments:

$\underset{9016-07-0004}{\text { Shipment }} \frac{\text { Manifest }}{02238} \quad \frac{\text { Date(s) of Disposal }}{11 / 05 / 2004} \quad \frac{\text { Cu/Ft }}{16.18} \quad \frac{\text { Process }}{\text { Landfill }} \quad \frac{\text { Disposal Location }}{\text { Mixed Waste }}$

Representing 16.18 Củbic feet of waste of at listed Disposal Facility landfill. Disposal is sulject to

Envirocare's Radioactive Material License, all other applicable licenses, permits and regulations, and the Disposal Agreement.

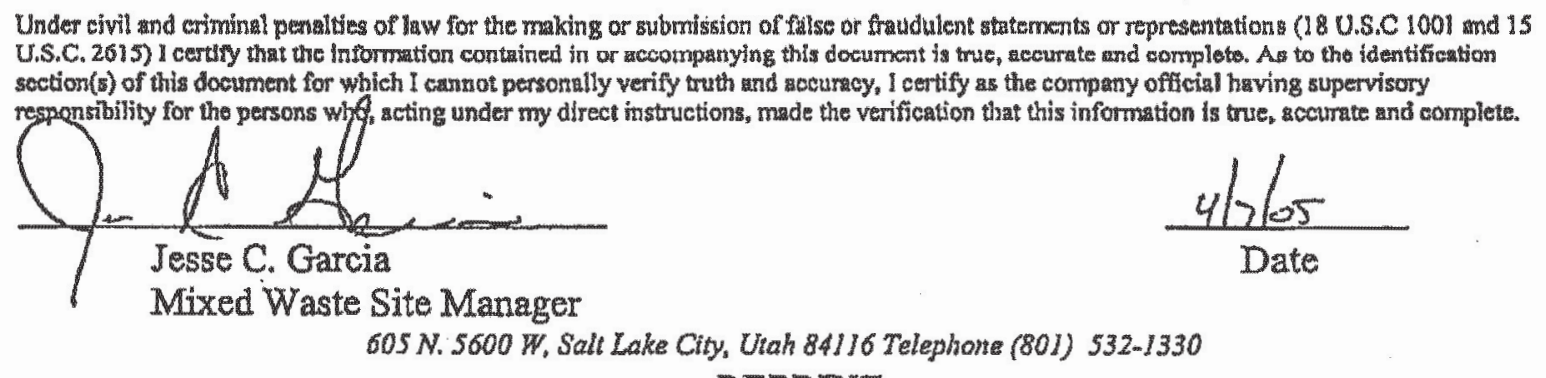





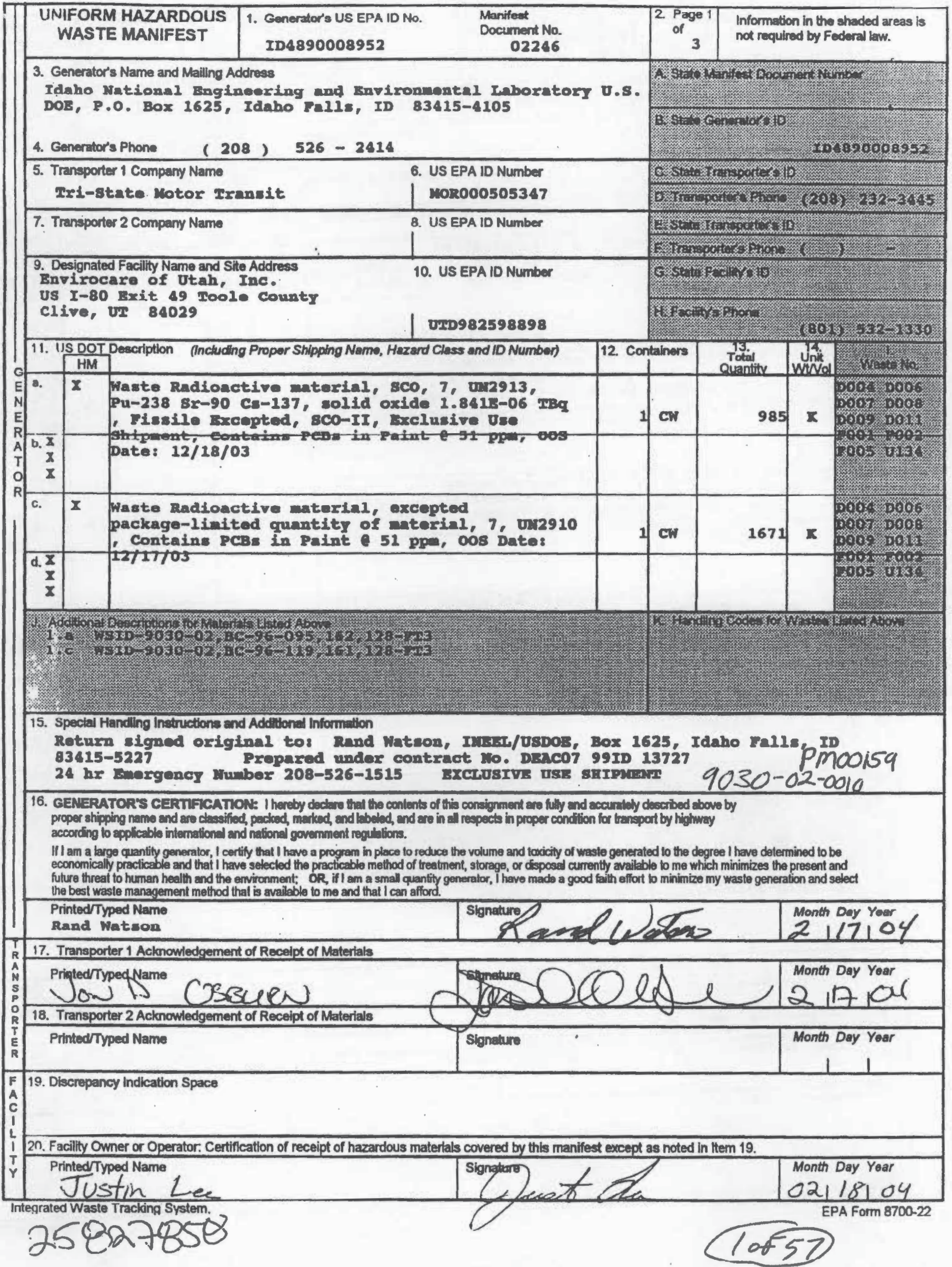




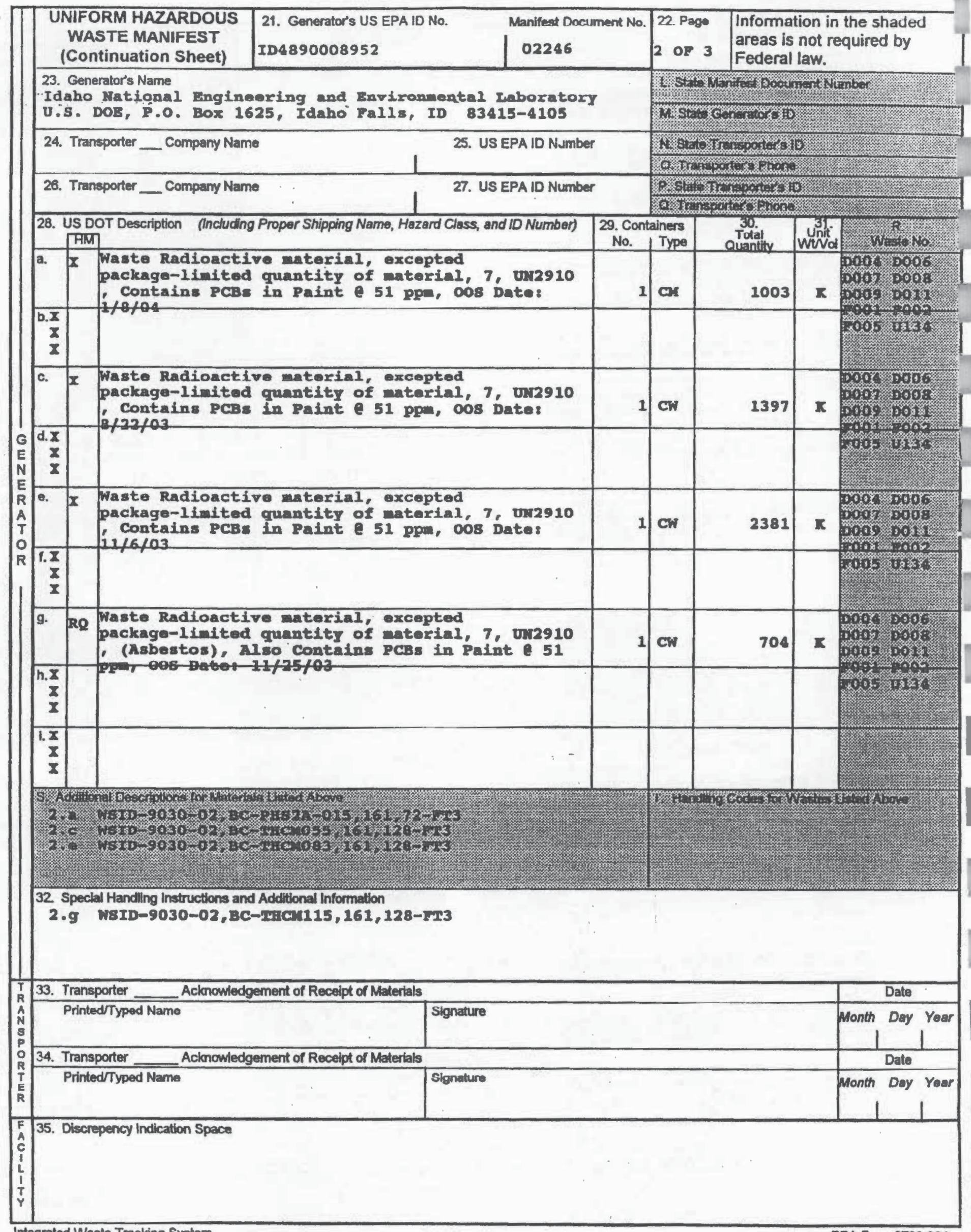




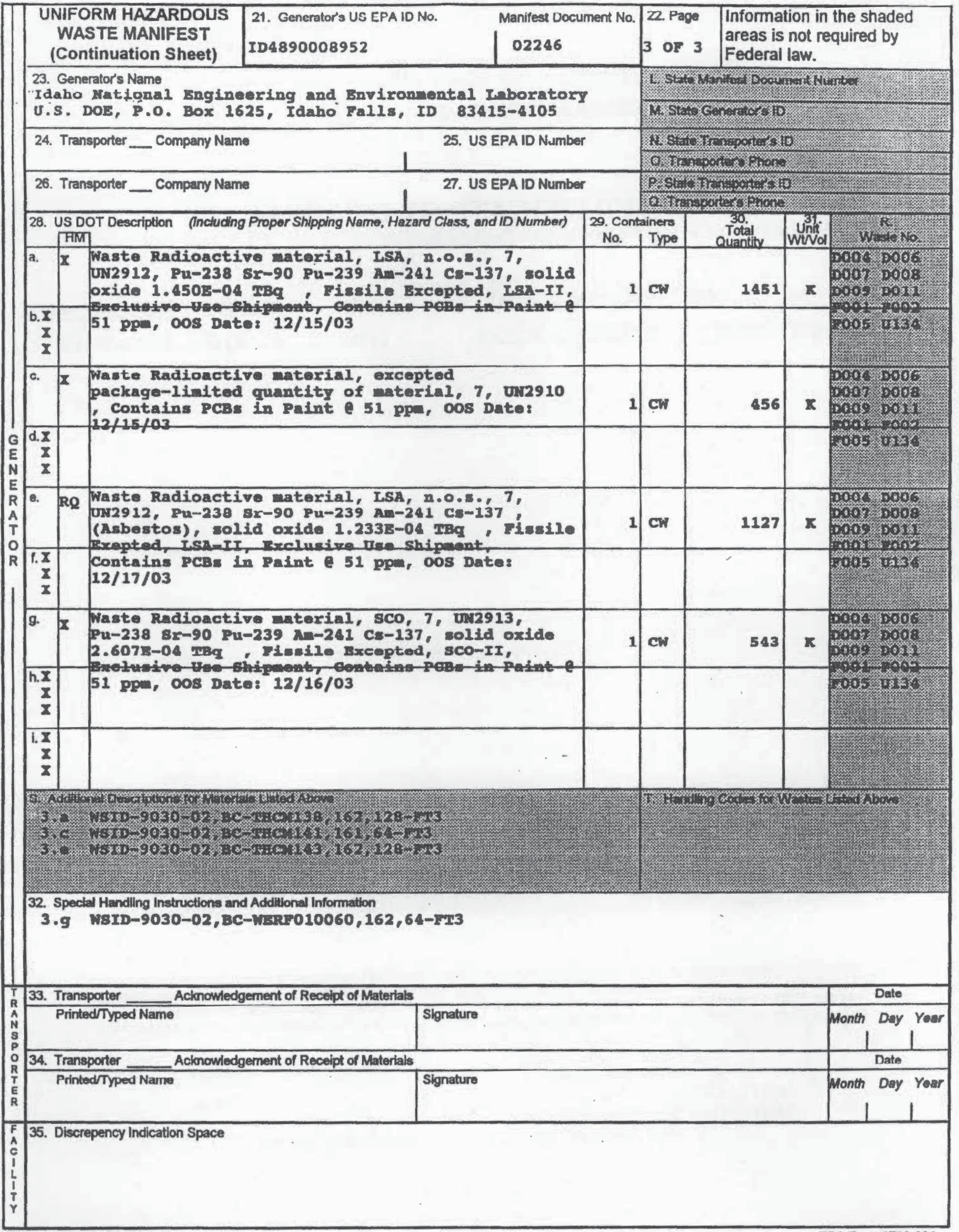


$\begin{array}{llllll}\text { OCT. 25. } 2004 & 7: 49 \text { AM } & \text { BECHTEL BWXT ID SAMPLE MANAGEMEN } & \text { NO. } 8167 & \text { P. } 17\end{array}$

ENVIROCARE OFUTAH, INC.

THE SAFE ALTERNATIVE

$3 \mathrm{mi}$. 5. Ext 49, 1-80

Clive, Uuh 84029 EPA

DD: UT98259889:

\section{CERTIFICATE OF DISPOSAL}

This Certificate acknowledges that the following manlfested shipments:

\begin{tabular}{|c|c|c|c|c|c|}
\hline Shipment & Manifest & Date(s) of Disposal & $\mathrm{Cu} / \mathrm{Ft}$ & Proceses: & Dienosal Location \\
\hline 30-02-0010 & 02246 & $8 / 23,24,26,27,30,2004$ & 1096 & Landrill & Mixed Waste \\
\hline
\end{tabular}

Representing 1096 Cubic feet of waste of at listed Disposal Facility landfill. Disponal is subject to

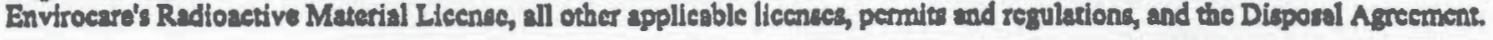

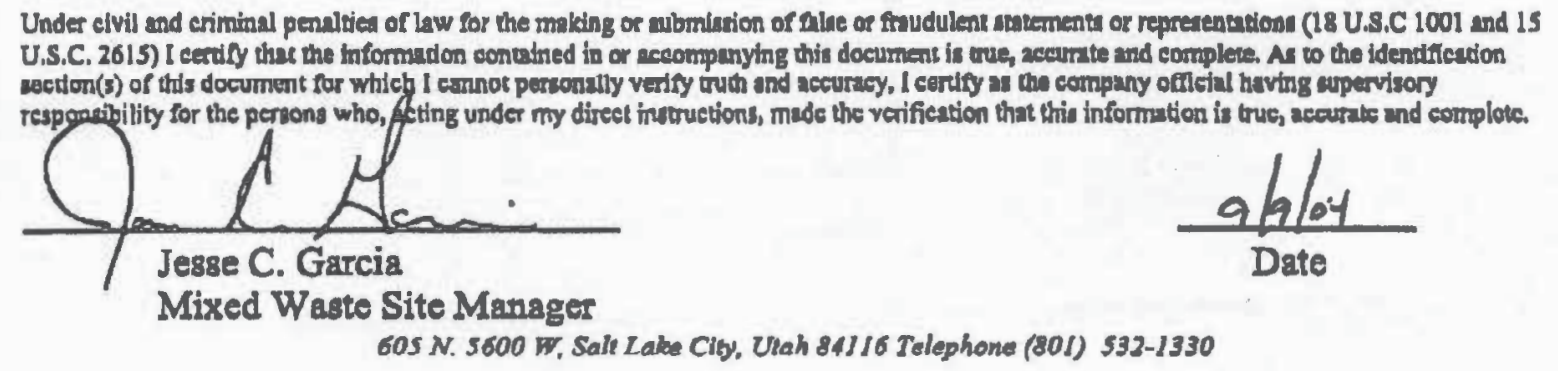


- 


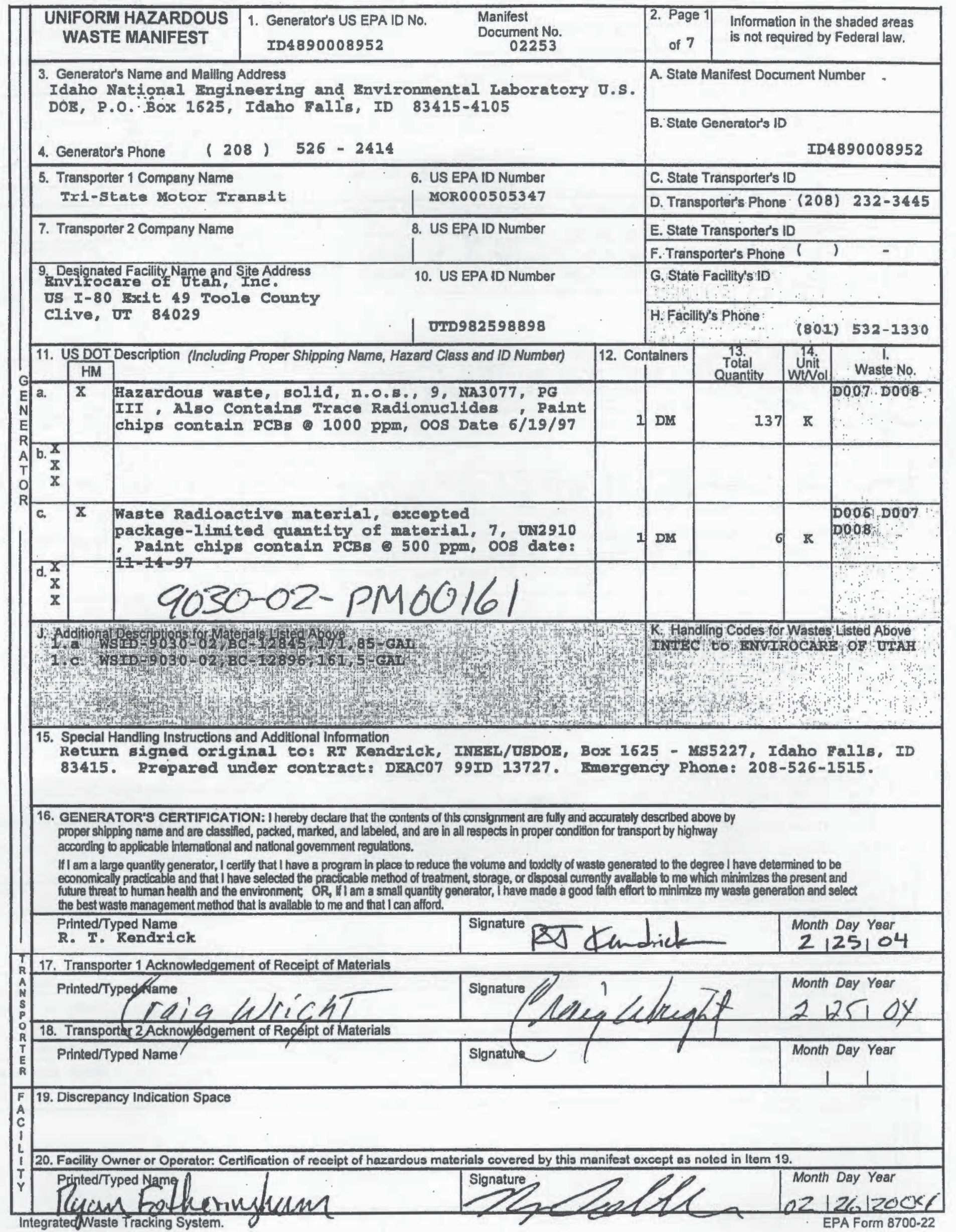




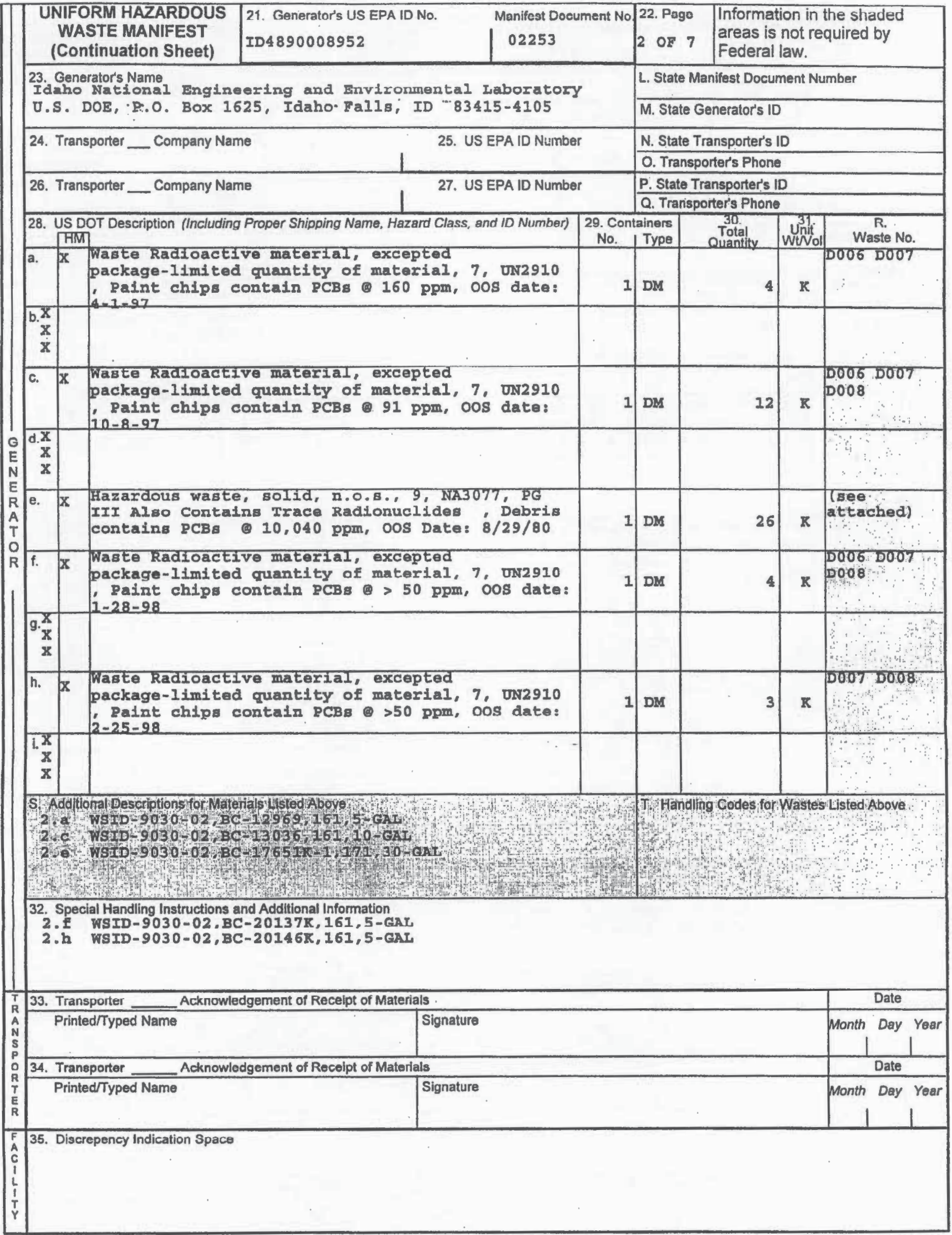




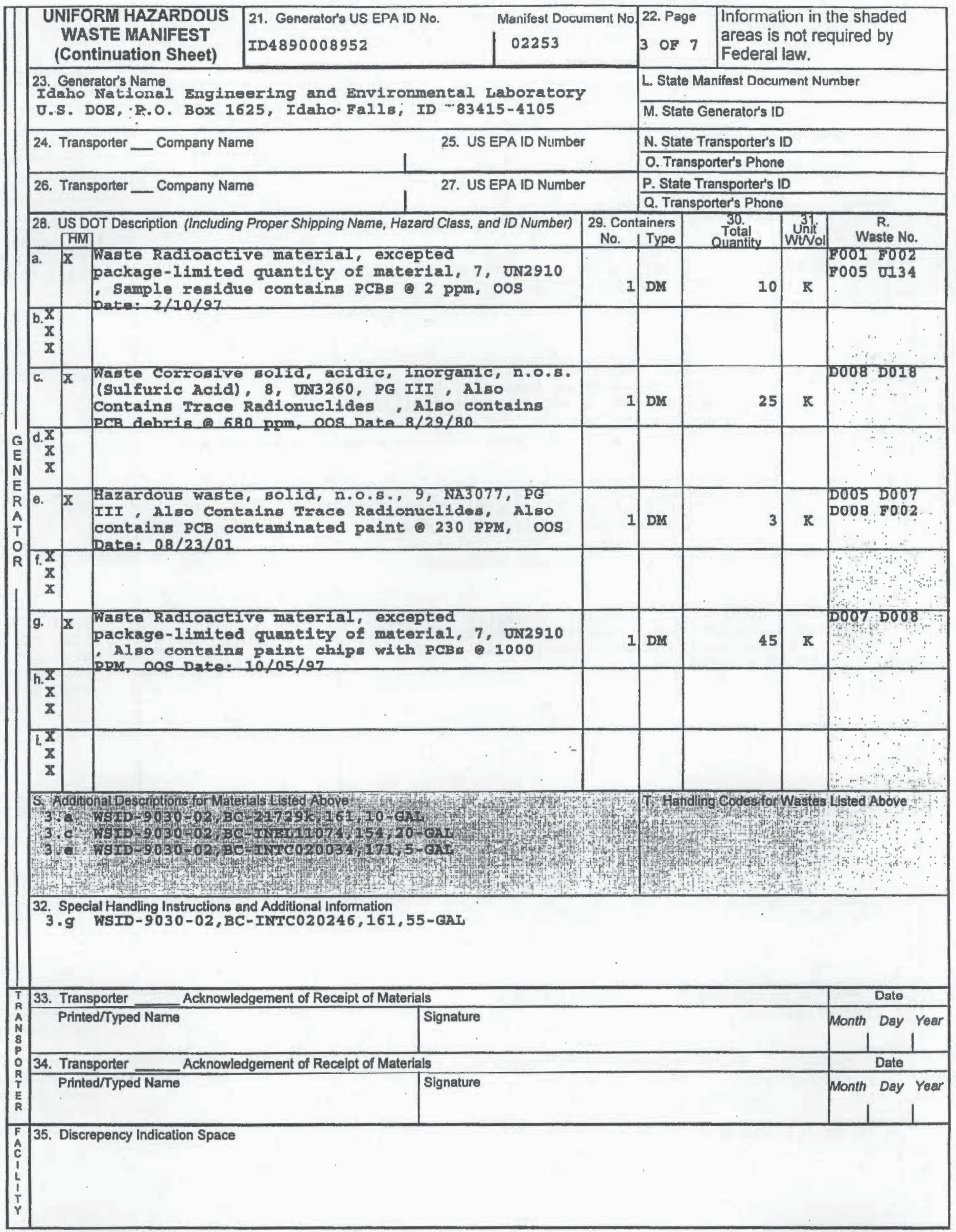




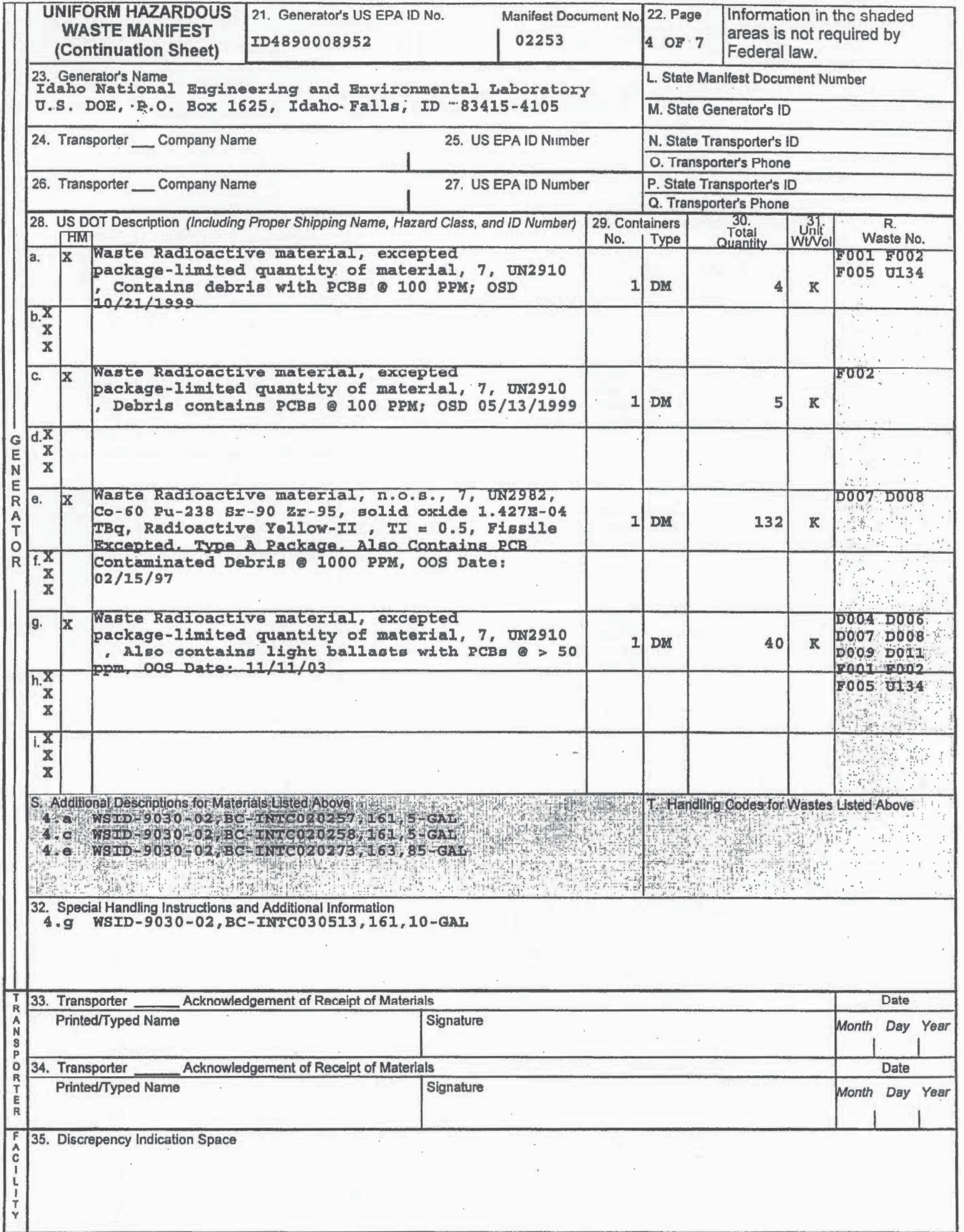




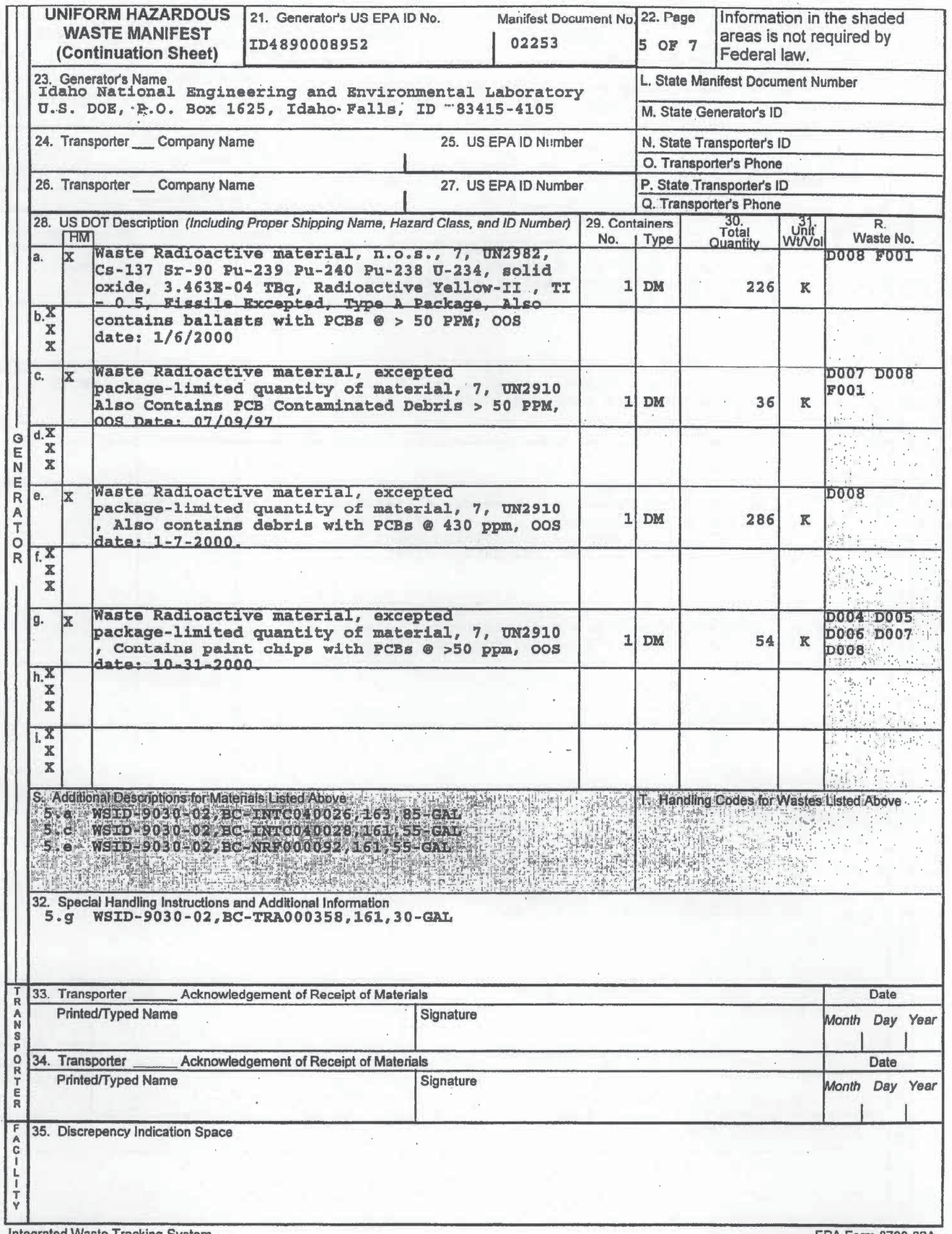




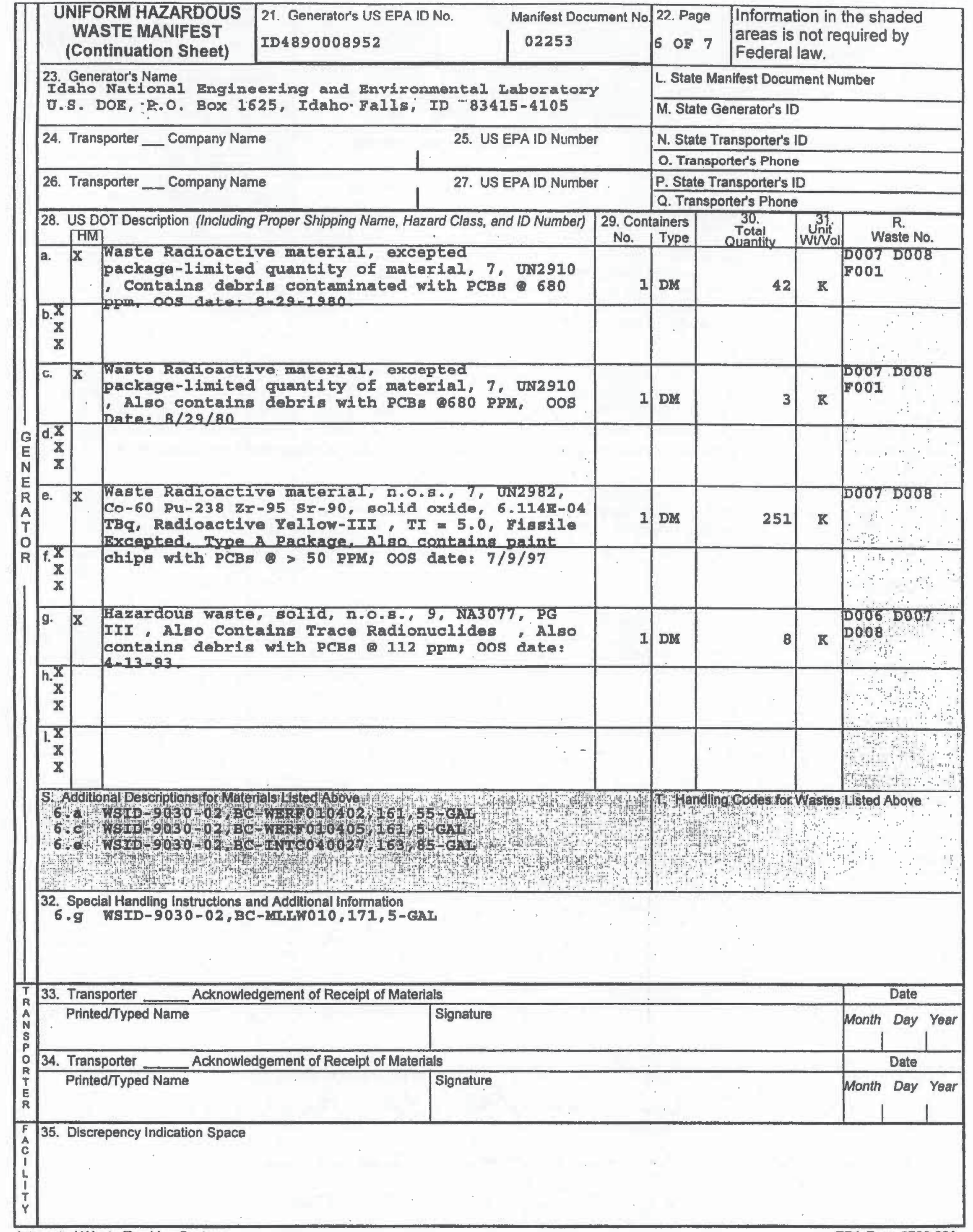




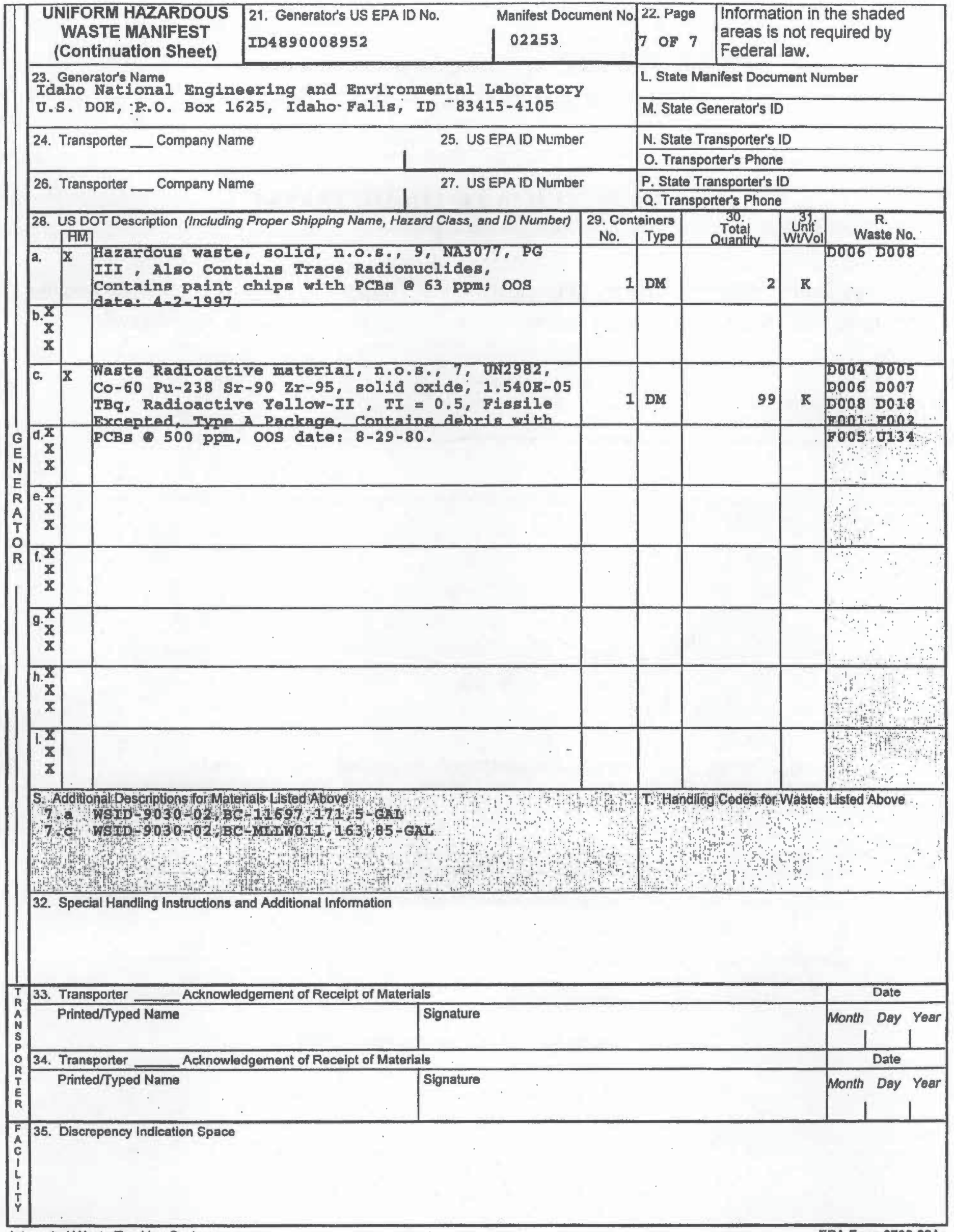




\section{ENVIROCARE OF UTAH, INC.}

THE SAFE ALTERNATIYE

3 mi. S. Ext. 49, 1-80

Clive, Utah 84029 EPA

ID: UT982598898

\section{CERTIFICATE OF DISPOSAL}

This Certificate acknowledges that the following manifested shipments:

$\frac{\text { Shipment }}{9030-02-0011} \frac{\text { Manifest }}{02253} \quad \frac{\text { Date(s) of Disposal }}{08 / 24 / 04,10 / 08 / 04} \cdot \frac{\text { Cu/Ft }}{107.61} \quad \frac{\text { Process }}{\text { Landfill }} \frac{\text { Disposal Location }}{\text { Mixed Waste }}$

$$
\text { HELEIVEU MoH Y YUO }
$$

Representing 107.61 Cubic feet of waste of at listed Disposal Facility landfill. Disposal is subject to Envirocare's Radioactive Material License, all other applicable licenses, permits and regulations, and the Disposal Agreement.

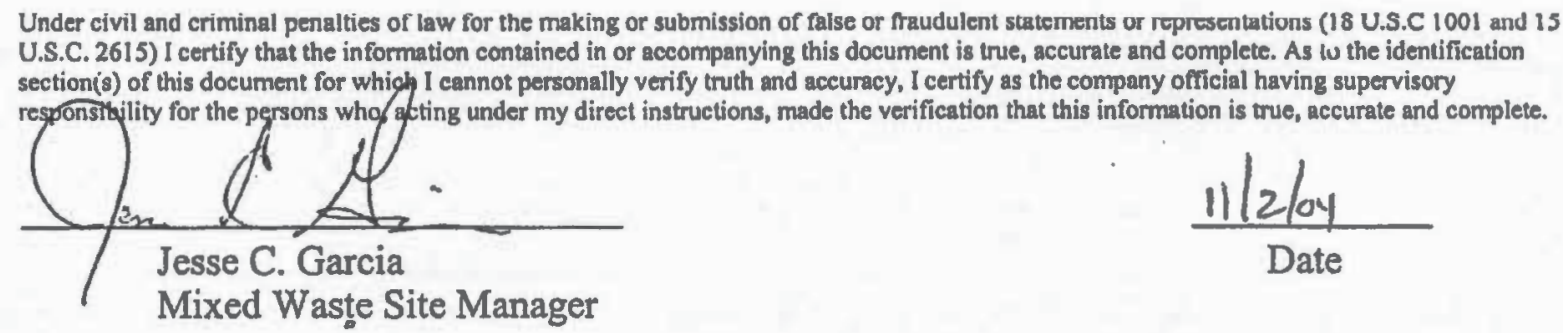

605 N. 5600 W. Salt Lake City, Uiah 84116 Telephone (80I) 532-1330 



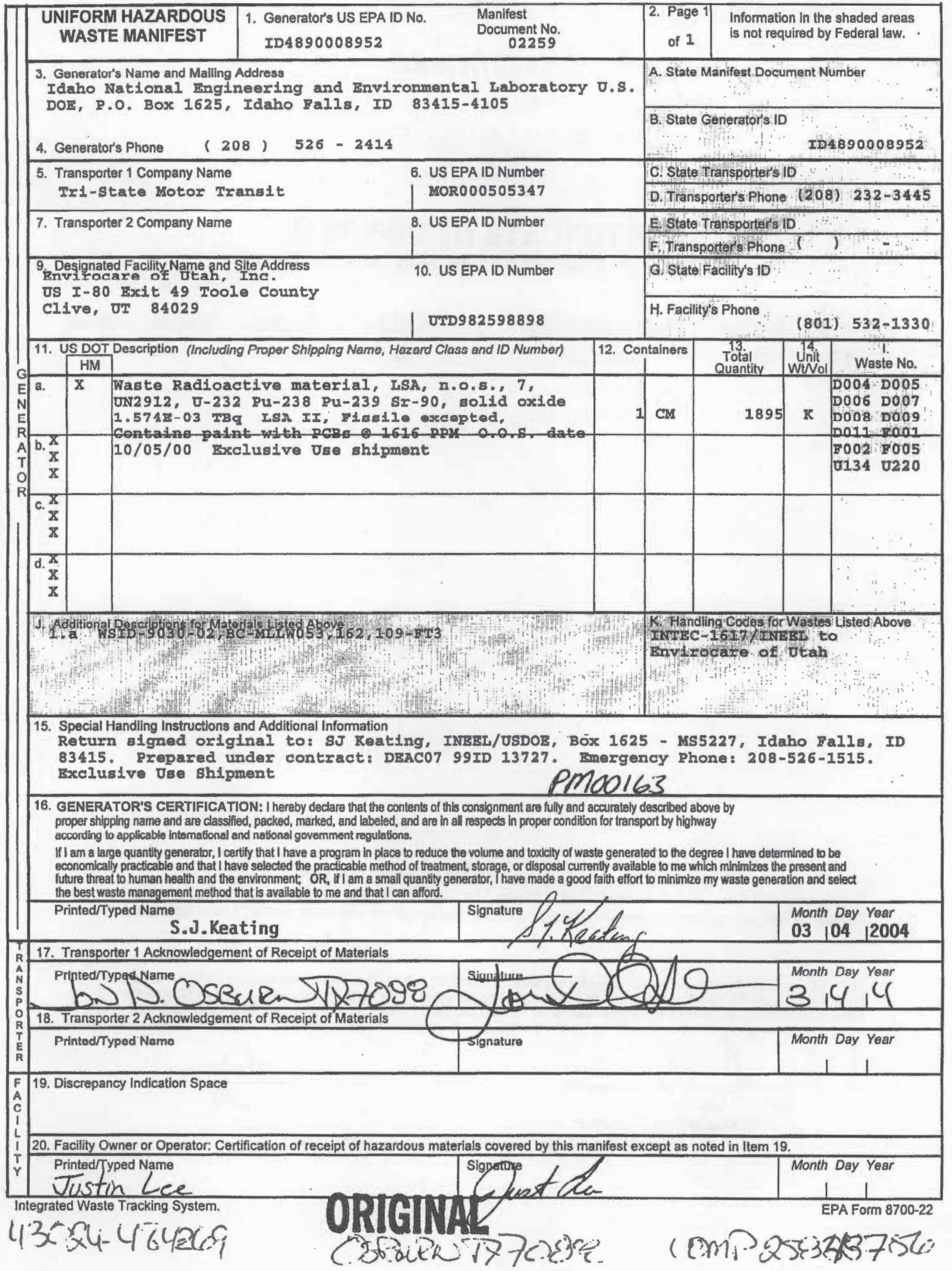




\section{ENVTROCARE}

OF UTAH, INC.

THE SAFE ALTERNATIVE

$3 \mathrm{mi} .3$. Ext 49 , Is0

Clive, Uruh 84029 EPA

DD: UT982598498

\section{CERTIFICATE OF DISPOSAL}

This Certificate acknowledges that the following manifosted shipments:

\begin{tabular}{|c|c|c|c|c|c|}
\hline Shipment & Manifest & Date(b) of Dimosal & $\mathrm{Cv} / \mathrm{st}$ & Proce:s: & Dispogel Location \\
\hline $9030-02-0012$ & 02259 & $09 / 30 / 2004$ & 109 & Landfill & Mixed Waute \\
\hline
\end{tabular}

Repreventing 109 Cubie feet of wate of at listed Disposal Facility landfil, Dispond is subject wo Envirocare's Redionctive Material Licenve, all other applicable lisenees, permits and regulations, aed the Disposal Apreement.

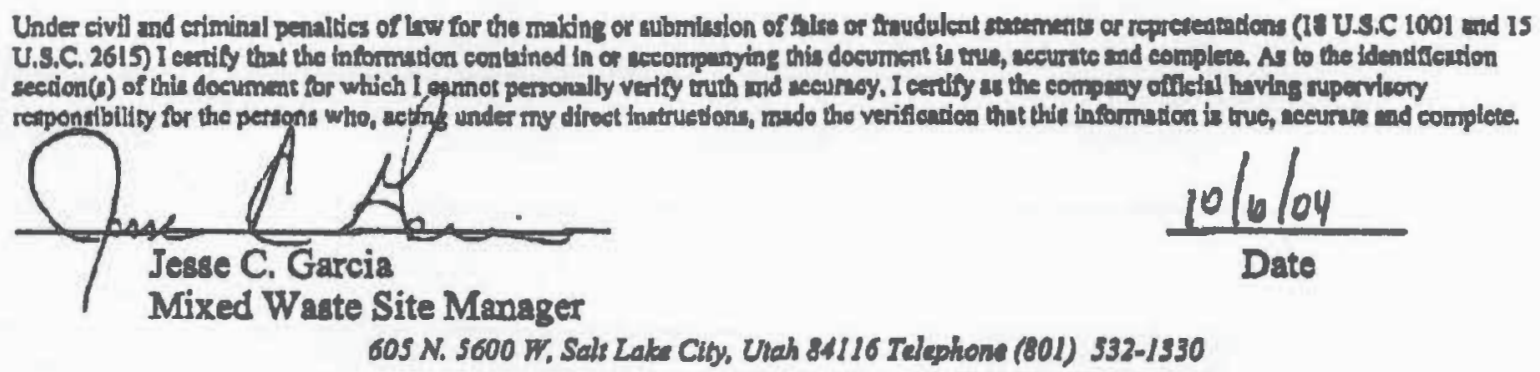





\begin{tabular}{|c|cc}
\hline $\begin{array}{c}\text { UNIFORM HAZARDOUS } \\
\text { WASTE MANIFEST }\end{array}$ & $\begin{array}{c}\text { 1. Generator's US EPA ID No. } \\
\text { ID4890008952 }\end{array}$ & $\begin{array}{c}\text { Manifest } \\
\text { Document No } \\
02265\end{array}$
\end{tabular}

3. Generator's Name and Mailing Address

Idaho National Engineering and Environmental Laboratory U.S. DOE, P.O. Box 1625, Idaho Falls, ID 83415-4105

4. Generator's Phone

(208)

52

$-2414$
A. State Manifest Document Number

B. State Generator's ID

ID 4890008952

6. US EPA ID Number UTD 988074712

8. US EPA ID Number

10. US EPA ID Number

9. Pesignated Facility Name and Site Address

(aragonite) ILC

11600 North Aptus Road

Aragonite, UT 84029

บ10981552177
C. State Transporter's ID

D. Transpoters Phone (801) 299-1900

E. State Transporters ID

F. Transporters phone ( )

H. Facility's Phone

(801) $323-8100$
G. State Facility's to full:
11. US DOT Description (Including Proper Shipping Nome, Hazard Class and ID Number) HM

E a. RQ Polychlorinated biphenyls, solid, 9, 0N2315, PG

N III Contalns Ballasts with $\mathrm{PCB}>50 \mathrm{ppm}$ OOs

탕

A. b.

T. $11-25-03$

b. Non-DOT Regulated PCBs PCB Debris, OOS 9-02-03

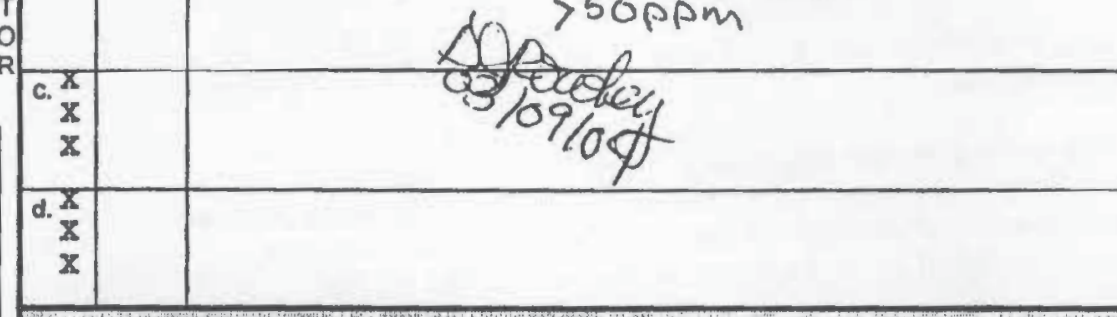

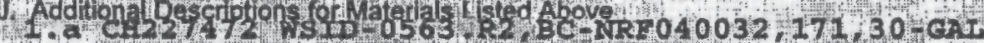

1 . b CI227501, ws TD-3322, BC-NR7040033, 30-GAT
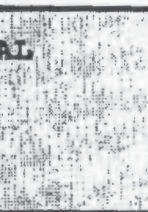

$\mid$\begin{tabular}{l|} 
12. Cont \\
1 \\
1
\end{tabular}

12. Containers

Total

. I." Quantity Wnit Wol : Waste No.

K. Handing Codes for Wastos Listed Above NRF LOND 174

SALES ORDBR 109744467 $\mathrm{CC} \# 3.818$

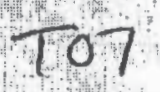

15. Special Handling Instructions and Additional Information

Return aigned original to: D.J. Rowley, Idaho National Engineering Environmental

Iaboratory/OS DOB, P.O. Box 1625, Idaho Eal1s, ID 83415-4105. Prepared undex contract \#DEACOT 99ID 13727. USDOE 24-Hx. Emergency Phone: (208) 526-1515.

16. GENERATOR'S CERTIFICATION: I hereby dectare that the contents of this consignment are fully and accurately described above by proper shipping name and are classified, packed, marked, and labeled, and are in all respects in proper condition for transport by highway according to applicable Intemational and national govemment regulations.

If I am a large quantity generator, I certify that I heve a program in place to reduce the volume and toxicity of waste generated to the degree I have determined to be economically practicable and that I have selected the practicable method of treatment, storage, or disposal currenty avallable to me which minimizes the present and future threat to human health and the environment. OR, if I am a small quantify generator, I have made a good faith effort to minimize my waste generatlon and select the best waste management method that is available to me and that I can afford.

Printed/Typed Name

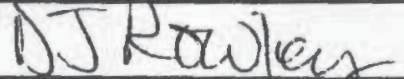

R 17. Transporter 1 Acknowledgement of Receipt of Matorials

Printed/Typed Name

U)

18. Transporter 2 Acknowledgement of Receipt of Materials

Printed/Tyoed Name

西

F 19. Discrepancy Indication Space

$\hat{c}$

L

20. Facility Owner or Operator: Certification of receipt of hazardous materials covered by this manifest except as noted in Item 19.

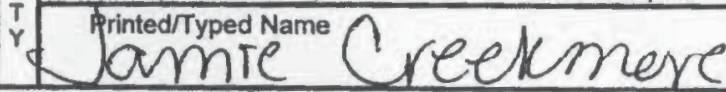

integrated Waste Tracking System.
Manth Day Year $0311010^{2}$ 
Clean Harbors Aragonite LLC

11600 North Aptus Road

Aragonite UT 84029

EPA ID UTD981552177

November 11, 2004

DJ ROWLEY

Ineel US DOE

47 miles West of Idaho Falls on US Hwy 20

Scoville.ID, 83415

Re: Certificates of Disposal

Dear DJ ROWLEY

This letter and the attached CD Log constitute your Certificate(s) of Disposal for the waste that was shipped to our facility for disposal.

This is to certify that the waste referenced on the attached CD Log and manifested to the above referenced Clean Harbors facillty was processed and disposed of in accordance with 40 CFR 761 (and 40 CFR 264 if applicable). Your waste has been properly treated and any residue from this waste has been disposed of at an approved and permitted Faclity.

Under civil and criminal penalties of law for the making or submission of false or fraudulent statements or representations (18 U.S.C. 1001 and U.S.C. 2615). I certify that the information contained in or accompanying this document is true, accurate and complete. As to the identified section(s) of this document for which I cannot personally verify truth and accuracy, I certify as the company official having supervisory responsibility for the persons who, acting under my direct instructions, made the verification that this information is true accurate, and complete.

Clean Harbors appreciates you as a valued customer. If you should have any questions or concerns please do not hesitate to contact one of our customer/facility representatives.

Sincerely,

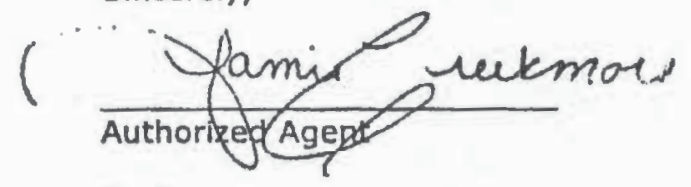

Enclosures 
Generator:

CD Nbr

$11137423-83$

Irackine Nor

4802202

Co Nor

$11137423-84$

Irackina Nor

5007934
Ineel US DOE 47 miles West of Idaho Falls on US Hwy 20 Scoville, ID 83415

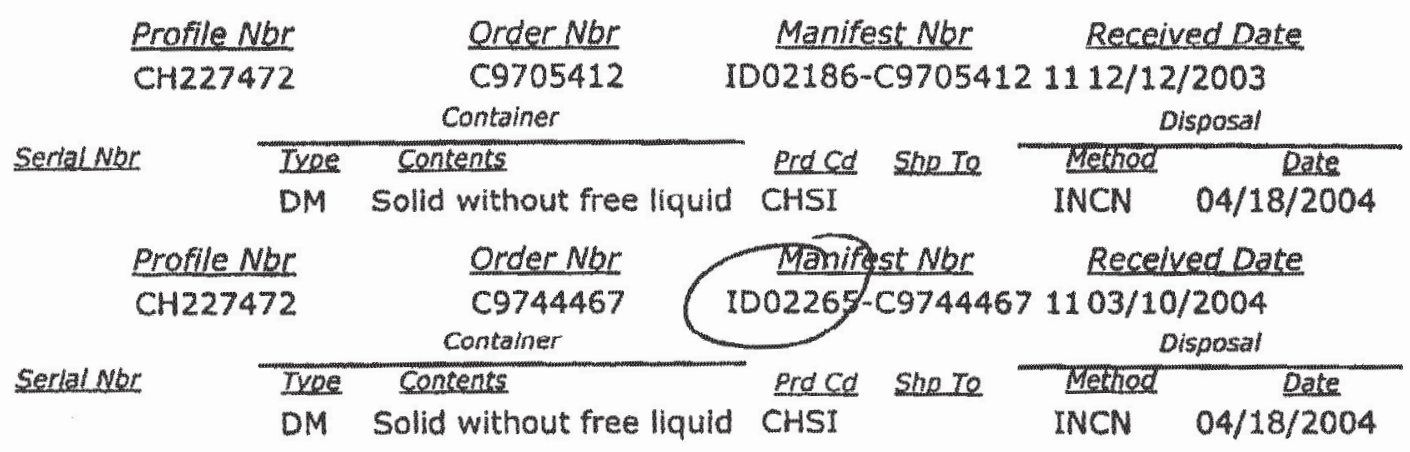

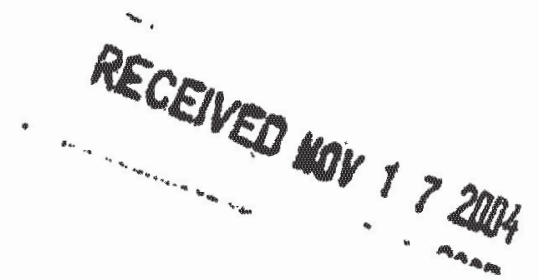



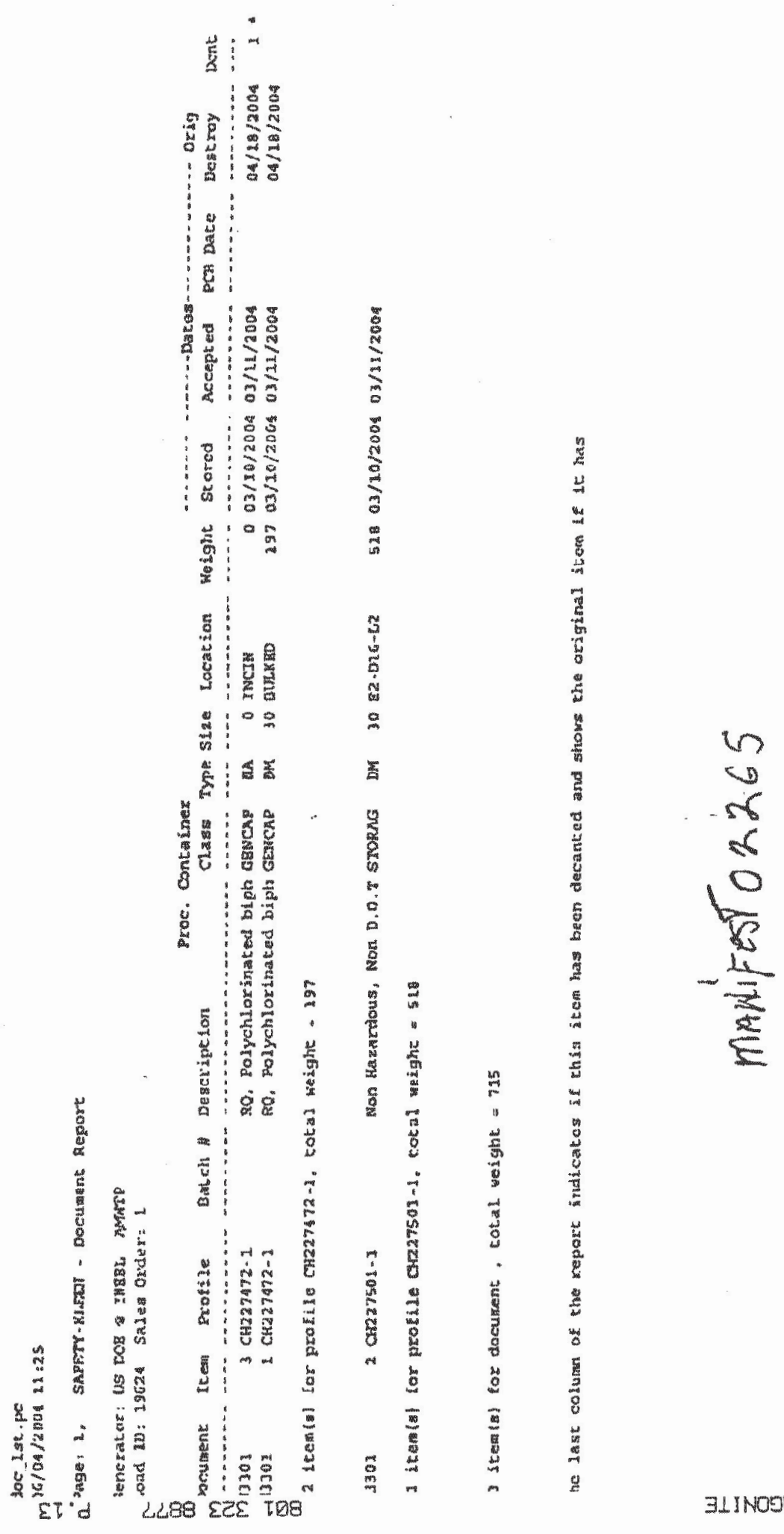
13305

\begin{tabular}{c|cc}
\hline $\begin{array}{c}\text { UNIFORM HAZARDOUS } \\
\text { WASTE MANIFEST }\end{array}$ & $\begin{array}{c}\text { 1. Generator's US EPA ID No. } \\
\text { ID4890008952 }\end{array}$ & $\begin{array}{c}\text { Manifest } \\
\text { Document No. } \\
02269\end{array}$
\end{tabular}

3. Generator's Name and Mailing Address

Idaho National kngineering and Environmental Laboratory $0 . S$.

DOE, P.O. BOX 1625, Idaho Falls, ID 83415-4105

4. Generator's Phone (208) $526-2414$
5. Transporter 1 Company Name
IW Company
6. US EPA ID Number
UTD 988074712
7. Transporter 2 Company Name
8. US EPA ID Number
$\begin{array}{ll}\text { 9. Pesignaled Facilly Name and Site Address } & \\ \text { Clean harbors Environmental } & \text { 10. US EPA ID Number }\end{array}$
(aragonite) ILC
11600 North Aptus Road
Aragonite, UT 84029
UTD 981552177
E State Transporters ID
G. Slate Foollitys ID
H. Facility 's Phone

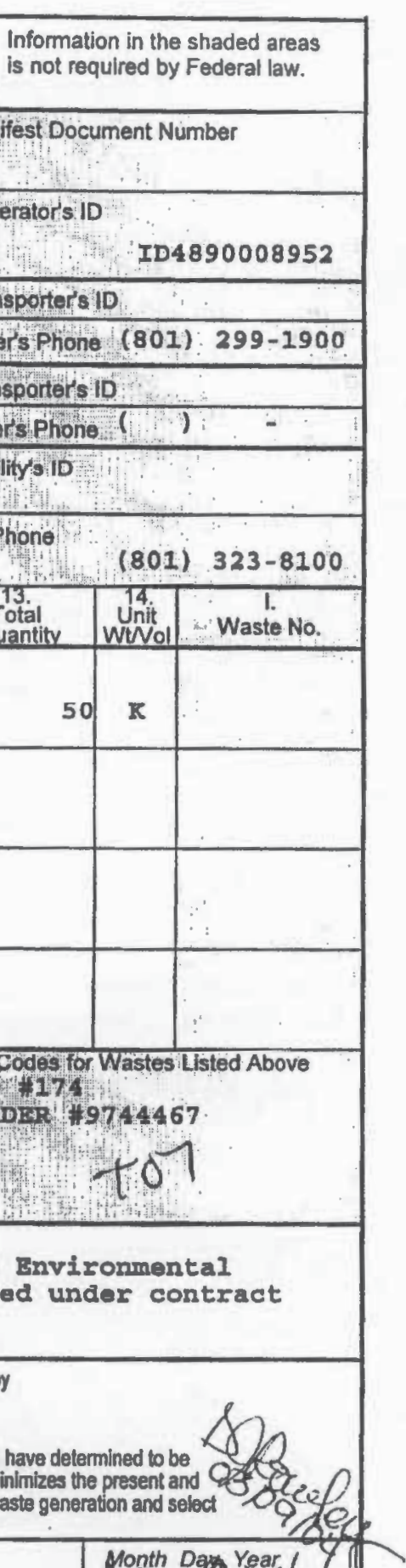

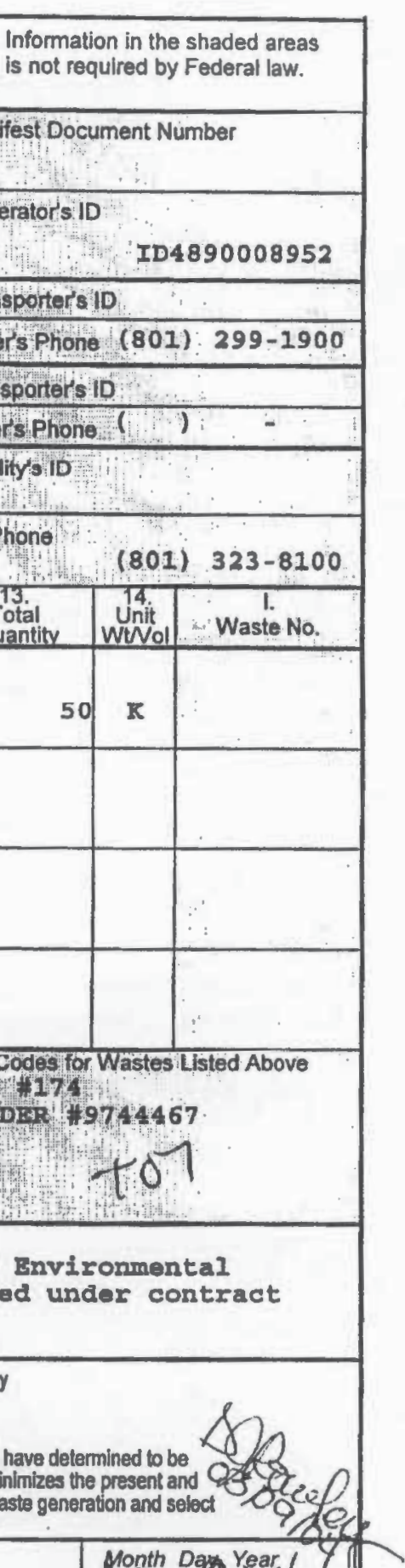

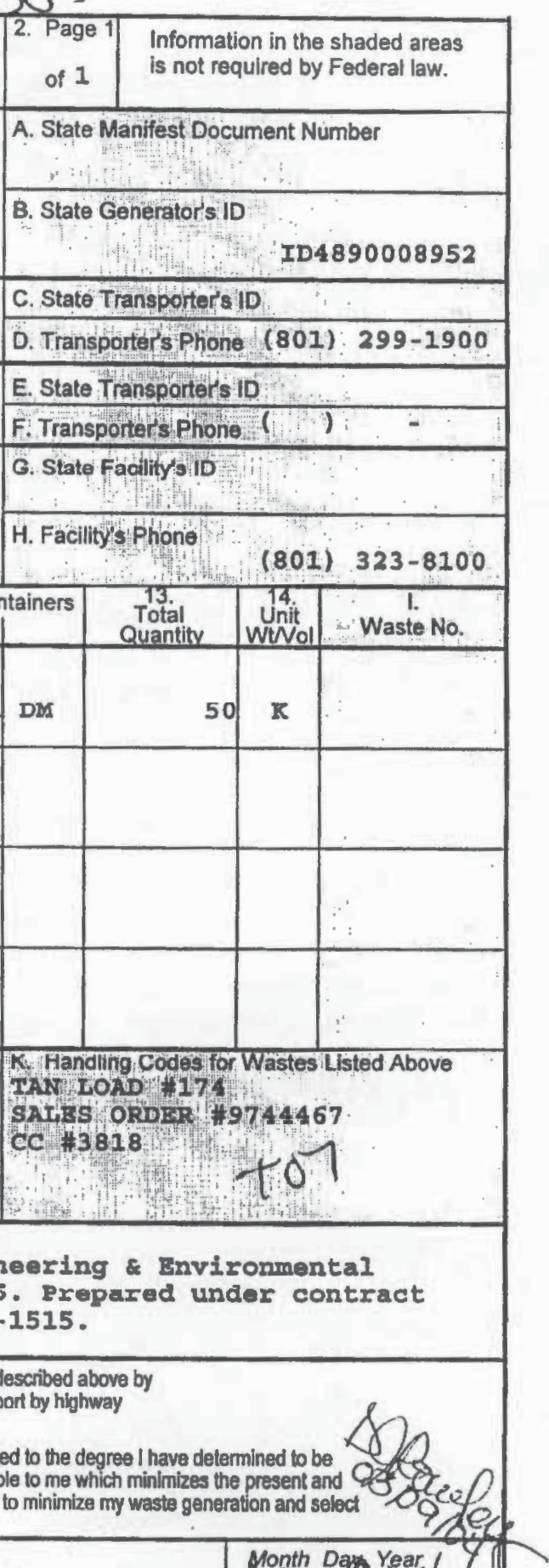

B. State Generalors ID

11. US DOT Description (Including Proper Shipping Name, Hazard Cless and ID Number) $H M$

E a. $\quad$ RQ Polychlorinated biphenyls, solid, 9, UN2315, PG

N

E

A b.

Tे

c.

$x$

d. $\frac{x}{x}$

$\mathbf{x}$

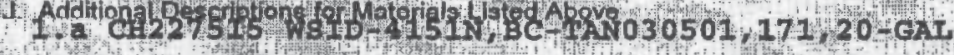
III PCB Oil, oOs 7/14/2003

\begin{tabular}{|l}
$x$ \\
$x$ \\
$x$ \\
\hline \\
\hline
\end{tabular}

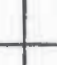

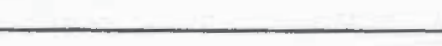

\begin{tabular}{|l|l|}
\hline & \\
\hline & \\
\hline
\end{tabular}

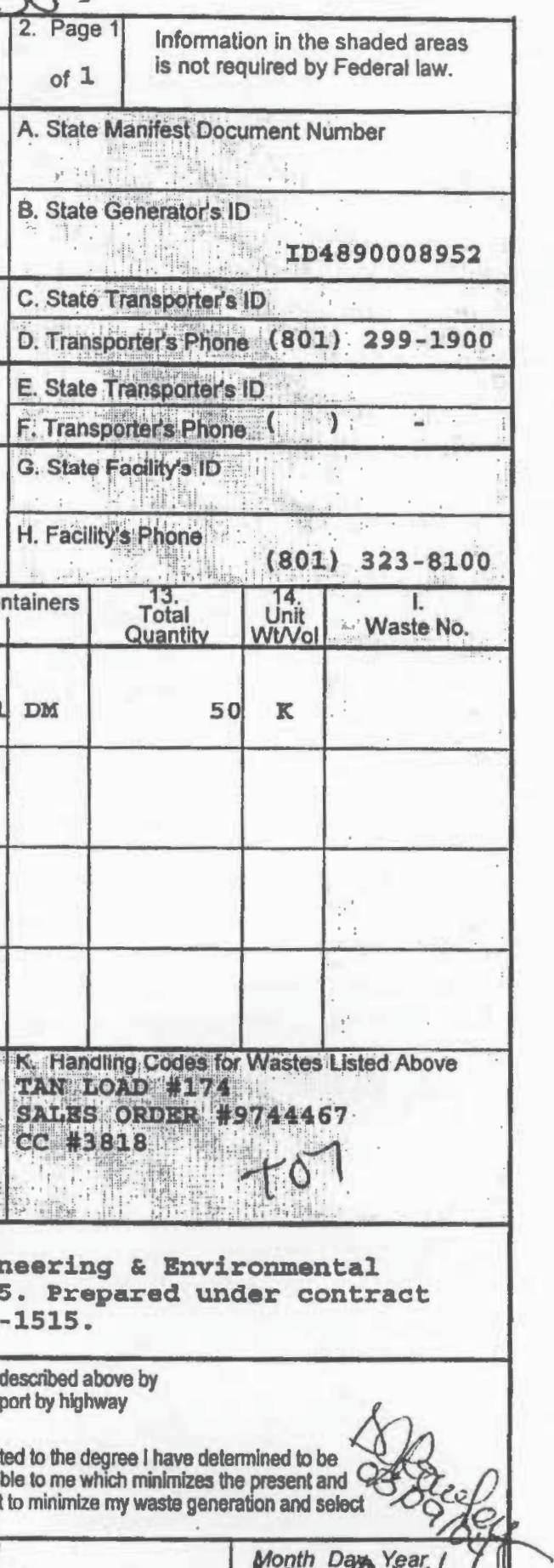

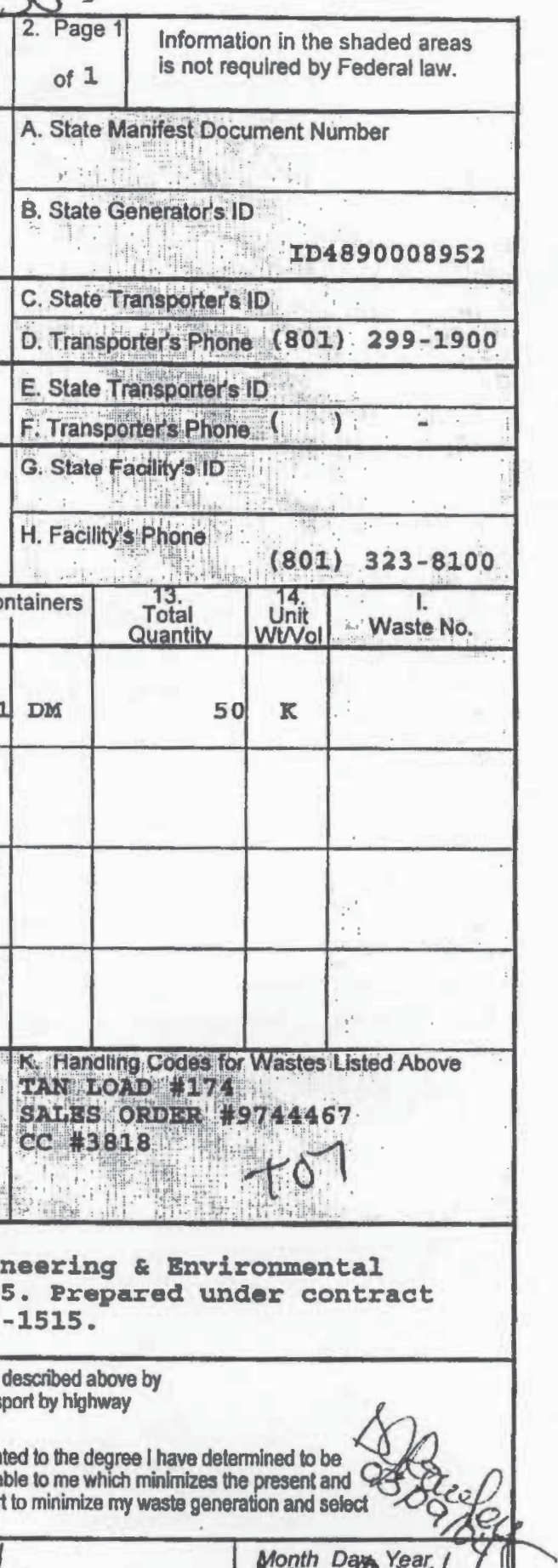

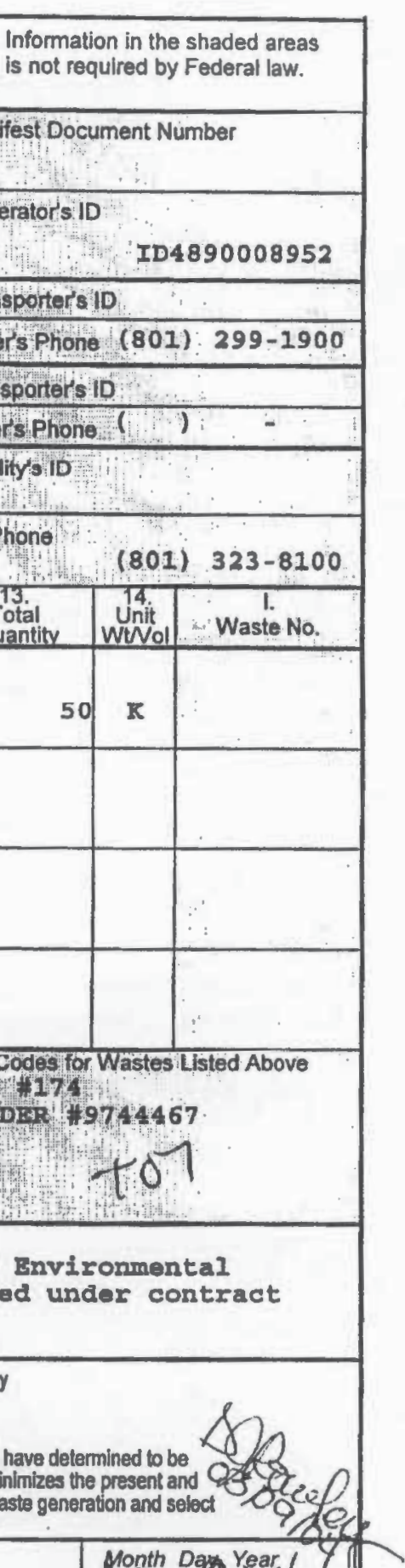

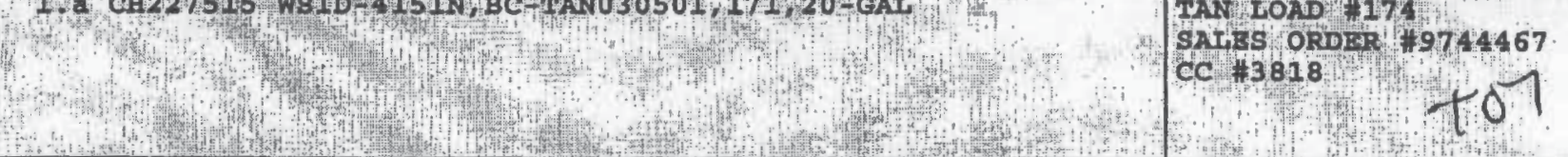

15. Special Handling Instructions and Additional Information

Return signed original to: D.J. Rowley, Idaho National Bngineering \& Environmental

Laboratory/OS DOE, P.O. Box 1625. Idaho Fa11a, ID 83415-4105. Frepared under contract \#DEAC07 99ID 13727. USDOR 24-Fr. Emergency Phone: (208) 526-1515.

16. GENERATOR'S CERTIFICATION: I hereby declare that the contents of this consignment are fully and accurately described above by proper shipping name and are classified, packed, marked, and labeled, and are in all respects in proper condition lor transport by highway according to applicable international and national government regulations.

If I am a large quantity generator, I certify that I have a program in place to reduce the volume and toxicity of waste generated to the degree I have determined to be economically practicable and that I have selected the practicable method of treatment, storage, or disposal currently avallable to me which minimizes the present and future threat to human health and the environment; OR, If I am a small quantity generator, I have made a good faith aifort to minimize my waste generafion and select the best waste management method that is available to me and that I can afford.

Printed/Typed Name

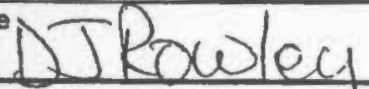

17. Transporter 1 Acknowledgement of Receipt of Materials

N PrintedrTyped Name

Uick

Jinc

$\mathrm{ci} /$

Printed/Typed Namo

19. Discrepancy Indication Space

ment afRecéipt of Materials
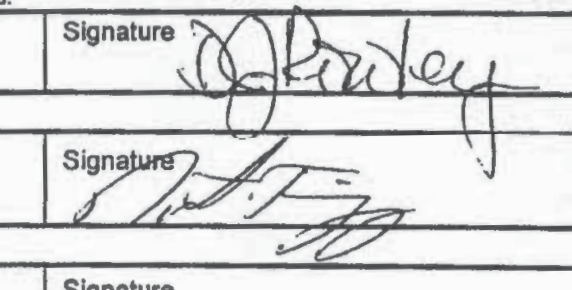

1 DM

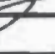

Signature

$(2$

$+2$

Month Day Year M3onth Dos Year

Month Day Year (0) 310910-1

20. Facility Owner or Operator. Certification of receipt of hazardous materials covgred by this manifest except as noted in ltem 19.

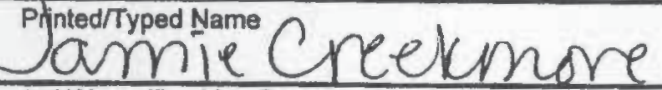

Integrated Waste Tracking System. 
11600 North Aptus Road Aragonite, UT 84029

801.323.8877

www.cleanharbors.com

JUNE 07, 2004

Environmental Manager US DOE @ INEEL AMWTP HIGHWAY 20 \& VAN BUREN IDAHO FALLS, IDAHO 83415

RE: Certificates of Disposal

Dear Environmental Manager:

Enclosed please find your Certificate(s) of Disposal and accompanying detailed report(s) for the waste that was shipped to our facility for treatment. Your original manifest number is referenced on both of these documents along with a Clean Harbors Aragonite document number.

Your waste has been properly treated and the residue from this waste has been disposed of at an approved and permitted hazardous waste. landfill.

Clean Harbors appreciates you as a valued customer. If you should have any questions or concerns please do not hesitate to contact one of our customer/facility representatives at (801) 323-8100.

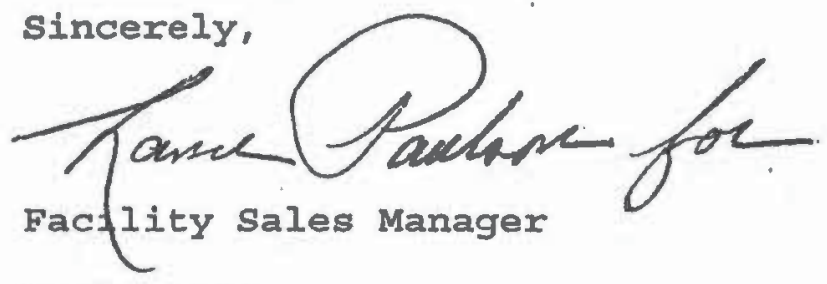

Enclosures 
3

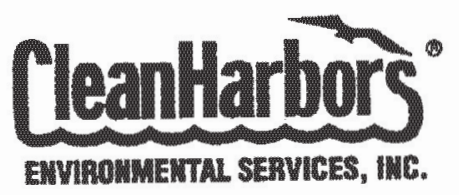

11600 North Aptus Road

Arragonite, UT 84029

801.323 .8877

www.cleanharbors.com

JUNE 07,2004

US DOE @ INEEL AMWTP

HIGHWAY 20 \&AN BUREN

IDAHO FALLS, IDAHO 83415

EPA ID: ID4 $890 \quad 008 \quad 952$

\author{
Certificate of Disposal \\ No. 202684
}

Customer Manifest: 02269 Document: N3305 destroyed as of MARCH 13, 2004

This is to certify that the hazardous material manifested to Clean Harbors on the above Clean Harbors Aragonite Document Number was disposed of by " incineration in accordance with 40 CFR 761 (and 40 CFR 264 if applicable) as of the above cextification date.

Attached is a detailed report which identifies the date(s) of disposal. Residue from this waste has been disposed of at an approved and permitted - Hazardous Waste Landfill.

- Under civil and criminal penalties of law for the making or submission of false or fraudulent statements or representations (18 U.S.C. 1001 and 15

- U.S.C. 2615). I certify that the information contained in or accompanying this document is true, accurate, and complete. As to the identified section(s) of this document for which I cannot personally vexify truth and accuracy, I certify as the company official having supervisory responsibility for the persons who, acting under my direct instructions, made the verification that this information is true, accurate, and complete.

Clean Harbors, Aragonite UT

EPA ID \# UTD 981.552177
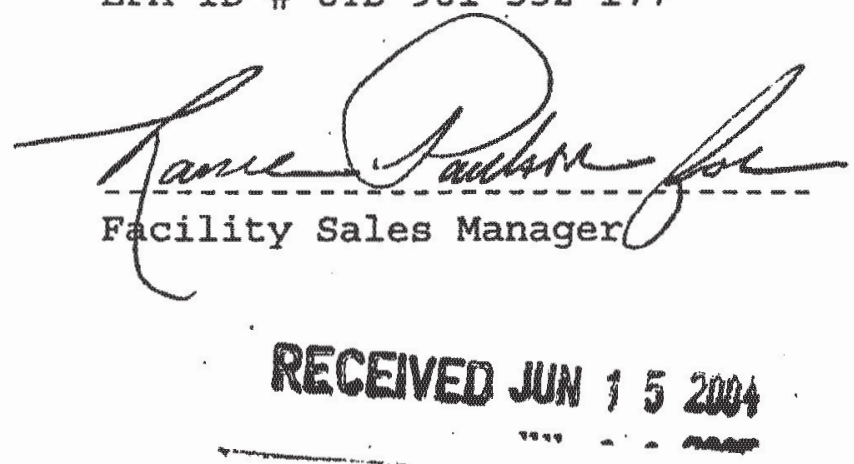

4: "People and Technology Creating a Better Environment" 
Page: 2 Certiflcate of Disposal - Detail Report 06/07/2004 11:23

Generator: 705603 US DOE INEEL AMHTE

CD Documert Item state Cugtomer Types Weight

-

202684 N3305

1 ID02269

02269

DM

$11003 / 10 / 200403 / 13 / 2004$ 
- Clean Harbors Aragonite LLC

11600 North Aptus Road

Aragonite UT 84029

EPA ID UTD981552177

November 11, 2004

DJ ROWLEY

Ineel US DOE

47 miles West of Idaho Falls on US Hwy 20

SCOVILLE ID, 83415

Re: Certificates of Disposal

\section{Dear DJ ROWLEY}

This letter and the attached CD Log constitute your Certificate(s) of Disposal for the waste that was shipped to our facility for disposal.

This is to certify that the waste referenced on the attached $C D$ Log and manifested to the above referenced Clean Harbors facility was processed and disposed of in accordance with 40 CFR 761 (and 40 CFR 264 if applicable). Your waste has been properly treated and any residue from this waste has been disposed of at an approved and permitted Facllty.

Under civil and criminal penalties of law for the making or submission of false or fraudulent statements or representations (18 U.S.C. 1001 and U.S.C. 2615). I certify that the information contained in or accompanying this document is true, accurate and complete. As to the identified section(s) of this document for which I cannot personally verify truth and accuracy, I certify as the company official having supervisory responsibility for the persons who, acting under my direct instructions, made the verification that this information is true accurate, and complete.

Clean Harbors appreciates you as a valued customer. If you should have any questions or concerns please do not hesitate to contact one of our customer/facility representatives.

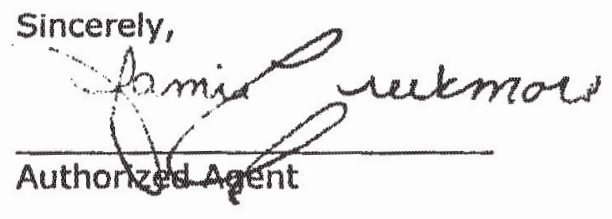

Enclosures 
Generator:
\[ \ddot{C D N b r} \]

$11137046-60$

Tracking Nbr 5008359
Ineel US DOE 47 miles West of Idaho Fals on US Hwy 20 SCOVMLL, 10 83415

Profile Nb

Order Nor

C9744467

Manifest Nbr

Received Date ID02269-C97444671103/10/2004 Container

Serial Nor

$\frac{\text { Container }}{\text { Type Contents }} \frac{\text { PrdCd shp To }}{\text { DM Liquid/Solid Mixture }}$

\begin{tabular}{|c|c|}
\hline \multicolumn{2}{|c|}{ Disposal } \\
\hline Method & Date \\
\hline $\mathrm{INCN}$ & $03 / 13 / 2004$ \\
\hline
\end{tabular}




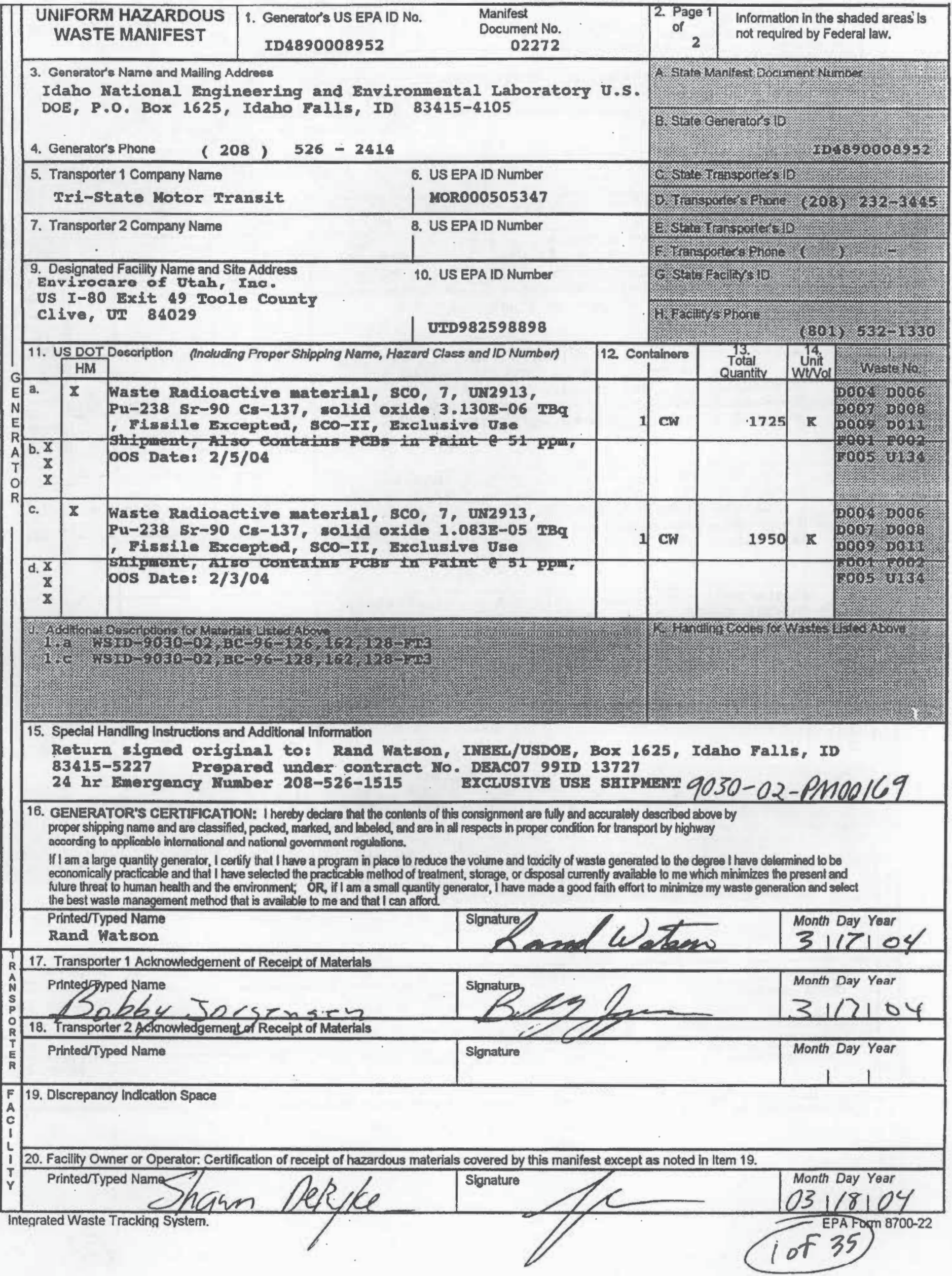




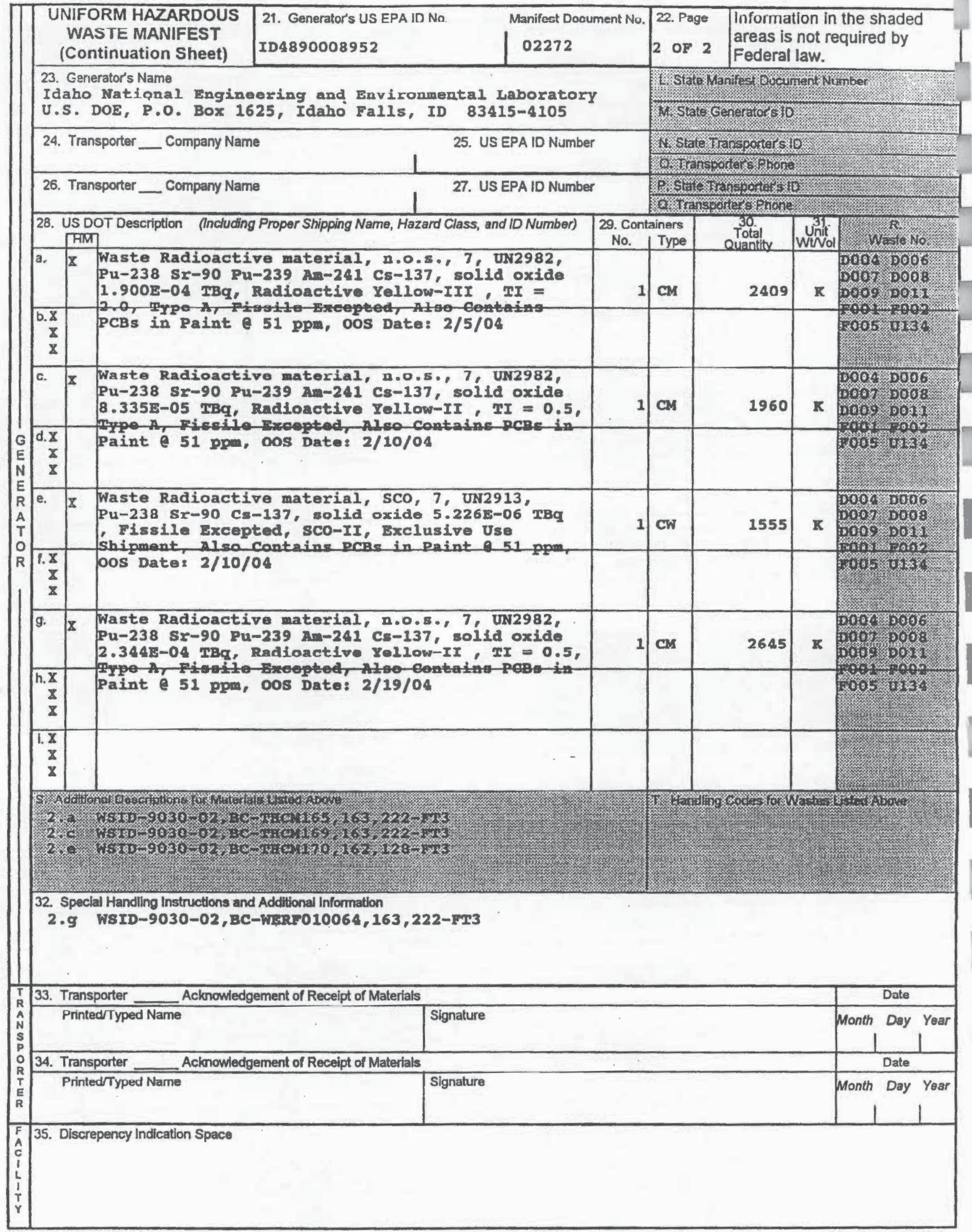




\section{ENVIROCARE}

OF UTAH, INC.

\section{THE SAFE ALTERNATTVE}

3 mi. S. Ext. 49, 1-80

Clive, Utah 84029 EPA

LD: UT982598898

\section{CERTIFICATE OF DISPOSAL}

This Certificate acknowledges that the following manifested shipments:

\begin{tabular}{|c|c|c|c|c|c|}
\hline Shipment & Manifest & Date(s) of Disposal & $\mathrm{Cu} / \mathrm{Ft}$ & Process & Disposal Location \\
\hline $9030-02-0013$ & 02272 & $\begin{array}{c}09 / 29 / 2004 \\
09 / 28 / 2004 \\
11 / 13 / 2004 \\
09 / 23 / 204\end{array}$ & 1050 & Landfill & Mixed Waste \\
\hline
\end{tabular}

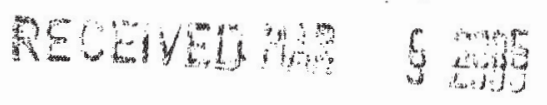

Representing 1050 Cubic feet of waste of at listed Disposal Facility landfill. Disposal is subject to Envirocare's Radioactive Material License, all other applicable licenses, permits and regulations, and the Disposal Agreement.

Under civil and criminal penalties of law for the making or submission of false or fraudulent statements or representations (18 U.S.C 100 a and 15 U.S.C. 2615) I eertify that the information contained in or accompanying this document is true, accurate and complete. As to the identification section(s) of this document for which I cannot personally verify truth and accuracy, I certify as the company official having supervisory responsibility for the persons, who, acting under my direct instructions, made the verification that this information is true, accurate and complete.

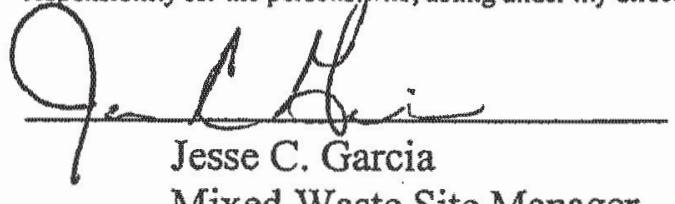

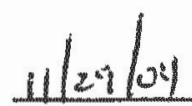

Date 



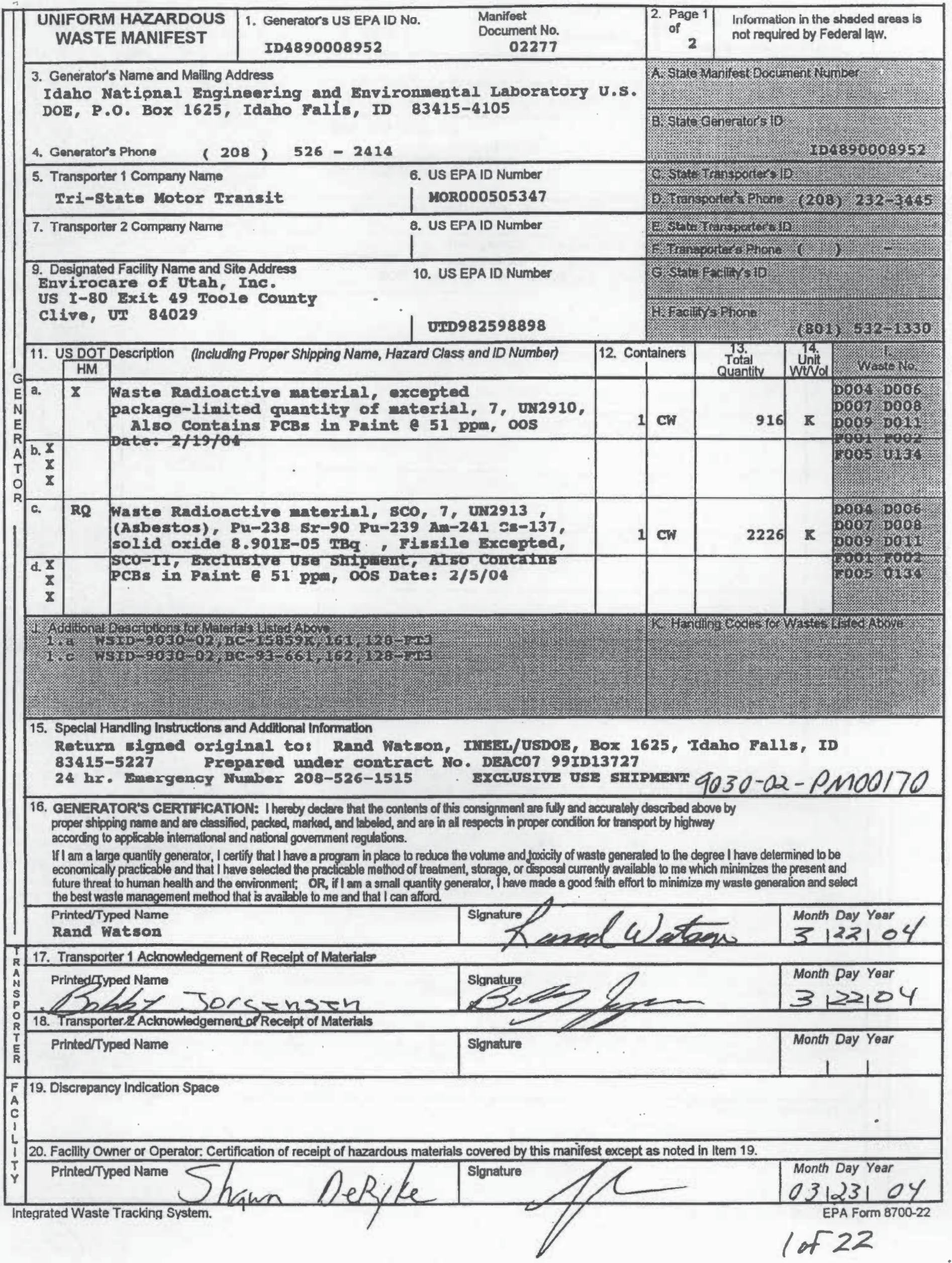




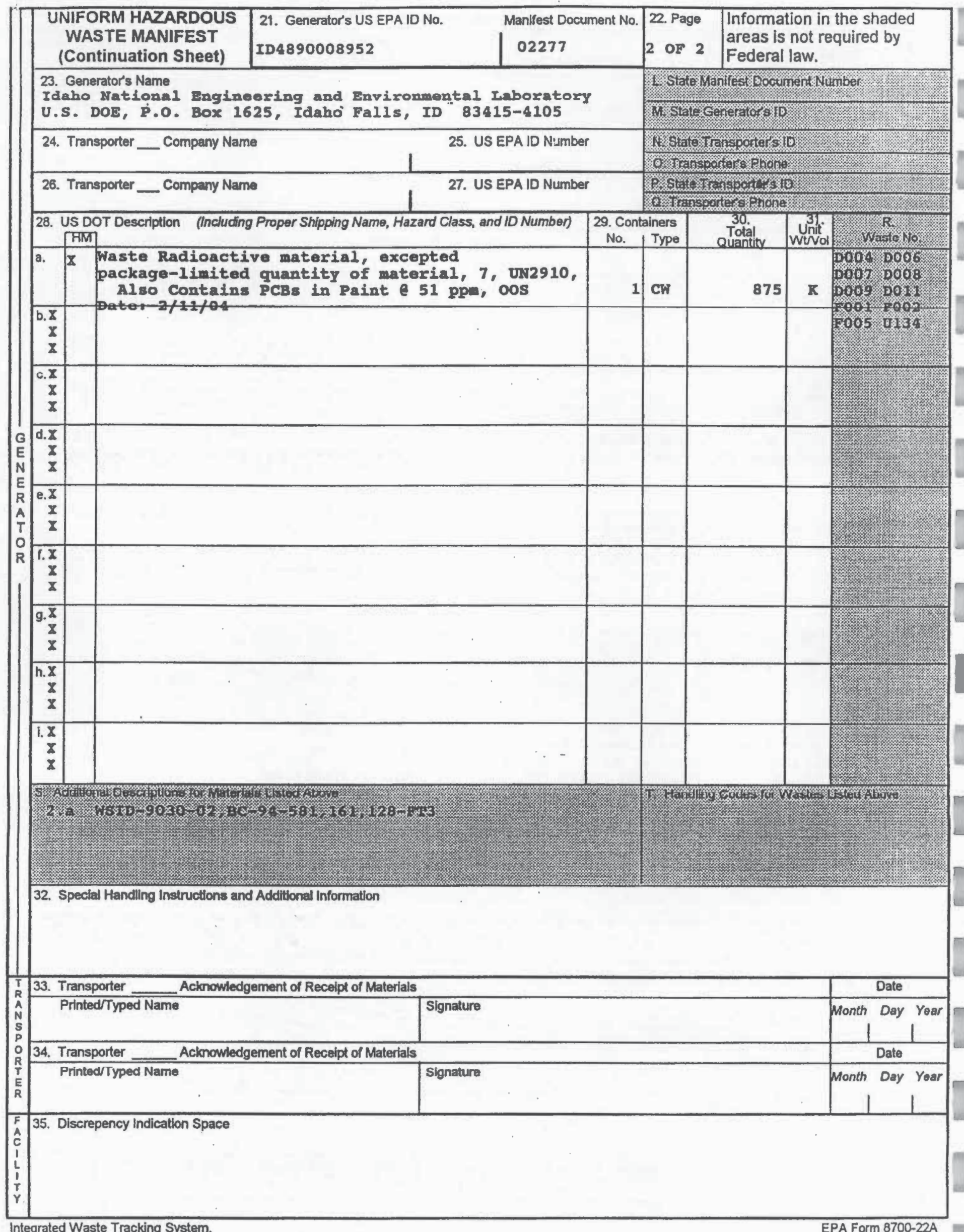




\section{ENVIROCARE}

OF UTAH, INC.

THE SAFE ALTERNATIVE

3 mi. S. Ext. $49,1-80$

Clive, Utah 84029 EPA

ID. UT982598898

\section{CERTIFICATE OF DISPOSAL}

This Certificate acknowledges that the following manifested shipments:

$\underset{9030-02-0014}{\text { Shipment }} \frac{\text { Manifest }}{02277} \quad \frac{\text { Date(s) of Disposal }}{08 / 28 / 2004} \quad \frac{\text { Cu/Ft }}{384} \quad \frac{\text { Process }}{08 / 29 / 2004} \quad \frac{\text { Disposallocation }}{\text { Landfill }} \quad$ Mixed Waste

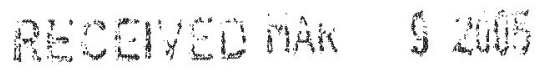

Representing 384 Cubic feet of waste of at listed Disposal Facility landfill. Disposal is subject to

Envirocare's Radioactive Material License, all other applicable licenses, permits and regulations, and the Disposal Agreement.

*

Under civil and criminal penalties of law for the making or submission of false or fraudulent statements or representations (18 U.S.C 1001 and 15 U.S.C. 2615) I certify that the information contained in or accompanying this document is true, accurate and complete. As to the identification section(s) of this document for which I cannot personally verify truth and accuracy, I certify as the company official having supervisory responsibility for the persons who, acting under my direct instructions, made the verification that this information is true, accurate and complete.

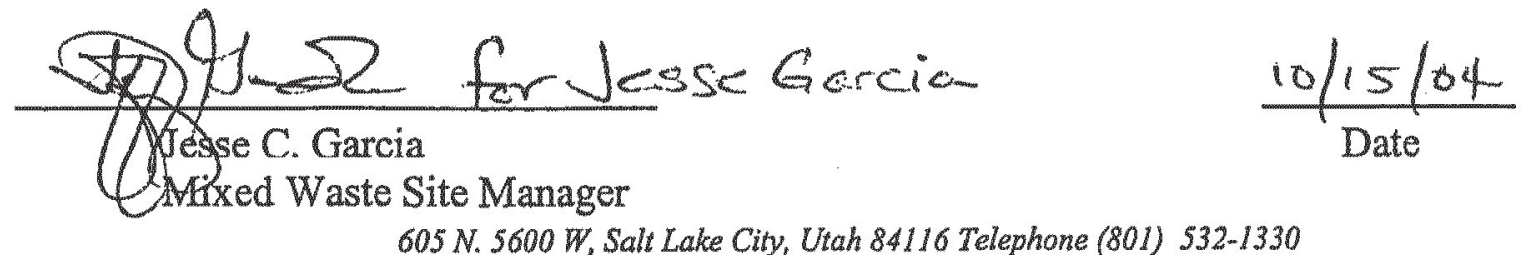





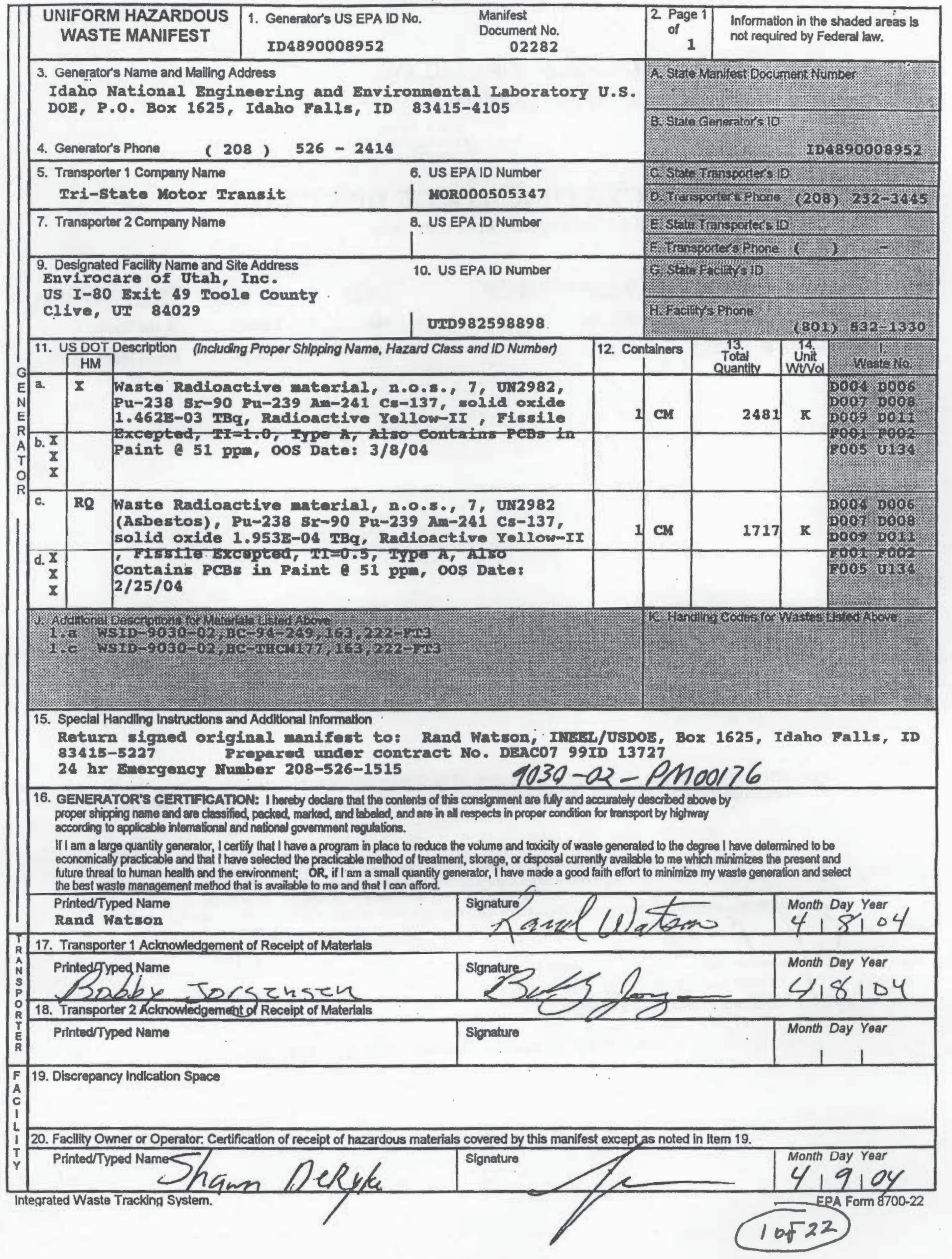


ENVIROCARE OF UTAH, INC.

THE SAPE ALTERNATIVE

$3 \mathrm{mils}$. Exe 49, 1-80

Clive, Urah 84029 EPA

ID: UT982598898

\section{CERTIFICATE OF DISPOSAL}

This Certificate acknowledges that the following manifested shipments:

\begin{tabular}{|c|c|c|c|c|c|}
\hline Shipment & Manifest & Drters) of Disposal & $\mathrm{C} n / \sqrt{\mathrm{Tt}}$ & Process & Dicongal Loction \\
\hline $9030-02-0015$ & 282 & 09/22/04 & 444 & Lendfill & Mixed Waste \\
\hline $9030-02-0020$ & 02327 & 09/29/04 & 128 & Lendfill & Mixed Waste \\
\hline
\end{tabular}

Representing 572 Cubic feet of waste of at listed Disposal Facility landall. Dirposal is subjeet to Bnvirocare's Redionetive Materin! Lieanec, all other upplieable licenses, permits nd regulations, und the Dieponal Agreement.

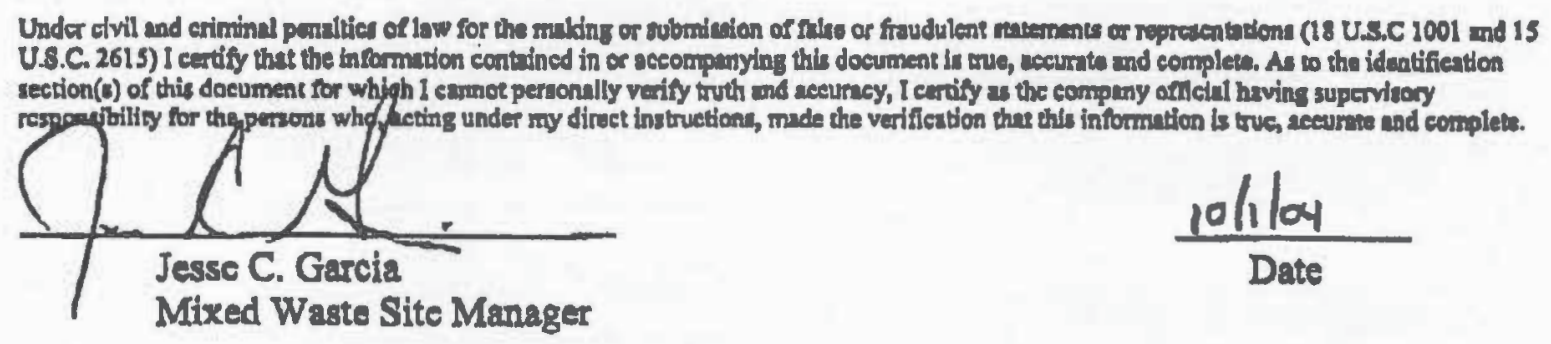

605 N. 5600 W. Salt Lake City, Utah 81116 Telephone (801) 532-1330 



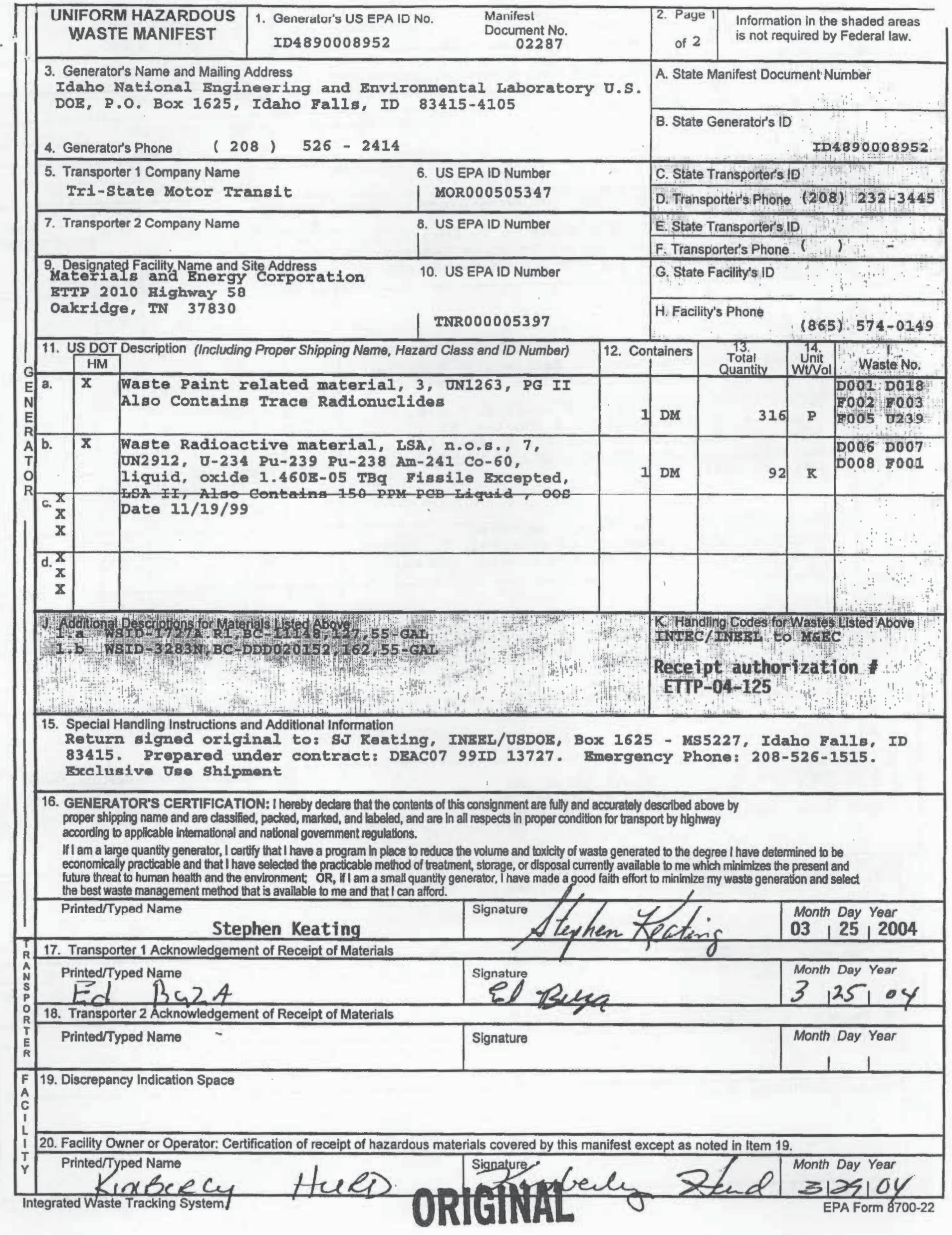




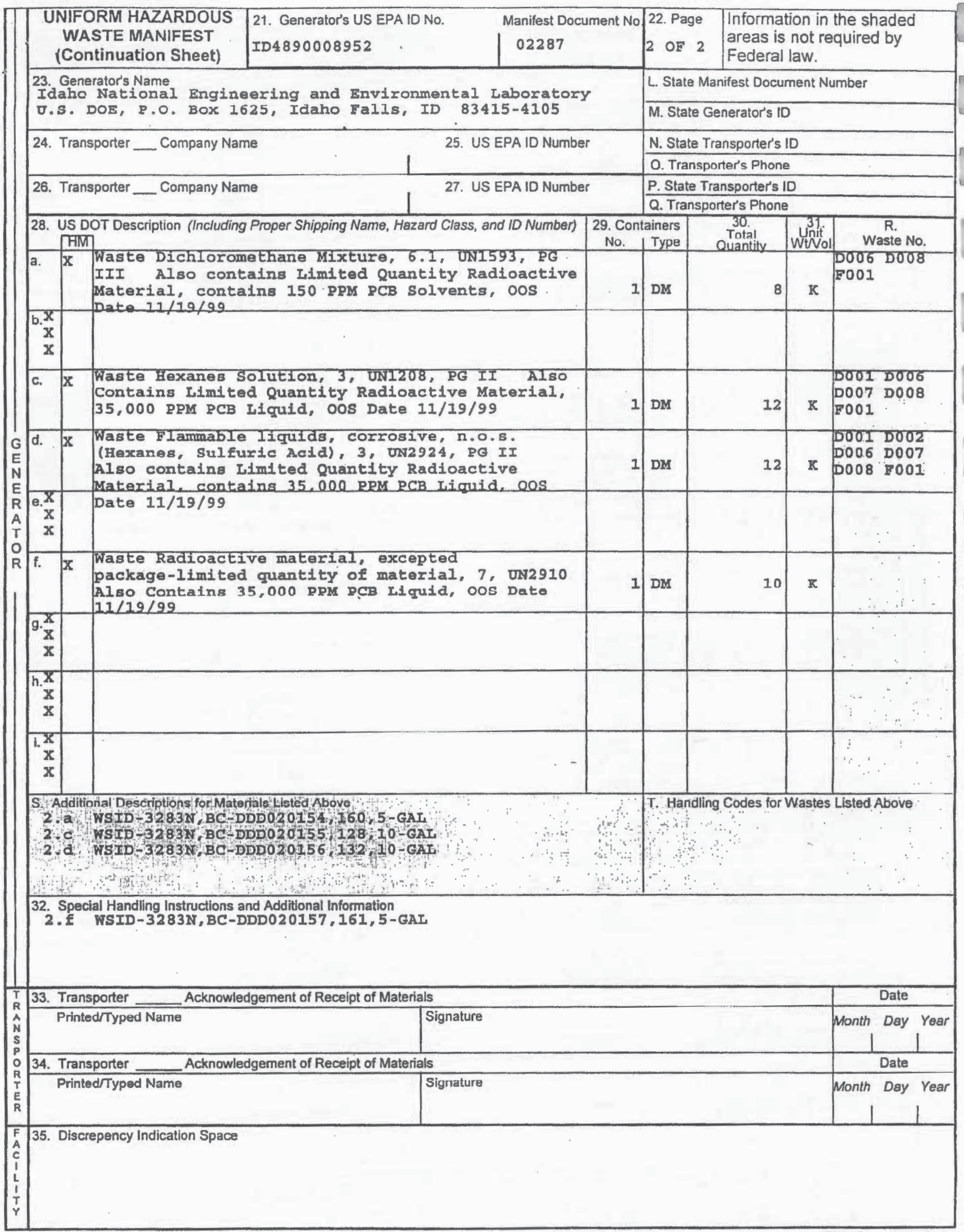





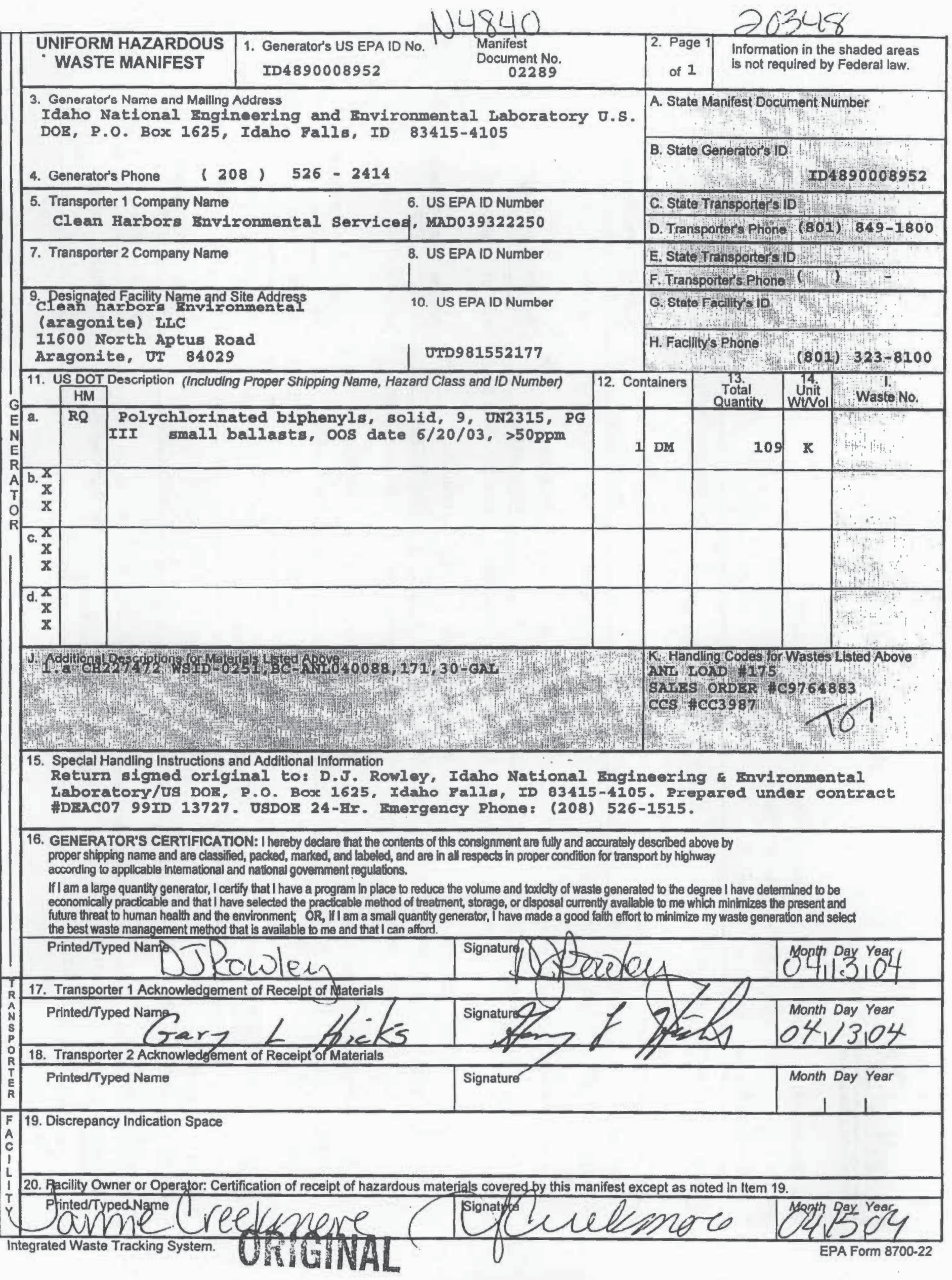




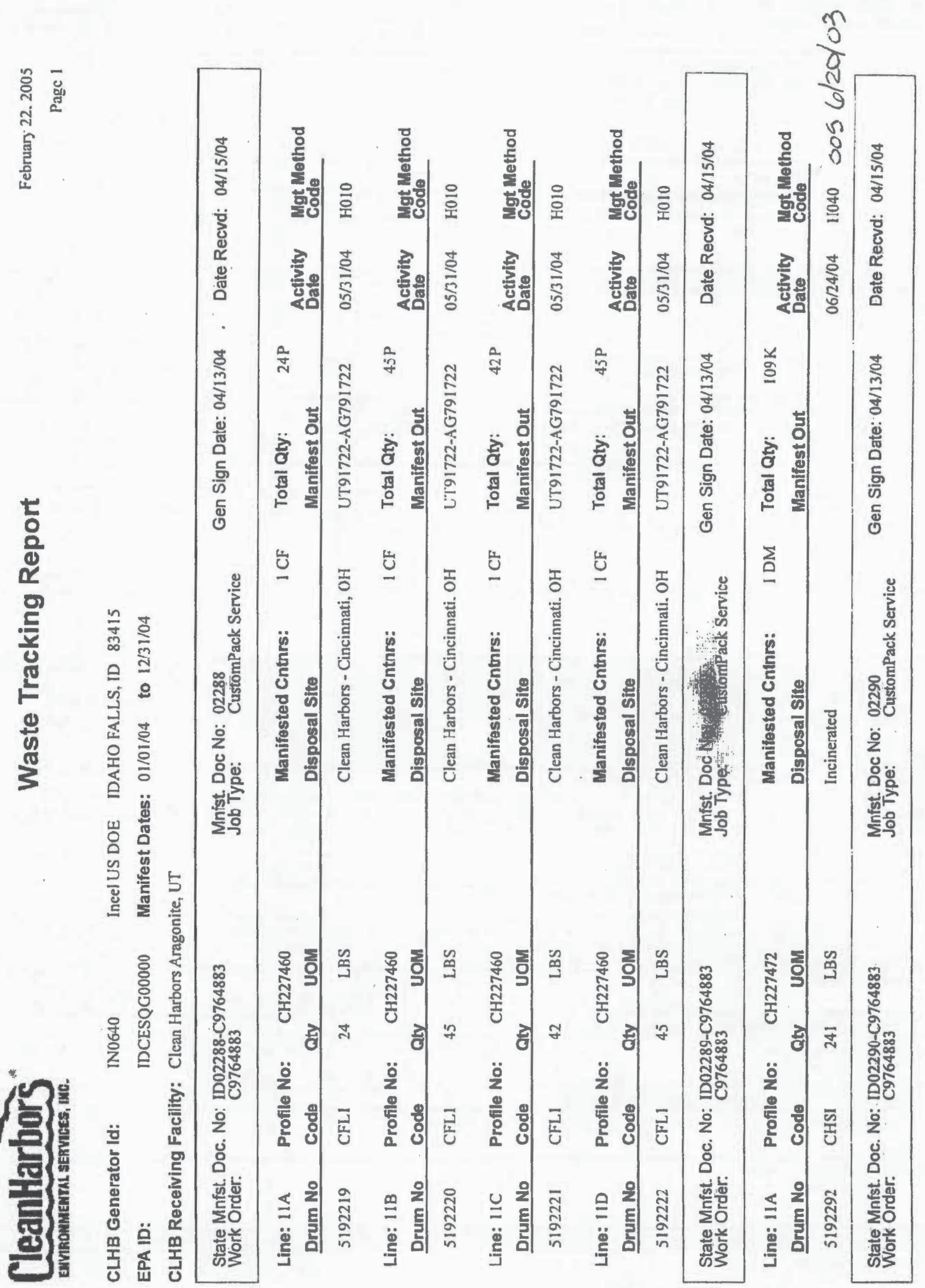



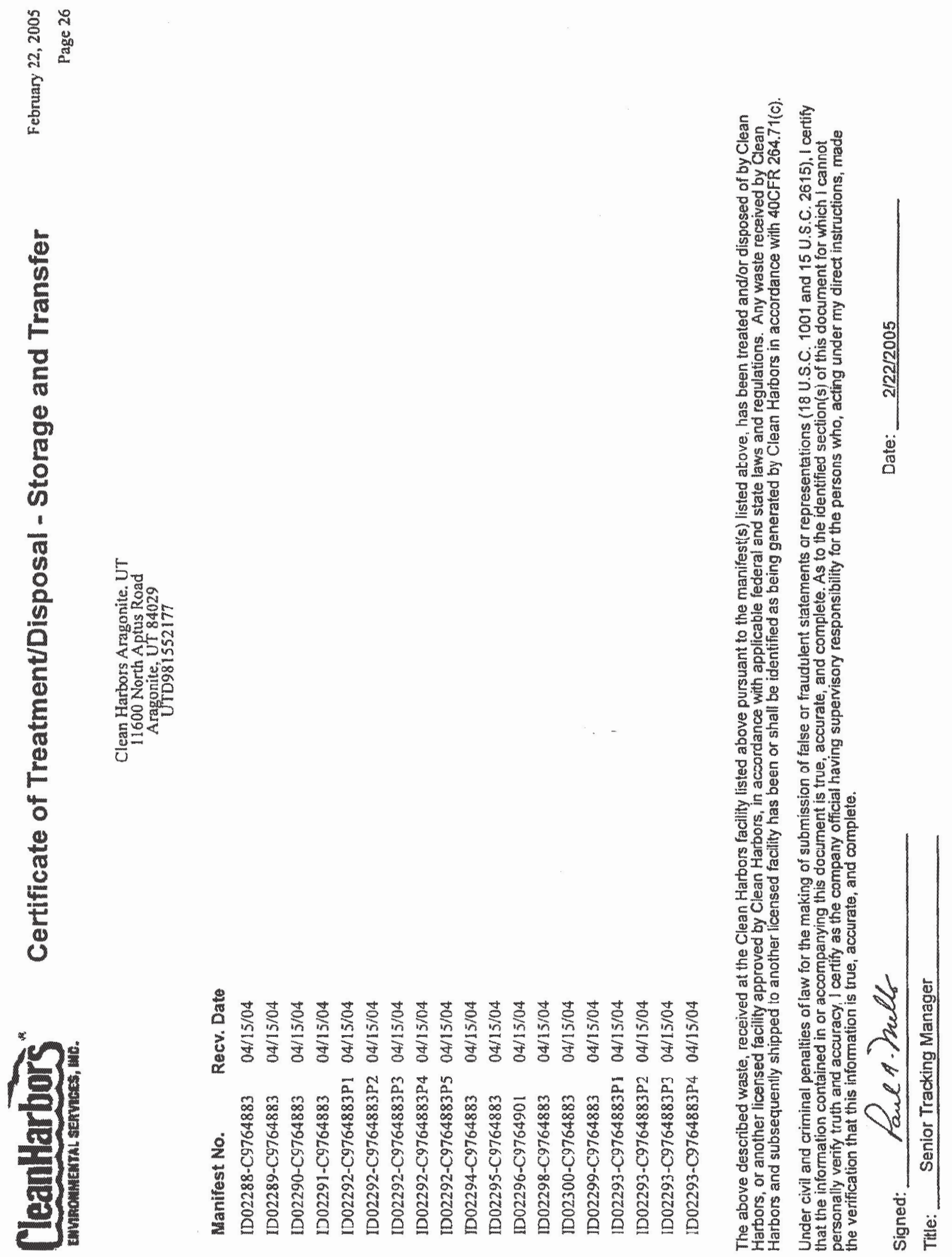
. 



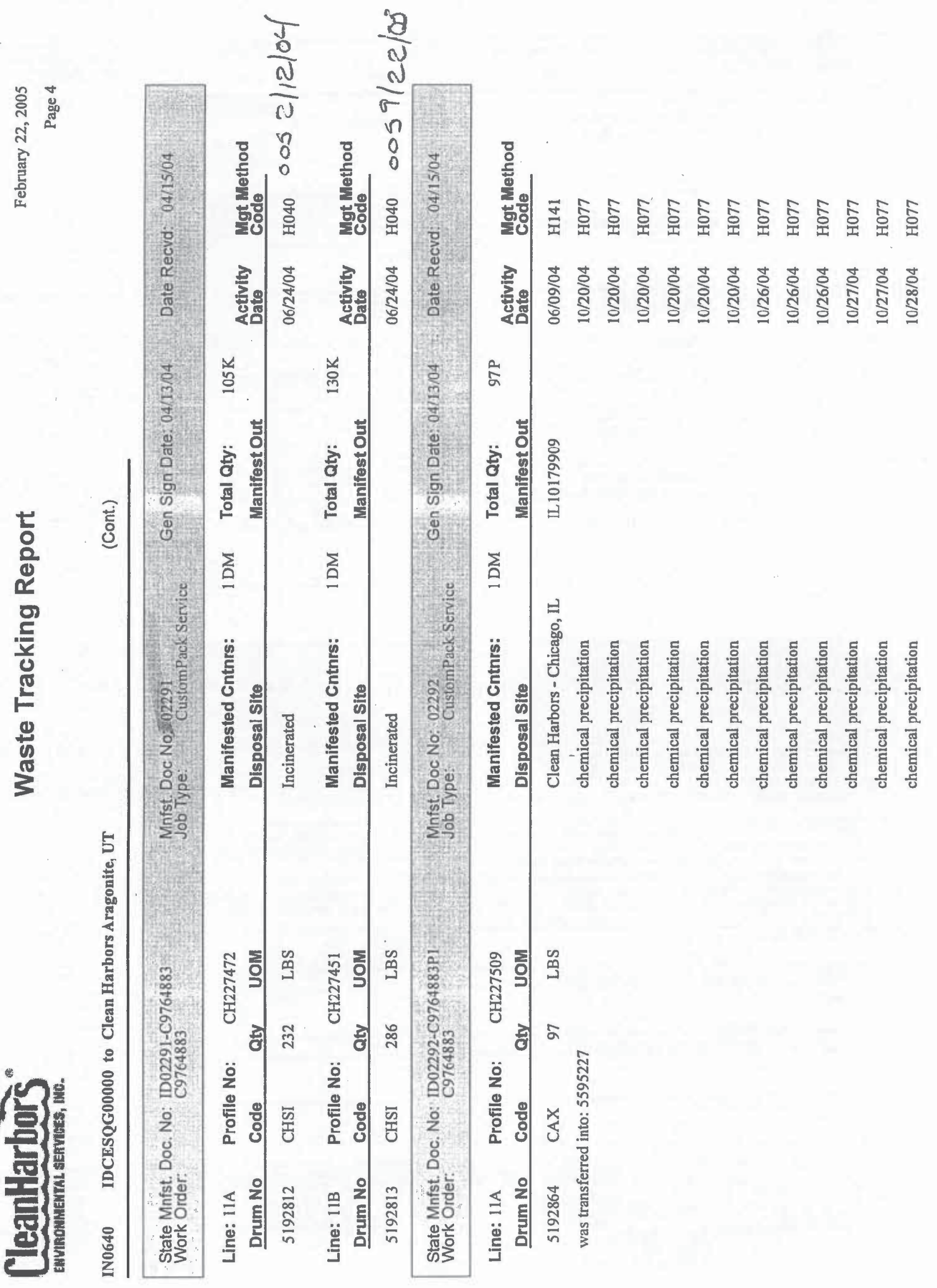



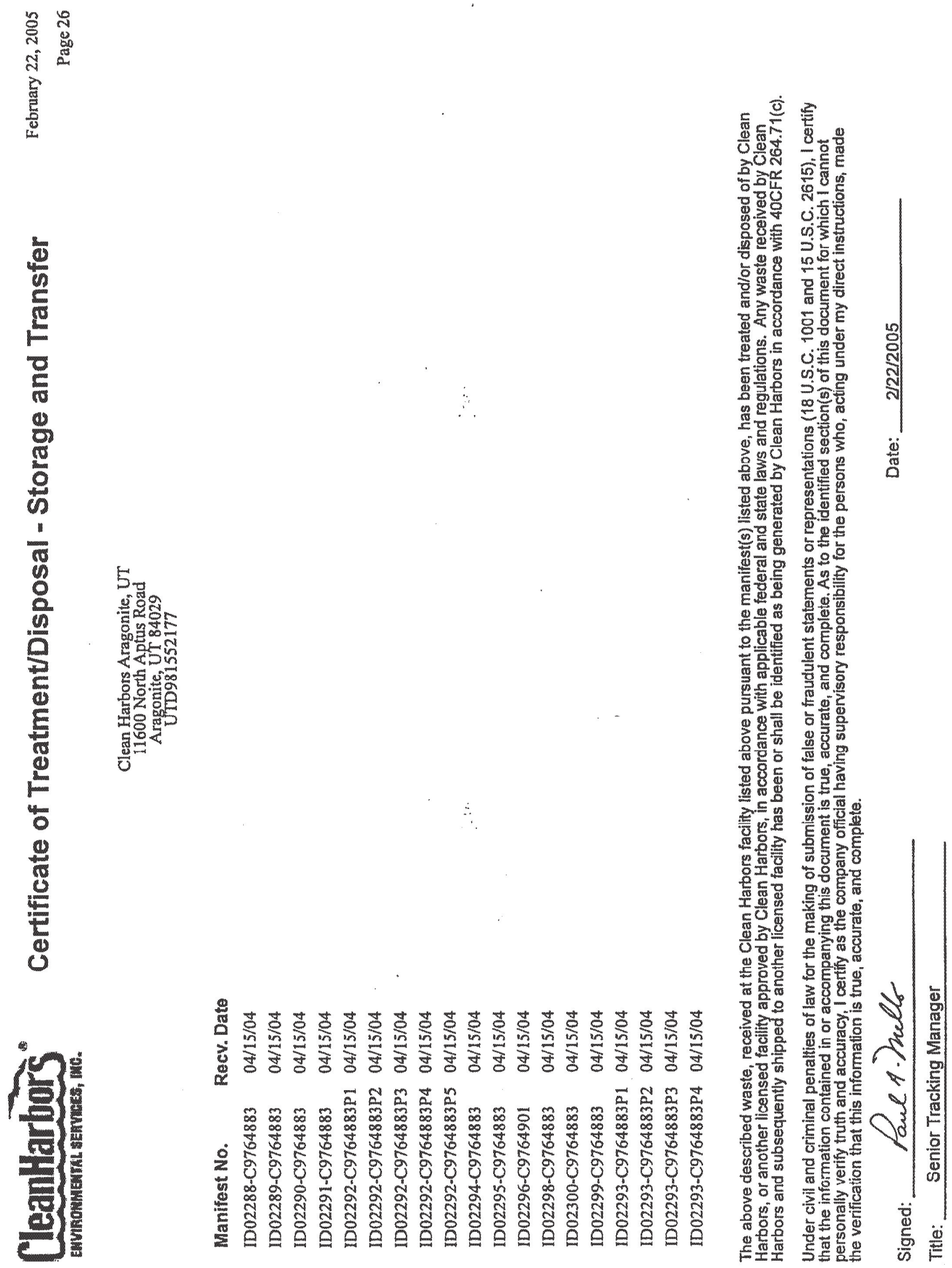



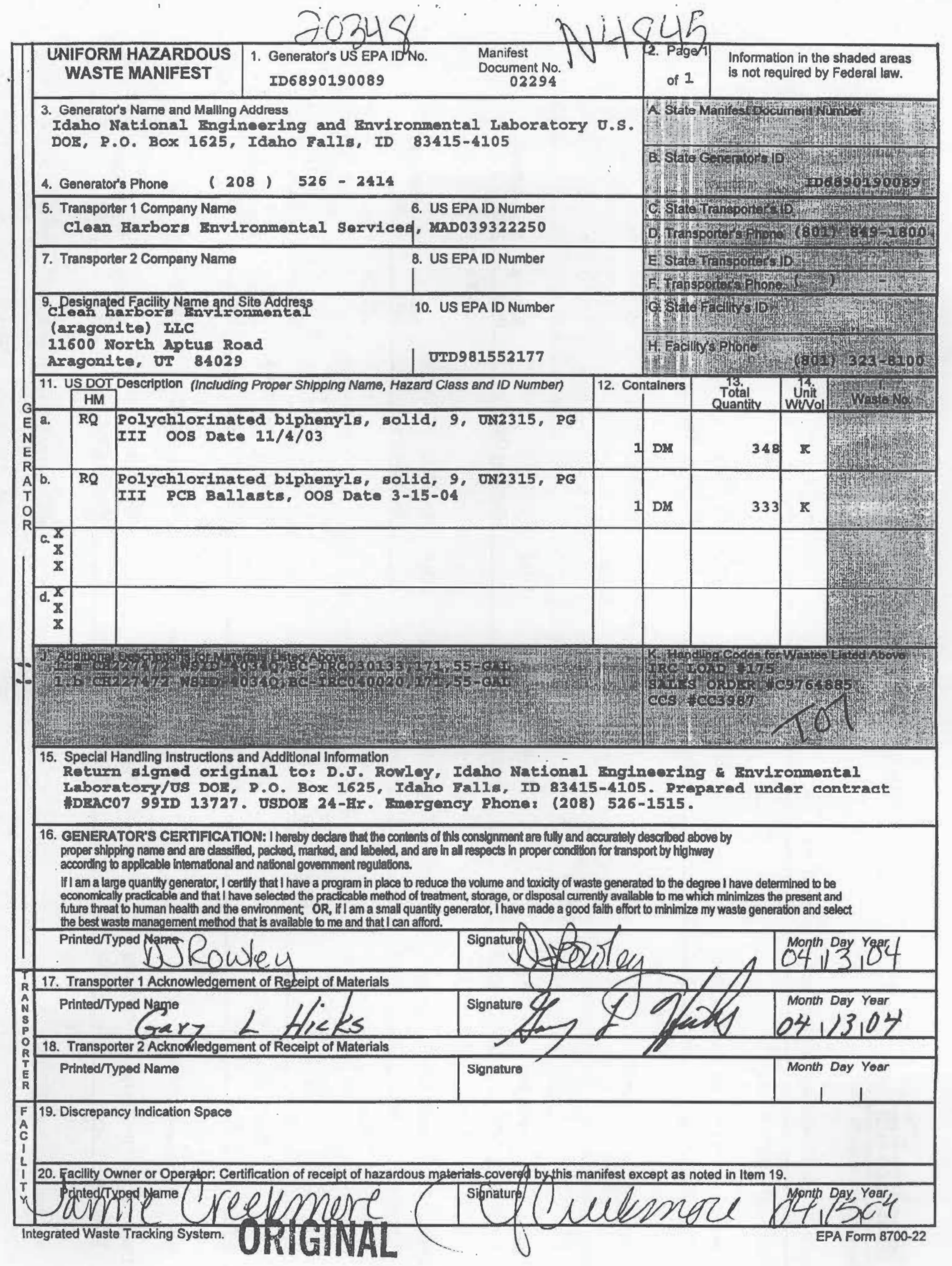



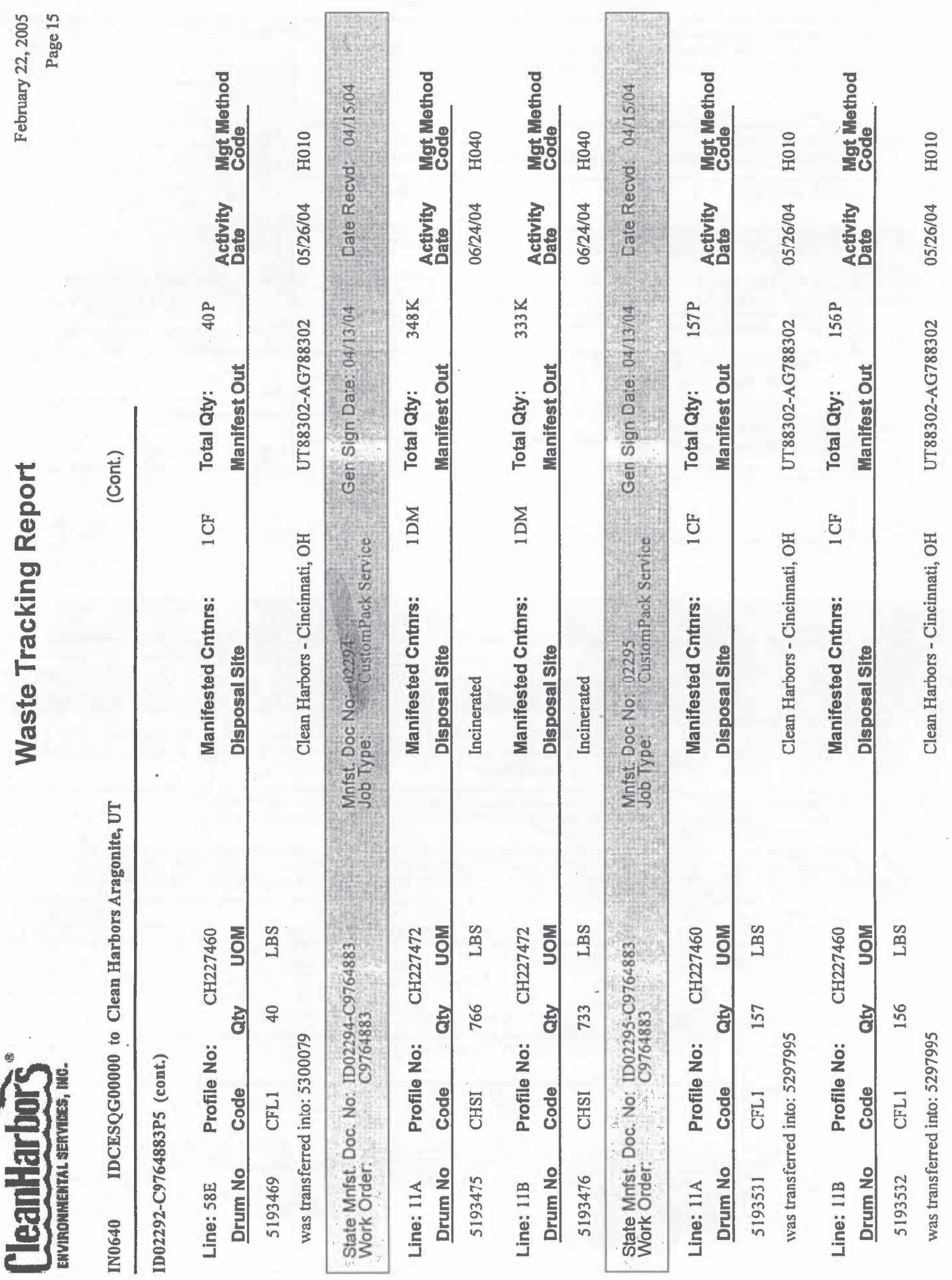

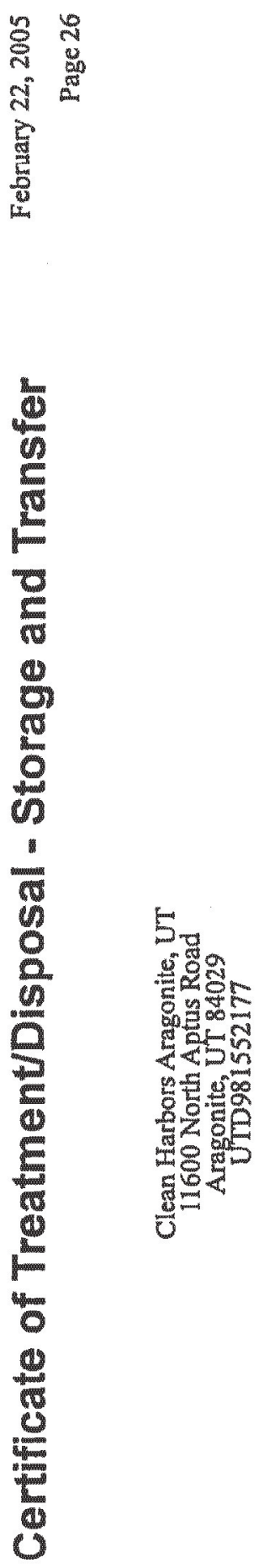

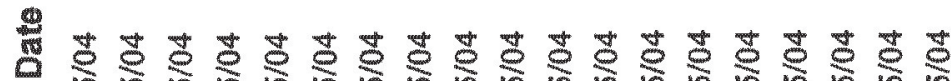
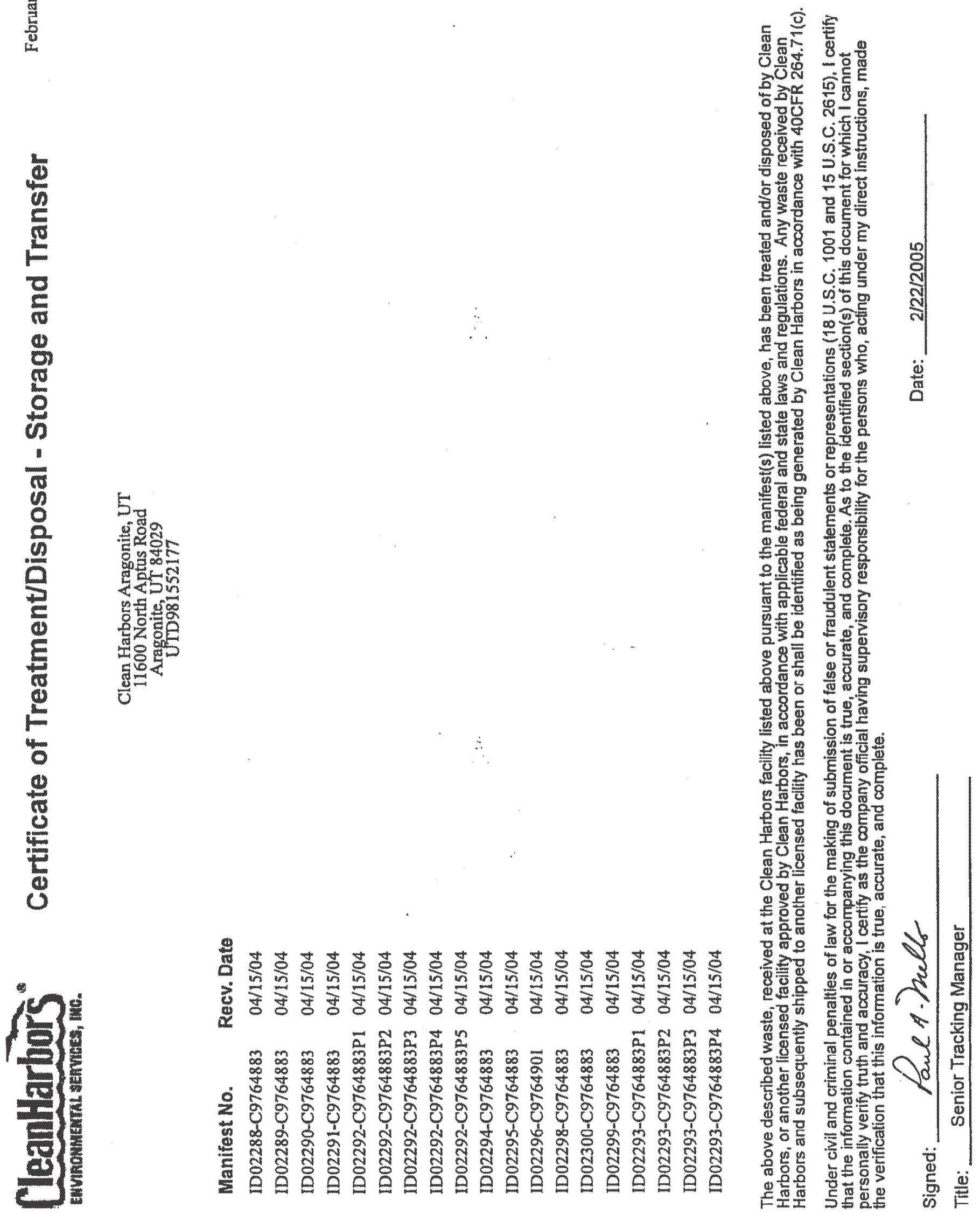

3. Generator's Name and Mailing Address

Idaho National Ingineering and Environmental Laboratory 0.S. DOE, P.O. Box 1625, Idaho Fa11B, ID 83415-4105

4. Generator's Phone ( 208$) 526-2414$
5. Transporter 1 Company Name
6. US EPA ID Number

clean Harbors Environmental

7. Transporter 2 Company Name

al Services

8. USEPAID MUmber

8. US EPA ID Number

9. Pesignated Facility Name and Site Address

(aragonite) IIC

11600 North Aptus Road

Aragonite, UT 84029

10. US EPA ID Number

OTD981552177

11. US DOT Description (including Proper Shipping Name, Hazard Class and ID Number) HM

E a. Non-DOT Regulated PCBg PCB Debris, 91 PRM, OOS

\begin{tabular}{l|l|l|l}
\hline R & & & \\
A b. & $\begin{array}{l}\text { Non-DOT Regulated PCBa PCB Debris, } 91 \text { PRM, OOS } \\
3-10-04\end{array}$ & $\begin{array}{l}10 \\
\text { T }\end{array}$ &
\end{tabular}

R

c. Non-DOT Regulated PCBs 91 ppm PCB Debris, OOS

Date3/17/04

d. $\mathrm{x}$

$\mathrm{x}$

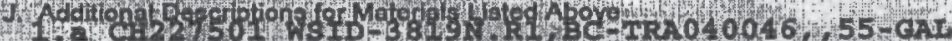

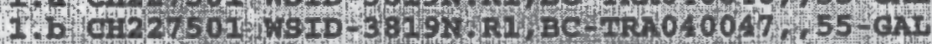

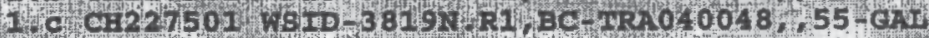

19.

Wh

15. Special Handling Instructions and Additional information

Raturn algned original to: D.J. Rowley, Idaho National Engineering \& Environmental

Iaboratory/US DOE, P.O. Box 1625. Idaho Falls, ID 83415-4105. Prepared undar contract \#DEAC07 99ID 13727. USDOR 24-Kr. Emergency Phone: (208) 526-1515.

16. GENERATOR'S CERTIFICATION: I hereby dectare that the contents of this consignment are fully and accurately described above by proper shipping name and are classified, packed, marked, and labeled, and are in all respects in proper condition for transport by highway according to appllicable international and national govemment regulations.

III am a large quanlity generator, I certify that I have a program in place to reduce the volume and toxicity of waste generaled to the degree I have determined to be economicaliy practicable and that I have selected the practicable method of trealment, storage, or disposal currenty avaliable to me which minimizes the present and future threat to human health and the environment: $O R$, if I am a small quanfity generator, I have made a good falth offort to minlmize my waste generation and select the best waste management method that is available to me and that I can afford.

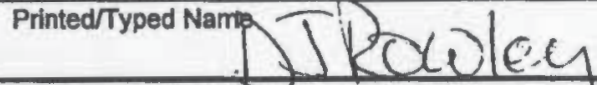

17. Transporter 1 Acknowledgement of Receipt of Materials

Printed/Typed Name

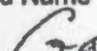

18. Transporter 2 Acknow

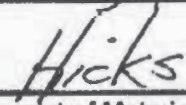

Printed/Typed Name

19. Discrepancy Indication Space

A

1 20. Facility Owner or Operator: Certification of receipt of hazardous materials covered by this manifest except as noted in ltem 19.

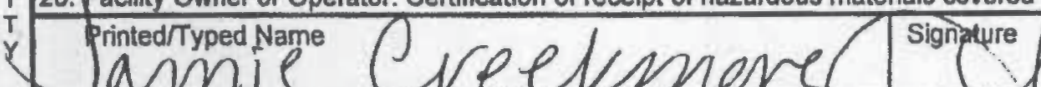

Integrated Waste Tracking System.
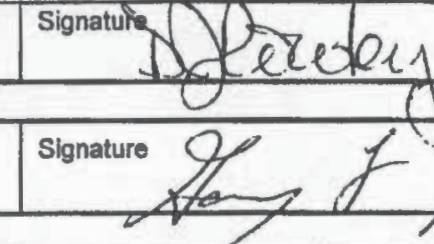

Signature
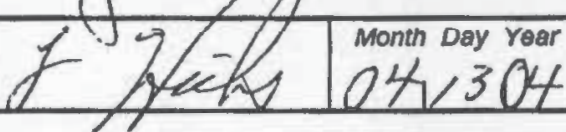

8952

$+1$

(2)




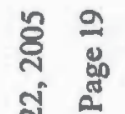

.

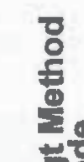

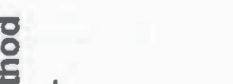

窟

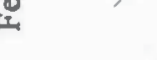

농ำ

.

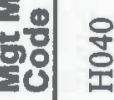

裹视

唼

言

。

密

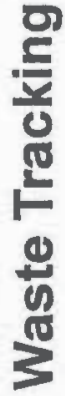

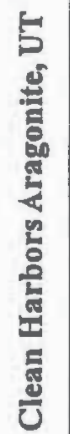

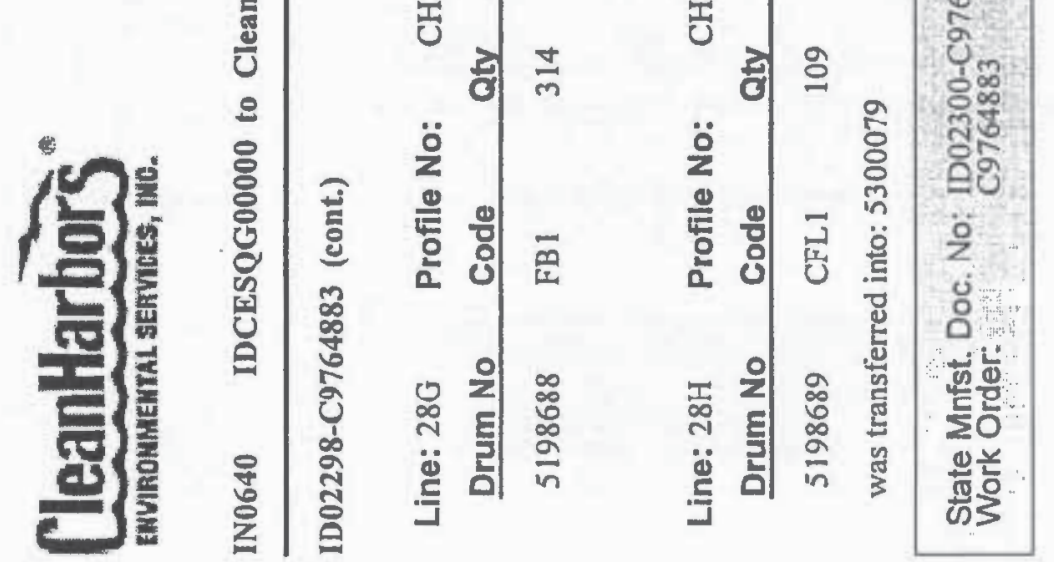

芳言嵒

눙

总

ถี

这

卷

i.

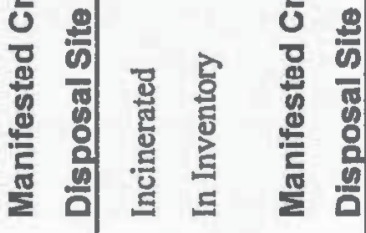

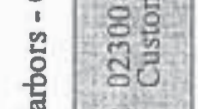

帚

ปี

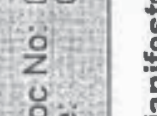

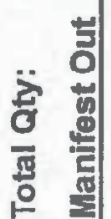

ชิ

율 造

递

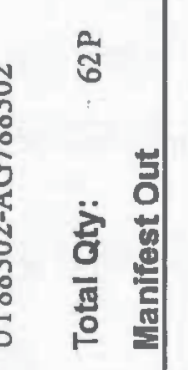

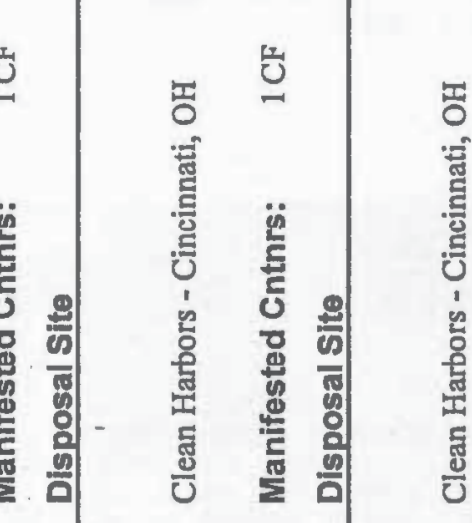

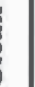




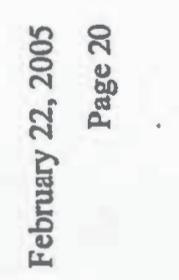

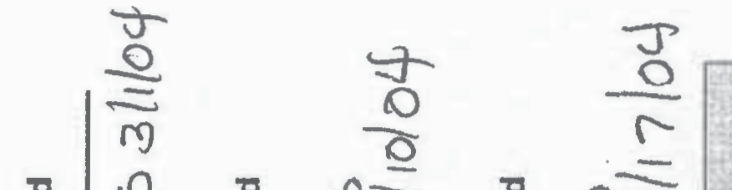

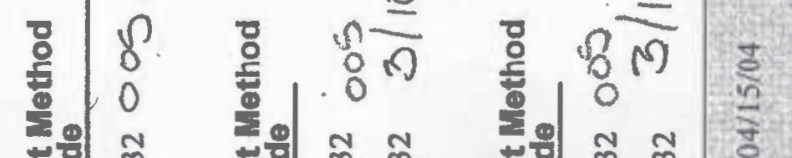

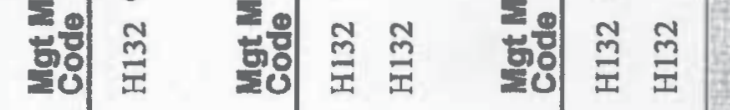

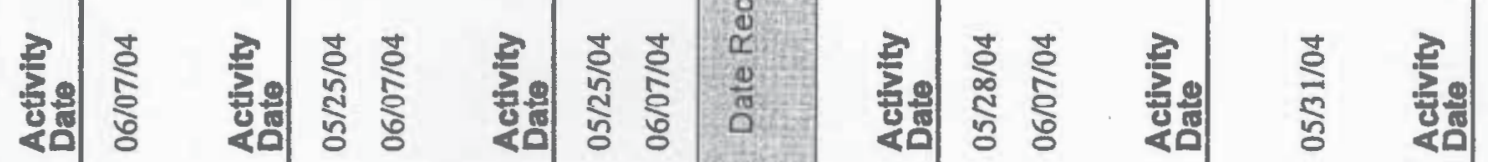

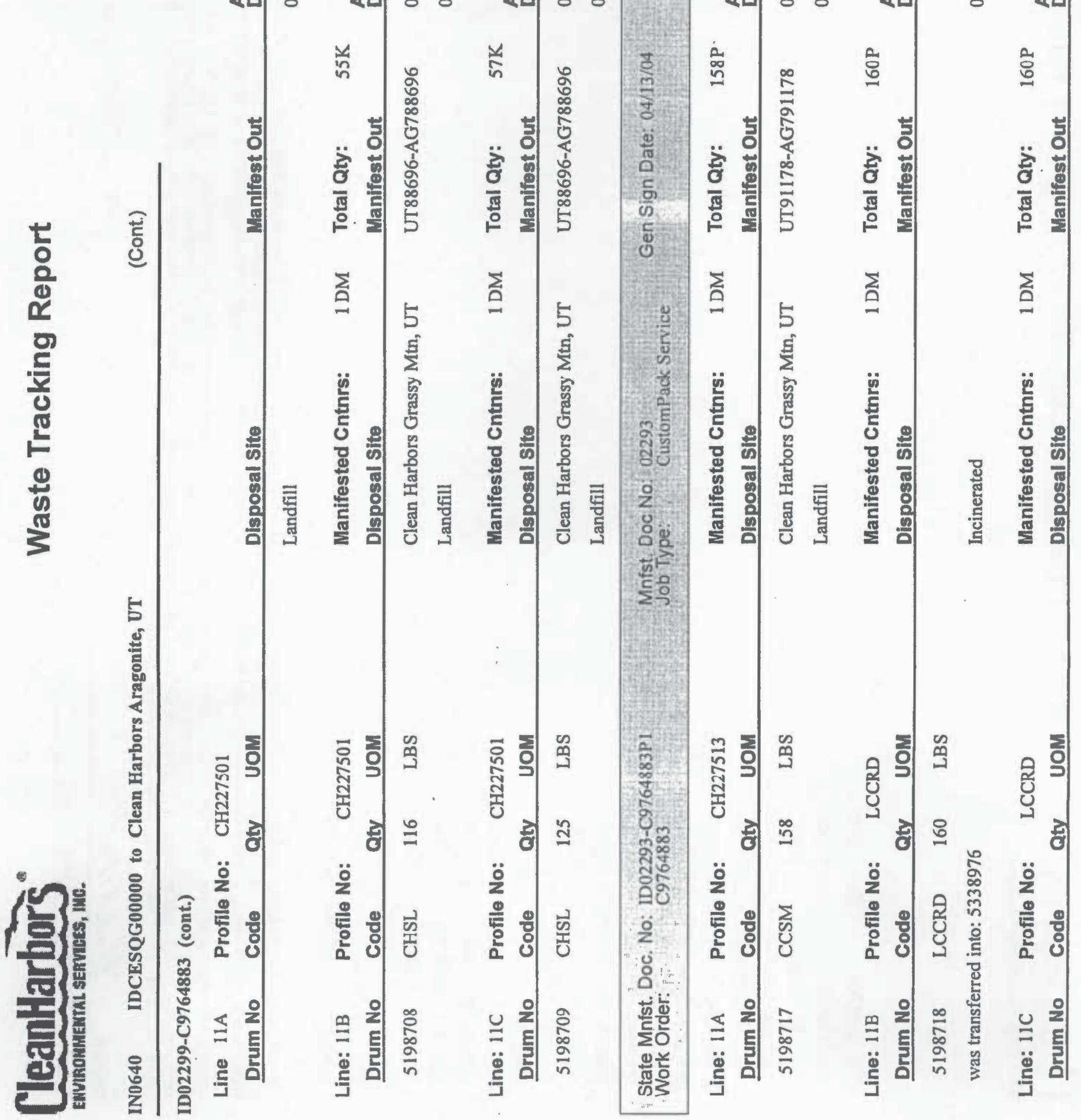



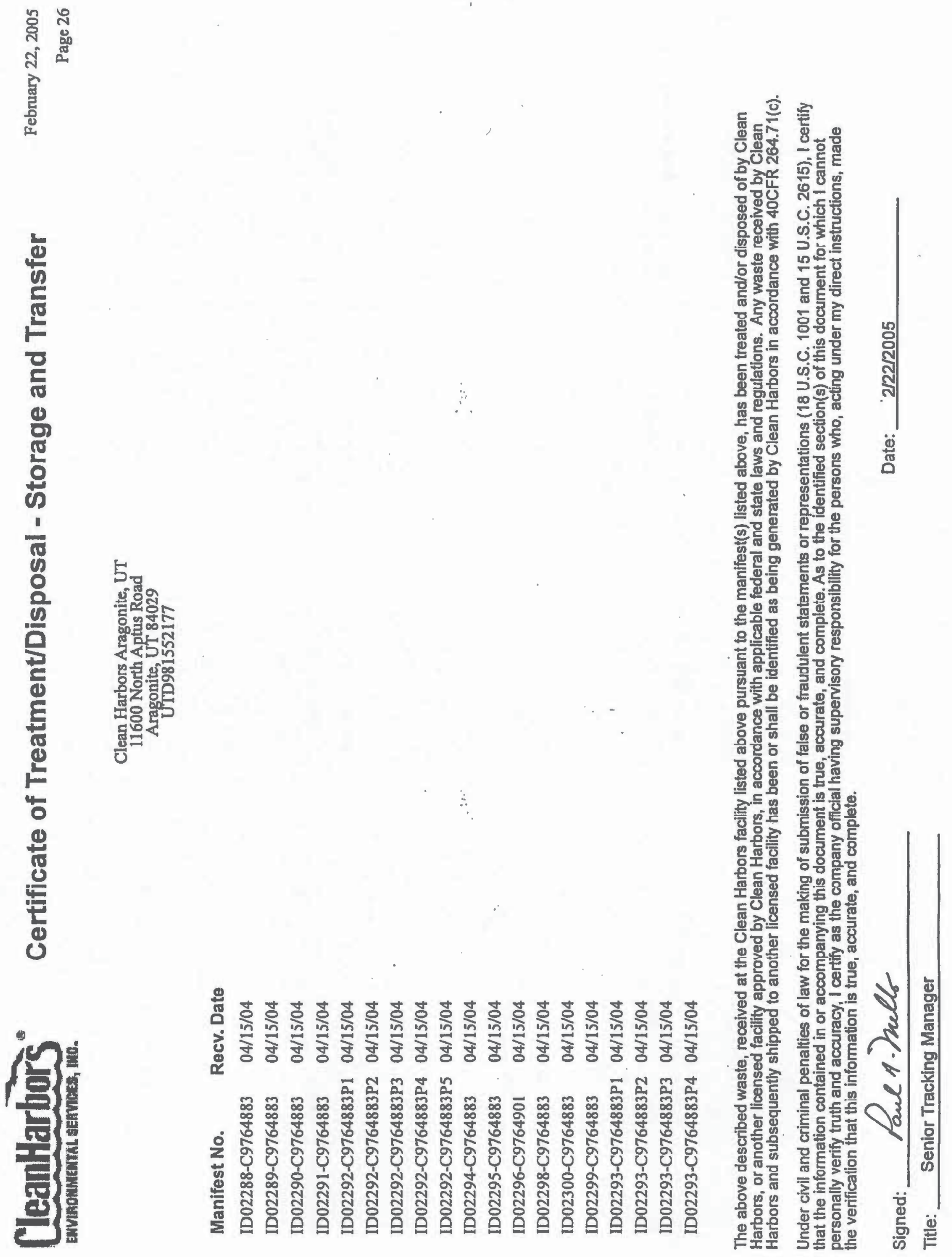



\begin{tabular}{|c|cc|c|c}
\hline $\begin{array}{c}\text { UNIFORM HAZARDOUS } \\
\text { WASTE MANIFEST }\end{array}$ & $\begin{array}{c}\text { 1. Generator's US EPA ID No. } \\
\text { ID4.890008952 }\end{array}$ & $\begin{array}{c}\text { Manifest } \\
\text { Document No. } \\
02306\end{array}$ & $\begin{array}{c}\text { 2. Page 1 } \\
\text { of } 3\end{array}$ & $\begin{array}{c}\text { Information in the shaded areas } \\
\text { is not required by Federal la' }\end{array}$ \\
\hline
\end{tabular}

3. Generator's Name and Mailing Address

Idaho National $\mathrm{kng}$ ineering and Environmental Laboratory U.S.

DOE, P.O. BOX 1625. Idaho Fal1s, ID 83415-4105

4. Generator's Phone (208) $526-2414$

\begin{tabular}{|l|l|}
\hline $\begin{array}{l}\text { 5. Transporter } 1 \text { Company Name } \\
\text { Tri-state Motor Transit }\end{array}$ & $\begin{array}{l}\text { 6. US EPA ID Number } \\
\text { MORO00505347 }\end{array}$ \\
\hline 7. Transporter 2 Company Name & 8. US EPA ID Nüber
\end{tabular}

A. State Manifest Document Number

B. State Generator's ID:

9. Degignated Facility Name and Site Address
Envirocare of Utah, Inc.

10. US EPA ID Number

US I-80 Exit 49 Toole County C11ve, UT 84029

DTP982598898

(6.s.

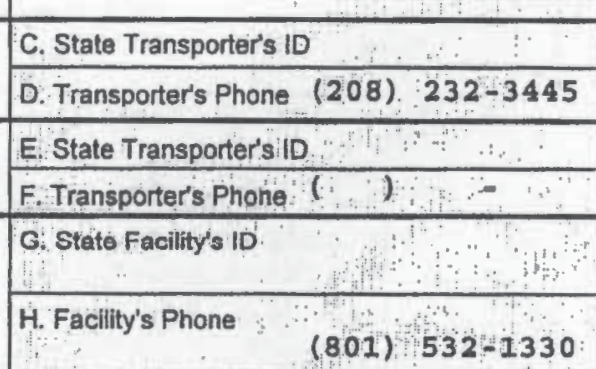

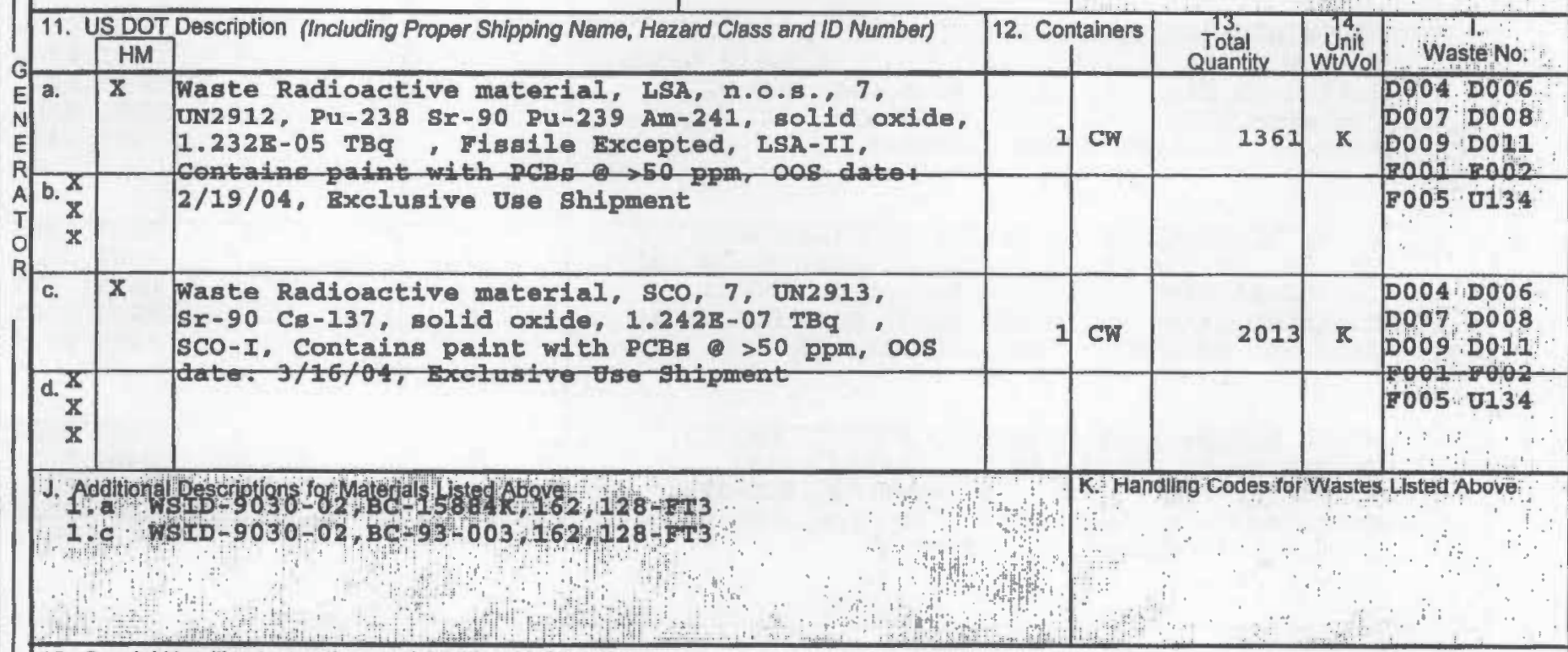

15. Special Handling Instructions and Additional Information

Return Signed orlginal to: RT Kendrick, INEEL / USDOE, BOx 1625 - MS5227, Idaho Ialls, Id

83415. Prepared under contract: DEAC07 99ID 13727. Emergency Phone: 208-526-1515.

Exclualve Uвe shipment

$9030-02-P M 00178$

16. GENERATOR'S CERTIFICATION: I hereby declare that the contents of this consignment are fully and accurately described above by

proper shipping name and are classified, packed, marked, and labelad, and are in all respects in proper condlibon for transport by highway

according to applicable infernational and national govermment regulations.

III am a large quantity generator, I certify that I have a program in place to reduce the volume and toxicily of waste generated to the degree I have determined to be economically practicable and that I have selected the practicable method of treatment, storage, or disposal currently available to me which minimizes the present and future threat to human health and the environment; OR, III am a small quantity generator. I have made a good falth effort to minimize my waste generation and select the best waste management method that is avallable to me and that I can afford.

Printed/Typed Name

R. T. Kendrick

\begin{tabular}{|l|l|l|} 
Signature & Month Day Year \\
$4,20,2004$
\end{tabular}

17. Transporter 1 Acknowledgement of Receipt of Materials

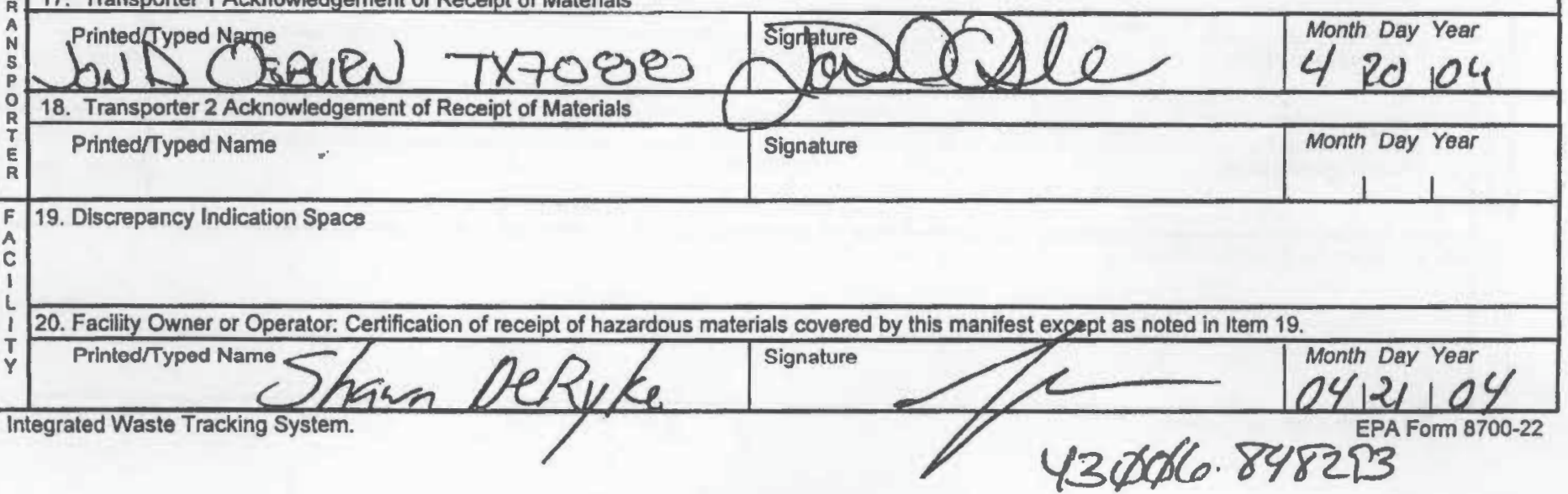




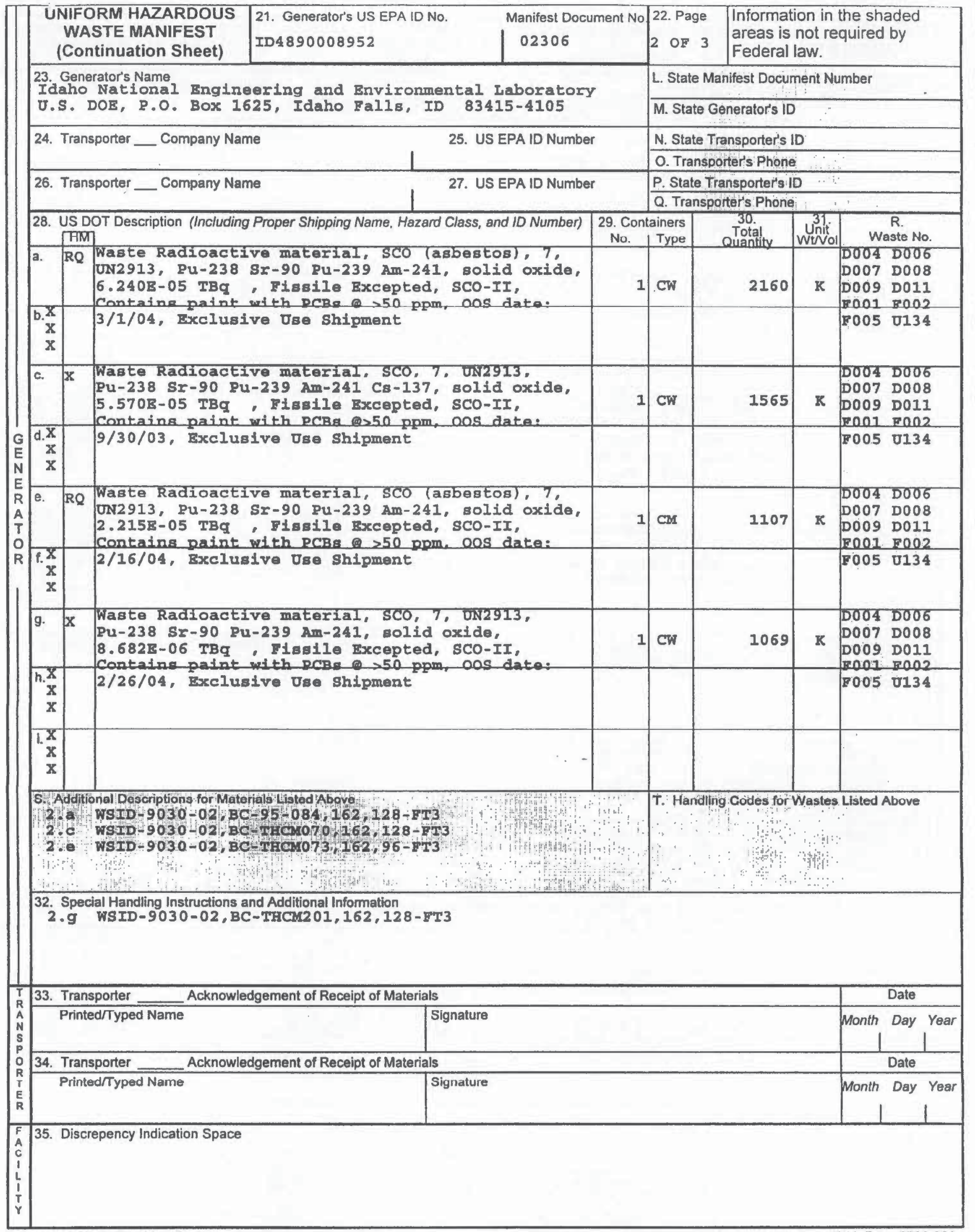




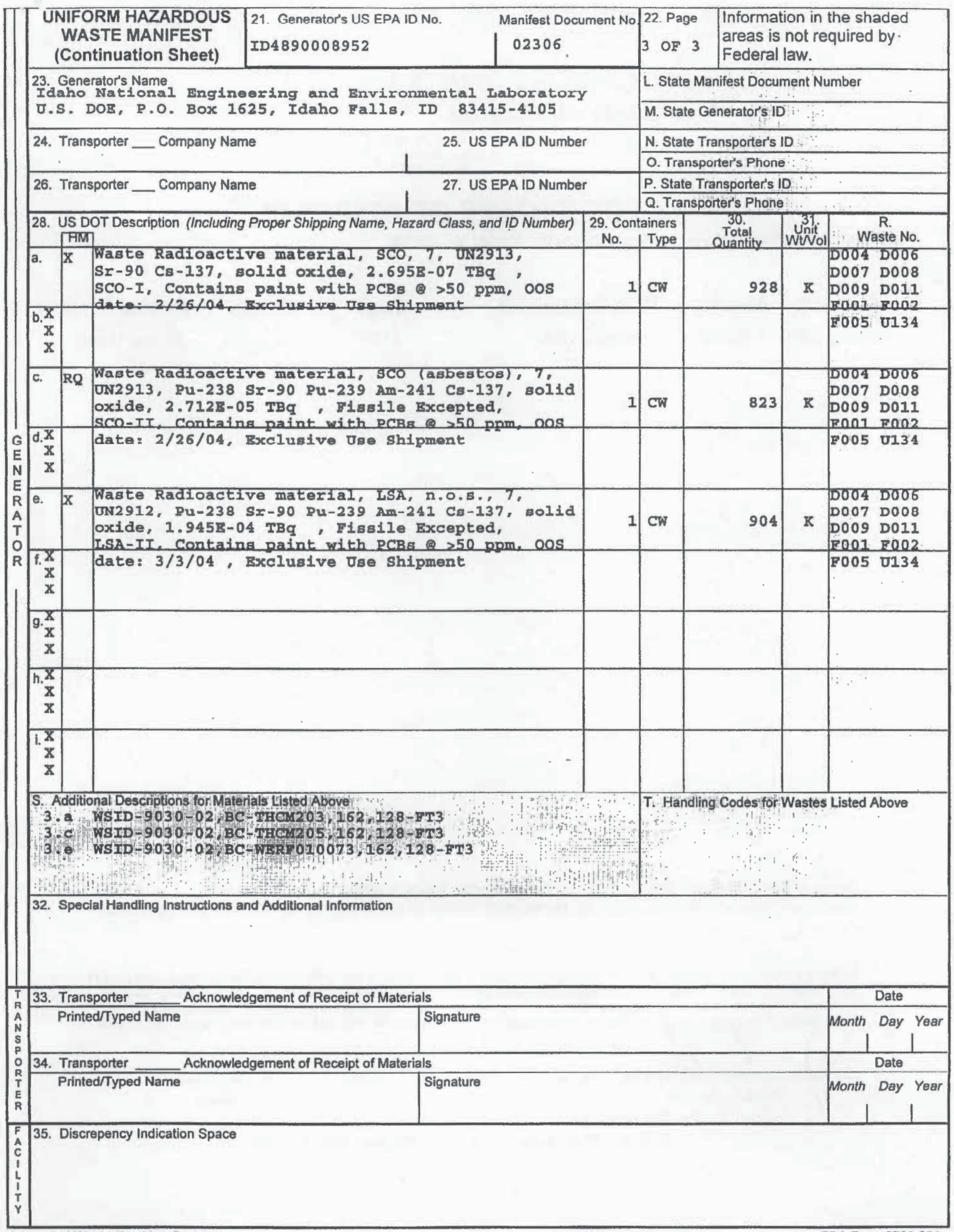


$\begin{array}{lllll}\text { OCT. 25. } 2004 & 7: 49 \text { AM } & \text { BECHTEL BWXT ID SAMPLE MANAGEMEN } & \text { N0.8167 } & \text { P. } 21\end{array}$

ENVIROCARE OF UTAH, INC.

THE SAFE ALTERNATIVE

$3 \mathrm{mi}$. S. Exh. 49, 1-80

Clive, Uth $84029 \mathrm{EPA}$

ID: UT982598898

\section{CERTIFICATE OF DISPOSAL}

This Cartfleate acknowledges that the following manifested shipments;

\begin{tabular}{|c|c|c|c|c|c|}
\hline Shipment & Manifeat & Date(b) of Disposal & $\mathrm{Cu} / \mathrm{Rt}$ & Process & Dispos l Laction \\
\hline $9030-02-0018$ & 02306 & $8 / 24,8 / 27 / 04$ & 1120 & Landrill & Mixed Waste \\
\hline
\end{tabular}

Representing 1120 Cubic feet of waste of at lioted Disposal Facility landfin. Disposal in nubject to Esvirocare's Radiosetive Material Lieense, all other applieabie lieenses, permira and regulations, and the Diapoesal Agreement.

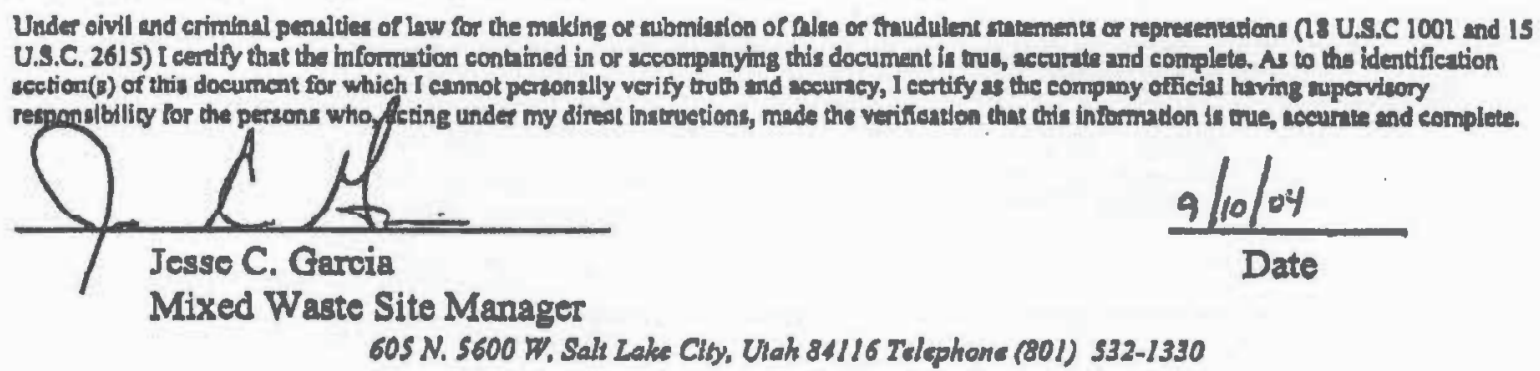





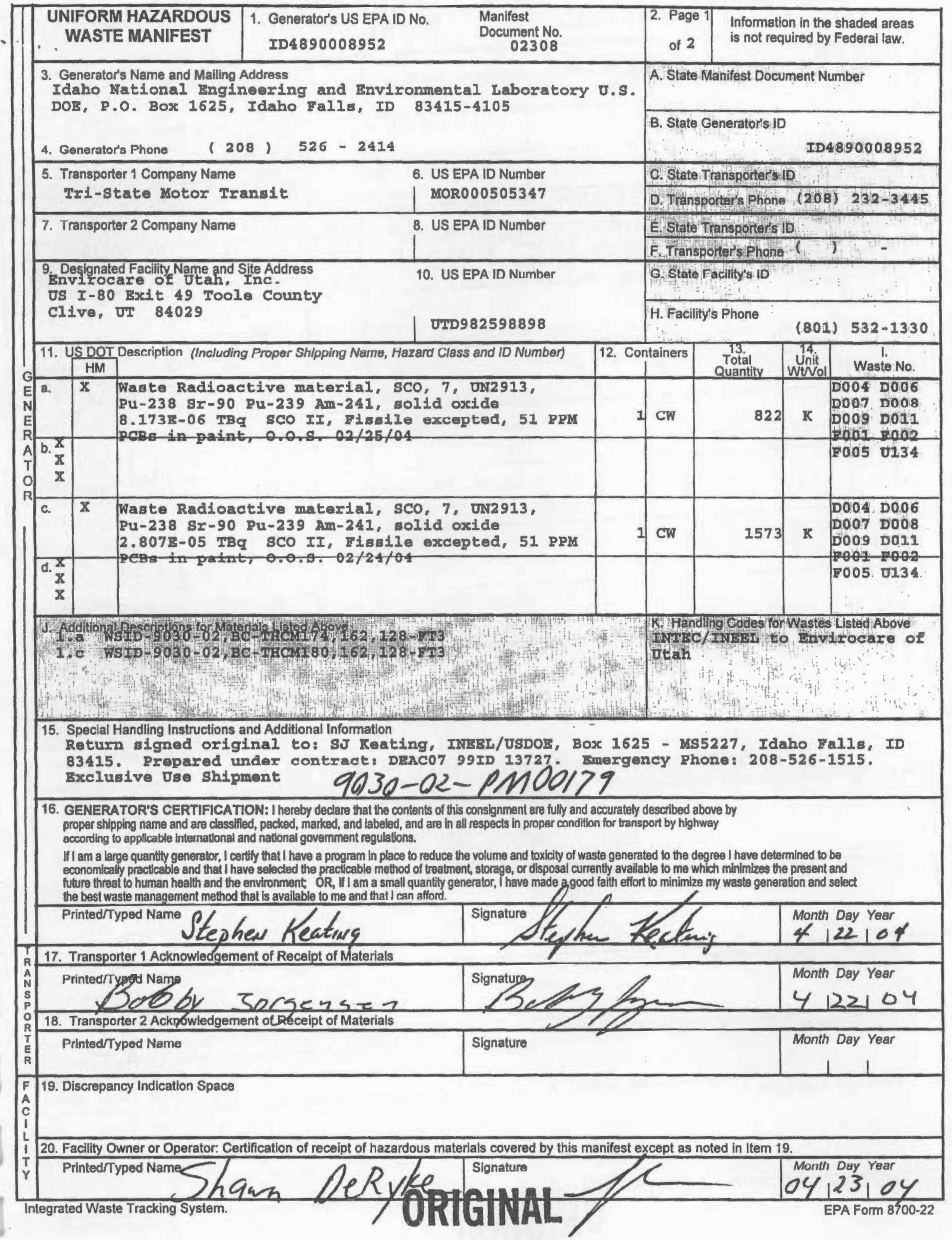




\section{$\int \begin{gathered}\text { UNIFORM HAZARDOUS } \\ \text { WASTE MANIFEST } \\ \text { (Continuation Sheet) }\end{gathered}$}

21. Generator's US EPA ID No.
ID4890008952

23. Generator's Name

Idaho National Engineering and Envixonmental Laboratory

J.s. DOE, P.O. Box 1625, Idaho Ealls, ID 83415-4105

\begin{tabular}{|l|c|}
\hline 24. Transporter _ Company Name & 25. US EPA ID Number \\
\hline 26. Transporter___Company Name & 27. US EPA ID Number \\
\hline
\end{tabular}

28. US DOT Description (Including Proper Shipping Name, Hazard Class, and ID Number) 20 Q. Trabsporter's Phone

\begin{tabular}{|c|c|c|c|c|c|c|}
\hline 28. & $\begin{array}{l}\text { US DOT Description (Including Proper Shipping Name, Hazard Class, and ID Number) } \\
\text { BIM] }\end{array}$ & $\begin{array}{l}\text { 29. Cont } \\
\text { No. }\end{array}$ & $\begin{array}{l}\text { tainers } \\
\text { Lype }\end{array}$ & $\begin{array}{l}30 \\
\text { Total } \\
\text { Ouantity }\end{array}$ & unit & Waste No. \\
\hline a. & 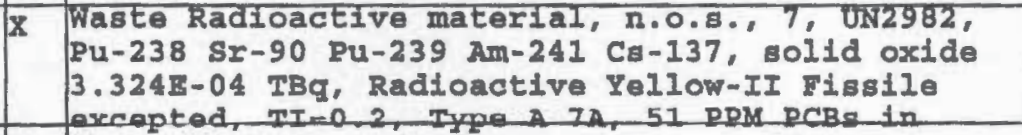 & 1 & $C M$ & 2318 & $\mathbf{k}$ & 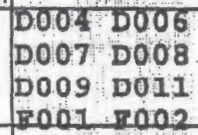 \\
\hline \begin{tabular}{|l} 
b. $\mathbf{x}$ \\
$\mathbf{x}$ \\
$\mathbf{x}$
\end{tabular} & paint, $0.0 .5 .03 / 16 / 04$ & & & & & P0.05 0134 \\
\hline $\begin{array}{r}\text { c. } x \\
x \\
x\end{array}$ & & & & & & 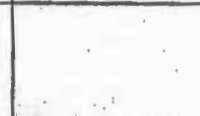 \\
\hline $\begin{array}{r}\text { d. } X \\
x \\
X\end{array}$ & & & & & & . \\
\hline e. $\begin{array}{l}x \\
x \\
x\end{array}$ & & & & & & \\
\hline f. $\frac{x}{x}$ & & & & & & : \\
\hline g. $\frac{x}{x}$ & & & & & & : $\because \because \quad \because$ \\
\hline h. $\frac{x}{x}$ & & & & & & \\
\hline 1. $\frac{x}{x}$ & & 1- & & & & $\begin{array}{r}\cdots \\
\vdots\end{array} \vdots$ \\
\hline \multicolumn{3}{|c|}{ 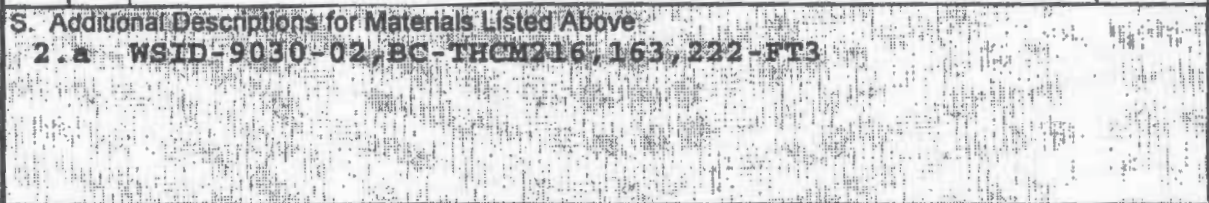 } & \multicolumn{4}{|c|}{ 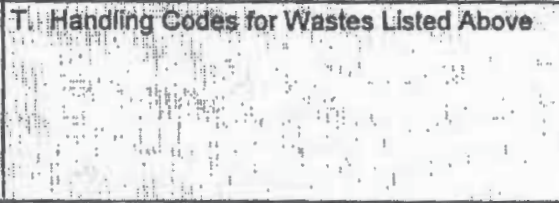 } \\
\hline
\end{tabular}

32. Special Handling Instructions and Additional Information

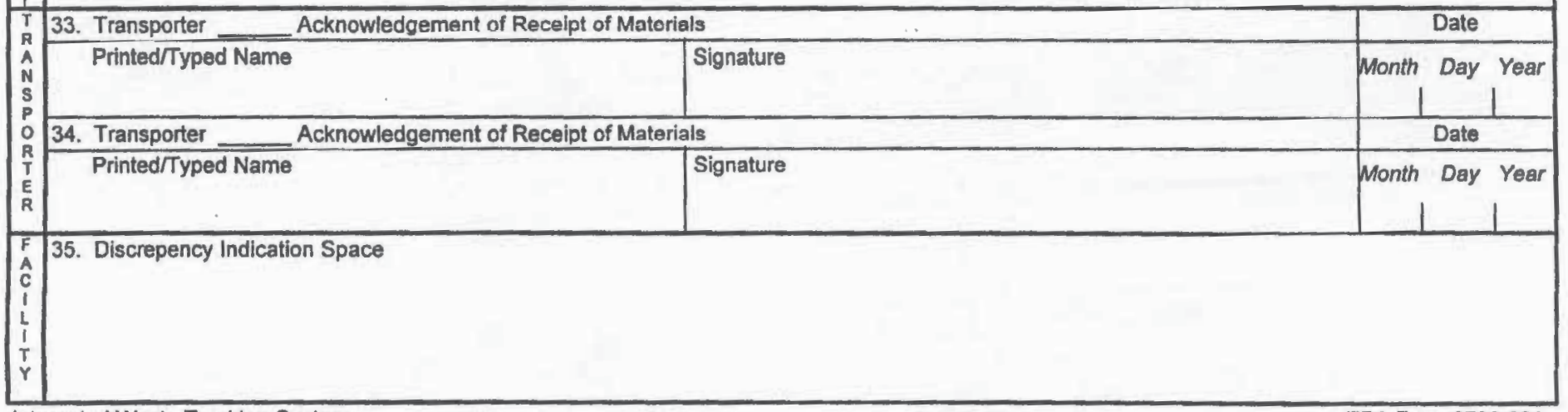


OCT.25.2004 7:48AM BECHTEL BWXT ID SAMPLE MANAGEMEN $\quad$ N0.8167 P. 15

\section{ENVTROCARE OFUTAH, INC. \\ THE SAFE ALTERNATTVE \\ 3 mit. S. Exec $49,10.50$ \\ Clve, Urh 84029 ERA

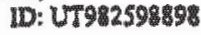

\section{CERTIFICATE OF DISPOSAL}

This Certificate acknowledges that the following manifested shioments:

\begin{tabular}{|c|c|c|c|c|c|}
\hline Shipment & Monifest & Date(s) of Disposal & Cus at & Proces & Disnonullos ation \\
\hline $9030-02-0016$ & 02308 & $8 / 28 / 04,9 / 1 / 04$ & 384 & Lad dTW & Mixed Womte \\
\hline
\end{tabular}

Representing 384 Cubic feet of waste of at listed Dimposal Facilty landfun. Disposal d subject to

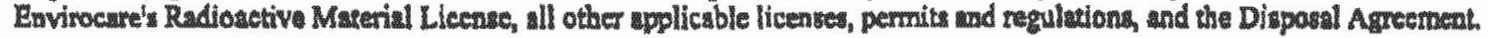

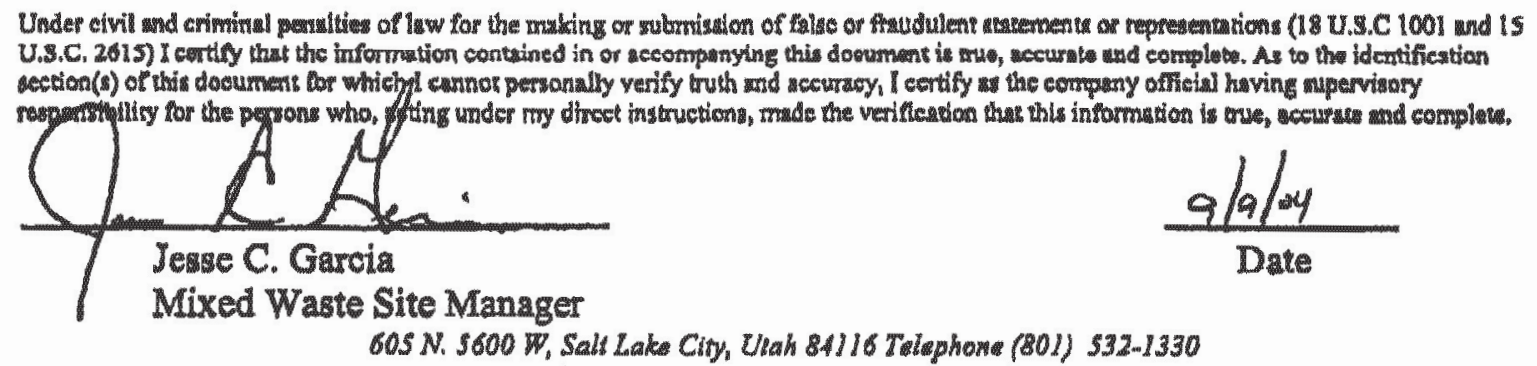





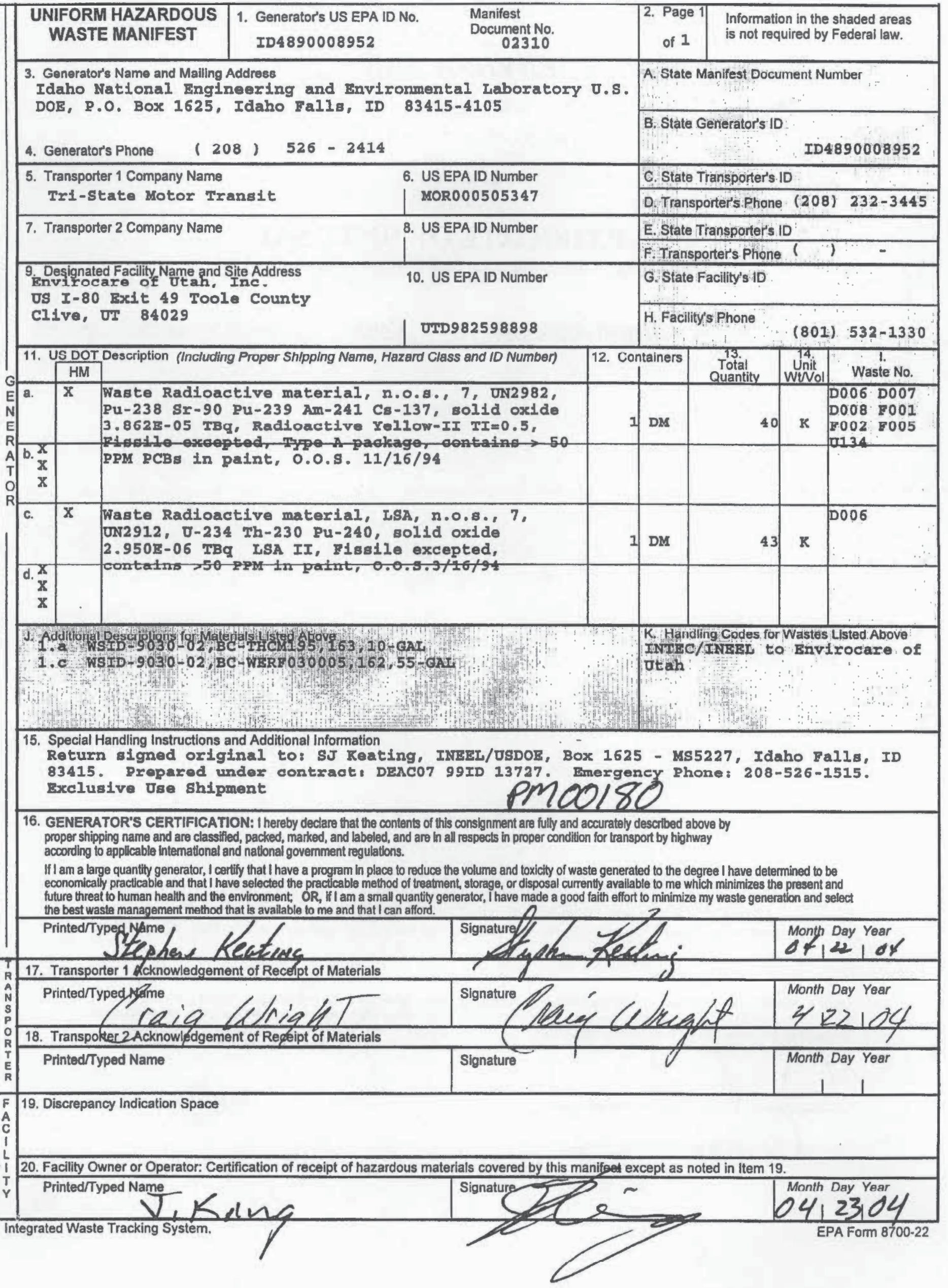




\section{ENVIROCARE}

OF UTAH, INC.

THE SAFE ALTERNATIVE

3 mi. S. Ext. $49,1-80$

Clive, Utah 84029 EPA

ID: UT982598898

\section{CERTIFICATE OF DISPOSAL}

; This Certificate acknowledges that the following manifested shipments:

$\frac{\text { Shipment }}{9030-02-0017} \quad \frac{\text { Manifest }}{02310} \quad \frac{\text { Date(s) of Disposal }}{11 / 28 / 2004} \quad \frac{\mathrm{Cu} / \mathrm{Ft}}{8.69} \quad \frac{\text { Process }}{\text { Landfill }} \quad \frac{\text { Disposal Location }}{\text { Mixed Waste }}$

Representing 8.69 Cubic feet of waste of at listed Disposal Facility landfill. Disposal is subject to Envirocare's Radioactive Material License, all other applicable licenses, permits and regulations, and the Disposal Agreement.

Under civil and criminal penalties of law for the making or submission of false or fraudulent statements or representations (18 U.S.C 1001 and 15 U.S.C. 2615) I certify that the information contained in or accompanying this document is true, accurate and complete. As to the identification section(s) of this document for which I cannot personally verify truth and accuracy, I certify as the company official having supervisory responsibility for the persons who, agting under my direet instructions, made the verification that this information is true, accurate and complete.
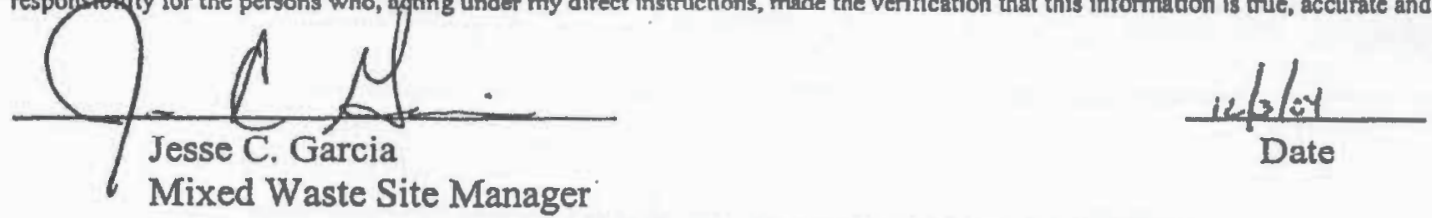

605 N. 5600 W, Salt Lake City, Utah 84116 Telephone (801) 532-1330 



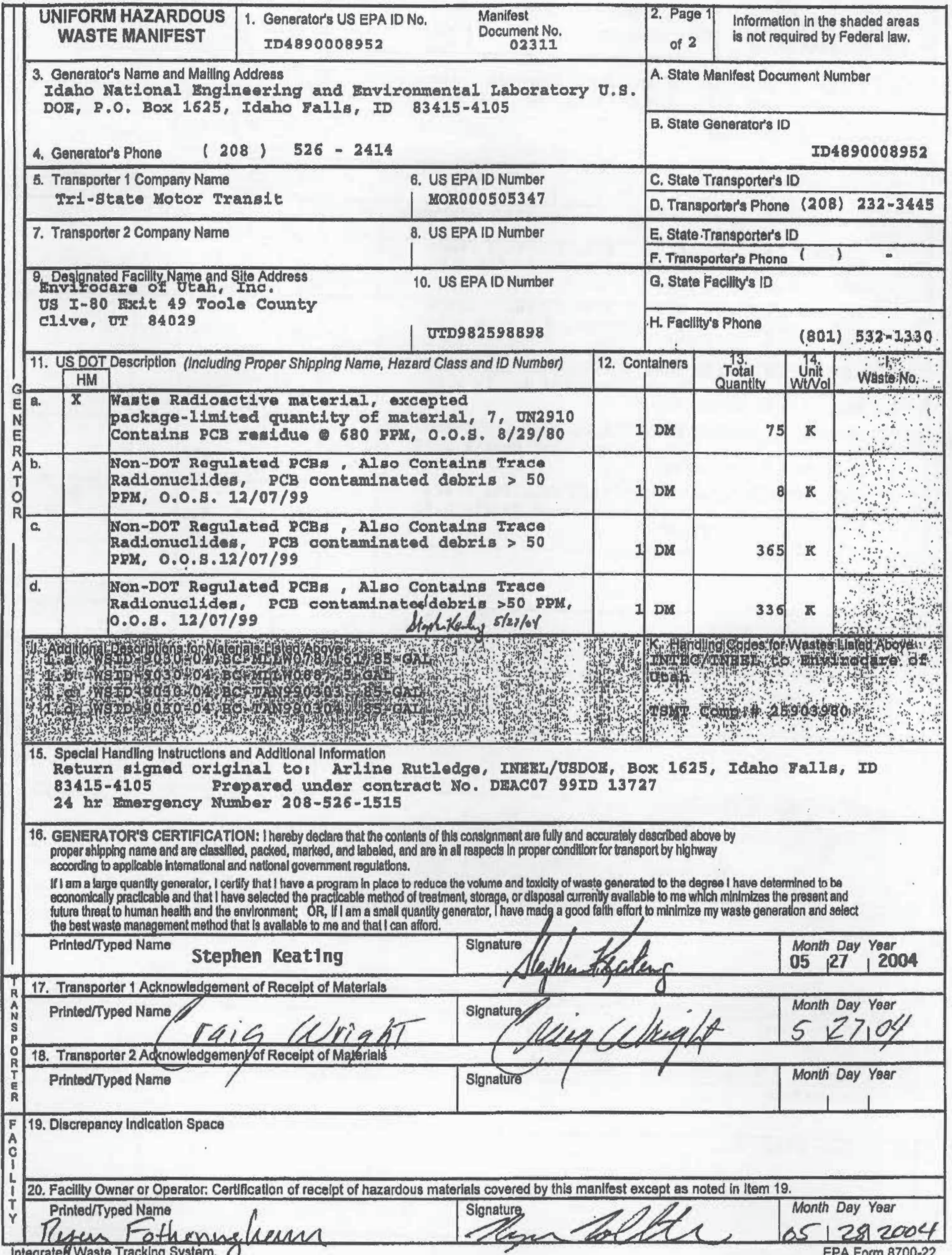




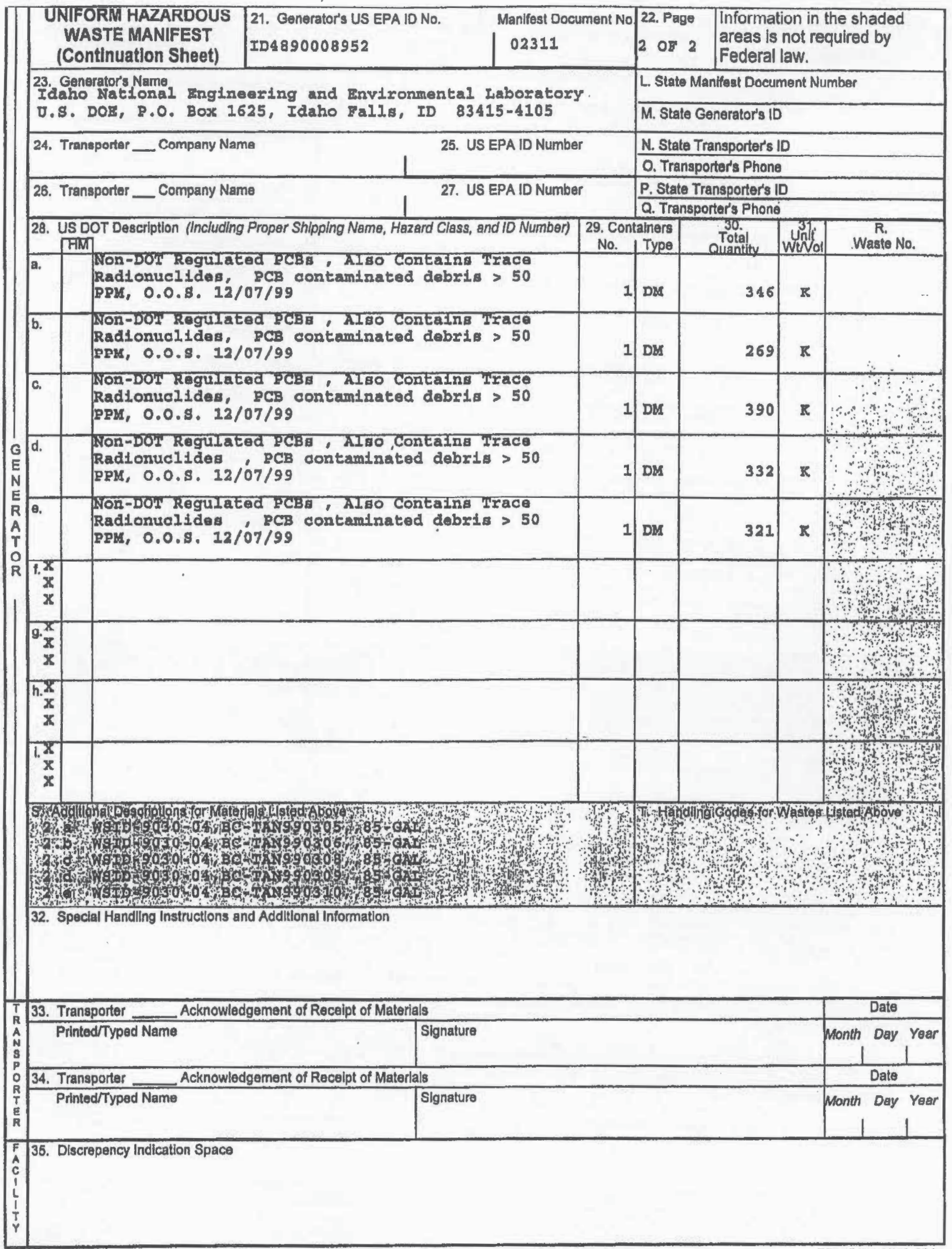




\section{ENVIROCARE}

OF UTAH, INC.

THE SAFE ALTERNATIVE

3 mi. S. Ext. $49,1-80$

Clive, Utah $84029 \mathrm{EPA}$

ID: UT982598898

\section{CERTIFICATE OF DISPOSAL}

: This Certificate acknowledges that the following manifested shipments:

$\frac{\text { Shipment }}{9030-04-0001} \quad \frac{\text { Manifest }}{02311} \quad \frac{\text { Date(s) of Disposal }}{12 / 43 / 2004} \quad \frac{\text { Cu/Ft }}{91.57} \quad \frac{\text { Process }}{\text { Landfill }} \quad \frac{\text { Disposal Location }}{\text { Mixod Waste }}$

Representing 91.57 Cubic feet of waste of at listed Disposal Facility landfill. Disposal is subjcct to Envirocare's Radioactive Material License, all other applicable licenses, permits and regulations, and the Disposal Agreement.

Under civil and criminal penalties of law for the making ar submission of false or frudulent statements or representations (18 U.S.C 1001 and 1 . U.S.C. 2615) I certify that the information contained in or accompanying this document is true, accurate and corraplete. As to the identification section(s) of this document for Which I cannot personally verify truth and accuracy, I cervify as the company official having supervisory responsibility for the persons $y$ fo, acting under my direet insuructions, made the verification that this intormation is true, accurate and complete.
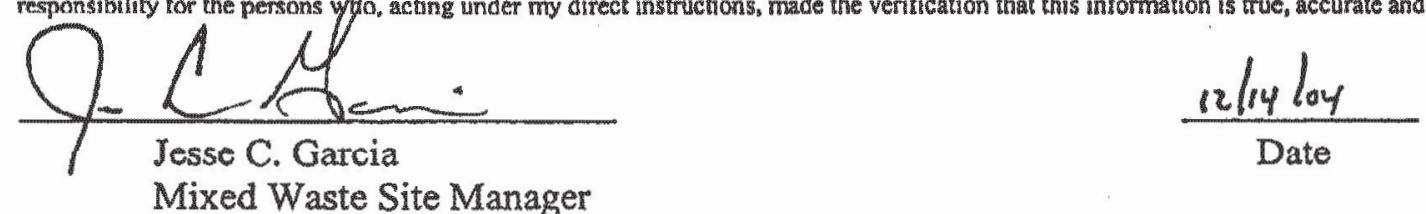

605 N. 5600 W, Salt Lake City, Uiah 84110 Telephone (801) $532-1330$ 


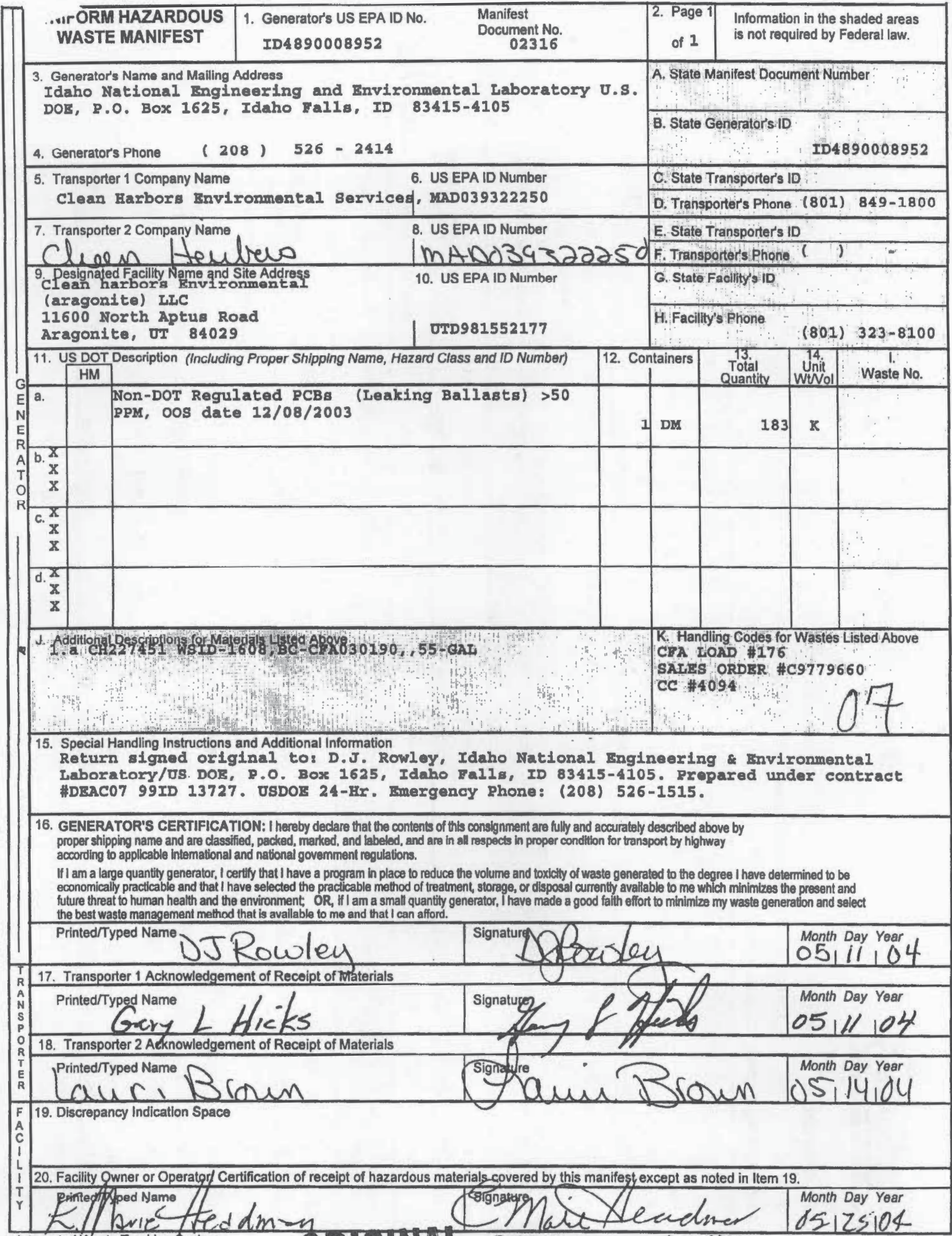

integrated Waste Tracking system. 


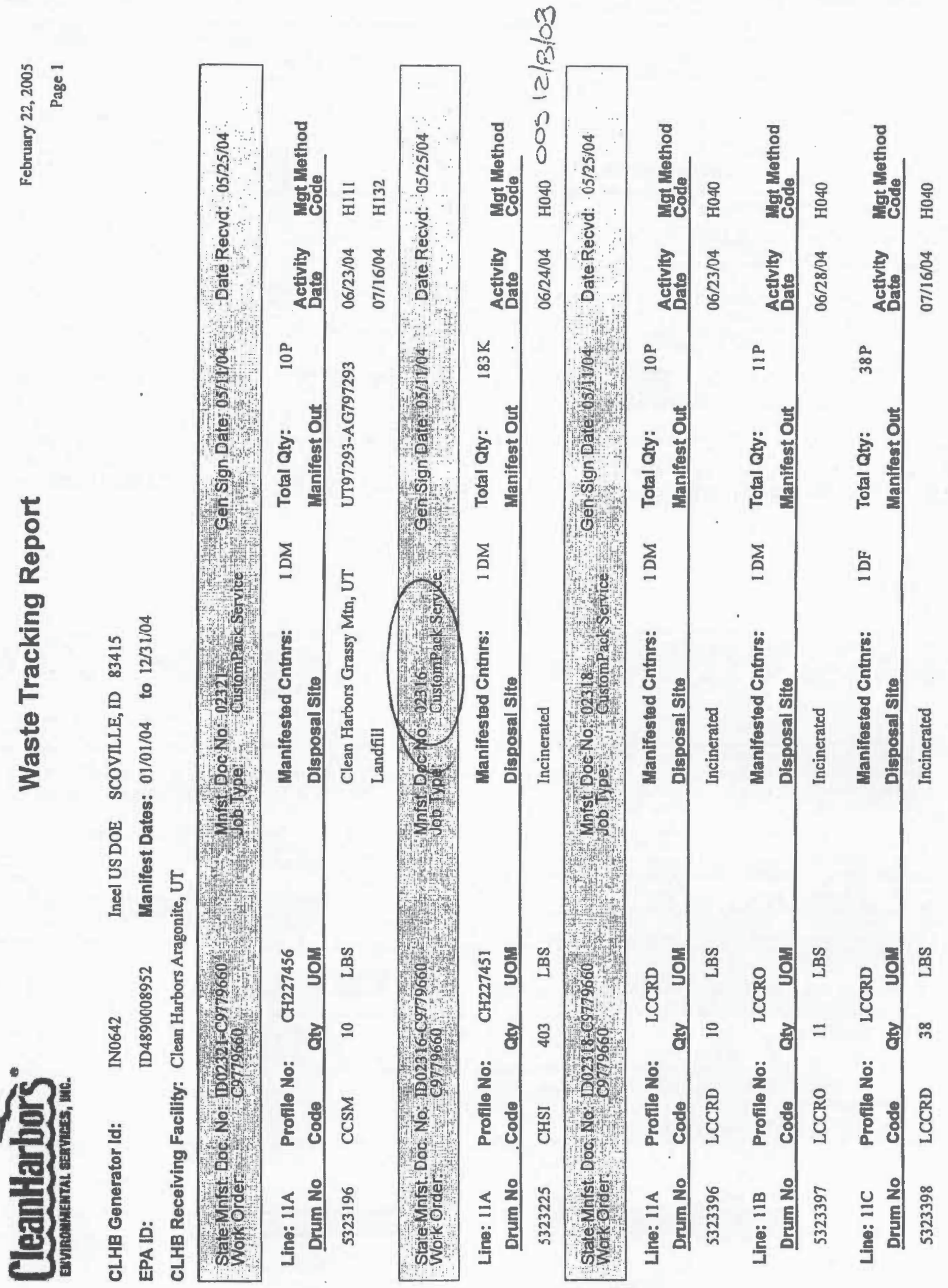



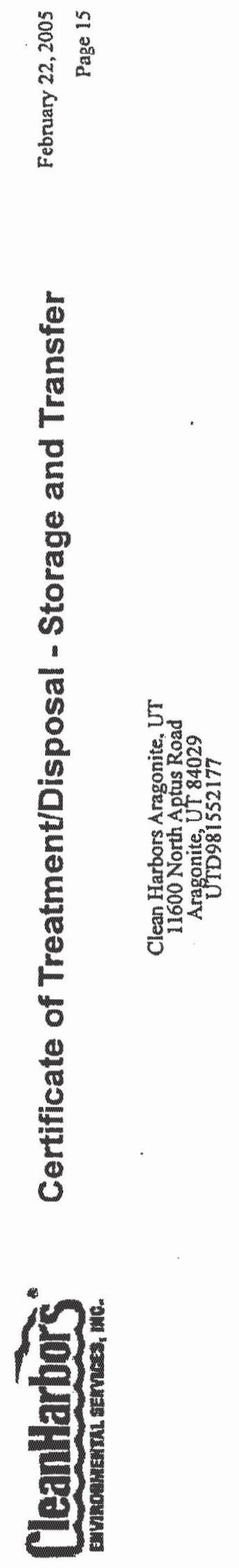
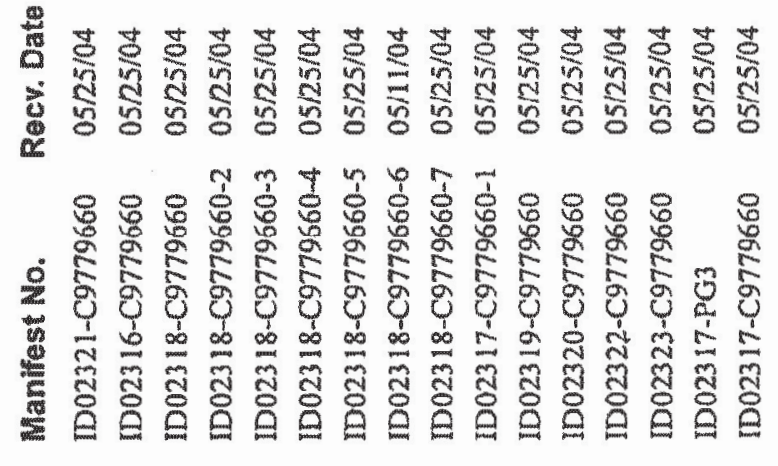

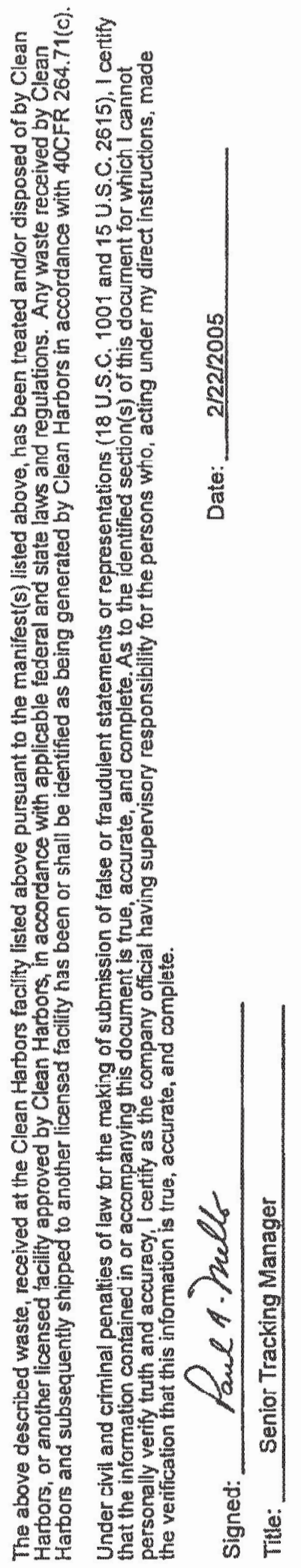





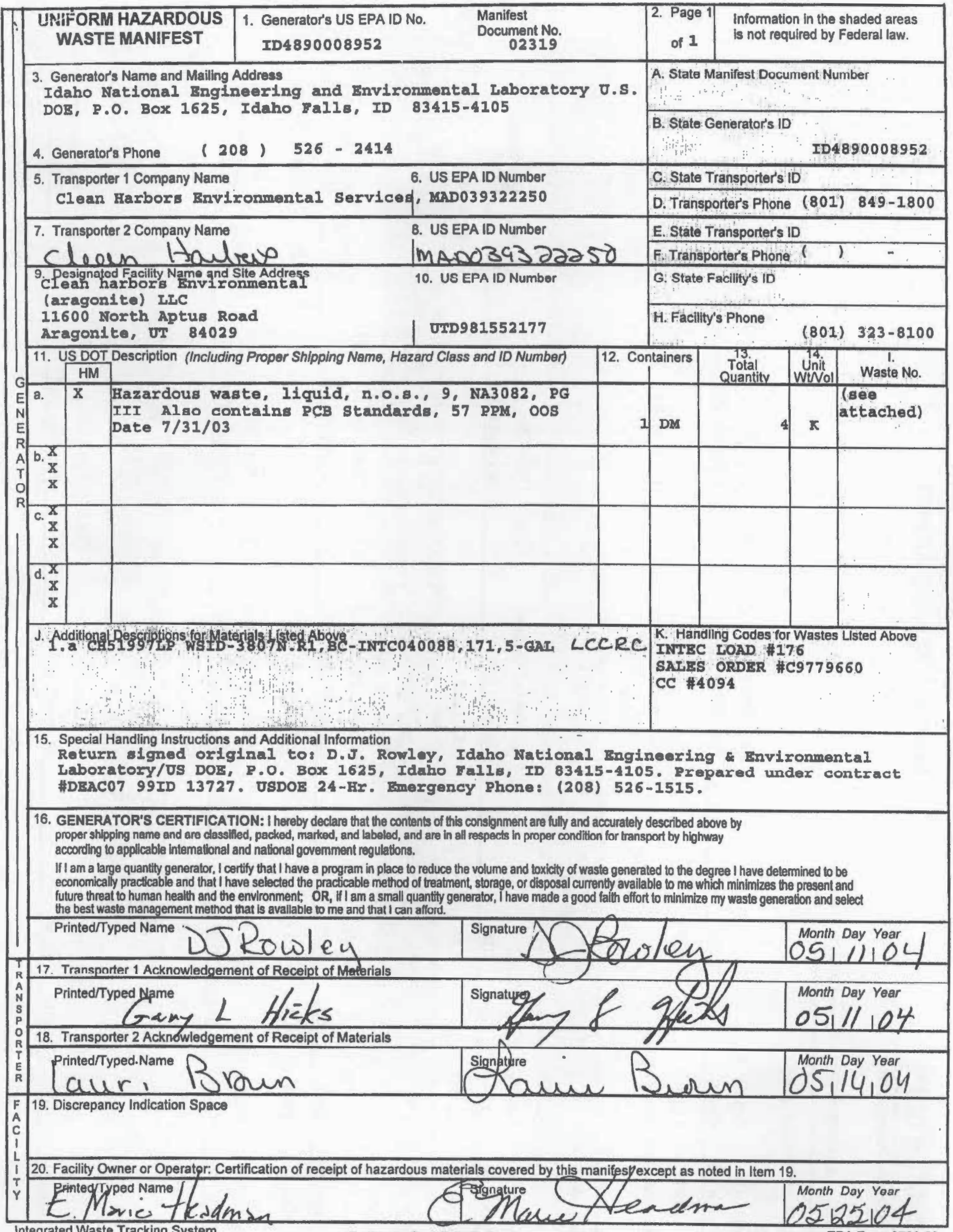

integrated Waste Tracking System. 


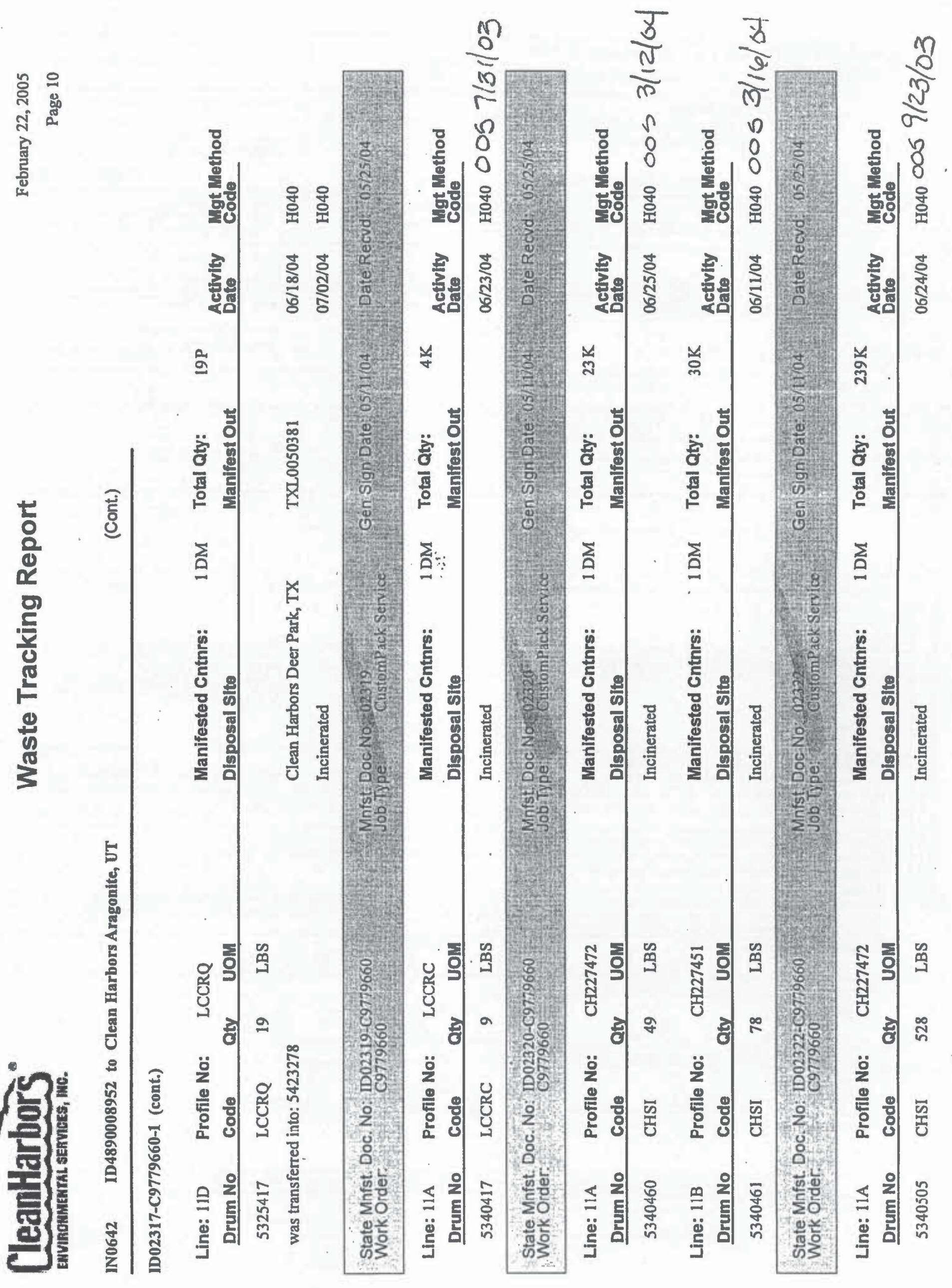




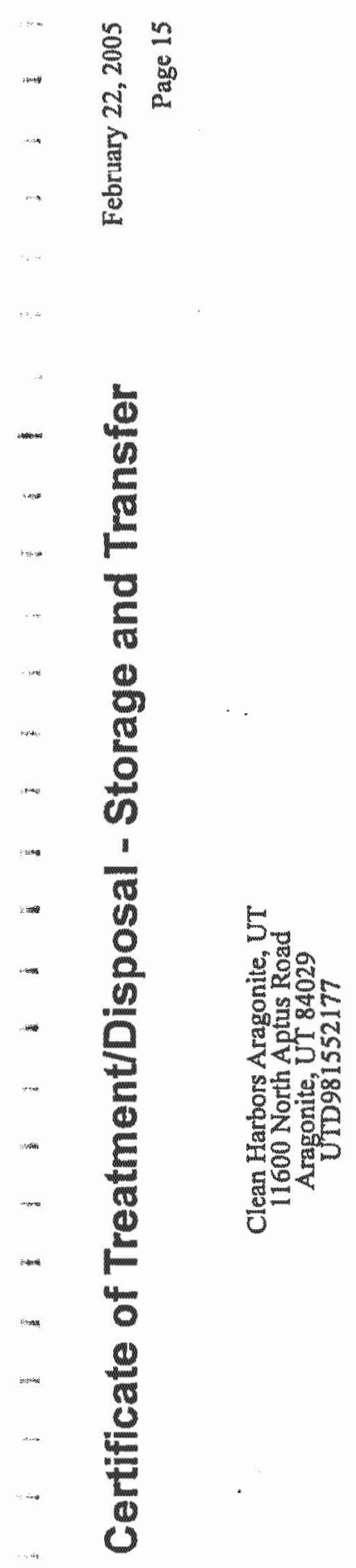

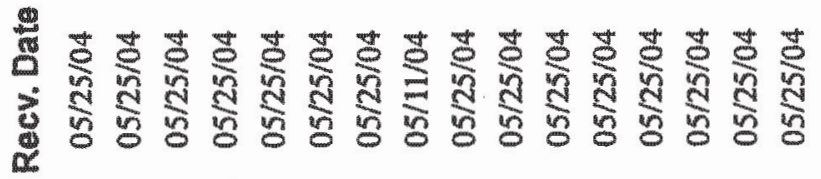
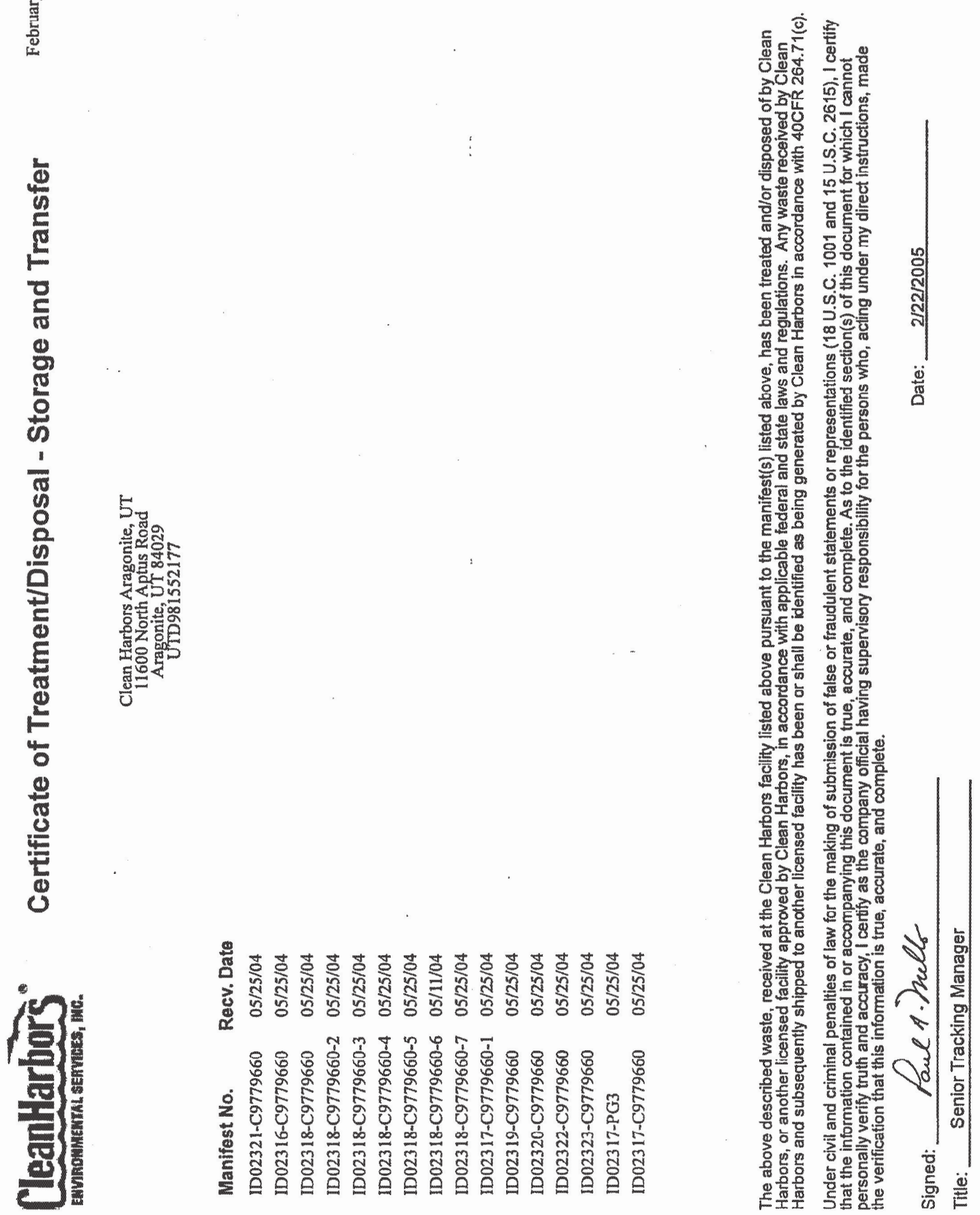



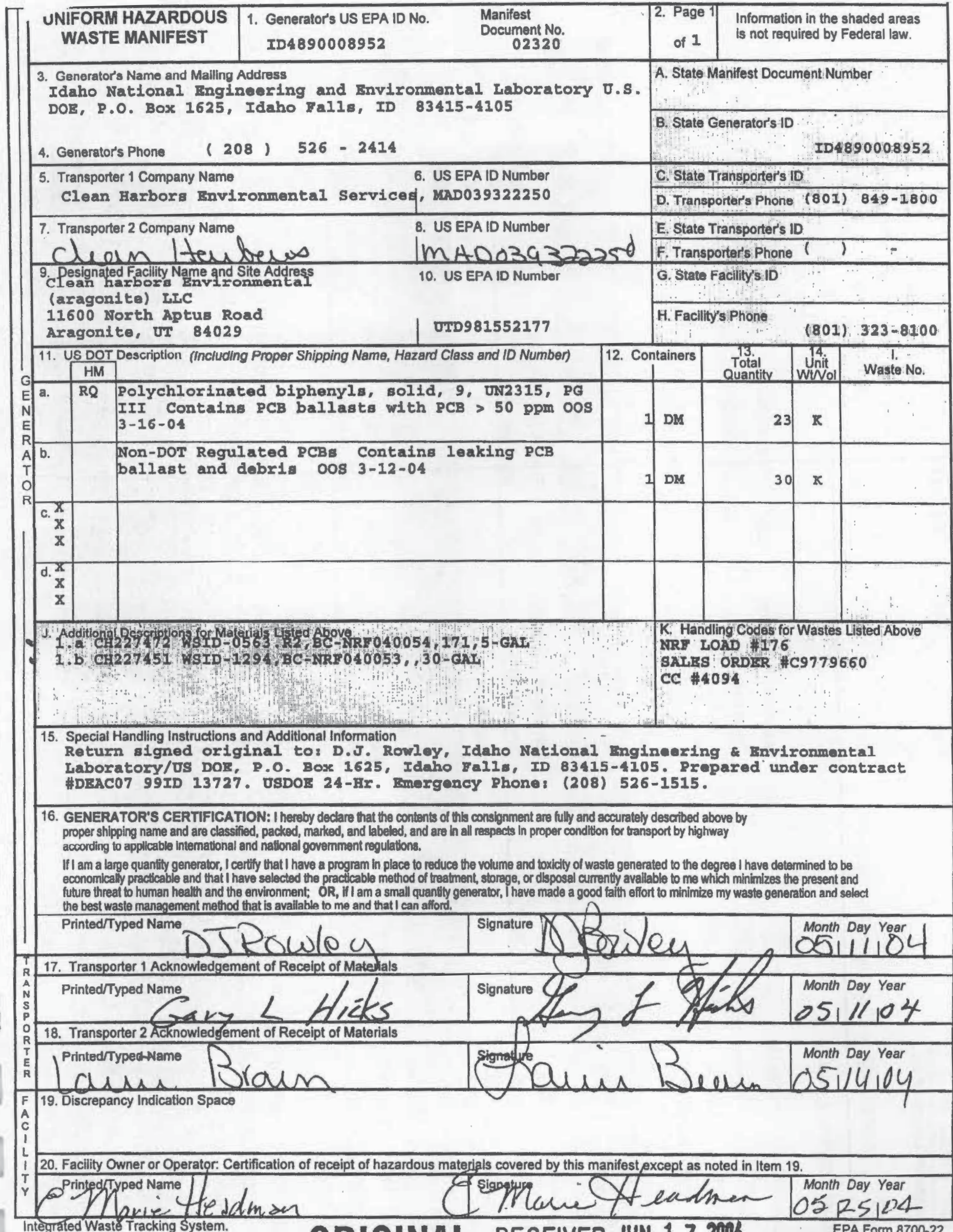




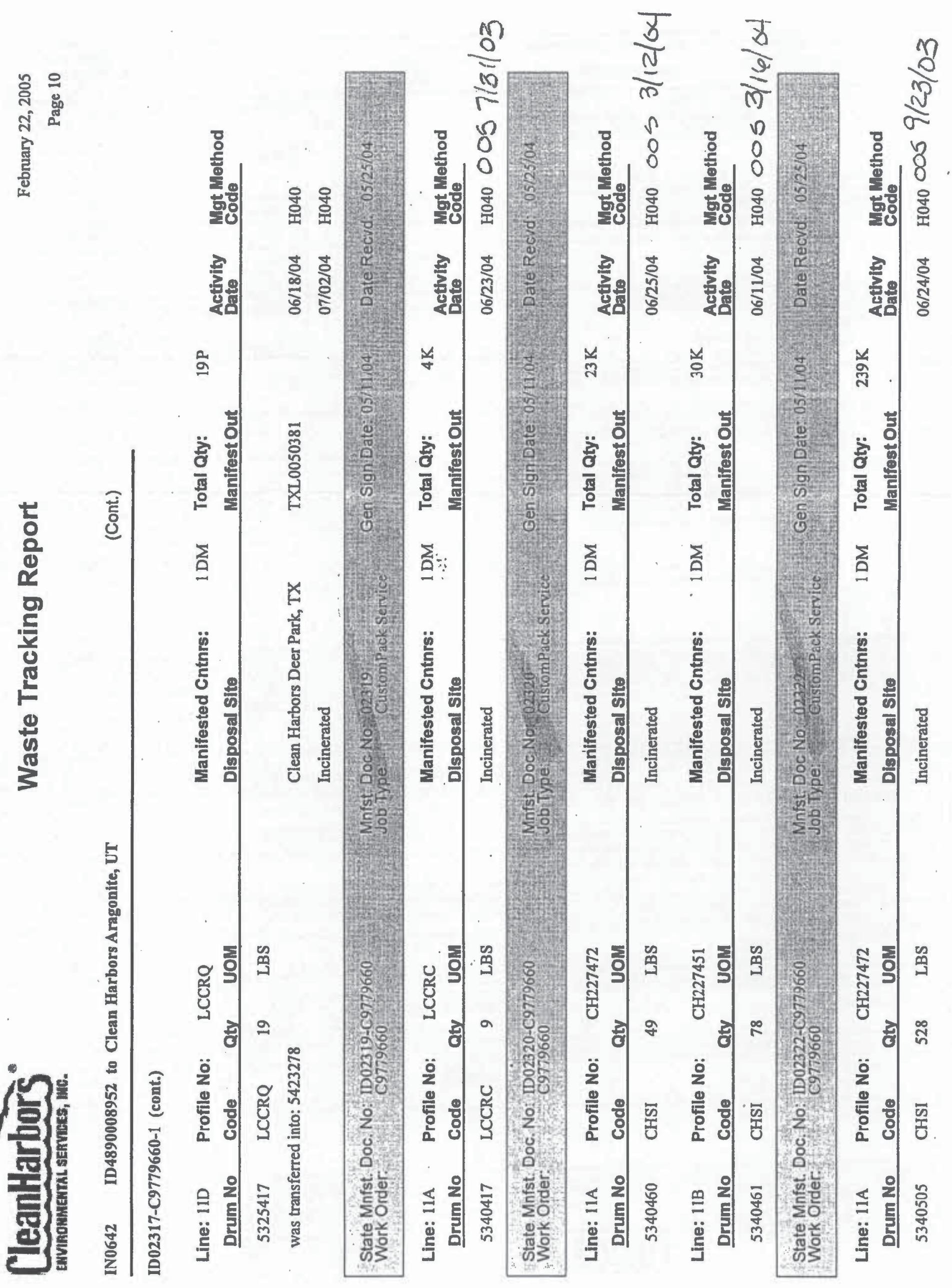



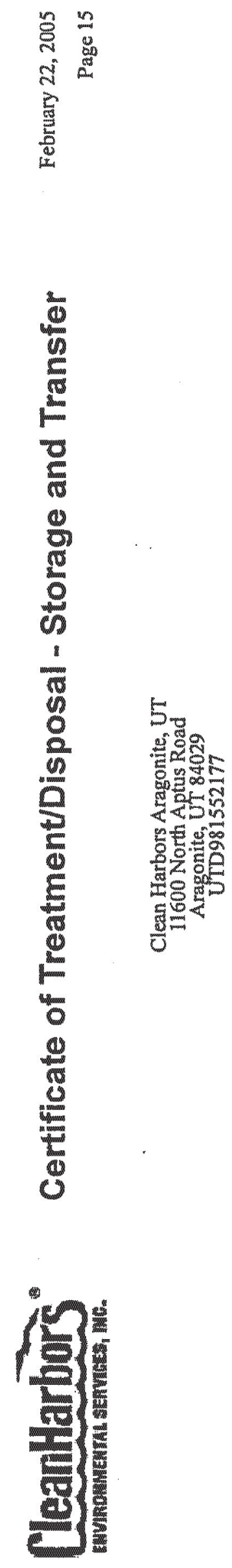
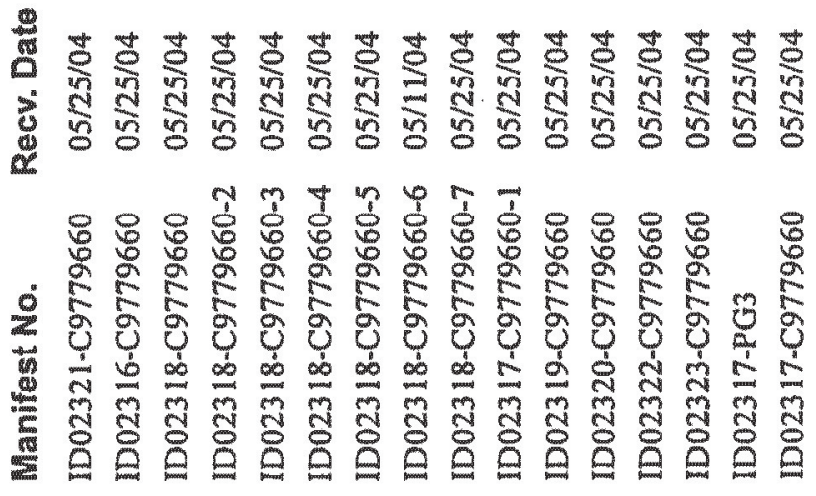

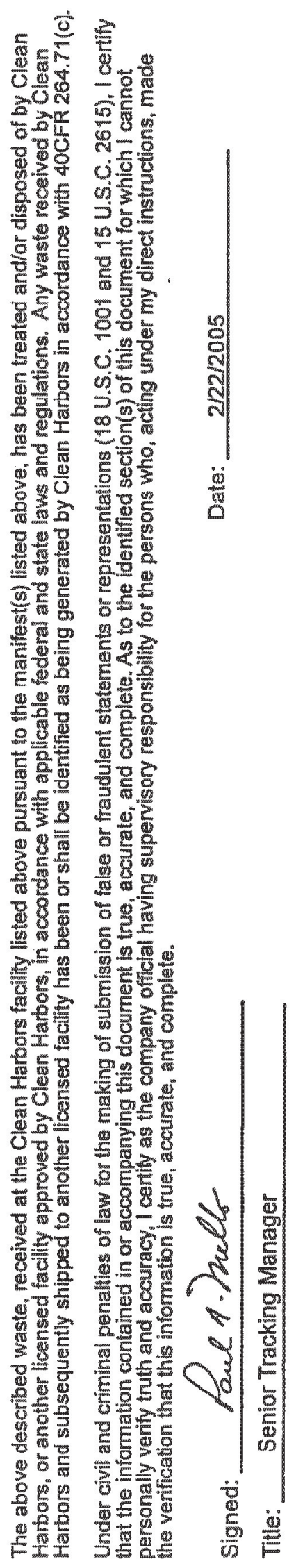





\begin{tabular}{|c|cc|c|c|}
\hline WORM HAZARDOUS & $\begin{array}{c}\text { 1. Ganerators US EPA ID No. } \\
\text { IDASTE MANIFEST }\end{array} 890008952$ & $\begin{array}{c}\text { Manifest } \\
\text { Document No. } \\
02322\end{array}$ & $\begin{array}{c}\text { 2. Page } \\
\text { of } 1\end{array}$ & $\begin{array}{l}\text { Information in the shaded areas } \\
\text { is not required by federal law. }\end{array}$ \\
\hline
\end{tabular}

3. Generator's Name and Maling Address

Idaho National Ingineering and Enviromental Laboratory U.S.

DOE, P.O. BOX 1625, Idaho Fal1s, ID 83415-4105

A. State Manifest Document Number

4. Generator's Phone (208) $526-2414$
5. Transperter 1 Company Name
6. US EPA ID Number

Clean Harbor Environmental Serviced, MAD039322250

7. Transporter 2 Company Name

8. US EPA ID Number

9. Pesignated Facility Name and Site Address

1

10. US EPA ID Number

(aragonite) LLC

11600 North Aptus Road

Aragonite, UT 84029

UTD981552177

B. State Cenerator's ID

$+$

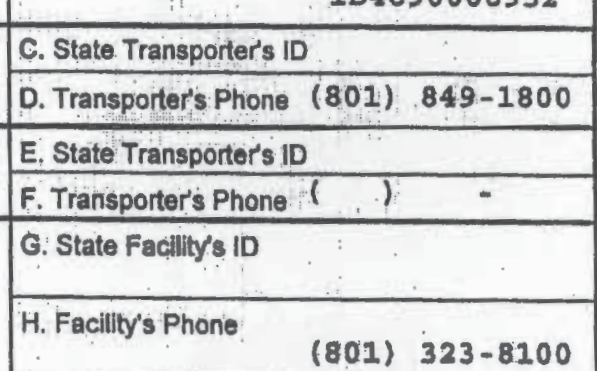

11. US DOT Description (Including Proper Shipping Name, Hazard Class and ID Number) \begin{tabular}{l|l|l|l} 
& HM & \\
E a. & Non-DOT Regulated PCBa $>500$ PPM PCB Capacitors,
\end{tabular} \begin{tabular}{l|l} 
E. & Non-DOT Regulated PCBa $>500$ PPM PCB Capacitors, \\
Los Date $9 / 23 / 03$ & \\
\hline
\end{tabular} A b. Non-DOT Regulated PCBs PCB Debris, Dos Date A $10 . \quad 3 / 24 / 04$

C. Non-DOT Regulated PCBa PCB Debria, 91 PRM, OOS c. $\quad \begin{aligned} & \text { Non-DOT Regulated PCB PCB Debria, } 91 \text { PRM, OOS } \\ & \text { Date } 3 / 31 / 04\end{aligned}$

d. Non-DOT Regulated PCBa 91 PPM PCB Debria, 003

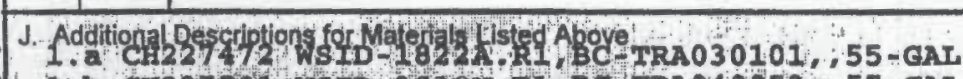

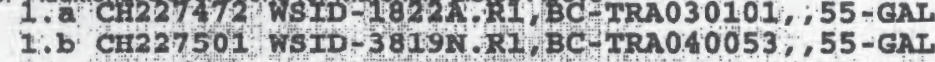

1.C CH2 27501; WSID-3819K.R1, BC-TRA040064, 55-GAL

1.d CH222501 WSID-3819N.RI,BC-TRA040070, $55-$ GAI

\begin{tabular}{|c|c|c|c|c|}
\hline 12. Con & tainers & $\begin{array}{c}\text { Total } \\
\text { Quantity } \\
\end{array}$ & $\begin{array}{c}\text { Unit } \\
\text { Wuivol } \\
\end{array}$ & Waste No. \\
\hline 1 & DM & 239 & $\mathbf{K}$ & \\
\hline 1 & DM & 68 & $\mathbf{K}$ & \\
\hline 1 & DM & 67 & $\mathbf{K}$ & \\
\hline 1 & DM & 66 & $\mathbf{K}$ & \\
\hline$\therefore$ & $\begin{array}{l}\text { K. Ha } \\
\text { Tra } \\
\text { gALI } \\
\text { CC }\end{array}$ & $\begin{array}{l}\text { ng Codes for } \\
\text { AD \#175 } \\
\text { ORDER } \\
9.4\end{array}$ & laste & sted Above. \\
\hline
\end{tabular}

15. Special Handling Instructions and Additional Information

Return signed original to: D.J. Rowley, Idaho National Inglneoring \& Invironmental

Iaboratory/US DOE, P.0. Box 1625, Idaho Falle, ID 83415-4105. Prepared under contract

HDEAC07 99ID 13727. USDOE 24-HI. Bmergency Phone: (208) 526-1515.

16. GENERATOR'S CERTIFICATION: I hereby declare that the contents of this consignment are fully and accurately described above by proper shipping name and are classlifed, packed, marked, and labeled, and are hi all respects in proper condition for transport by highway according to applicable intemational and national government regulations.

If I am a large quantity generalor, I certify that I have a program in place to reduce the volume and toxiclly of waste generated to the degree I have determined to be economicaly practicable and that i have selected the practicable melhod of treatment, storage, or disposal currently avaliable to me which minimizes the present and huture threat so human haalth and the environment, $O R$, if I am a small quantity generator, I have made a good faith effort to minimize my waste generation and select the best waste management method that is avallabie to me and that I can afford.

Printed/Typed Name DJ Rowlen

17. Transporter 1 Acknowiedgement of Receipt of Majerials

Prinled/Typed Nage
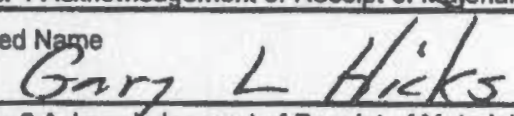

18. Transporter 2 Acknowledgement of Receipt of Materials

Printed/Typed.Name

9. Discrepancy Indication Space
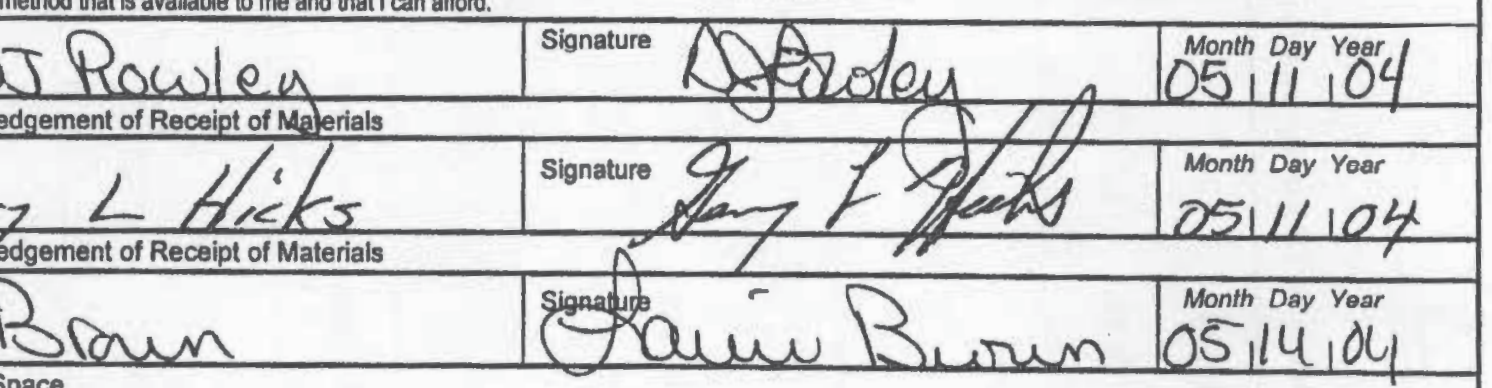

i

20. Facility Owner or Operator fertification of receipl of hazardous materials covered by this manifest except as noted in ltem 19.

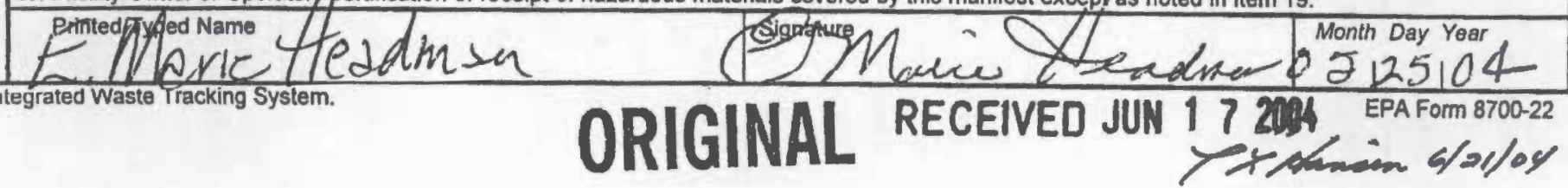




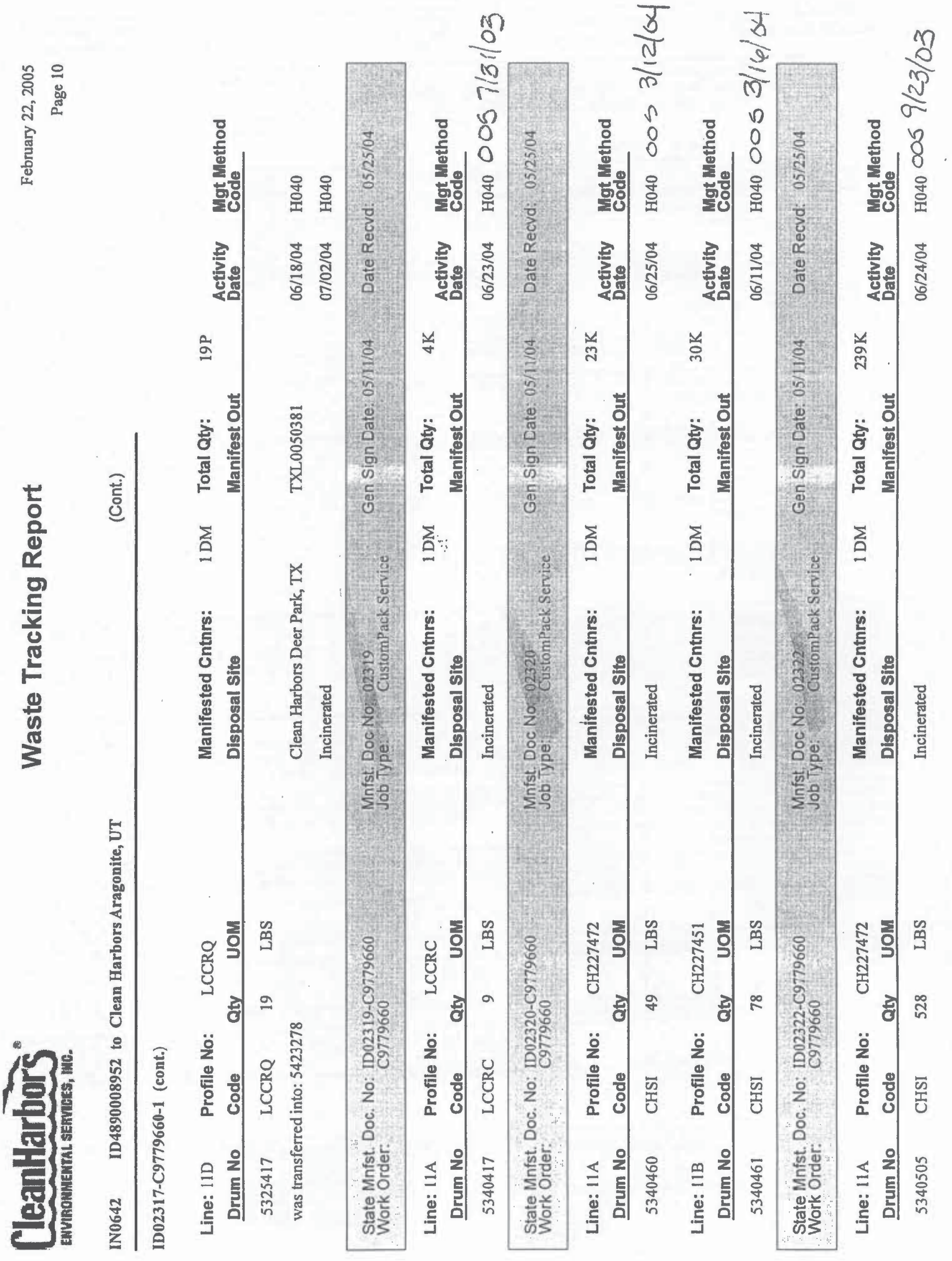



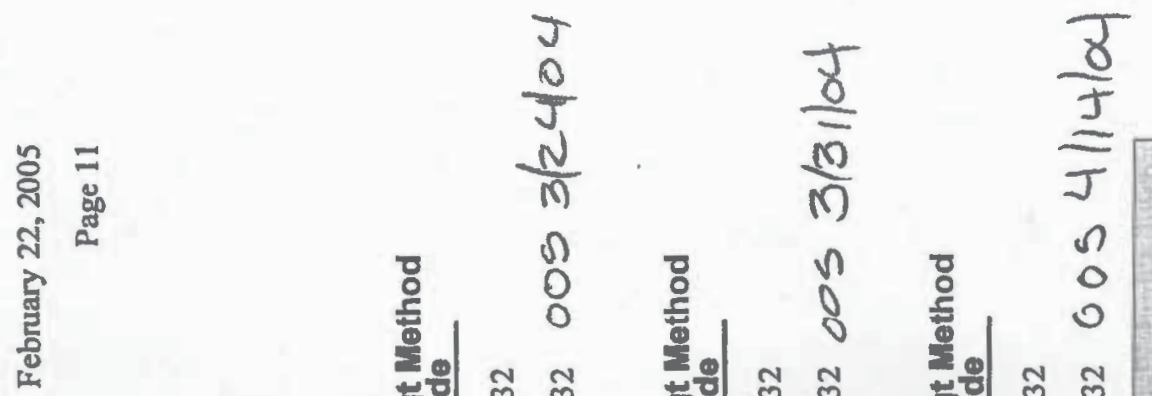

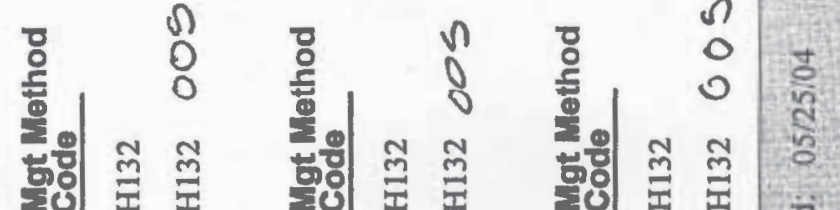

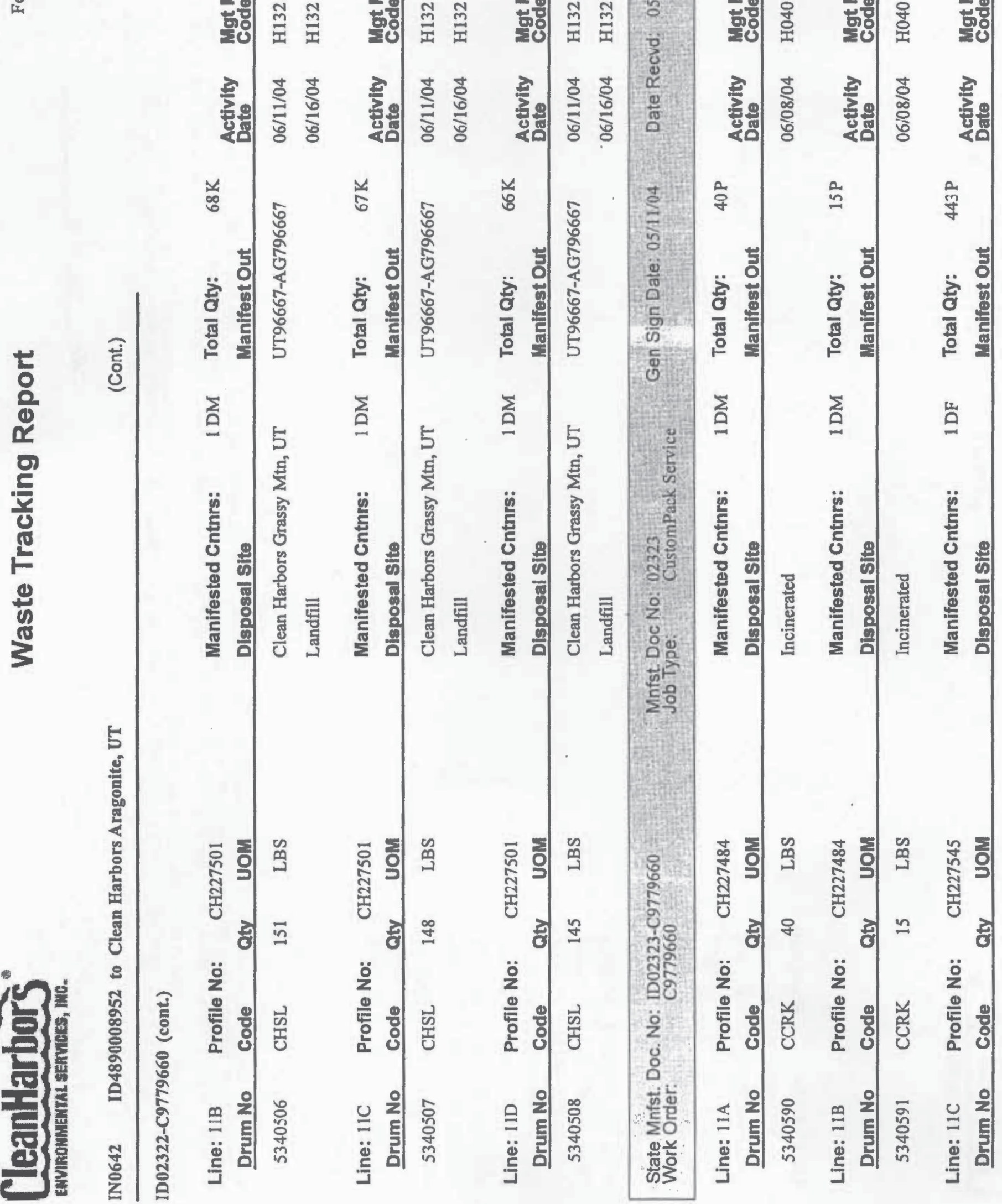



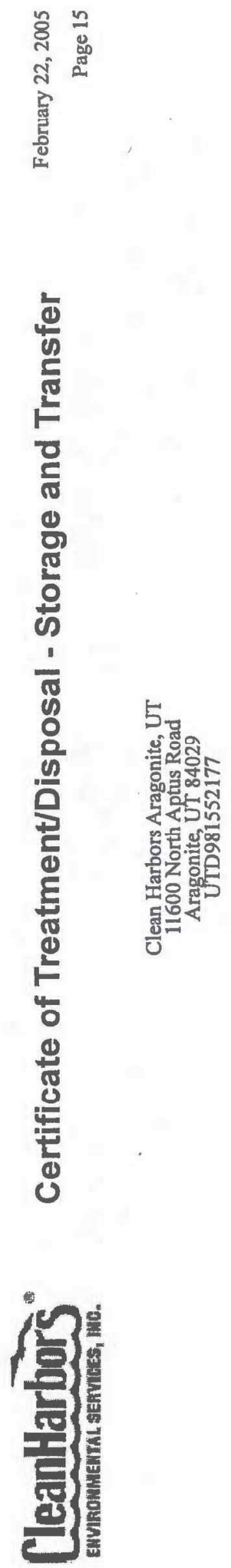
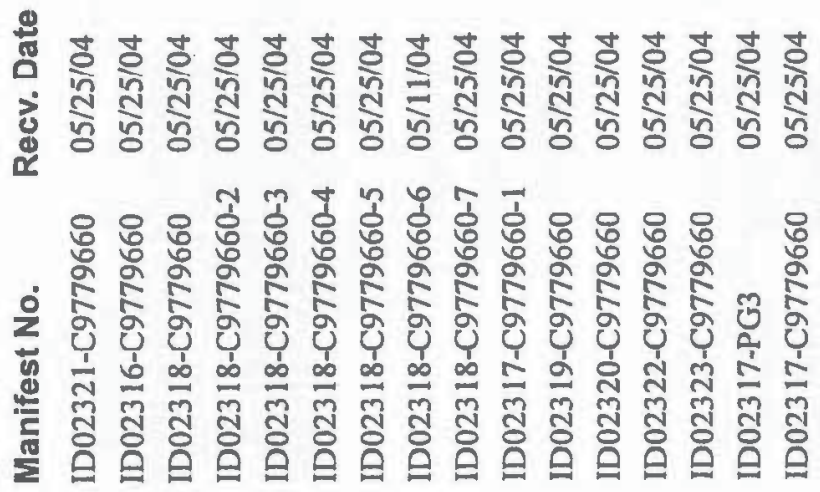

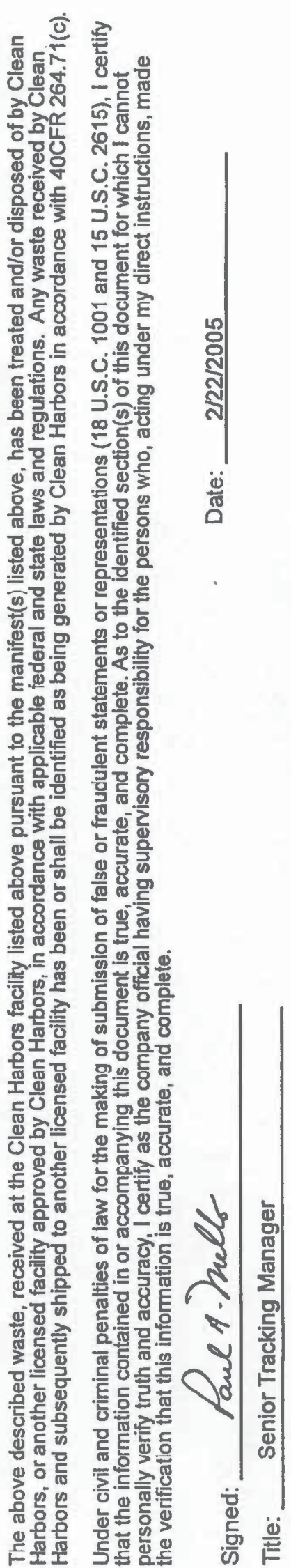





\begin{tabular}{|c|c|c|c|c|}
\hline $\begin{array}{c}\text { UNIFORM HAZARDOUS } \\
\text { WASTE MANIFEST }\end{array}$ & $\begin{array}{c}\text { 1. Generators US EPA ID No. } \\
\text { ID4890008952 }\end{array}$ & $\begin{array}{c}\text { Manifest } \\
\text { Document No. } \\
02324\end{array}$ & $\begin{array}{c}\text { 2. Page 1 } \\
\text { of } 3\end{array}$ & $\begin{array}{c}\text { Information in the shaded areas } \\
\text { is not required by Federal law. }\end{array}$
\end{tabular}

3. Generator's Name and Mailing Address
Idaho National Eng ineering and Environmental Laboratory U.s.
DOE, P.O. BOx 1625, Idaho Falls, ID 83415-4105

A. State Manifost Documont Number

B. State Generator s 10

4. Generator's Phone (208) $526-2414$

5. Transporter 1 Company Name
Iri-State Motor Transit

\begin{tabular}{|ll}
\hline 7. Transporter 2 Company Name & 8. US EPA ID Number
\end{tabular}

9. Designated Facility Name and Site Address
Envirocare of Utah, Inc.

os I-80 Exit 49 Toole County

clive, UT 84029

6. US EPA ID Number $\quad$ C. State Transporters 10

MOR000505347 D. Transpotersiphone (208) 232-3445

$1 D 4890008952$

E state Transpoiter is id.

TThansporters Phohe ( )

G. Stater Facility's 10

UTD 982598898

H. Facilty s Phione

$(801) 532-1330$

11. US DOT Description (Including Proper Shipping Name, Hazand Class and ID Number)

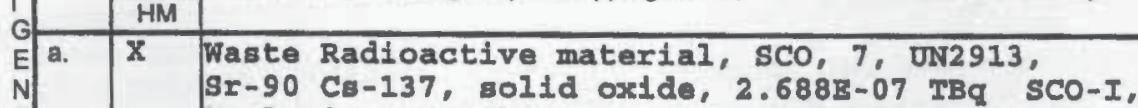
E Exclubive Use shipment, Contains paint with PCBs

A b. $x$

T⿱宀

\begin{tabular}{l|l|l|l}
$\mathrm{T}$ & $\mathbf{x}$ & & \\
$\mathrm{x}$ & & \\
\hline c. & $\mathrm{X}$ & waste Radioactive material, SCO, 7, ov2913,
\end{tabular}

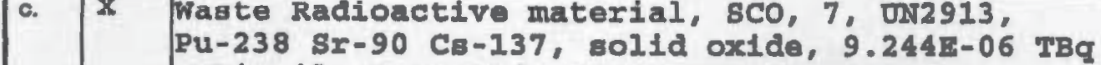

Pu-238 Sr-90 CB-137, solid oxide,

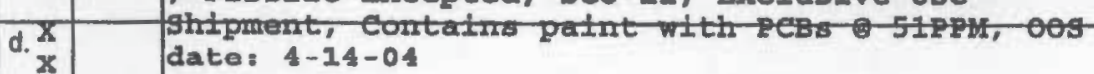

$\mathbf{x}$

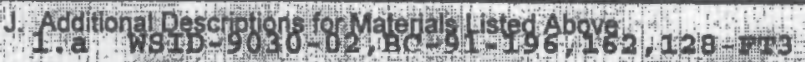

1.c WSID- $000-02, \mathrm{BC}-92-103-\mathrm{A}, 162,126-1 \mathrm{~T}$

(1)

(15

\begin{tabular}{|c|c|c|c|c|}
\hline 12. Cont & ainers & $\begin{array}{c}13 \\
\text { Total } \\
\text { Quantity }\end{array}$ & $\begin{array}{c}14 \\
\text { Unit } \\
\text { witNo }\end{array}$ & Waste No. \\
\hline 1 & CW & 1012 & 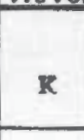 & $\begin{array}{ll}D 004 & D 006 \\
D 007 & D 008 \\
0009 & D 011 \\
\text { Bo01 } & 002\end{array}$ \\
\hline & & & & 7005 U134 \\
\hline 1 & CW & 2007 & $\mathbf{R}$ & 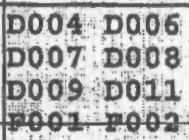 \\
\hline & & & & 7005 0134 \\
\hline
\end{tabular}

K. Handilige Gode for Wastes listed Abovo

TSMP Comp 25903949

(1)

15. Special Handling Instructions and Additional Information

Return Bigned orlginal to: RT Kendrick, INEFL for OsDö, Box 1625 - MS 5227, Idaho Falla,

ID 83415. Prepared under contract: DEAC07 99ID 13727. Emergency phone: 208-526-1515.

Exclustve Use shipment.

PM 00184

16. GENERATOR'S CERTIFICATION: I hereby declare that the contents of this consignment are fully and aceurataly described above by proper shipping name and are claselfied, packed, marked, and tabeled, and are in all respects in proper condition for transport by highway according to applicable intemational and national government regulations.

III am a large quantity generator, I certify that I have a program in place to reduce the volume and toxicly of waste generated to the degree I have determined to be economically practicable and that I have selected the practicable method of treatment storage, or disposal currently available to me which minimizes the present and future threat to human health and the environment, $O R$, 11 I am a small quantity generator, thave madis a good falth efior to minimize my waste generation and seloct the best waste management method that is available to me and that I can afford.
Printed/Typed Name
R. T. Kendrick
Signature RT thative
Month Day Yoar
5111104

17. Transporter 1 Acknowledgement of Receipt of Materials

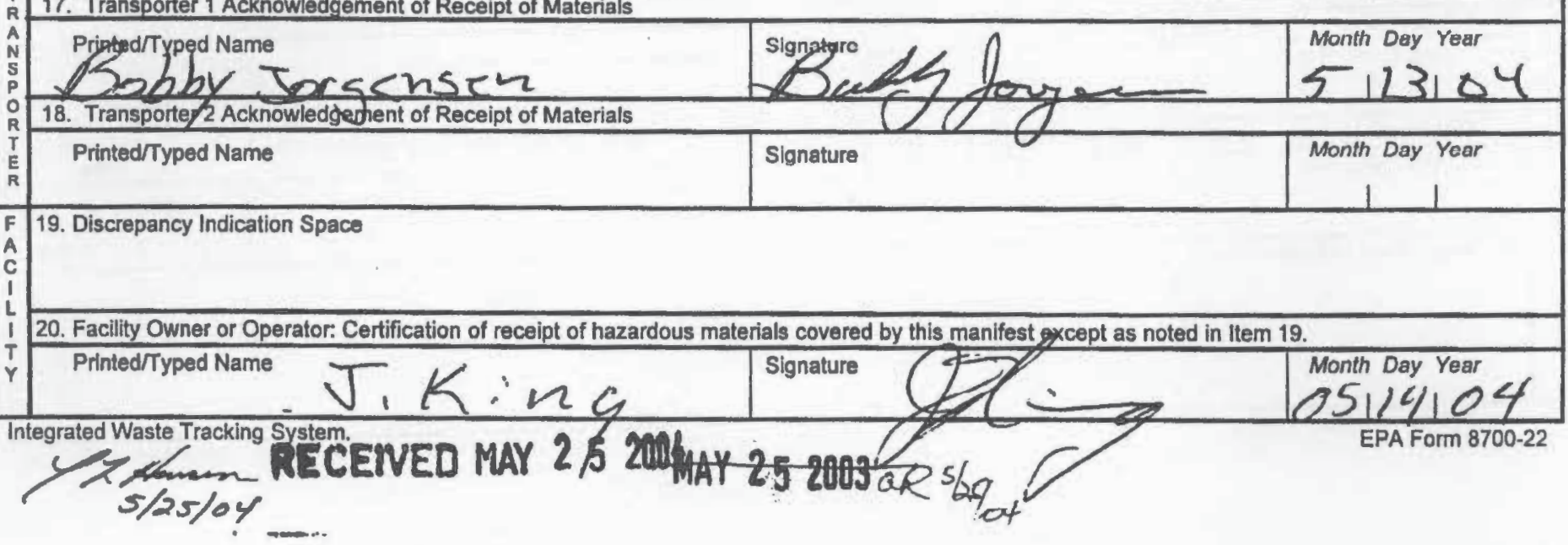




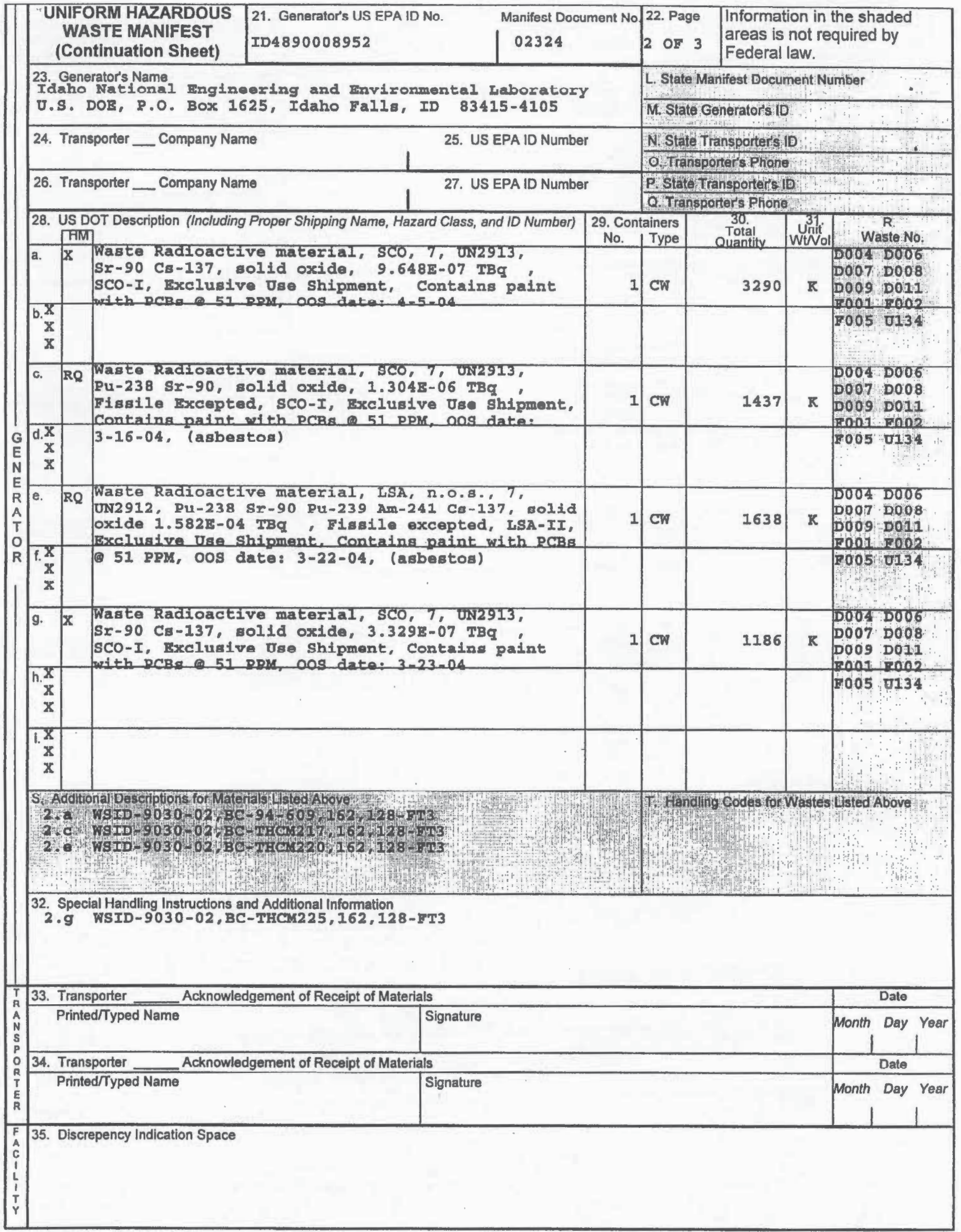




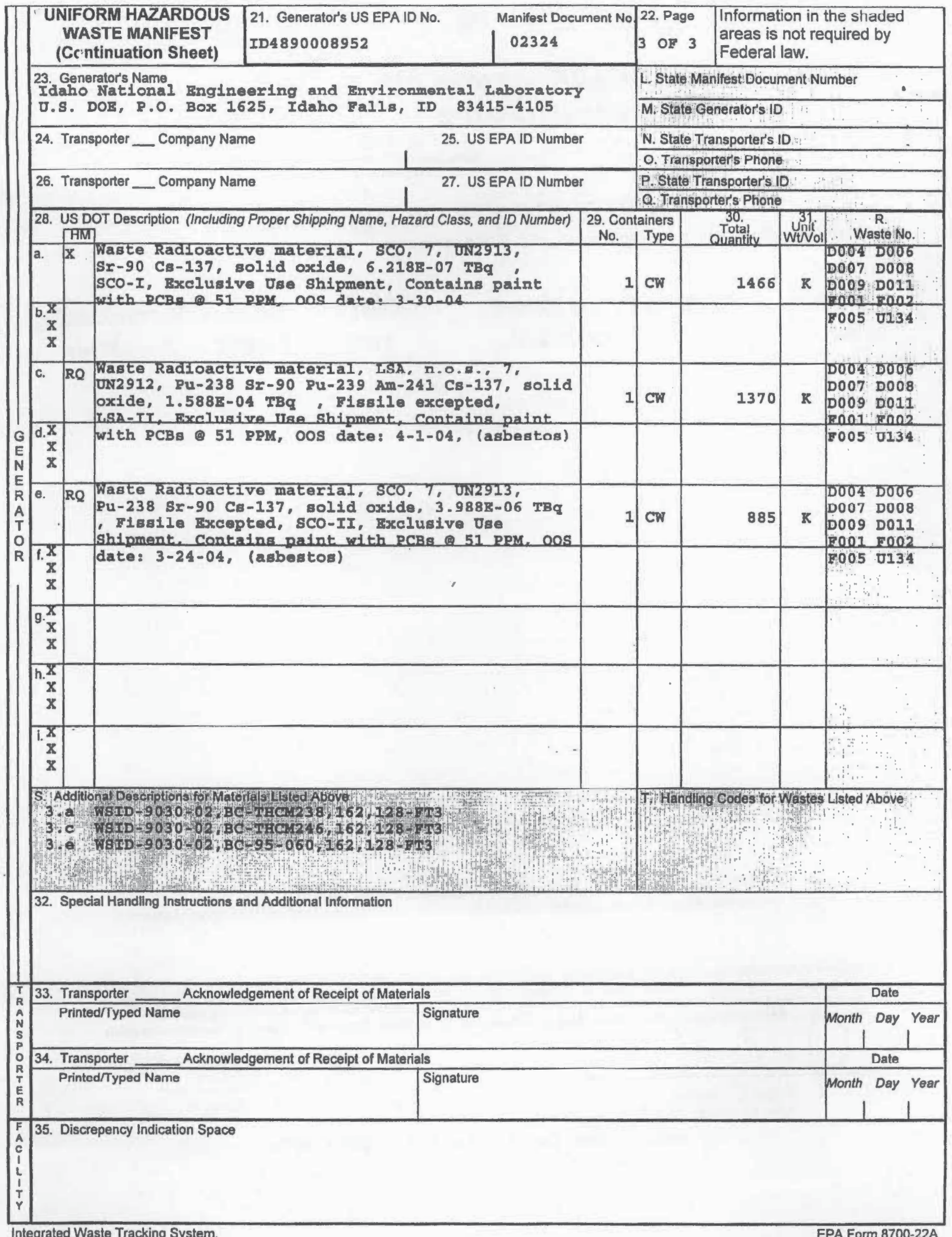




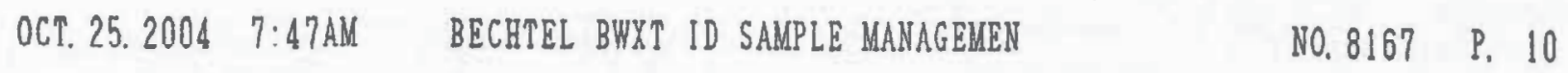

ENVIROCARE OF UTAH, INC.

THE SAFE ALTERNATTVE

3 mi. S. Exh 49, I-80

Clive, Uenh 84029 EPA

ID; UT982598898

\section{CERTIFICATE OF DISPOSAL}

This Certiflcate acknowledges that the following manifested shipments:

\begin{tabular}{|c|c|c|c|c|c|}
\hline Shipment & Manifest & Date(s) of Disposal & $\mathrm{Cu} / \mathrm{St}$ & Processe & Dirposal Location \\
\hline $9030-02-0021$ & 02324 & $8 / 24,27,28,2004$ & 1152 & LandFull & Mired Waste \\
\hline
\end{tabular}

Representing 1152 Cubic foet of waste of at listed Disposal Facility landfil. Disposal is aubjest to Brvirocure'e Radionctive Material Lleense, ell other applieable licensea, permite and regulations, end che Difponal Agrenment.

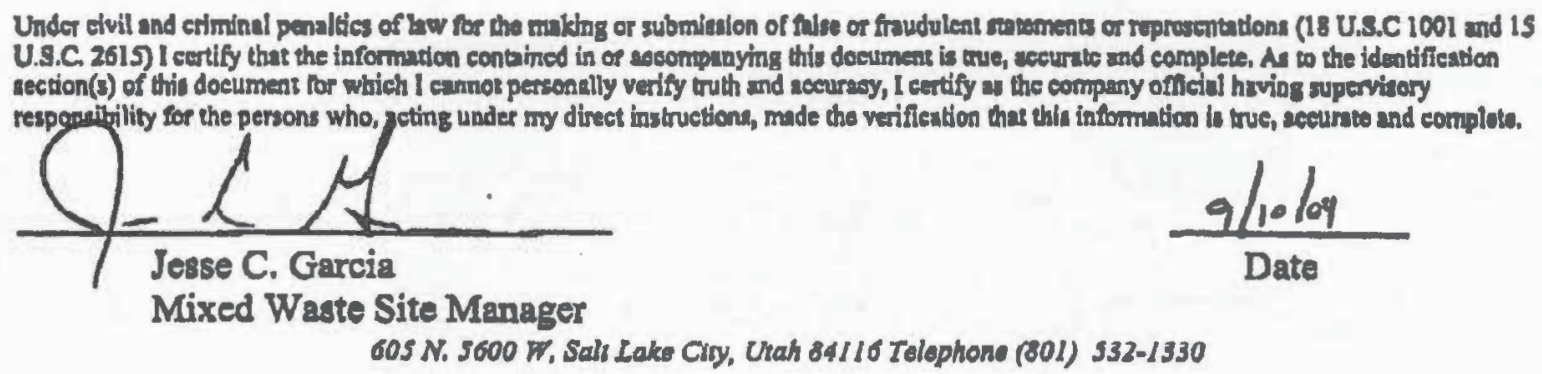





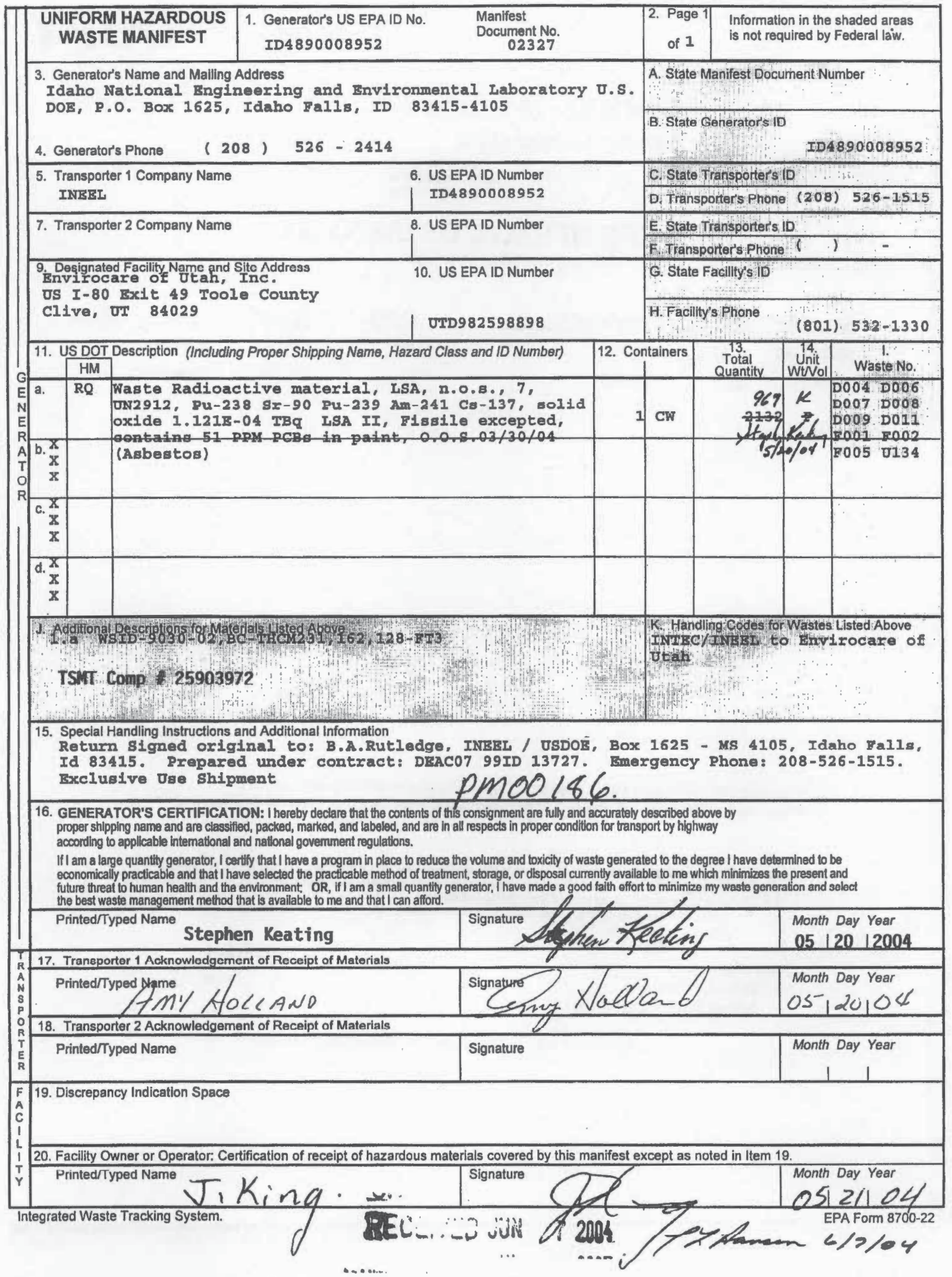


ENVIROCARE OFUTAH, INC.

TERE SAFE ALTERNATTVE

$3 \pi$. S. But, 49, In 30

Citive, Uthen $84029 \mathrm{EPA}$

ID; UT922598898

\section{CERTIFICATE OF DISPOSAL}

This Certticate acknowledges that the following manlfested shlpments:

\begin{tabular}{|c|c|c|c|c|c|}
\hline Shinment & Manifest & Date(s) of Disposal & $\mathrm{Cu} / \mathrm{Ft}$ & Process & Dinposel Location \\
\hline $9030-02-0015$ & 02282 & $09 / 22 / 04$ & 444 & Lanafili & Moxed Wasto \\
\hline $9030-02-0029$ & 02327 & $09 / 29 / 04$ & 128 & Landaill & Mixxed Waste \\
\hline
\end{tabular}

Ropresenting 572 Cubic feot af waste of at listed Disposal Facility landrill. Disporal is subject to

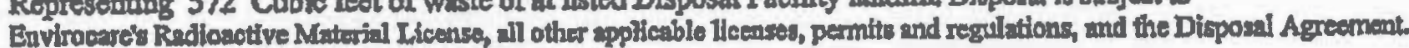

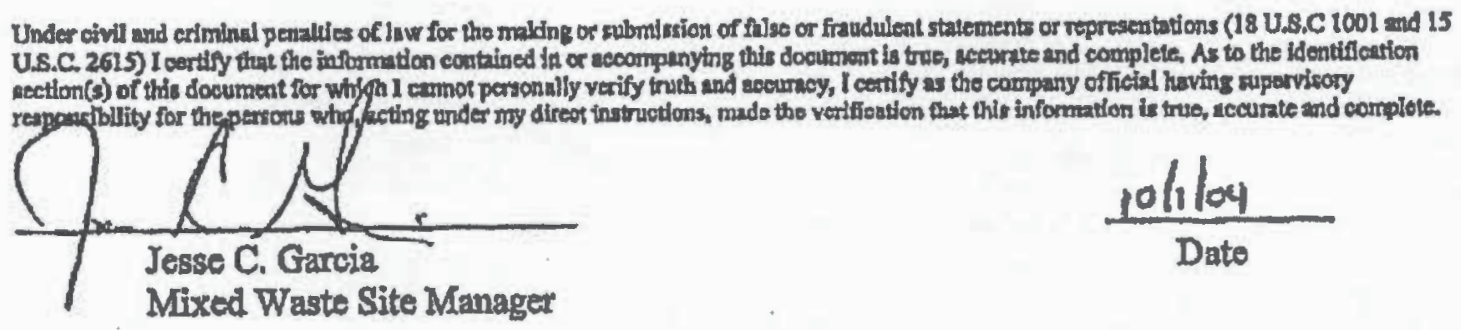

605 N. 5800 W. Sell Lake Cing, Whah 84116 Thlephone (801) 532-1330 



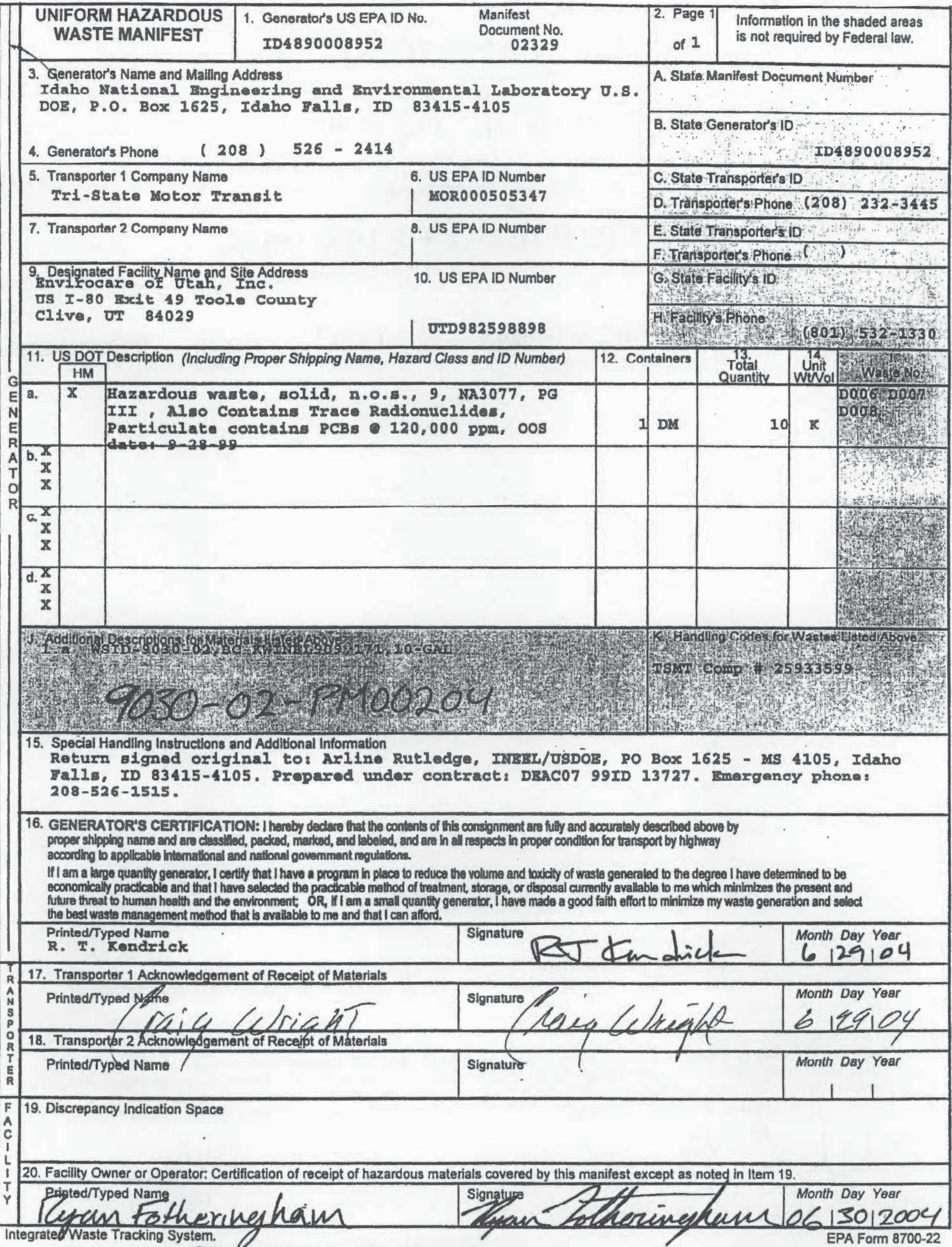

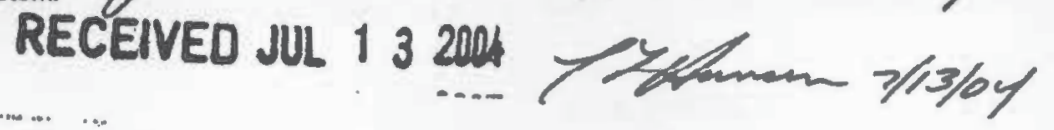




\section{ENVIROCARE}

OF UTAH, INC.

\section{THE SAFE ALTERNATIVE}

$3 \mathrm{ml}$. S. Ext. $49,1-80$

Clive, Utah 84029 EPA

ID: UT982598898

\section{CERTIFICATE OF DISPOSAL}

This Certificate acknowledges that the following manifested shipments:

\section{Shipment}

9030-02-0022

\section{Manifest 02329}

\section{$\mathrm{Cu} / \mathrm{Ft}$}

1.34
Process

Landfill

\section{Disposal Location} Mixed Waste

Representing 1.34 Cubic feet of waste of at listed Disposal Facility landfill. Disposal is subject to Envirocare's Radioactive Material License, all other applicable licenses, permits and regulations, and the Disposal Agreement.

Under civil and criminal penalties of law for the making or submission of false or fraudulent statements or representations (18 U.S.C 1001 and 15 U.S.C. 2615) I certify that the information contained in or accompanying this document is true, accurate and complete. As to the identification section(s) of this document for which I cannot personally verify truth and accuracy, I certify as the company official having supervisory responsibility for the persons who, adting under my direct instructions, made the verification that this information is true, accurate and complete.

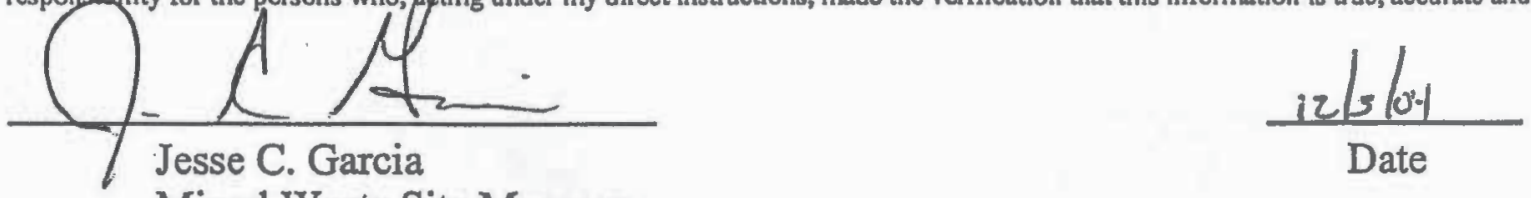





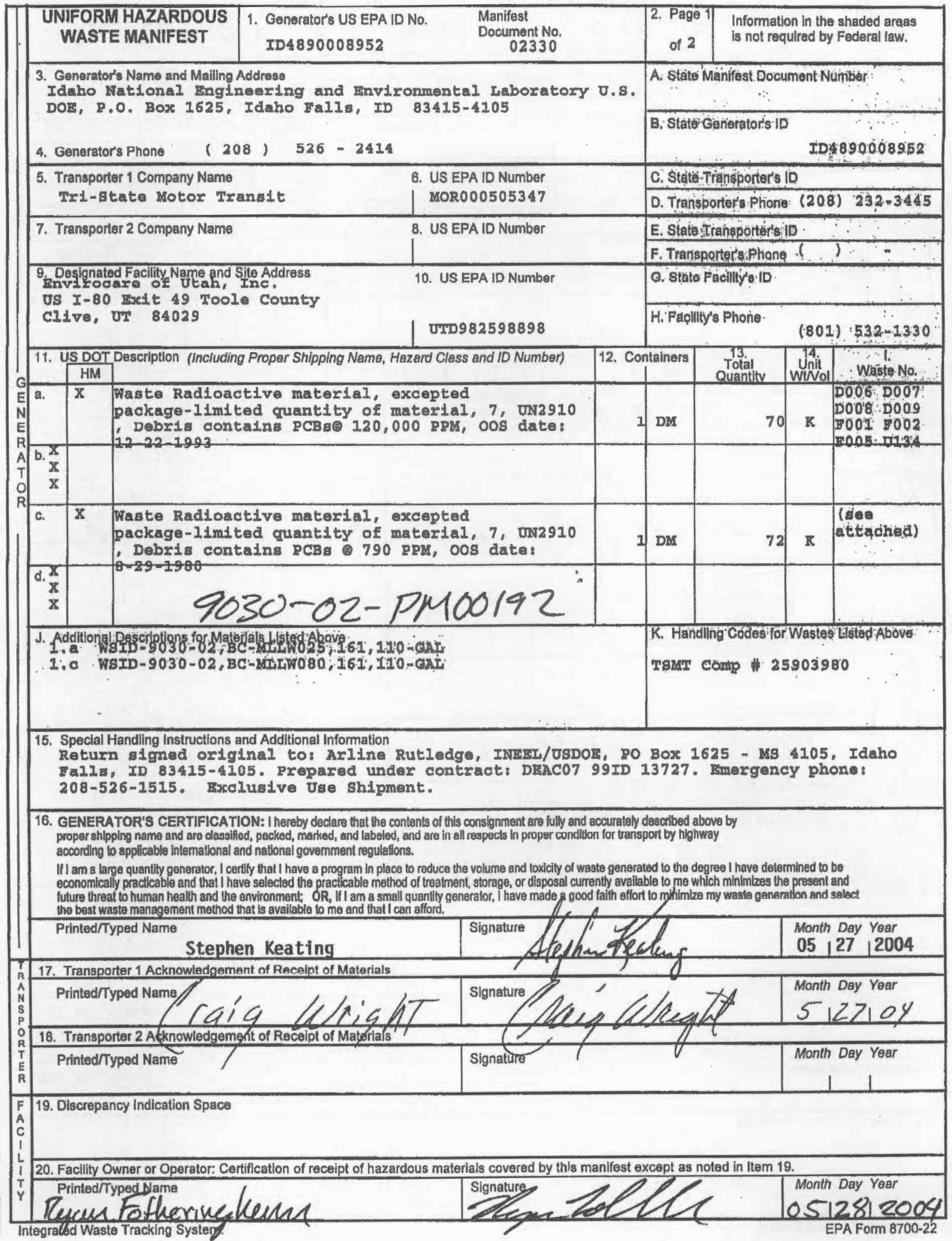




\begin{tabular}{|c|c|c|c|c|c|c|c|c|}
\hline \multicolumn{3}{|c|}{$\begin{array}{l}\text { UNIFORM HAZARDOUS } \\
\text { WASTE MANIFEST } \\
\text { (Continuation Sheot) }\end{array}$} & \multicolumn{2}{|l|}{$\begin{array}{l}\text { 21. Generator's US EPA ID No. } \\
\text { ID4890000852 }\end{array}$} & $\begin{array}{ll}\text { 22. Page } \\
2 \text { OI } 2\end{array}$ & \multicolumn{3}{|c|}{$\begin{array}{l}\text { Information in the shaded } \\
\text { areas is not required by } \\
\text { Federal law. }\end{array}$} \\
\hline & \multirow{2}{*}{\multicolumn{4}{|c|}{$\begin{array}{l}\text { 23. Generators Name } \\
\text { Idaho National Engineering and Environmental Laboratory } \\
\text { U.S. DOE, P.O. Box 1625, Idaho Falls, ID } 83415-4105\end{array}$}} & \multicolumn{4}{|c|}{ L. State Manlfost Document Number } \\
\hline & & & & & \multicolumn{4}{|c|}{ M. Stata Genarator's ID } \\
\hline \multirow{2}{*}{\multicolumn{5}{|c|}{ 24. Transporter__ Company Name }} & \multicolumn{4}{|c|}{ N. State Transporter's ID } \\
\hline & & & & & \multicolumn{4}{|c|}{ O. Transporter's Phone } \\
\hline \multirow{2}{*}{\multicolumn{5}{|c|}{ 26. Transporter__ Company Name }} & \multirow{2}{*}{\multicolumn{4}{|c|}{ P. State Transperter's ID }} \\
\hline & & & & & & & \multicolumn{2}{|c|}{$\begin{array}{l}\text { Q. Transporter's Phone } \\
30\end{array}$} \\
\hline \multicolumn{4}{|c|}{$\begin{array}{l}\text { 28. US DOT Descrlption (Including Propor Shipping Name, Hazard Class, and ID Number) } \\
\text { HMM }\end{array}$} & \begin{tabular}{|c|}
$\begin{array}{r}29 . \text { Cont } \\
\text { No. }\end{array}$ \\
\end{tabular} & \begin{tabular}{|l|} 
tainers \\
Type \\
\end{tabular} & $\begin{array}{l}30 . \\
\text { Tolal } \\
\text { Quvantly }\end{array}$ & $\begin{array}{l}3 \text { 3nit } \\
\text { Wivol }\end{array}$ & $\begin{array}{c}\text { R. } \\
\text { Wasto No. }\end{array}$ \\
\hline & & 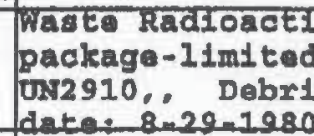 & 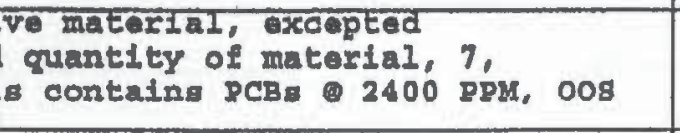 & ting & DM & Quantity & pouvon & (abeo \\
\hline & {$\left[\begin{array}{l}x \cdot \frac{x}{x} \\
x\end{array}\right]$} & & & & & & & \\
\hline & c. & 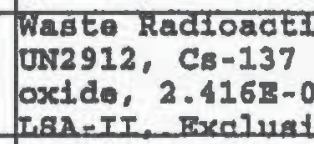 & 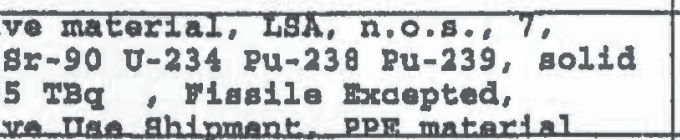 & 1 & DM & 20 & $\mathrm{~K}$ & $\because$ \\
\hline E & $\begin{array}{c}\mathrm{d} . \mathrm{x} \\
\mathrm{x} \\
\mathrm{x}\end{array}$ & contains PCBs & 60 PPK, oOS date: 1-17-2001 & & & & & \\
\hline & $\begin{array}{r}0 . \frac{x}{x} \\
x\end{array}$ & & & & & & & \\
\hline R & $\begin{array}{r}\mathbf{x} \\
\mathbf{x} \\
\mathbf{x}\end{array}$ & & & & & & & \\
\hline & $9 \cdot \frac{x}{x}$ & & & & & & & \\
\hline & $\begin{array}{r}\mathrm{x} \cdot \mathrm{x} \\
\mathrm{x} \\
\mathrm{x}\end{array}$ & & & & & & & on \\
\hline & $\begin{array}{r}1 . x \\
x \\
x\end{array}$ & & t & & & & & \\
\hline & sidid & 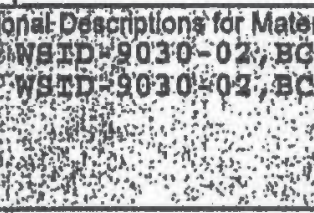 & 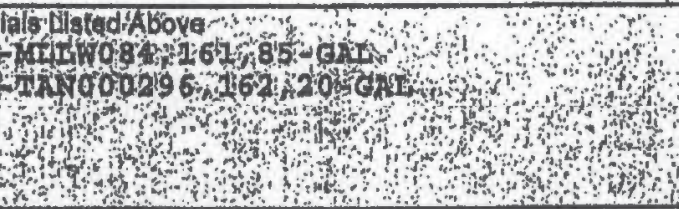 & 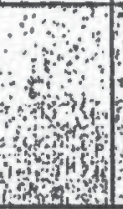 & Thtaho & 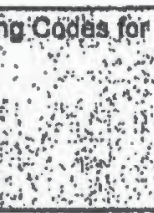 & wastes & 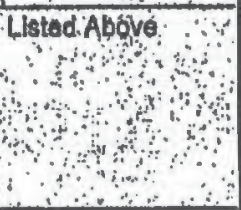 \\
\hline & 32. $\mathrm{s}$ & cial Handling Instructions a & nd Additional Information & & & & & \\
\hline \multicolumn{8}{|c|}{ 33. Transporter _ Acknowledgement of Receipt of Materials } & Date \\
\hline & & ed/Typed Name & Signature & & & & & Month Day Year \\
\hline : & \multicolumn{7}{|c|}{ 34. Transporter __ Acknowledgement of Recelpt of Materials } & Date \\
\hline & & edityped Name & Slgnature & & & & & Month Day Year \\
\hline $\bar{F}$ & 35. 0 & repency Indleation Space & & & & & & \\
\hline
\end{tabular}




\section{ENVIROCARE}

OF UTAH, INC.

THE SAFE ALTERNATIVE

3 mi. S. Exh. $49,1.80$

Glive, Utah $84029 \mathrm{EPA}$

ID: UT982598898

\section{CERTIFICATE OF DISPOSAL}

This Certificate acknowledges that the following manifested shipments:

$\frac{\text { Shipment }}{0030-02-0023} \quad \frac{\text { Manifest }}{02330} \quad \frac{\text { Date(s) of Disposal }}{11 / 28 / 2004} \quad \frac{\text { Cu/ft }}{43.45} \quad \frac{\text { Process }}{\text { Landfill }} \quad \frac{\text { Disposal Location }}{\text { Mixed Waste }}$

Representing 43.45 Cubic feet of waste of at listed Disposal Facility landfull. Disposal is subject to Envirocare's Radiozctive Material License, all other applicable licenses, permits and regulations, and the Disposal Agreement.

Under civil and criminal penalties of law for the making or subnission of false or fraudulent statements or representations (18 U.S.C 1001 and 15 U.S.C. 2615) I certify that the inforration contained in or accompanying this document is true, accurate and complete. As to the identification section(s) of this document for which I cannot personally verify truth and accuracy, I certify as the company official having supervisory responsibility for the persons ho, acting under my direct instructions, made the verification that this information is true, accurate and complete.
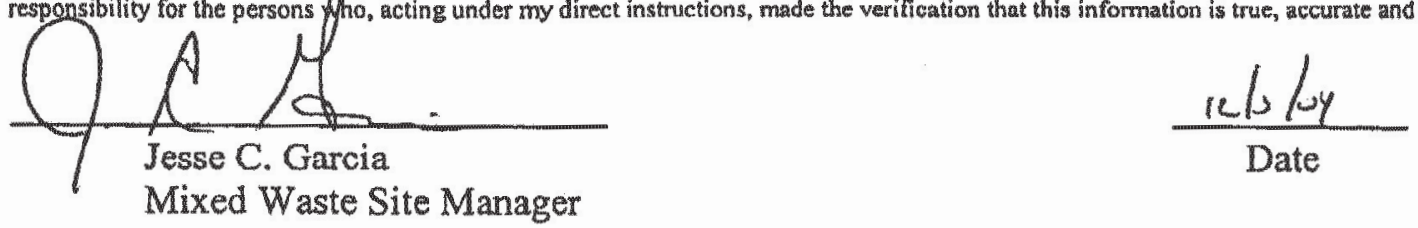

605 N. 5600 W, Salt Lake City, Utah 841/6 Telephone (801) 332-1330 



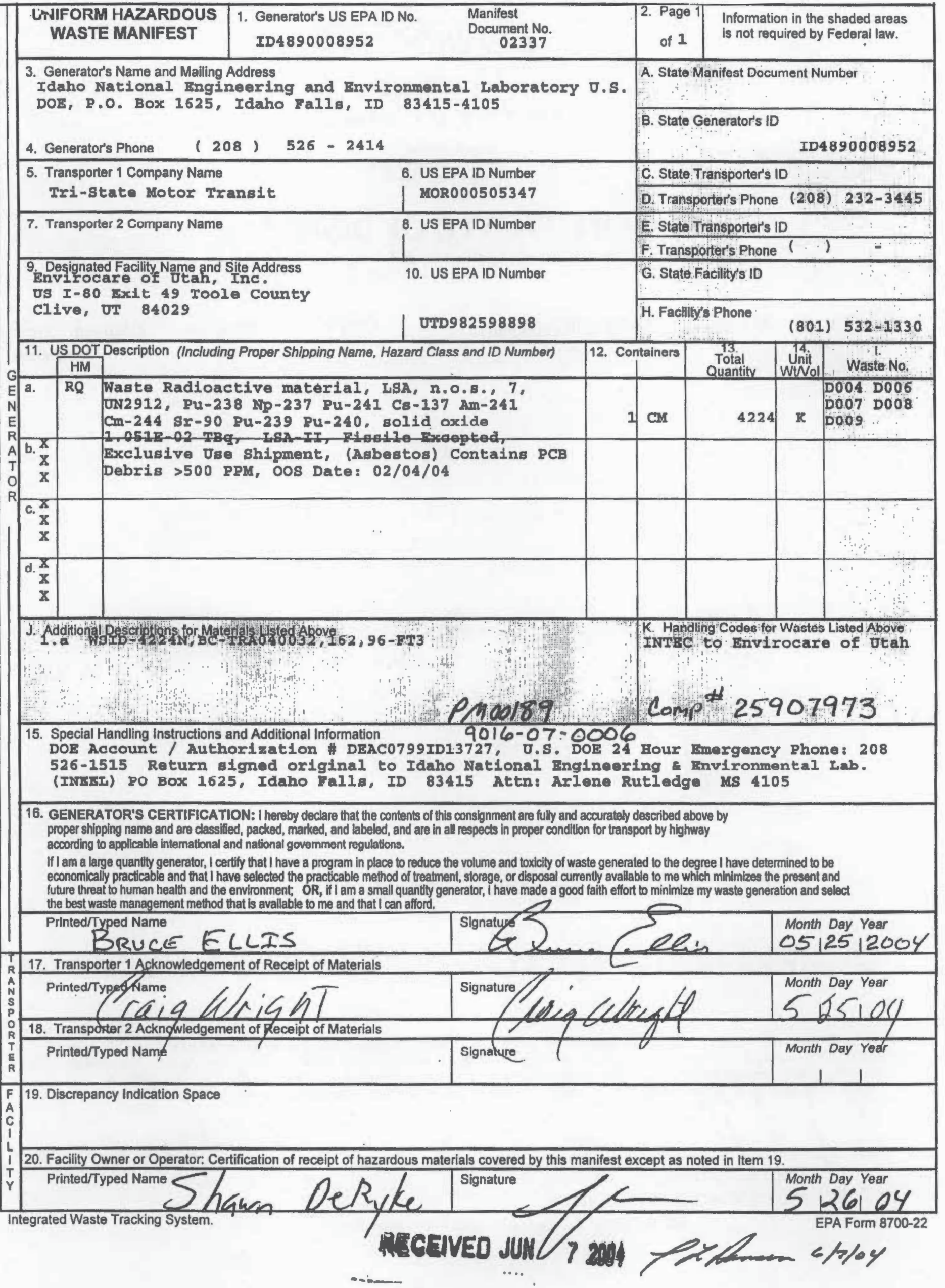




\section{ENVIROCARE}

OF UTAH, INC.

\section{THE SAFE ALTERNATIVE}

3 mi. S. Ext. $49,1-80$

Clive, Utah 84029 EPA

ID: UT982598898

\section{CERTIFICATE OF DISPOSAL}

This Certificate acknowledges that the following manifested shipments:

$\frac{\text { Shipment }}{9016-07-0006} \quad \frac{\text { Manifest }}{02337} \quad \frac{\text { Date(s) of Disposal }}{11 / 24 / 2004} \quad \frac{\text { Cu/Ft }}{96} \quad \frac{\text { Process }}{\text { Landfill }} \quad \frac{\text { Disposal Location }}{\text { Mixed Waste }}$

Representing 96 Cubic feet of waste of at listed Disposal Facility landfill. Disposal is subject to Envirocare's Radioactive Material License, all other applicable licenses, pernaits and regulations, and the Disposal Agreement.

Under civil and criminal penalties of law for the making or submission of false or fraudulent statements or representations (18 U.S.C 1001 and 15 U.S.C. 2615) I certify that the information contained in or accompanying this document is true, accurate and complete. As to the identification section(s) of this document for which I cannot personally verify truth and accurncy, I certify as the company official having supervisory responsibility for the persons who, acting under my direct instructions, made the verification that this information is true, accurate and cornplete.

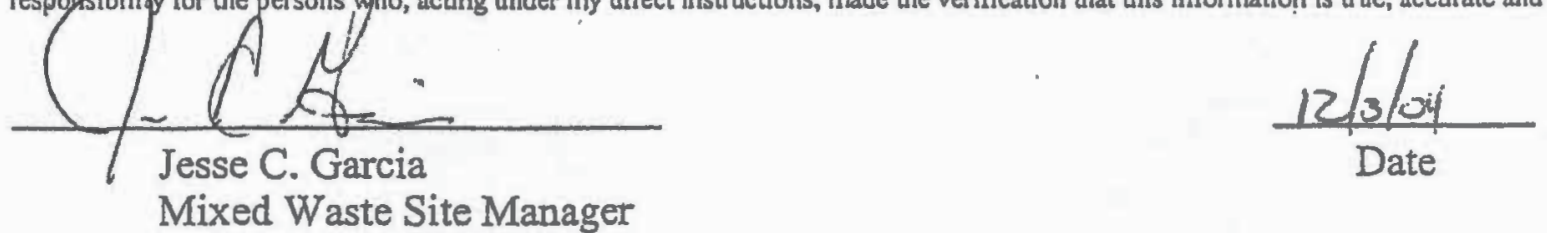





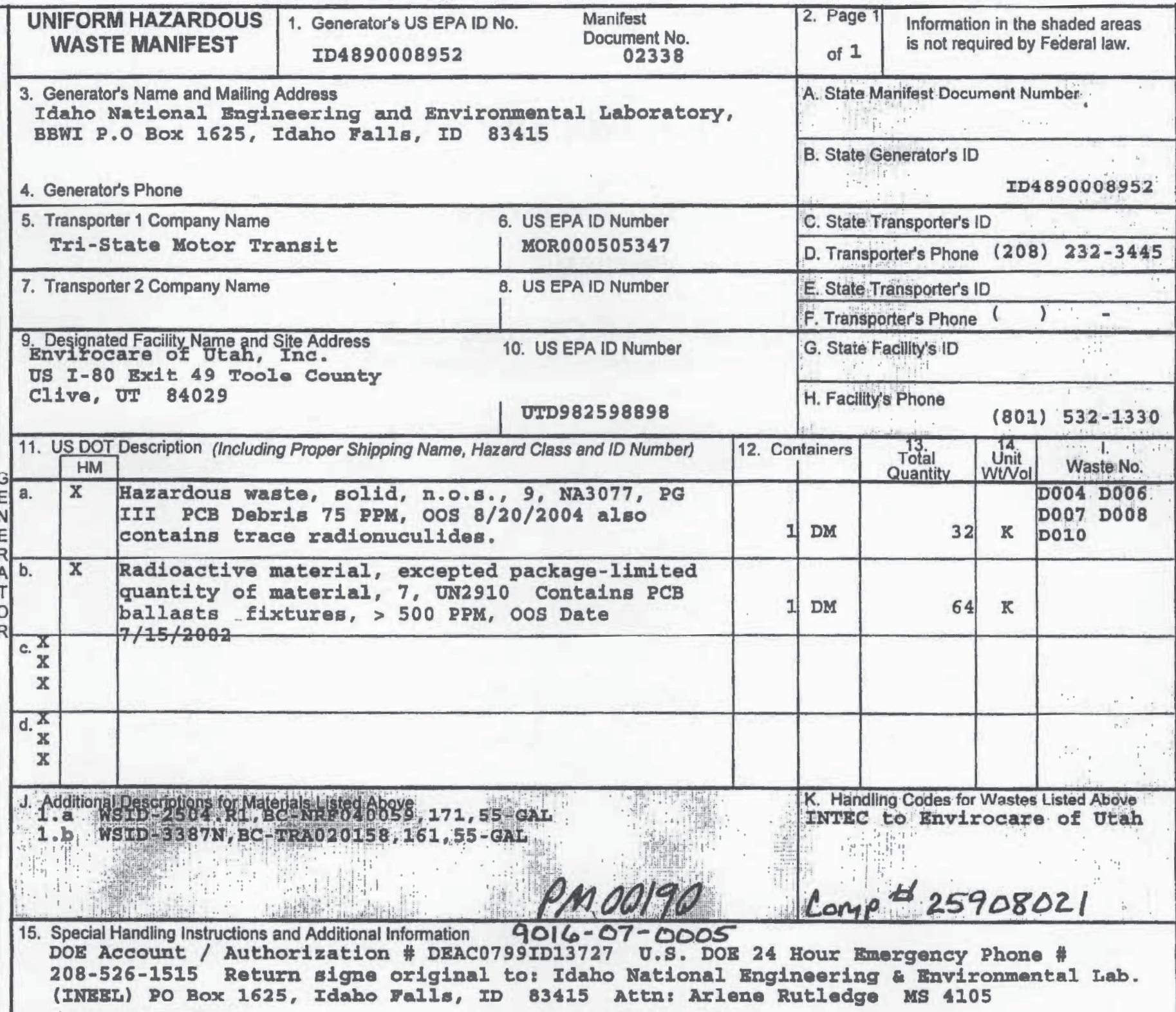

16. GENERATOR'S CERTIFICATION: I hereby declare that the contents of this consignment ane fully and accurately described above by proper shlpplng name and are classified, packed, marked, and labeled, and are in all respects in proper condltion for transport by highway according to applicablo intemational and national govermment regulations.

III am a large quantity generator, I certify that I have a program in place to reduce the volume and loxicity of waste generated to the degree I have determined to be economically practicable and that I have selected the practicable method of treatment, storage, or disposal currently avallable to me which minimizes the present and future threat to human health and the environment; $\mathrm{OR}$, if I am a small quantity generator, I have made a good faith effort to minimize my waste generation and select the best waste management method that is available to me and that $I$ can afford.

Printed/ryped Name

Bruce Ellits

17. Transporter 1 Acknowledgement of Receipt of Materials

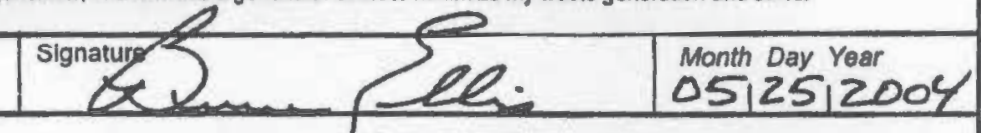

L

Printed/Typed Name

Tobly Jarszhstry

18. Transporter 2 Acknowledgement ff Receipt of Materials

Printed/Typed Name

19. Discrepancy Indication Space

A

i

20. Facility Owner or Operator. Certification of receipt of hazardous materials covered by this manifest except as noted in ltem 19.

Y Printed/Typed Name

Integrated Waste Tracking System.

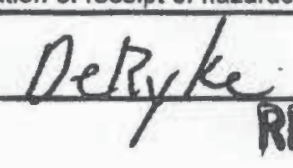




\section{ENVIROCARE}

OF UTAH, INC.

TEEE SAFE ALTERNATTVE

3 m. S. Exh. 49, 3-80

Clive, Ulah $84029 \mathrm{EPA}$

ID: UTOR3598898

\section{CERTIFICATE OF DISPOSAL}

This Certifieate acknowledger that the following manifested shipments;

$\frac{\text { Shipment }}{\text { 8016-07-0005 }} \frac{\text { Manifest }}{02338} \quad \frac{\text { Date(s) of Disposal }}{14105 / 2004} \quad \frac{\text { Cu/fit }}{14.7} \quad \frac{\text { Process }}{\text { Landill }} \quad \frac{\text { Disposal Location }}{\text { Mixed Wroto }}$

Representing 14.7 Cubic feet of waste of at listed Dispesal Facility landill. Disposal is subject to Envirocare's Radioactive Material License, all other applicable licenses, permits and regulations, and the Disposal Agrcement.

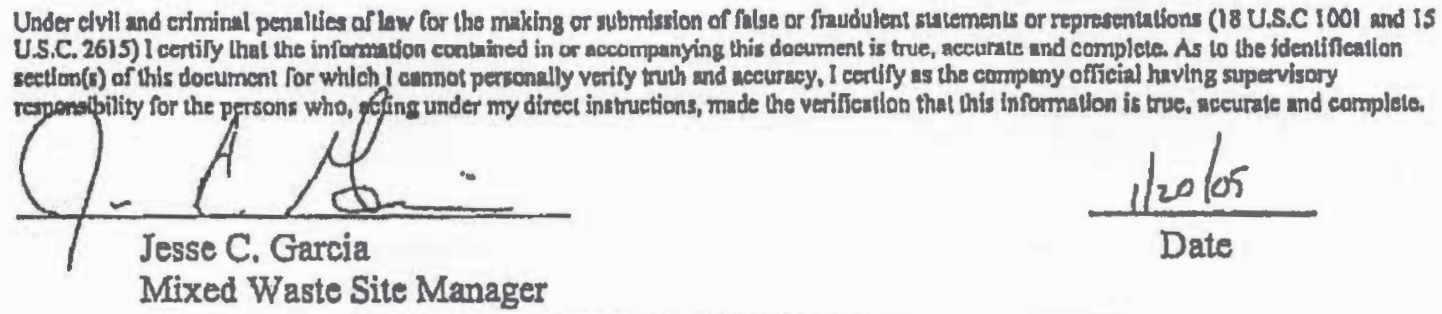

605 N. 5600 W, Sall Lake Cig, Uiah 81116 Telephone (801) 532-1330 

UNIFORM HAZARDOUS WASTE MANIFEST
1. Generator's US EPA ID No. ID4890008952
Manifest

Document No. 02341

\section{Page 1 Information in the shaded areas \\ of 1

3. Generator's Name and Mailing Addrese

Idaho National Engineering and Environmental Laboratory U.S. DOE, P.O. Box 1625, Idaho Falla, ID 83415-4105

A. State Manifest Document Number

B. State Generator's ID

4. Generators Phone (208) $526-2414$
5. Transporter 1 Company Name
Tri-gtate Motor Transit
6. US EPA ID NUmber MORO00505347
C. State Transporters 10
D. Transporter's Phone $(208) \quad 232-3445$
7. Transporter 2 Company Name
8. US EPA ID Number
E State Transpetter's ID
F Transpoter's Phone (
9. Designated Facility Name and Site Address
Materials and Energy Corporation
10. US EPA ID Number
ETIP 2010 Highway 58
Oakxidge, TN 37830
TWR000005397
G. State Facility's ID
H. Facillty's Phone
(865) $574-0149$

\begin{tabular}{|c|c|c|c|c|c|c|c|}
\hline 11. & SDOT & Description (Including Proper Shipping Name, Hazard Class and ID Number) & 12. Cont & tainers & $\begin{array}{l}\text { Total } \\
\text { Totantity }\end{array}$ & $\begin{array}{c}\text { Unit } \\
\text { Wivol }\end{array}$ & Waste No. \\
\hline a. & & $\begin{array}{l}\text { Non-DOT Regulated PCBs Also Contains Trace } \\
\text { Radionuclides PCB debris } 60 \text { PPM oos date } \\
5 / 9 / 01\end{array}$ & 1 & DM & 159 & $\mathbf{k}$ & \\
\hline b. & & $\begin{array}{l}\text { Ton-DOT Regulated PCBs Also Contains Trace } \\
\text { Radionuclides PCB Debris } 60 \text { ppm oos } 5 / 9 / 2001\end{array}$ & 1 & $\mathrm{DM}$ & 8 & $\mathbf{K}$ & \\
\hline c. & $\mathbf{X}$ & $\begin{array}{l}\text { Waste Radioactive material, excepted } \\
\text { package-limited quantity of material, 7, on2910 }\end{array}$ & 1) & DM & 51 & 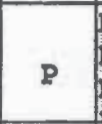 & $\begin{array}{l}\text { D004 D006 } \\
\text { Do07 D008 } \\
\text { D009 D011 }\end{array}$ \\
\hline d. $\frac{x}{x}$ & & & & & & & F005 0134: \\
\hline $\begin{array}{l}1 \\
1 \\
1\end{array}$ & : & 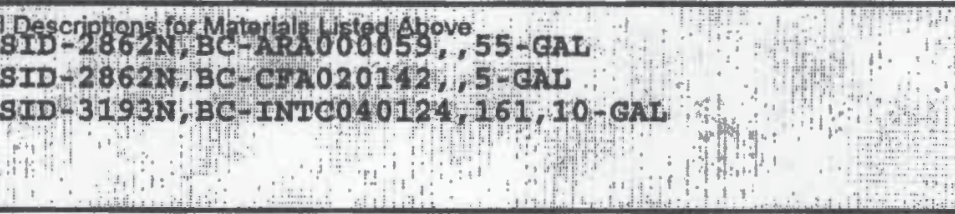 & & $\begin{array}{r}\text { Yhom } \\
\text { Yrom }\end{array}$ & $\begin{array}{l}\text { Codoefor } \\
\text { N18c To } \\
90896 \\
04\end{array}$ & Wastes & Heted Above \\
\hline
\end{tabular}

15. Special Handling Instructions and Additional Information

Return elgned original to: Arlene Rutledge, Idaho National Englneering \& Environmental

Laboratory/Us DOs, P.O. Box 1625, Idaho Falls, ID 83415-4105. Prepared under contract \#DEAC07 99ID 13727. USDOB 24-Hr. Jmergency Phone: 208 526-1515.

16. GENERATOR'S CERTIFICATION: I hereby declare that the contents of this consignment are fully and accurately described above by proper shipping name and are classilied, packed, marked, and labeled, and are in all respects in proper condition for transport by highway according to applicable intemational and national government regulations.

If I am a large quantily generator, I certify that I have a program in place to reduce the volume and toxicity of waste generated to the degree I have determined to be economically practicable and that I have selected the practicable method of treatment, storage, $\alpha$ dlsposal currently available lo me which minimizes the present and future threat to human health and the environment: $\mathrm{OR}$, If I am a small quantity generator, I have made a good faith effort to minimize my waste generation and select the best waste management method that is avallable to me and that I can afford

\section{Printed/Typed Name}

122

17. Transporter 1 Acknowledgement of Receipt of Materials

Pilliartiaped Name

18. Transporter 2 Acknowledgement of Receipt of Materials

Printed/Typed Name

19. Discrepancy Indication Space
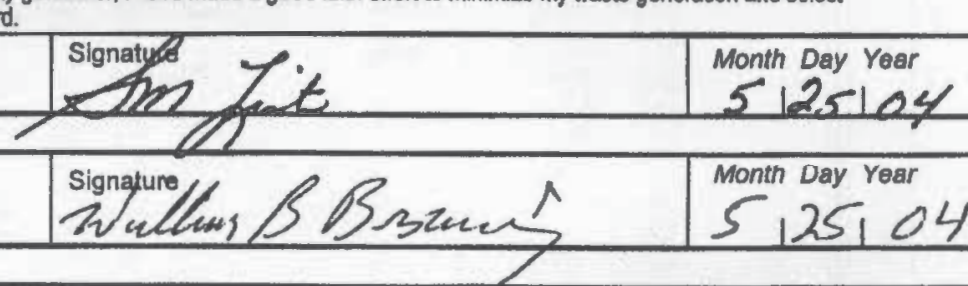

Signature

Month Day Yaar

20. Facility Owner or Operator: Certification of receipt of hazardous materials covered by this manifest except as noted in ltem 19.

Printeg/Typed Name

tratser /y
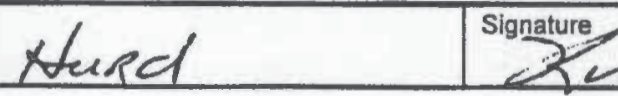

mber sturel

Month Day Year

Integrated Waste Tracking System. 


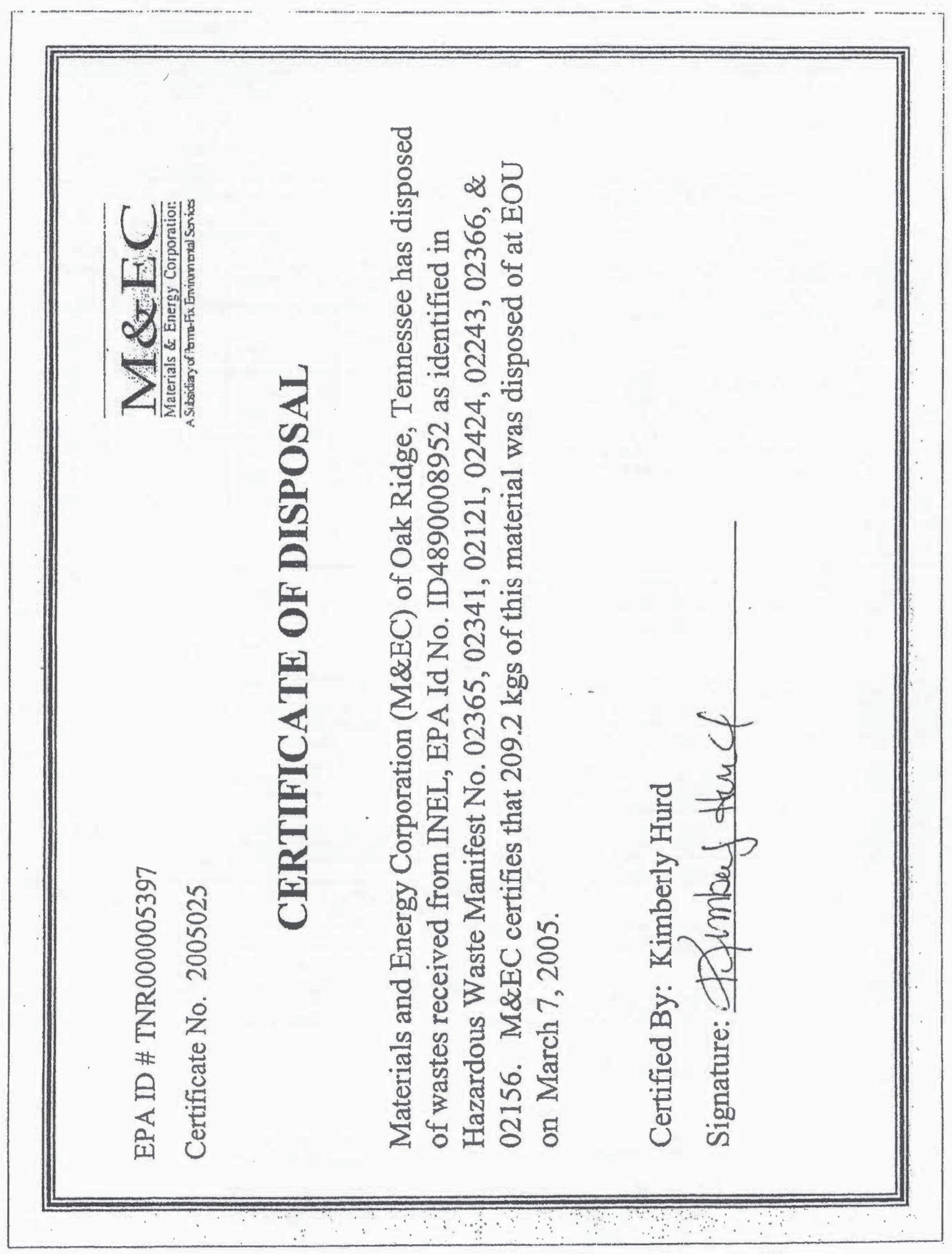





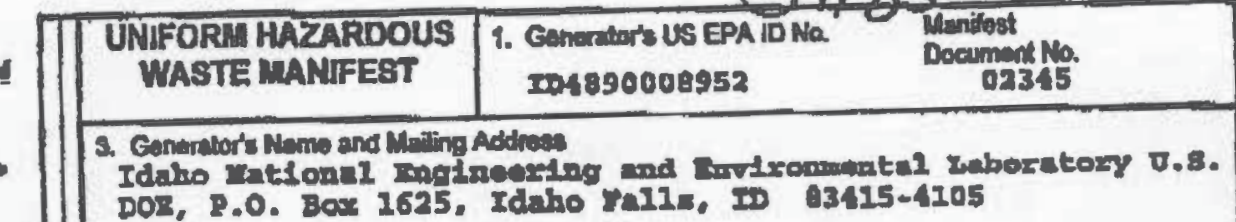

4. Generatate Phone $(208) 526-2414$
5. Tranponar 1 Corrpeny Nams
6. US EPA D Numbar Clean Barbors raviromontal servieed, Mo039322250

\begin{tabular}{|c|c|}
\hline 7. Trompoiter 2 Compeny None & 8. US EPA DD Mumber \\
\hline 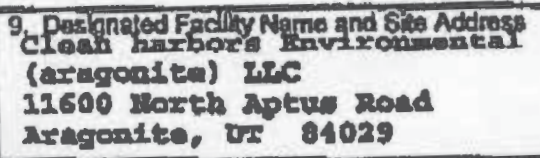 & 10. US EPA to Number \\
\hline
\end{tabular}

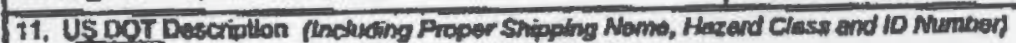

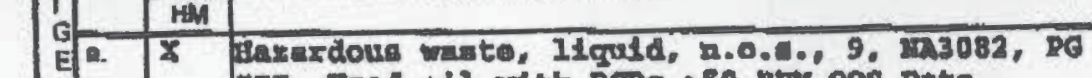

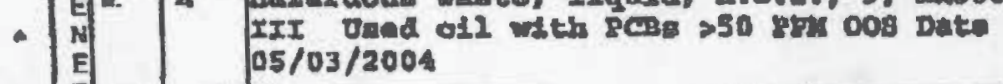

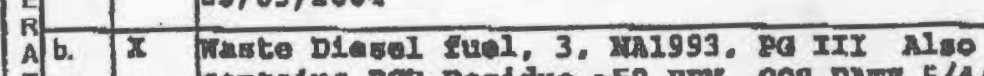

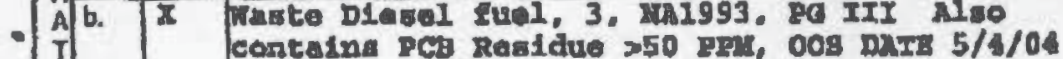

o

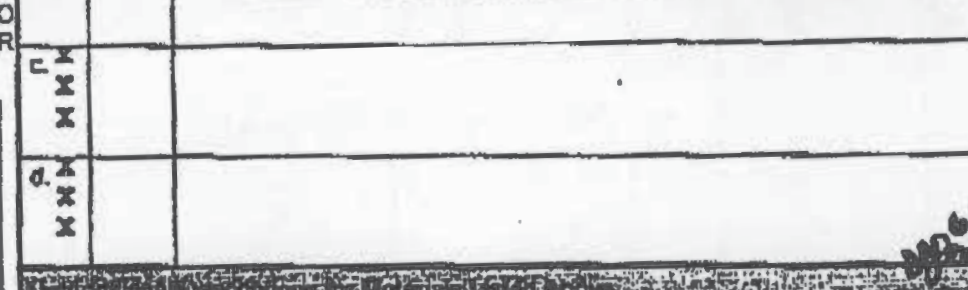

1.

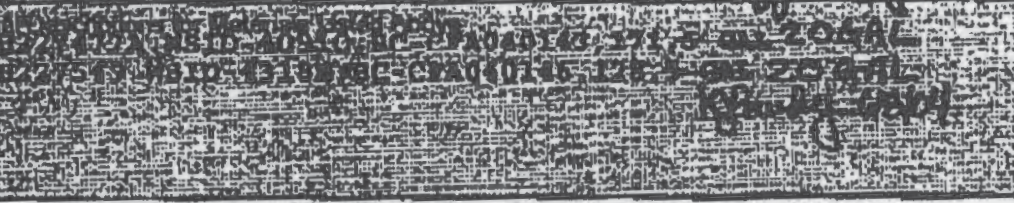

15. Special Handing instructions and Addidiond uniormation

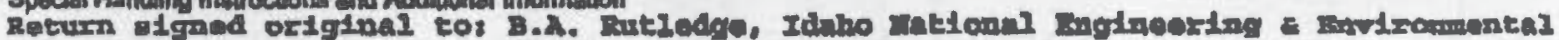

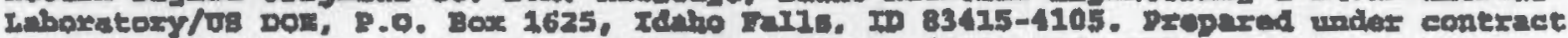

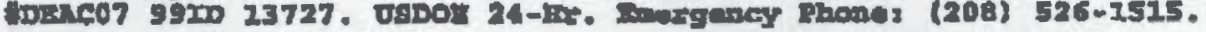

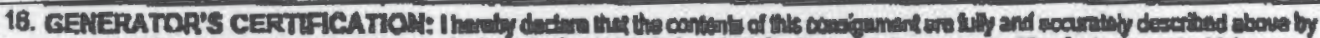

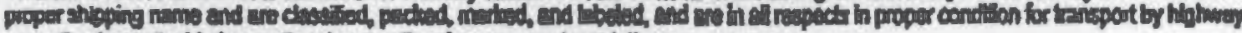

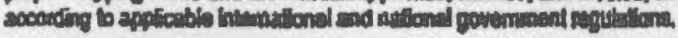

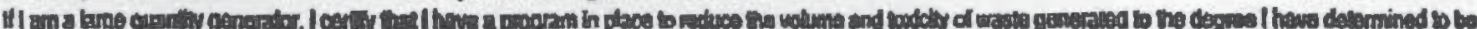

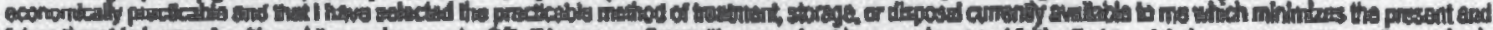

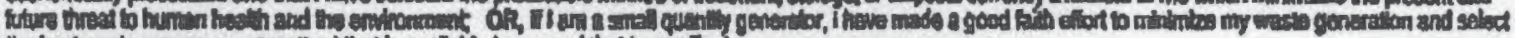

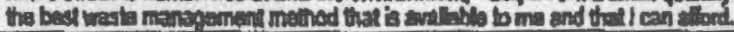

Printedry Nousleas

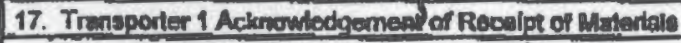

Pinted Typed Nanre

Laph L Hicks

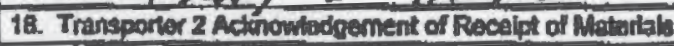

Frinted Inped Nemo

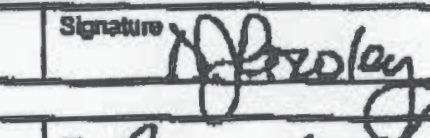

1 intomition in the shadad area.

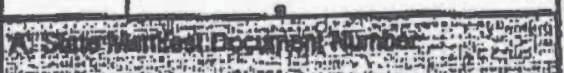

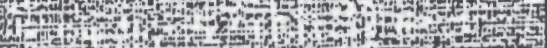
7 .

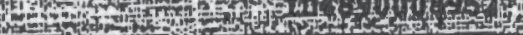

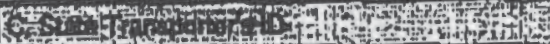

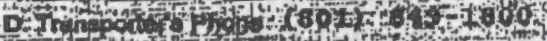

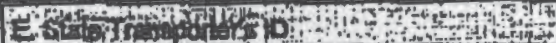

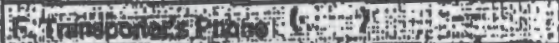

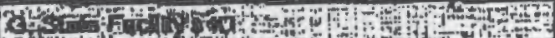
i

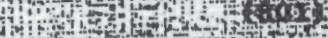

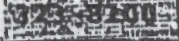

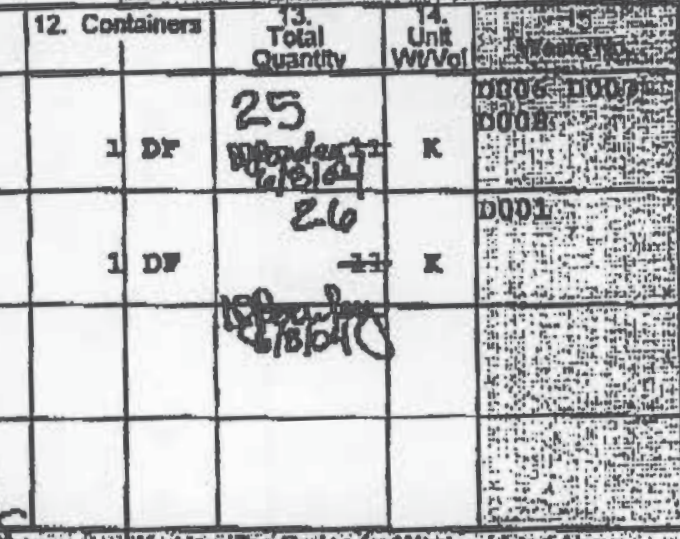

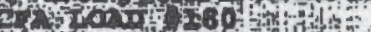

Ped Thow: tox: 


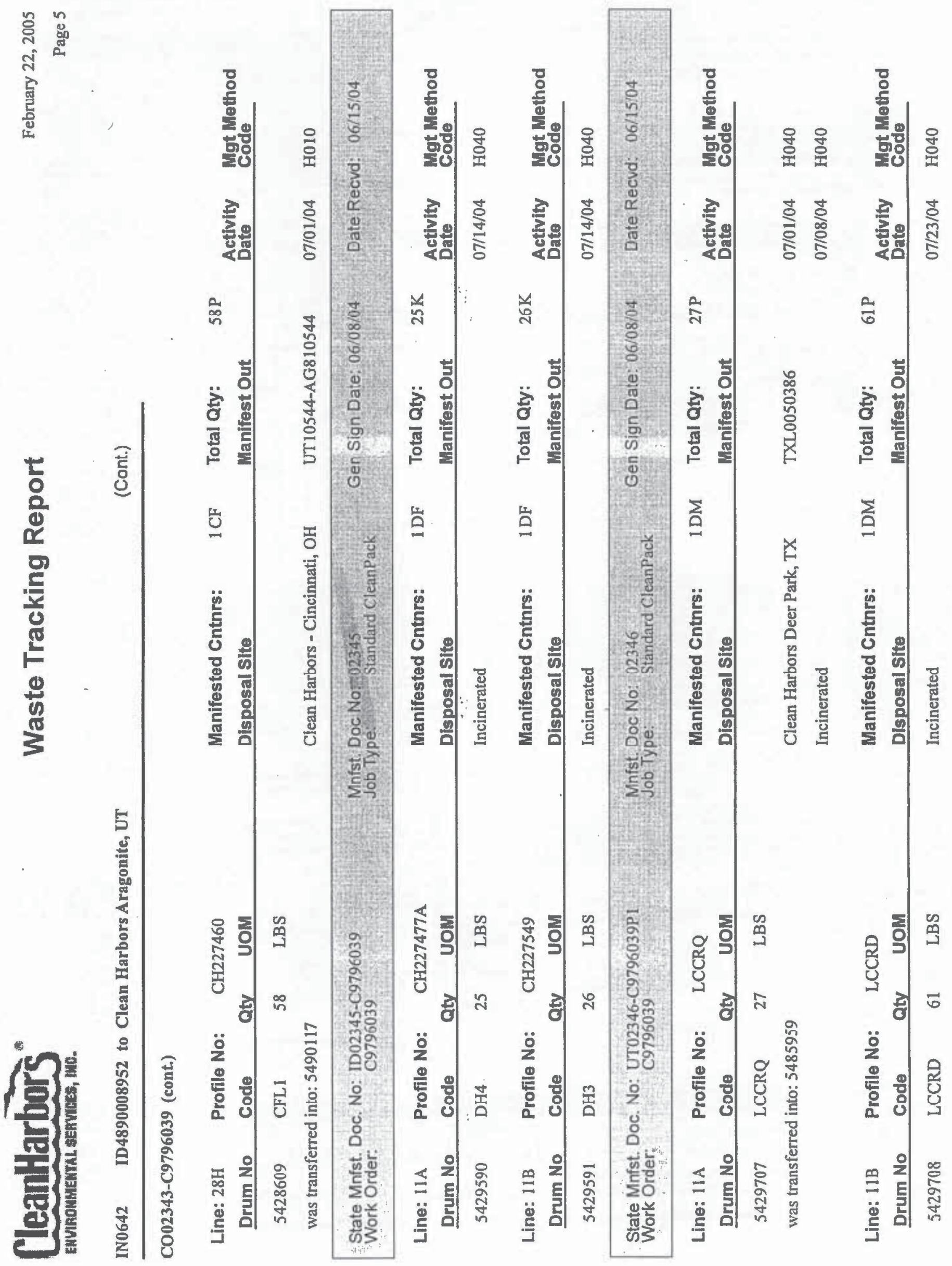



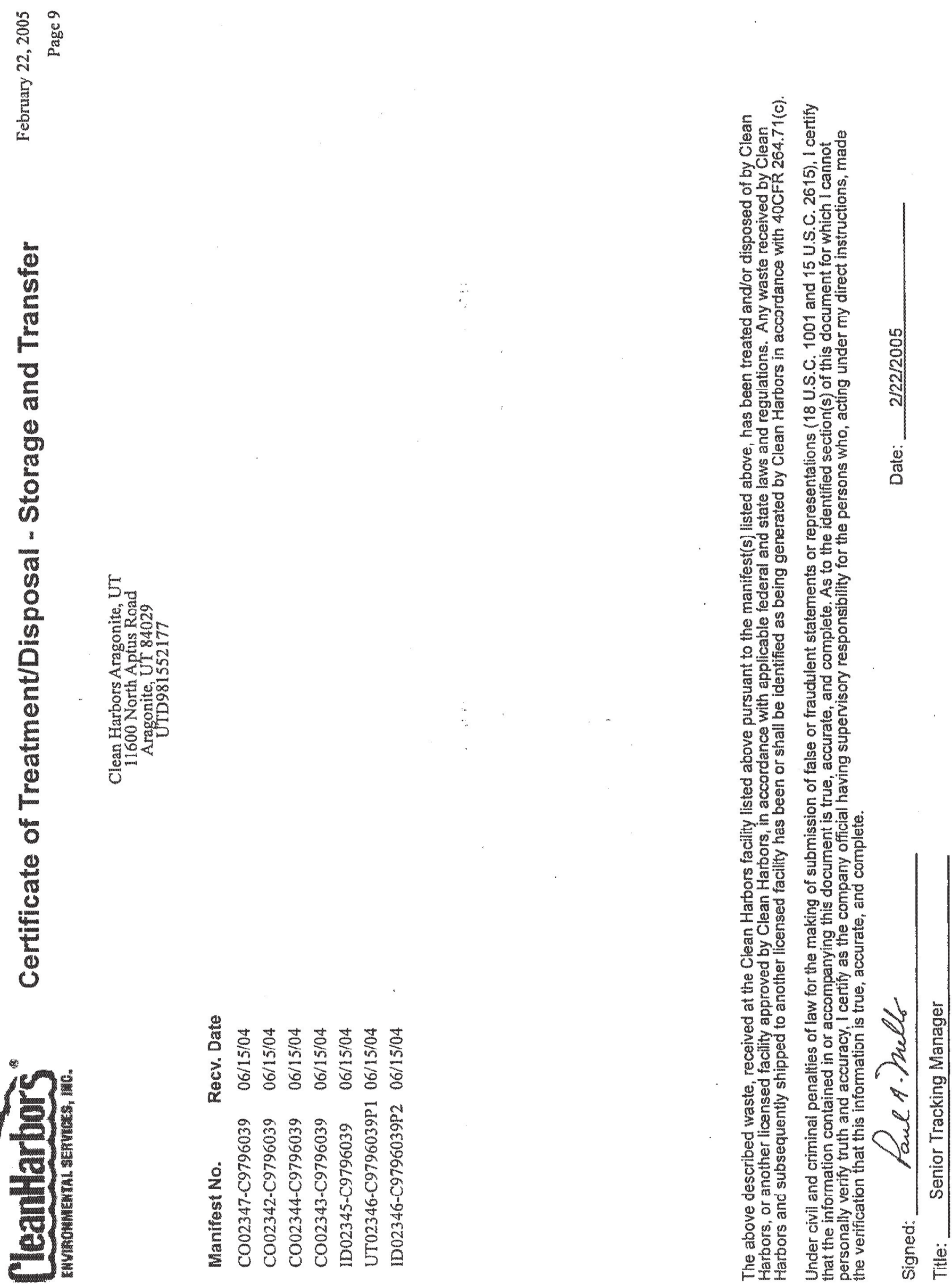



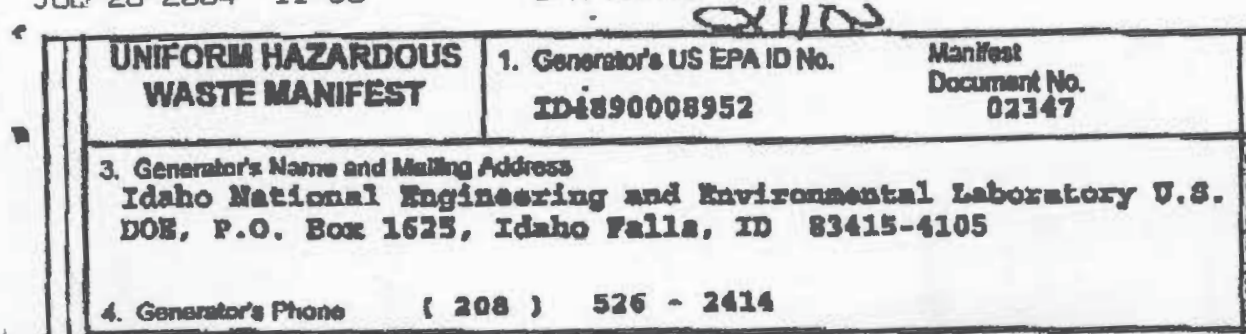

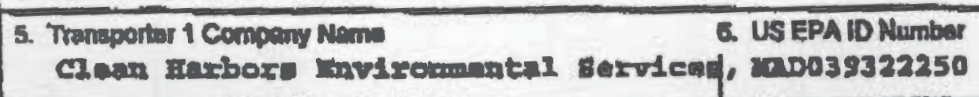

\begin{tabular}{|c|c|c|}
\hline 7. Transpottar 2 company Nim & 6. US EPA 10 Minitor & 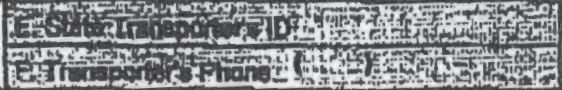 \\
\hline 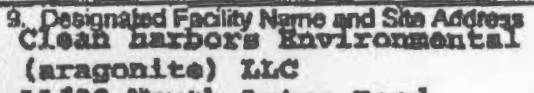 & 10. US EPA IO Number & 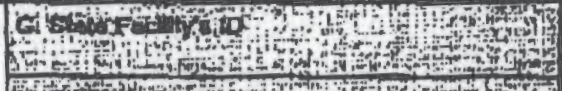 \\
\hline $\begin{array}{l}12600 \text { worth Aptup rowd } \\
\text { Mragondte, or } 84029\end{array}$ & 0ro981552177 & 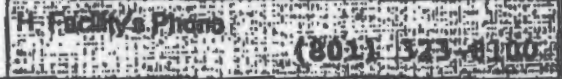 \\
\hline
\end{tabular}

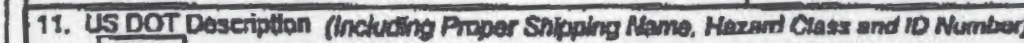

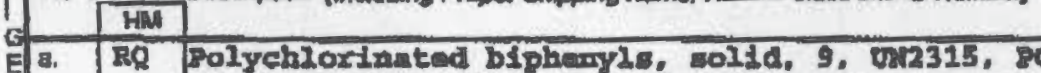

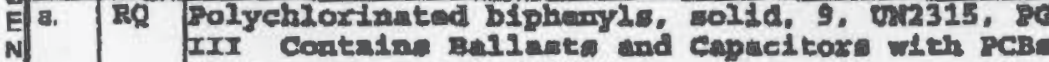
E 50 ppin 008 bate $11-17-03$

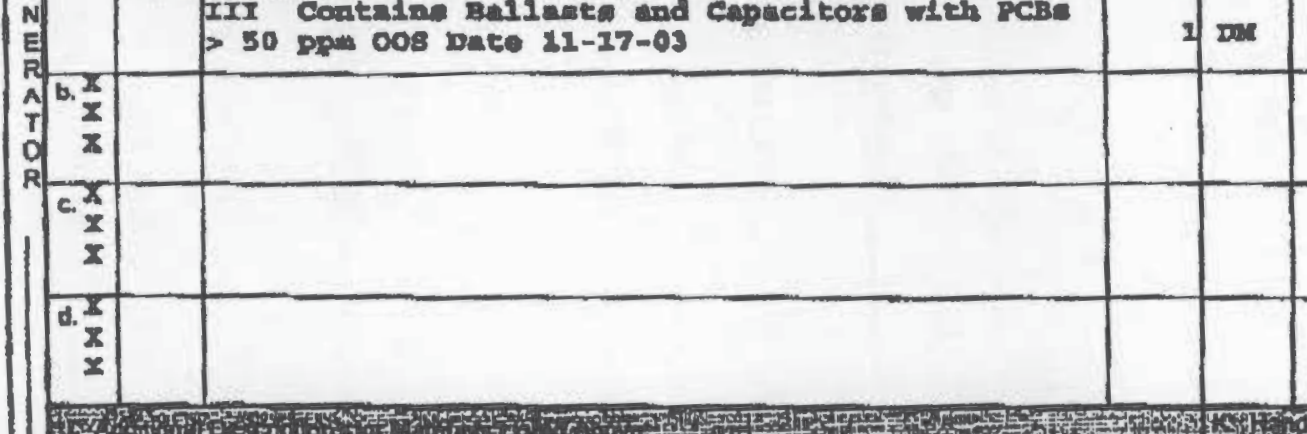

\section{d 1 \\ . Page of upromation in the shaded arees}

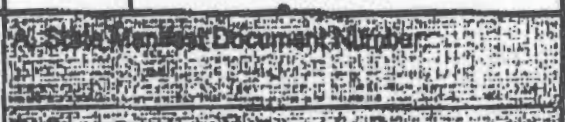
7. 17.5. The

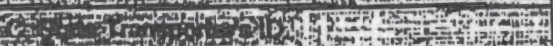
If

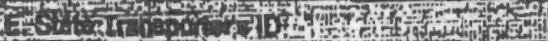
C.:-

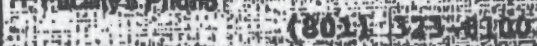

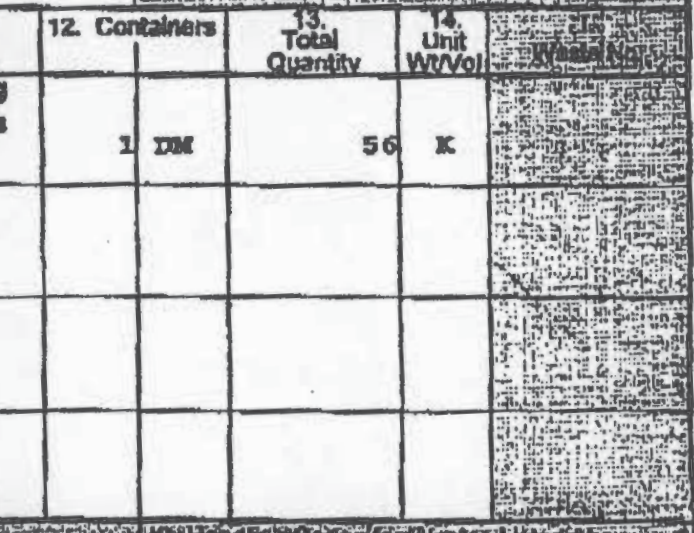
13. Fon H.

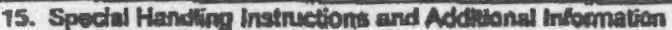

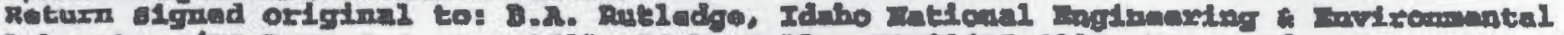

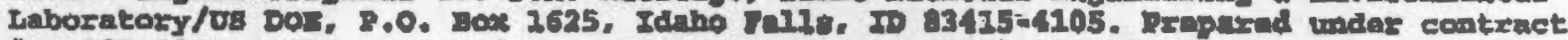

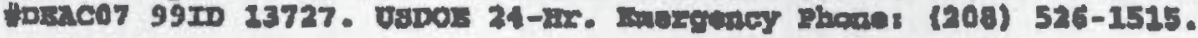

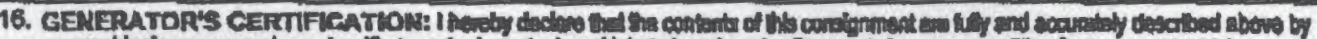

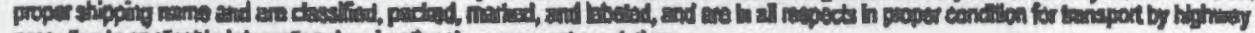

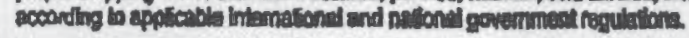

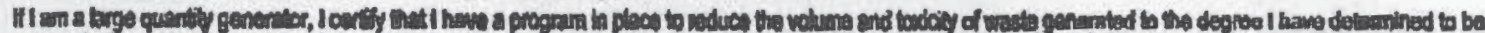

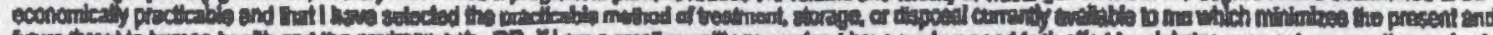

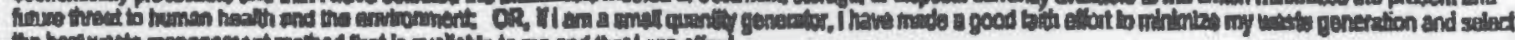

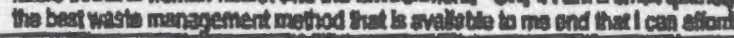

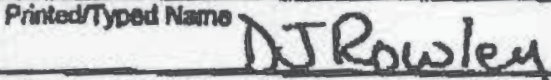

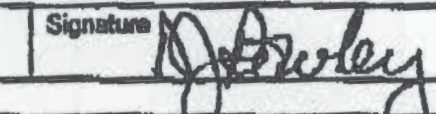

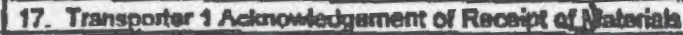
Printad Typod Nym

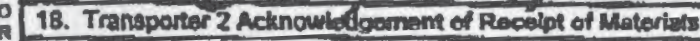

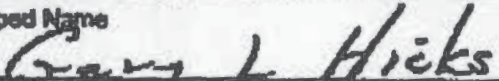 Printedrypod stamo

P.

n.

F 19. Diserepancy lndication Spece

A

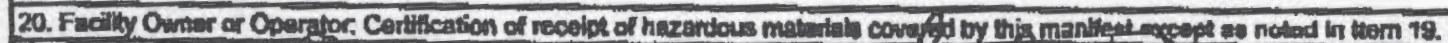

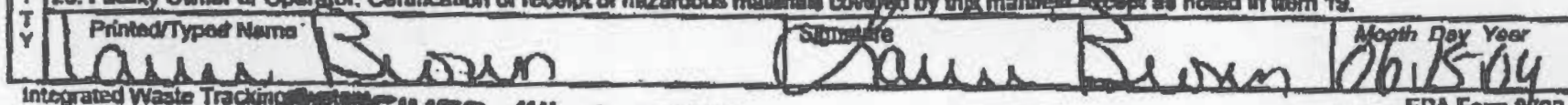

Intrograted waste Tracking , RECENED JUL 262414

EPA Frm 800022 


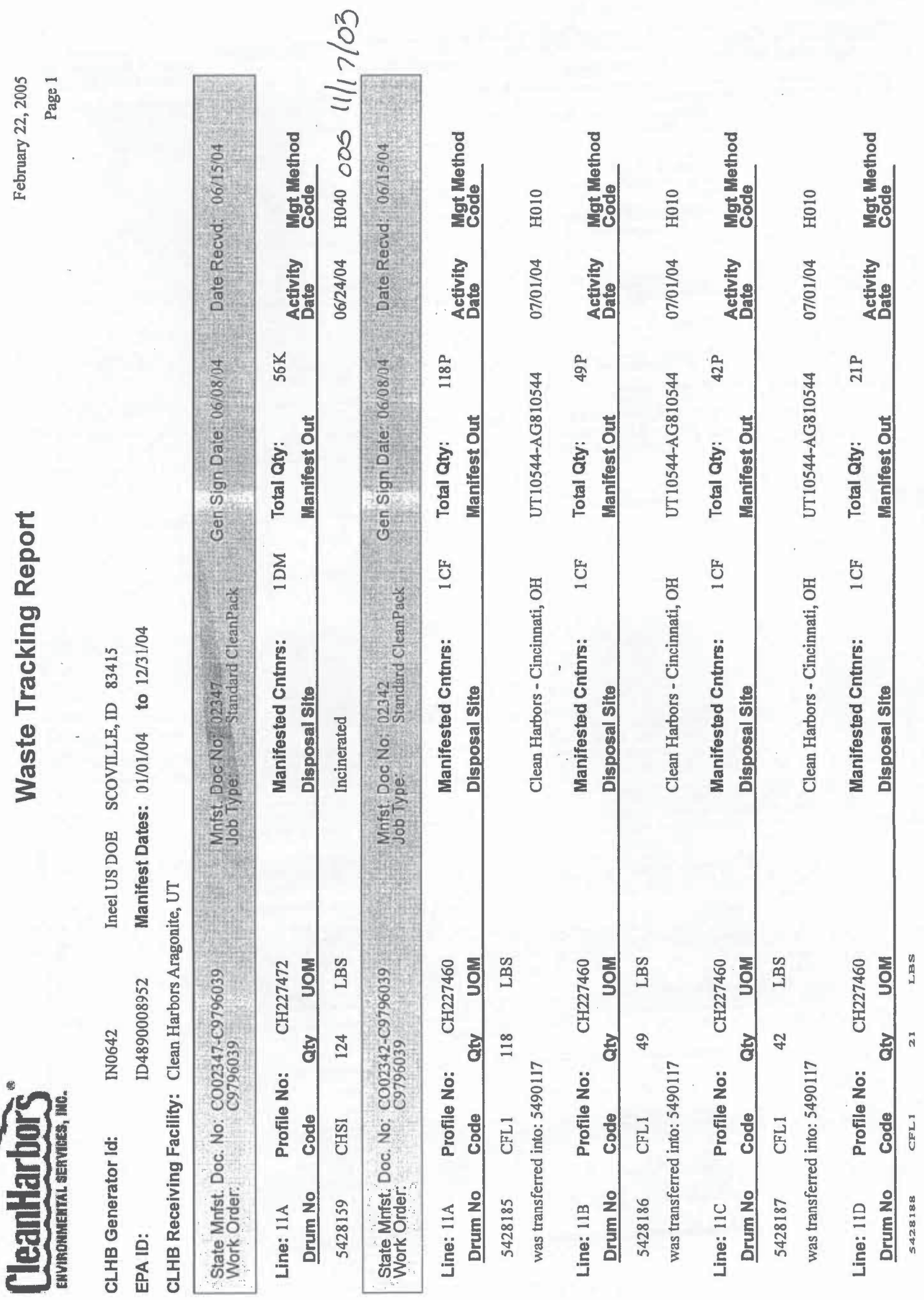



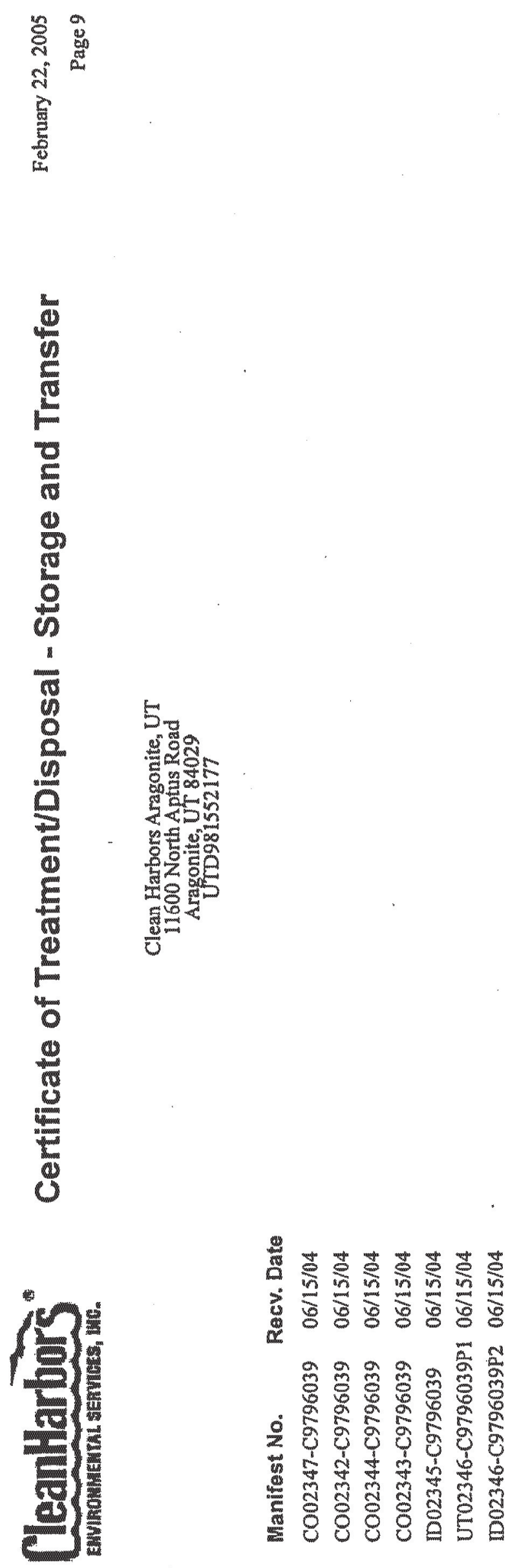

a $a$ o 0 b

क융

- 5252525

- 8 \& $858 \%$

แ

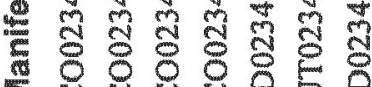

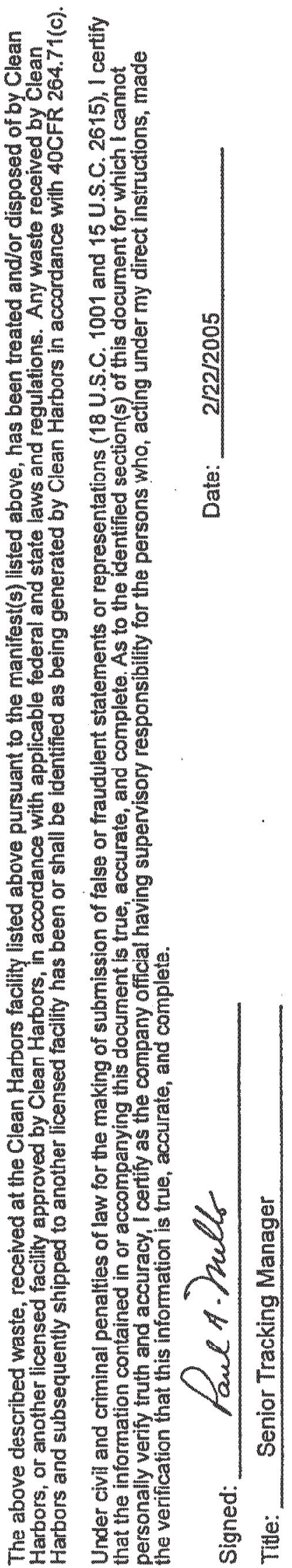





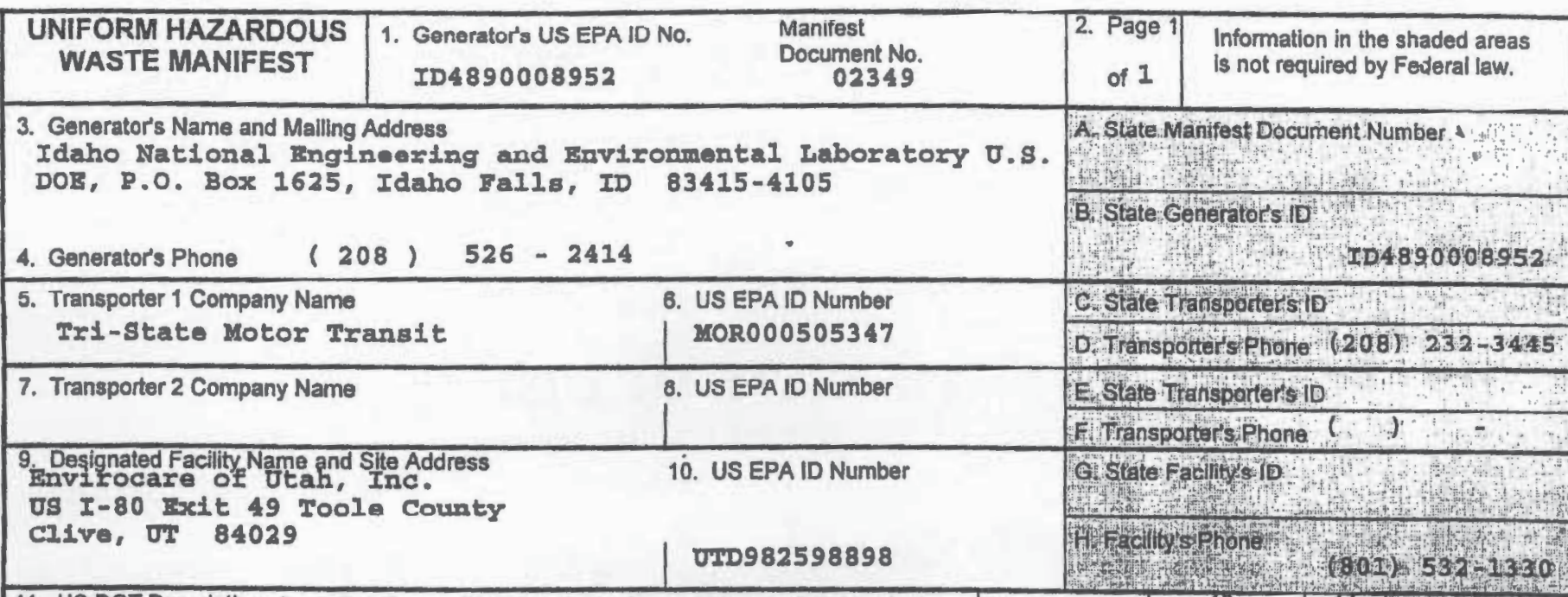

\begin{tabular}{|c|c|c|c|c|c|c|c|}
\hline 11. & $\frac{\mathrm{SDO}}{\mathrm{HM}}$ & Description (Including Proper Shipping Name, Hazard Class and ID Number) & 12. Con & talners & $\begin{array}{l}\text { Total } \\
\text { Tuantity }\end{array}$ & $\begin{array}{c}\text { Th, } \\
\text { Unit } \\
\text { Whal }\end{array}$ & 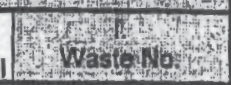 \\
\hline a. & $\bar{x}$ & 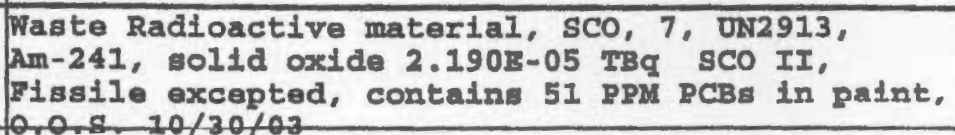 & 1 & $\mathrm{CW}$ & 1248 & Nowe a & 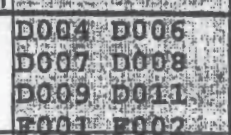 \\
\hline b. $\frac{x}{x}$ & & & & & & & Fo, whos \\
\hline c. $\begin{array}{r}x \\
x \\
x\end{array}$ & & & & & & & 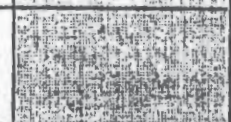 \\
\hline d. $\frac{x}{x}$ & & & & & & & 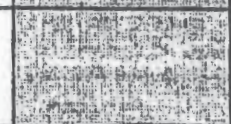 \\
\hline (t) & & 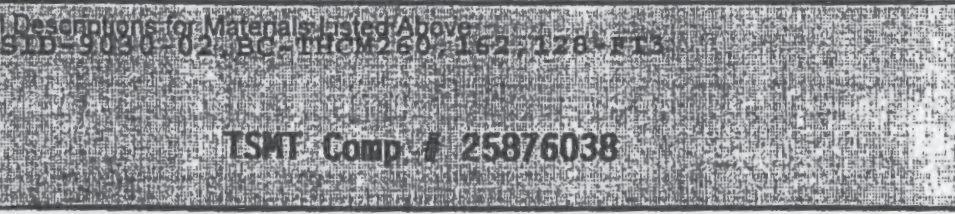 & Hith & King & 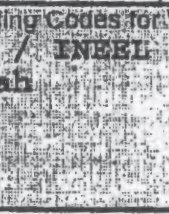 & Wastos & 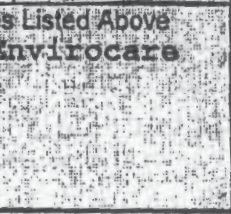 \\
\hline
\end{tabular}

15. Special Handling Instructions and Additional Information

Return S1gned orIglnal to: B.A.Rutledge, INEEL / DSDOR, Box 1625 - MS 4105, Idaho Fa118, Id 83415. Propared under contract: DaAC07 99ID 13727. Znergonoy Phope: 208-526-1515. Brclusive 0ee shipmant $9030-02-p 1100199$

16. GENERATOR'S CERTIFICATION: I heneby dectare that the contents of this consignment are fully and accurately described above by proper shippling name and are classified, packed, marked, and labeled, and are in all respects in proper condition for transport by highway according to applicable international and national govemment regulations.

IfI an a large quantity generatoe, I cerlify that I have a program in place to reduce the volume and boxicity of waste generated to the degree I heve determined to be economizally practicable and that I have selected the practicable method of treatment, storage, or disposal currently avallable to me which minimizes the present and

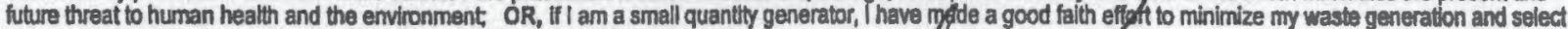
the best waste management method that is wailable to me and that I can afford.

Printed Typed Name

Stephen Keating

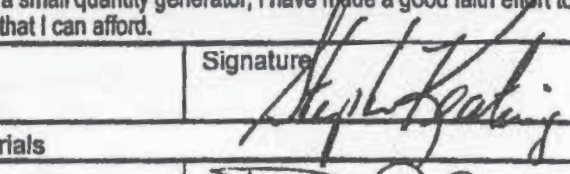

R 17. Transporter 1 Acknowledgement of Recelpl of Materials

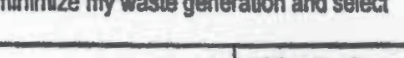

Idaho National Engineering and Invironmental Iaboratory $0 . \mathbf{s .}$

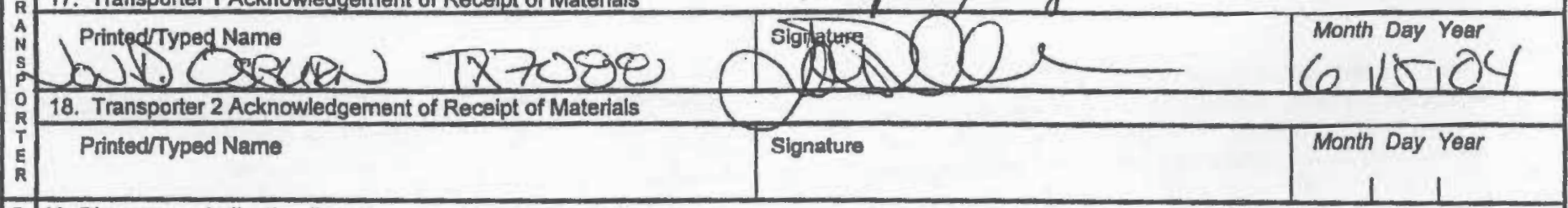

F 19. Discrepancy Indication Space

20. Faclity Owner or Operator: Certirication of receipt of hazardous materials covered by this manifest except as noted in item 19.

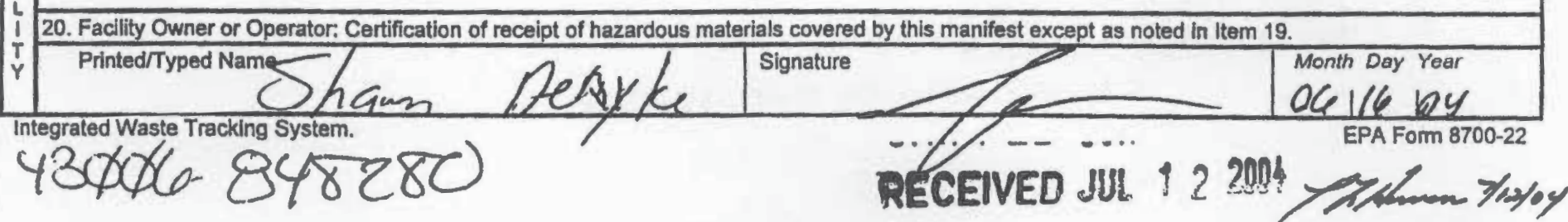




\section{ENVIROCARE}

OF UTAH, INC.

\section{THE SAFE ALTERNATIVE}

3 mi. S. Ext. $49,1-80$

Ciive, Utah 84029 EPA

ID: UT982598898

\section{CERTIFICATE OF DISPOSAL}

This Certificate acknowledges that the following manifested shipments:

$\underset{9030-02-0025}{\frac{\text { Shipment }}{02349}} \frac{\text { Manifest }}{10 / 08 / 2004} \quad \frac{\text { Date(s) of Disposal }}{128} \quad \frac{\text { Process }}{\text { Landfill }} \quad \frac{\text { Disposal Location }}{\text { Mixed Waste }}$

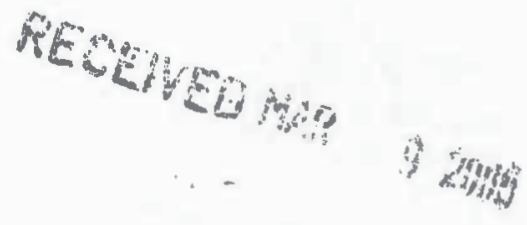

Representing 128 Cubic feet of waste of at listed Disposal Facility landfill. Disposal is subject to

Envirocare's Radioactive Material License, all other applicable licenses, permits and regulations, and the Disposal Agreement.

Under civil and criminal penalties of law for the making or submission of false or fraudulent statements or representations (18 U.S.C 1001 and 15 U.S.C. 2615) I certify that the information contained in or accompanying this document is true, accurate and complete. As to the identification section(s) of this document for which I cannot personally verify truth and accuracy, I certify as the company official having supervisory respoesibility for the persons why acting under my direct instructions, made the verification that this information is true, accurate and complete.
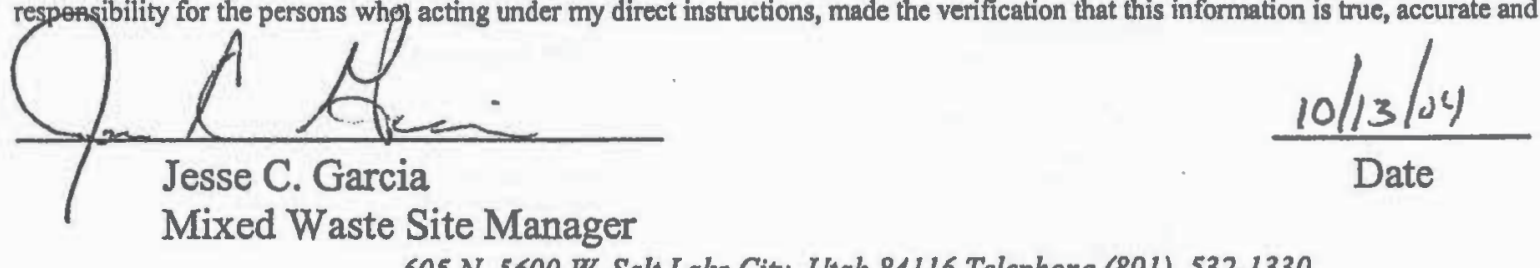

605 N. 5600 W. Salt Lake City, Utah 84116 Telephone (801) 532-1330 



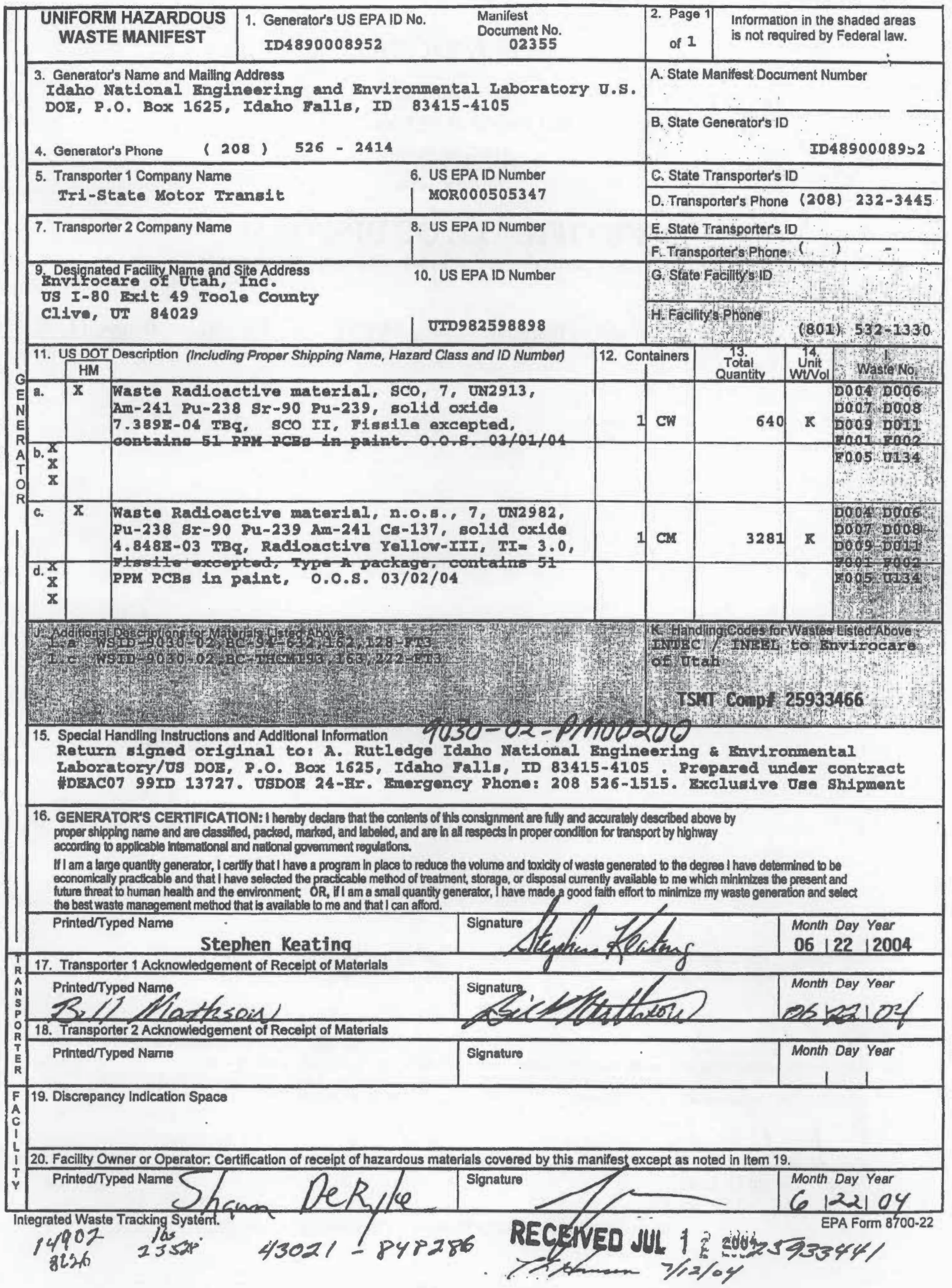




\section{ENVIROCARE}

OF UTAH, INC.

\section{THE SAFE ALTERNATIVE}

3 mi. S. Ext. 49 , $1-80$

Clive, Utah 84029 EPA

ID: UT982598898

\section{CERTIFICATE OF DISPOSAL}

This Certificate acknowledges that the following manifested shipments:

Shipment

9030-02-0024

\section{Manifest}

02355
Date(s) of Disposal

11/27/2004

\section{$\mathrm{Cu} / \mathrm{Ft}$}

350
Process

Landfill

\section{$\underline{\text { Disposal Location }}$}

Mixed Waste

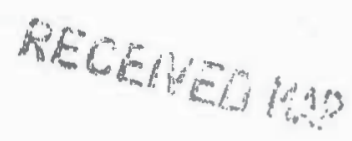

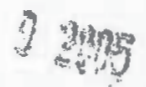

Representing 350 Cubic feet of waste of at listed Disposal Facility landfill. Disposal is subject to Envirocare's Radioactive Material License, all other applicable licenses, permits and regulations, and the Disposal Agreement.

\footnotetext{
Under civil and criminal penalties of law for the making or submission of false or fraudulent statements or representations (18 U.S.C 1001 and 15 U.S.C. 2615) I certify that the information contained in or accompanying this document is true, accurate and complete. As to the identification section(s) of this document for which I cannot personally verify truth and accuracy, I certify as the company official having supervisory respongibility for the persons who, afting under my direct instructions, made the verification that this information is true, accurate and complete.

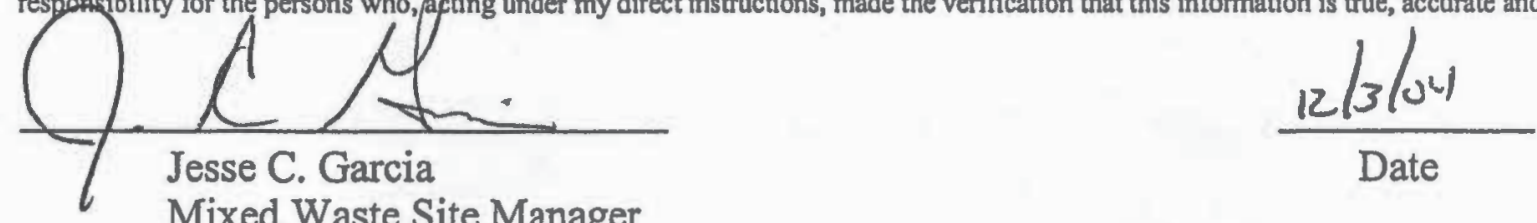





\begin{tabular}{|c|c|c|c|c|}
\hline $\begin{array}{c}\text { UNIFORM HAZARDOUS } \\
\text { WASTE MANIFEST }\end{array}$ & $\begin{array}{c}\text { 1. Generators US EPA ID No. } \\
\text { ID4890008952 }\end{array}$ & $\begin{array}{c}\text { Manifost } \\
\text { Document No. } \\
02355\end{array}$ & $\begin{array}{c}\text { Page 1 } \\
\text { of } 1\end{array}$ & $\begin{array}{l}\text { Information in the shaded areas } \\
\text { is not required by Federal law. }\end{array}$ \\
\hline
\end{tabular}

3. Generator's Name and Mailing Address

Idaho Natlonal Engineering and Environmental Laboratory $0 . S$.

DOE, P.O. Box 1625, Idaho Falls, ID 83415-4105

A. State Manifest Document Number

4. Generator's Phone (208) $526-2414$

\begin{tabular}{|c|c|c|}
\hline \multirow{2}{*}{$\begin{array}{l}\text { 5. Transporter } 1 \text { Company Name } \\
\text { Iri-state Motor Transit }\end{array}$} & \multirow{2}{*}{$\begin{array}{l}\text { 6. US EPA ID Number } \\
\text { MOR000505347 }\end{array}$} & \multirow{2}{*}{$\begin{array}{l}\text { C. State Transporter's ID } \\
\text { D. Transporter's Phone }(208) \quad 232-3445\end{array}$} \\
\hline & & \\
\hline 7. Transporter 2 Company Name & 8. US EPA ID Number & E. State Transporters ID \\
\hline $\begin{array}{l}\text { 9. Designated Facility Name and Site Address } \\
\text { znvirocare of Utah, Inc. } \\
\text { US I-80 Exit } 49 \text { Toole County } \\
\text { CIIve, UT } 84029\end{array}$ & 10. US EPA ID Number & $\begin{array}{l}\text { G. State Facilitys sD } \\
\text { H: Facilityls Phone } \\
(801) \quad 532-1330\end{array}$ \\
\hline
\end{tabular}

11. US DOT Description (Including Proper Shipping Name, Hazand Class and ID Number) \begin{tabular}{l|l|l|} 
& $\mathrm{HM}$ & \\
$\mathrm{E}$ & $\mathrm{X}$ & Faste Radioactive material, SCO, 7, UN2913,
\end{tabular}

E a. $\mathrm{X} \quad \begin{aligned} & \text { Waste Radioactive material, SCO, 7, UN29 } \\ & \mathrm{Am}-241 \text { Pu-238 }\end{aligned}$

티 $7.389 \mathrm{z}-04 \mathrm{TBq}$, sCo II, Flesile excepted,

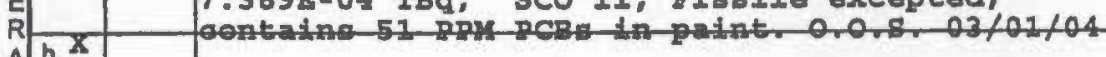

A

O $\mathrm{X}$

c. $\mathrm{X}$

Tast (1)

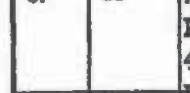

Radioactre material, n.0.8., 7, UN2982, 4.848E-03 IBq, Radioactive Yellow-III, TI=3.0,

d. $\frac{x}{x}$ Ftod te excepted, Typerk package, contatms 51

$\mathbf{x}$ PPM PCBs in paint, 0.0.s. 03/02/04

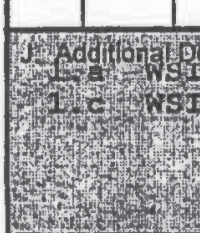

15. Special Handling Instructions and Additional Information $7030-02-470020 \%$

\begin{tabular}{|c|c|c|c|c|}
\hline 12. Cor & tainers & $\begin{array}{l}\text { Total } \\
\text { Total } \\
\text { Quantity }\end{array}$ & $\begin{array}{l}14, \\
\text { Unit } \\
\text { WiNo }\end{array}$ & Wastenop \\
\hline 1 & CW & 640 & $\mathbf{K}$ & 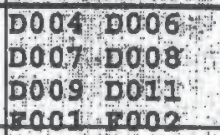 \\
\hline & & & & F0.5 0134 \\
\hline 1 & $\mathrm{CM}$ & 3281 & $\mathbf{K}$ & 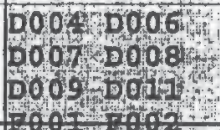 \\
\hline & & & & 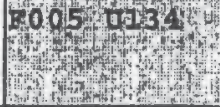 \\
\hline
\end{tabular}

Return aigned original to: A. Rutledge Idaho National Engineering \& Invironmental

Laboratory/09 DOE, P.O. Box 1625, Idaho Pal1s, ID 83415-4105 . Prepared under contract \#DEAC07 99ID 13727. USDOF 24-Hr. Fmergency Phone: 208 526-1515. Exclusive Use shipment

16. GENERATOR'S CERTIFICATION: I hereby declare that the contents of this consignment are fully and aceurately described above by proper shipping name and are ctassined, packed, marked, and labeled, and are in all respects in proper condtion for transport by highway according to applicable Intemational and nallonal govemment regulations.

III I am a large quantity generator, I certify that I have a program in place to reduce the volume and toxicity of waste generated to the degree I have determined bo be economically practicable and that I have selected the practicable method of treatnent, storage, or disposal currently avaliable to me which minimizes the present and future threat to human health and the environment: $O R$, if I am a small quantity generator, I have made a good faith effiort to minimize my waste generation and select the best waste management method that is availablo to me and that I can afford.

Printed/Typed Name

Stephen Keating

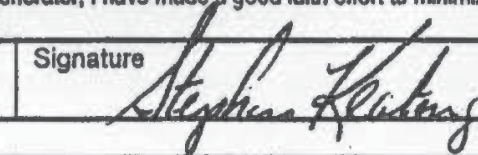

17. Transporter 1 Acknowledgement of Receipt of Materials

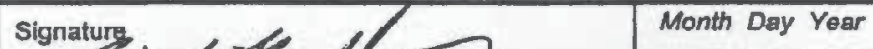

\section{PrintedTyped Name}

25

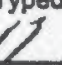

athsoid L

18. Transporter 2 Acknowledgement of Receipt of Materials

Printed/Typed Name

19. Discrepancy Indication Space

20. Facility Owner or Operator: Certification of receipt of hazardous materials covered by this manifest except as noted in ltem 19

Printed/Typed Name

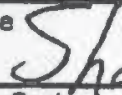

hesan

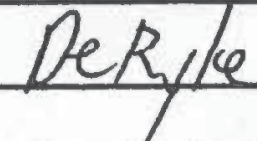

Signature

(n)

(6)

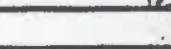

3522102

Integrated Waste Tracking System 14907
2126

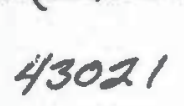
1847286 Signature

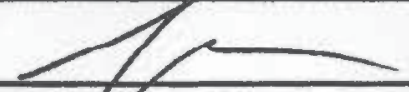




\section{ENVIROCARE}

OF UTAH, INC.

\section{THE SAFE ALTERNATIVE}

3 mi. S. Ext. 49, 1-80

Clive, Utah 84029 EPA

ID: UT982598898

\section{CERTIFICATE OF DISPOSAL}

; This Certificate acknowledges that the following manifested shipments:

$\frac{\text { Shipment }}{9030-02-0024} \quad \frac{\text { Manifest }}{02355} \quad \frac{\text { Date(s) of Disposal }}{11 / 27 / 2004} \quad \frac{\text { Cu/Ft }}{350} \quad \frac{\text { Process }}{\text { Landfill }} \quad \frac{\text { Disposal Location }}{\text { Mixed Wasto }}$

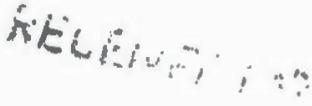

$$
\begin{aligned}
& ?: y 5
\end{aligned}
$$

Representing 350 Cubic feet of waste of at listed Disposal Facility landfill. Disposal is subject to

Envirocare's Radioactive Material License, all other applicable licenses, permits and regulations, and the Disposal Agreement.

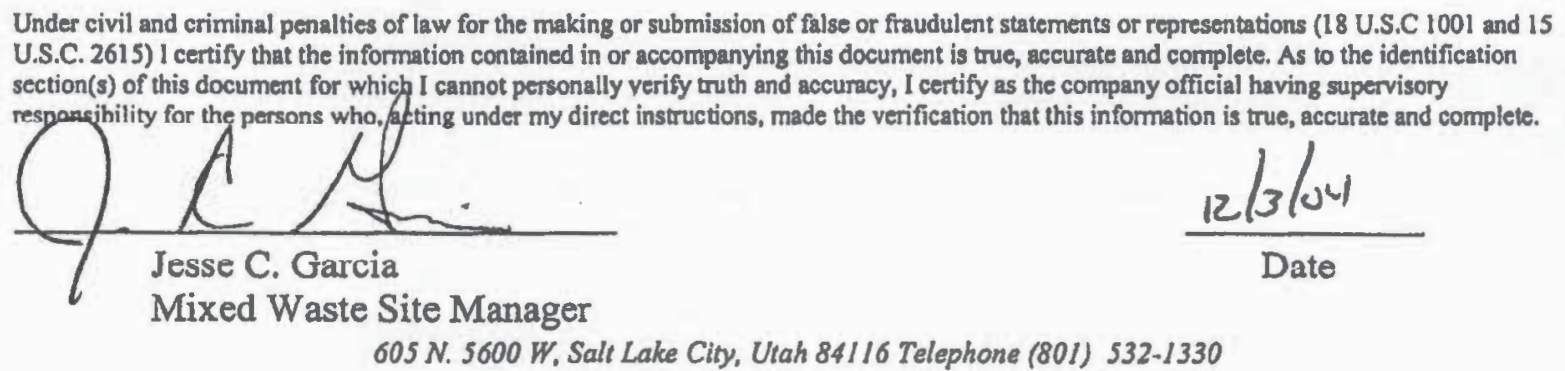





\begin{tabular}{|c|c|c|c|c|}
\hline $\begin{array}{l}\text { UNIFORM HAZARDOUS } \\
\text { WASTE MANIFEST }\end{array}$ & $\begin{array}{l}\text { 1. Generator's US EPA ID No. } \\
\text { ID4890008952 }\end{array}$ & $\begin{array}{l}\text { Manifest } \\
\text { Document No. } \\
02365\end{array}$ & $\begin{array}{c}\text { 2. Page } \\
\text { of } 5\end{array}$ & $\begin{array}{l}\text { Information in the shaded areas } \\
\text { is not required by Federal law. }\end{array}$ \\
\hline \multirow{2}{*}{\multicolumn{3}{|c|}{$\begin{array}{l}\text { 3. Generator's Name and Malling Address } \\
\text { Idaho National Engineexing and Environmental Iaboratory 0.S. } \\
\text { DOF, P.O. Box 1625, Idaho Falls, ID } 83415-4105\end{array}$}} & \multicolumn{2}{|c|}{ A. State Manifest Document Number } \\
\hline & & & \multicolumn{2}{|c|}{ B. State Generator's ID } \\
\hline \multirow{2}{*}{\multicolumn{2}{|c|}{$\begin{array}{l}\text { 5. Transporter } 1 \text { Company Name } \\
\text { Tri-state Motor Transit }\end{array}$}} & \multirow{2}{*}{$\begin{array}{l}\text { 6. US EPA ID Number } \\
\text { MOR000505347 }\end{array}$} & \multicolumn{2}{|c|}{ C. State Transporter's ID } \\
\hline & & & D. Transpe & ter's Phone (208) 232-3445 \\
\hline \multirow{2}{*}{\multicolumn{2}{|c|}{ 7. Transporter 2 Company Name }} & \multirow[t]{2}{*}{ 8. US EPA ID Number } & \multicolumn{2}{|c|}{ E. State Transporter's ID } \\
\hline & & & F. Transpo & er's Phone: ? \\
\hline \multicolumn{2}{|l|}{$\begin{array}{l}\text { 9. Designated Facility Name and Si } \\
\text { Materials and Energy } \\
\text { ETrP } 2010 \text { Eighway } 58 \\
\text { Oakridge, TI } 37830\end{array}$} & 10. US EPA ID Number & \multicolumn{2}{|c|}{ G. State Facility's 10 Faclity's Phone } \\
\hline
\end{tabular}

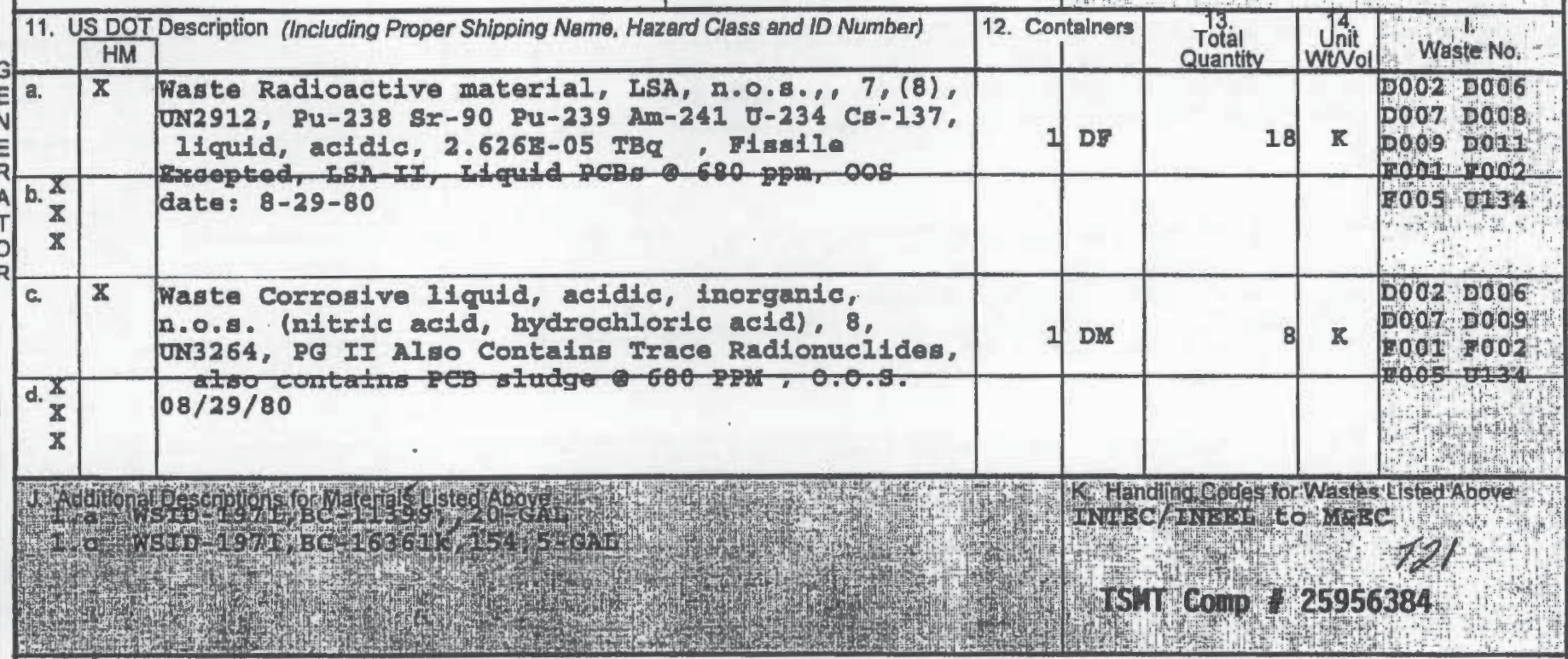

15. Special Handling Instructions and Additional Information

Return signed original to: $\mathbf{A}$. Rutledge Idaho Vationai Ingineering a Evironmental.

Laboratory/0g DOF, P.0. Box 1625, Idaho Fal1s, ID 83415-4105. Prepared under contract \#DEAC07 99ID 13727. USDOE 24-Ix. Emergency Phone: 208 526-1515. Exelusive Use 8hipment

16. GENERATOR'S CERTIFICATION: I hereby dedare that the contents of this consignment are fully and accurately described above by proper shipping name and are classtified, packed, marked, and labeled, and are in all respects in proper condition for transport by highway according to applicable internatlonal and national government regulations.

If I am a large quanttly generator, I certily that I have a program in place to reduce the volume and toxicly of waste generated to the degree I have determined to be economicaly practicable and that I have selected the practicable method of treatment, storage, or disposal currentty avallable to me which minimizes the present and future threat to human healih and the environment OR, II I am a small quantily generator, I have made gooed faith affort to minimize my wasto generabion and select the best waste management method that is avallable to me and that I can afford. Printed/Typed Name

\section{Stephen Keating}

17. Transporter 1 Acknowledgement of Receipt of Materials

PrintedTyped Nangy 18. Transporter 2 Acknowledgeprent of Receipt of Materials Printed/Typed Name

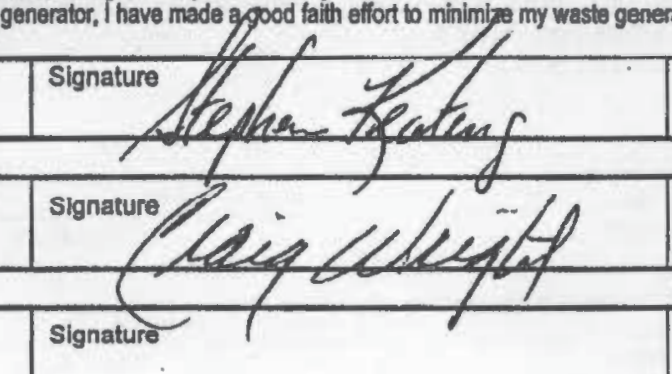

19. Discrepancy Indication Space

A

i

1 20. Facility Owner or Operator: Certification of receipt of hazardous materials covered by this manifest except as noted in ltem 19.

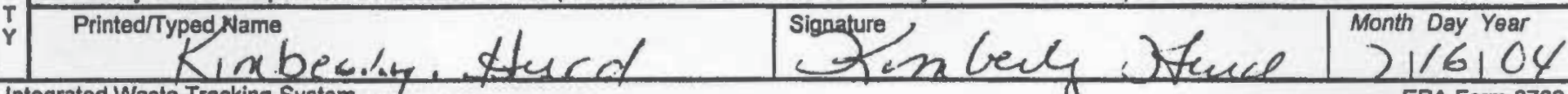
Integrated Waste Tracking System RECEIVED AU6 2 200h

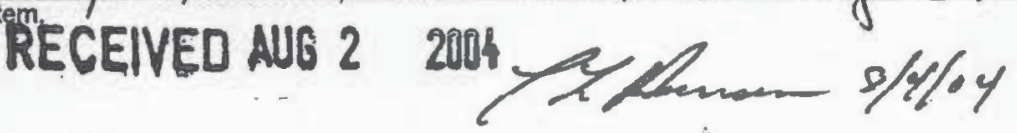




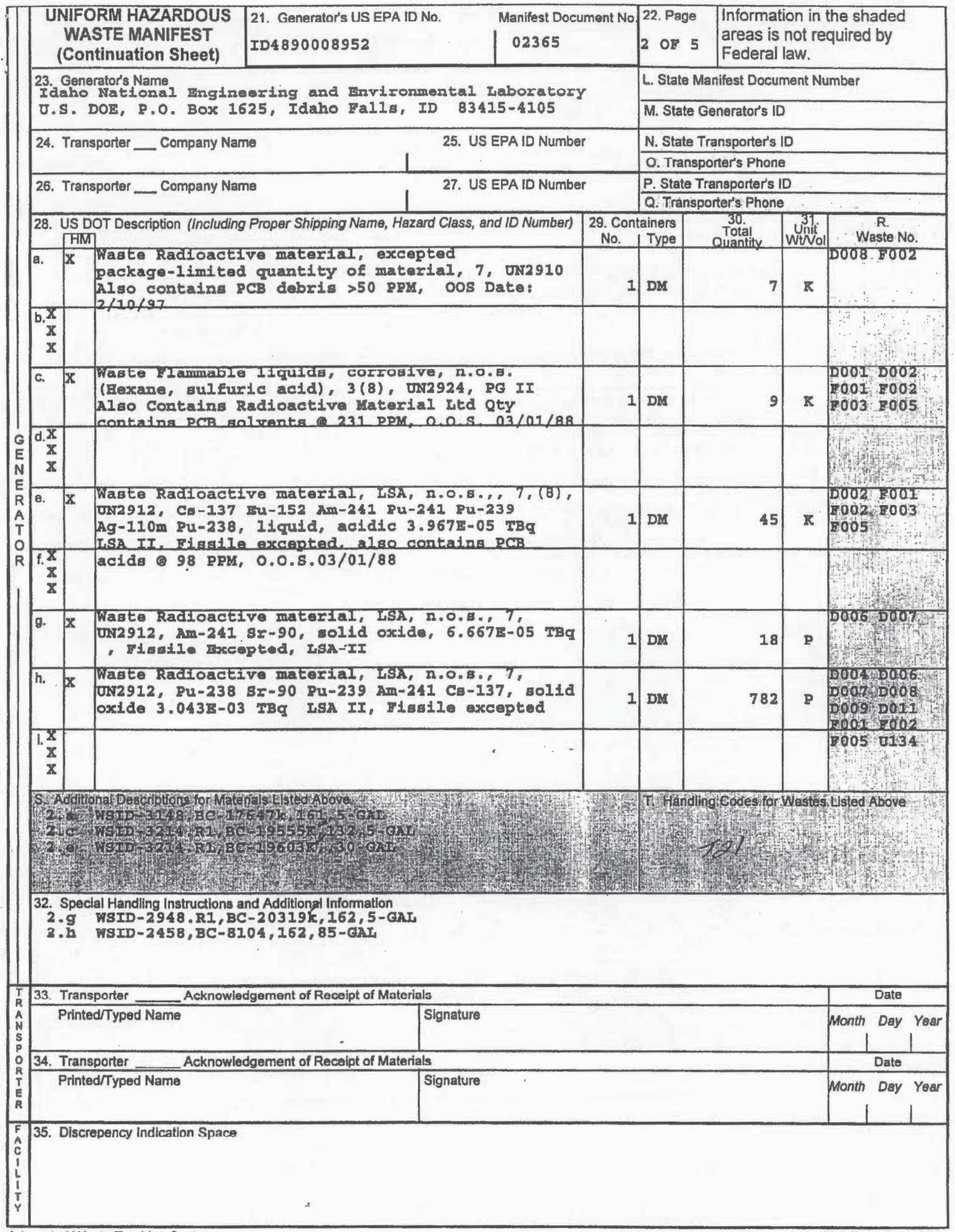




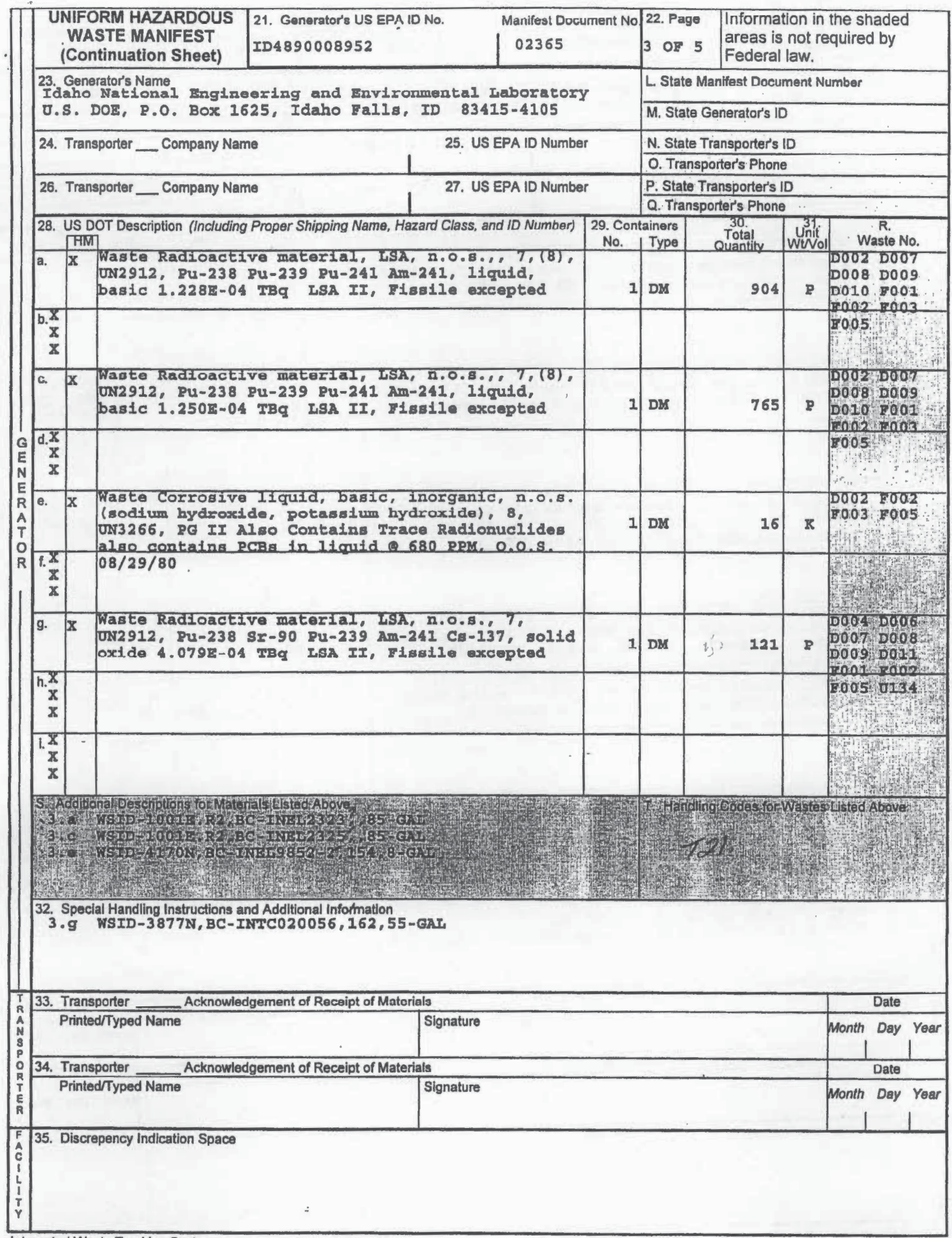




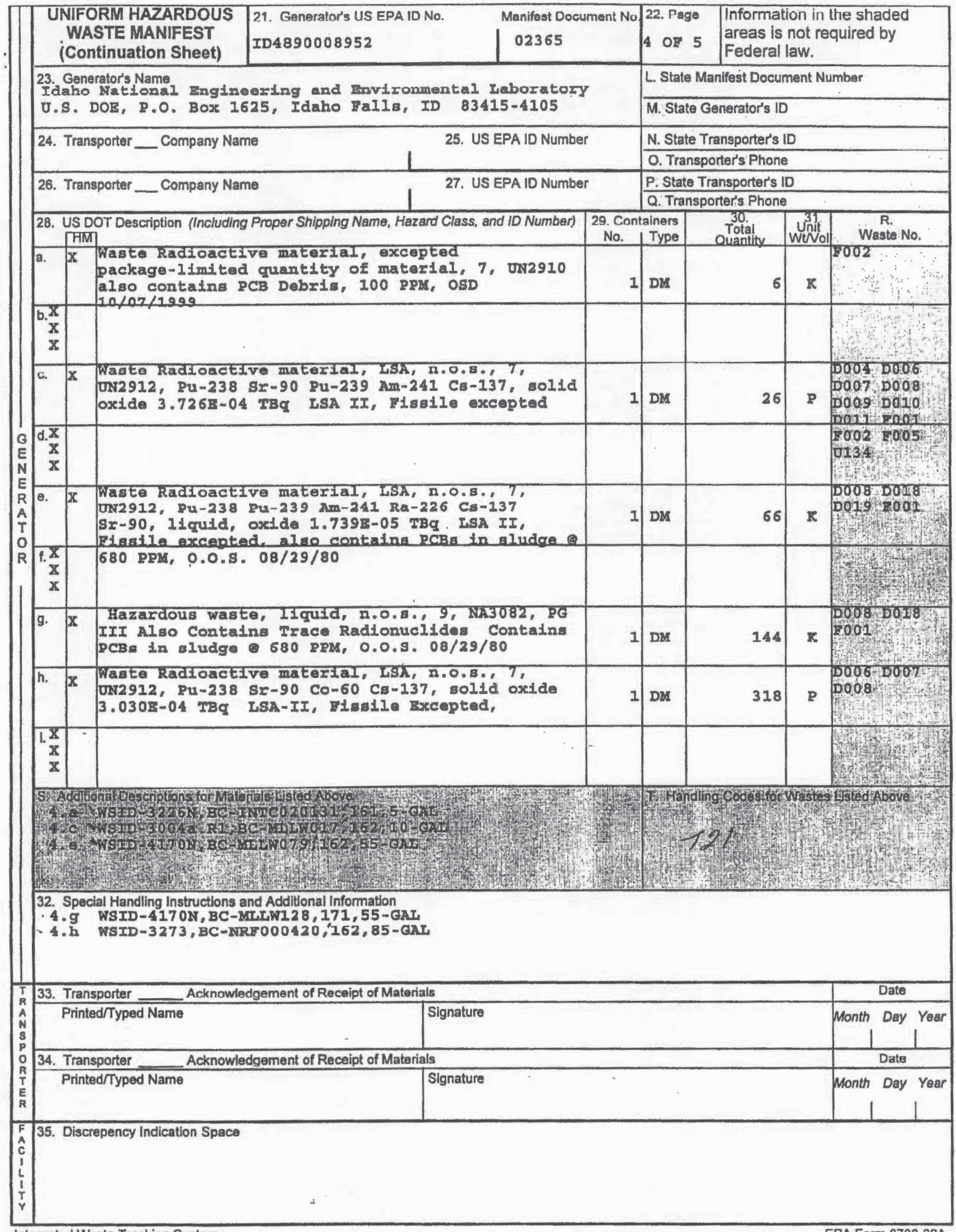




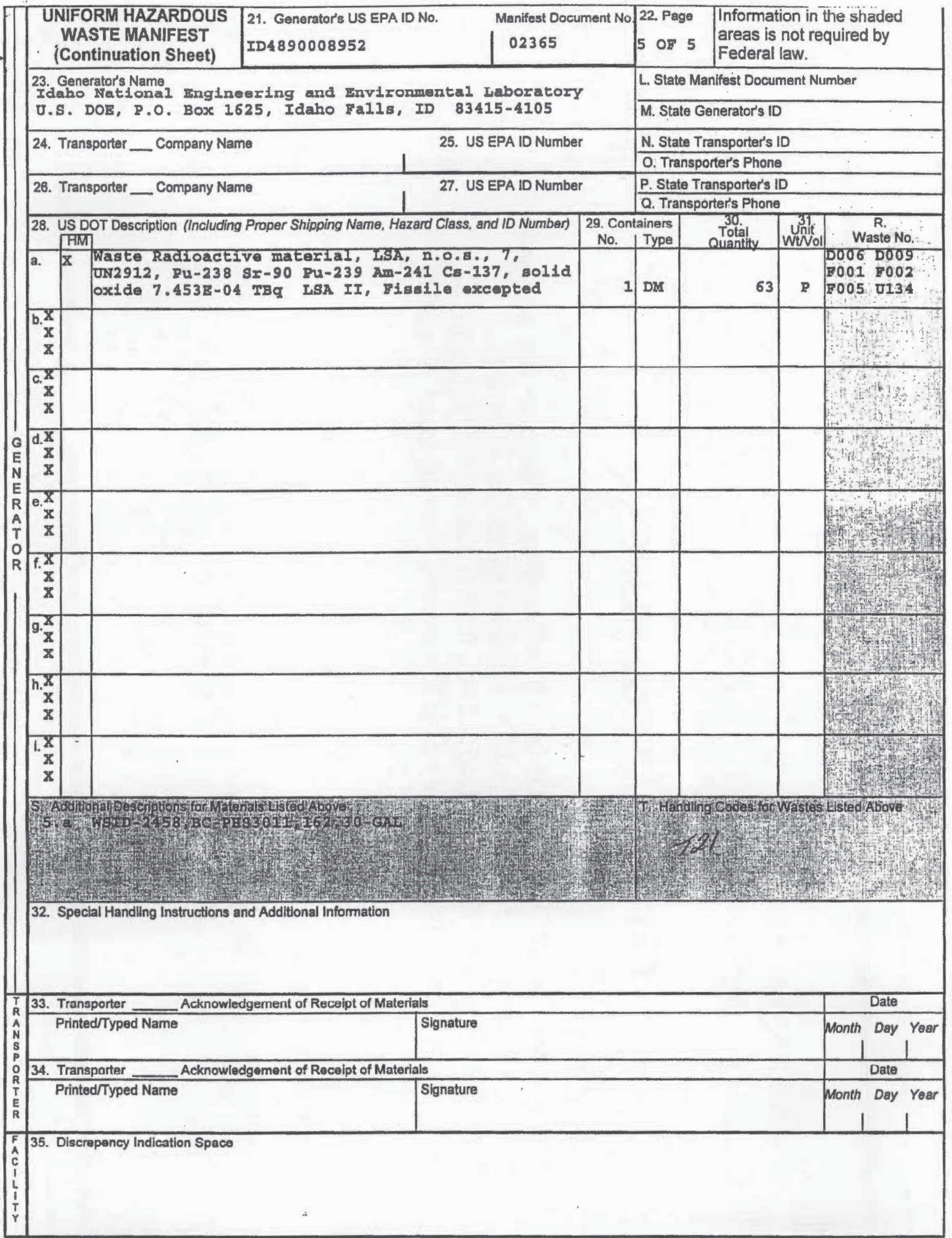




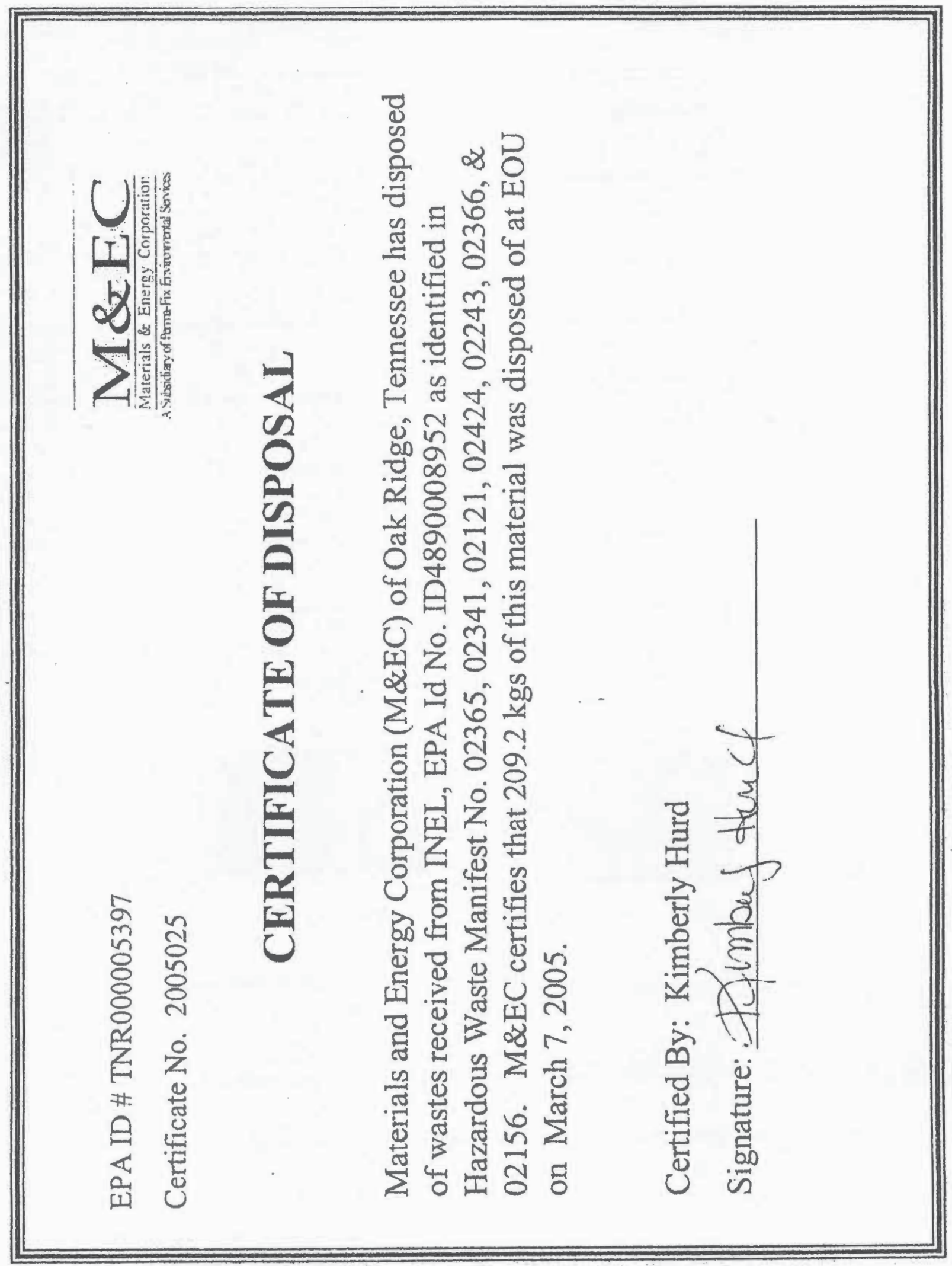




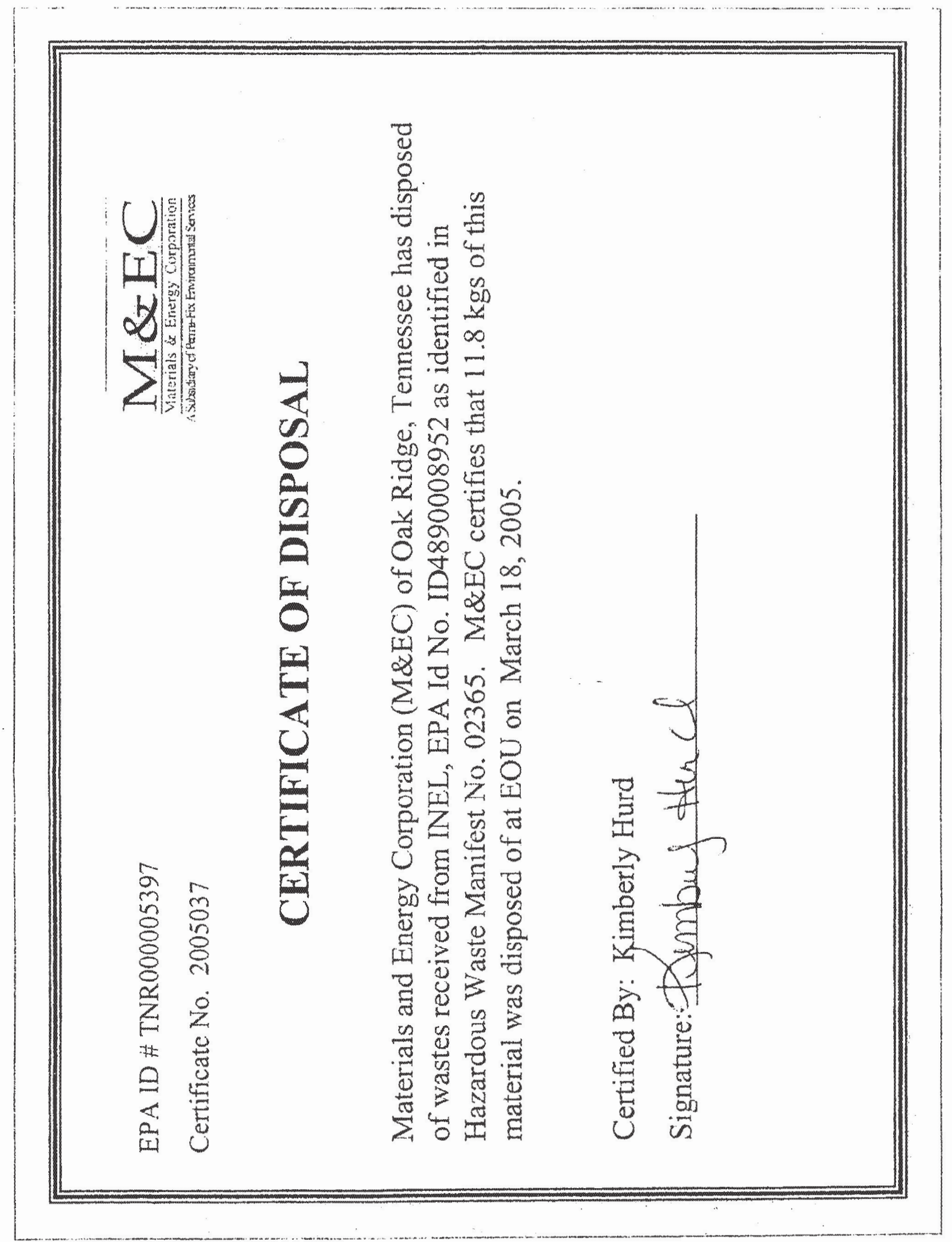




- IITORM HAZARDOUS WASTE MANIFEST
1. Generator's US EPA ID No. ID6890190089
Manifest
Document No. 02368

3. Generator's Name and Mailing Address

Idaho National Enginearing and Environmental Iaboratory 0.5 . DOE, P.O. BOX 1625, Idaho Falls, ID 83415-4105

4. Generator's Phone (208) $526-2414$

5. Transporter 1 Company Name Clean Barbor: Environmental services

6. US EPA ID Number

7. Transporter 2 Company Name

月, MND039322250

9. Pesignated Facility Name and Site Address

(aragonite) IIC

11600 North Aptus Road

Aragonita, UT 84029
8. US EPA IO Number

10. US EPA ID Number

UTD981552177 \begin{tabular}{c|c}
\hline 2. Page & $\begin{array}{l}\text { information in the shaded areas } \\
\text { is not required by Federal law. }\end{array}$ \\
of 1 &
\end{tabular}

A. State Marifest Document Number

B. State Generator's ID

ID6890190089

C. State Transporter's id

D. Transporter's Phone (801) 849-1800

E. State Transporter's ID

F Transporter's Phone ( ) =

G. State Facilly's ID

H. Facillty's Phone

(801) $323-8100$

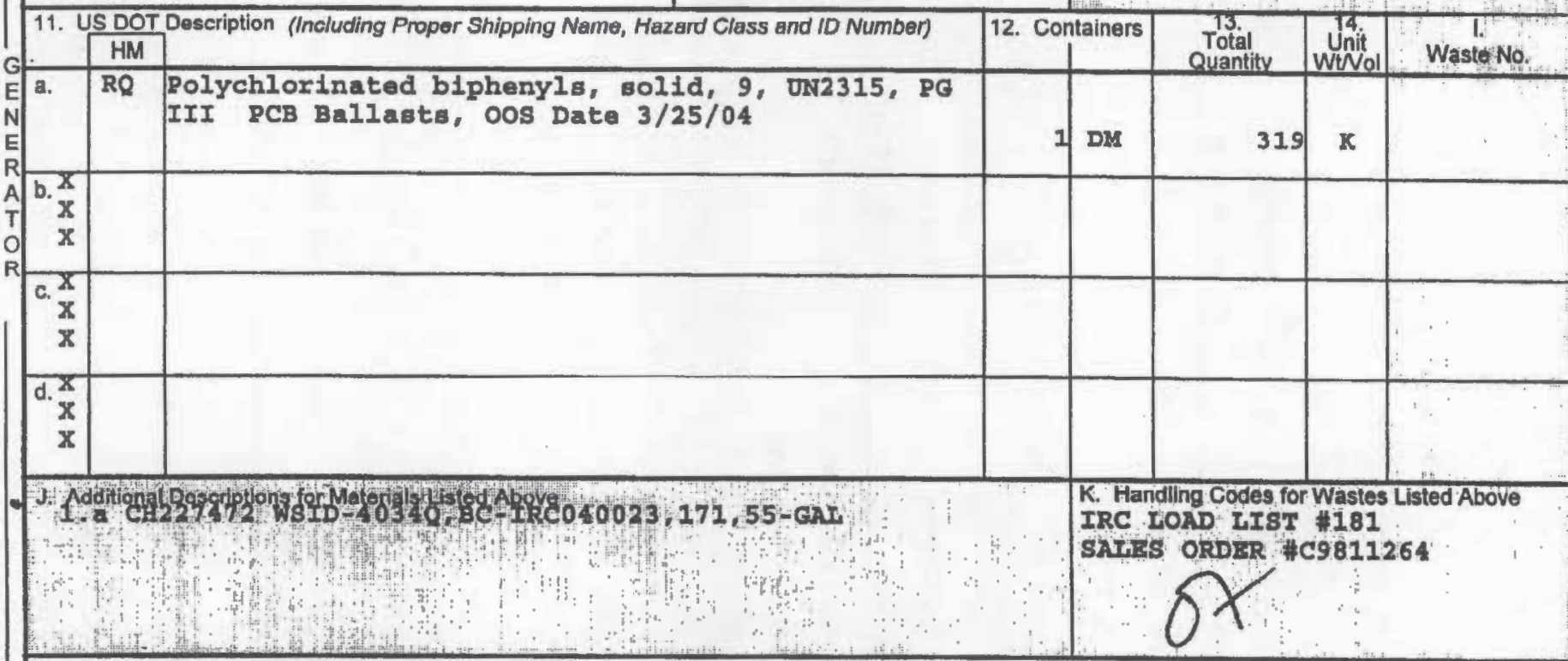

15. Special Handling Instructions and Additional Information

Return signed original to: B.A. Rutledge, Idaho National Ingineering Invironnental Iaboratory/us DOR. P.O. Box 1625, Idako Falls, ID 83415-4105. Prepared under contract \#DEAC07 99ID 13727. USDOE 24-Ex. Emargency Phone: (208) 526-1515.

16. GENERATOR'S CERTIFICATION: I hereby declare that the contents ol this consignment are fully and accurately described above by proper shipping name and are classified, packed, marked, and labeled, and are in all respects in proper condition for transport by highway according to applicable international and national govemment regulations.

III am a large quantity generator, I certify that I have a program in place to reduce the volume and toxicity of waste generated to the degree I have detemined to be economically practicable and that I have selected the practicable method of treatment, storage, or disposal currenty avallable to me which minimizes the present and future threat to human health and the environment; $O R$, if I am a small quantily generator, I have made a good falth ellort to minimize my waste generalion and select the best waste management method that is available to me and that I can afford

Printed/Typed Name

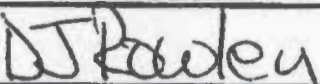

17. Transporter 1 Acknowledgement of Receipt of Naterials

Printed/Typed Namp
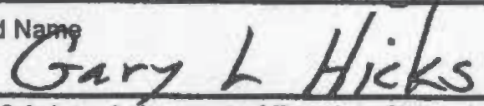

18. Transporter 2 Acknowledgement of Receipt of Materials

Printed/Typed Name

Signature
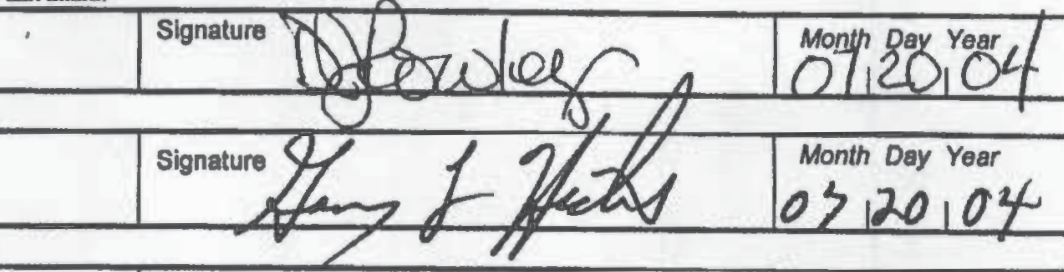

Signature

Month Day Year

19. Discrepancy Indication Space

A

A

20. Facility Owner or Operator. Certification of receipt of hazardous materials co fered by thits manifest except as noted in ltem 19.

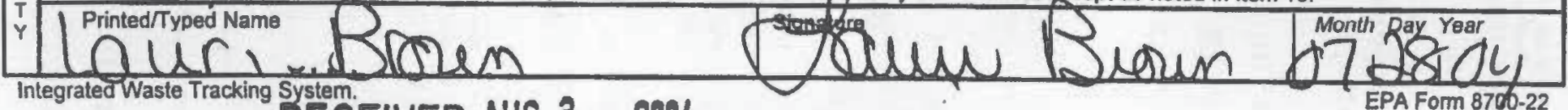

Integrated Waste Tracking System. RECEIVED AUG 320144 

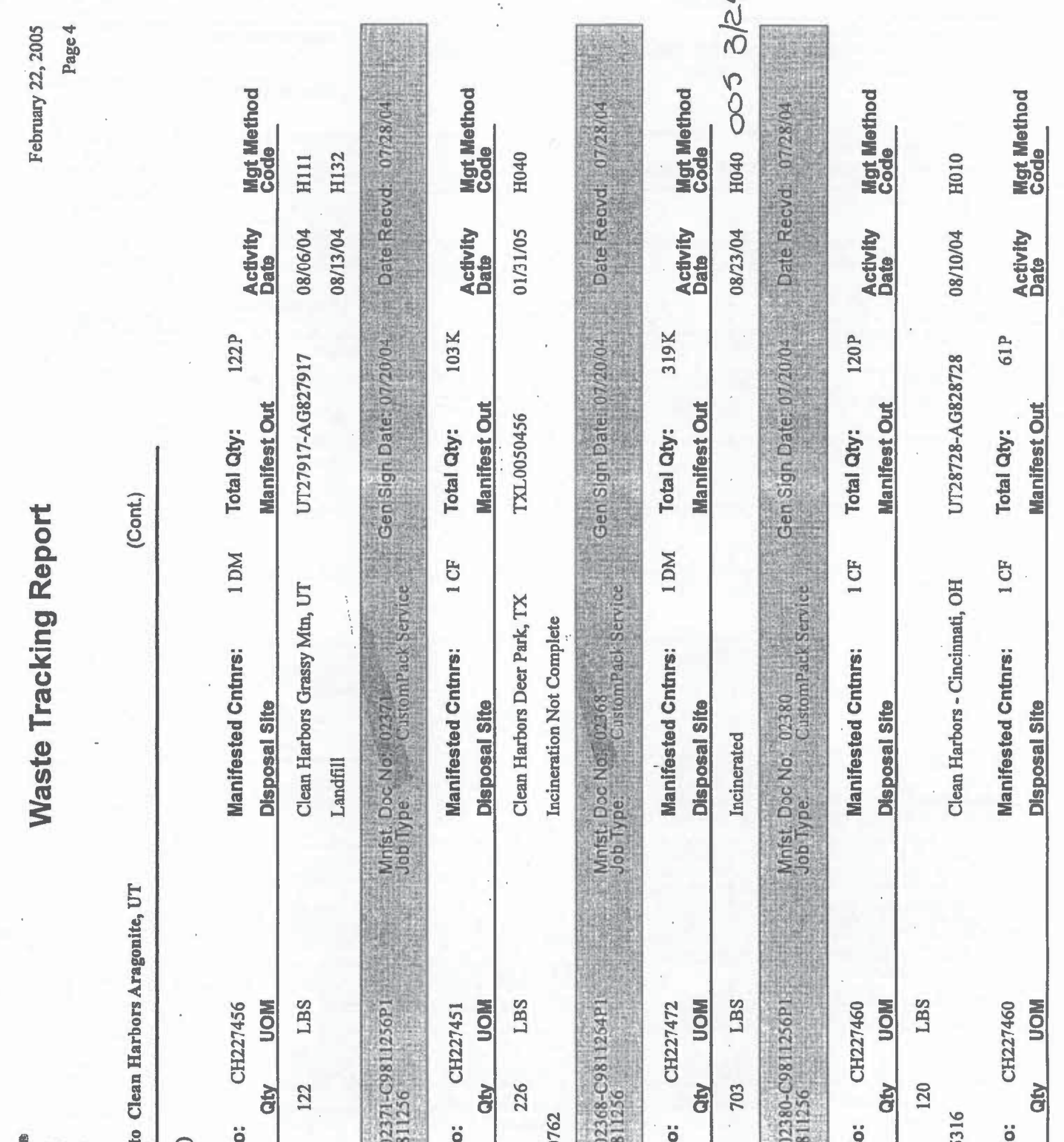

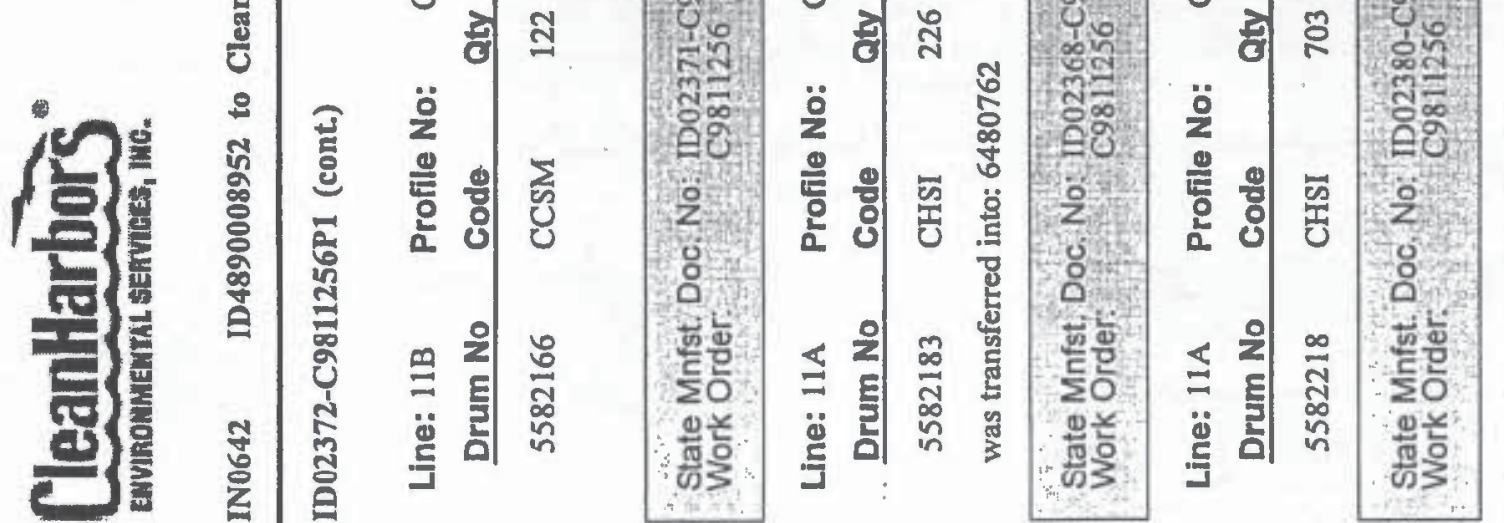

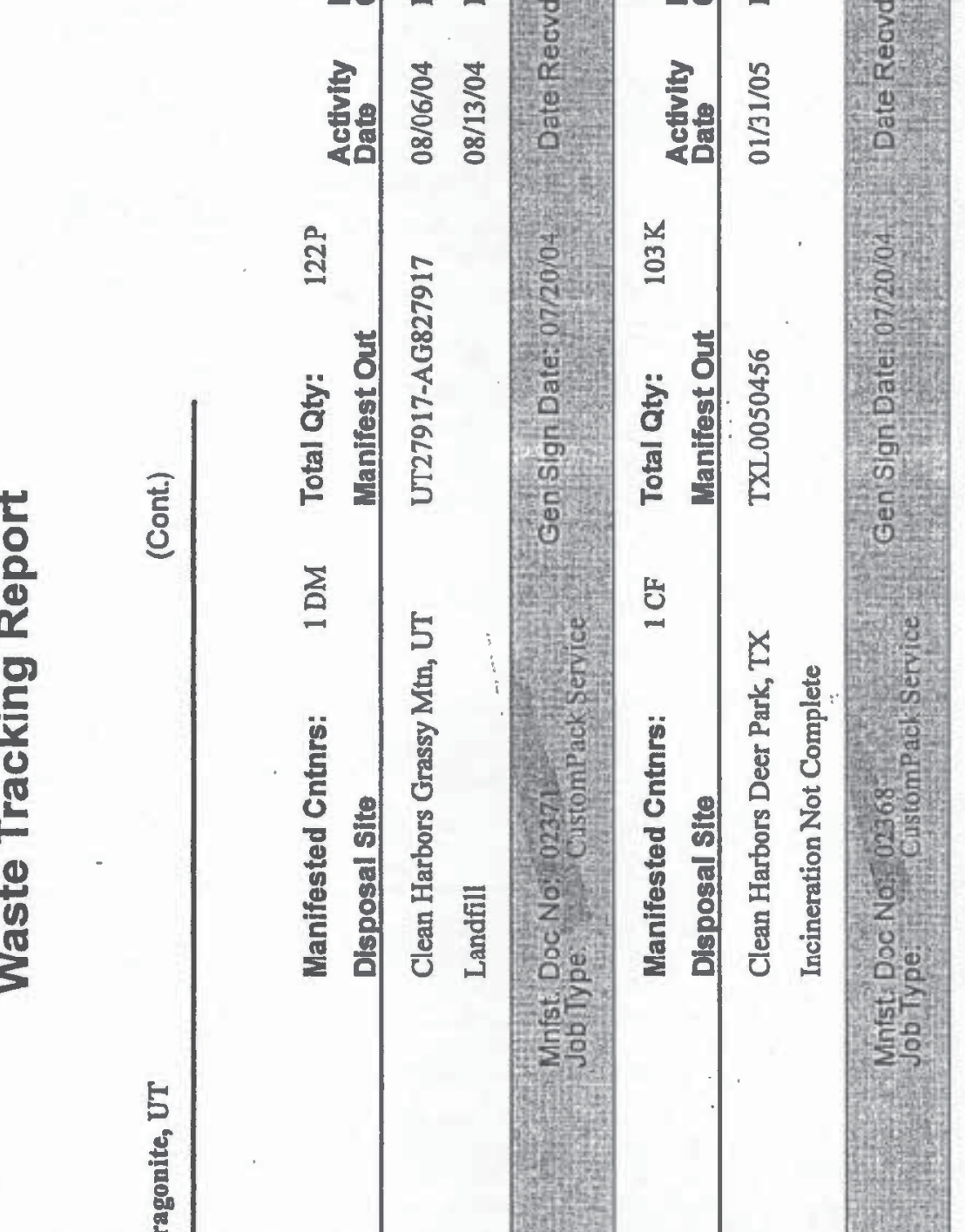

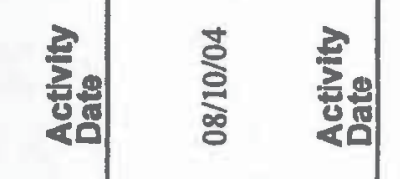

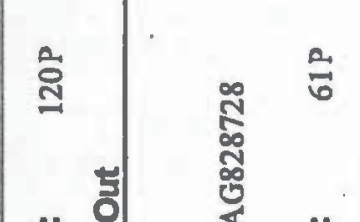
苍

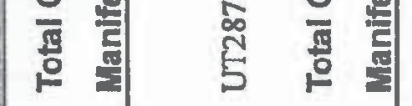
吉

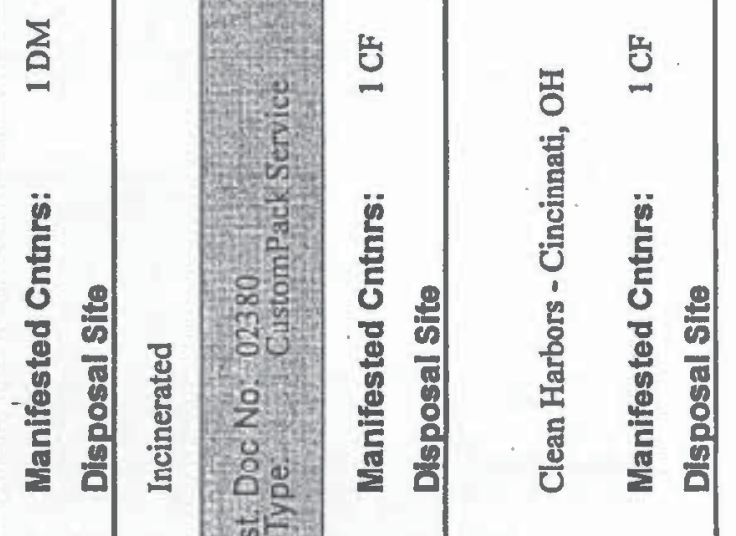
>5.

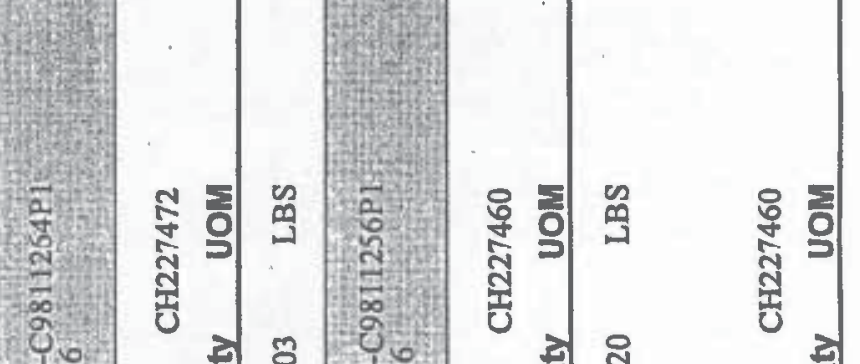

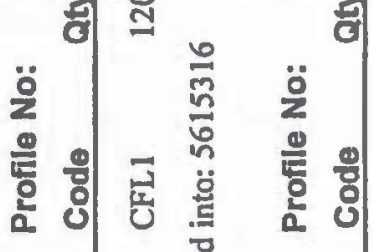
च

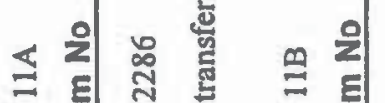

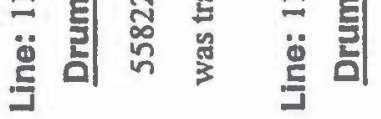



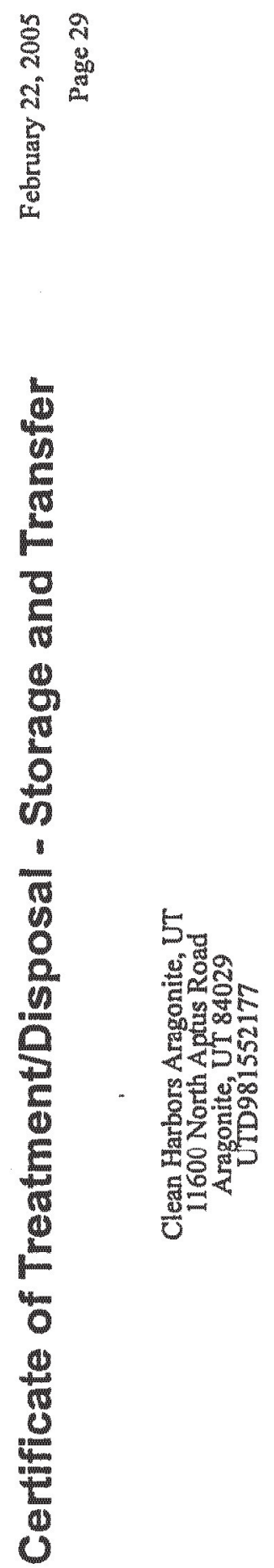

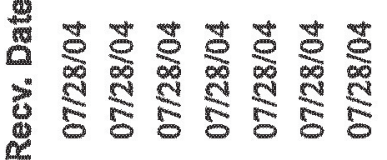
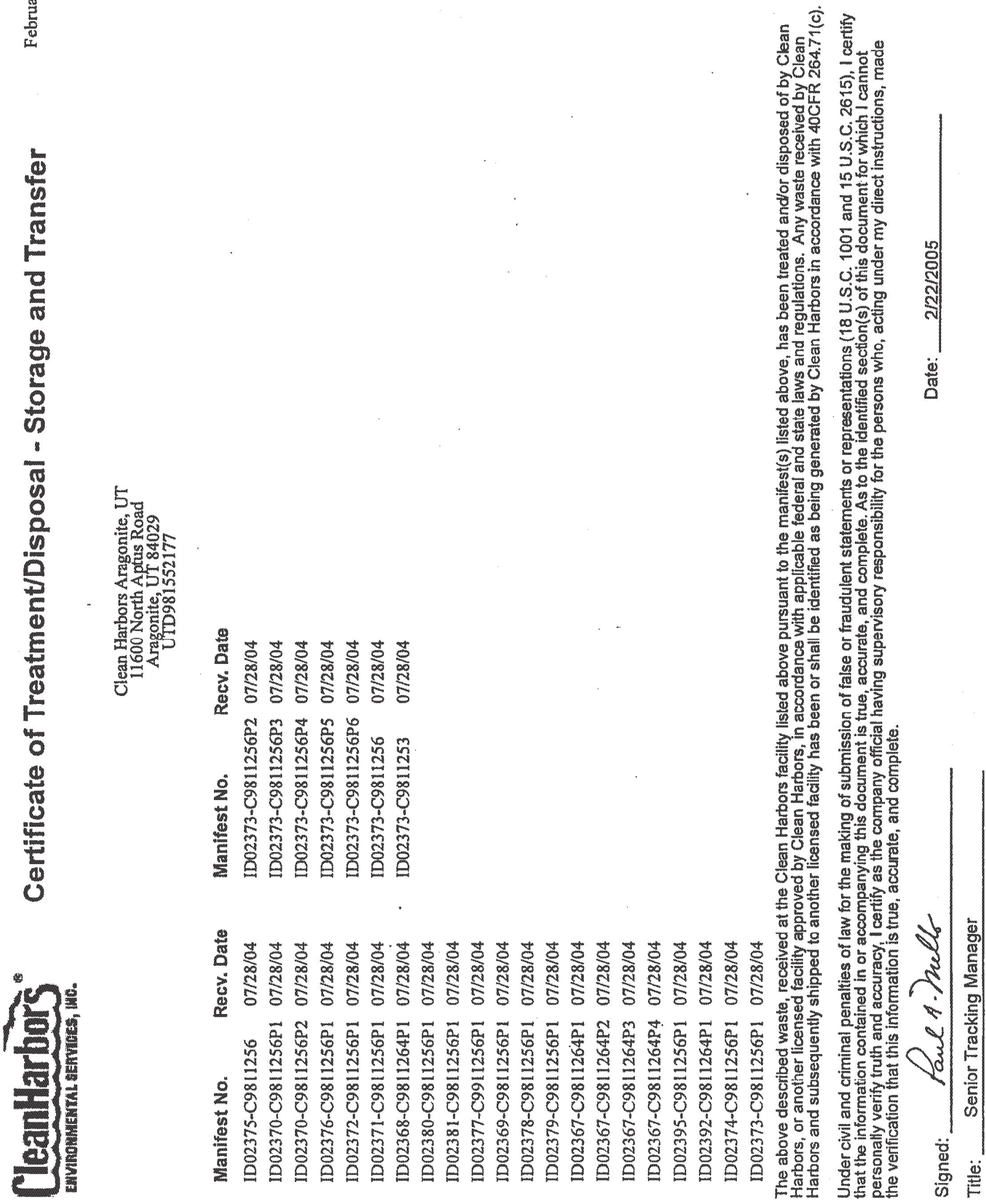

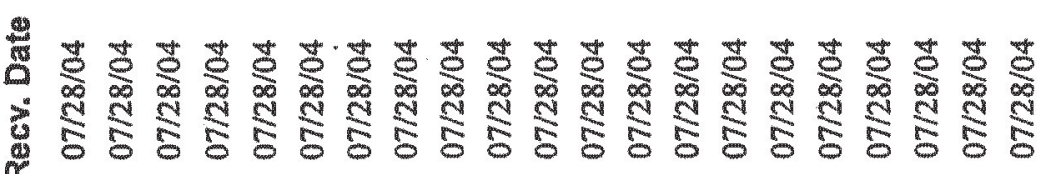

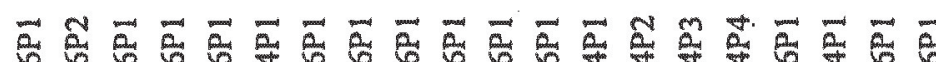

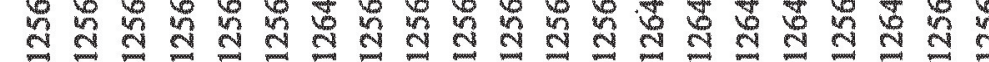

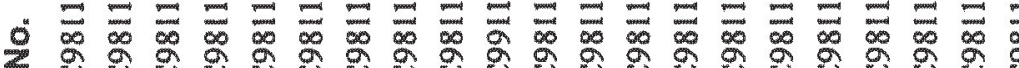

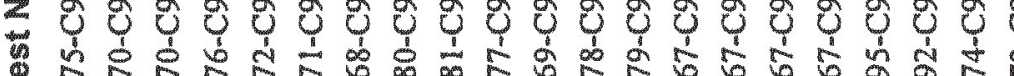

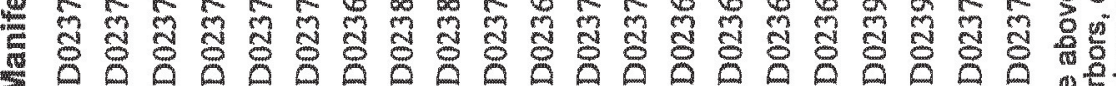



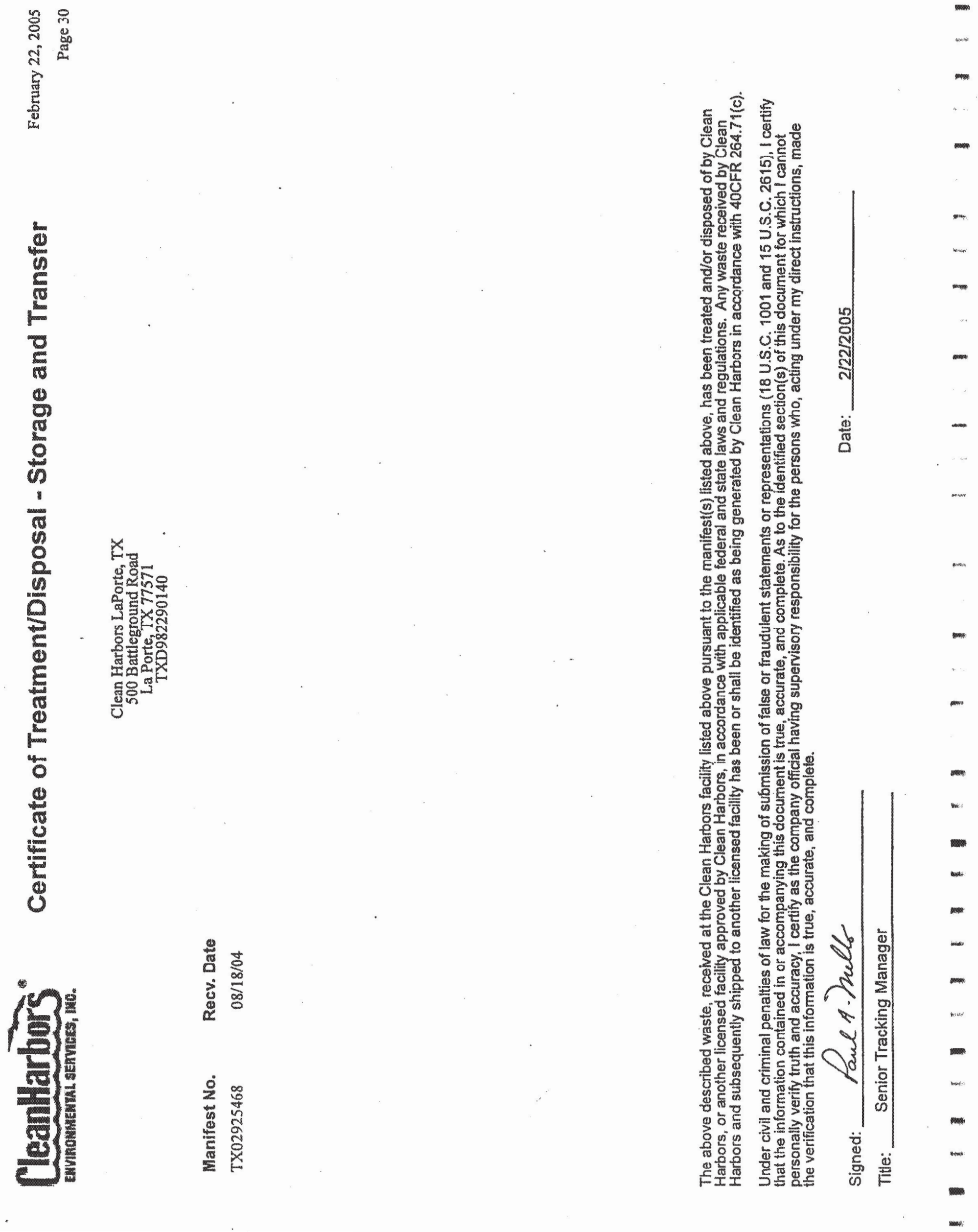



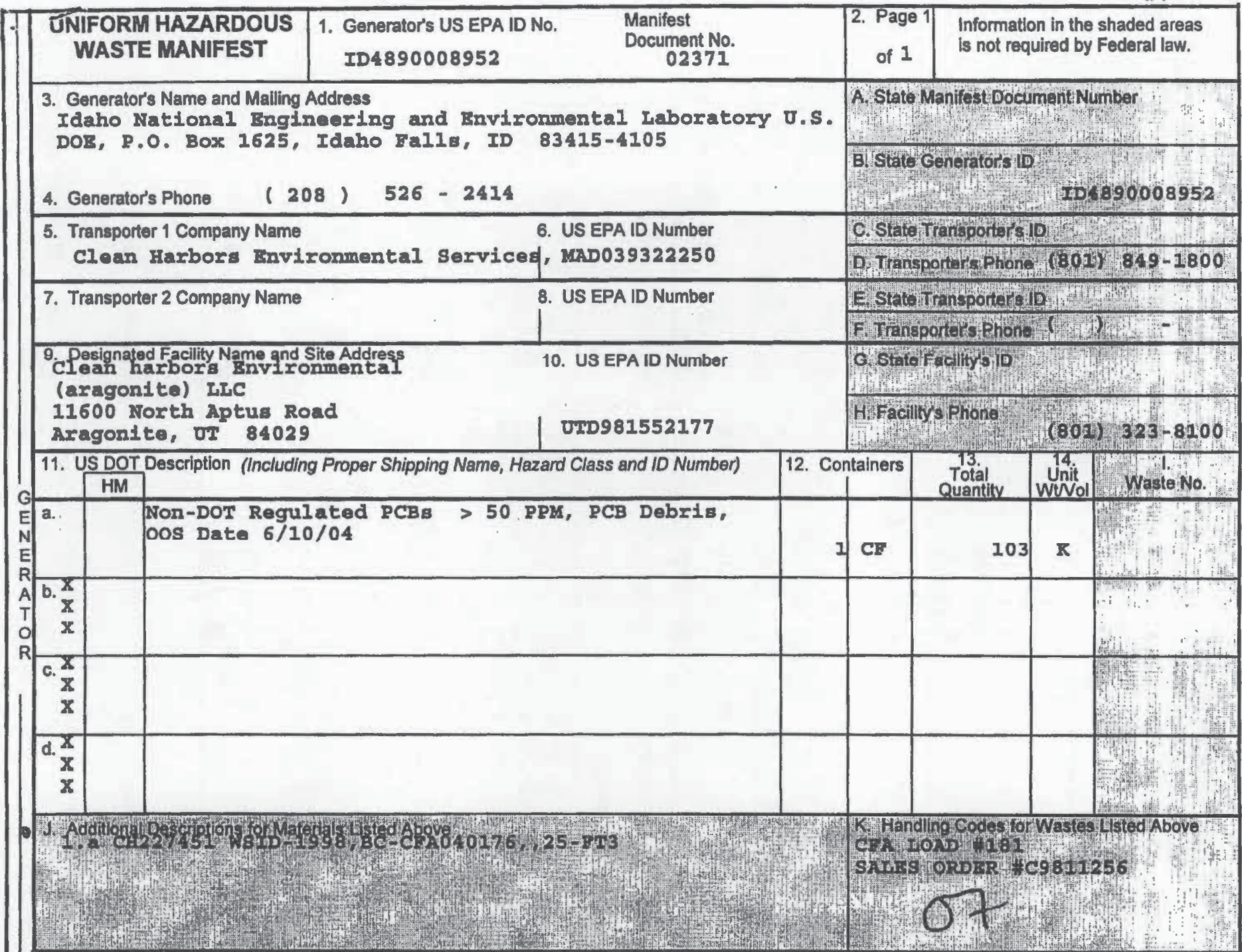

15. Special Handling Instructions and Additional Information

Return sigmed original to: B.X. Rutledge, Idaho National Inginearing E Evironmental

Iaboratory/OS DOE, P.O. Box 1625, Idaho Falis, ID 83415-4105. Prepared under contract \#DEAC07 99ID 13727. USDOZ 24-Kr. Imergency Phone: (208) 526-1515.

16. GENERATOR'S CERTIFICATION: I hereby declare that the contents of this consignment are fully and accurately described above by proper shippling name and are classilied, packed, marked, and labeled, and are in all respects in proper condlition for trensport by highway according to applicable international and national government regulations.

If I am a large quantity generator, I certify that I have a program in place to reduce the volume and toxicity of waste generated to the degree I have determined to be economicaliy practicable and that I have selected the practicable method of treatment, storage, or disposal currenty avallable to me which minimizes the present and future threat to human health and the environment; OR, III am a small quantity generator, I have made a good faith effort to minimize my waste generation and select the best waste management method that is avallable to me and that I can afford.

Printed/Typed Name JTROX oleu

17. Transporter 1 Acknowledgement of Recejpt of Matterials

Printed/Typed Name

18. Transporter 2 Acknowlectement of Receipt of Materials Printed/Typed Name

$\frac{2 \text { Ackno }}{2}$

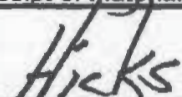

19. Discrepancy Indication Space generato 


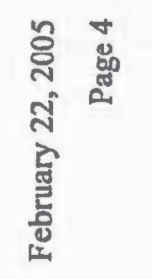



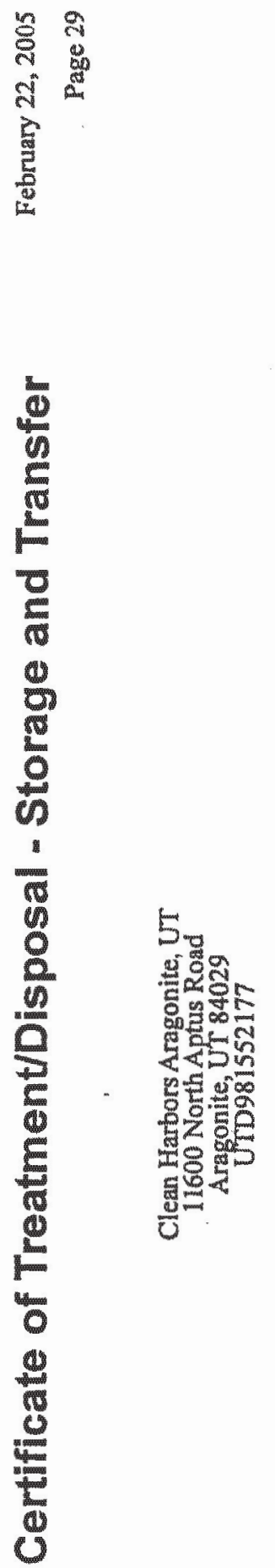

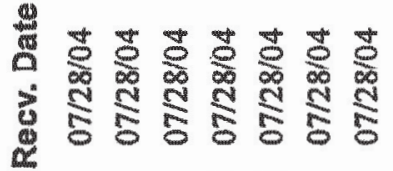
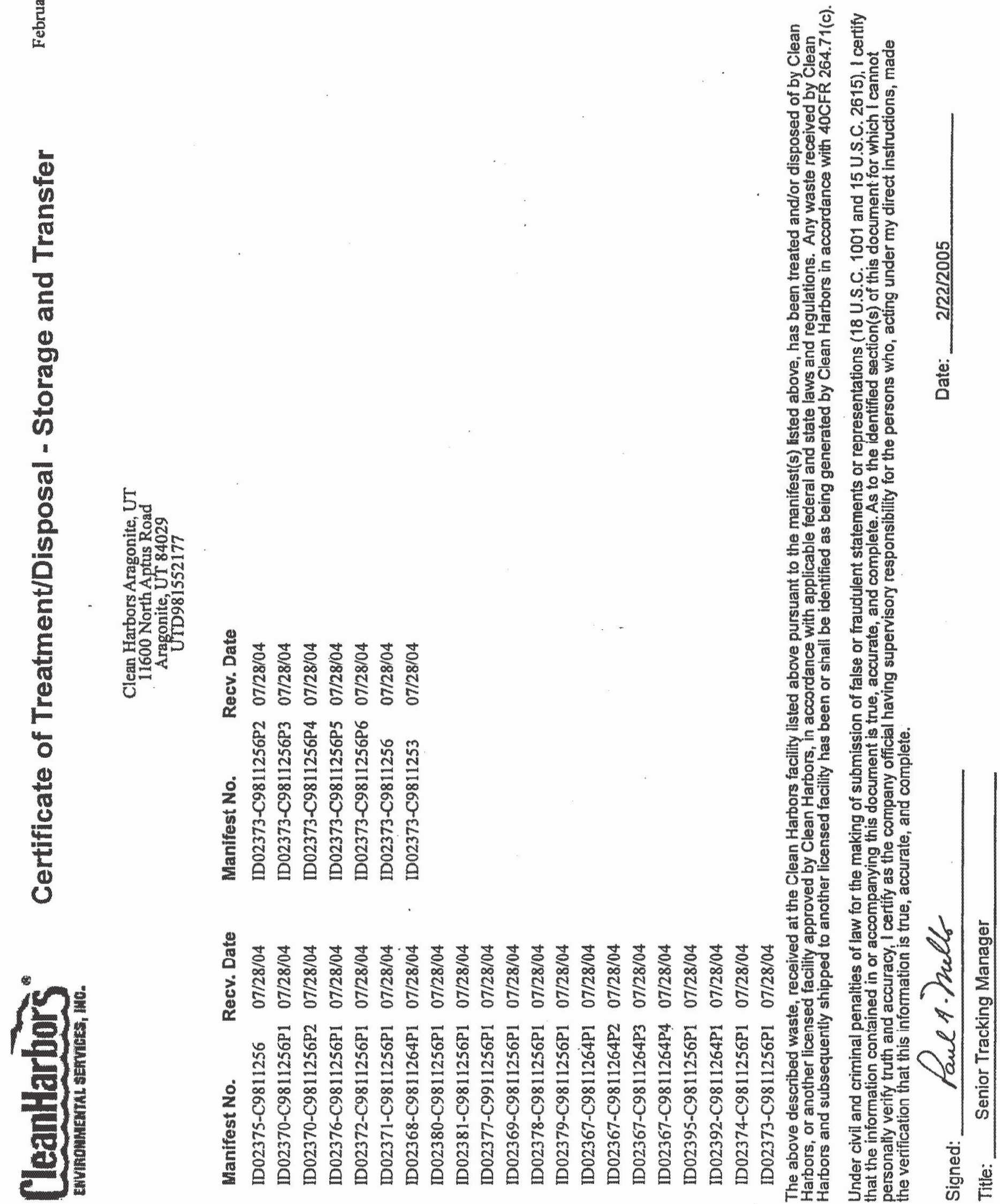

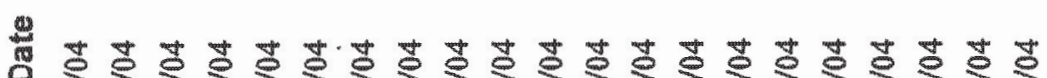

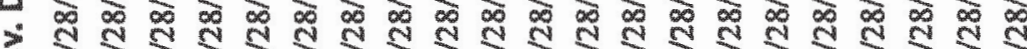

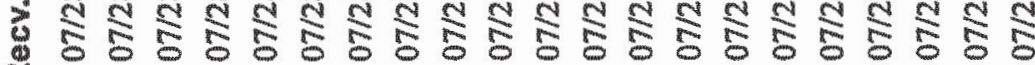

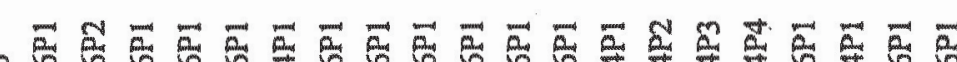

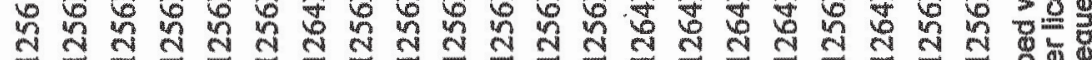

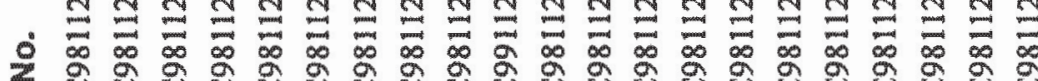
z

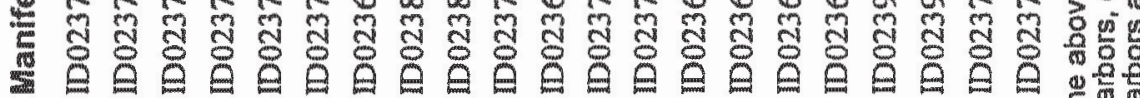



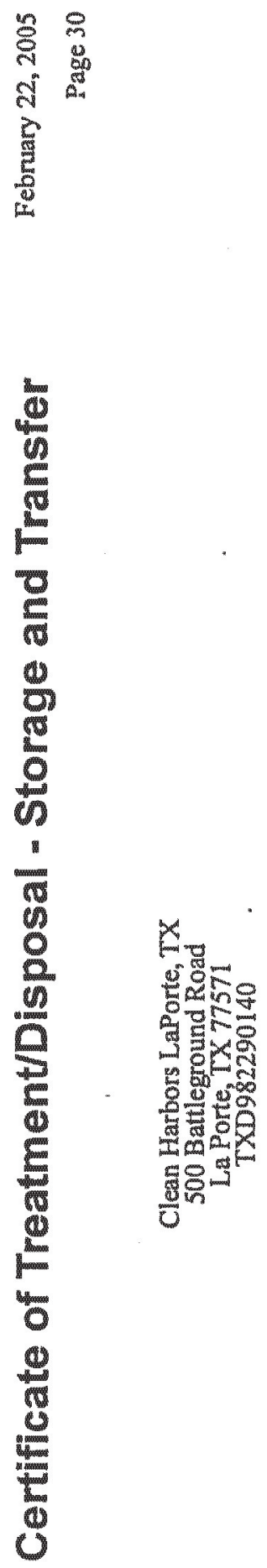

둘

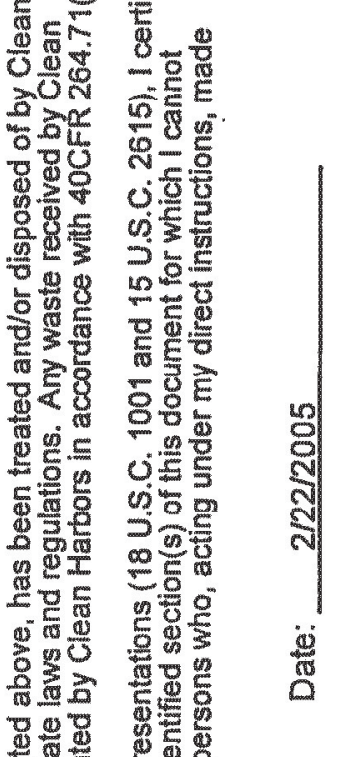

造

홍류

당

영므

운

ơㅇํㅇ

E.

의

$5=$

⿷匚

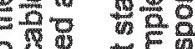

요을

$\mathrm{s}$

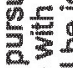

당

흠듣

है․․

흘 흥

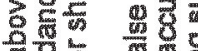

뚠

क

뜸

둥

2.5

농용

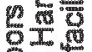

둥

䟢

\% 3.

0 氙

$+0 \frac{2}{0}$

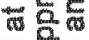

8
0
0
0

5 훙응

골 들

훙은믈

을 8

훈

4 $\sum 0$

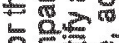

을륭류

융응

$\frac{2}{8}$

눈.을
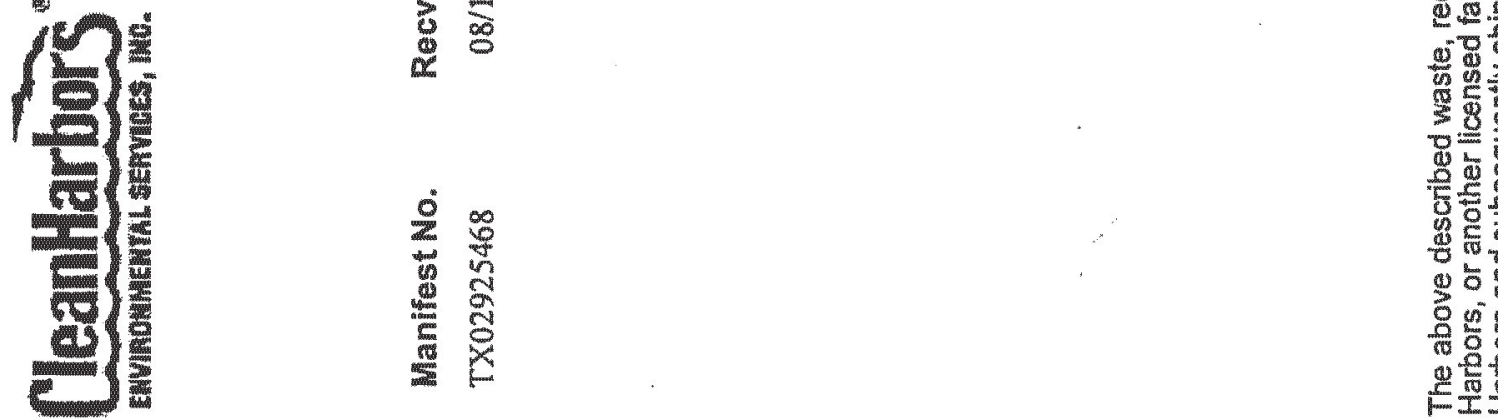

w

0 :

몬드 5 ำ

\&

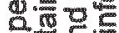

क 55

5855

튼 는

0 한

른

폴

동

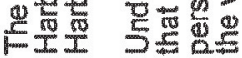

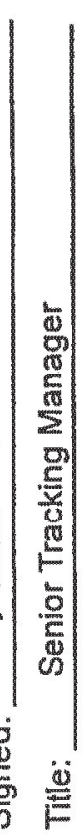




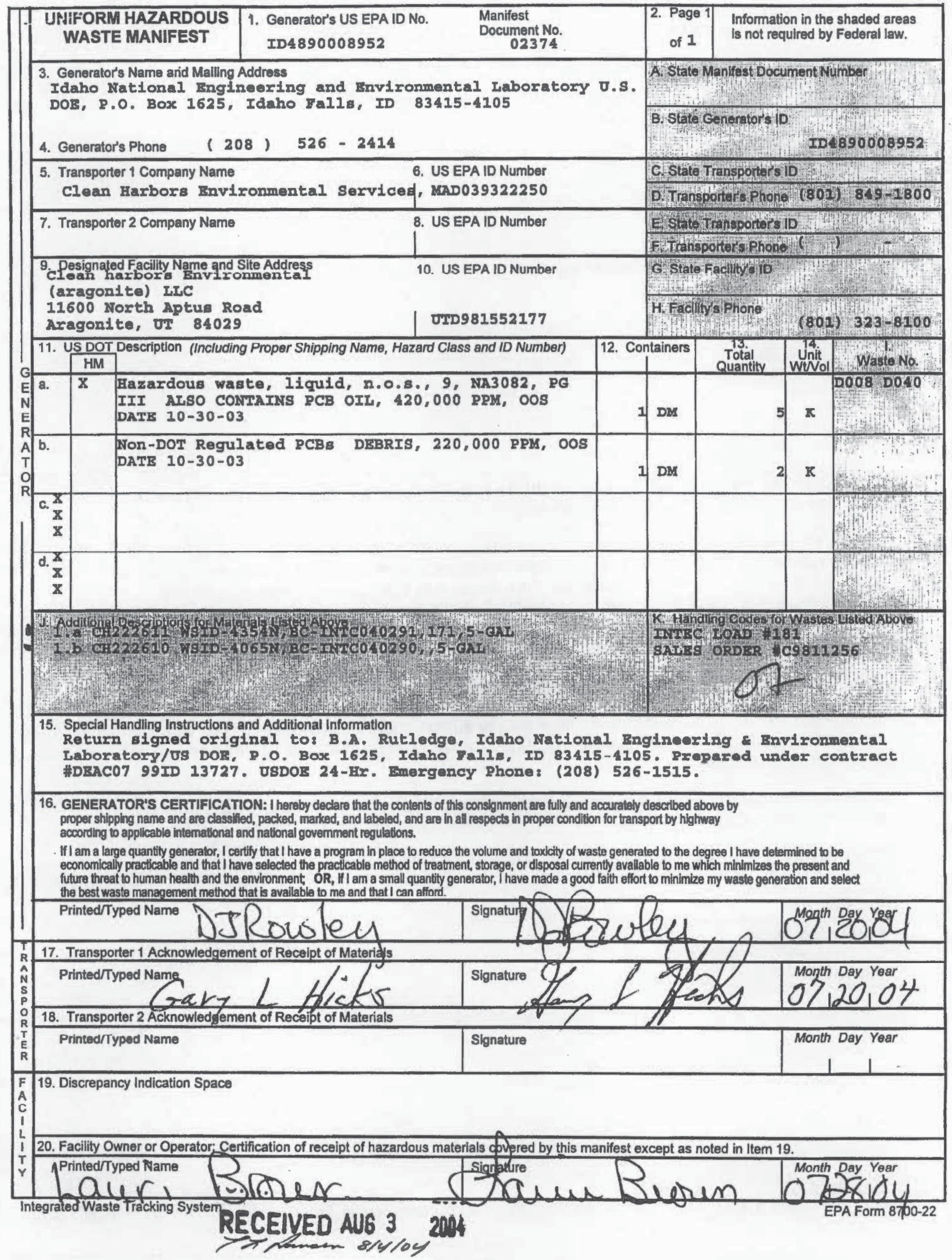


Clean Harbors Aragonite LLC

11600 North Aptus Road

Aragonite UT 84029

EPA ID UTD981552177

November 11, 2004

DJ ROWLEY

Ineel US DOE

47 miles West of Idaho Falls on US Hwy 20

SCOVILLE ID, 83415

Re: Certificates of Disposal

Dear DJ ROWLEY

This letter and the attached CD Log constitute your Certificate(s) of Disposal for the waste that was shipped to our facility for disposal.

This is to certify that the waste referenced on the attached CD Log and manifested to the above referenced Clean Harbors facility was processed and disposed of in accordance with 40 CFR 761 (and 40 CFR 264 if applicable). Your waste has been properly treated and any residue from this waste has been disposed of at an approved and permitted Facility.

Under civil and criminal penalties of law for the making or submission of false or fraudulent statements or representations (18 U.S.C. 1001 and U.S.C. 2615). I certify that the information contained in or accompanying this document is true, accurate and complete. As to the identifled section(s) of this document for which I cannot personally verify truth and accuracy, I certify as the company official having supervisory responsibility for the persons who, acting under my direct instructions, made the verification that this information is true accurate, and complete.

Clean Harbors appreciates you as a valued customer. If you should have any questions or concerns please do not hesitate to contact one of our customer/facility representatives.

Sincerely,

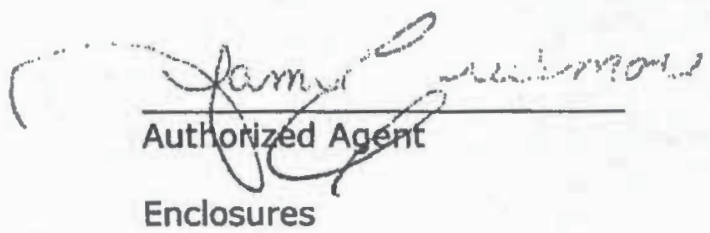


Generator:

CD Nbr

11156843 - 5

Tracking Nbr

5585019
Ineel US DOE 47 miles West of Idaho Falls on US Hwy 20 SCOVILLE, ID 83415

Manifest $\mathrm{Nbr} \quad$ Received Date

Profile $\mathrm{Nbr}$

Order $\mathrm{Nbr}$

C9811256

ID02374-C9811256P1 107/28/2004

Container

Serial Nbr

Tyoe contents

DM Liquid with no solids

Prdcd Sho To

\begin{tabular}{|c|c|}
\hline \multicolumn{2}{|c|}{ Disposal } \\
\hline Methed & Date \\
\hline INCN & $08 / 28 / 2004$ \\
\hline
\end{tabular}




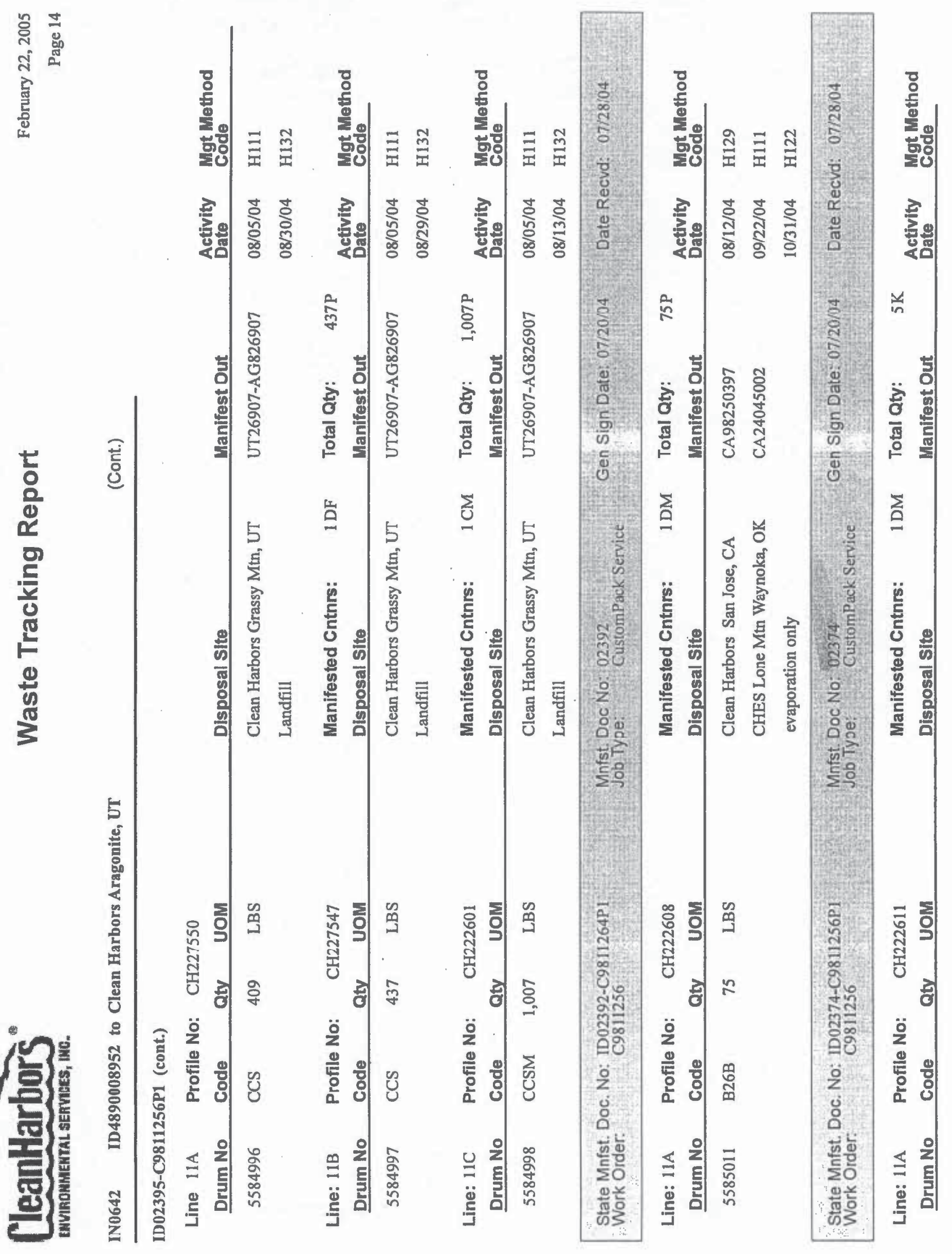



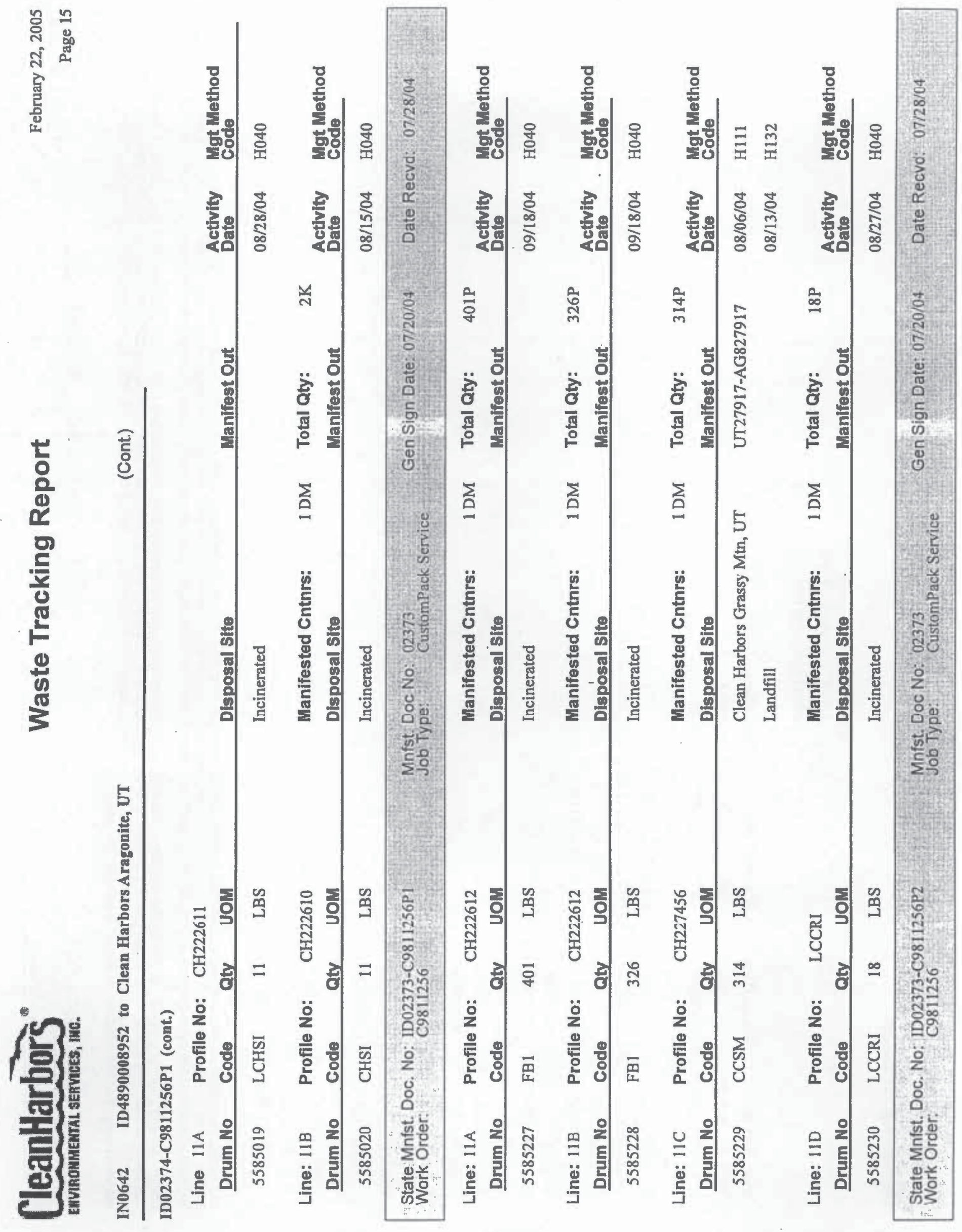

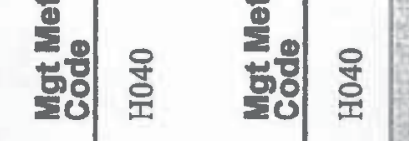

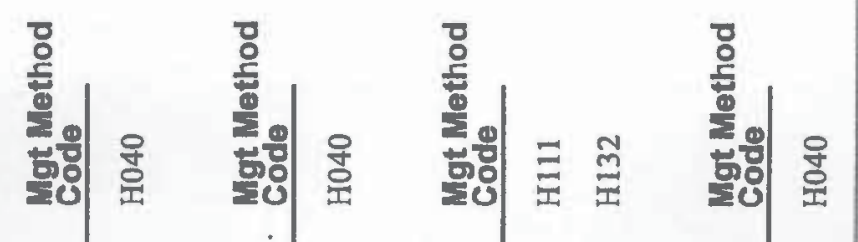

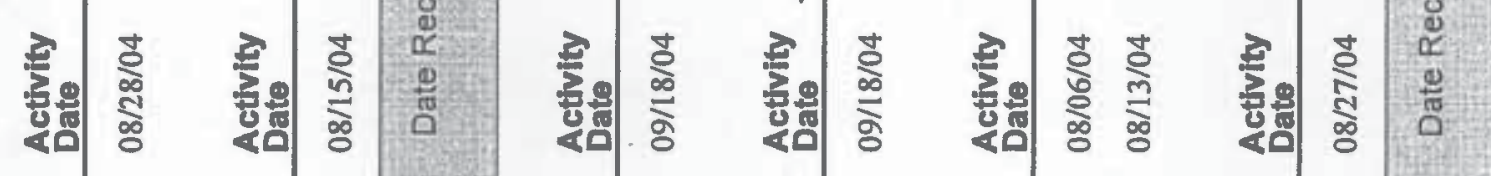



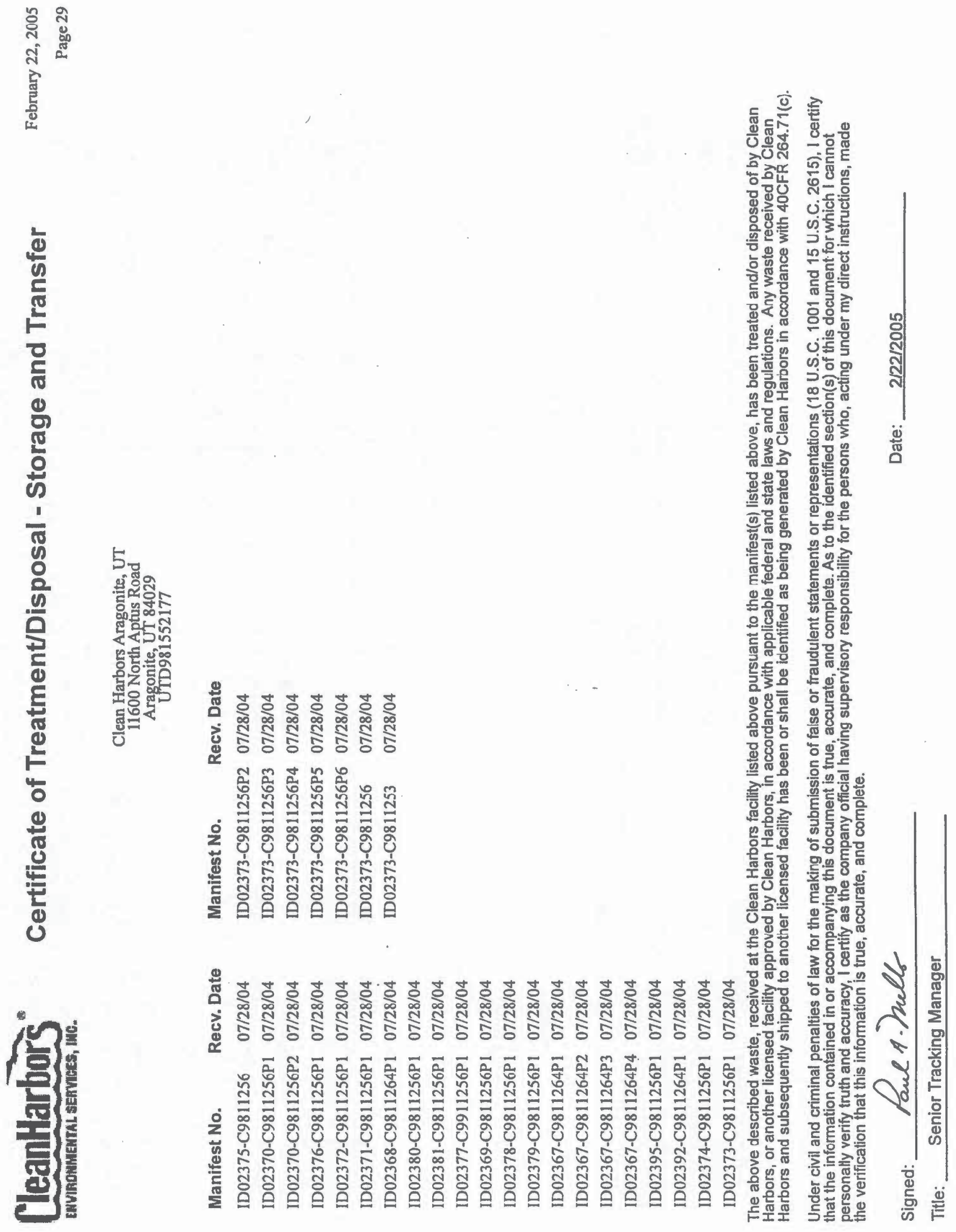

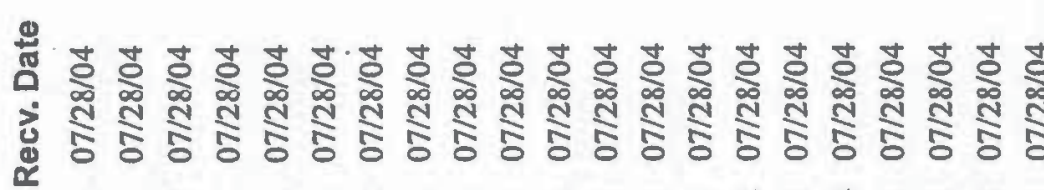



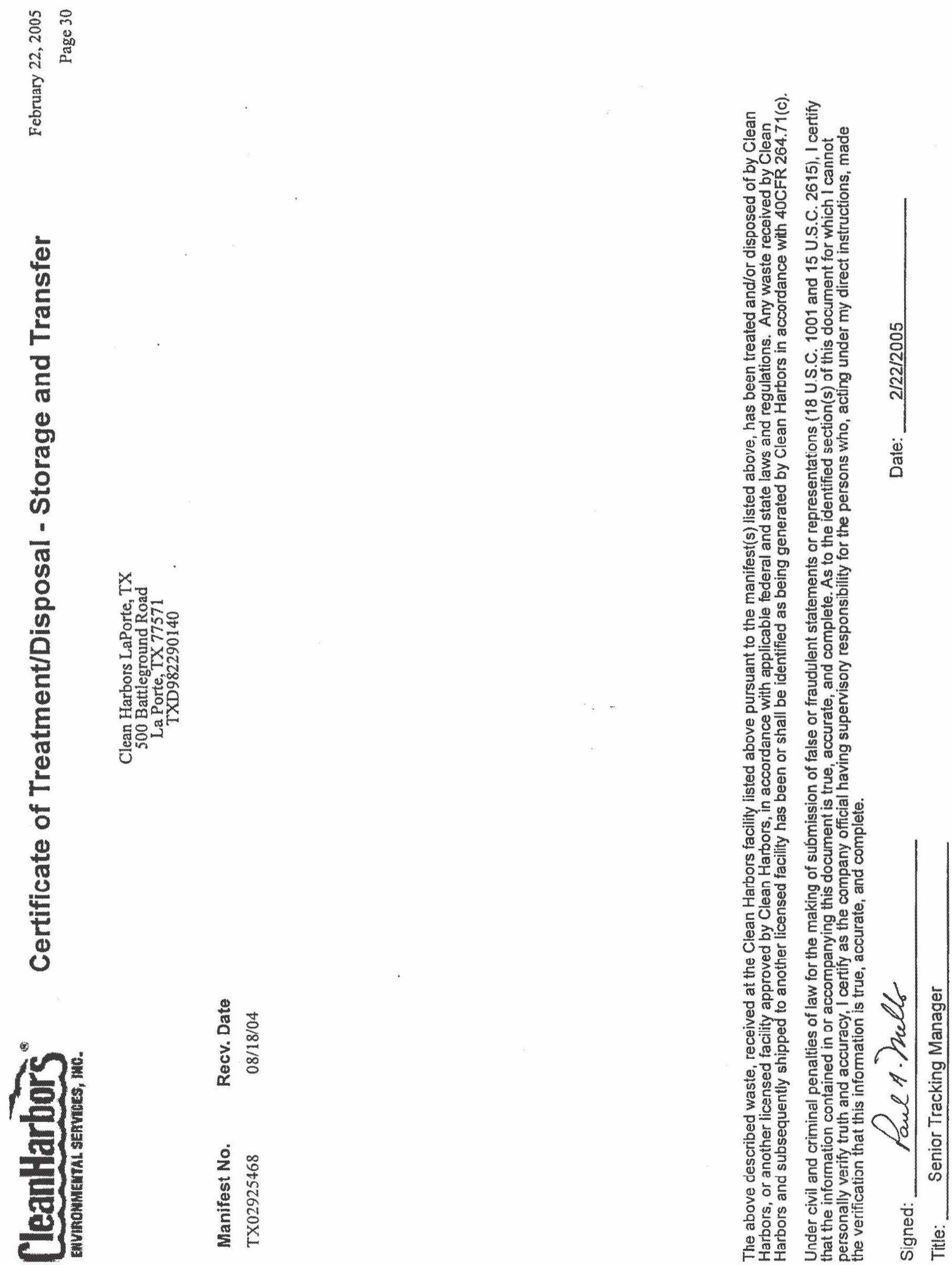



\begin{tabular}{|c|c|c|}
\hline $\begin{array}{l}\text { UNFORM HAZARDOUS } \\
\text { WASTE MANIFEST }\end{array}$ & $\begin{array}{l}\text { 1. Generator's US EPA ID No. } \\
\text { ID4890008952 }\end{array}$ & $\begin{array}{l}\text { Manifest } \\
\text { Document No. } \\
02376\end{array}$ \\
\hline
\end{tabular}

4. Generator's Phone (208) $526-2414$

5. Transporter 1 Company Name 6. US EPA ID Number Clear Harbors Environmental Serviced, unD039322250

\begin{tabular}{|l|l|}
\hline 7. Transporter 2 Company Name & 8. US EPA ID Number \\
\hline 9. Pesignated Facility Name and Site Address & 10. US EPA ID Number
\end{tabular}

(aragonite) ILC

11600 North Aptus Road

Aragonite, UI 84029

UTD981552177

\begin{tabular}{c|c}
\hline 2. Page 1 & $\begin{array}{l}\text { Information in the shaded areas } \\
\text { is nol required by Federal law. }\end{array}$ \\
\hline
\end{tabular}

A. State Manitest Document Number

B State Conerators 10

ID4 890008959

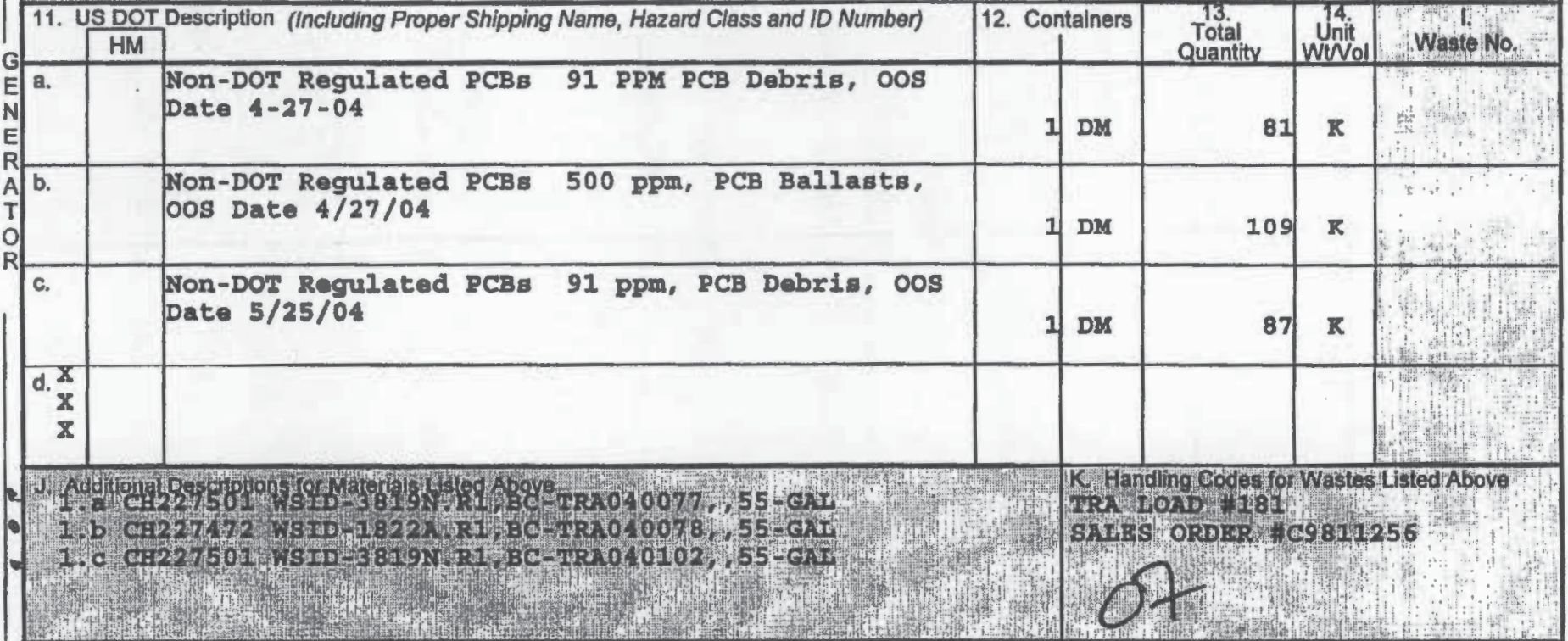

15. Special Handling Instructions and Additional Information

Return aigned original to: B.X. Rutledge, Idaho National Engineering Environmental

Iaboratoxy/0B Dor, P.O. Box 1625, Idaho Fa118, ID 83415-4105. Prepared under contract WDAC07 99ID 13727. UsDOB 24-Kr. Emergency Phone: (208) 526-1515.

16. GENERATOR'S CERTIFICATION: I hereby declare that the contents of this consignment are fully and accuratoly describod above by proper shipping name and are classified. packed, marked, and labelad, and are in all respects in proper condtition for transport by highway according to applcable intemational and national govemment regulations.

If I am a large quantity generator, I certity that I have a program in place to reduce the volume and toxiclity of waste generated to the degree I have delermined to be economically practicable and that I have selected the practcable method of treatment, storage, or disposal currentily available to me which minlmizes the present and future threat to human healti and the environment. $O R$, fif am a small quantly generator, i have made a good faith effort to minimize my waste generation and select the best waste management method that is available to me and that i can afford.

Printed/Typed Name 7 Signature 7 Month Day Year

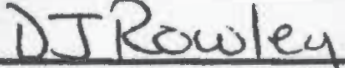

17. Transporter 1 Acknowledgement of Receipt of Meterials Printed/Typed Ngme

(mer 12

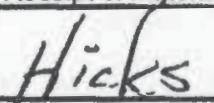

18. Transporter 2 Acknowledgement of Receipt of Materials

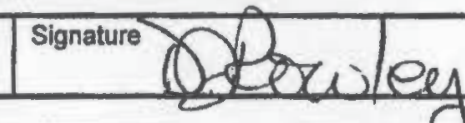

(2) $2 \times 1 ; \mathrm{Ces}_{4}$

Signature 71130 Month Day Year

07120104

107.20104

\begin{tabular}{|l|l|}
\hline Printed/Typed Name & Signature
\end{tabular}

19. Discrepancy Indication Space

A

L

20. Facility Owner or Operator. Certification of receipt of hazardous materials colfted by this manifest except as noted in Item 19. Printed/Typet Name
aldral integrated Waste Tracking sys RE CEIVEO AU6 3 .

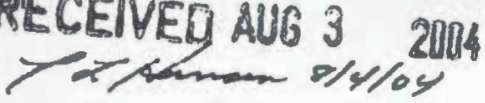




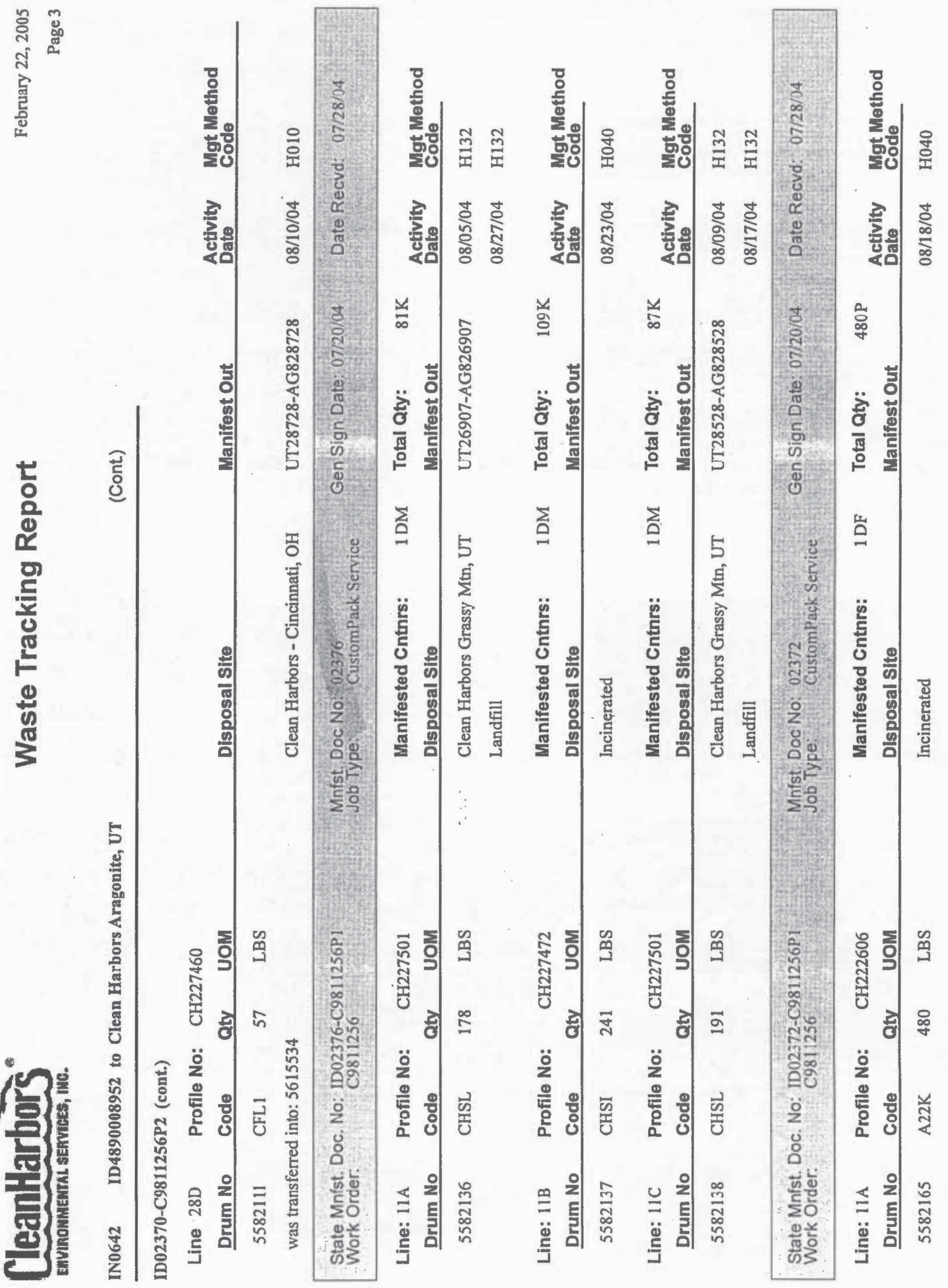



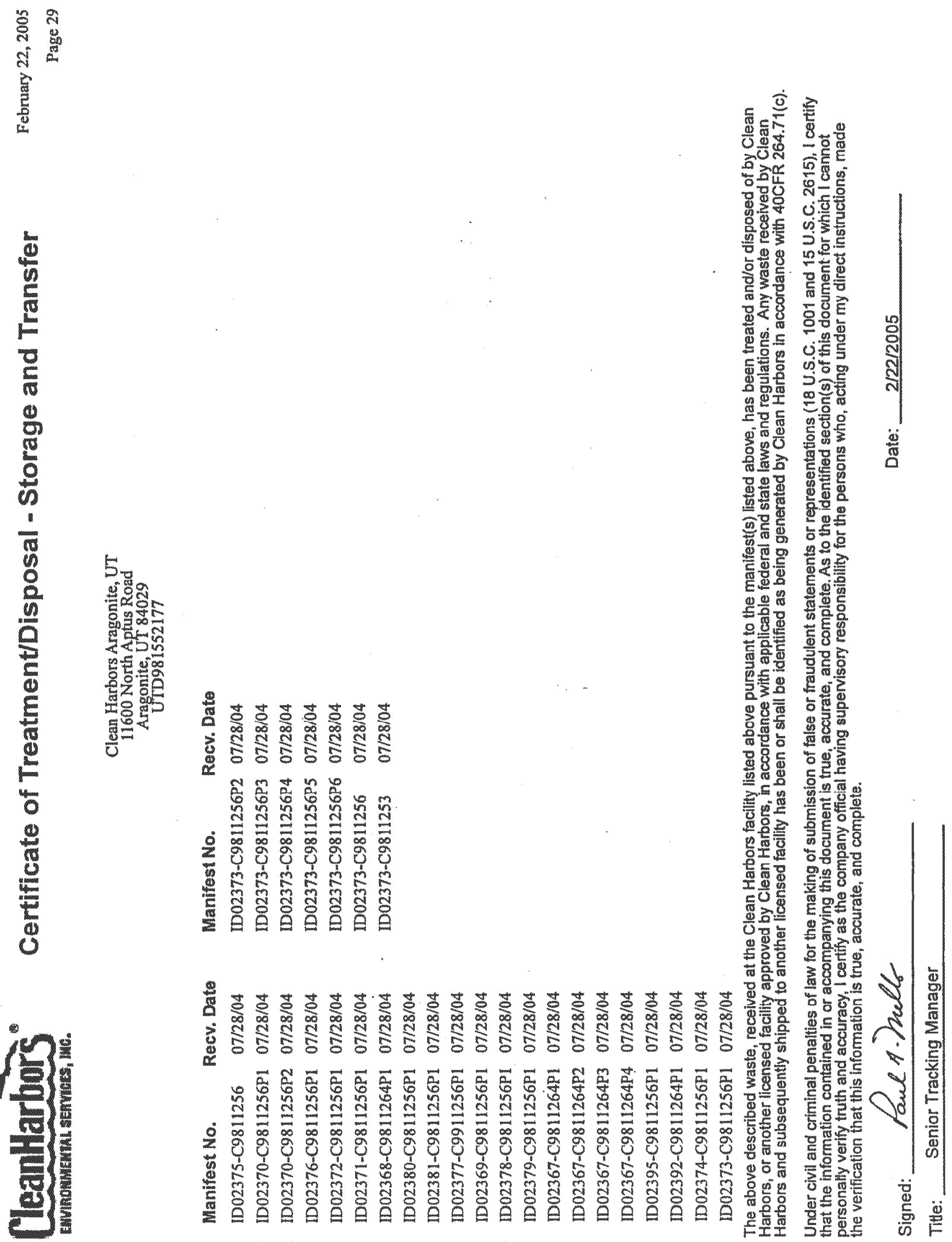

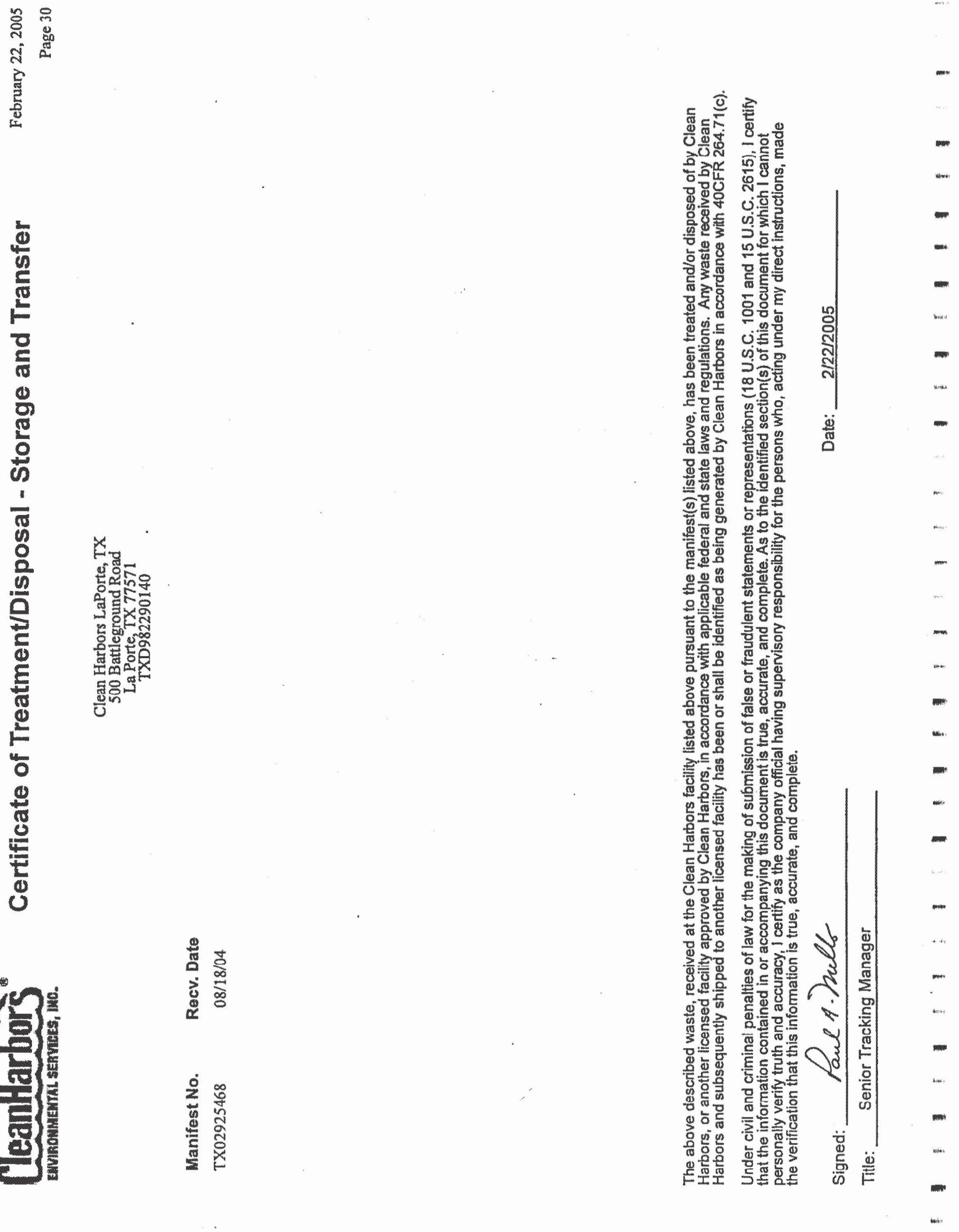



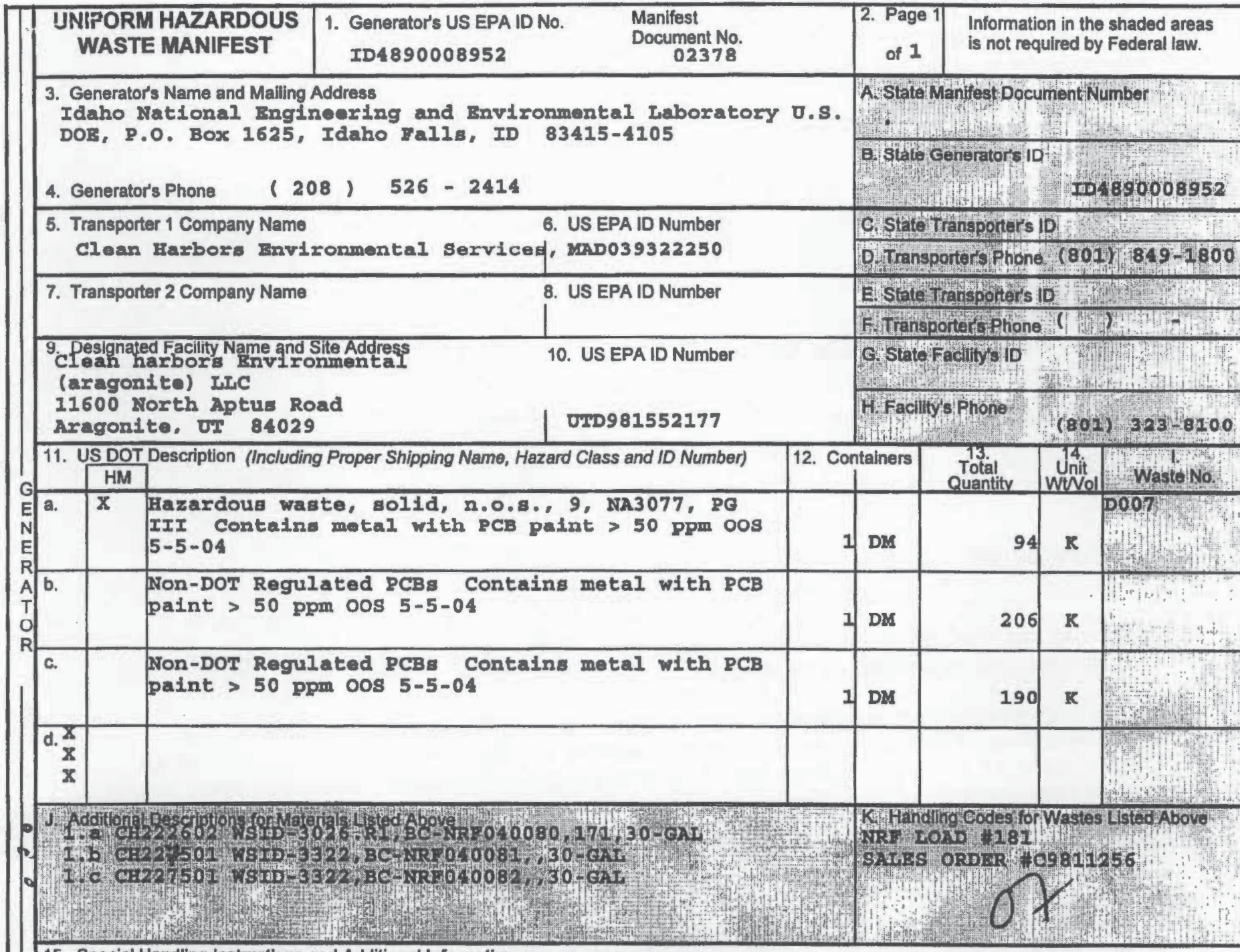

15. Special Handling Instructions and Additional Information

Return algned original to: B.A. Rutledga. Idaho National Ingineoring E Evironmontal Iaboratory/08 DOF, P.O. Box 1625, Idaho Balls, ID 83415-4105. Prepared under contract \#DEAC07 99ID 13727. U8DOE 24-Er. Emergency Rhone: (208) 526-1515.

16. GENERATOR'S CERTIFICATION: I hereby declare that the contents of this consignment are fully and accurately described above by proper shipping name and are classliled, packed, marked, and labeled, and are in all respects in proper condilition for transport by highway according bo applicable intemational and national govemment regulations.

If I am a large quantity generator, I certily that I have a program in place to reduce the volume and toxictly of waste generated to the degree I have determined to be oconomically practicable and that I have selected the practicable method of treatnent, storage, or disposal cumentty avallablo to me which minimizes the present and future threat to human health and the envisonment: OR, If I am a smal quantity generator, I have mede a good laith effort to minimize my waste generalion and select the besi waste management method that is available to me and that I can afford.

Printed/Typed Name i. 17. Transporter 1 Acknowledgement of Receipt of Materials Printed/Typed Name aer $>1$ 18. Transporter 2 Acknowledgement of Receipt of Materials Printed/Typed Name Heks 10.75

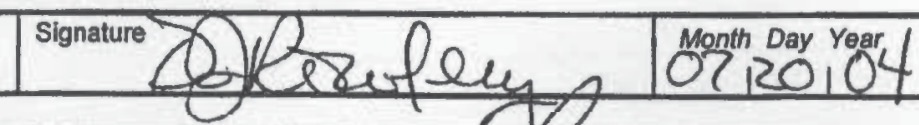
Signature 121 Month Day Year 20. Facility Owner or Operator: Centification of receipt of hazardous materials co dred by this manifest except as noted in ltem 19.

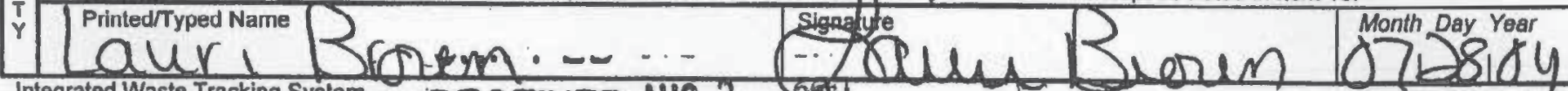
Integrated Waste Tracking System. 
Clean Harbors Aragonite LLC

11600 North Aptus Road

Aragonite UT 84029

EPA ID UTD981552177

November 11, 2004

DJ ROWLEY

Ineel US DOE

47 miles West of Idaho Falls on US Hwy 20

SCOVỊLLE ID, 83415

Re: Certificates of Disposal

Dear DJ ROWLEY

This letter and the attached CD Log constitute your Certificate(s) of Disposal for the waste that was shipped to our facility for disposal.

This is to certify that the waste referenced on the attached CD Log and manifested to the above referenced Clean Harbors facility was processed and disposed of in accordance with 40 CFR 761 (and 40 CFR 264 if applicable). Your waste has been properly treated and any residue from this waste has been disposed of at an approved and permitted Facility.

Under civil and criminal penalties of law for the making or submission of false or fraudulent statements or representations (18 U.S.C. 1001 and U.S.C. 2615). I certify that the information contained in or accompanying this document is true, accurate and complete. As to the identified section(s) of this document for which I cannot personally verify truth and accuracy, I certify as the company official having supervisory responsibility for the persons who, acting under my direct instructions, made the verification that this information is true accurate, and complete.

Clean Harbors appreciates you as a valued customer. If you should have any questions or concerns please do not hesitate to contact one of our customer/facility representatives.

Sincerely,

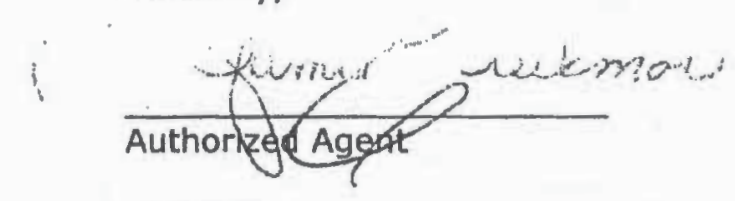

Enclosures 


\begin{tabular}{|c|c|c|c|c|c|}
\hline \multirow[t]{2}{*}{ Mianiresc ivor } & \multicolumn{2}{|c|}{$10023 / 8-C 9811256 P 11$} & \multirow{2}{*}{\multicolumn{2}{|c|}{ Generator }} & \multirow[b]{2}{*}{ Received Date } \\
\hline & Profile $\mathrm{Nbr}$ & Order Nbr & & & \\
\hline $11155311-1$ & $\mathrm{CH} 222602$ & C9811256 & $\begin{array}{l}\text { Ineel US DOE } 47 \text { miles West of Idaho } \\
\text { Hwy } 20 \text { SCOVILLE, ID } 83415\end{array}$ & Falls on US & $07 / 28 / 2004$ \\
\hline & & \multicolumn{2}{|r|}{ Container } & \multicolumn{2}{|c|}{ Disposal } \\
\hline$\frac{\text { Tracking Nbr }}{5582455}$ & Serial $\mathrm{Nbr}$ & $\frac{\text { Type }}{\text { DM }}$ Cont & $\begin{array}{l}\text { ents } \\
\text { without free liquid } \text { CHSI }\end{array}$ & $\begin{array}{l}\text { Method } \\
\text { INCN }\end{array}$ & $\frac{\text { Date }}{10 / 20 / 2004}$ \\
\hline
\end{tabular}




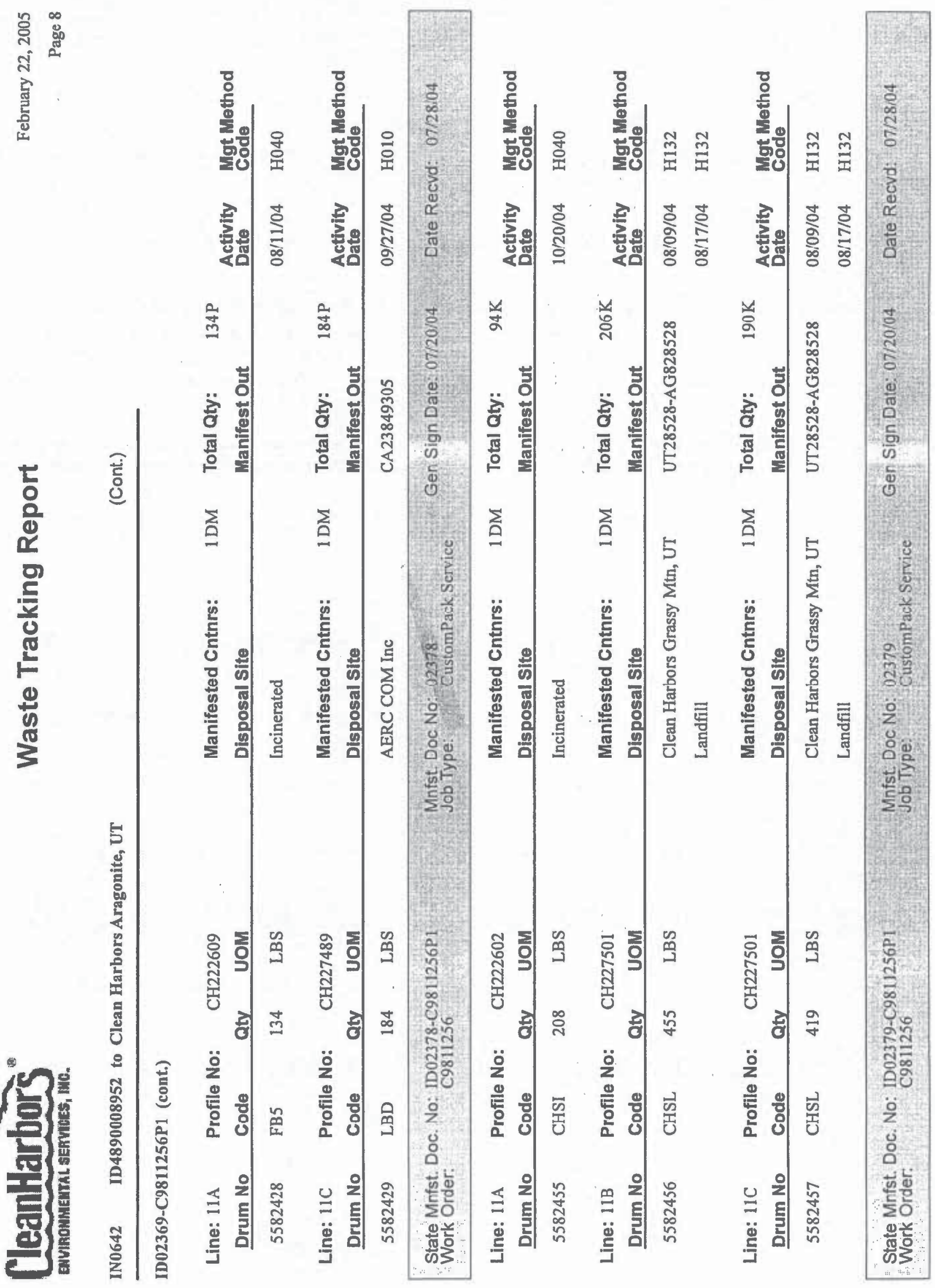



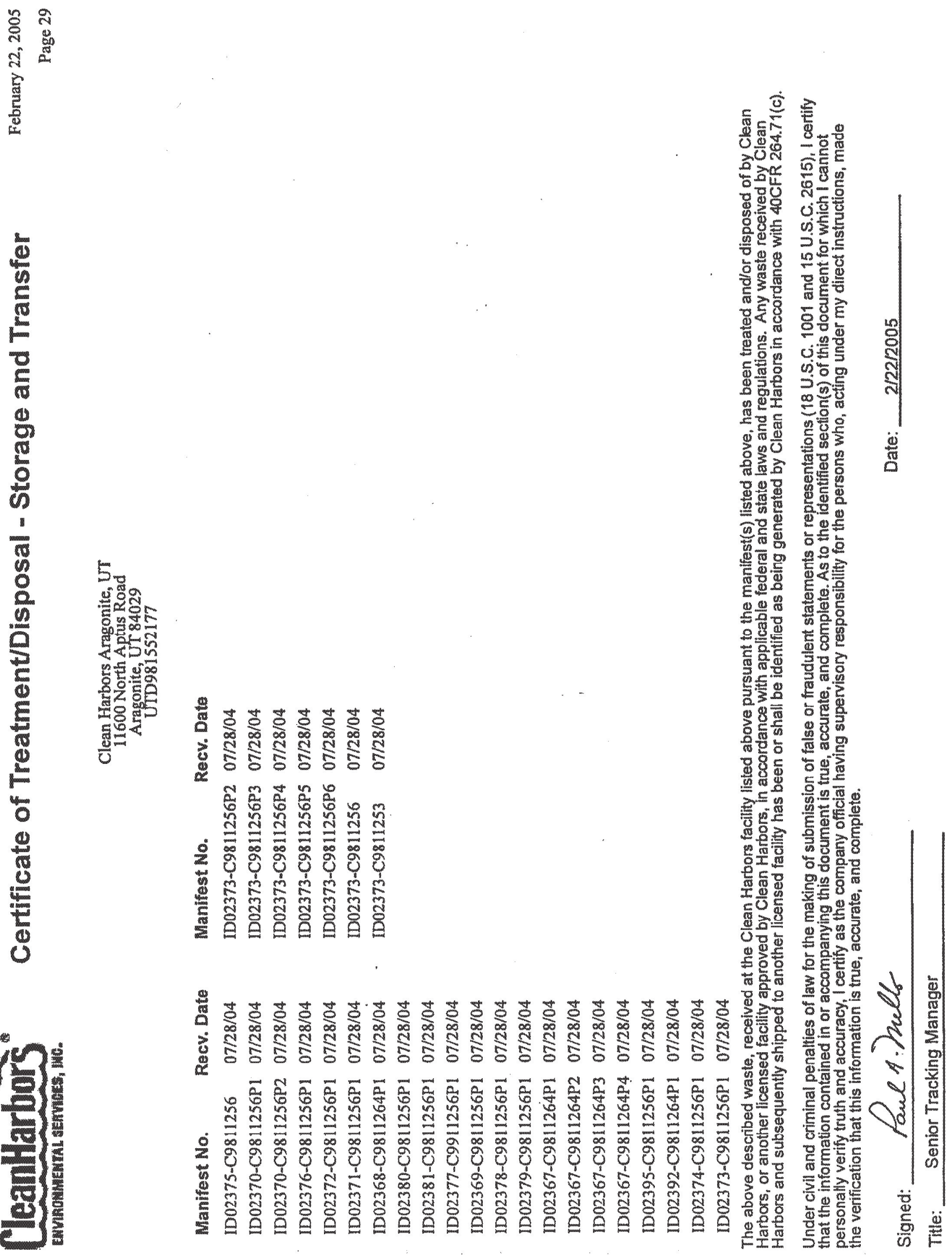

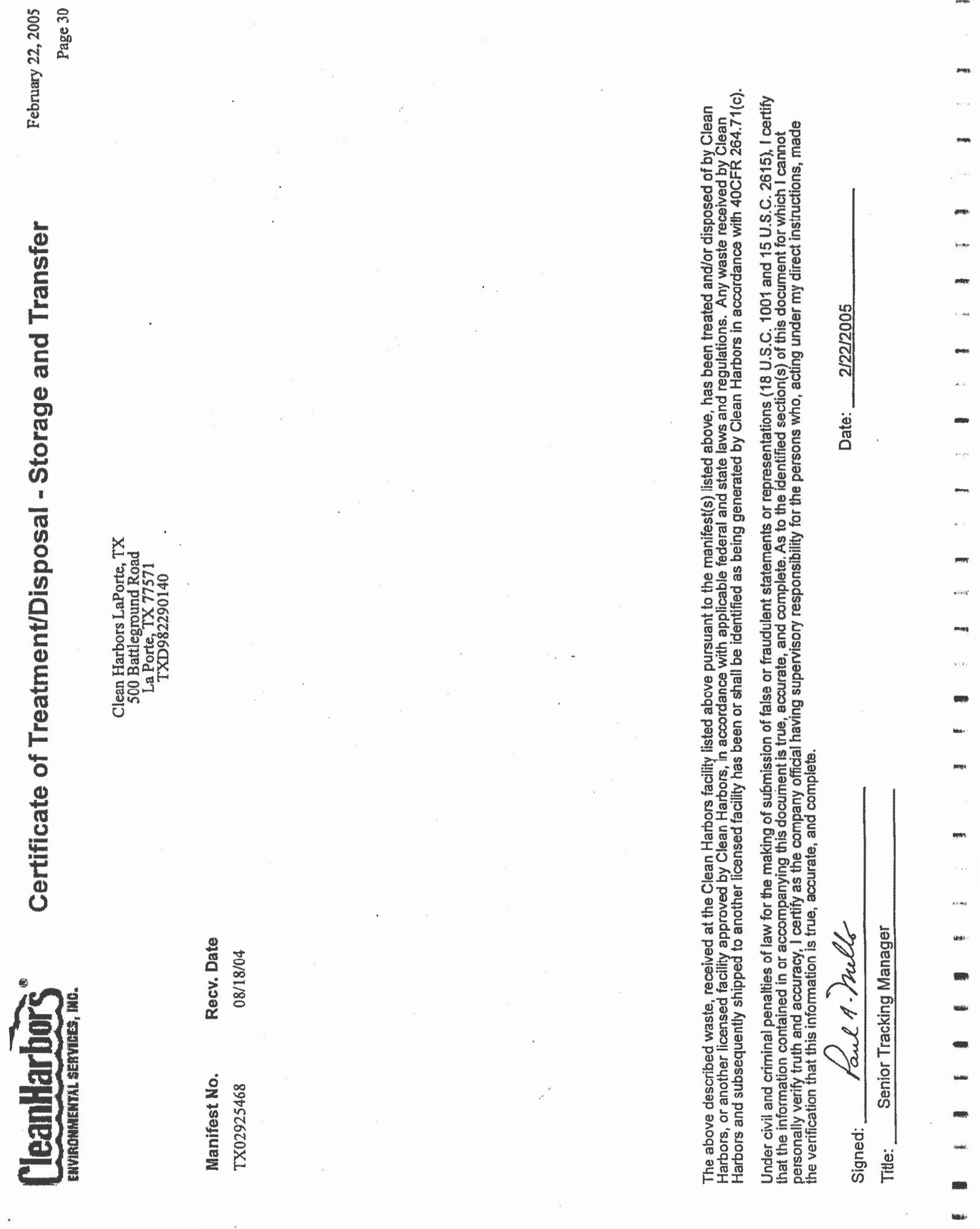



\begin{tabular}{c|cc|c|c|}
\hline $\begin{array}{c}\text { UNIFORM HAZARDOUS } \\
\text { WASTE MAANIFEST }\end{array}$ & $\begin{array}{l}\text { 1. Generator's US EPA ID No. } \\
\text { ID4890008952 }\end{array}$ & $\begin{array}{l}\text { Manifest } \\
\text { Document No. } \\
02381\end{array}$ & $\begin{array}{c}\text { 2. Page 1 } \\
\text { of } 2\end{array}$ & $\begin{array}{l}\text { Information in the shaded areas } \\
\text { is not required by Federal law. }\end{array}$ \\
\hline
\end{tabular}

3. Generator's Name and Mailing Address

Idaho National Englneering and Environmental Laboratory $0 . s$. DOE, P.O. BOX 1625, Idaho Falls, ID 83415-4105

\section{Generator's Phone (208) $526-2414$}
5. Transporter 1 Company Name
6. US EPA ID Number
Clean Harbors Environmental Servicea, MAD039322250

\begin{tabular}{l|l|}
\hline 7. Transporter 2 Company Name & 8. US EPA ID Number \\
\hline $\begin{array}{l}\text { 9. Pesignafed Facility Name gnd Site Address } \\
\text { (aragonite) ILC }\end{array}$ & 10. US EPA ID Number \\
$\begin{array}{l}11600 \text { North Aptua Road } \\
\text { Aragonite, Or 84029 }\end{array}$ & UTD981552177 \\
\hline
\end{tabular}

11. US DOT Description (Including Proper Shipping Name, Hazard Class and ID Number) N

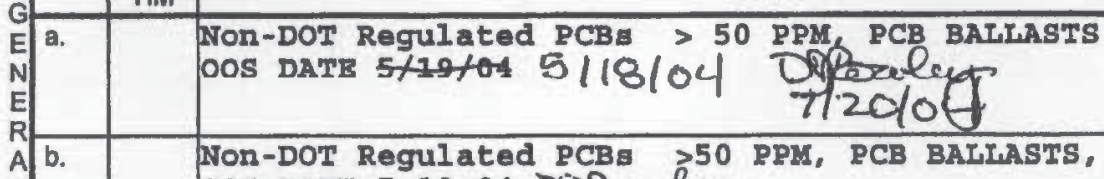
oOS DATE - 5 -19-0. De Powly 5-18-04 $712010 \$$ Non-DOT Regulated PCBs $>50$ PPM, PCB BALLASTS, OOS DATE 5-19-04 5-18-O4

d. Non-DOT Regulated PCBB $>50$ PRM, PCB BALLASTS, OOS DATE 5-19-04

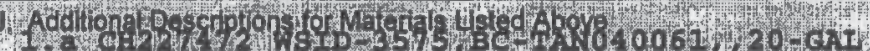

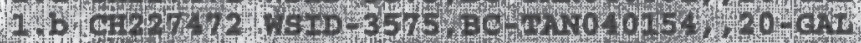

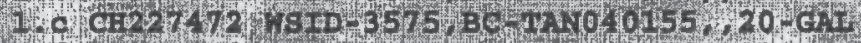

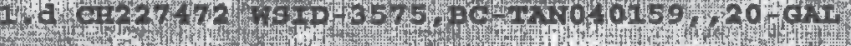

15. Special Handling Instructions and Additional Information

Return Blgned original to: B.A. Rutledge, Idaho National Ingineering Environmental

Laboratory/US DOz, P.O. Box 1625, Idako Falle, ID 83415-4105. Prepared undex contract \#DrAC07 99ID 13727. USDOF 24-Hx. Emergency Phone: (208) 526-1515.

16. GENERATOR'S CERTIFICATION: I hereby declare that the contents of this consignment are fully and accurately described above by proper shlipping name and are classlfied, packed, marked, and labeled, and are in all respects in proper condilion for transport by highway according to applicable international and national government regulations.

If I am a large quantity generator, I certfy that I have a program in place to reduce the volume and toxkclly of waste generated to the degree I have determined to be economically practicable and that I have selected the practicable method of treatment, storage, or disposal currenty avallable to me which minimizes the present and future threat to human health and the environment: $O R$, if I am a small quantity generator, lhave made a good faith effort to minimize my waste generalion and select the best waste management method that is available to me and that I can afford.
Printed/Typed Name
DSRowley

17. Transporter 1 Acknowledgement of Receipt of Malerials

\begin{tabular}{l|l} 
R & 17. Transporter 1 Ackno \\
N & Printed/Typed Name
\end{tabular}

18. Transporter 2 Acknowledgement of Receipt of Materials
Printed/Typed Name

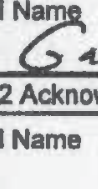

19. Discrepancy Indication Space

.
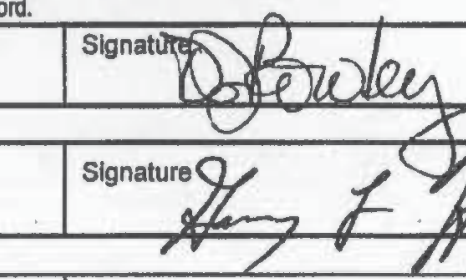

Signature Month Day Year

Month Day Year 0320,04

\begin{tabular}{|c|c|c|c|c|}
\hline \multicolumn{2}{|c|}{ 12. Containers } & $\begin{array}{l}\text { Total } \\
\text { Quantity }\end{array}$ & $\begin{array}{c}\text { Un. } \\
\text { Unit } \\
\text { Wol }\end{array}$ & Waste No \\
\hline 1 & DM & 77 & $\mathbf{K}$ & \\
\hline 1 & DM & 107 & $\mathbf{K}$ & \\
\hline 1 & $\mathbf{D M}$ & 91 & $\boldsymbol{K}$ & \\
\hline 1 & $D M$ & 125 & $\mathbf{K}$ & \\
\hline
\end{tabular}

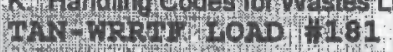
STHAS OFDRR IC9811256

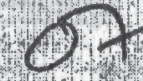




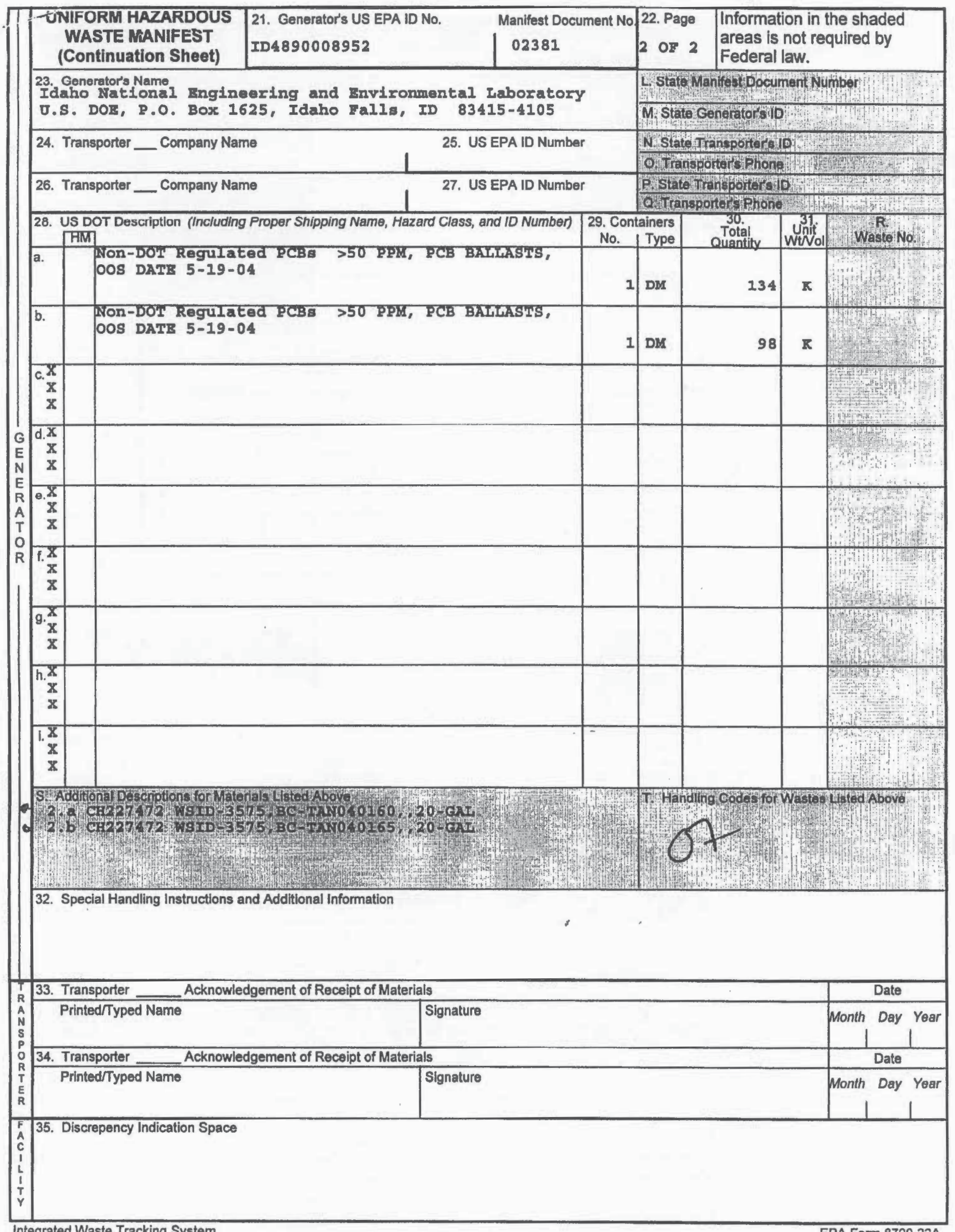




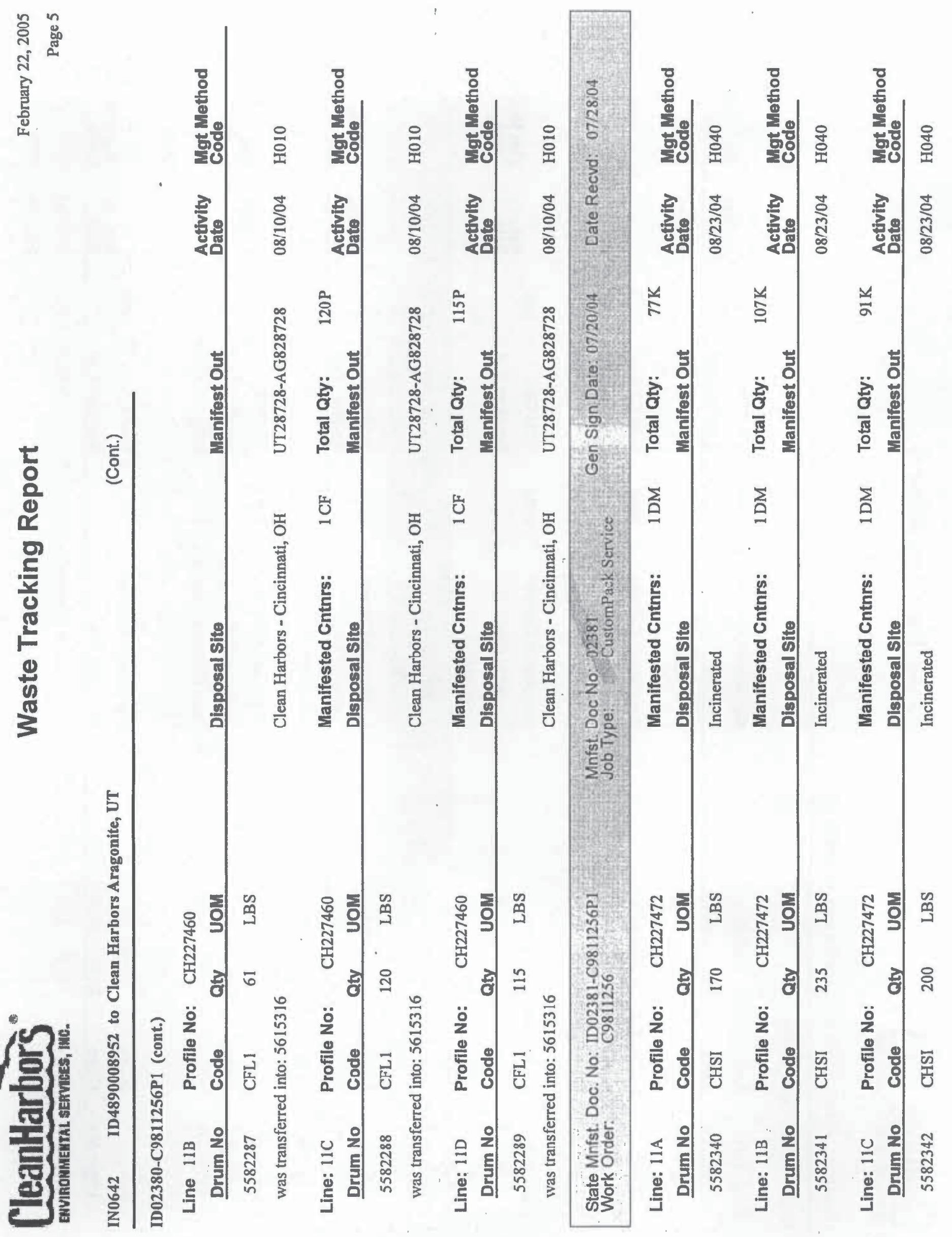




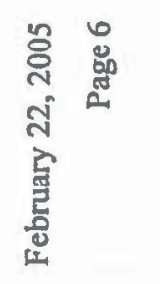

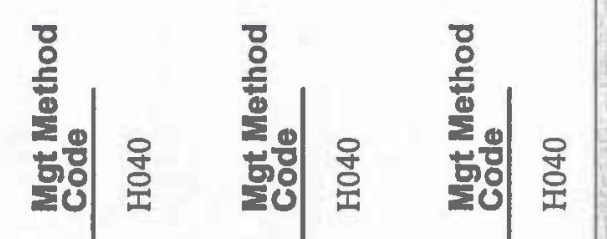

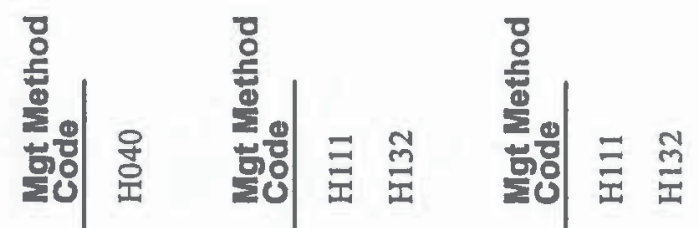

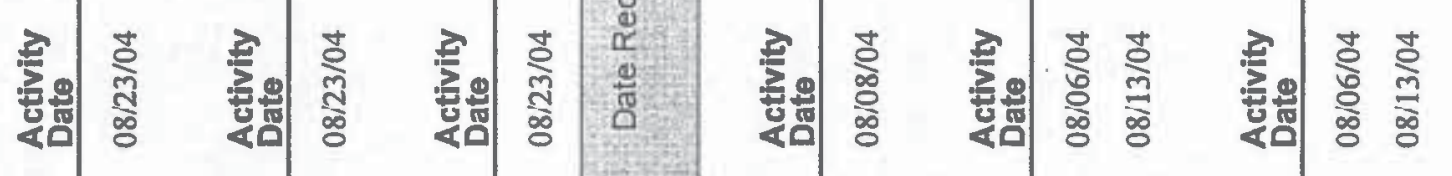

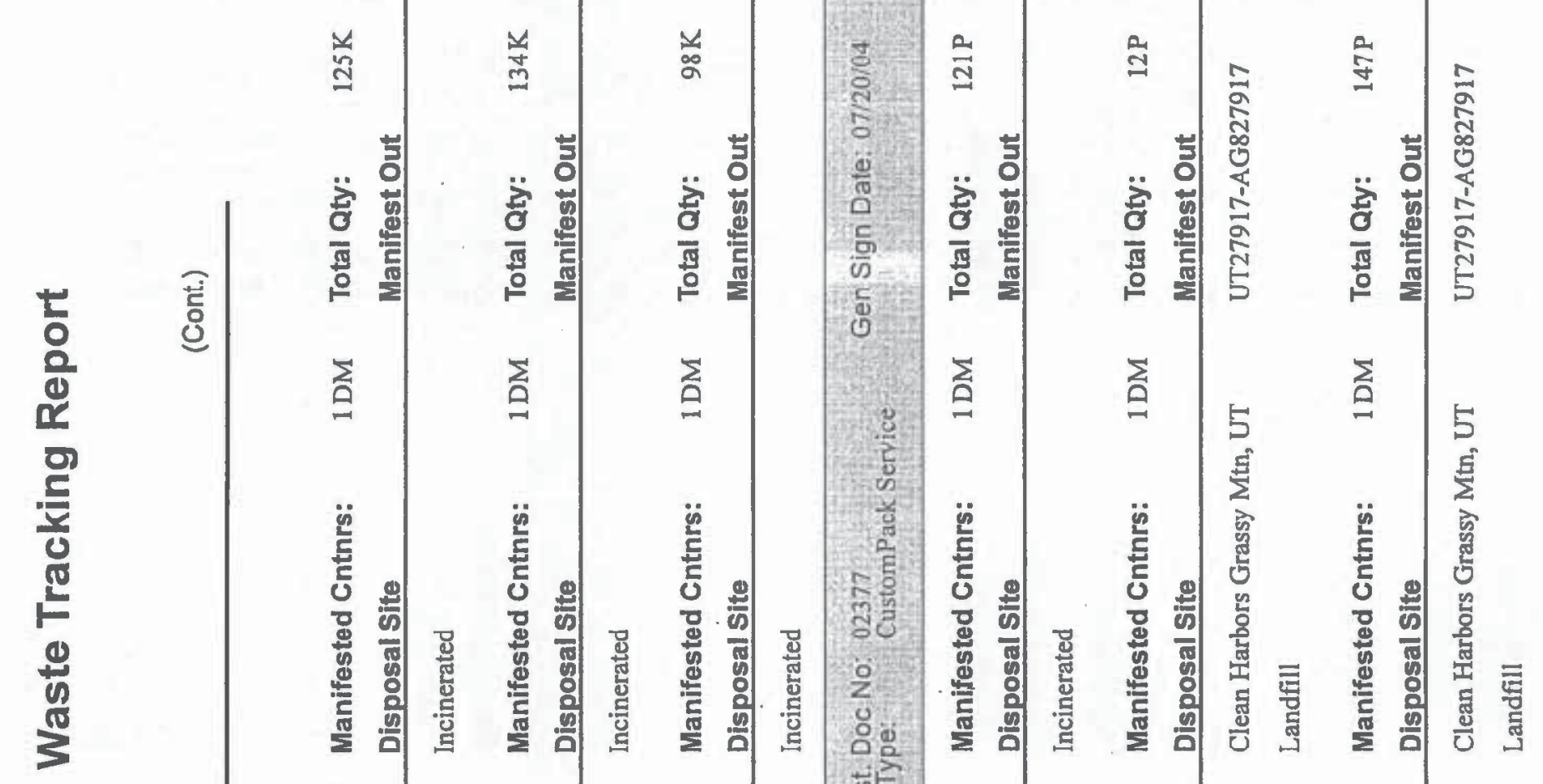

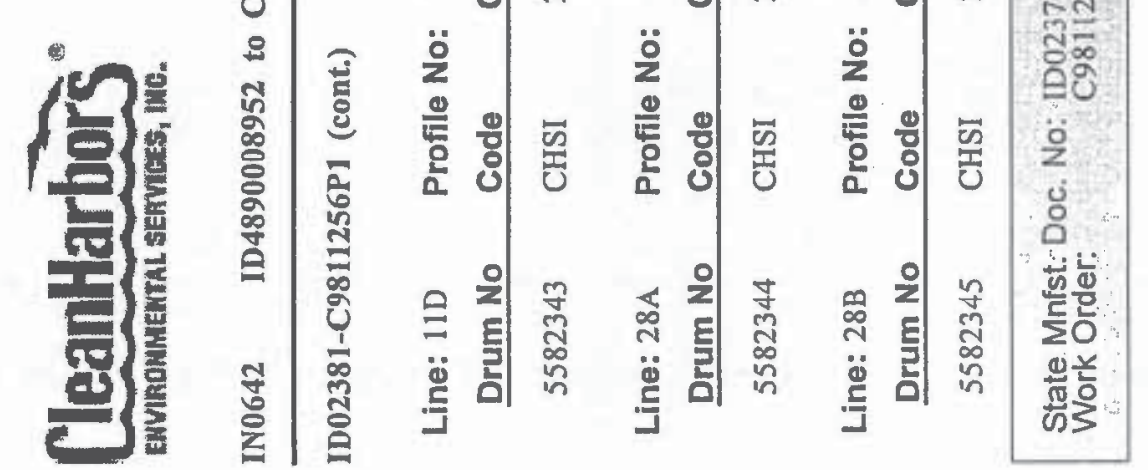

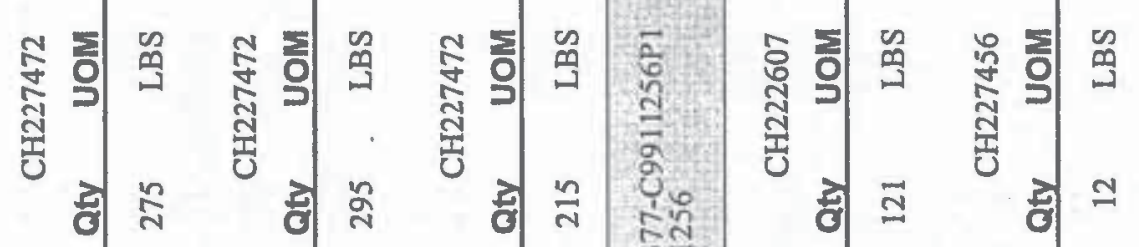

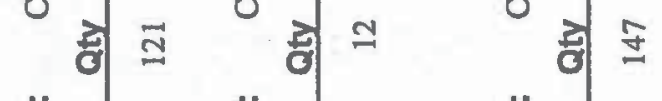

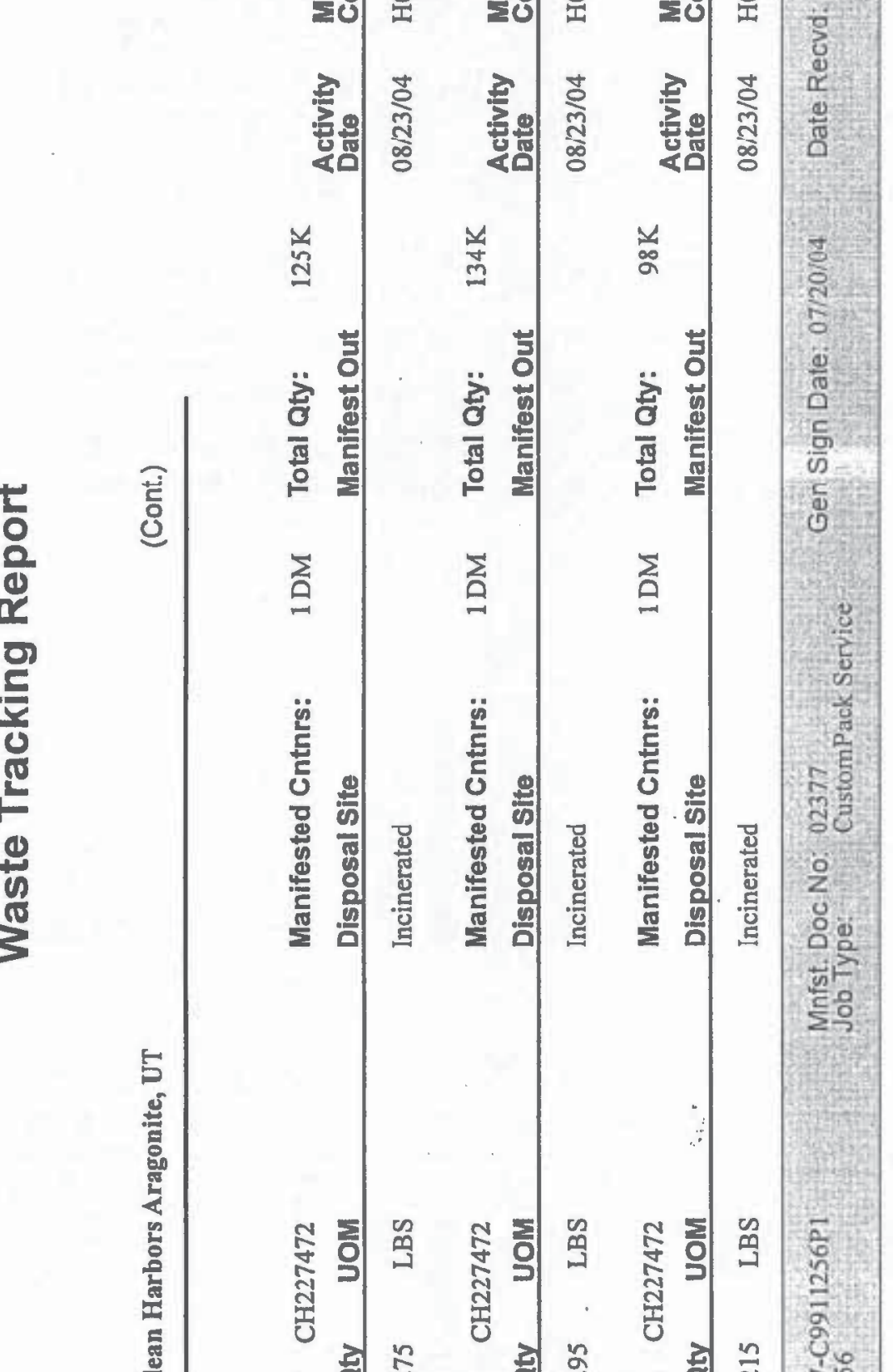



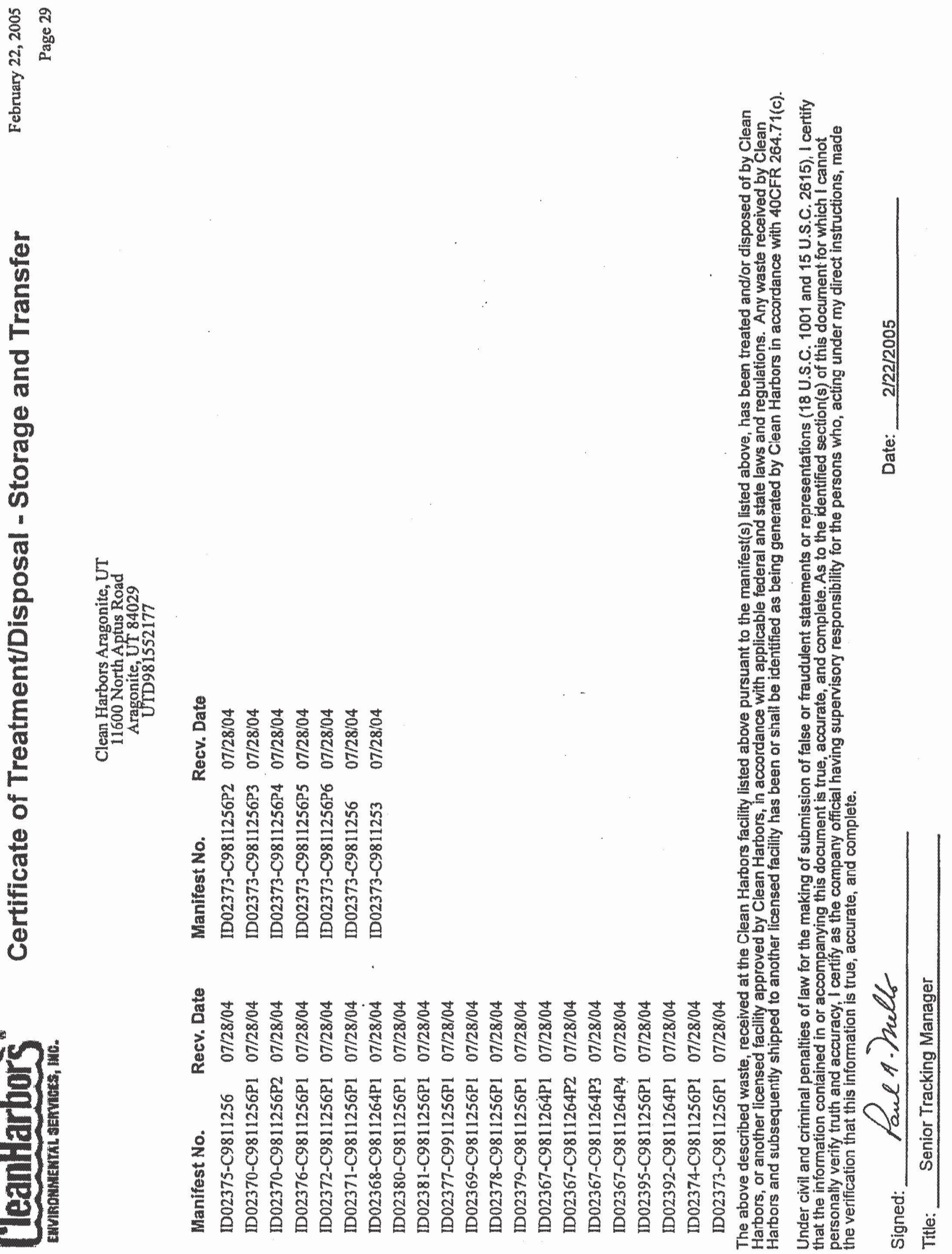

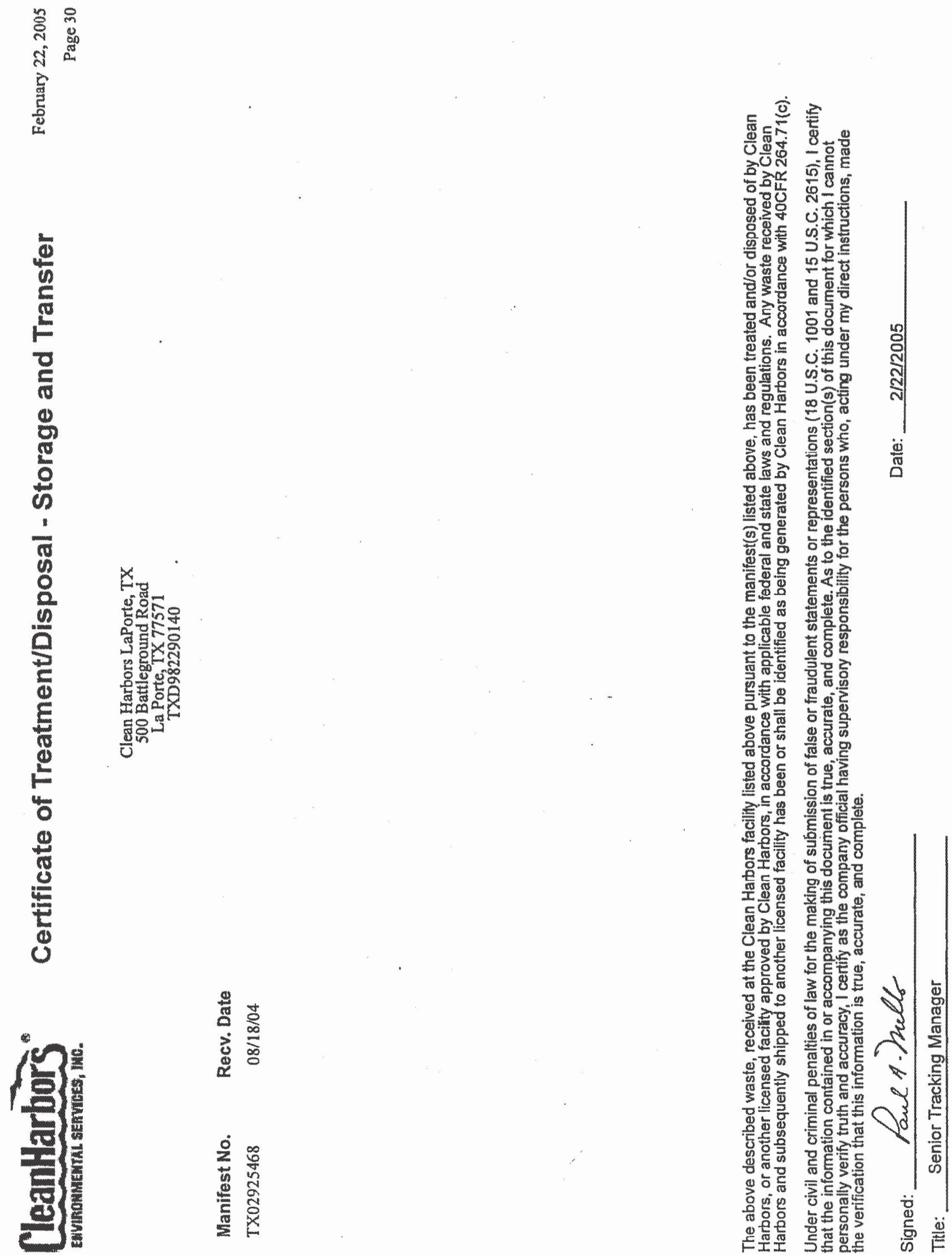



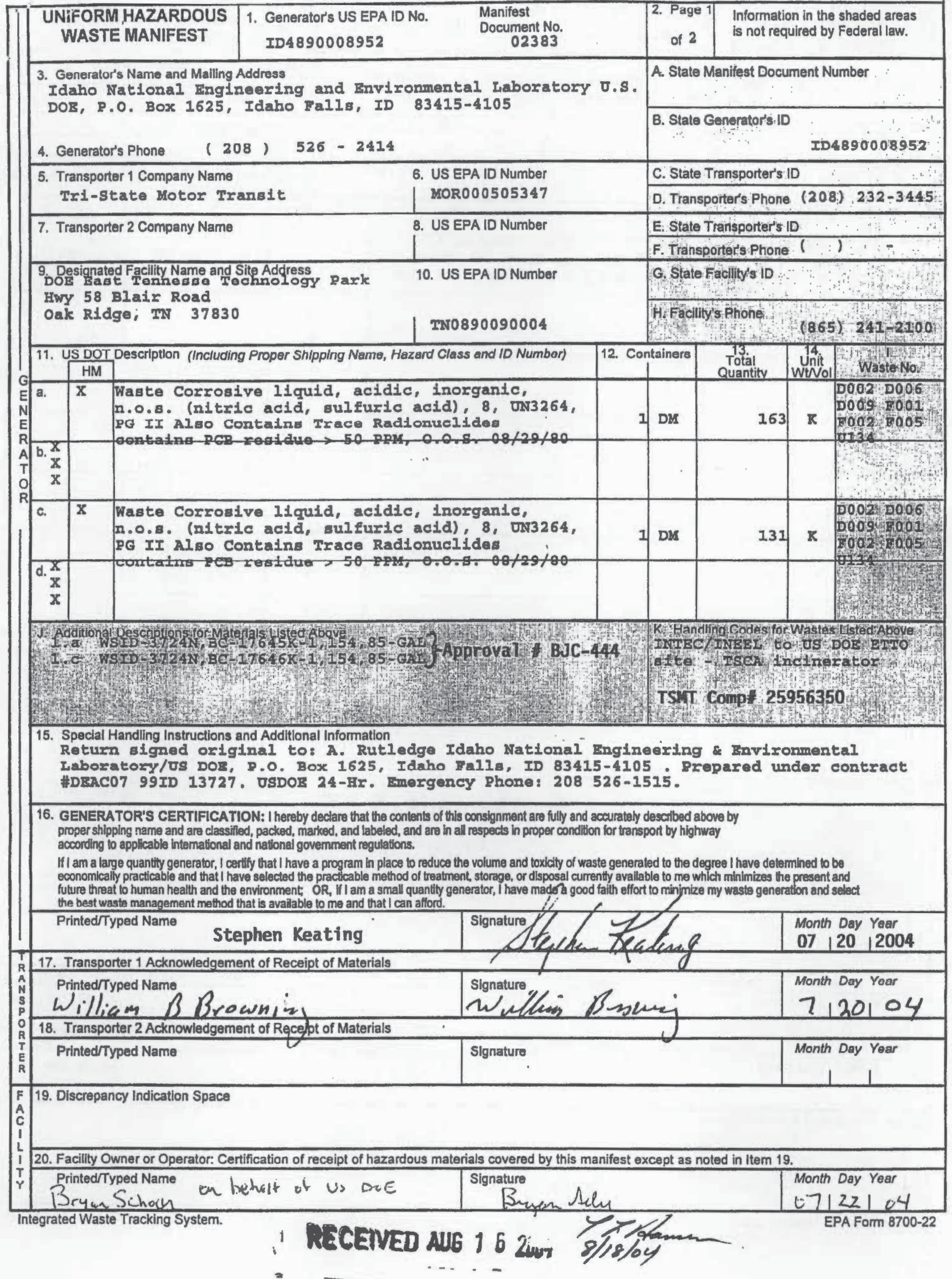




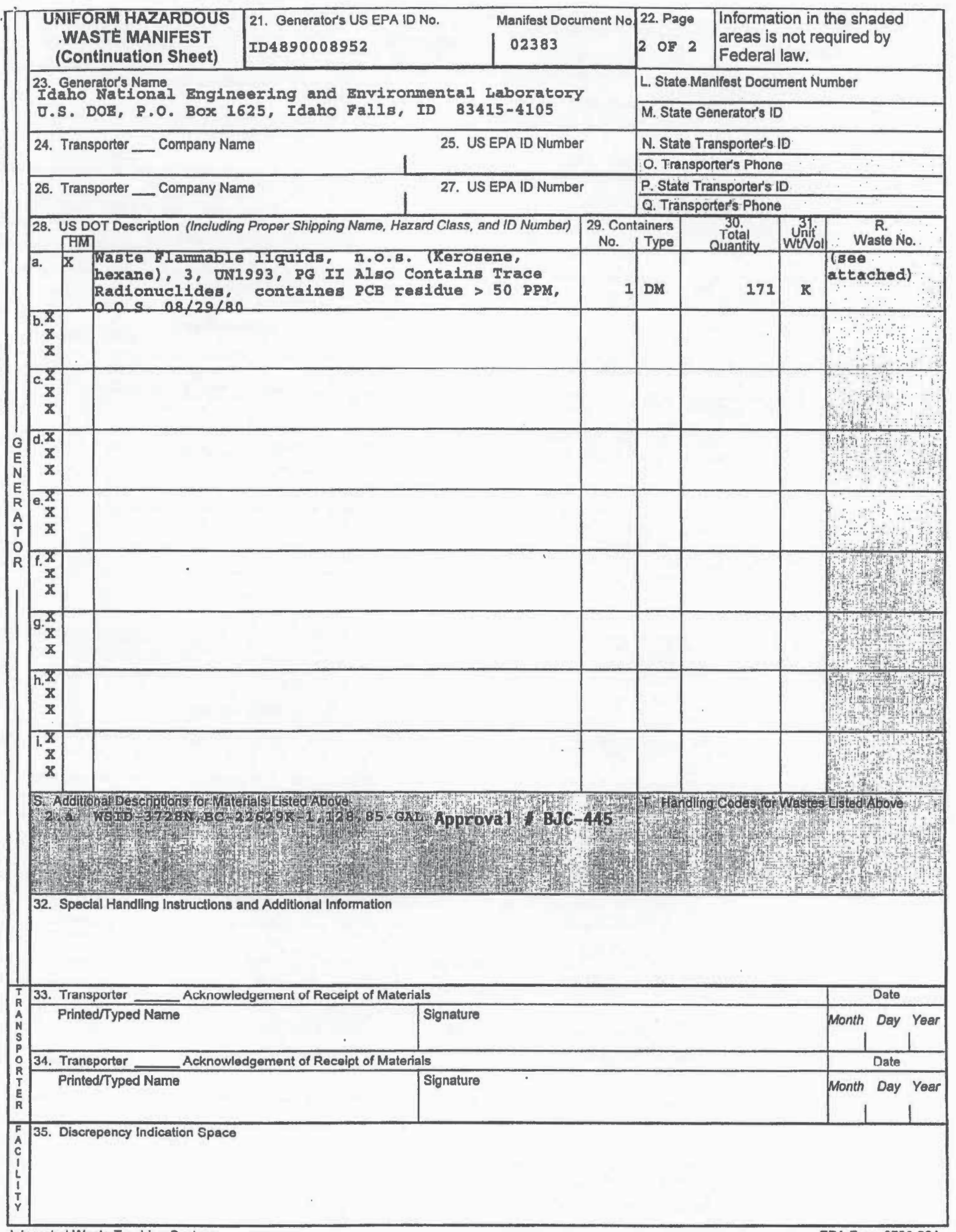





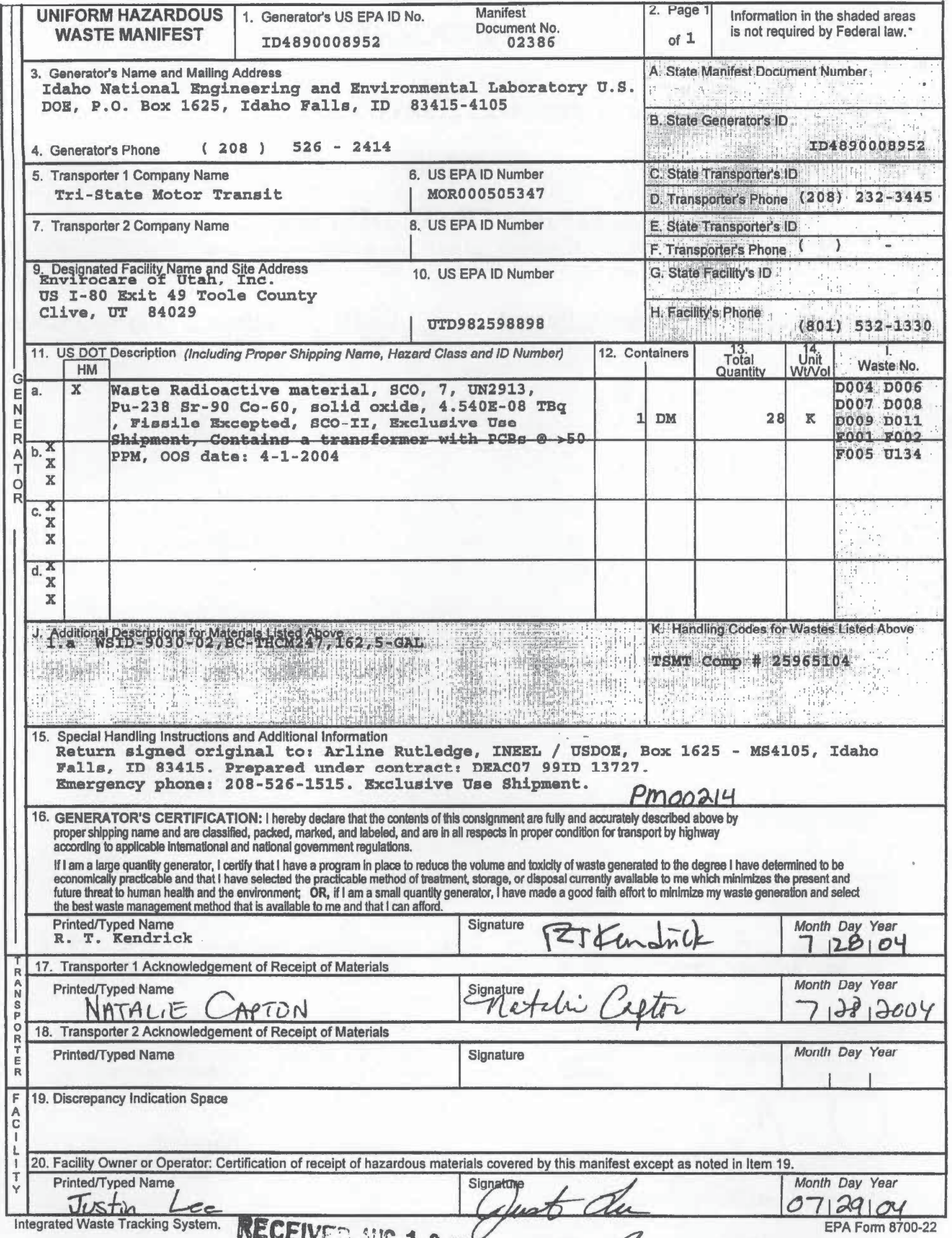

TION: I hereby decc
certity that I have a p
have selected the pro
APT TON
EPA ID Number

000505347

10. US EPA ID Number

UTD982598898

Arline Rutledge, INEEL / DSDOF, Box 1625 - MS4105, Idaho

nder contract: DEAC07 99ID 13727.

5. Exclusive Use shipment.

Pmo0214 according to applicable intemation

I am a large quantity gen the best waste management $m$
Printed/Typed Name

. T. Kendrick 


\section{ENVIROCARE}

OF UTAH, INC.

\section{THE SAFE ALTERNATIVE}

3 mi. S. Ext. 49, I-80

Clive, Utah 84029 EPA

ID: UT982598898

\section{CERTIFICATE OF DISPOSAL}

This Certificate acknowledges that the following manifested shipments:

$\frac{\text { Shipment }}{9030-02-0026} \frac{\text { Manifest }}{02386} \cdot \frac{\text { Date(s) of Disposal }}{12 / 10 / 2004} \quad \frac{\text { Cu/Ft }}{0.67} \quad \frac{\text { Process }}{\text { Landfill }} \quad \frac{\text { Disposal Location }}{\text { Mixed Waste }}$

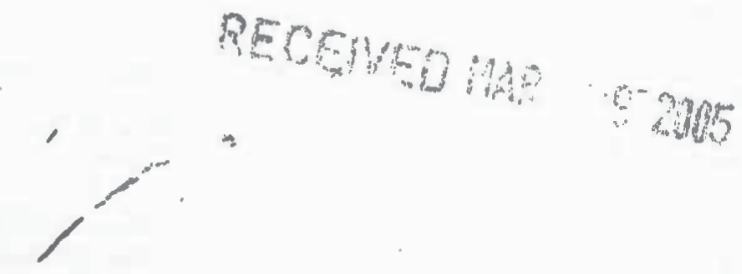

Representing 0.67 Cubic feet of waste of at listed Disposal Facility landfill. Disposal is subject to Envirocare's Radioactive Material License, all other applicable licenses, permits and regulations, and the Disposal Agreement.

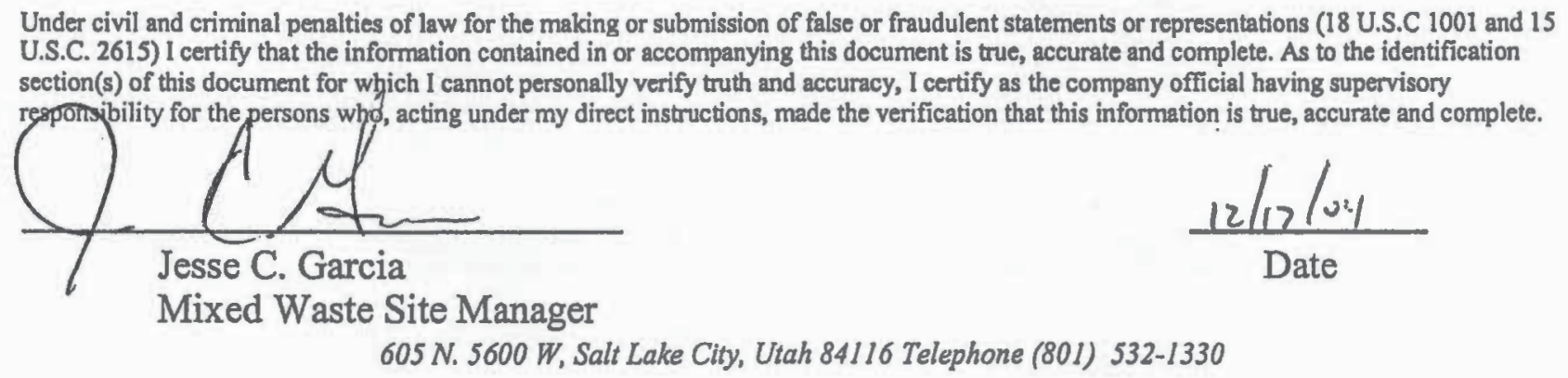





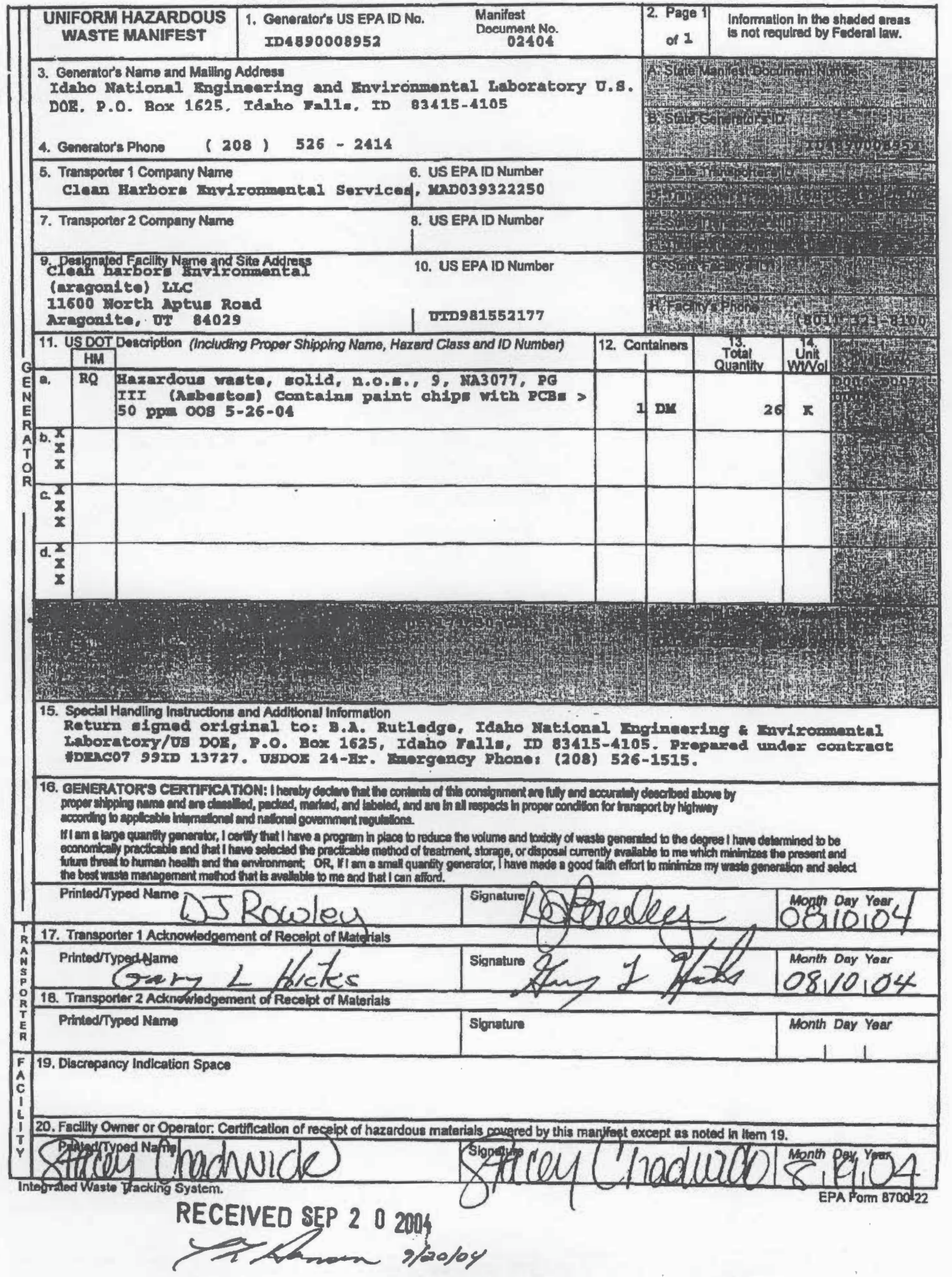


Generator:

CD Nbr

$7124323-1$

Tracking Nbr

5671331
Ineel US DOE 47 miles West of Idaho Falls on US Hwy 20 SCOVILLE, ID 83415

Profile $\mathrm{Nbr}$

$\mathrm{CH} 222623$

Order $\mathrm{Nbr}$

C9829752

Manifest $\mathrm{Nbr}$

Received Date container ID $2404-C 982975211$ 08/19/2004

$\underline{\text { Serial Nor }}$

Type Contents

DM Solid without free liquid CHSI
Disposal

$\underline{\text { Shp TO }}$

\begin{tabular}{cc}
\multicolumn{2}{c}{ Disposal } \\
\hline Method & $\stackrel{\text { Date }}{\text { INCN }}$ \\
$03 / 05 / 2005$
\end{tabular}




\section{MAR-15-2804 08:10

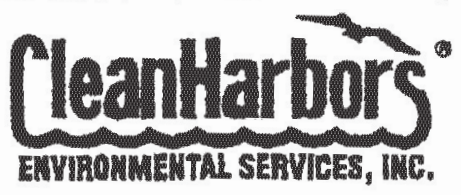

S K ARAGONITE

11600 North Aprus Roud Aragonite, UT 84029

801.323 .8100

Fax 801.323 .8877

www. cleanharbors.com

MARCH 12, 2004

Environmental Manager

IDAHO NATIONAL ENG E ENVIRONME

$\because$ DOE PO BOX 1625

IDAHO FALLS, IDAHO 834254105

RE: Certificates of Disposal

Dear Enviromental Marager:

Enclosed please Eind your certificate(s) of Disposal and accompanylng detailed report(s) for the waste that was shipped to our facility for treacment. Your original manifest number is referenced on both

* of. these documents along with a Clean Harbors Aragonite document number.

- Your waste has beer properly treated and the residue from this waste - has been disposed of at an approved and permitted hazardous waste landfil1.

Clean Harbors appreciates you as a valued customer. If you should

- have any questions or concens please do not hesitate to contact one of oun customer/facility representatives at (801) 323-8100.

(1)

sincerely,

$\cdots$

.

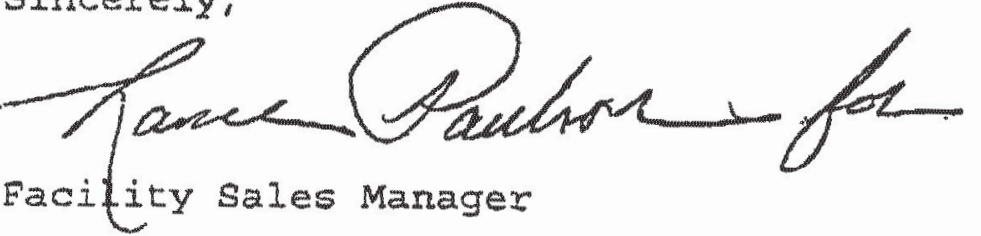

Enclosures 
March 07, 2005

DJ ROWLEY

Ineel US DOE

47 miles West of Idaho Falls on US Hwy 20

SCOVILLE ID, 83415

Re: Certificates of Disposal

\section{Dear DJ ROWLEY}

This letter and the attached CD Log constitute your Certificate(s) of Disposal for the waste that was shipped to our facility for disposal.

This is to certify that the waste referenced on the attached CD Log and manifested to the above referenced Clean Harbors facility was processed and disposed of in accordance with 40 CFR 761 (and 40 CFR 264 if applicable). Your waste has been properly treated and any residue from this waste has been disposed of at an approved and permitted Facility.

Under clvil and criminal penalties of law for the making or submission of false or fraudulent statements or representations (18 U.S.C. 1001 and U.S.C. 2615). I certify that the information contained in or accompanying this document is true, accurate and complete. As to the identified section(s) of this document for which I cannot personally verify truth and accuracy, I certify as the company official having supervisory responsibility for the persons who, acting under my direct instructions, made the verification that this information is true accurate, and complete.

Clean Harbors appreciates you as a valued customer. If you should have any questions or concerns please do not hesitate to contact one of our customer/facility representatives.

Sincerely,

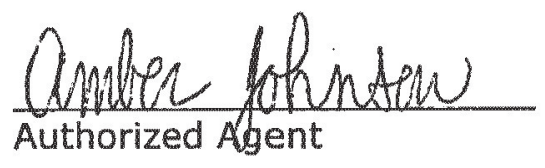

Enclosures 

-

\begin{tabular}{|c|c|c|c|c|}
\hline $\begin{array}{c}\text { UNIFORM HAZARDOUS } \\
\text { WASTE WANUFEST }\end{array}$ & $\begin{array}{l}\text { 1. Generator's US EPA IO No. } \\
\text { ID4890008952 }\end{array}$ & $\begin{array}{l}\text { Manifest } \\
\text { Document No. } \\
\text { 02:05 }\end{array}$ & 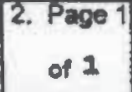 & $\begin{array}{l}\text { Infomalion in the shaded areas } \\
\text { b not required by Foderl law. }\end{array}$ \\
\hline
\end{tabular}

3. Geniarator's Neme and Mulling Address

Idubo Natlonal inglumarlag and Envixonmental Iaboratory 0.8.

DOE, P.0. Box 1625, Idabo Fa11s, ID 83415-1105

4. Gonerctors Phose (208) $526-2414$

5. Trunsportor 1 Company Nama $\quad$ 6. US EPA ID Number

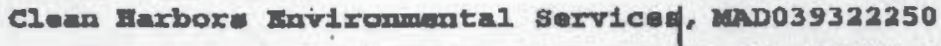

7. Transpotter 2 Company Name $\quad$ 8. US EPA ID Number

$\begin{array}{ll}\text { 9. Pashmaled faclity Name and site Address } & \text { 10. US EPA ID Number }\end{array}$

(aremoniteo) tric

11600 Nortel Iptun Rond

aragonite, or 84029

Uro981552177

11. USDOT Description (Including Propar Shipoing Name, Hazard Class and 1D Mumber)

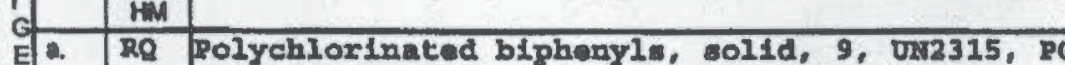

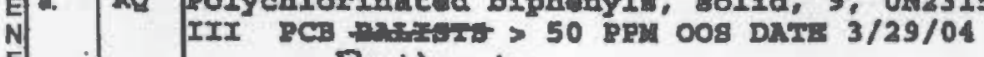

E

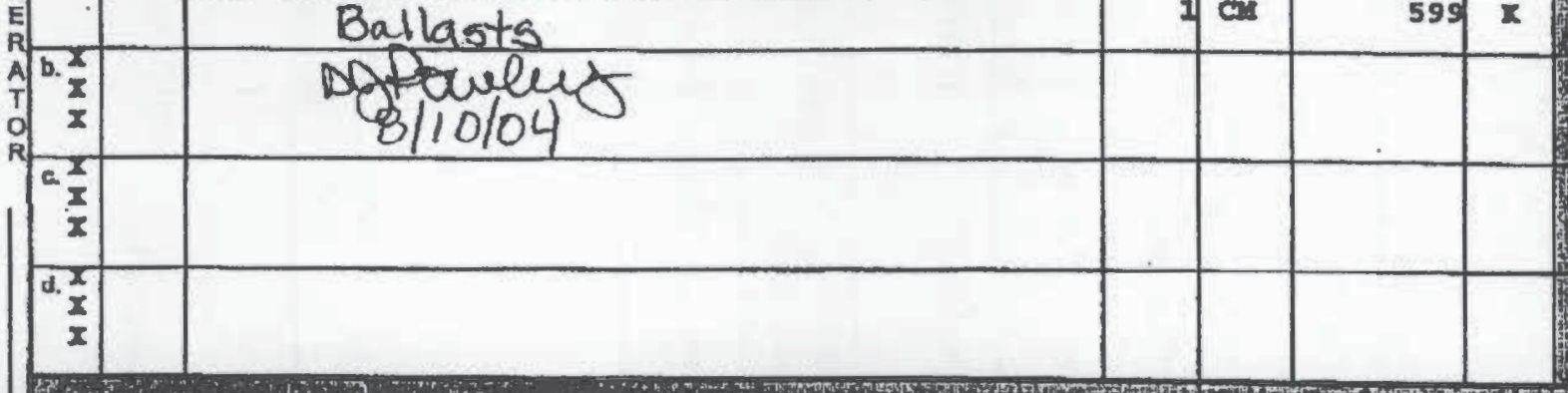

(1)

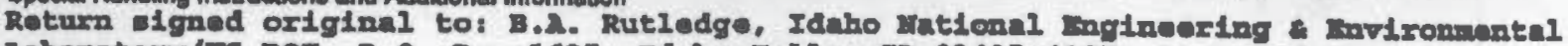

Iuboratory/08 Dos, P.O. Box 1625, Idaho Fe11s, ID 83415-4105. Propared under contrect

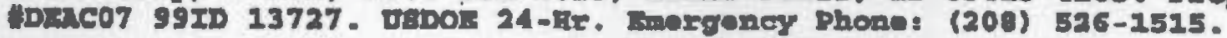

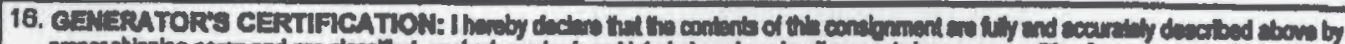

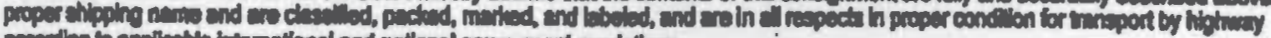

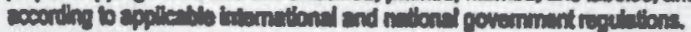

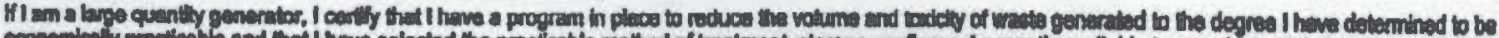

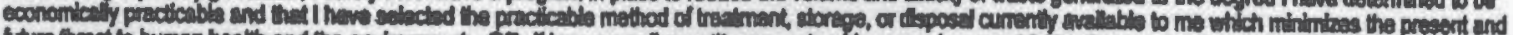

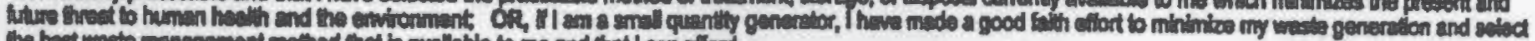

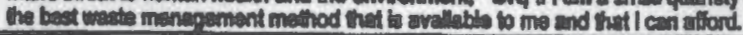

Printed Typed Nama

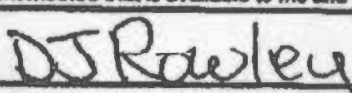

17. Transporter 1 Acknowledgement of Recolps of Malo lals

A Pinted/Typed Name

\$

18. Transporter 2 Acknowizogemant of Recolot of Materials

$x^{2}-2-2$

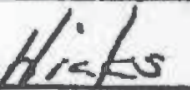

Printed/Typed Nane

19. Discrepancy Indication Space
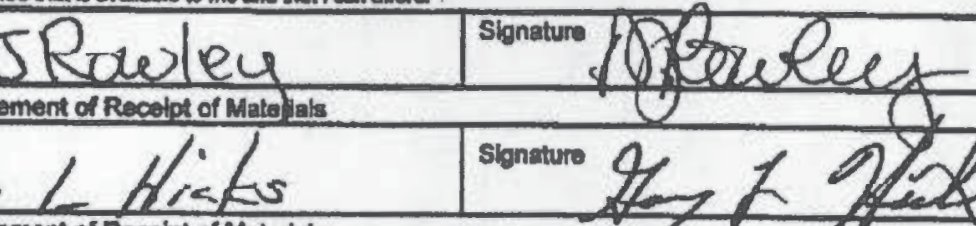

I)

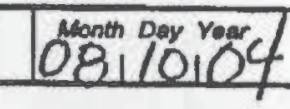

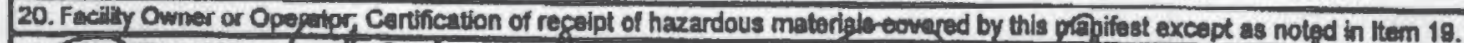

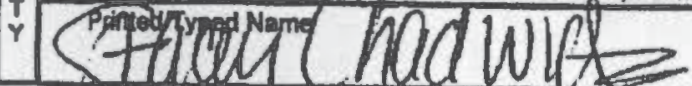

Integred Wasto Tracing Systom.

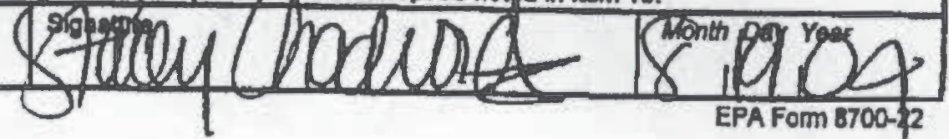

RECEIVER SEP 2 \& 2094

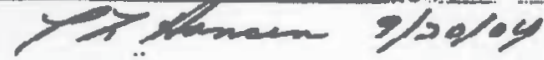




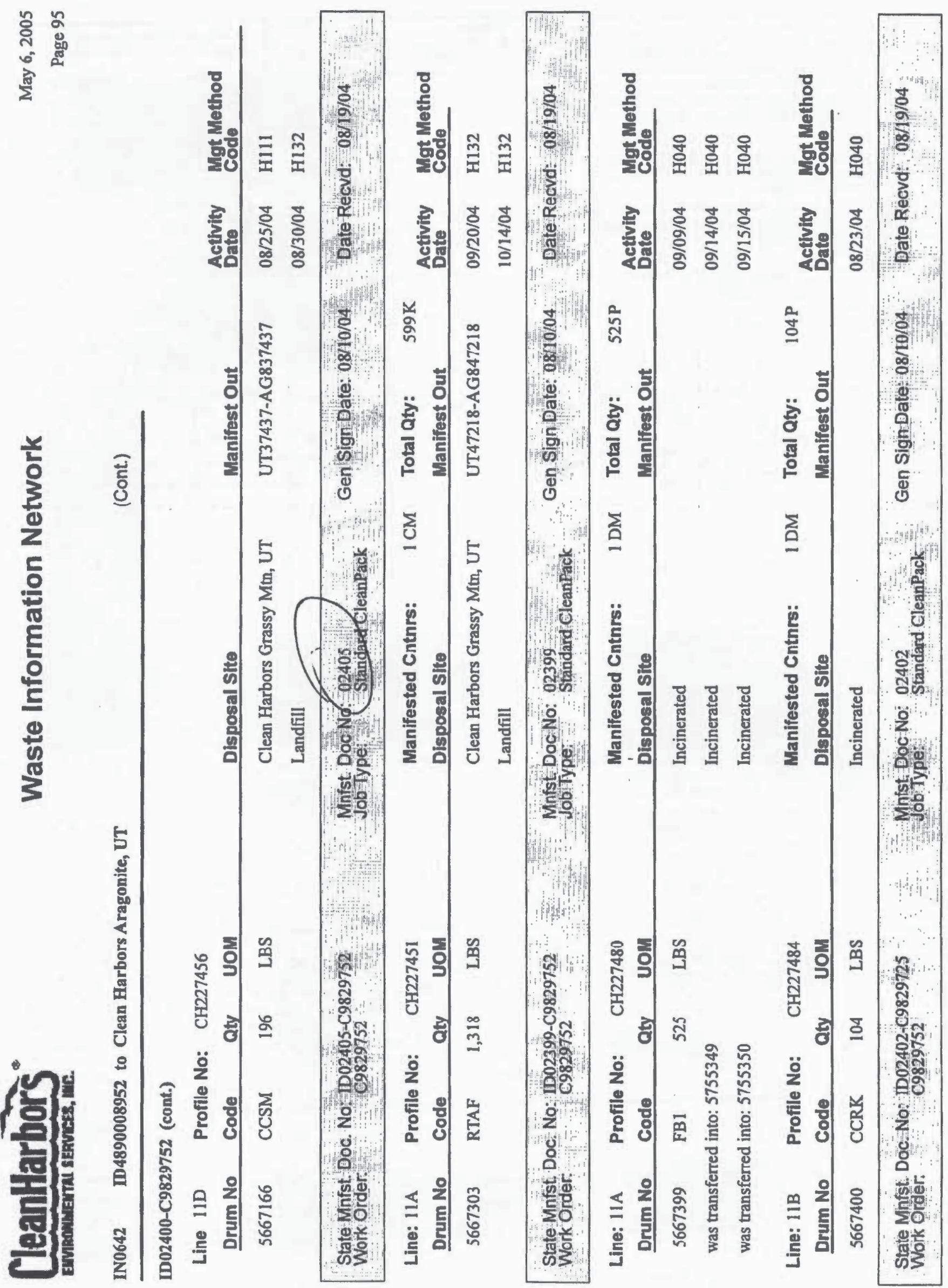




\author{
Clean Harbors Aragonite, UT \\ 11600 Narth Aptus Road \\ Aragonite. UT 84029
}

\begin{tabular}{|c|c|c|c|c|c|c|c|}
\hline 10. & & & & & & & \\
\hline $1002346-C 979603912$ & $06 / 15 / 04$ & $1002373 \times 4811256 \mathrm{P}$ & $07 / 28 / 04$ & $1002401-\cos 29752-4$ & $08 / 19 / 04$ & $1002457-C 2857181$ & $10 / 13 / 04$ \\
\hline $1502375-C 9811256$ & 07/28/04 & $1002373-\cos 11756)^{12}$ & $07 / 28 / 04$ & $1002464-\cos 297.32$ & $08 / 19 / 04$ & $1002463-C 9857181$ & $10 / 13 / 04$ \\
\hline $1002370-981125611$ & $07 / 28 / 04$ & $1002373-0981125683$ & $07 / 28 / 04$ & $1002435 . c 9846116$ & $09 / 17 / 04$ & $1002467-\mathrm{cos} 57181$ & $10 / 12 / 04$ \\
\hline $1002370-C 981125612$ & $07 / 28 / 04$ & $1002373 \times c 91125694$ & $07 / 28 / 04$ & $1002332 \times C 9846116$ & $09 / 17 / 04$ & $1002462-09857181-1$ & $10 / 13 / 04$ \\
\hline $1 D 02376-C 9811256 \mathrm{P}$ & $07 / 28 / 04$ & $1002373-C 9811258 \mathrm{PS}$ & $07 / 28 / 04$ & $1002433-C 9846116$ & 09117104 & $10024824 C 985718 ! 2$ & $10 / 13 / 04$ \\
\hline $1 D 02372 \times C 98112561$ & $07 / 28 / 04$ & $1002373-\mathrm{C} 9811256 \mathrm{PG}$ & $07 / 28 / 04$ & $1002431-\operatorname{Cos} 46116$ & $09 / 17 / 04$ & $1002461-C 2857181$ & $10113 / 04$ \\
\hline $1002371 . C 4811256 \mathrm{PI}$ & $07 / 28 / 04$ & $1002373-69811256$ & $07 / 28 / 04$ & $1002554-C 9857172$ & $10 / 33 / 04$ & $10024 \$ 2-C 98571819 \mathrm{PC}$ & $10 / 22 / 04$ \\
\hline $1002368-\operatorname{Cos} 11264 I^{3}$ & $07 / 28 / 04$ & $1 D 02373-C 4811253$ & $07 / 28 / 04$ & $1002453-C 0857172$ & $10 / 13 / 04$ & 1002452-Co8571819s & $16 / 12 / 04$ \\
\hline $1202380-\mathrm{C} 9811256 \mathrm{~B}$ & $07 / 28 / 04$ & $1002403 \cdot C 9829700$ & $08 / 19 / 04$ & $1002466-C 9857175$ & $10 / 13 / 04$ & $1002452-C 9857181$ & $10 / 12 / 04$ \\
\hline $1002381-C 9811256 \mathrm{P} 1$ & $07 / 28104$ & $1002409-09829752$ & $08117 / 04$ & $1002456-19857178$ & $10 / 13 / 04$ & Uro2501-C9875262 & $1 / 1 / 18 / 04$ \\
\hline $1002377-C 9911256 \mathrm{P} 1$ & $07 / 28 / 04$ & $1002408-c 9896752$ & $08 / 19 / 04$ & $1002455-C 9857180$ & $10 / 13 / 04$ & UT02502-C9875262 & $1 / / 18 / 04$ \\
\hline $1002369 \cdot \mathrm{C} 9811256^{\circ 1}$ & $07 / 28 / 04$ & 1D02407-C9829752-1 & 08/19/04 & $1002464 . C 9857180$ & $10 / 13 / 04$ & UT02498-C9875262 & $11 / 18 / 04$ \\
\hline $1002378-\mathrm{CS} 811256 \mathrm{P}^{\mathrm{O}}$ & $07 / 28 / 04$ & $1002407-43629752 . ?$ & $08 / 19 / 04$ & 10024650087181 & $10 / 12 / 04$ & (1702406-C0375262 & $11 / 18 / 04$ \\
\hline $1002379-\mathrm{C} 9811256 \mathrm{PI}$ & $07 / 28 / 04$ & $1002400-09820752$ & $08 / 1904$ & $1002452-C 9857181 P_{1}$ & $10 / 14 / 04$ & Uт02A96-C0875262-2 & $13 / 18 / 04$ \\
\hline $1002367 \times 09811264 P 1$ & $07 / 28 / 04$ & IDn2405-C9829752 & $68 / 19 / 04$ & $1002451-09857181-1$ & $10 / 12 / 04$ & บT02496-C9875262-3 & $1 / / 18 / 04$ \\
\hline $1002367-\mathrm{C} 4811264 \mathrm{P2}$ & $07 / 28104$ & $1002399-69829752$ & $08 / 19 / 04$ & $1002452.0257181 \mathrm{P}\}$ & $10 / 1404$ & UTO2496-C875262: & $11 / 18 / 104$ \\
\hline $1002367 \times C 9311264 \mathrm{P3}^{3}$ & $07 / 28 / 04$ & $1007402-08829725$ & $08 / 19 / 04$ & $1002451-\cos 57181-2$ & $10 / 12 / 04$ & $1002504-09875262$ & $11 / 18 / 04$ \\
\hline $1002367-C 9811264 P 4$ & $07 / 28 / 04$ & $1002406-6989952$ & $08 / 19 / 04$ & $1002451-69857181-3$ & $10 / 12 / 04$ & $1002503 . C 9875262$ & $11 / 18 / 04$ \\
\hline$[D 02395-C 98[1256 B]$ & $07 / 28 / 04$ & IDO2401.09829752.1 & $08 / 19 / 04$ & $1002460-C 985718 !$ & $10 / 13 / 04$ & $1002495-C 9875262$ & $11 / 18 / 04$ \\
\hline $1002392-09811264 \% 1$ & $07 / 28 / 144$ & $102401-C 9829752-3$ & $08 / 19 / 04$ & 1002459.09857181 & $10 / 12 / 04$ & $1002495-\operatorname{cog} 75262=2$ & $11 / 18 / 04$ \\
\hline$\left[002324-\operatorname{Cos}\left[1256 \mathrm{P}^{2}\right]\right.$ & 07/28/04 & $10032401-\operatorname{cs} 829752-3$ & $08 / 19 / 04$ & 1002458.09857181 & $10 / 13 / 04$ & $1002499-\mathrm{Cog} 75262-1$ & $11 / 18 / 04$ \\
\hline
\end{tabular}

The above described waste, pecelved at the Clean Harbors facifty listed above pursuant to the mantest(s) listed above, has bean treated and/or disposed of by Clean Harbors, or another fiecensed tacility approved by Clean Harbors, in accordance with applicable rederal and state laws and regulations. Any waste raceived by Clean Harbors and subsequently shipped to another licensed facility has been or shall be identfied as being geveratad by Clean Habors in accordance with $40 \mathrm{CF}$. 26.4 .74 (c).

Under chil and criminal penalties of law for the making of submission of false or frawdulent statements or representations (18 U.S.C. 3001 and 15 U.S.C. 2615\% 1 certhy that the frfom personally vorfy truth and accuracy, I certify as the company official having supervisory responsibility for the persons who, acting under my direct instructons, made the verification that this information is true, accurate, and complete.

Signed:

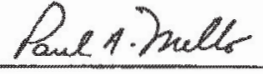

Date: $5 / 6 / 2005$

Title: Senior Tracking Manager 


$\sqrt{187 \quad \text { of } 1 9 0 \longdiv { 7 5 \% }}$

Certificate of Treatment/Disposal - Storage and Transfer

May 6, 2005

Cleantarbors

Page 187

\author{
Clean Harbors Aragonite, UT \\ 11600 North Aptus Road \\ Aragonite. UT 84029 \\ UTD981552177
}

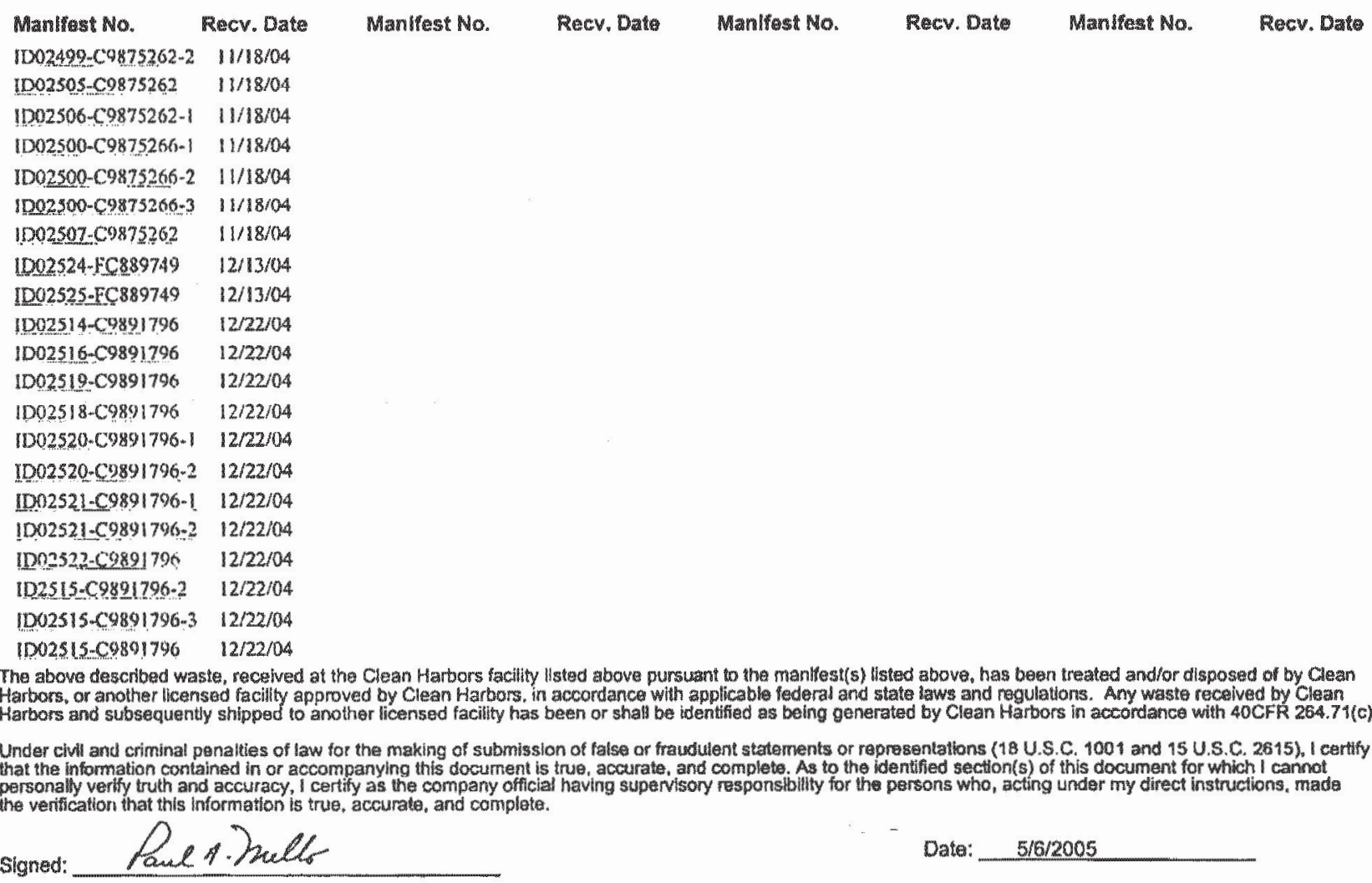

Titio:

senior Tracking Manager 



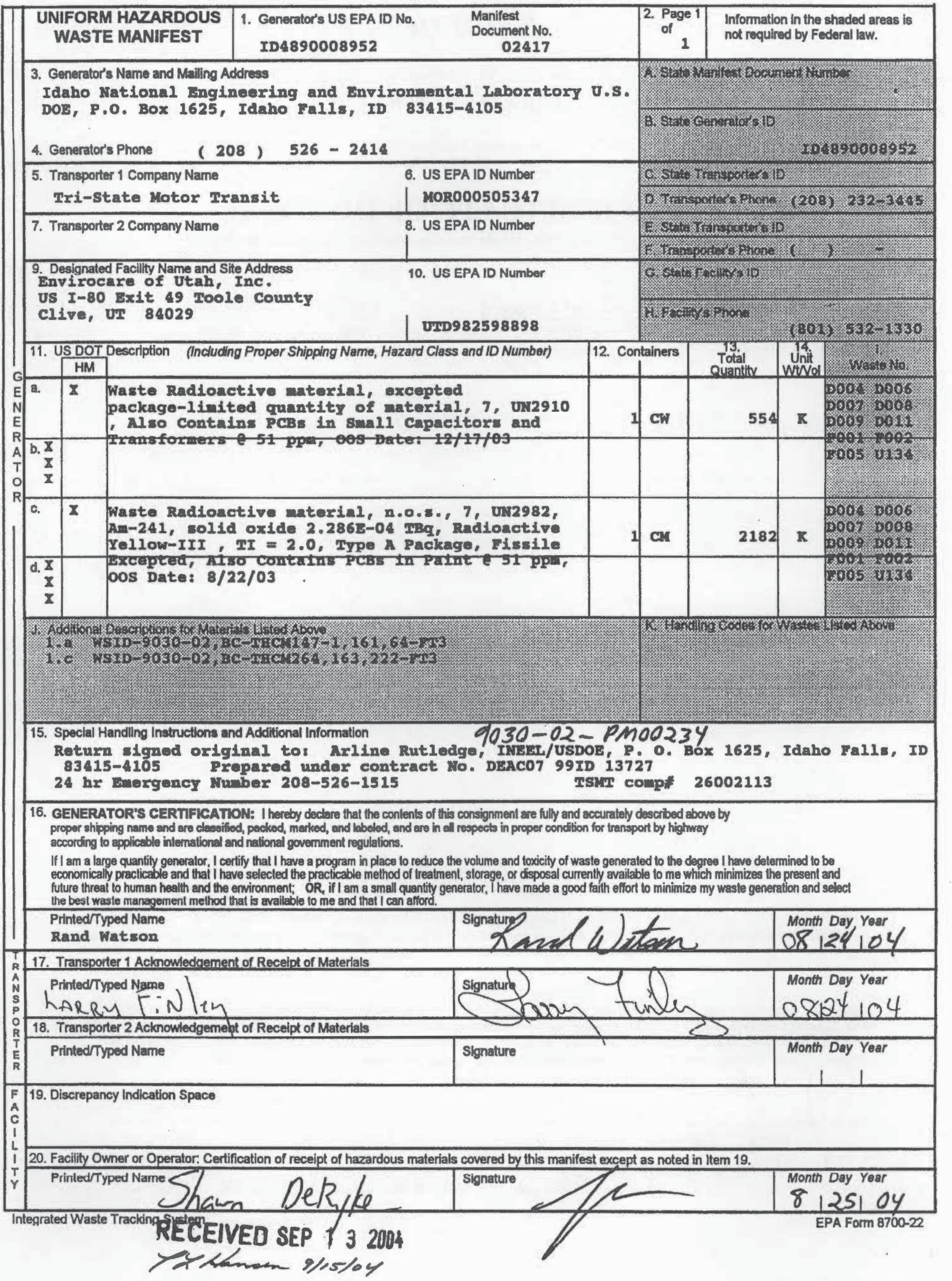




\section{ENVIROCARE}

OF UTAH, INC.

THE SAFE ALTERNATIVE

3 mi. S. Ext. $49,1-80$

Clive, Utah 84029 EPA

ID: UT982598898

\section{CERTIFICATE OF DISPOSAL}

This Certificate acknowledges that the following manifested shipments:

$\frac{\text { Shipment }}{9030-02-0027} \quad \frac{\text { Manifest }}{02417} \quad \frac{\text { Date(s) of Disposal }}{12 / 01 / 2004} \quad \frac{\text { Cu/Ft }}{286} \quad \frac{\text { Process }}{\text { Landfill }} \quad \frac{\text { Disposal Location }}{\text { Mixed Waste }}$

Representing 286 Cubic feet of waste of at listed Disposal Facility landfill. Disposal is subject to Envirocare's Radioactive Material License, all other applicable licenses, permits and regulations, and the Disposal Agreement.

Under civil and criminal penalties of law for the making or submission of false or fraudulent statements or representations (18 U.S.C 1001 and 15 U.S.C. 2615) I certify that the information contained in or accompanying this document is true, accurate and complete. As to the identification section(s) of this document for which I cannot personally verify truth and accuracy, I certify as the company official having supervisory responsibility for the persons who, adting under my direct instructions, made the verification that this information is true, accurate and complete.
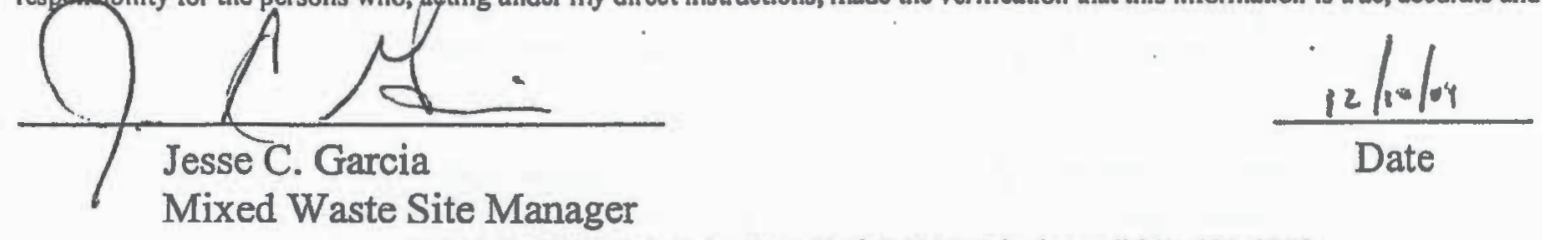



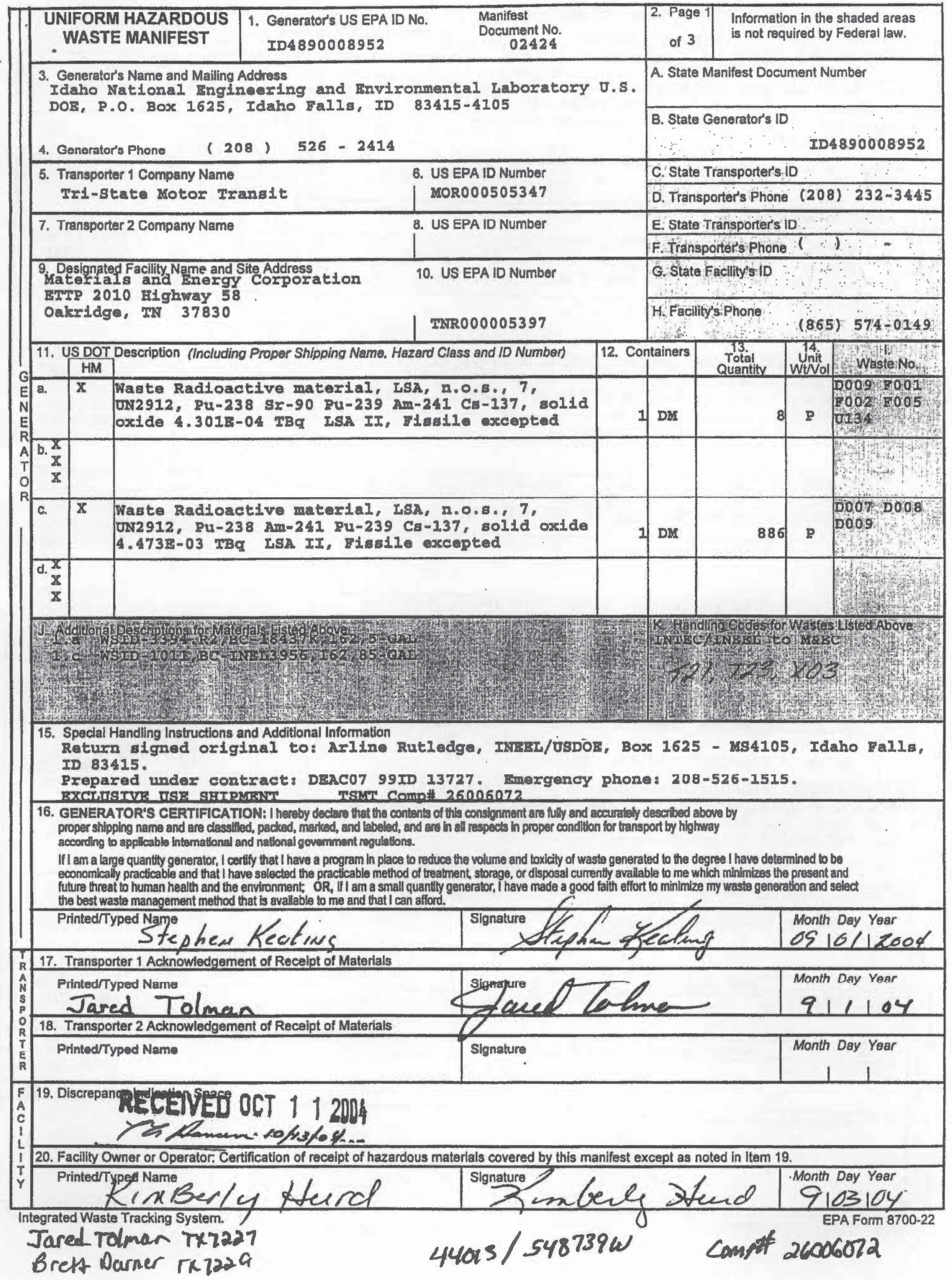




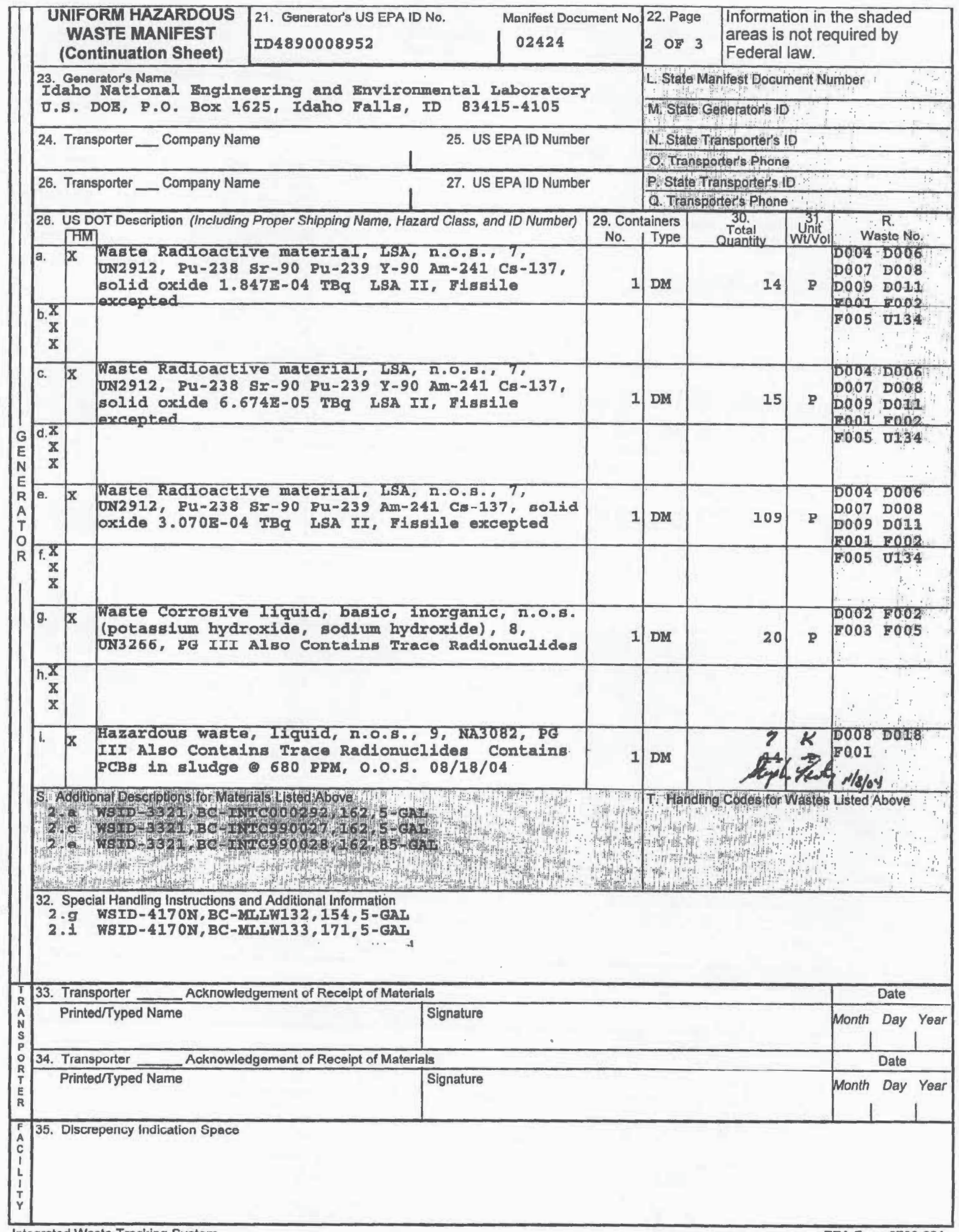




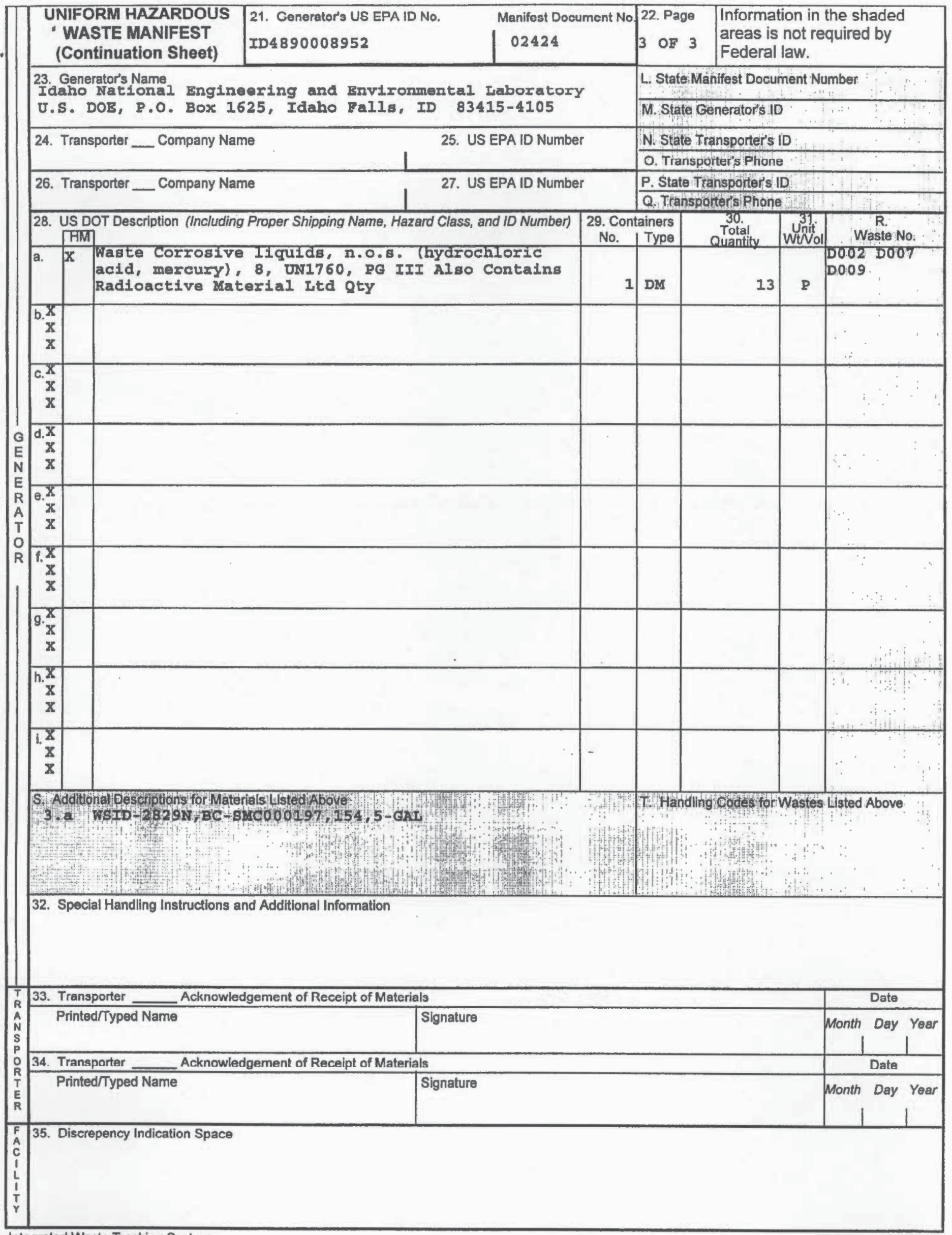





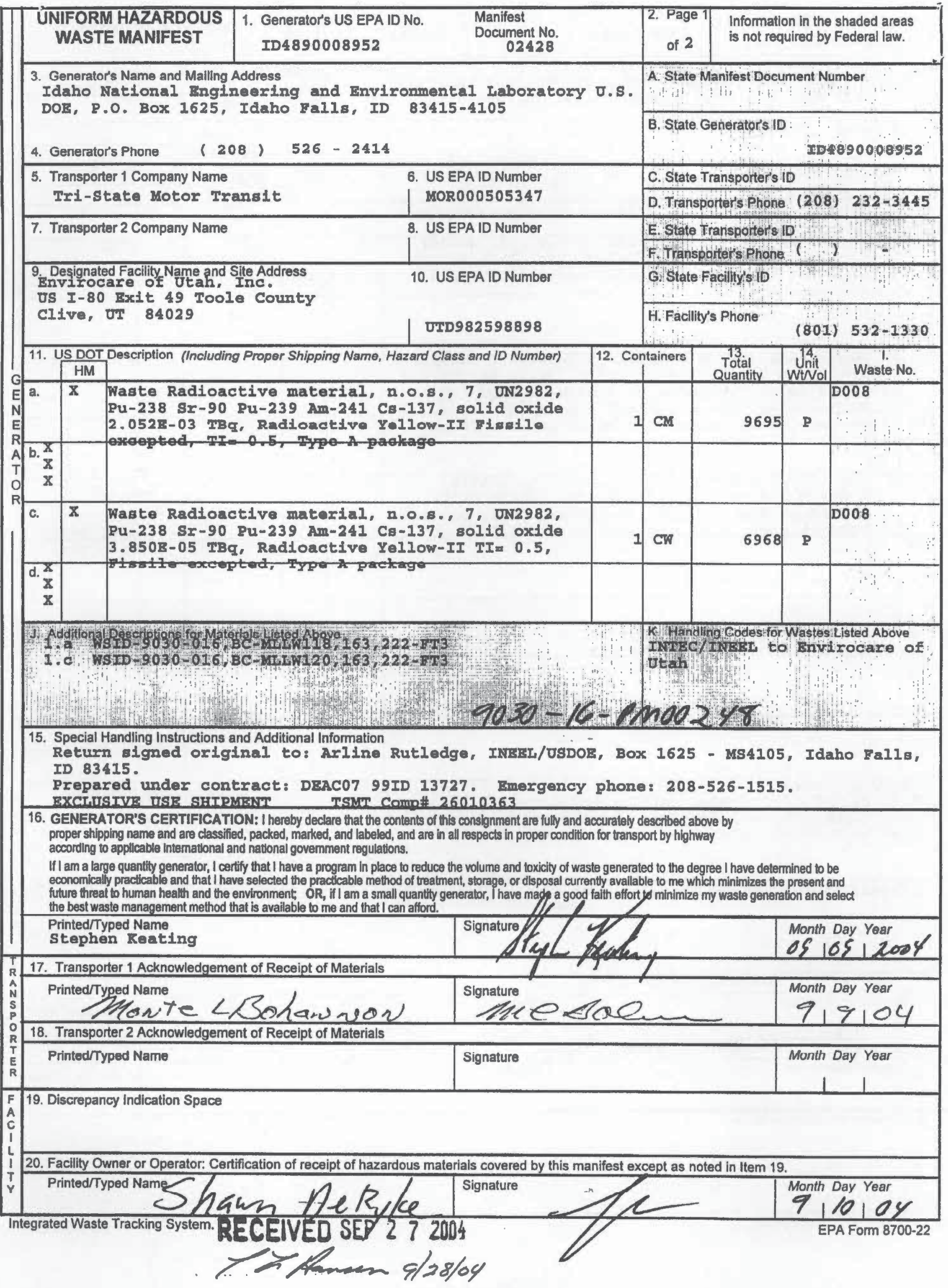




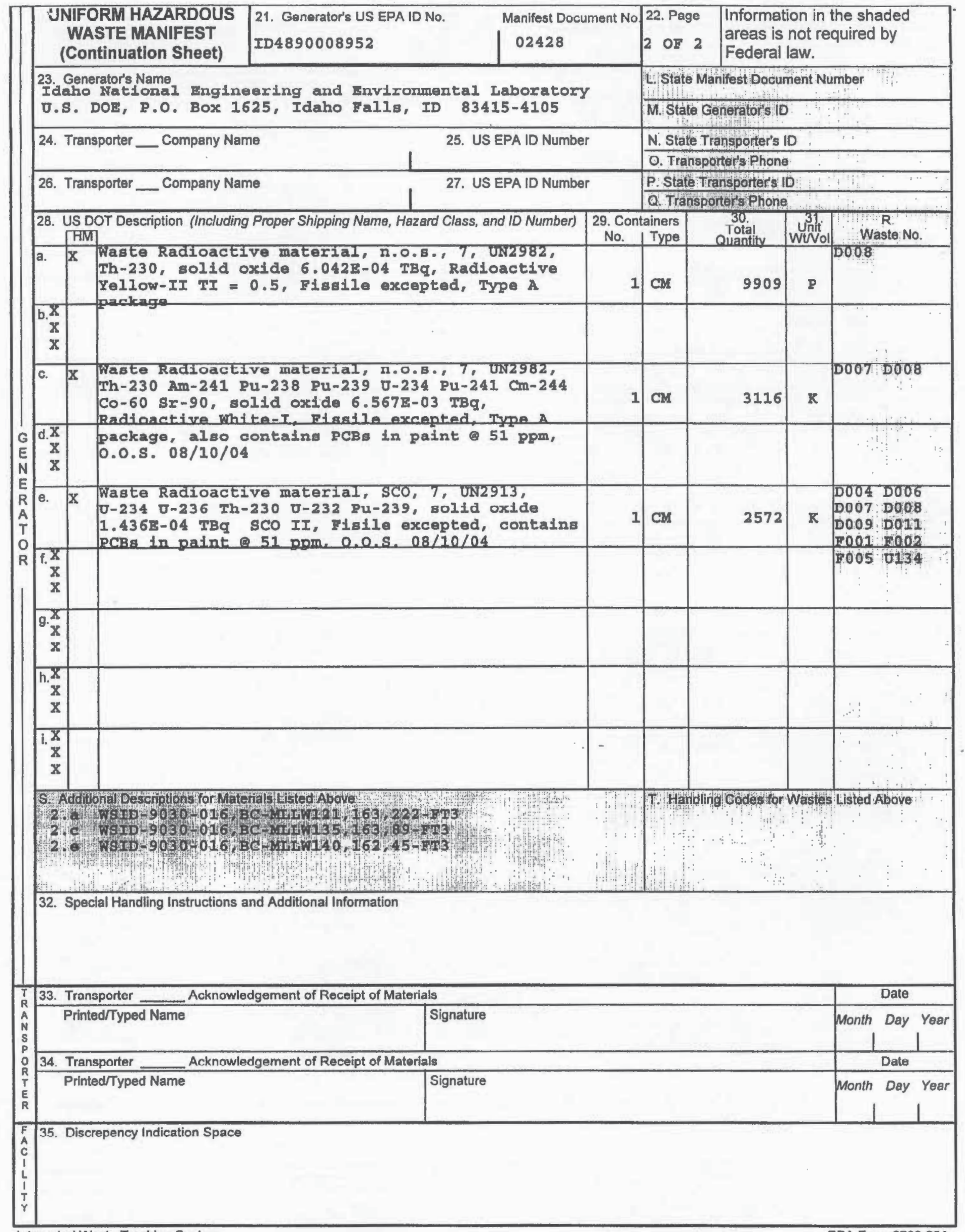


ENVIROCARE

OF UTAH, INC.

THE SAFE ALTERNATIVE

3 mi. S. Ext. $49,1+80$

Clive, Utah $84029 \mathrm{EPA}$

ID: UT982598898

\section{CERTIFICATE OF DISPOSAL}

This Certificate acknowledges that the following manifested shipments:

$\frac{\text { Shipment }}{9030-16-0006} \quad \frac{\text { Manifest }}{02428} \quad \frac{\text { Date(s) of Disposal }}{12 / 15 / 2004} \quad \frac{\text { Cu/Ft }}{12 / 18 / 2004} \quad \frac{\text { Process }}{\text { Landfill }} \quad \frac{\text { Disposal Location }}{\text { Mixed Waste }}$

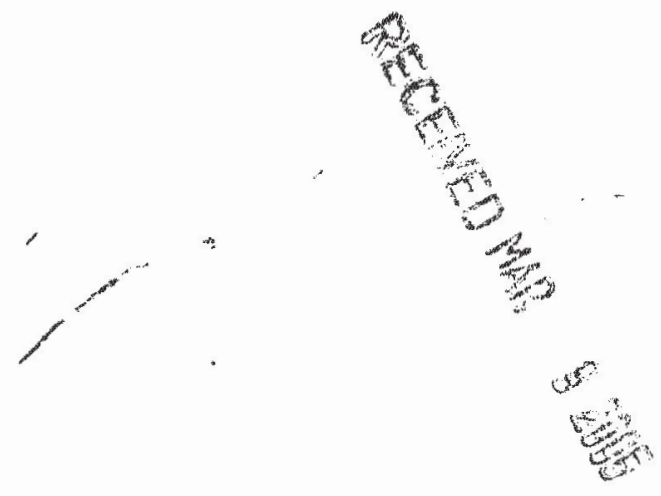

Representing 264 Cubic feet of waste of at listed Disposal Facility landfill. Disposal is subject to Envirocare's Radioactive Marerial License, all other applicable licenses, permits and regulations, and the Disposal Agreement.

Under civil and criminal penalties of law for the making or submission of false or fradulent statenents or representations (18 U.S.C 100 and 15 U.S.C. 2615) I certify that the information contained in or accompanying this document is true, accurate and complete. As to the identification section(s) of this document for which hcannot personally verify truth and accuracy, I certify as the company official having supervisory yesponsigility for the persons who, agthg under my direct instructions, made the verification that this information is true, accurate and complete.
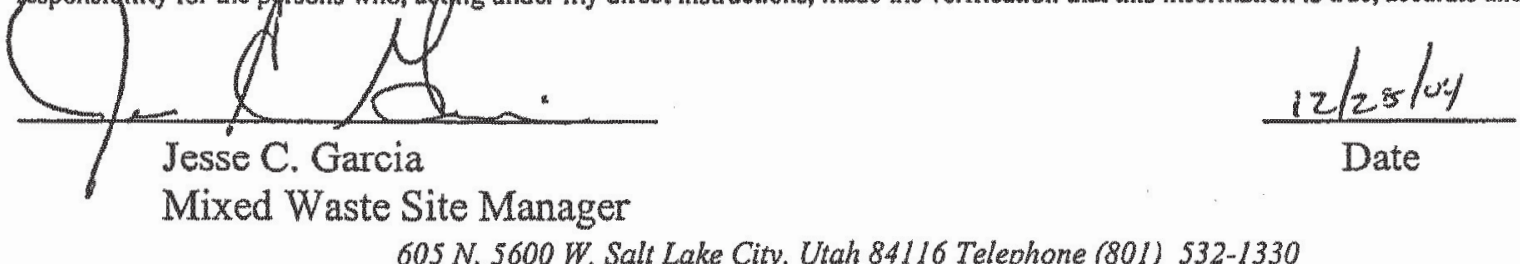

605 N. 5600 W, Salt Lake City, Utah 84116 Telephone (801) 532-1330 



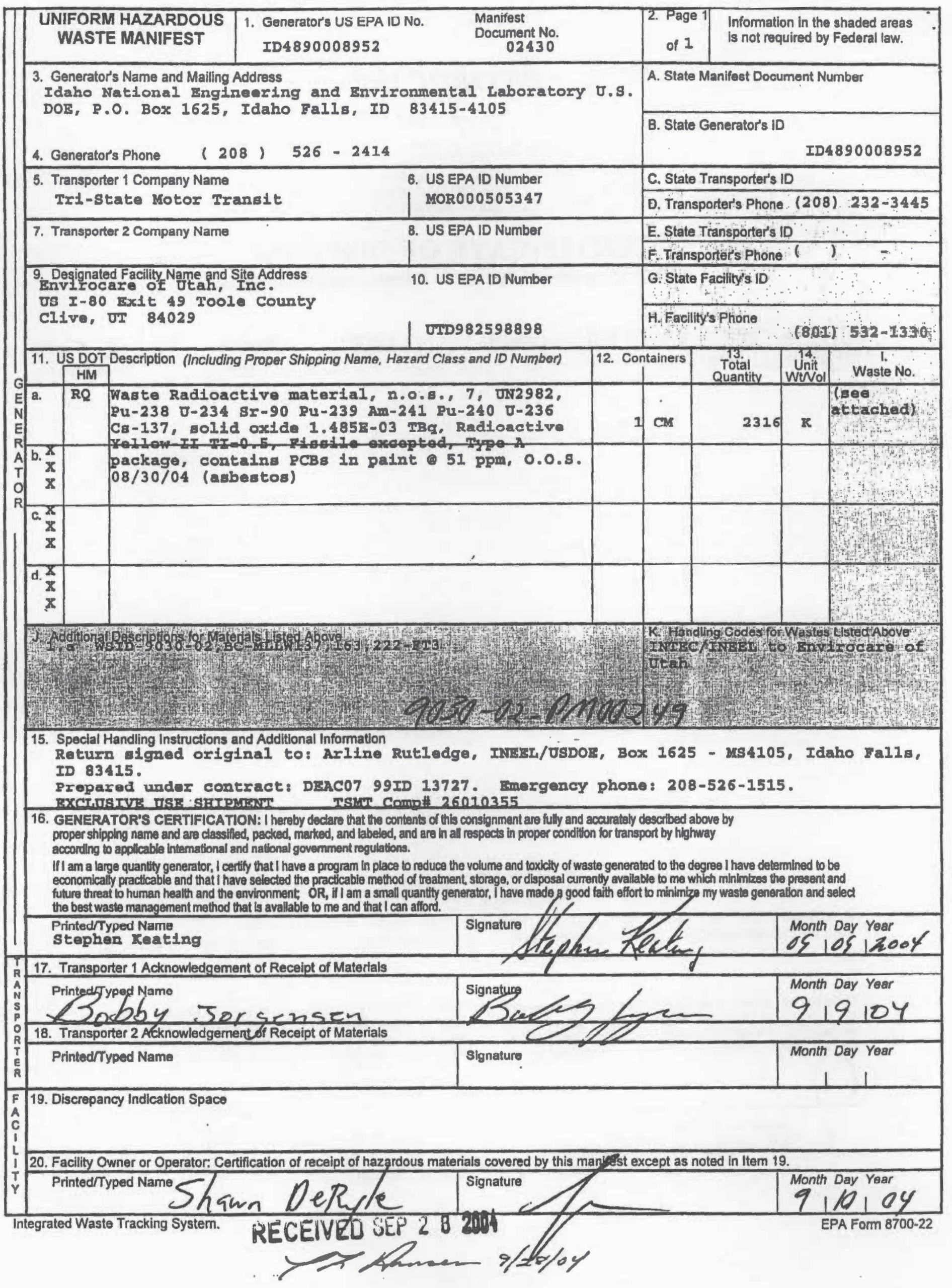




\section{ENVIROCARE}

OF UTAH, INC.

THE SAFE ALTERNATIVE

3 mi. S. Ext. $49,1-80$

Clive, Utah $84029 \mathrm{EPA}$

ID: UT982598898

\section{CERTIFICATE OF DISPOSAL}

This Certificate acknowledges that the following marifested shipments:

$\frac{\text { Shipment }}{9030-02-0029} \frac{\text { Manifest }}{02430} \quad \frac{\text { Date(s) of Disposal }}{01 / 05 / 2005} \quad \frac{\text { Cu/Ft }}{222} \quad \frac{\text { Process }}{\text { Landfil }} \quad \frac{\text { Disposal Location }}{\text { Mixod Wasto }}$

Representing 222 Cubic feet of waste of at listed Disposal Facility landfill. Disposal is subject to Envirocare's Radioactive Material License, all other applicable licenses, permits and regulations, and the Disposal Agreement.

Under civil and criminal penalties of law for the making or submission of false or fraudulent statements or representations (18 U.S.C 1001 and 15 U.S.C. 2615) I certify that the information contained in or accompanying this document is true, accurate and cormpiete. As to the identification section(s) of this document for which I carnot personally verify truth and accuracy, I certify as the company offieial having supervisory responsibility for the persons who, acting under my direct inatruetions, made tho yerifieation that this information is true, aceurate and complete.
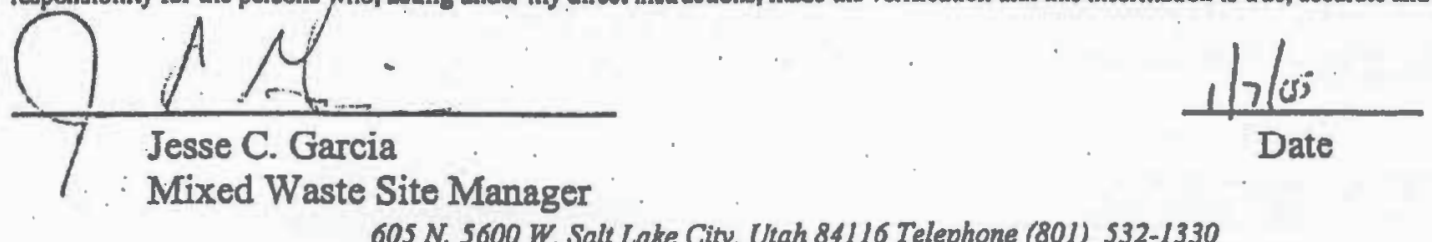



\begin{tabular}{|c|c|c|}
\hline $\begin{array}{c}\text { UNIFORM HAZARDOUS } \\
\text { WASTE MANIFEST }\end{array}$ & $\begin{array}{l}\text { 1. Generator's US EPA ID No. } \\
\text { ID4890008952 }\end{array}$ & $\begin{array}{l}\text { Manifest } \\
\text { Document No. } \\
02433\end{array}$ \\
\hline
\end{tabular}

4. Generator's Phone (208) $526-2414$

\begin{tabular}{|l|l|}
\hline 5. Transporter 1 Company Name & 6. US EPA ID Number \\
Clean Eaxbora Envixonmental Serviced, MAD039322250
\end{tabular}

2. Page 1 Information in the shaded areas

of 1 is not required by Federal law.

A. Stale Manifest Document Number

B. State Generator's ID

Transporter 2 Company Name

8. US EPA ID Number

10. US EPA ID Number

9. Pesignated Facility Name and Site Address

(aragonite) IIC

11600 North Aptur Road.

Aragonite, OI 84029

UTD981552177

ID\$890008952

C. State Transporter's ID

D. Transporter's Phone (801) 849-1800

E. State Transporter's ID

F. Transporters Phone ( ) -

G. State Faclity's ID

H. Facilly's Phone

(801) 323-8100

11. US DOTDescription (Including Proper Shipping Name, Hazard Cless and ID Number)

\begin{tabular}{l|l|l|}
$\mathrm{G}$ & $\mathrm{HM}$ & \\
$\mathrm{E}$ & $\mathrm{X}$ & Hazardous waste, sol1d, $\mathrm{x.0.8.}, 9, \operatorname{Nn} 3077, \mathrm{PG}$
\end{tabular}

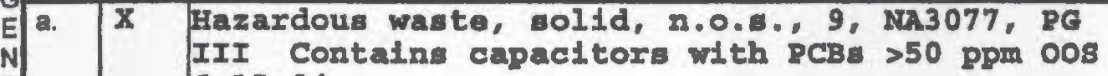

E

III $-15-04$

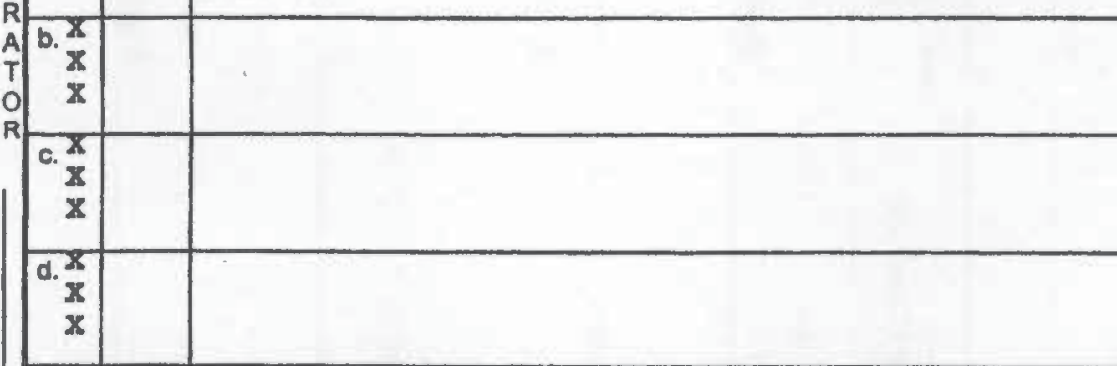

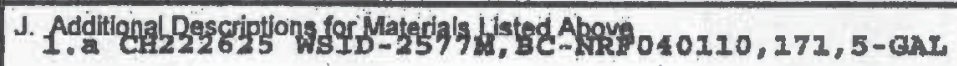

K. Haindling Codes for Wastes Listad Above

INIRE IOAD: \#183

gATES ORDER "C9846116

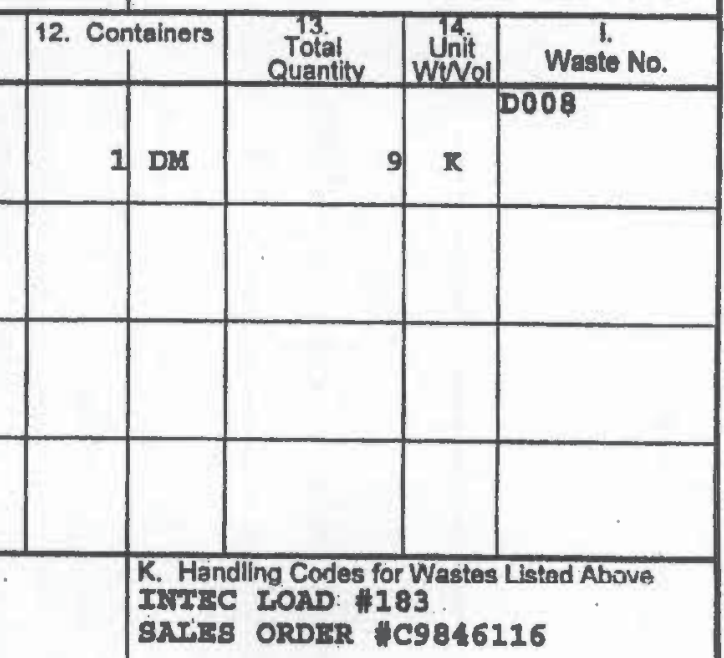

15. Special Handling Instructions and Additional Information

Return signed original to: B. A. Rutledge, Idaho National Ergineoring Environmental

Laboratory/0S DOF, P.O. Box 1625, Idaho Fa11e, ID 83415-4105. Propared undex contract

WDEAC07 99ID 13727. USDOR 24-Hx. Emergoncy Phone: (208) 526-1515.

16. GENERATOR'S CERTIFICATION: I hereby declare that the contents of thile consignment are fully and accurataly described above by

proper shipping name and are classhliled, packed, marked, and labeled, and ave in all respocts in proper condition for transport by highway

acconding to applicable intemational and natbonal govemnent regulations.

III am a lange quantlly generator, I certify that I have a program h place to reduce the volume and toxichly of waste generated to the degree I have determined to be

economically practicable and that I have selected the practicable method of treatment, storage, or disposal currently available to me which minimizes the present and

future threal to human health and the environment. OR, if I am a small quantily generator. I have made a good faith effort to minimize my waste generation and select the best waste management method that is avallable to me and that I can afford.

Printed/Typed Name

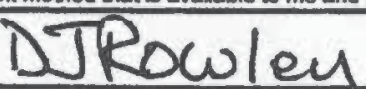

17. Transparter 1 Acknowledgement of Recelpt of Matofials

Printed/Typed Name

Sery L Biks

18. Transporter 2 Acknowledgement of Receipt of Materials

Printed/Typed Name

R

F

19. Discrepancy Indication Space

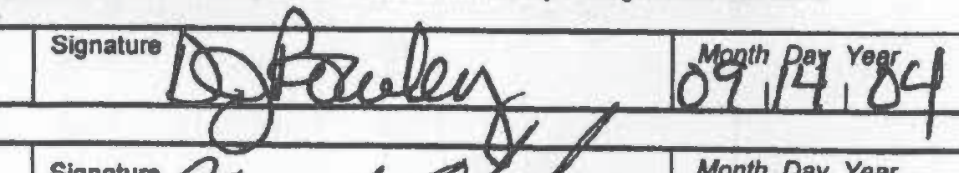

C.

20. Facility Owner or Operator: Certification of receipt of hazardous materials covered by this manifest except as noted in ltem 19.

Pringed/Typed Name, Prinedrit)

Integrated Waste Tracking System.

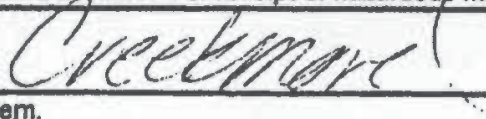

RECEIVED OCT - 52014

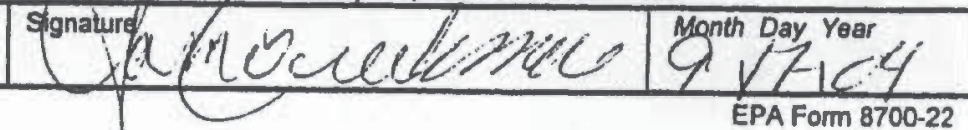




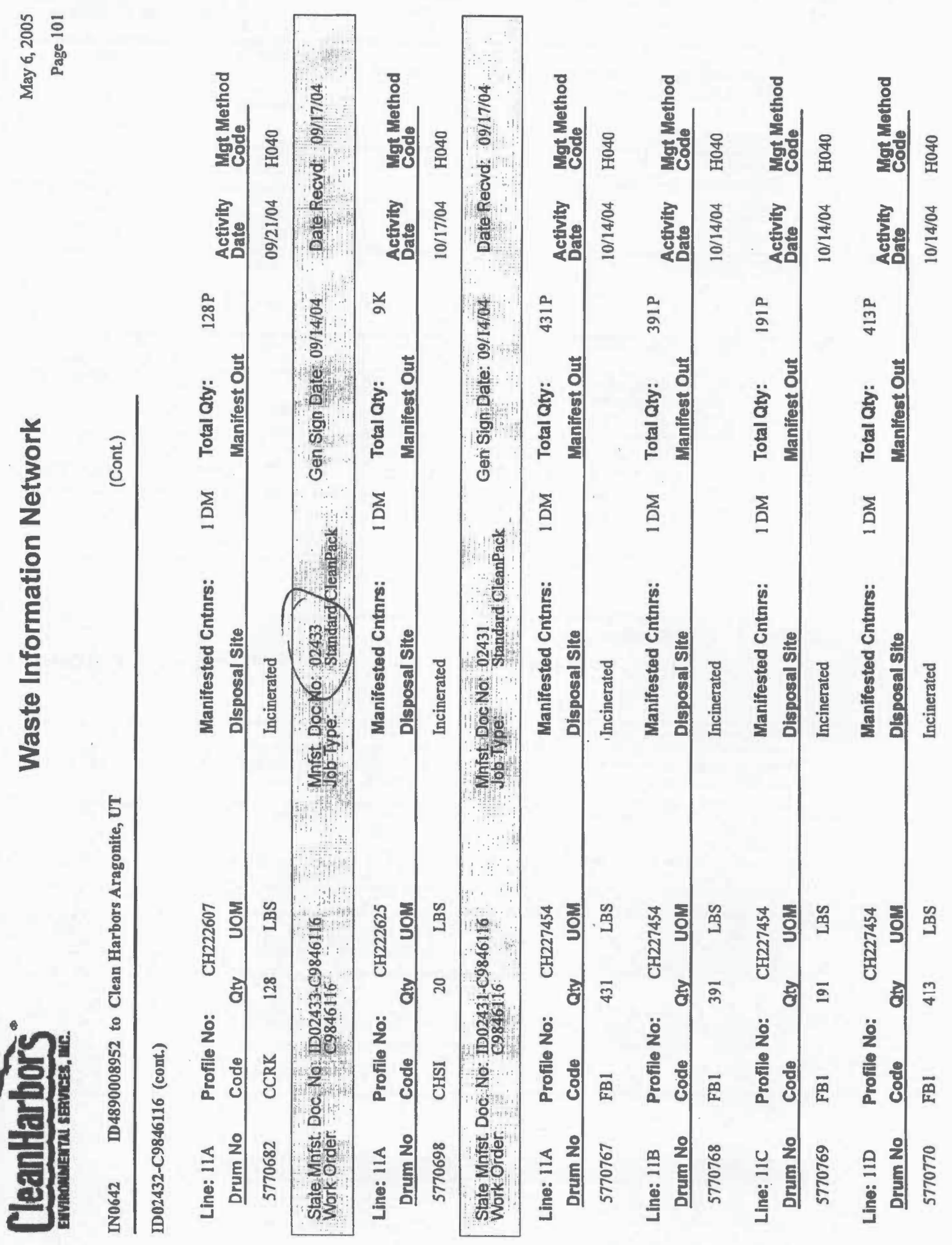




186 of $190 \sqrt{75 \% \sqrt{14}}$

Cleantharbors

\section{Certificate of TreatmentDisposal - Storage and Transfer}

May 6.2005:

Page 183

\begin{abstract}
Manifest No. Recv. Date 1002346-C9796039P2 06/15/104 ID02375-C9811256 07/28/04 $1002370-998112561107 / 28 / 04$ [D02370-C9811256P2 07/28/04 ID02376-CU811256P1 07/28/04 $1002372-C 0811256 \mathrm{PI} \quad 07 / 28 / 04$ 1D02371-C0811256P1 07/28104 ID02368-C9811264P1 07/28/04 ID023:0-C981125621 $07 / 28 / 04$ $1002381-\operatorname{Co8} 11256 \mathrm{P} !$ 07/28/01 ID02377.C9911256P! 07/28/04 $10023696981125691 \quad 07 / 28 / 04$ $1002378-C 9811256 \mathrm{PI} \quad 07 / 28 / 04$ 1002379. COU1125681 07/28/04 1002367-99811264P! 07/28104 ID02367-C9811264P2 07/28/04 $100236 \%-C 9811264 \mathrm{P3} \quad 07 / 28104$ 1002367-C9811264P4 07/28/04 $1002395-C 9811256 \mathrm{P} 1 \quad 07 / 28 / 04$ $1002392-C 98112641107 / 28104$ $1002374-C 2811256 \mathrm{P1} \quad 07 / 28104$
\end{abstract}

1002373-C9811256P1 07/28/04 $1002373 \times C 9811256 \mathrm{P}^{2} \quad 07 / 28104$ $1003373-C 984125613 \quad 07 / 28104$ 1002373-Cos11256P4 07/28/04 ID02373-C9811256Ps 07/28/04 ID02373-COS1125686 07/28/04 1002373-C9811256 07/28/04 $1002373-C 9811253 \quad 07 / 28 / 04$ $1002403-c 9829700 \quad 08 / 19 / 04$ ID02400-Co820752 08/17/04 [DO2408-C9829752 08/19/04 1002407-C9829752-1 08/19104 1002407-Cos29752-? 08/19/04 $1002400-C 082925208 / 10104$ ID02405-C9829752 08/19/04 $1002399 . C 0822752 \quad 08 / 19 / 04$ 1002402-00320725 08/19/04 1002406-C982975z 08/19/04 $1002401-C 9822253-1 \quad 08 / 19 / 04$ 102401-C9829752-2 08/19/04 $1002401-C 9828722-3 \quad 08 / 19 / 04$
$1002401-698297524 \quad 08 / 19 / 04$ 1002404-C9829752 08/19/04 $1002435-C 9840116 \quad 09 / 17 / 04$ $1002432-C 9846116009 / 17104$ ID02433-C9846116 09/17/04 [D02431-Co846116 0\%17/04 $1002454-C 9857172 \quad 10 / 13 / 04$ $1002453-08857172 \quad 10 / 13 / 04$ $1002466-C 9857175 \quad 10 / 13 / 04$ $1002456-09857178 \quad 10 / 13 / 04$ $1002455-C 9857180 \quad 10 / 13 / 04$ $1002464.09857180 \quad 10 / 13 / 04$ $1002465-C 98578 ! \quad 10 / 12 / 04$ 1002452-C985781PL 10/14/A $1002451-C 9857181 \cdot 1 \quad$ 10/12/04 1002452-C9857181P3 10/14/04 $1002451-C 9857181-2 \quad 10 / 1204$ 1002451-CO857181-3 10/12/04 $1002460-C 9857181$ 10/13/04 $1002459-C 9857181 \quad 20 / 12 / 04$ $1003458-09857181 \quad 10 / 13 / 04$
$1002457.09857181 \quad$ 10/13/04 $1002463 \mathrm{Cg} 57181 \quad$ 10/13/04 ID02467-C9857181 10/12/04 $1002462-C 9857181-1$ 1013/04 IDO2462-C9857181-2 10/13/04 $1002461.02857181 \quad$ 10/13/104 1D02452.C0857181PC 10/12/04 1002452-C9857181P5 16/12/04 $1002452-09857181 \quad 10 / 12 / 04$ UT02501-C9875262 11/1804 UT02502.C9875262 11/18/04 UT02488-C9875262 11/18104 UT02496-C9875262 11/18/04 17T02486-C8875262:2 11/1804 UT02496-C9875262-3 $11 / 18104$ UTO2496-C9875262-4 IU18104 $100250469875262 \quad 11 / 18104$ 1002503.Co87236 $\quad 11 / 1104$ $1002495-C 9873263 \quad 11 / 1804$ [D02495-C9875262-2 $11 / 1804$ $1002499-69875262.1 \quad 11 / 18104$

The above desscribed waste, recelved at the Clean Harbors facilly listed above pursuant to the manifest(s) llsted above, has bren treated andior disposad of by Clear

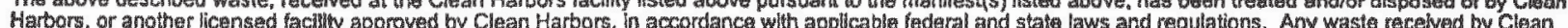

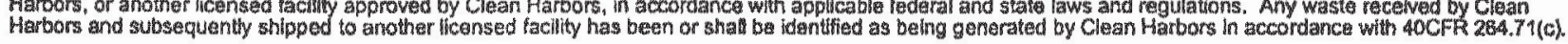

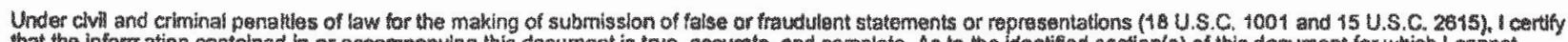
that the inforriation contained th or accompanylng this document is trus, accurate, and complete. As to the loentiffed section(s) of this document for which i cannot

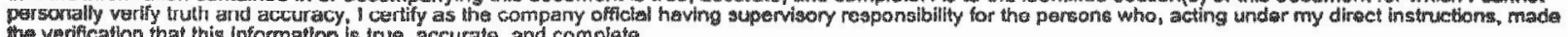
the varitication that this information is trus, accurate, and complete.

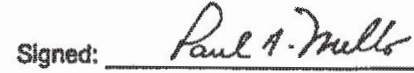

Date: $5 / 6 / 2005$

THe: Senior Tracking Managar 


\section{Cleantlarbors:

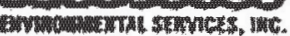

\section{Certificate of Treatment/Disposal - Storage and Transfer}

\author{
Cleant Harbors Aragonite. UT \\ 11600 North Aptus Road \\ A ragonite, UT 84029 \\ UTD 98152177
}

\begin{abstract}
Manifest No. REecv. Dat
ID02499-C9875262-2 $\quad 11 / 18 / 0$

ID02505-C9875262 /1/18/04

$1002506.69875262+1 \quad 11 / 18 / 04$

1D02500-C9875266-1 11/18/04

$1002500-08875266-2 \quad 11 / 18 / 04$

1D02500-C5875366-3 $\quad 11 / 1804$

$1002507.09875262 \quad 11 / 18104$

ID02524-FC889749 12/13/04

$1002525-F C 389749 \quad 12 / 13 / 04$

1002514-Corg1795 12/22/04

1002516-C9891796 12/22/04

m02519-C9891796 12/2204

D002518-C9891796 12/22/04

tro2570-Co891706: 12/2204

ID02520-Co891796-2 12/22/04

ID02521.C989172\%:- 12/22/04

$1002521-\operatorname{Cos} 91796-2 \quad 12 / 22 / 04$

ID02523-C?891796 12/22/04

1D2515-C9891796-2 12/22/04

$1002515-09891796-3 \quad 12 / 22104$

$1002315-C 2891726$

$12 / 22 / 04$
\end{abstract}

Manifest No.

Recy, Date

Manifost No.

Rev. Dat

Manifest No.

Recv. Date

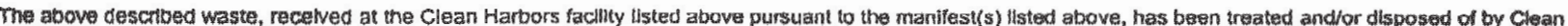
Hatbors, or another licensed facilty aporoved by Clean Harbors, in accordance with apolicabla federal and state laws and reoulations. Any was te received by Cleass

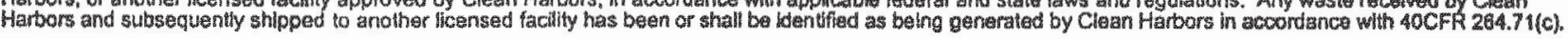

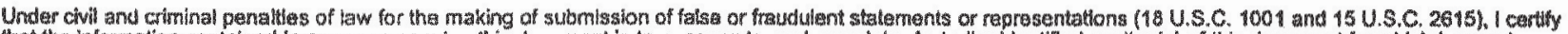
that the information contained in or accompanying this documant is trese, accurate, and complate. As to the identifled section(a) of this document for which l cannot personally verify truth and accuracy, I certify as the compeny offichl having supervisory responsibitly for the porsons who, acting undor my direct instruetions, medo

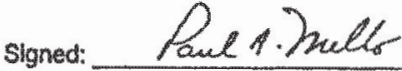

Date:

$5 / 612005$
May 6,2005

Page 187

Titse: Senior Tracking Manager 



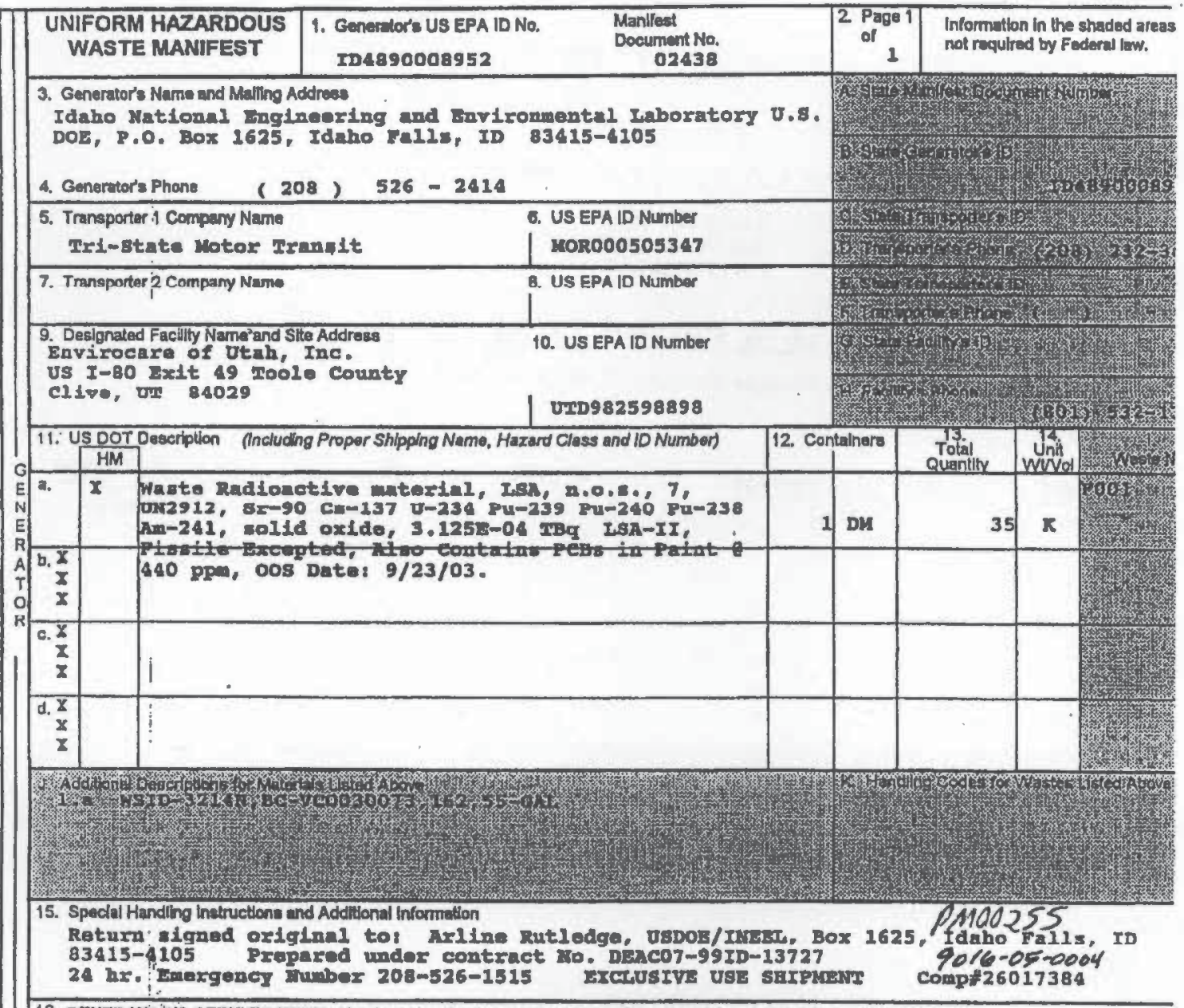

16. GENERATOR'S CERTIFICATION: I hereby daclare trat the conlents of this coneigmment are filly and Bceurataly daseribed abowe by proper shippigh nama and are classilied, pecked, maskad, and labeled, and are in all respects in proper condilion for transport by highway sconding to opplicable inlemationd and national government regulalisne.

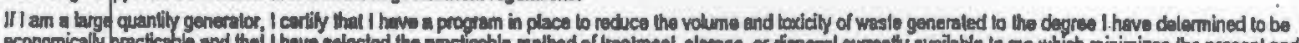

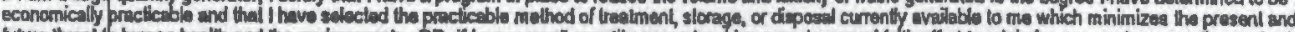

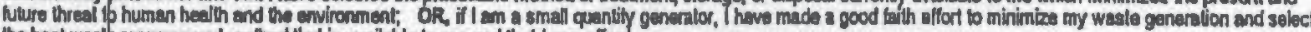
the besi wasl manegemenl method that is availoble to me and that I can afford. \begin{tabular}{|l|l|l|l|}
\hline Printed/Typod Name & Month Day Yeer
\end{tabular}

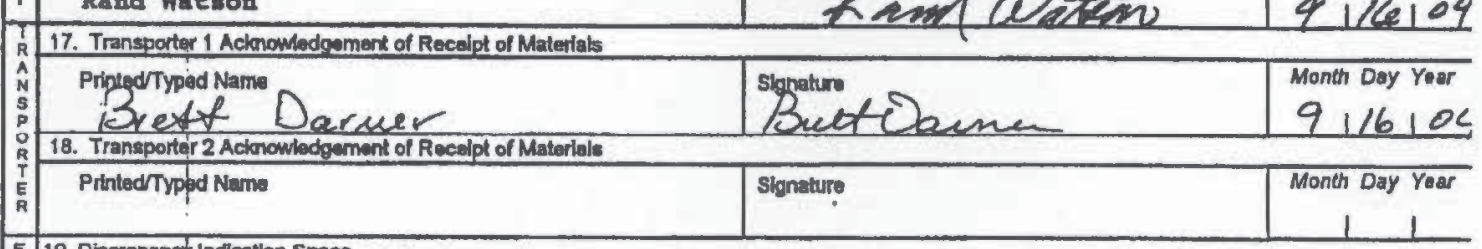

$\mathrm{F}$
$\mathrm{A}$
$\mathrm{C}$

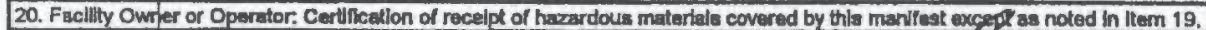

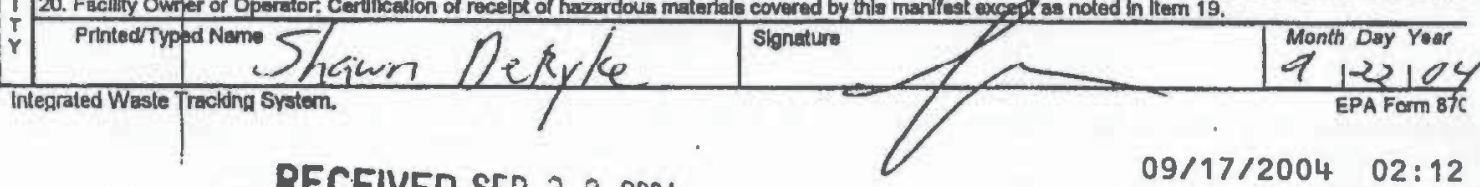

RECEIVED SEP 232004

$09 / 17 / 2004 \quad 02: 12$

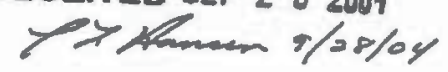




\section{ENVIROCARE}

OF UTAH, INC.

\section{THE SAFE ALTERNATIVE}

3 mi. S. Ext. 49, $1-80$

Clive, Utah 84029 EPA

ID: UT982598898

\section{CERTIFICATE OF DISPOSAL}

This Certificate acknowledges that the following manifested shipments:

$\frac{\text { Shipment }}{9016-05-0004} \frac{\text { Manifest }}{02438} \cdot \frac{\text { Date(s) of Disposal }}{12 / 15 / 2004} \quad \frac{\text { Cu/Ft }}{7.35} \quad \frac{\text { Process }}{\text { Landfill }} \quad \frac{\text { Disposal Loction }}{\text { Mxed Math }}$

Representing 7.35 Cubic feet of waste of at listed Disposal Facility landfill. Disposal is subject to

Envirocare's Radioactive Material License, all other applicable licenses, permits and regulations, and the Disposal Agreement

Under clvil and criminal penalties of law for the making or submission of false or fraudulent statements or representations (18 U.S.C 1001 wils U.S.C. 2615) I certify that the information contained in or accompanying this document is true, accurate and complete. As to the identifieation section(s) of this document for which I cannot personally verify truth and accuracy, I certify as the company ofricial having supervisory respoussibility for the persons who, seting under my direct instructions, made the verification that this information is true, accurate and comphate
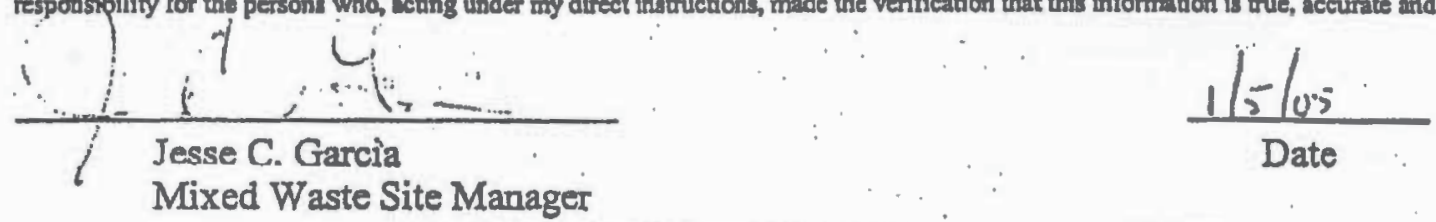

605 N. 5600 W, salt Lake City, Uhah 84116 Telephone (801) 532-1330 



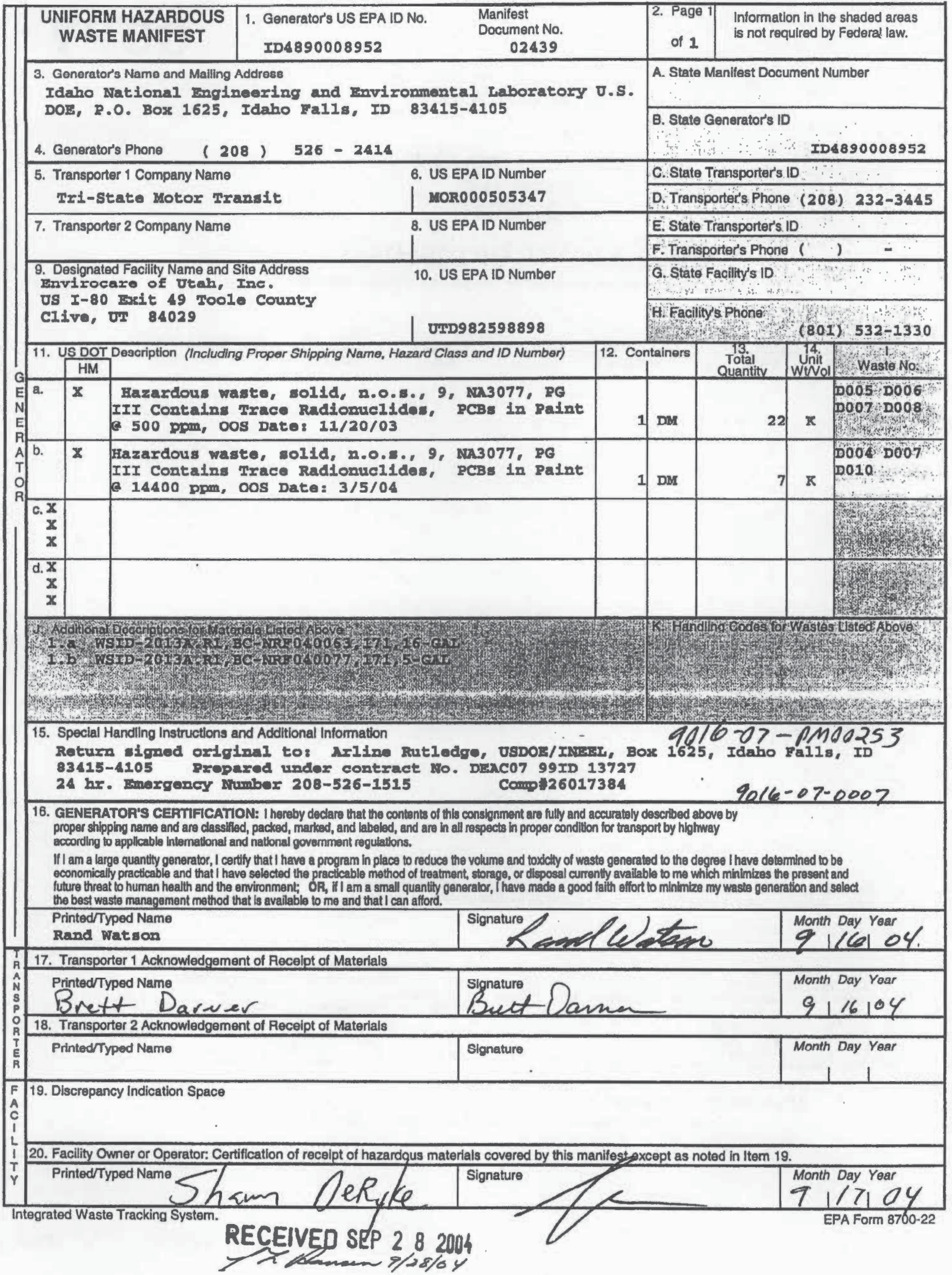




\section{ENVIROCARE}

OF UTAH, INC.

\section{THE SAFE ALTERNATIVE}

3 mi. S. Bxi, 49, 1-80

Clive, Utuh 84029 IPPA

ID: UT982598898

\section{CERTIFICATE OF DISPOSAL}

This Certificato aclonowledges that the following manifested shipments:

$\frac{\text { Shipment }}{9018-07-0007} \frac{\text { Manifest }}{02438} \quad \frac{\text { Date(s) of Disposal }}{01 / 11 / 2005} \quad \frac{\text { Cu/Jit }}{2.81} \quad \frac{\text { Process }}{\text { Landrill }} \quad \frac{\text { Disposal Location }}{\text { Mlxed Wasle }}$

Representing 2.81 Cubic feet of waste of at listed Disposal Facility landfill. Disposal is subject to Envirocare's Redioactive Material Lieense, all other applicable licenses, parnits and regulations, and the Disposal Agreement.

Under civil and criminal penaltes of law for the making or subminion of folse or fmudulent statements af nepresentullons (18 U.S.C 1001 and is

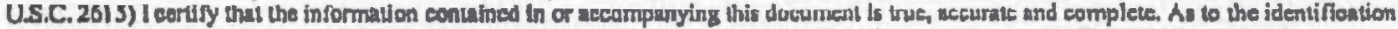
Beetion(s) of this document for which I cannot personally verify truth and accurncy, I tertify as the company ofmeial huving supervisory

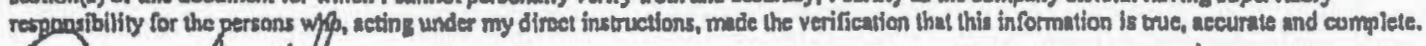

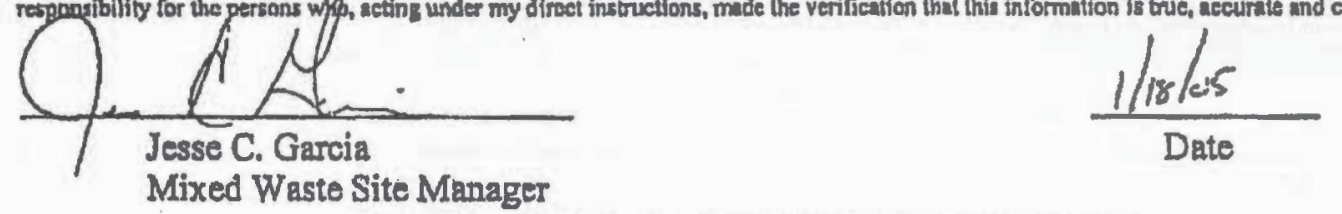

605 N. 5000 W, Sall Lake Cisy, Uiah 84116 Telaphons (B0I) 532-1330 



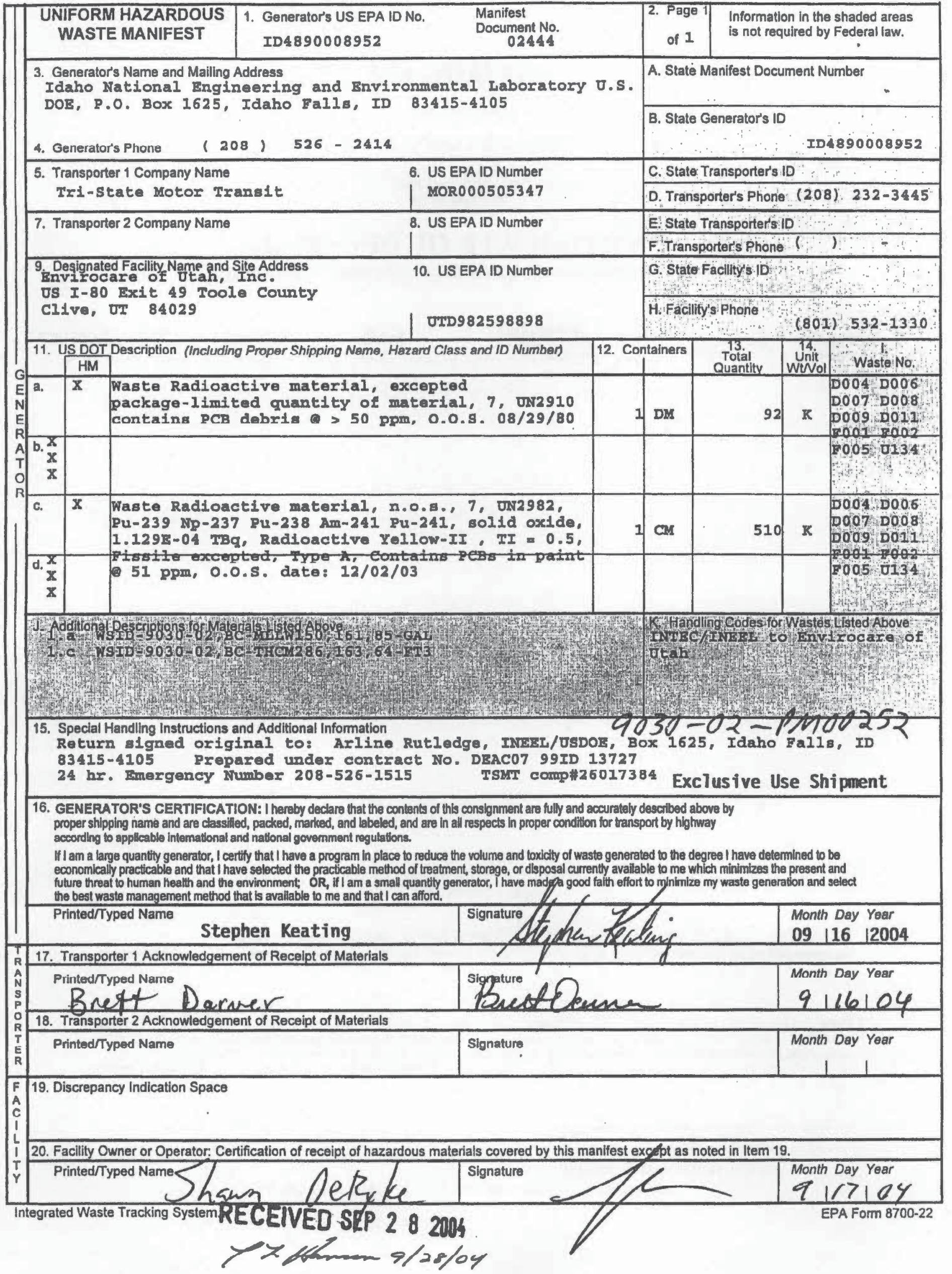




\section{ENVIROCARE}

OF UTAH, INC.

\section{THE SAFE ALTERNATIVE}

3 mi. S. Ext. 49, I-80

Clive, Utah 84029 EPA

ID: UT982598898

\section{CERTIFICATE OF DISPOSAL}

This Certificate acknowledges that the following manifested shipments:

$\frac{\text { Shipment }}{8030-02-0028} \frac{\text { Manifest }}{02444} \quad \frac{\text { Date(s) of Disposal }}{\begin{array}{l}12 / 17 / 2004 \\ 01 / 11 / 2005\end{array}} \quad \frac{\text { Cu/Ft }}{75.36} \quad \frac{\text { Process }}{\text { Landfil }} \quad \frac{\text { Disposal Location }}{\text { Mixed Wasto }}$

Representing 75.36 Cubic feet of waste of at listed Disposal Facility landfill. Disposal is subject to Envirocare's Radioactive Material License, all other applicable licenses, permits and regulations, and the Disposal Agreement.

Under civil and criminal penalties of law for the making or submission of false or fraudulent statements or representations (18 U.S.C 1001 and 15 U.S.C. 2615) I certify that the information contained in or accompanying this document is true, accurate and complete. As to the identification section(s) of this document for which I cemnot personally verify truth and aceuney, I certify as the company official having supervisory respgnsibility for the persons whp, acting under my direct instructions, made the verification that this information is true, accurate and complete.
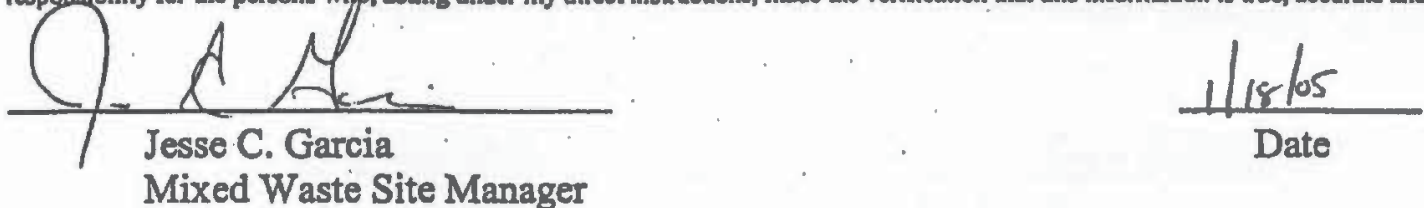

605 N. 5600 W, Salt Lake City, Utah 84116 Telephone (801) 532-1330 

ck

\begin{tabular}{|c|c|c|c|c|}
\hline $\begin{array}{c}\text { UWIFORM HAZARDOUS } \\
\text { WASTE MANIFEST }\end{array}$ & $\begin{array}{c}\text { 1. Generator's US EPA ID No. } \\
\text { ID6890190089 }\end{array}$ & $\begin{array}{c}\text { Manifest } \\
\text { Document No. } \\
02454\end{array}$ & $\begin{array}{c}\text { 2. Page } 1 \\
\text { of } 1\end{array}$ & $\begin{array}{l}\text { Information in the shaded areas } \\
\text { is not required by Federal law. }\end{array}$ \\
\hline
\end{tabular}

3. Generator's Name and Mailing Address

Idaho National Ingineering and Enviromental Laboratory 0.s.

DOE, P.O. Box 1625, Idaho Fal1E, ID 83415-4105

4. Generator's Phone (208) $526-2414$

5. Transporter 1 Company Name $\quad$ 6. US EPA ID Number

Clean HarborB Environmental Serviceq, MnD039322250

A. State Manifest bocumont Number

B. State Generaforts is

to6890190089

$\begin{array}{ll}\text { 7. Transporter } 2 \text { Company Name } & \text { 8. US EPA ID Number }\end{array}$

9. Pesignated Facility Name and Site Address

(aragonite) IIC

11600 North Aptus Road

Aragonite, UT 84029

10. US EPA ID Number

C. State Transponter s ID 17 . Thin

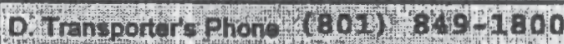

E State Transportera $1 \mathrm{D}$. :

Fintransponar'sehone (II)

G. Stato racility

H. Facilitys Phone

$(801)) 323-8100$

11. US DOT Description (Including Proper Shipping Name, Hazand Class and ID Number)

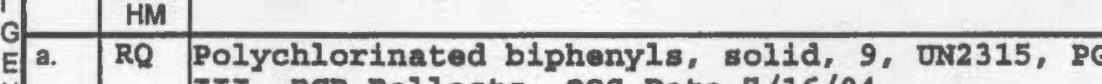
III PCB Ballasta, 00s Date $7 / 16 / 04$

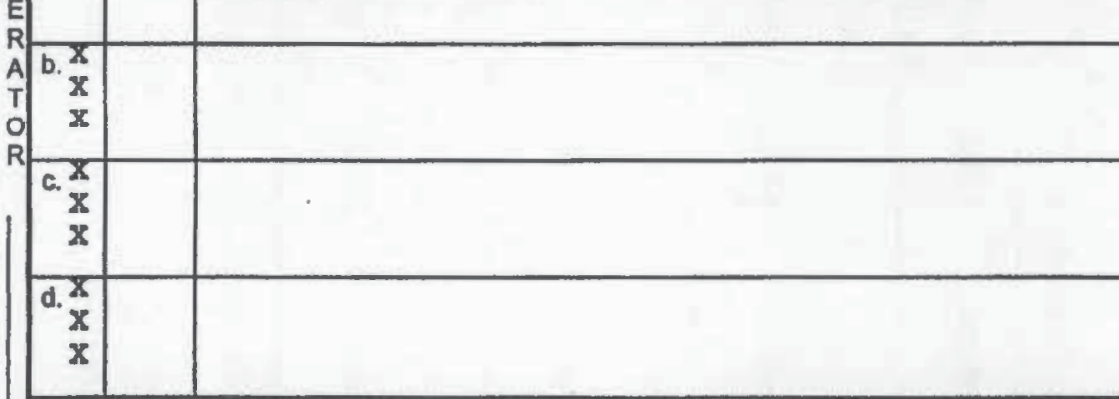

1 for ans

astats

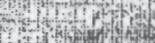
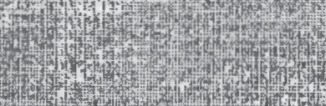

15. Special Handling Instructions and Additional Information

Return igned orlginal to: B.A. Rutledge, Idaho National Ingineering E Environmental

Iaboratory/US DOR, P.O. Box 1625, Idaho FallB, ID 83415-4105. Prapared under contract \#DEAC07 99ID 13727. USDOz 24-Hr. Energency Phone: (208) 526-1515.

16. GENERATOR'S CERTIFICATION: I hereby declare that the contents of this consignment are fully and accurably described above by proper shipping name and are classified, pecked, marked, and labolod, and ave in all respects in proper condition for transport by highway according to applicable intemattonal and nalional govemment regulations.

If I am a large quantity generator, I certify that I have a program in place lo reduce the volume and toxicity of waste generated to the degree I have defermined to be economically practicable and that I have selected the practicable method of treatment, storage, or disposal currently available to me which minimizes the present and future threat to human health and the environment; OR, III am a small quantily generator, I have made a good falth effort to minimize my waste generation and select the best waste management method that is avallable to me and that I can afford.

Printed/Typed Name

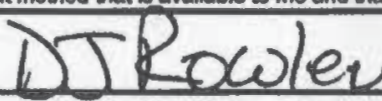

17. Transporter 1 Acknowledgement of Receipt of Material

Printed/Typed Nage

rar $<$
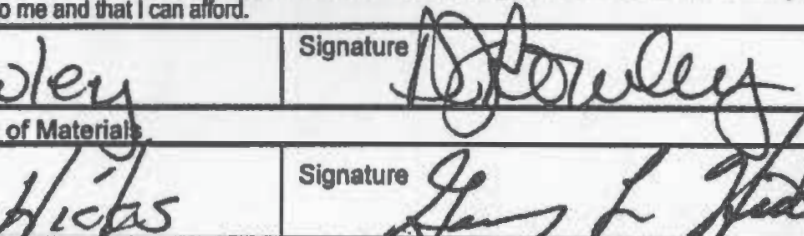

$10,84,104$

18. Transporter 2 Acknowledigement of Receipt of Materials

\begin{tabular}{|l|l} 
Printed/Typed Name & Signature
\end{tabular}

19. Discrepancy Indication Space

RECEIVED NOV 1 i 2004

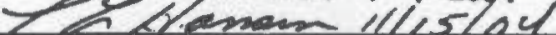

20. Facility Owner or Operator: Certification of receipt of hazardous materials covered by this manifest except as noted in ltem 19. 


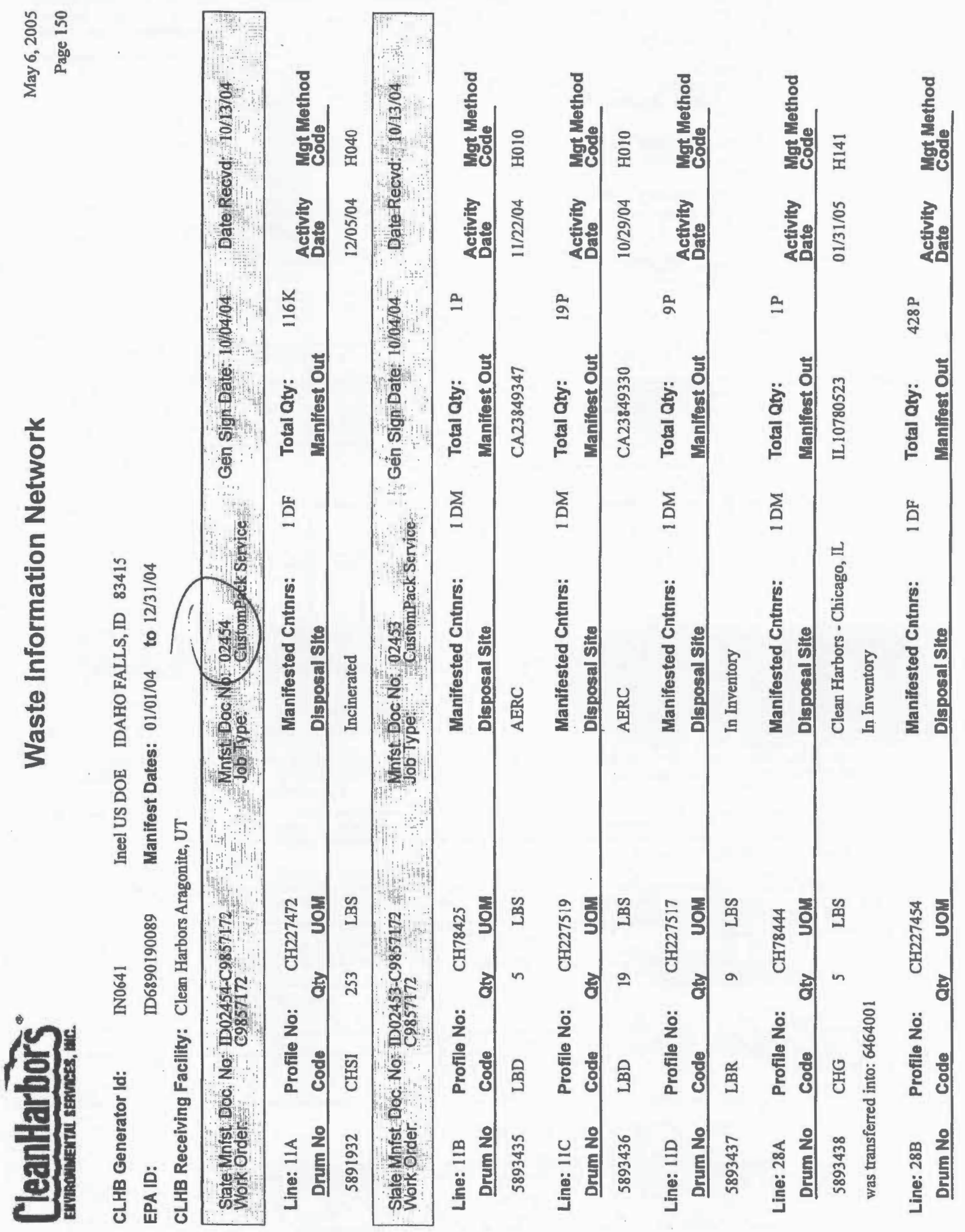




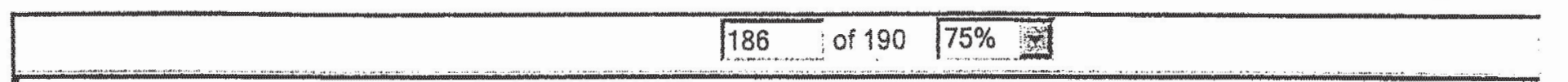

\section{Cleantlarbors̀}

Certificate of Treatment/Disposal - Storage and Transfer

\author{
Clean Harbors Aragonite. UT \\ 11600 North Aprus Road \\ Aragonite. UT 84029 \\ Aragonite, UT 8402
UTD 981552177
}

May 6.200s

Page 186

\begin{abstract}
Manifest Ho. Recv. Date [D02346-C979603992 00/15/04 1002375-C984256 07/28/04 1002370-C981125681 07/2804 $1002370-C 9811256 \mathrm{P} 2 \quad 07 / 28104$ 1D02376-C9811256P1 07/28004 1D02372-Cog11256P1 07/28/04 1002371-Ca811256P1 07/28/04 $1002368.0881126412107 / 28104$ 1002380-CO811256P1 07/28/04 $1002381-C 5 B 112568107 / 28 / 04$ IDO2377-C99L1256P4 07/28/04 1D02369-C9811256P! 07/28/04 $1002378-C O 811256 \mathrm{PI} \quad 07 / 28 / 04$ $1002379 . C 98113568107 / 28 / 44$ 1D02367-C9811264P1 07/28/04 ID02367-C9811264P2 07/28104 1002367-C9811264P3 07/28104 ID02367-C981126484 07/28/04 1D02395-C9811256P1 07/28/04 [D02392.C9811264P1 07/28/04 $1002374-09811256 \mathrm{PI} \quad 07 / 28 / 04$

1002373-C981125683 07/28/04 1D02373-Co811256P2 07/28/M $1002373 \mathrm{Cg} 11256 \mathrm{PI} \quad 07 / 2804$ $1002373-C 9811256 \mathrm{P4} \quad 07 / 2804$ $1002373-\mathrm{C} 81125695$ 07/28104 $1002373 \mathrm{COS11256 \textrm {P } 6} \quad 07 / 28104$ $1002373 \times 69811256 \quad 07 / 28104$ $1002373 \times 59811253 \quad 07 / 28104$ $1002403-C 9829700 \quad 08 / 19 / 04$ 1002409-C9829752 08/17/04 $1002408-C 9829752 \quad 08 / 19 / 04$ 1002407.C982975241 08/19/144 [D02407-C9829752-2 08/19/04 1002400-C9829752 08/19/44 1D02405-C8829752 08/19/04 1002399-C9829752 08/19/04 $1002402+00829735 \quad 08 / 39 / 04$ ID02406-C9829752 08/19/04 ID02401-C9829752-1. 08/19/04 102401-C9829752-2 08/19/04 1002401-C9829752-3 08/19/04

\begin{tabular}{|c|c|}
\hline & \\
\hline & \\
\hline & $117 / 04$ \\
\hline & $/ 1$ \\
\hline & \\
\hline 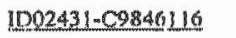 & $9 / 17 /$ \\
\hline & (n) \\
\hline & $0 / 13 / 04$ \\
\hline 75 & $0 / 13 / 04$ \\
\hline & $0 / 13 / 04$ \\
\hline & $0 / 1 / 3 / 04$ \\
\hline & $\alpha / 13 / 04$ \\
\hline & \\
\hline $181 \mathrm{PI}$ & $70 / 1404$ \\
\hline $7181-1$ & $10 / 12 / 04$ \\
\hline 4 ip & $10 / 14 / 0$ \\
\hline 100 & $10 / 12 / 0$ \\
\hline $7181-3$ & $10 / 121$ \\
\hline $00-698$ & $10 / 13 / 04$ \\
\hline & \\
\hline & \\
\hline
\end{tabular}

$1002401 . \operatorname{Cos} 29752+4 \quad 08 / 19704$ $002404.09829752 \quad 08 / 10 \% 04$

$1002457-C 9857181 \quad 10 / 13 / 04$ $1002463-0055718$ 10/13/04 $100246709857181 \quad 10 / 12 / 04$ $1002662-C 9857181-1 \quad 10 / 13 / 04$ 1002462.09857181 .2 10/13/04 1D02461-C9857181 10/13/04 1002452.C9857181P0 10/12/04 $1002452-0985718185$ 16/12/04 $1002452-C 9857181 \quad 10 / 12 / 04$ Uro2501.C9875262 I1/88/04 UT02502-C9875262 11/18/04 UT02498-C9875262 I//18104 Uro2486-C9875262 11/18/04 UTO2496-C9875262-2 11/18/04 Uro2496-C9875262-3 11/1804 UT02496-C9875262-4 H/18/04 $1002504-\cos 75262 \quad 11 / 1804$ $1002503.08875262 \quad 11 / 1804$ $1002495-69875262 \quad 11 / 18 / 04$ $1002495-\operatorname{Cos} 75262-2 \quad 11 / 1804$ $1002399.09875262-1 \quad 11 / 12 / 04$ The above daxcribed waste, racaived at the Clean Harbors facility llstad above pursuant to the mantest(s) listed above, has been traated andior disposad of by cilean

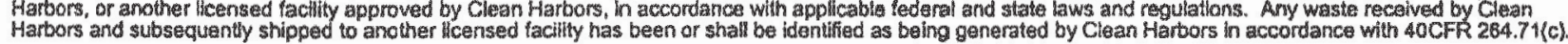

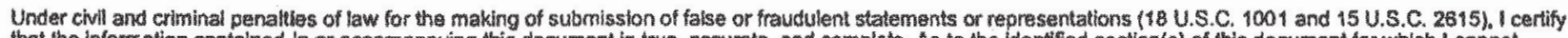
that the intomstion contalned In or accompanying this document is true. accurate, and complete. As to the identified sootion(s) of this document for which 1 cannot personally werify truth and accurracy, I certify as the company oficial having supervisory responsibility for the persons who, acthng under my direct instructions, mad. the verification that this information is true, accurate, and complets.

signed: Pane1.7heLC

Dat: $5 / 6 / 2005$
\end{abstract}

Tite: _ Senior Tracking Manager 


\begin{tabular}{|c|c|}
\hline Manifest No. & Recv. Date \\
\hline $1002492-c 9875262-2$ & $11 / 18 / 04$ \\
\hline $1002505-C 9875262$ & $11 / 18 / 04$ \\
\hline $1002506-\cos 75262-1$ & $11 / 18 / 04$ \\
\hline [D02500-C9875266-] & $11 / 18 / 04$ \\
\hline $1002500-\cos 75266-2$ & $11 / 18 / 04$ \\
\hline $1002500-C 9875266-3$ & $11 / 18 / 04$ \\
\hline $1002507-09875262$ & $11 / 18 / 04$ \\
\hline $1002524-F C 889749$ & $12 / 13 / 04$ \\
\hline $1002525+F C 889749$ & $12 / 13 / 84$ \\
\hline $1002514-C 9891796$ & $12 / 22 / 04$ \\
\hline $1002516-\operatorname{Cos} 91796$ & $12 / 22 / 04$ \\
\hline 1002519.69891796 & $12 / 22 / 04$ \\
\hline ID02518-C9891796 & $12 / 22 / 04$ \\
\hline $1002520-C 2891796-1$ & $12 / 22 / 04$ \\
\hline $1002520-02891796-2$ & $12 / 22 / 04$ \\
\hline $1002521-C 9891796-1$ & $12 / 22 / 04$ \\
\hline $1002521-C 9891796-2$ & $12 / 22 / 04$ \\
\hline $1002522-C 0891796$ & $12 / 22 / 04$ \\
\hline $1 D 2515-C 9891796-2$ & $12 / 22 / 04$ \\
\hline $1002515 \times 09891796.3$ & $12 / 22 / 04$ \\
\hline 1002515.02891796 & $12 / 22 / 04$ \\
\hline
\end{tabular}

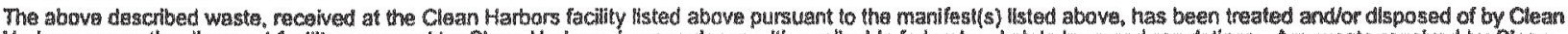
Harbors, or anothar licensed facilly apoproved by Clean Marbors, in accordance with applicable federal and state laws and reputations. Any waste recelyed by Clean

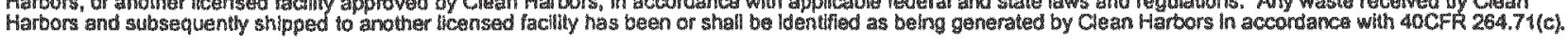

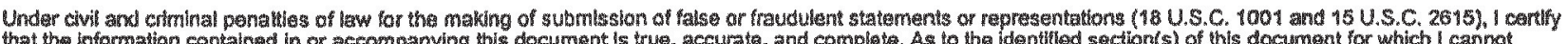

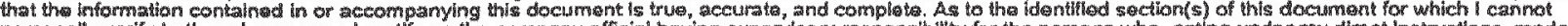
personalih verily truth and accuracy, I certhy as the company official having superwsery responsibilty for the persons who, acting under my direct instructons, made the verffication that this miormaton is true, accurate, and complete.

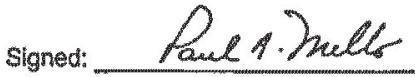

Date:

Clean Harbors Aragonite. UT

1600 North Aptus Roa

UTV9:1552177

Thtle: Senor Tracking Manager 

258772

$C R$

\begin{tabular}{c|cc}
\hline UNIFORM VIAZARDOUS & 1. Generator's US EPA ID No. & $\begin{array}{c}\text { Manifest } \\
\text { Document No. } \\
\text { WASTE MANIFEST }\end{array}$ \\
ID4890008952 & 02458
\end{tabular}

02458

2. Page 1

of 1

Information in the shaded areas is not required by Federal law.

3. Generator's Name and Mailing Address

Idaho National Engineering and Environmental Laboratory $0 . S$. DOE, B.0. BOx 1625, Idaho Fal1s, ID 83415-4105

4. Generator's Phone

$(208)$

$526-2414$

5. Transporter 1 Company Name

6. US EPA ID Number

Clean Harbor Invironmental Serviced, MaD039322250

A. State Manifest Document Number

Transporter 2 Company Name

8. US EPA ID Number

B. State Generators 1D

$\mathrm{ID} 8900008952$

\begin{tabular}{ll} 
7. Transporter 2 Company Name & 8. US EPA ID Number \\
\hline 9. Pesignated Facility Name and Site Address & 10. US EPA ID Number
\end{tabular}

Clean harbora Environmental

10. US EPA ID Number

(aragon1te) IIC

11600 North Aptus Road

Aragonite, UT 84029

UTD981552177

11. US DOT Description (Including Proper Shipping Name, Hazard Class and ID Number) \begin{tabular}{lll|l} 
& HM & \\
\hline a. & & Non-DOT Regulated PCBs Contains sample debris
\end{tabular}

\begin{tabular}{|c|c|}
\hline a. & $\begin{array}{l}\text { Non-DOT Regulated PCBa Contains sample debris } \\
\text { with pCBa }>50 \mathrm{ppm} \text { oOs 5-13-04 }\end{array}$ \\
\hline b. $\frac{x}{x}$ & . \\
\hline c. $\frac{x}{x}$ & \\
\hline d. $\frac{x}{x}$ & \\
\hline
\end{tabular}

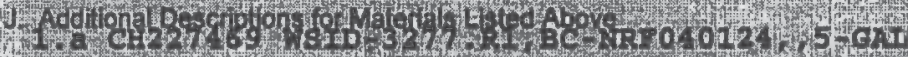
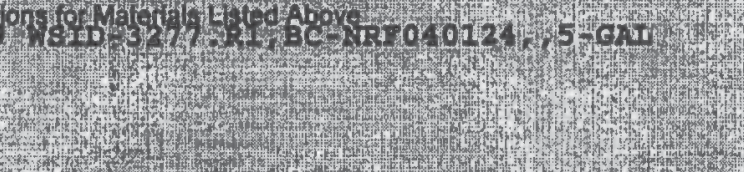

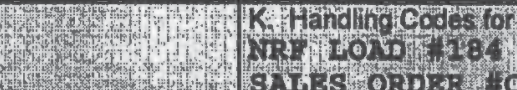

C. State Trunporthill

D. Transpoters phop (801) $) 849-1800$

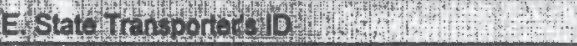

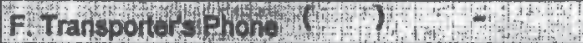

G. Stafo Eactity 510

H. Faclity sterione

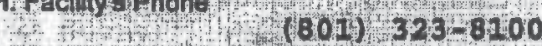

15. Special Handling Instructions and Additional Information

Return algnad original to: B.A. Rutledge, Idaho National Enginearing invironmental

Laboratory/09 DOZ, P.0. Box 1625. Idaho Fal1e, ID 83415-4105. Propared under contract

\#DEAC07 99ID 13727. USDOE 24-Fr. Fuergency Phone: (208) 526-1515.

16. GENERATOR'S CERTIFICATION: I hereby dectare that the contents of this construment are fully and accurately described above by

proper shipping name and are classified, packed, marked, and labeled, and ave h all respects in proper condilion for transport by highway

according to applicable intemational and nationsl govemnent regulations.

If I am a large quantity generalor, I certify that I have a program in place to reduce the volume and toxictly of waste generated to the degree I have determined to be economically practicable and that I have selected the practicable method of treatment, storage, or disposal currently avallable to me which minimizes the present and future threat to human healith and the environment OR, if I am a small quantity generator, I have made a good falth effort to minimize my waste generation and salect the best waste management method that is avaliable to me and that $I$ can afford.

Printed/Typed Name
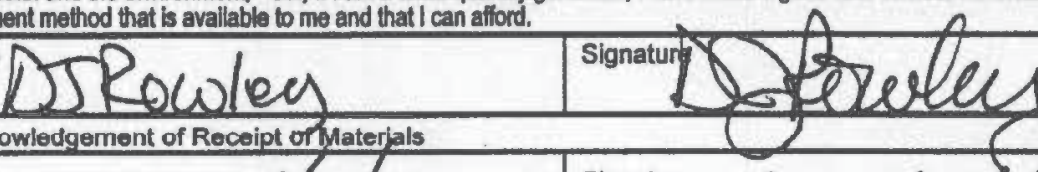

17. Transporter 1 Acknowledgement of Receipt of Materials

Printed/Typed Name

orer $\angle$

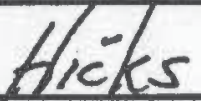

18. Transporter 2 Acknow edgement of Receipt of Materials

Printed/Typed Name

19. Discrepancy Indication Space

RECEIVED NOV 112004

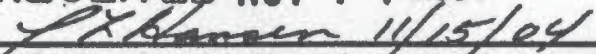

20. Facility Owner or Operator: Cartification of receipt of hazardous materials covered by this franifest except as noted in Item 19.

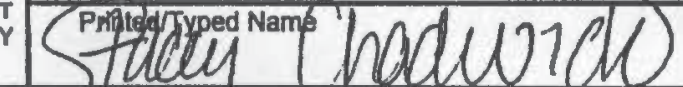

Integrated Waste Tlacking System.

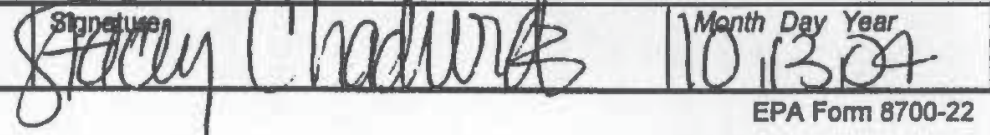




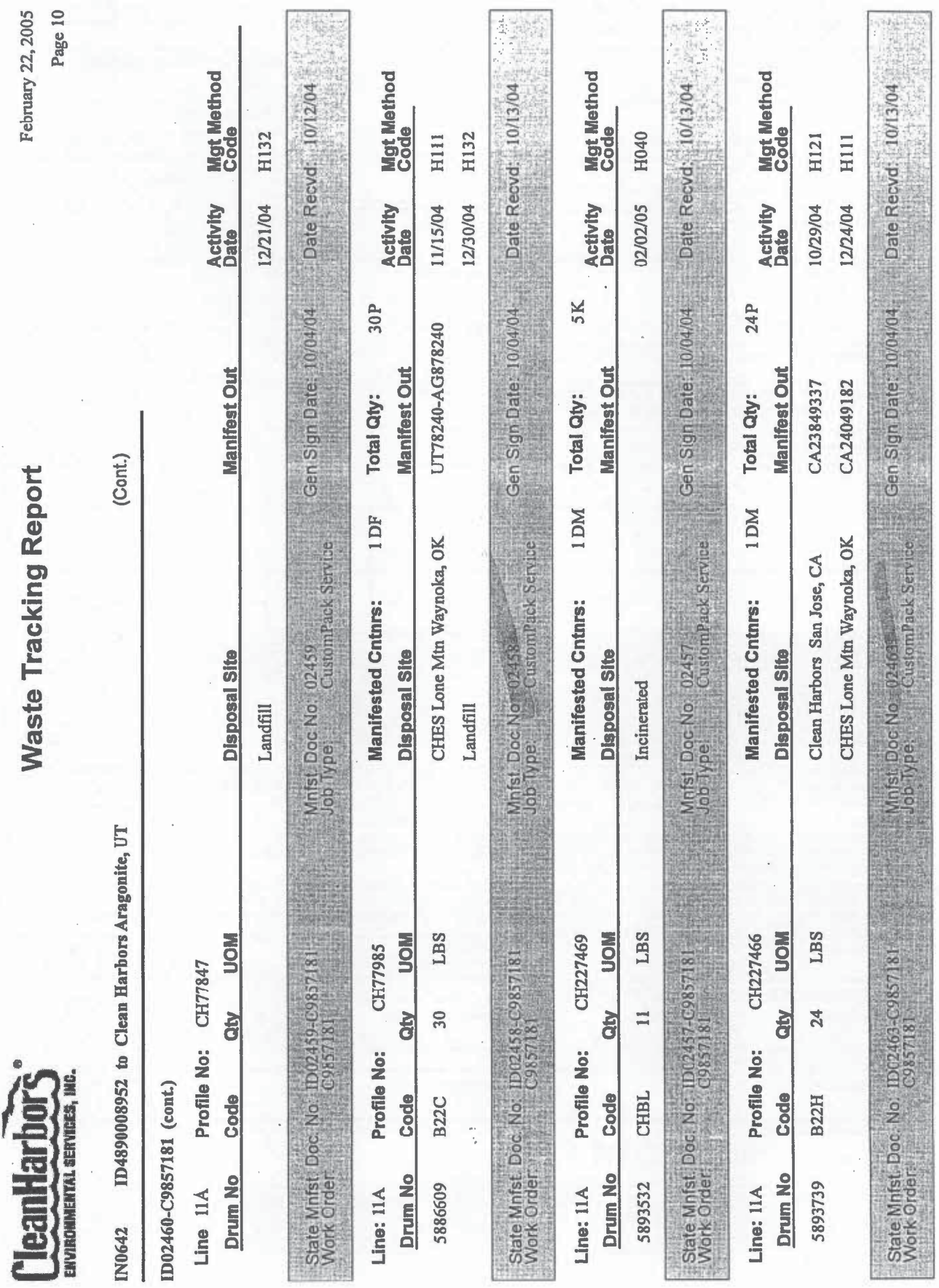



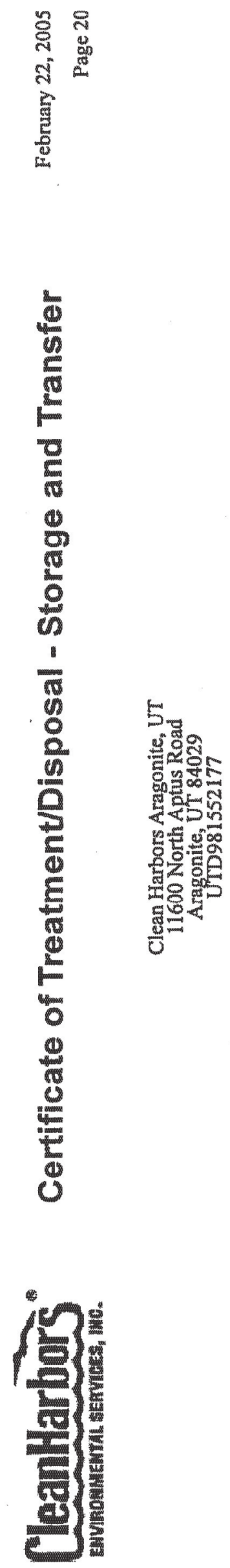

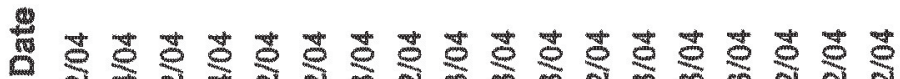
D.

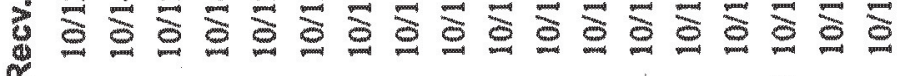

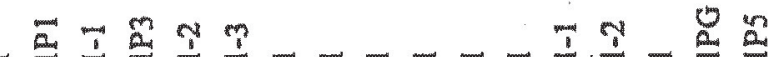

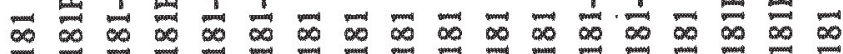

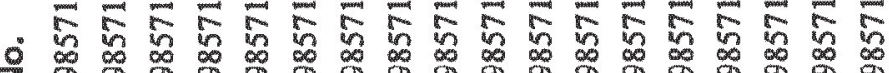

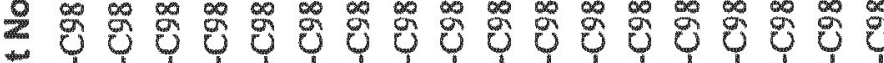
19. 

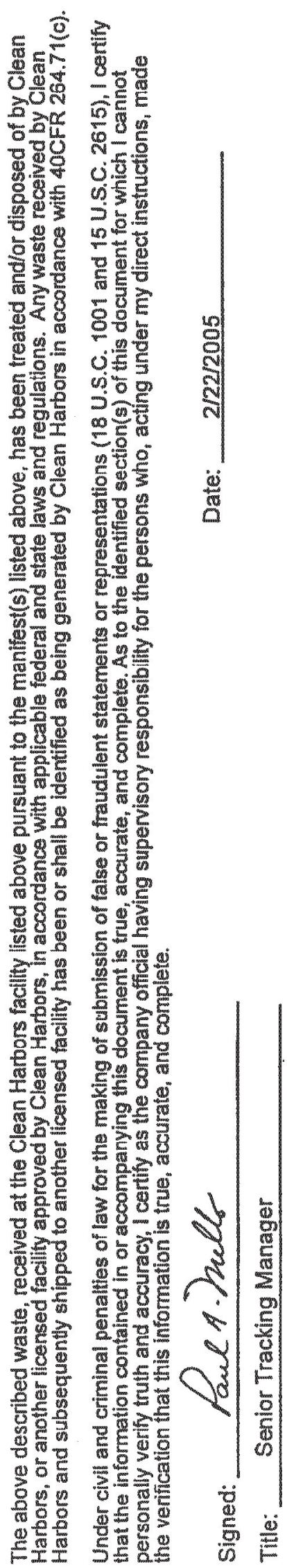





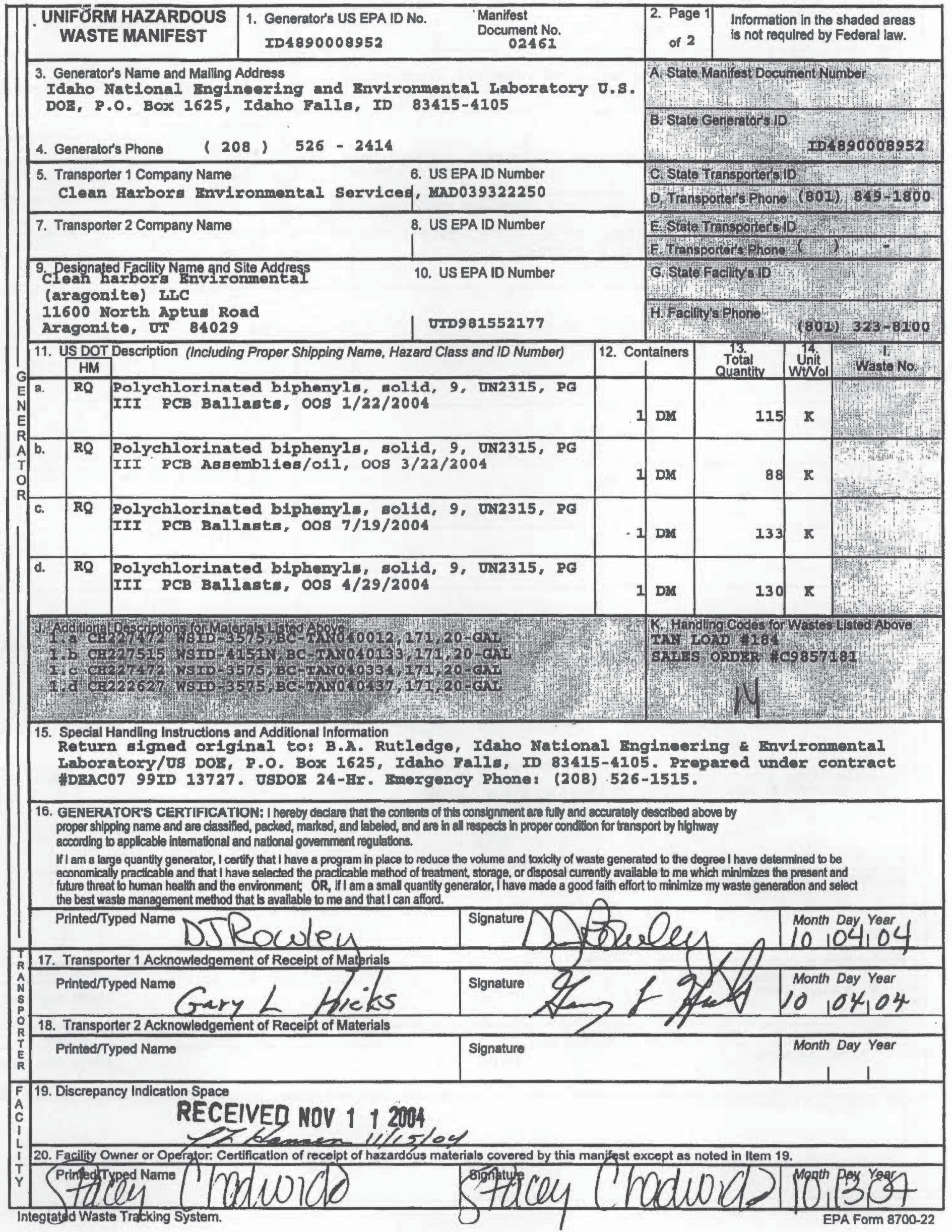




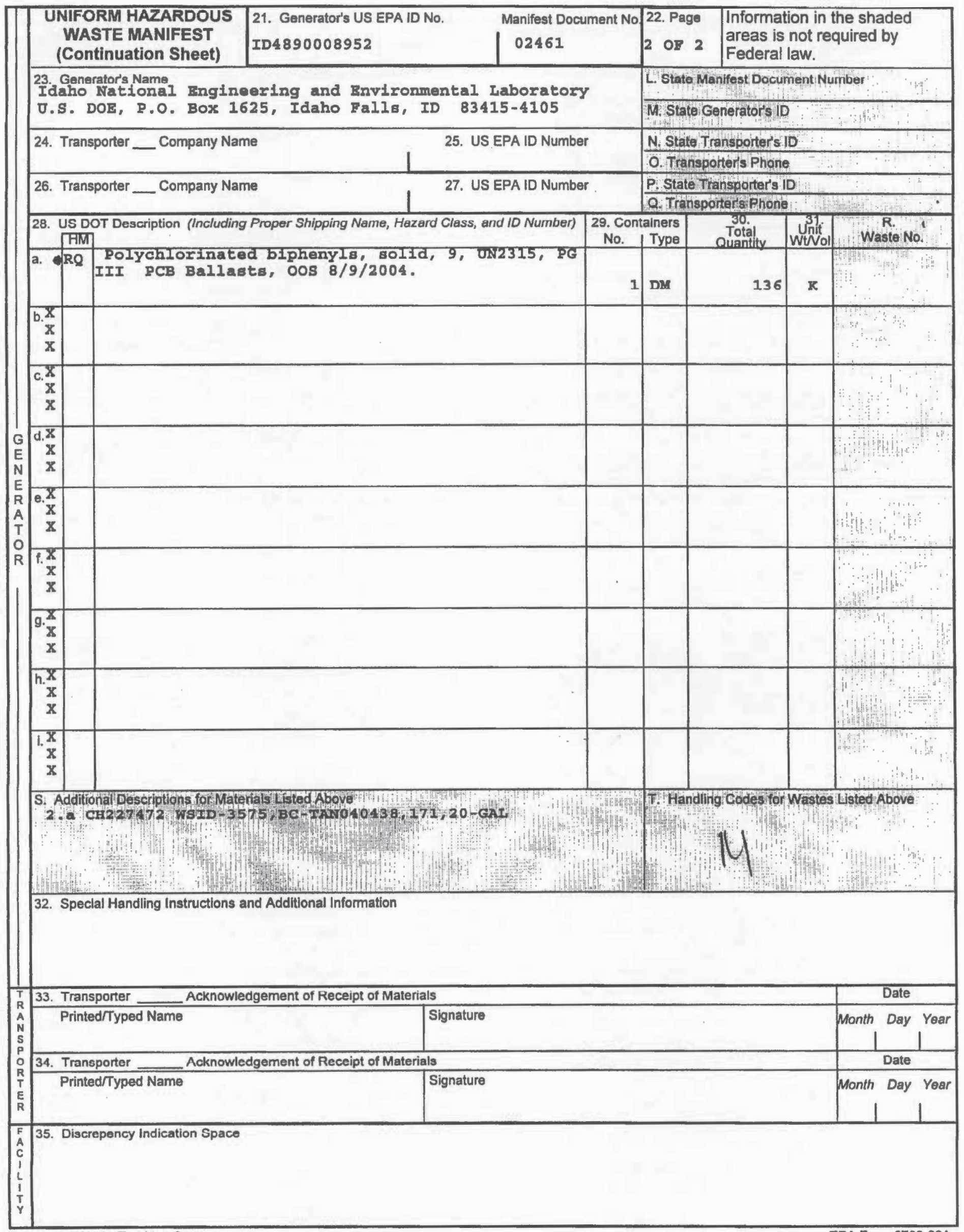



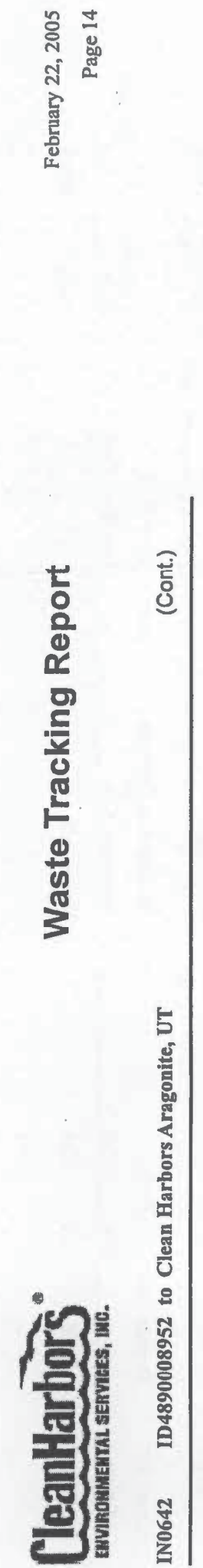

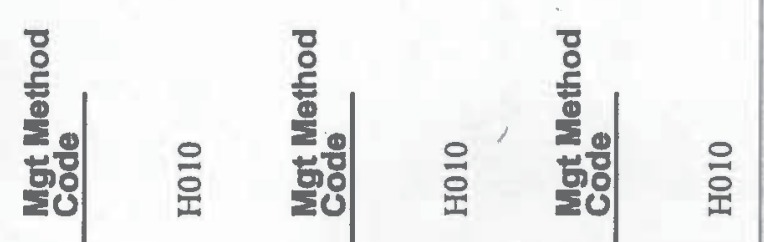

$\frac{\sqrt{n}}{0} \frac{n}{n}$

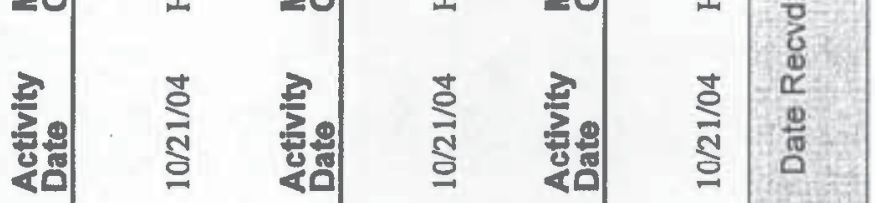

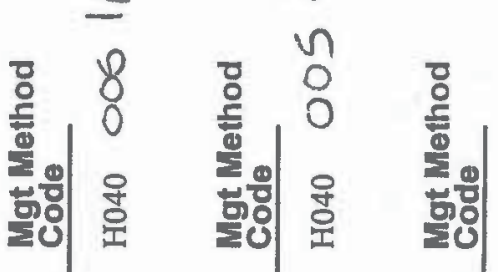

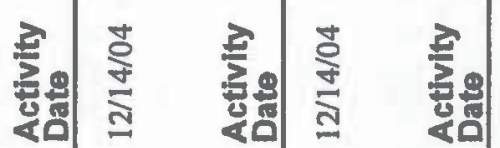

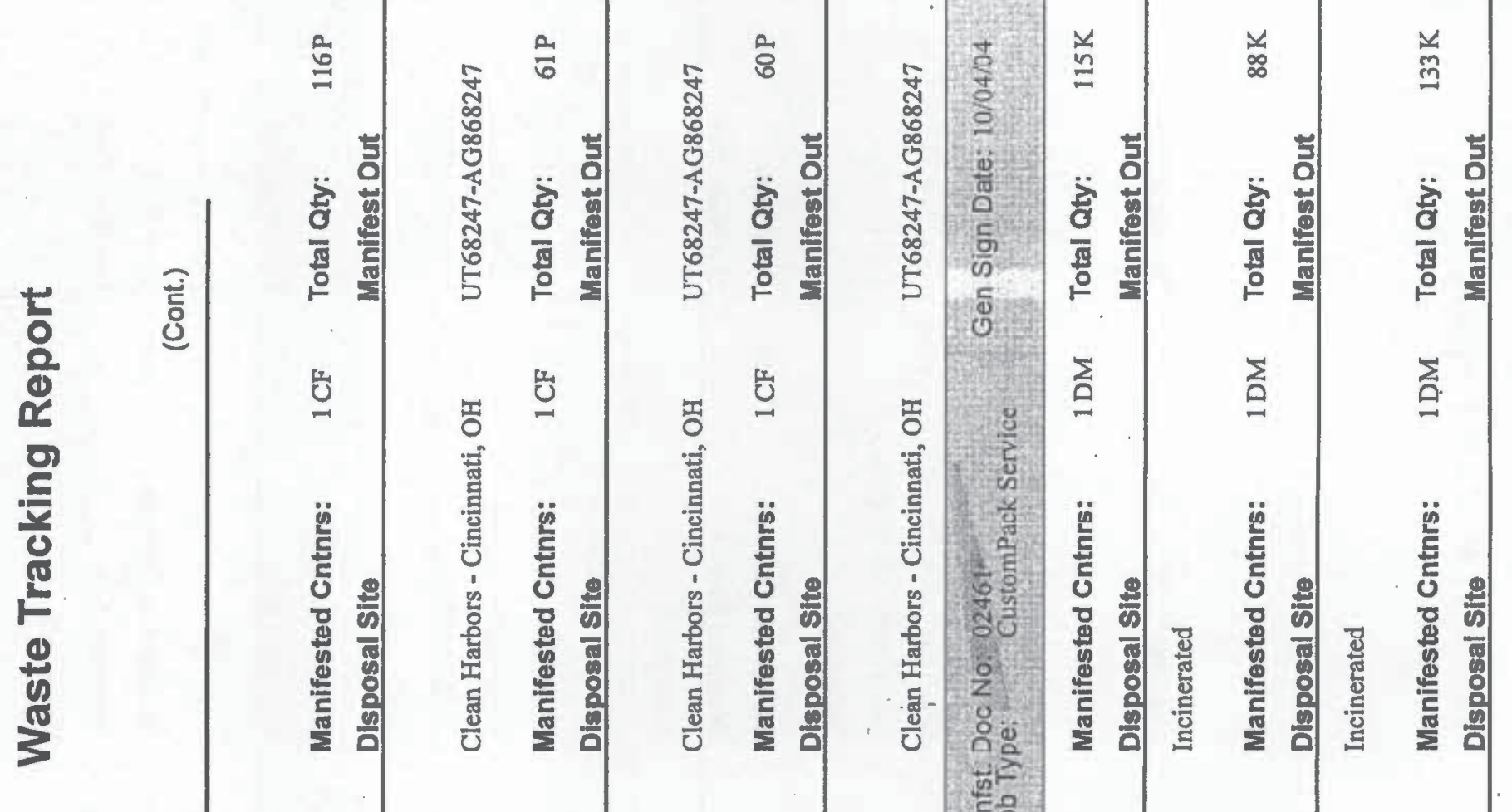

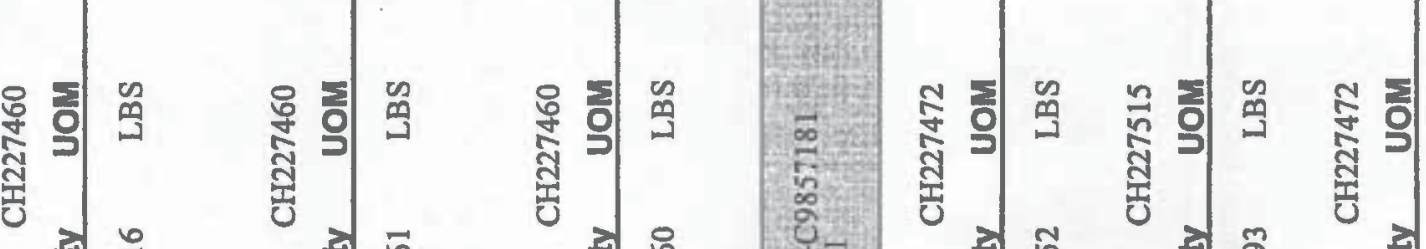
弱

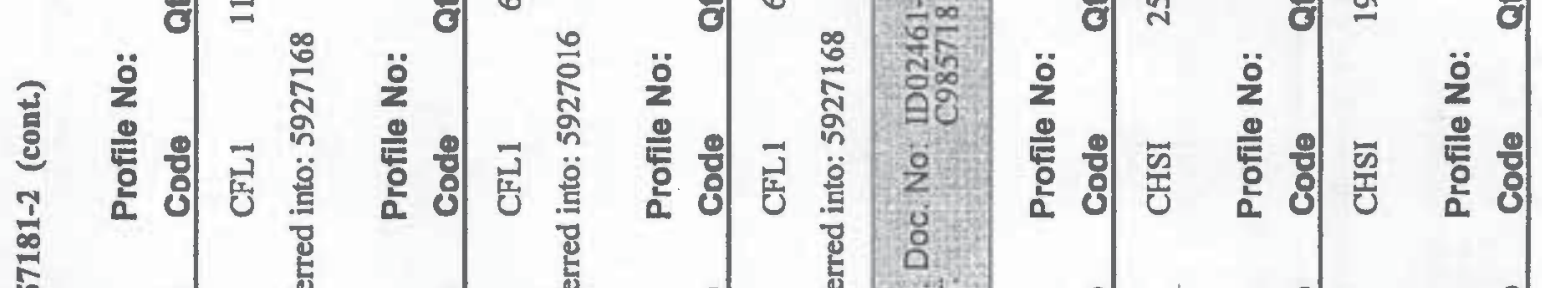

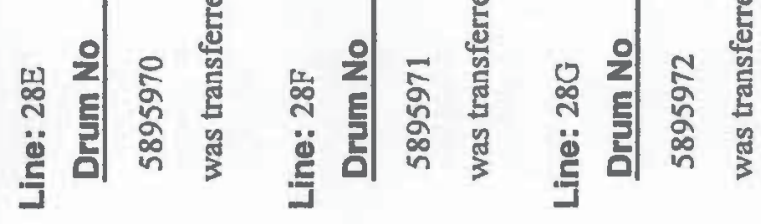
品

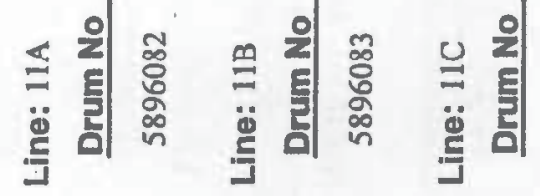


率

高

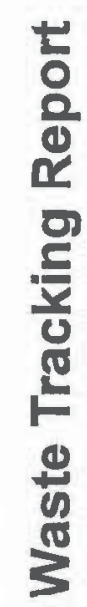

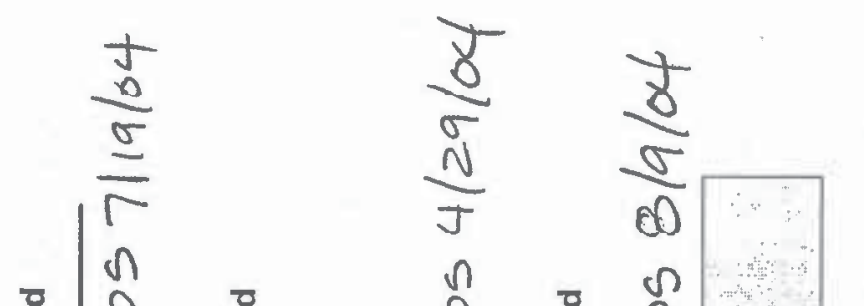

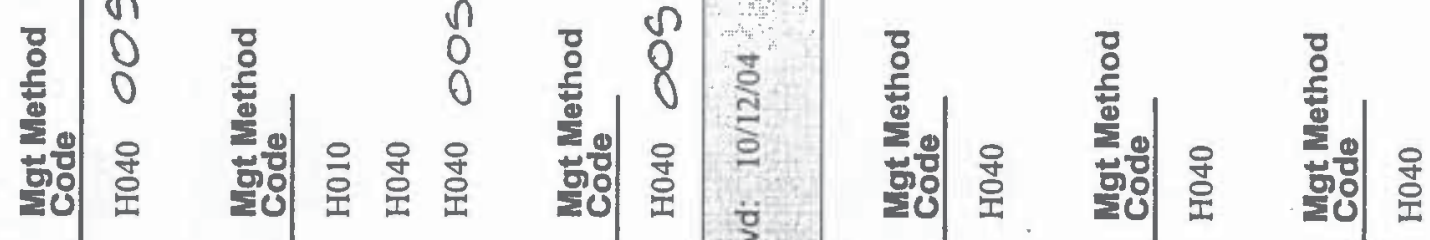

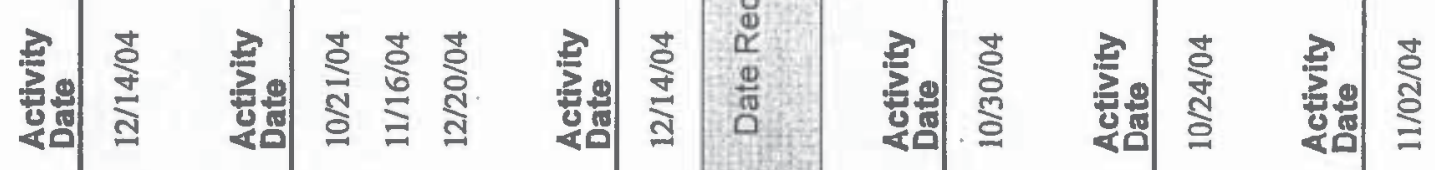
曾曾

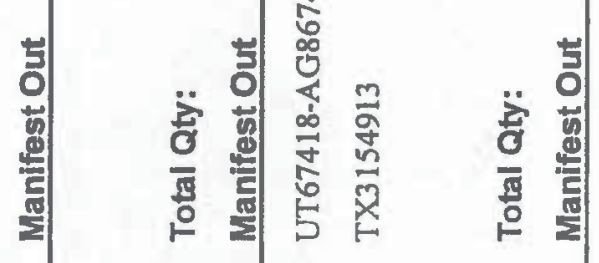

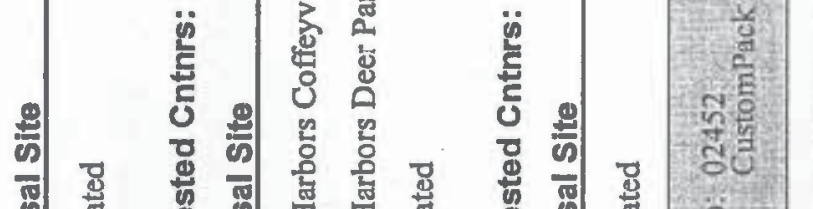

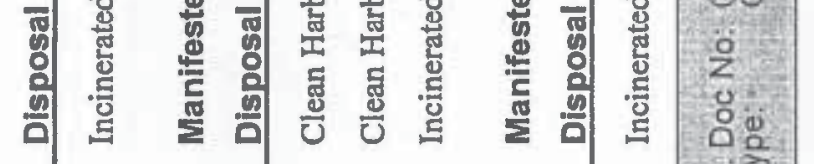

옹

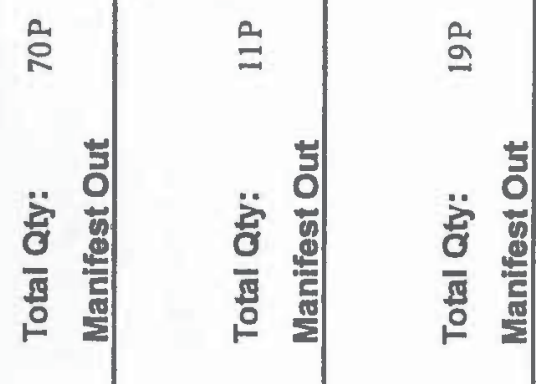

ב

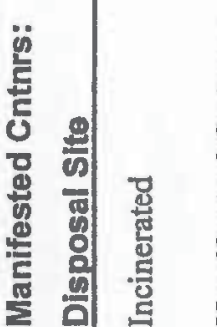

$\underset{\underline{\underline{a}}}{\Sigma}$

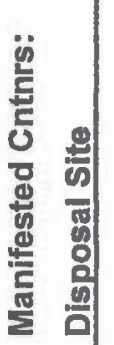

畜

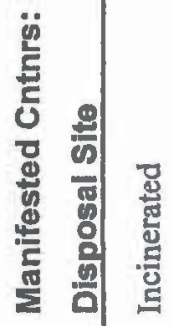

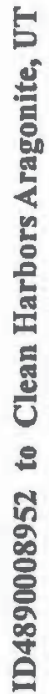

를

รี้
売

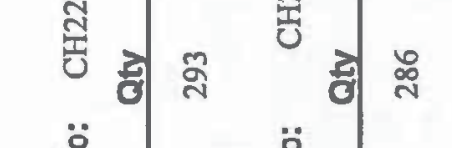

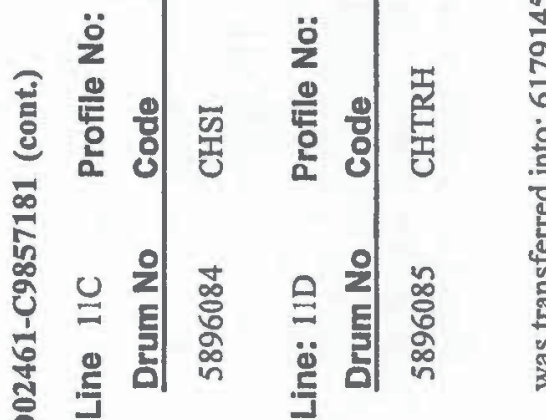

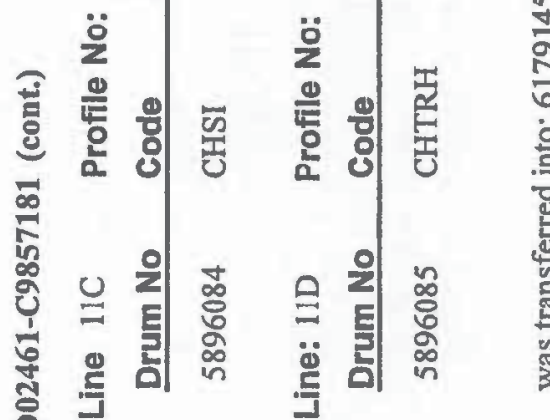

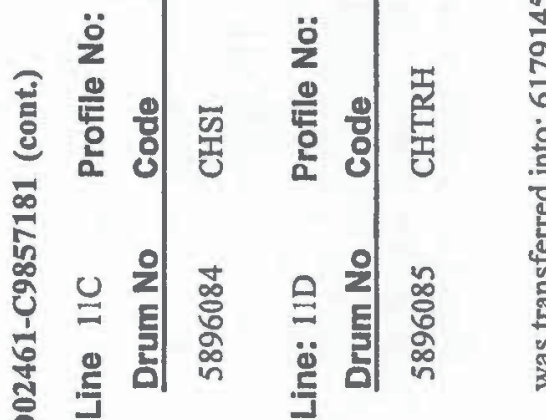

嵒

$\infty$

항

$\ddot{z}$

홍 윰

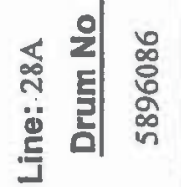

ลे

壱

$\infty$

8

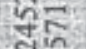

సैं

zo

is

फ்흄

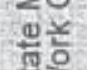

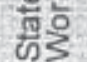

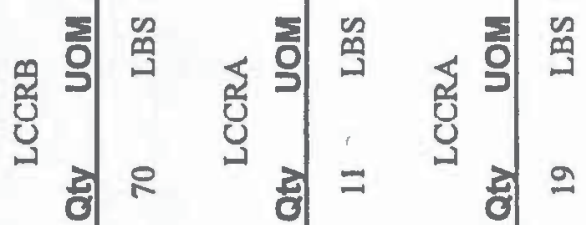

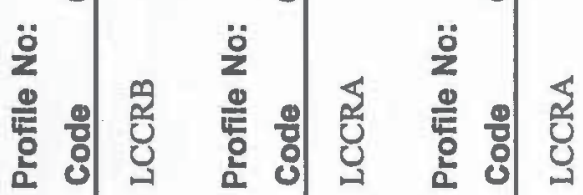

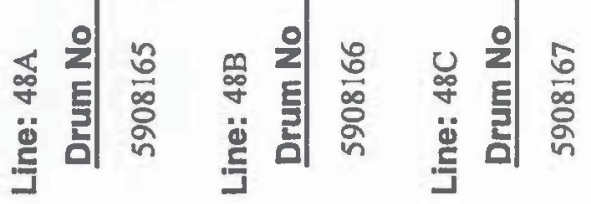



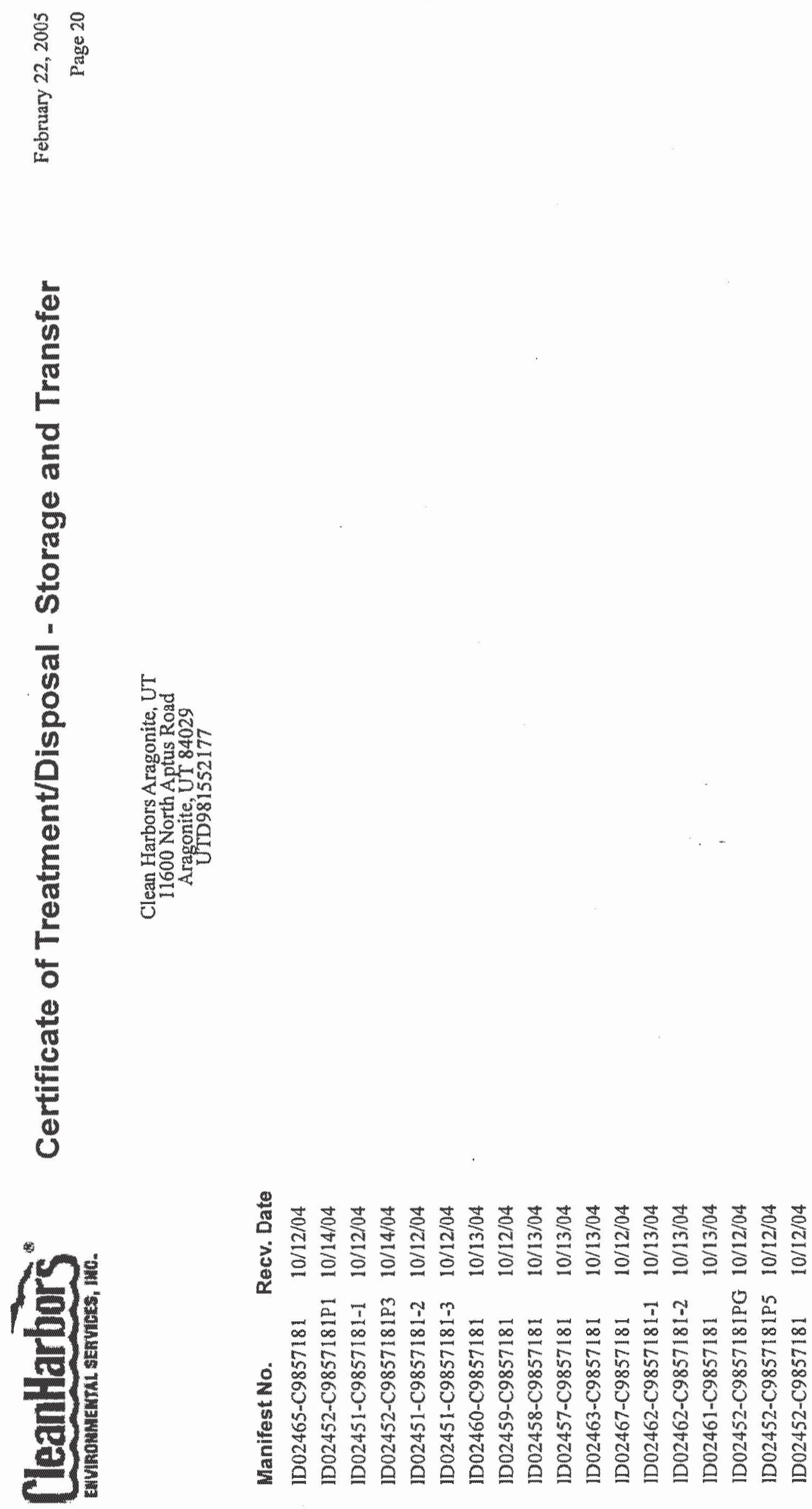
굴

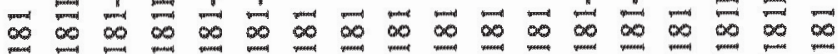
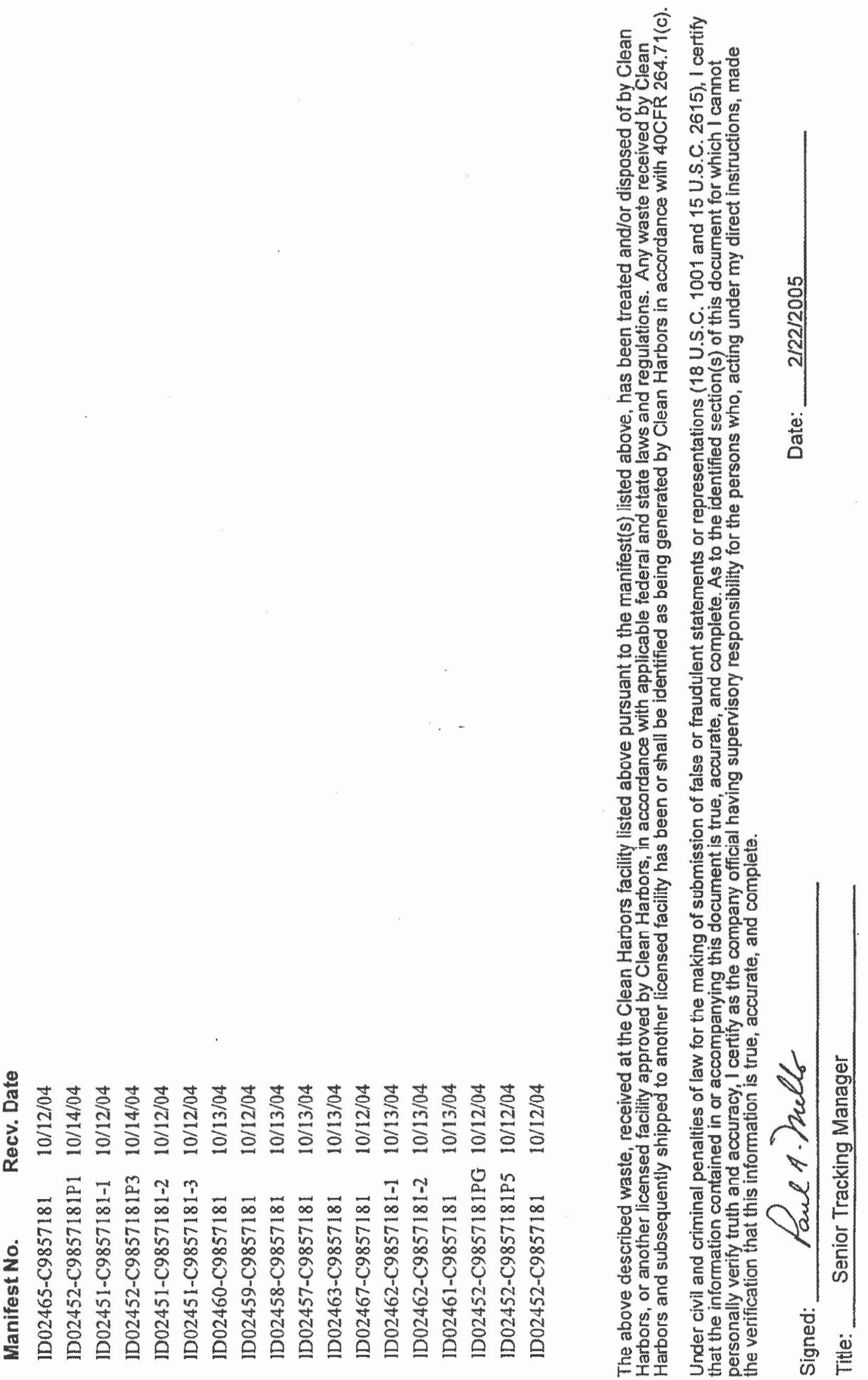



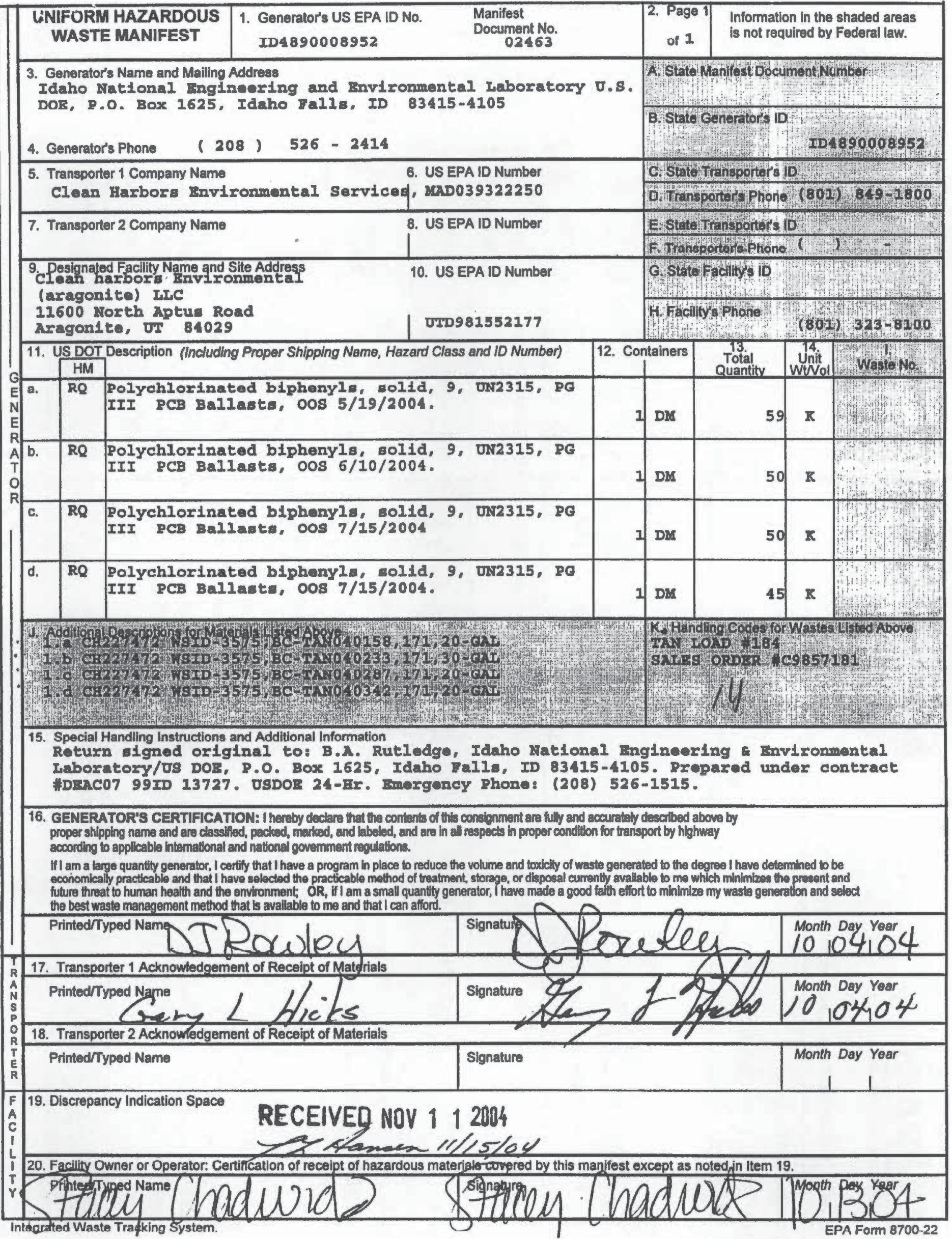




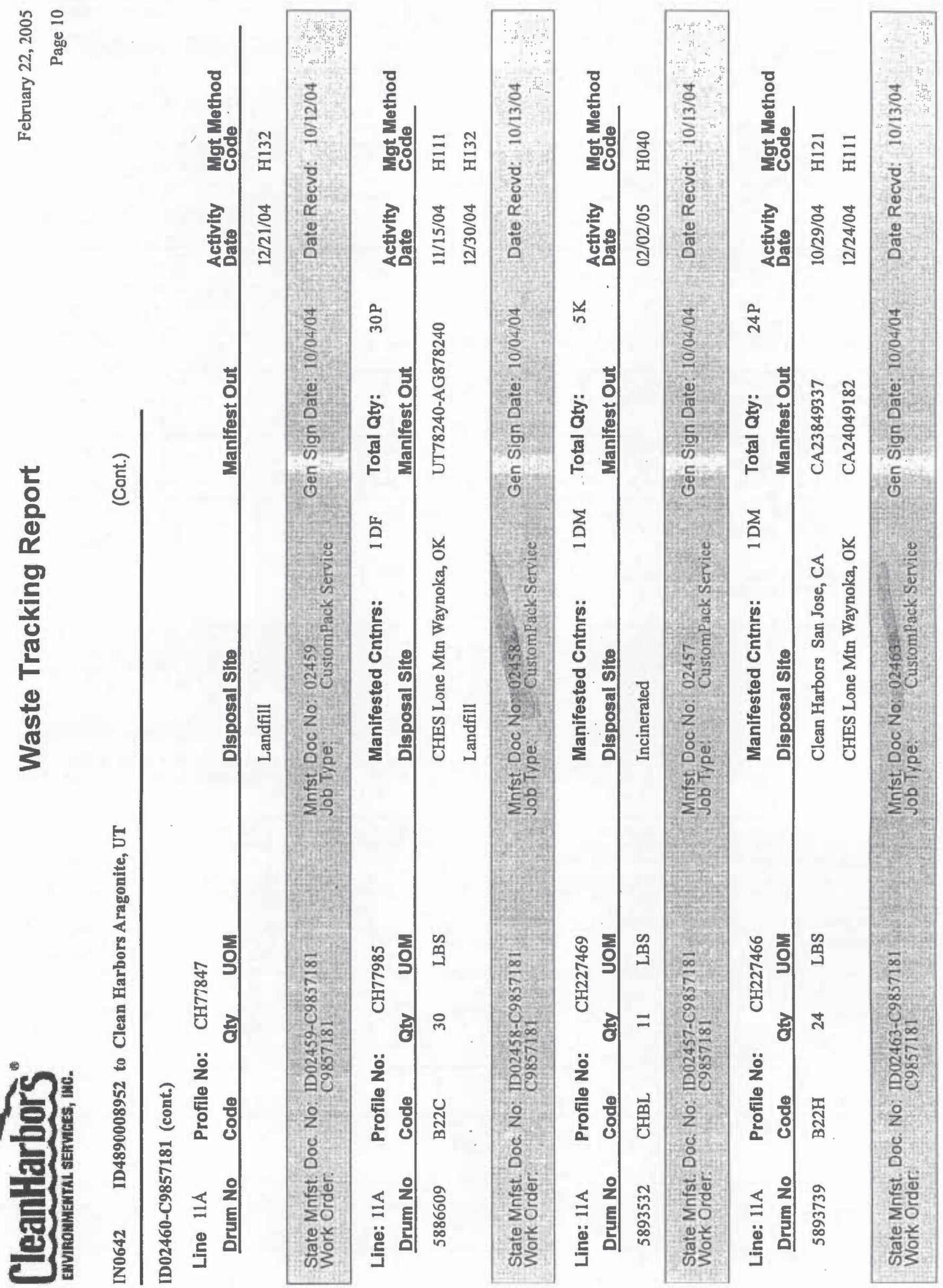




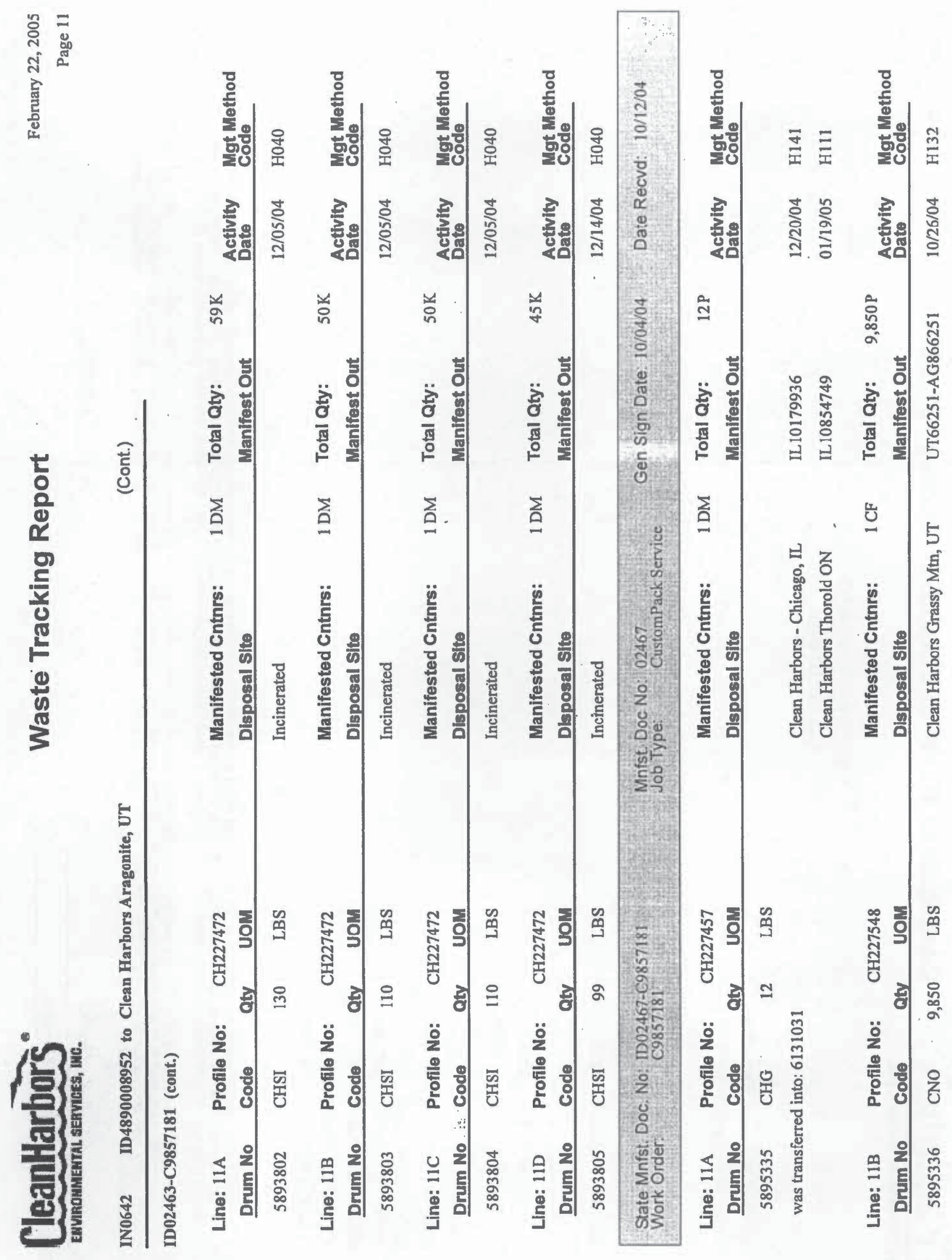



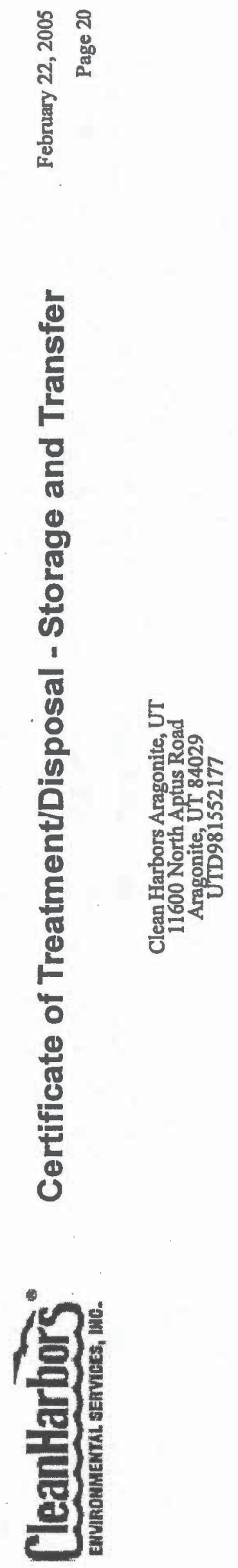

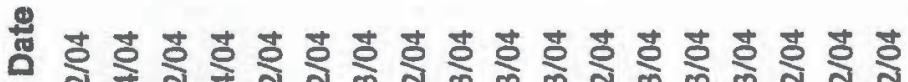

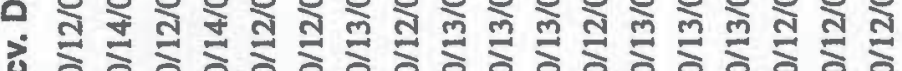

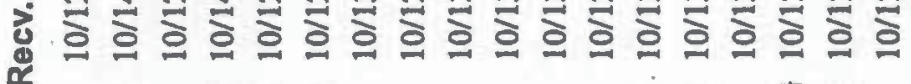

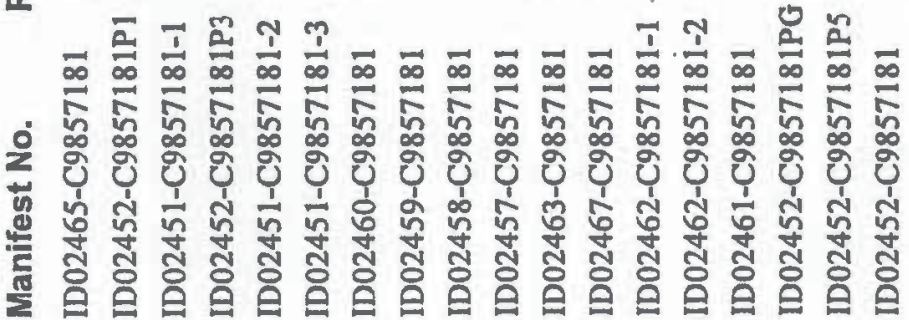

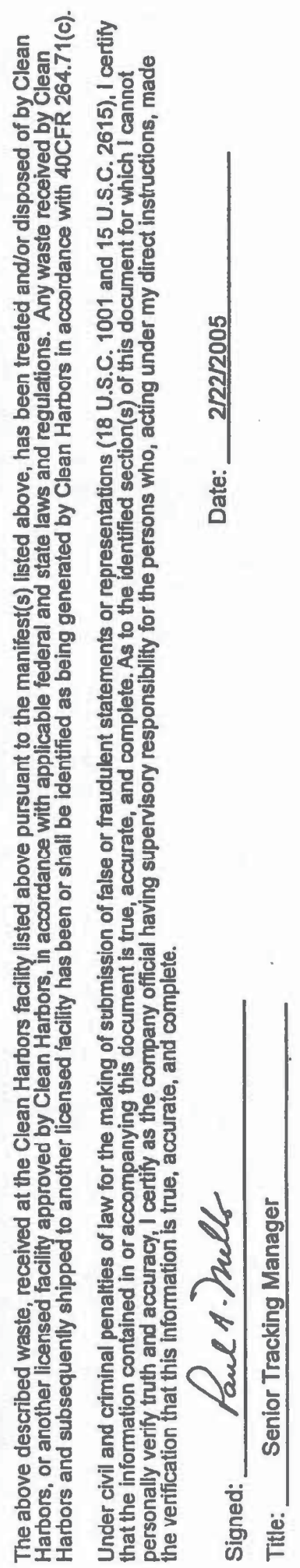





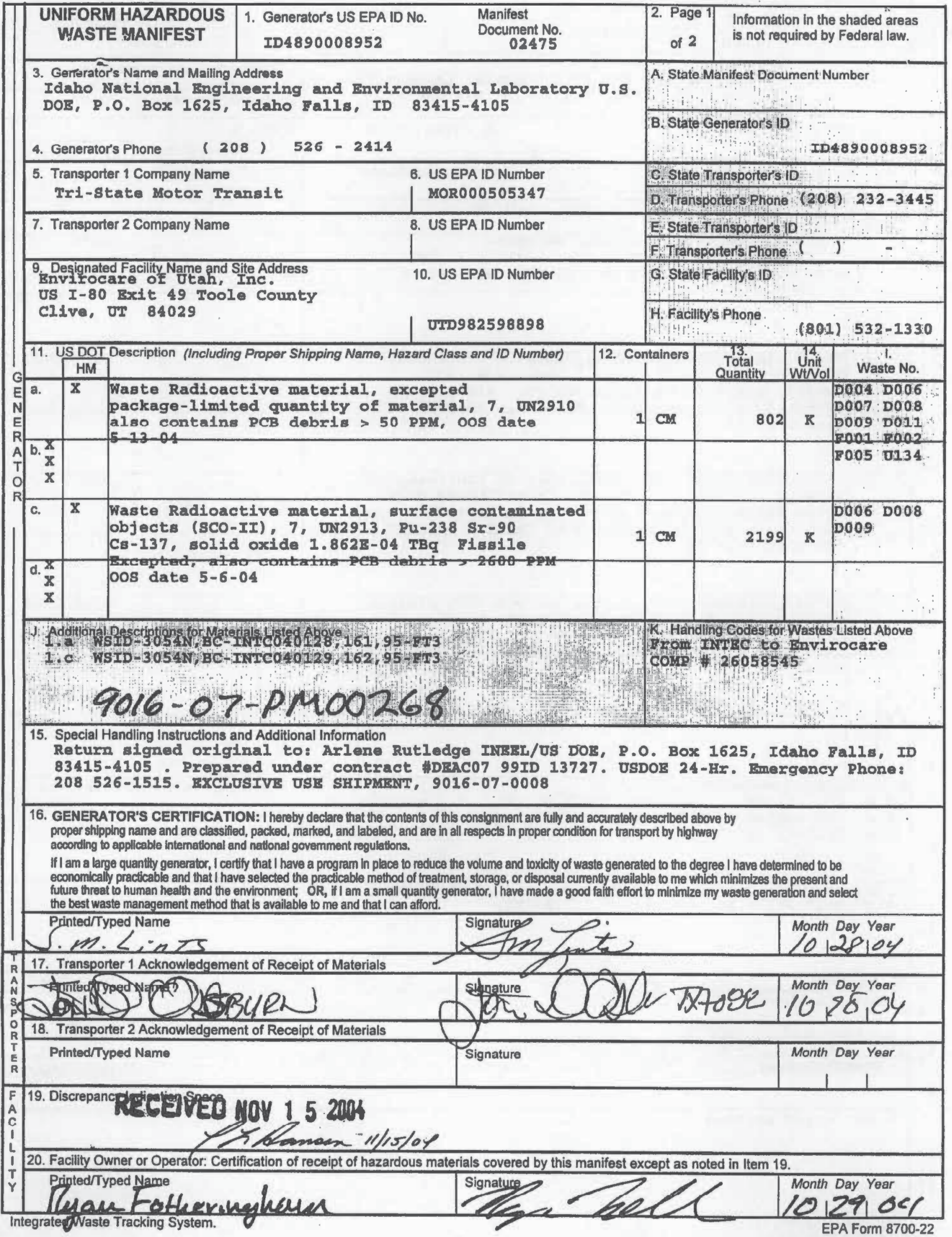




\begin{tabular}{|c|c|c|c|c|c|c|c|c|}
\hline & & $\begin{array}{l}\text { NIFORM HAZARDOUS } \\
\text { WASTE. MANIFEST } \\
\text { (Continuation Sheet) }\end{array}$ & $\begin{array}{l}\text { 21. Generator's US EPA ID No. } \\
\text { ID4890008952 }\end{array}$ & ument no: & $\begin{array}{l}\text { 22. Pag } \\
2 \mathrm{OF}\end{array}$ & $\begin{array}{l}\text { Informati } \\
\text { areas is } \\
\text { Federal }\end{array}$ & $\begin{array}{l}\text { tion in } t \\
\text { not rec } \\
\text { law. }\end{array}$ & $\begin{array}{l}\text { the shaded } \\
\text { quired by }\end{array}$ \\
\hline & & $\begin{array}{l}\text { Génerator's Name } \\
\text { aho National Engine }\end{array}$ & eering and Environmental Laboratory & & State & anifest Docun & ment Nur & umber \\
\hline & & S. DOE, P.O. BOX 16 & 525, Idaho Falls, ID 83415-4105 & & M.State & Senerator's ID & & \\
\hline & & Transporter___ Company Nan & 25. US EPA ID Numbe & & N. State & ransporter/s I & & \\
\hline & & & & & 0. Tran & oiter's Phone & & \\
\hline & & Transporter__ Company Nan & 27. US EPA 10 Numbe & & P. State & Fansporter's II & & \\
\hline & & $\begin{array}{l}\text { US DOT Description (Including } \\
\text { HM] }\end{array}$ & $\frac{1}{1 \text { Proper Shipping Name. Hazard Class, and ID Number) }}$ & $\begin{array}{r}29 . \text { Conta } \\
\text { No. }\end{array}$ & \begin{tabular}{|l|l} 
Q. Tran \\
tainers \\
I Type
\end{tabular} & 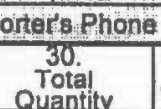 & $\begin{array}{l}3 \\
\text { unit } \\
\text { wevol }\end{array}$ & $\begin{array}{c}\text { R. } \\
\text { Waste No. }\end{array}$ \\
\hline & & \begin{tabular}{|l|l|}
$x$ & Waste Radioact \\
package-1imited \\
also contains \\
$5 / 10 / 04$
\end{tabular} & $\begin{array}{l}\text { ve material, excepted } \\
\text { quantity of material, } 7 \text {, UN2910 } \\
\text { CB debris > 50 PPM, oos date }\end{array}$ & 1 & $\mathrm{CM}$ & 776 & pouvo & Doob: \\
\hline & b. $\frac{x}{x}+$ & & & & & & & \\
\hline & & 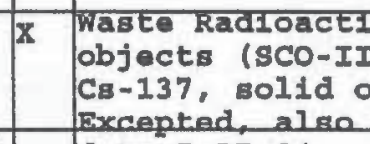 & 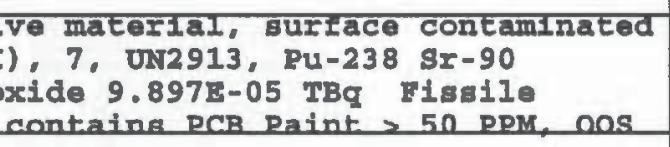 & 1 & $\mathrm{CW}$ & 1263 & $\mathbf{x}$ & 0006 D008 \\
\hline & $\begin{array}{r}\text { d. } X \\
x \\
X\end{array}$ & date $5-27-04$ & & & & & & \\
\hline & & \begin{tabular}{|l|l|}
$x$ & Waste Radioacti \\
objects (sco-II \\
solid oxide 1.4 \\
Alse contains.
\end{tabular} & 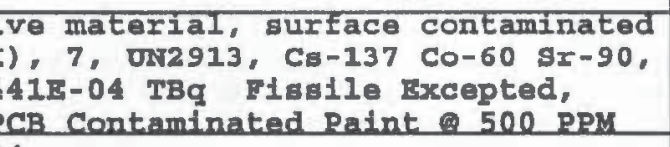 & 1 & CW & 1859 & $\mathrm{x}$ & 1008 \\
\hline $\mathbf{R}$ & f. $\frac{x}{x}$ & oos date $8-02-0$ & & & & & & $\therefore$ \\
\hline & g. & 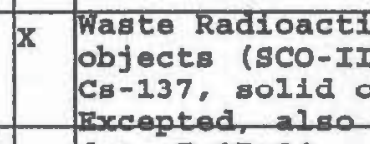 & 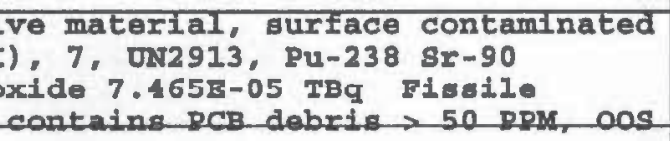 & 1 & $C M$ & 906 & $\mathbf{x}$ & D006 D009 \\
\hline & $\begin{array}{r}\operatorname{co} . \mathbf{x} \\
\mathbf{x} \\
\mathbf{x}\end{array}$ & date $5-17-04$ & & & & & & \\
\hline & \begin{tabular}{|l|l|}
$x$ \\
$x$
\end{tabular} & & & & & & & \\
\hline & S. & 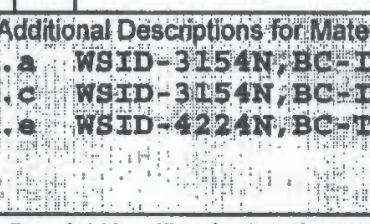 & 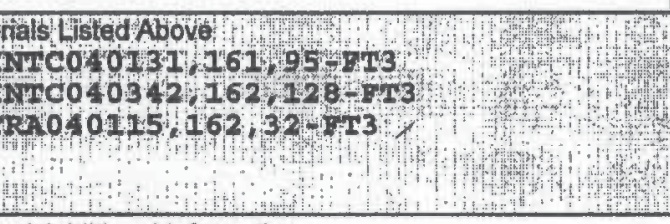 & mention & Thang & 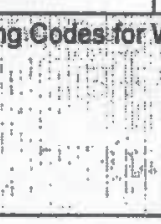 & Wastes & Listed Above \\
\hline & 2 . 32. & $\begin{array}{l}\text { Special Handling Instructions a } \\
.9 \text { WSID-3054N, BC-I }\end{array}$ & $\begin{array}{l}\text { Additional Information } \\
\text { rC040259,162,95-ET3 }\end{array}$ & & & & & \\
\hline & 33.7 & Transporter __ Acknowle & dgement of Receipt of Materials & & & & & Date \\
\hline $\begin{array}{l}A \\
N \\
S\end{array}$ & & Printed/Typed Name & Signature & & & & & Month Day Year \\
\hline $\begin{array}{ll}0 \\
0 \\
0\end{array}$ & & Transporter & dgement of Receipt of Materials & & & & & Date \\
\hline $\mathbf{R}$ & & Printed/Typed Name & Signature & & & & & Month Day Year \\
\hline $\begin{array}{l}1 \\
\vdots \\
\vdots \\
y\end{array}$ & & Discrepency Indication Space & & & & & & \\
\hline
\end{tabular}




\section{ENVIROCARE \\ OF UTAH, INC.}

\section{THE SAFE ALTERNATTVE}

3 txi. S. Ext $49,1-80$

Clive, Utah $84029 \mathrm{EPA}$

1D: UT982598898

\section{CERTIFICATE OF DISPOSAL}

This Certificate acknowledges that the following manifested shipmients:

\begin{tabular}{|c|c|c|c|c|c|}
\hline \multirow{2}{*}{$\frac{\text { Shipment }}{9016-07-0000}$} & Manifest & Date(s) of Disposal & $\mathrm{Cu} / \mathrm{Ft}$ & Process & Disposall Location \\
\hline & 02475 & $12 / 22 / 2004$ & 540 & Landfill & Mlxed Waste \\
\hline & & $12 / 23 / 2004$ & & & \\
\hline & & $12 / 28 / 2004$ & & & \\
\hline & & $12 / 29 / 2004$ & & & \\
\hline & & $1230 / 2004$ & & & \\
\hline
\end{tabular}

Representing 540 Cubic feet of waste of at listed Disposal Facility landfill. Disposal is subject to

Envirocare's Radioactive Material License, all other applicable licenses, permits and regulations, and the Disposal Agreement.

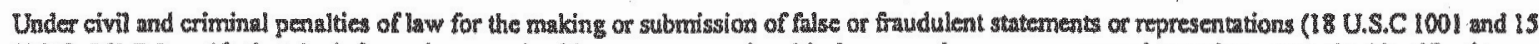
U.S.C. 2615) I certify that the intonnntion contained in or acconpranying this document is true, wceturato and complete. As to the identification

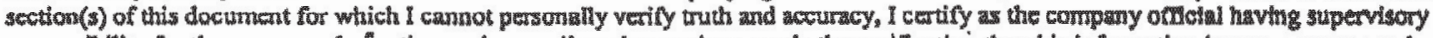
rewowsibility for the pernons who, acting under my direct instructions, made the verification that this information is true, wecurute and complete.
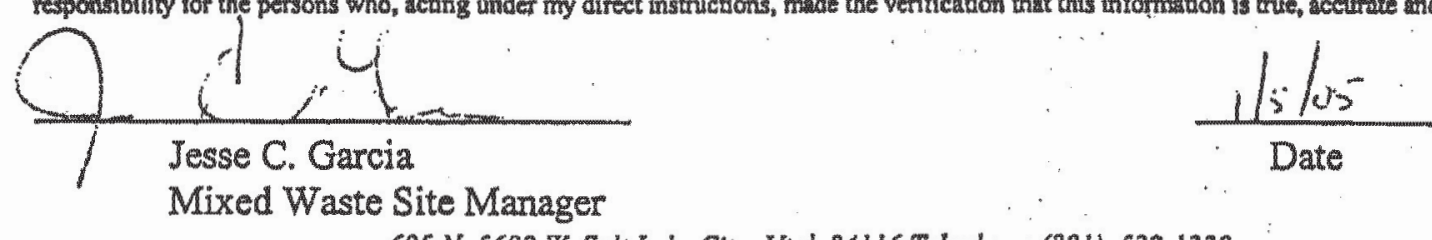

605 N. $\$ 600$ W, Salt Lake City, Utah 84116 Telephone (801) $532-1330$ 



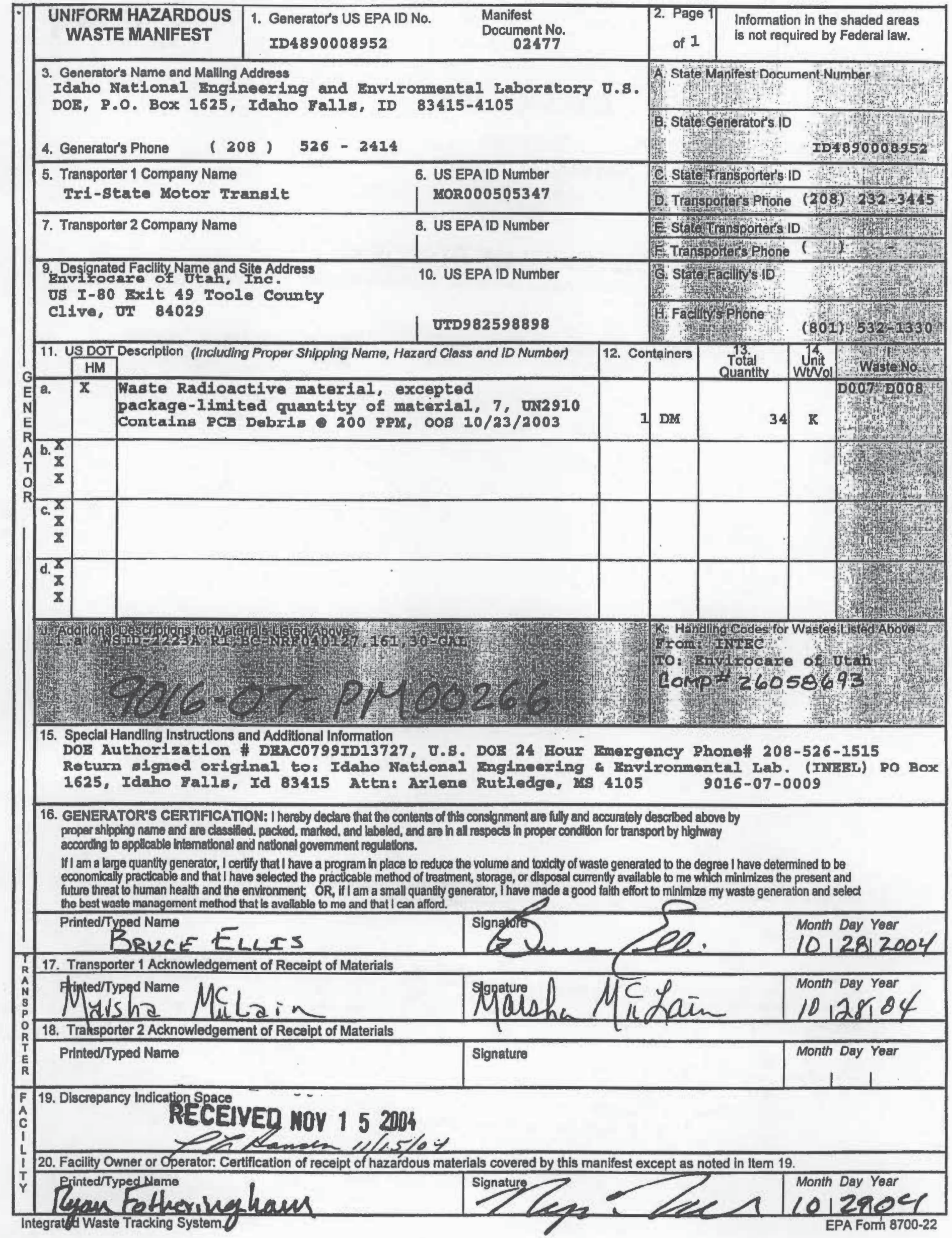




\section{ENIIROCARE}

OF UTAH, INC.

THE SAFE ALTERNATIYE

$3 \mathrm{ml}$. S. Ext. 49, 180

Clive, Uiah 84029 EPA

D: UTV82598898

\section{CERTIFICATE OF DISPOSAI}

This Certificate acknowledges that the following manifested shipments:

$\frac{\text { Shipment }}{9016-07-0000} \frac{\text { Manifest }}{02477} \quad \frac{\text { Date(s) of Disposal }}{04 / 11 / 2005} \quad \frac{\text { Cu/fit }}{4.0104} \quad \frac{\text { Process }}{\text { Landin }} \quad \frac{\text { Disposal Location }}{\text { Mbxad Wasle }}$

Representing 4.0104 Cubic feet of waste of at listed Disposal Facility landfill. Disposal is subject to Envirocarcis Radicootlve Material Lieenes, all other applieable licenses, permits and regulations, and the Disposal Agrecrnent.

Under ctvil and oriminal penalties of inw for the makins or submission of false or frnuduient statemonts or representations (IS U.S.C 1001 and 15

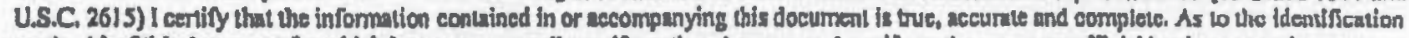
section(s) of this document for which I cannot personally verily outh and securacy, I cenifly as the compantry ofliojal having supervisory responsibility for the persons why acting under my disect instructions, mede the verifeation that this intormation is true, zeeuruce and compiete.
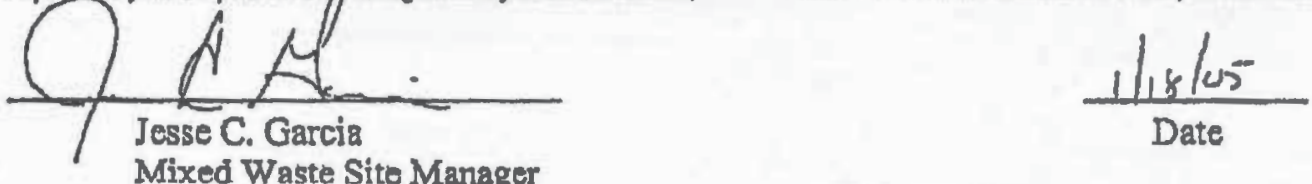

Mixed Waste Site Manager

605 N. 5600 W, Sall Lake Cly, Uiah 84116 Telephone (801) 532-1330 



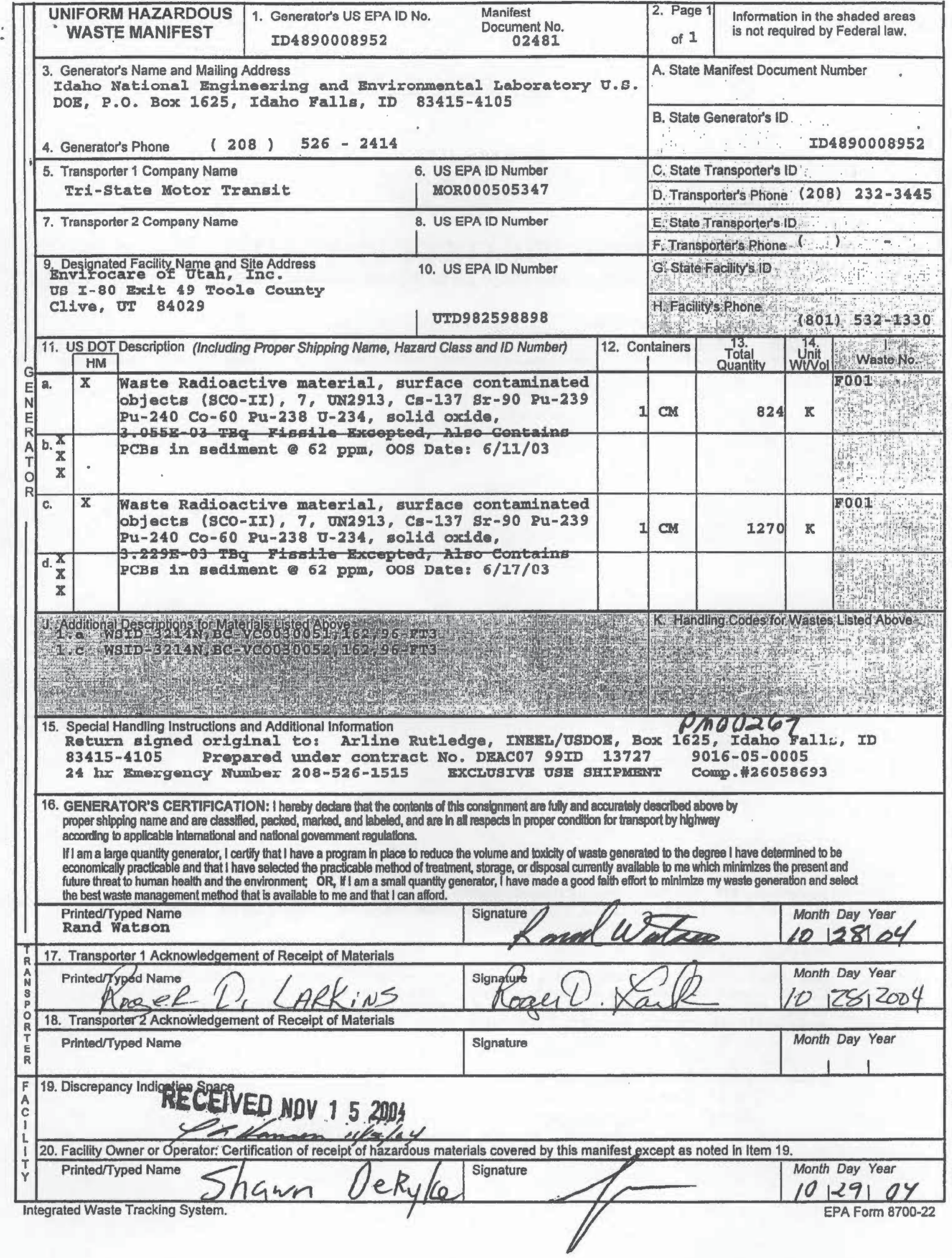




\title{
ENVIROCARE
}

OF UTAH, INC.

\section{THE SAFE ALTERNATIVE}

\author{
3 mi: S. Ext. $49,1-80$ \\ Clive, Utah 84029 EPA \\ 1D: UT982598898
}

\section{CERTIFICATE OF DISPOSAL}

This Certificate acknowledges that the following manifested shipments:

$\frac{\text { Shipment }}{9016-05-0005} \frac{\text { Manifest }}{02481} \frac{\text { Date(s) of Disposal }}{1215 / 2004} \cdot \frac{\text { Cu/Ft }}{12116 / 2004} \cdot \frac{\text { Process }}{\text { Landfilt }} \cdot \frac{\text { Disposal Location }}{\text { Mixed Waste }}$

Representing 192 Cubic feet of waste of at listed Disposal Facility landfill. Disposal is subject to Envirocare's Radioactive Material License, all other applicable lienses, permits and regulations, and the Disposal Agreement.

Under civil and criminal penalties of law for the making or submission of frise or frauciulent statements or representations (18 U.S.C 1001 and is U.S.C. 2615) I certify that the information eontuined in or aceompanying this document is true, accurate and complete. As to the identification section(s) of this document for which I cansot personally verify outh and accuracy, I certify as the cormpany official having supervisory regparsibility for the persons who, acting under my direct instructions, made the verification thas this information is trut, aceunte and complete.

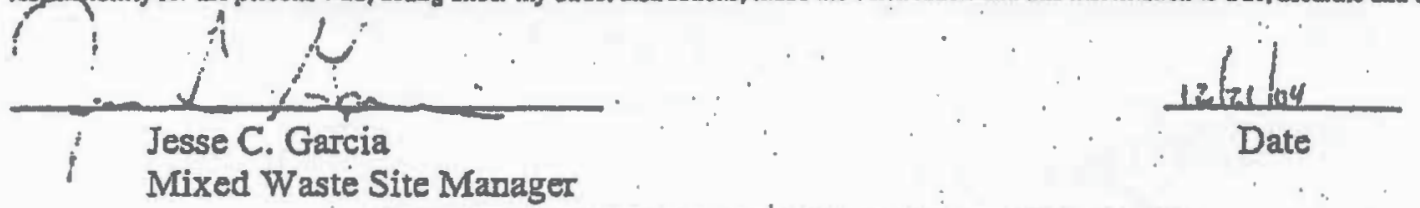

605 N. 5600 W. Sall Lake Ciy, Uiah 84116 Telephone (801) 532-1330 



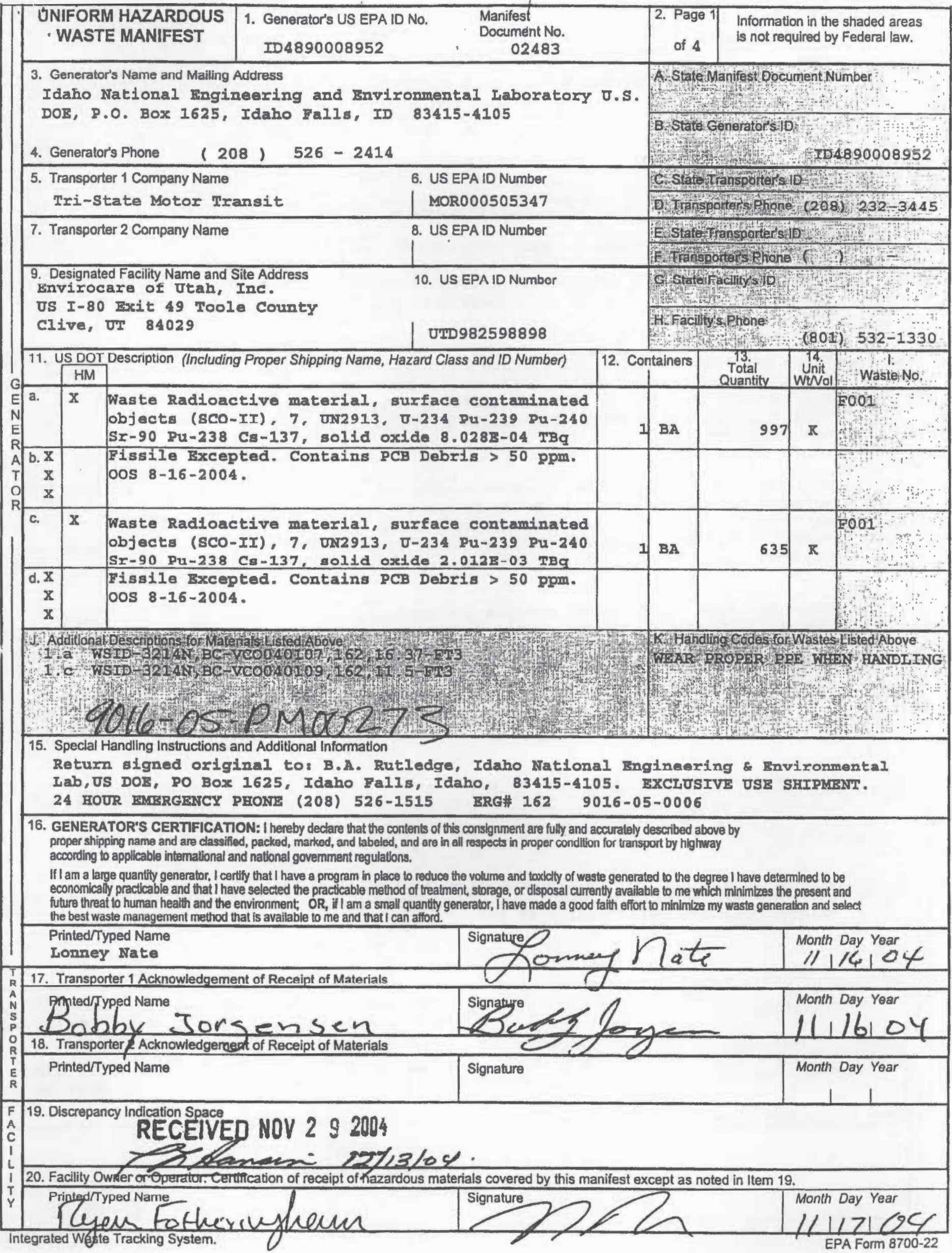




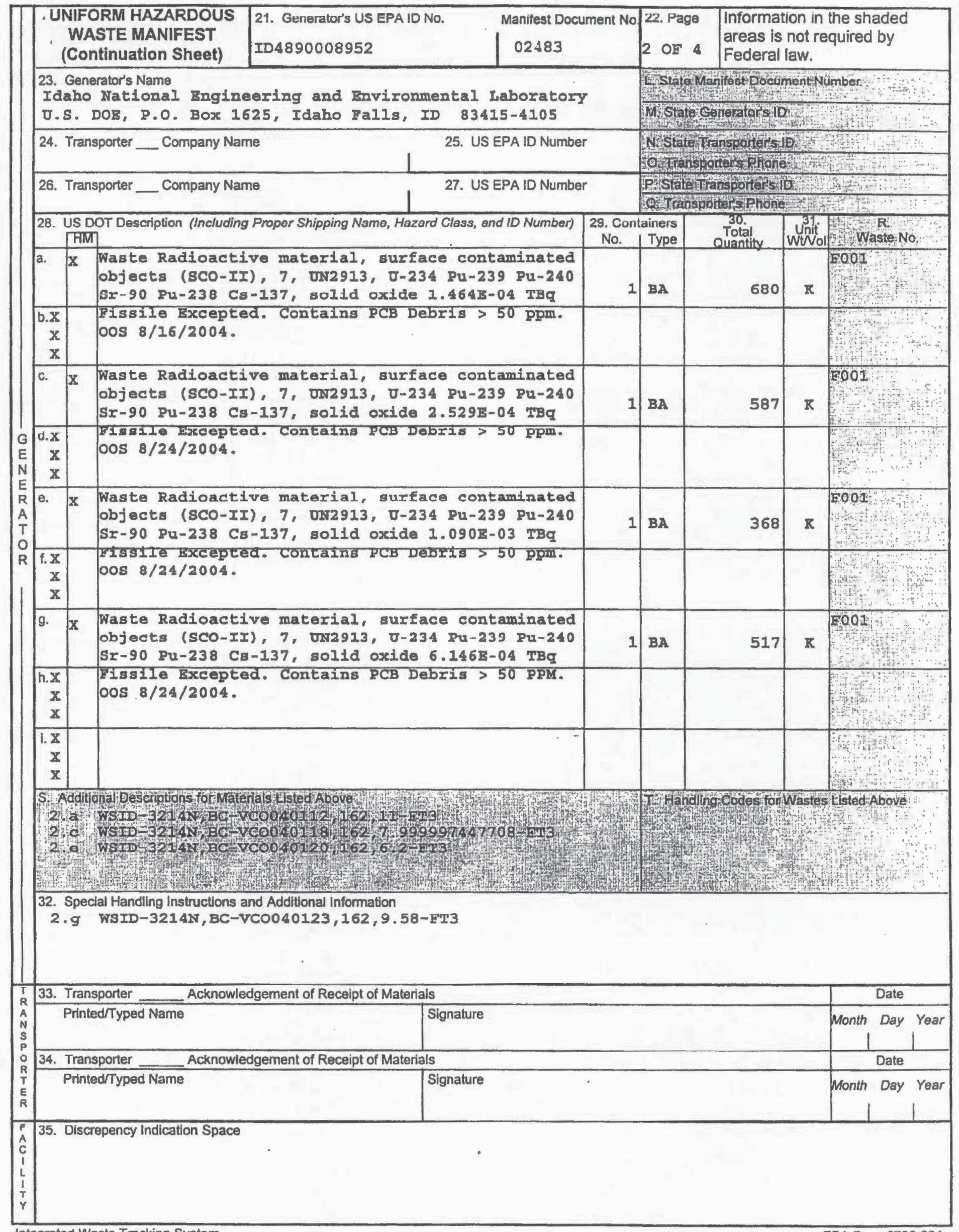




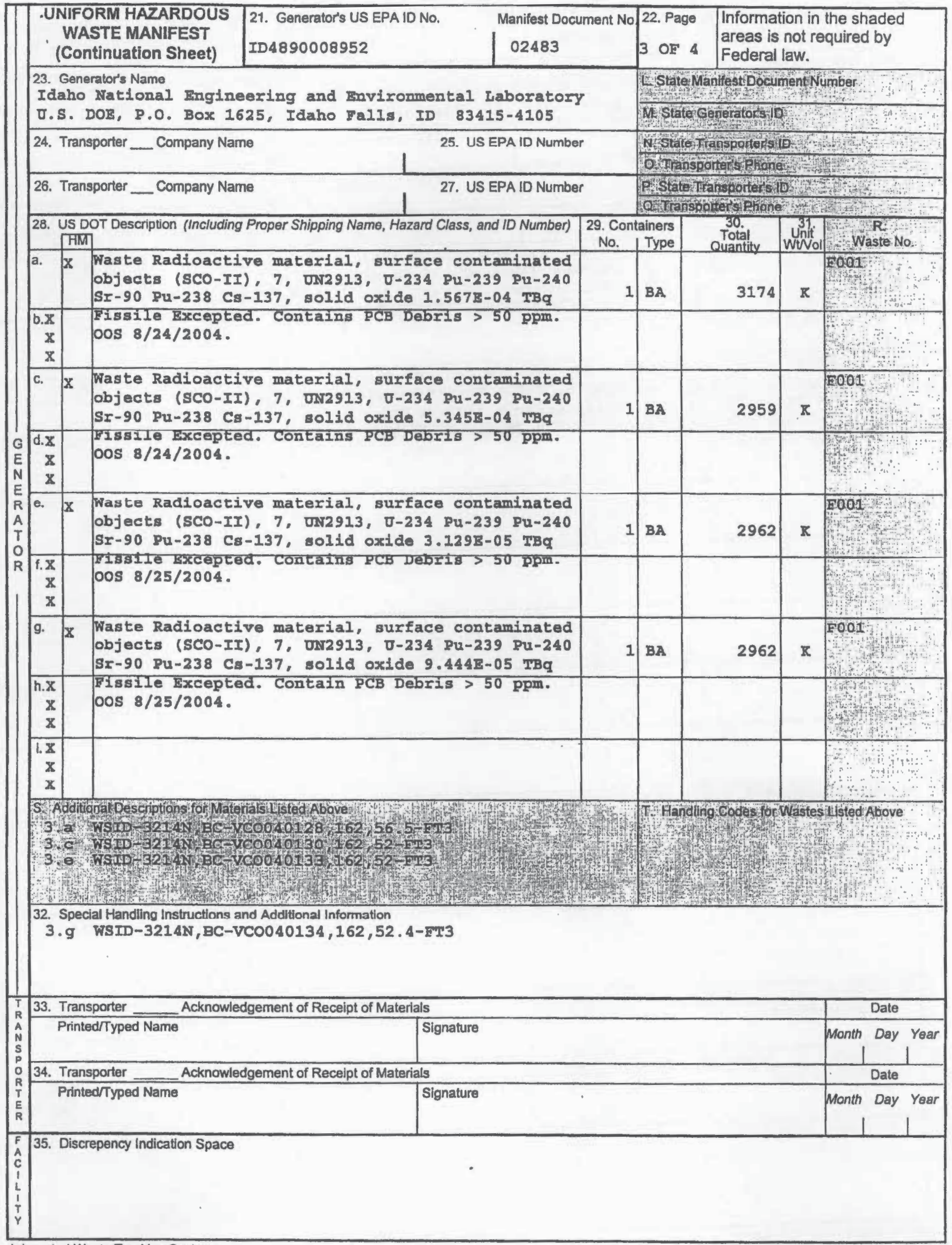




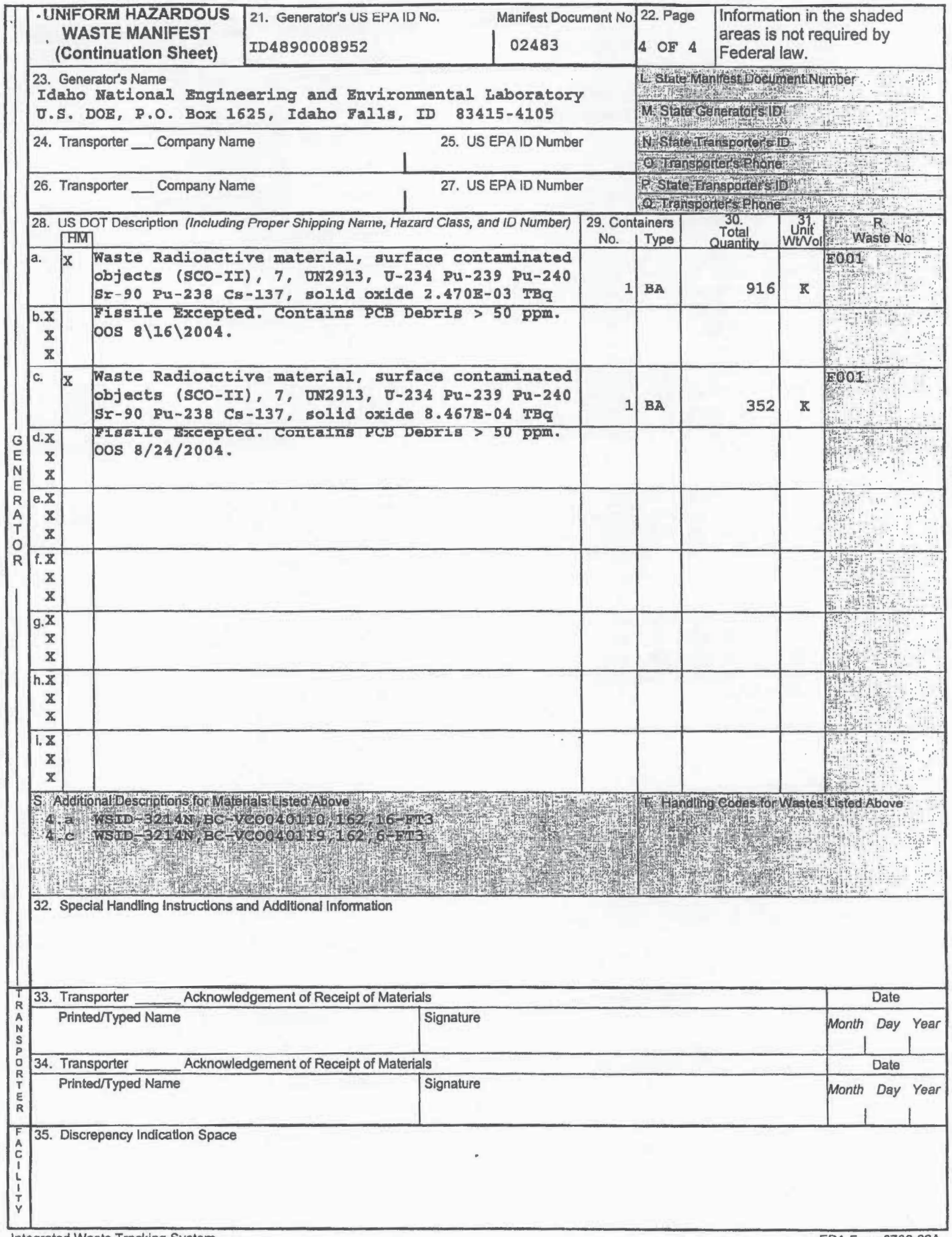




\section{ENVIROCARE}

OF UTAH, INC.

THE SAFE ALTERNATIVE

3 min. S. Ext 49,1480

Clive Uitah $84029 \mathrm{EPA}$

D: UTY82598898

\section{CERTTICATE OF DISPOSAL}

This Centificate acknowledges that the following manifested shipments:

$\frac{\text { Shipment }}{9016-05-0006} \frac{\text { Manifest }}{02483} \quad \frac{\text { Date(s) of Disposal }}{01107 / 2005} \quad \frac{\text { Ca/Ft }}{297.55} \quad \frac{\text { Process }}{\text { Landill }} \quad \frac{\text { Disposal Location }}{\text { Mixed Waste }}$

Represeating 297.5s Cubic feet of waste of at listed Disposal Facility landfill. Disposal is subject to

Envirocare's Radioactive Material License; all other applicable licenses, permits and regulations, and the Disposal Agreement.

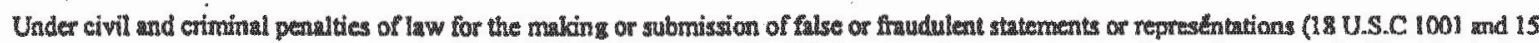

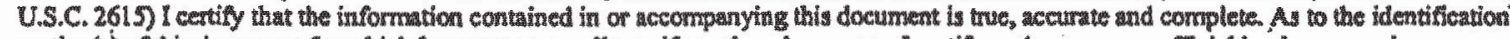
seetion(s) of this document for which I cannot personally verify truth and wecurney. I certify as the company official having supervisory

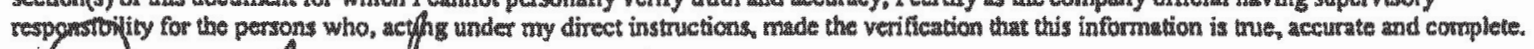
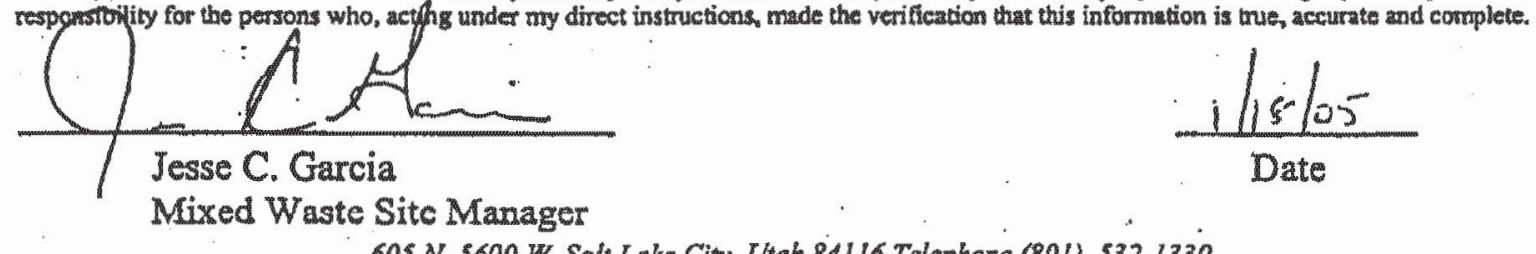

605 N. 5000 W. Salt Lake City, Utah 84116 Telephone (801) $332-1330$ 



\begin{tabular}{|c|c|c|}
\hline $\begin{array}{l}\text { UNIFORM HAZARDOUS } \\
\text { WASTE MANIFEST }\end{array}$ & $\begin{array}{l}\text { 1. Generator's US EPA ID No. } \\
\text { ID4890008952 }\end{array}$ & $\begin{array}{l}\text { Manifest } \\
\text { Document No. } \\
02484\end{array}$ \\
\hline
\end{tabular}

4. Generator's Phone (208) $526-2414$

\begin{tabular}{|c|c|}
\hline $\begin{array}{l}\text { 5. Transporter } 1 \text { Company Name } \\
\text { Tri-State Motor Transit }\end{array}$ & $\begin{array}{l}\text { 6. US EPA ID Number } \\
\text { MORO00505347 }\end{array}$ \\
\hline 7. Transporter 2 Company Name & 8. US EPA ID Number \\
\hline
\end{tabular}
9. Designated Facility Name and Site Address
Env1rocare of Utah. Inc.
US I-80 Exit 49 Toole County

10. US EPA ID Number

Clive, UT 84029

(1)

| UTD982598898

11. US DOT Description (Including Proper Shipping Name, Hazard Class and ID Number)
HM

\begin{tabular}{|c|c|c|}
\hline \multicolumn{3}{|c|}{$\begin{array}{l}\text { 11. US DOT Description (Including Proper Shipping Name, Hazard Class and ID Number) } \\
\text { HM }\end{array}$} \\
\hline a. & $\mathbf{x}$ & $\begin{array}{l}\text { Waste Radioactive material, surface contaminated } \\
\text { objects (SCO-II), 7, UN2913, O-234 Pu-239 Pu-240 } \\
\text { Sr-90 Pu-238 Ca-137, sol1d oxtde 1.571E-04 TBq }\end{array}$ \\
\hline $\begin{array}{r}\mathrm{x} \\
\mathrm{x} \\
\mathrm{x}\end{array}$ & & $\begin{array}{l}\text { Fissile excepted. Contains PCB debris > } 50 \text { ppm. } \\
\text { oos } 08 / 16 / 2004\end{array}$ \\
\hline c. & $x$ & $\begin{array}{l}\text { Waste Radioactive material, surface contaminated } \\
\text { objects (SCO-II), 7, ON2913, U-234 Pu-239 Pu-240 } \\
\text { SI-90 Pu-238 Cs-137, solid oxide } 2.897 \mathrm{~B}-03 \mathrm{TBq}\end{array}$ \\
\hline d. $\begin{array}{r}x \\
x \\
x\end{array}$ & & $\begin{array}{l}\text { Fissile excepted. Contains PCB debris > } 50 \text { ppm. } \\
\text { oos } 08 / 16 / 2004\end{array}$ \\
\hline
\end{tabular}

J. Additional Descriptions for Materials Listed Above

1.E WSID-3214N, BC-VCO0 40106, $162,40.8$-FT3

1. WSID -3214 N BC-YCO0 $40108,162,28.5$ - ET3

(1.

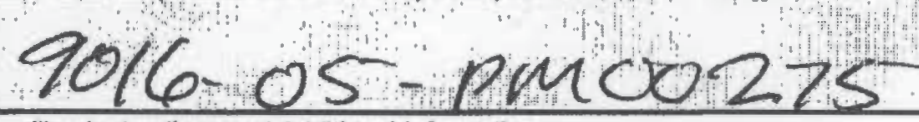

15. Special Handling Instructions and Additional Information

Return Bigned original to: B.A. Rutledge, Idaho National Engineering \& Environmental Lab, USDOE, Po Box 1625, Idaho Fa118, Idaho, 83415-4105. EXCLUSIVE USE SHIPMINT.
24 HOUR HMERGENCY PHONE
(208) $516-1515$
ERG\# 162
9016-05-0007

16. GENERATOR'S CERTIFICATION: I hereby declare that the contents of this consignment are fully and accurately described above by proper shipping name and are classified, packed, marked, and labeled, and are in all respects in proper condition for transport by highway according to applicabie international and national government regulations.

If I am a large quantity generator, I certily that I have a program in place to reduce the volume and toxkity of waste generated to the degree I have determined to be econornically practicable and that I have selected the practicable method of treatment, storage, or disposal currently available to me which minimizes the present and future threat to human health and the environment, OR, If I am a small quantity generator, I have made a good faith effort to minimize my waste generation and select the best waste management method that is available to me and that $I$ can afford.

Printed/Typed Name

Lonney Nate

17. Transporter 1 Acknowledgement of Receipt of Materials Printed/Typed Name

ClAYAE TIMSLEY

18. Transporter 2 Acknowledgement of Receipt of Materials Printed/Typed Name

E

19. Discrepancy Indizatior Space - - -

\title{
RECEIVED NOV 29 2004
}

20. Facility Owner or Operator: Certification of receipt onhâzardous materials covered by this manifest except as noted in Item 19.

Printed/Typed Name

lescas EoLh

Integrated Wfste Tracking System.
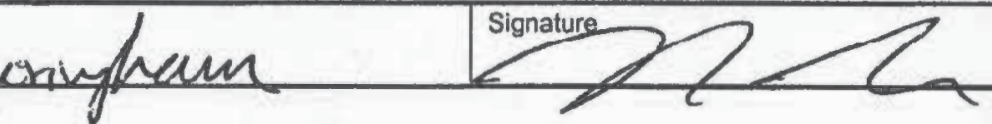

Month Day Year 


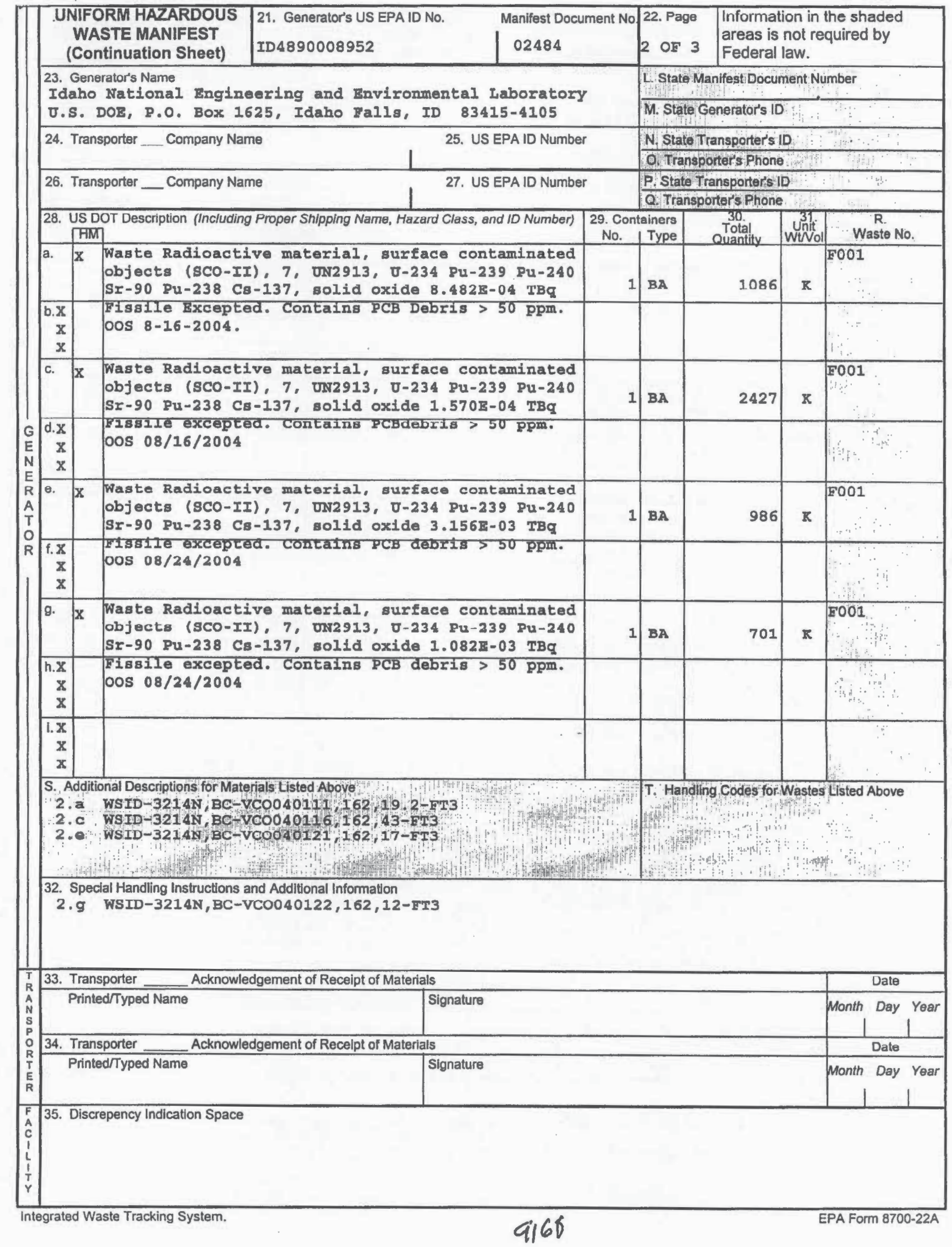




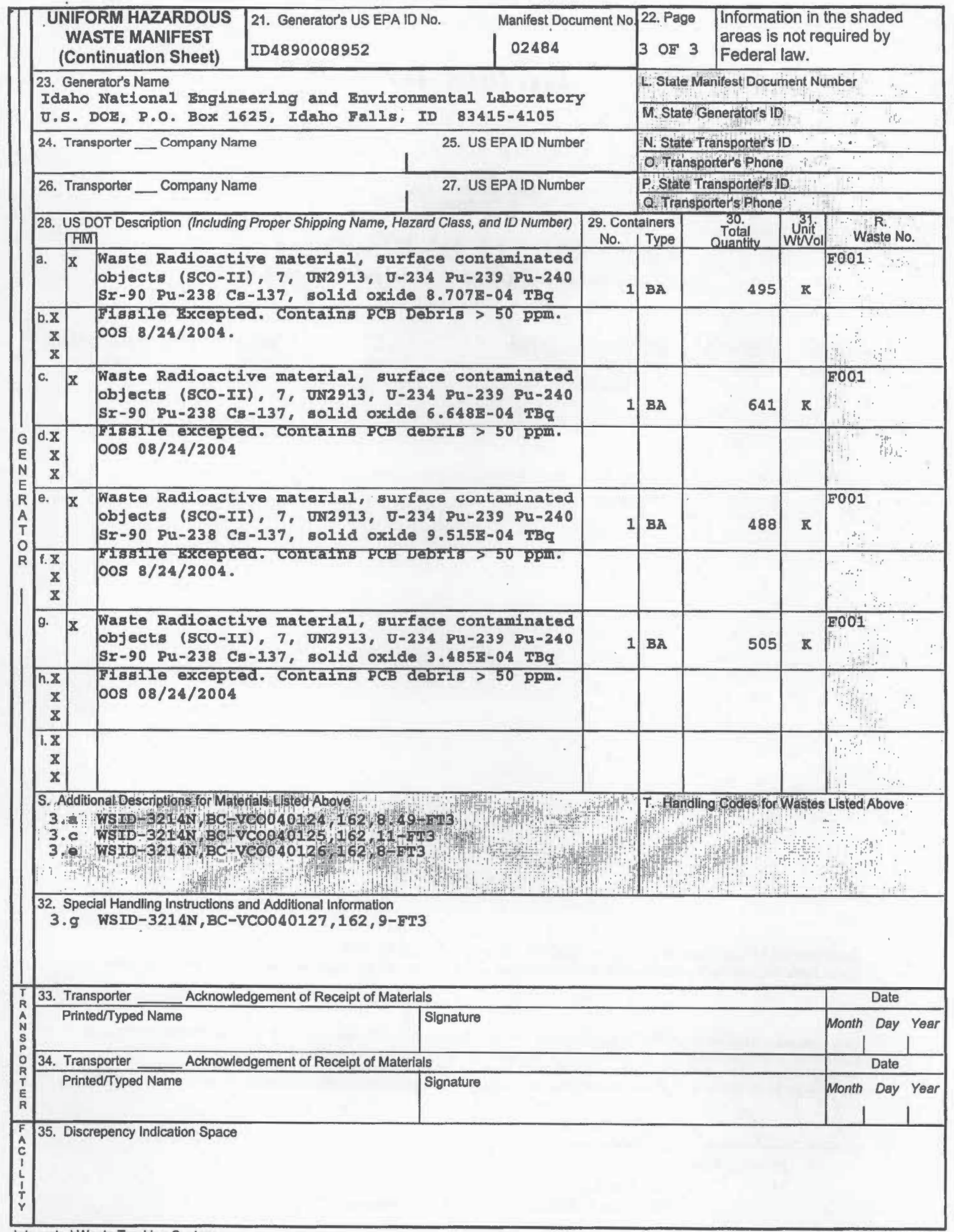




\section{ENVTROCARE}

OF UTAH, INC.

\section{THE SAFE ALTERNATIVE}

3 mi. S. Ext. 49, 1-80

Clive, Utah 84029 EPA

ID: UT982598898

\section{CERTIFICATE OF DISPOSAL}

This Certificate acknowledges that the following manifested shipments:

$\frac{\text { Shipment }}{9016-05-0007} \frac{\text { Manifest }}{02484} \frac{\text { Date(s) of Disposal }}{01 / 07 / 2005} \cdots \frac{\text { Cu/Ft }}{196.99} \cdots \frac{\text { Process }}{\text { Landifil }} \quad \frac{\text { Disposal Location }}{\text { Mlxed Waste }}$

Representing 196.99 Cubic feet of waste of at listed Disposal Facility landfill. Disposal is subject to Envirocare's Radiogctive Material License, all other applicable licenses, permits and regulations, and the Disposal Agreement.

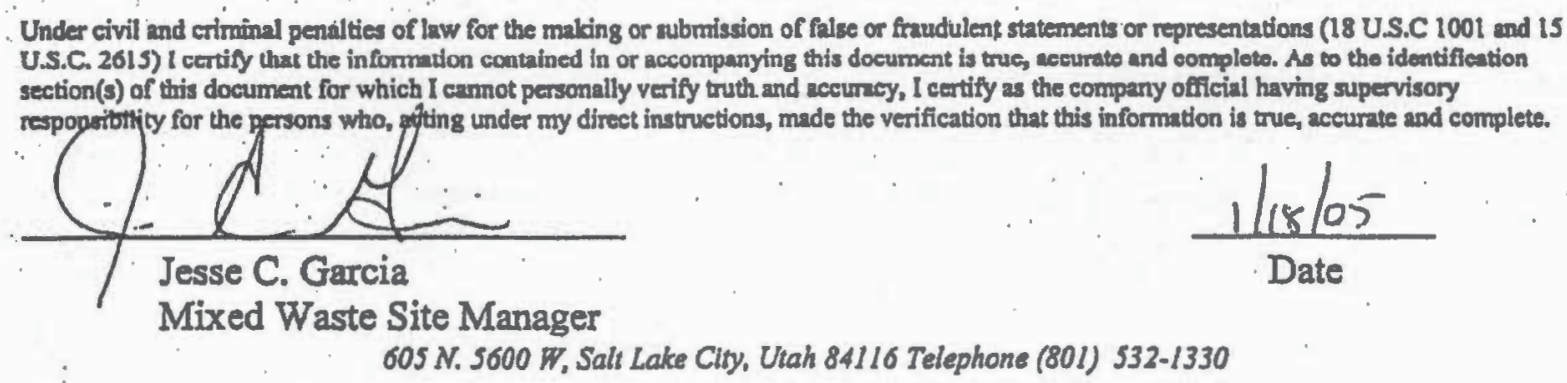





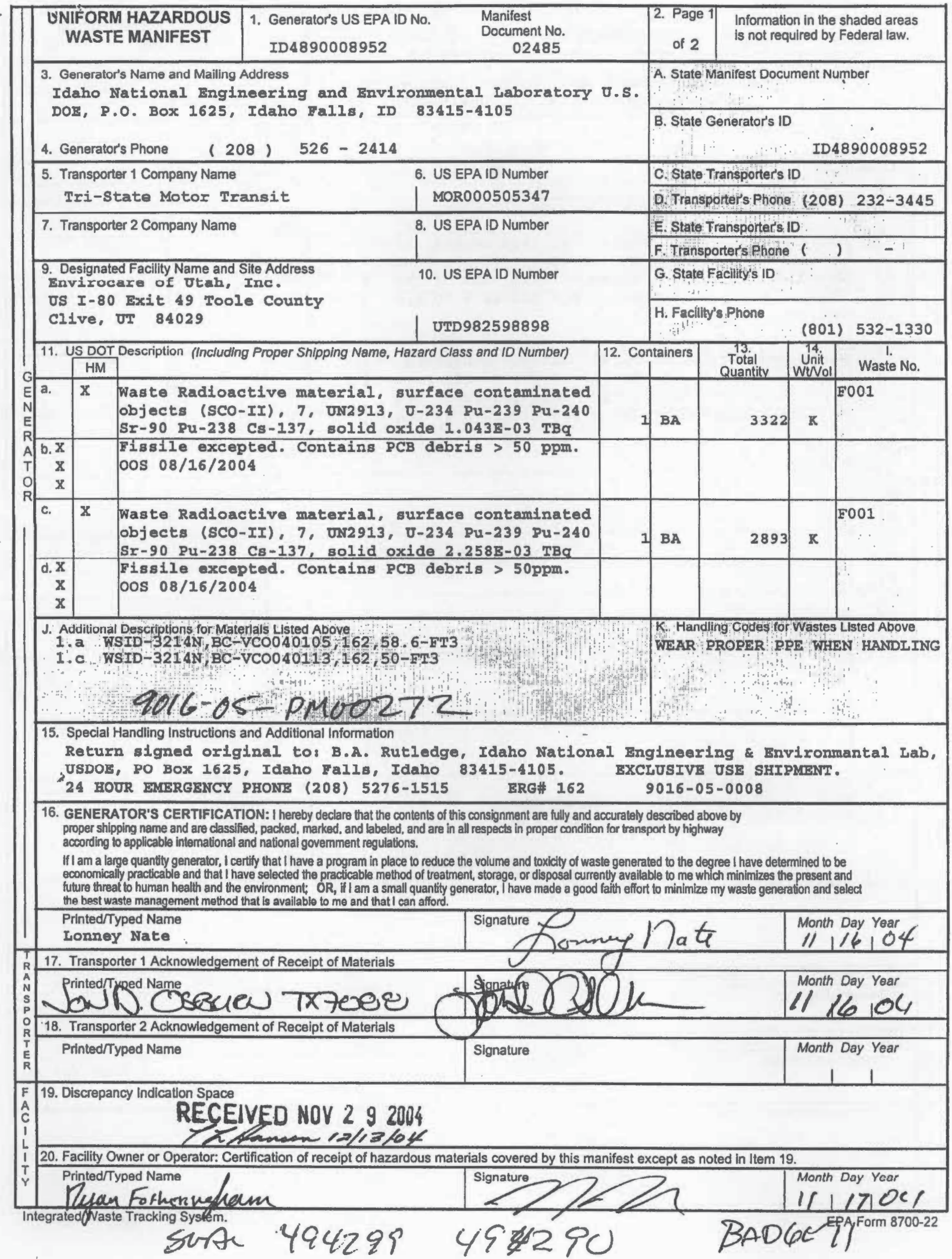




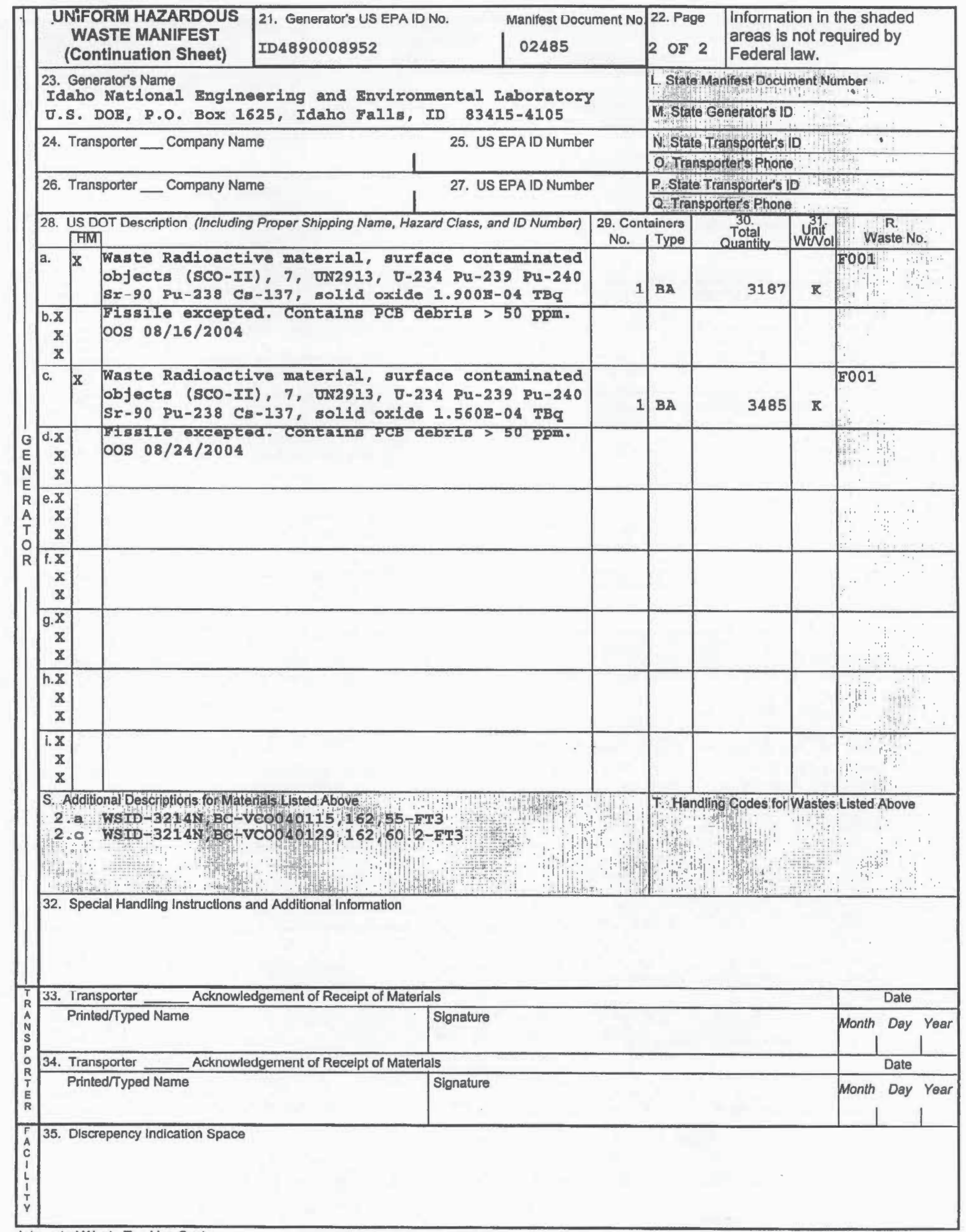




\section{ENITROCARE}

OF UTAH, DNC.

\section{THE SAIE ALTERNATTVE}

3 mis. S. Ext. 49,180

Clive, Utah 84029 EPA

D: UTY82598898

\section{CERTIFICATE OF DISPOSAL}

This Certificate acknowledges that following manifested shipments:

$\frac{\text { Shipment }}{9016-05-0008} \cdot \frac{\text { Manifest }}{02485} \cdot \frac{\text { Date(s) of Disposal }}{04 / 07 / 2005} \cdot \frac{\text { Cu/ft }}{223.8} \quad \frac{\text { Process }}{\text { Landfli }} \quad \frac{\text { Disposal Location }}{\text { Mixed Waste }}$

Represcatiog 223.8 Cubic feet of waste of at listed Disposal Ficility landfill. Disposal is subject to Envirocare's Radioactive Material License, all other applicable licenses, permits and regulations, and the Disposal Agreement.

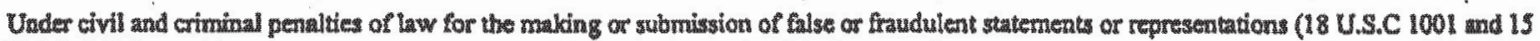

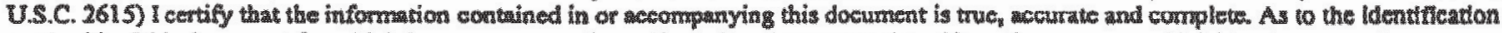
section(s) of this documest for winichyl cannot personally verify truth and accuracy, I certify as the company official havisg supervisory

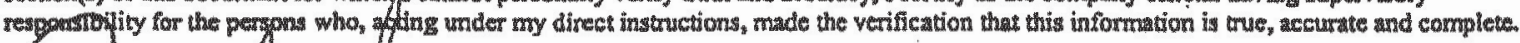

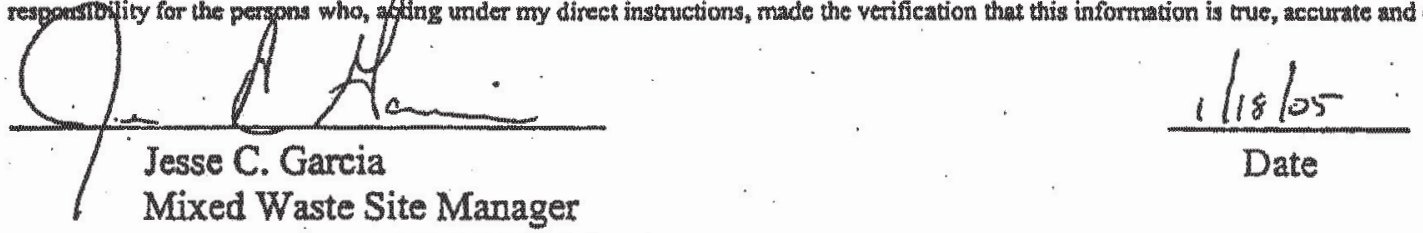

605 N. 5000 W. Salt take City, Utah 84116 Telephone (801) 532-1330 



\section{C}

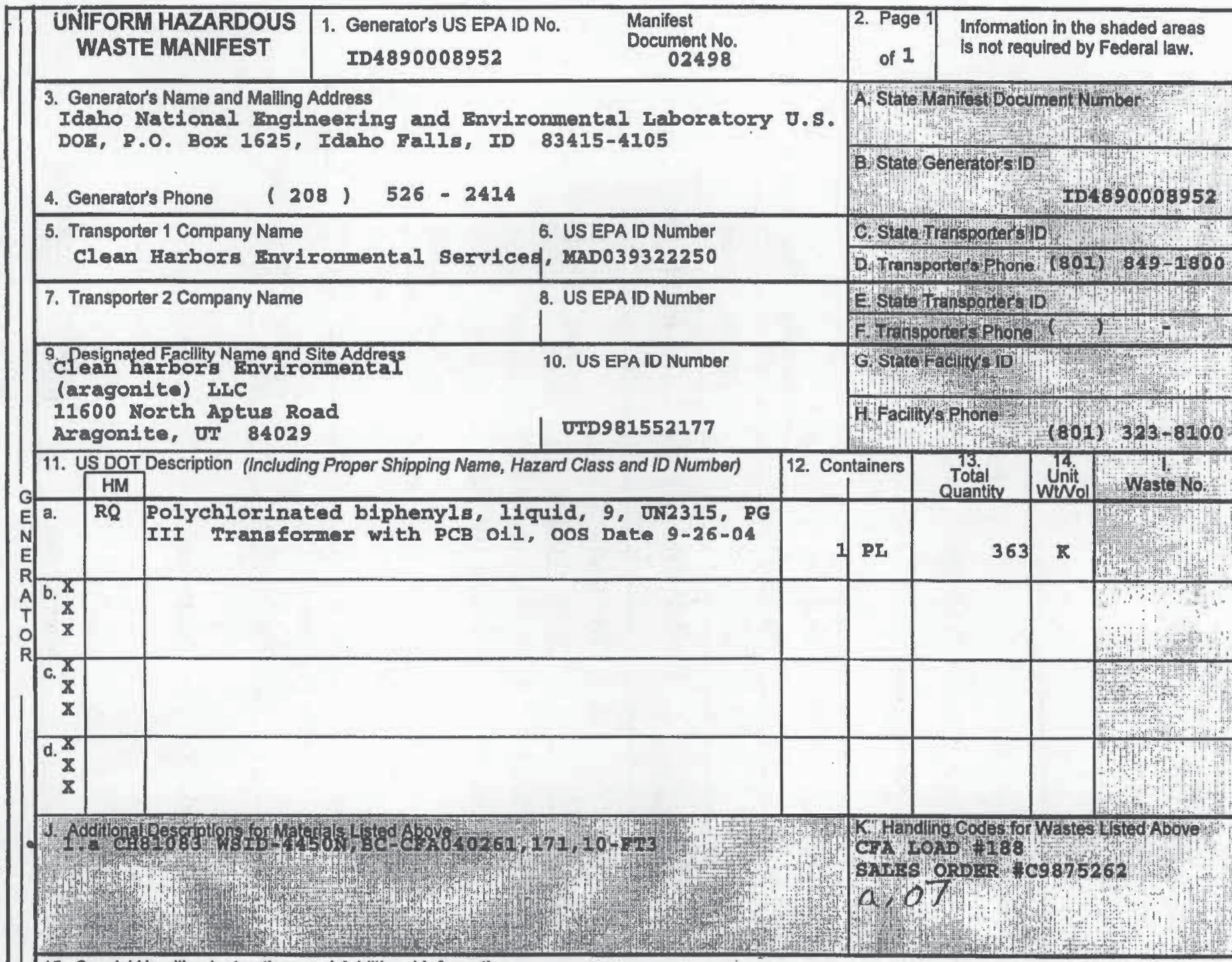

15. Special Handling Instructions and Additional Information

Return signed original to: B.A. Rutledge, Idaho National Ingineering \& Evironnental Iaboratory/US DOE, B.O. Box 1625, Idaho Balls, ID 83415-4105. Prepared under contract \#DEACO7 99ID 13727. USDOE 24-Hr. Emergency Phone: (208) 526-1515.

16. GENERATOR'S CERTIFICATION: I hereby dectare that the contents of this consignment are fully and accurately described above by proper shipping mame and are classified, packed, marked, and labeled, and are $h$ all respects in proper condlition for transport by highway according lo applicable intemational and national government regulations.

III am a large quantity generator, I certify that I have a program in place to reduce the volume and toxicily of waste generated to the degree I have determined to be economically practicable and that I have selected the practicable method of treatment, storage, or disposal currenty available to me which minimizes the present and future threat to human health and the environment. OR, if I am a small quantily generator, have made a good faith effort to minimize my waste generation and select the best waste management method that is available to me and that I can afford.

\section{Printed/Typed Nage}

DJ Rowley

17. Transporter 1 Acknowledgement of Recein of Materials

\begin{tabular}{l|l}
$\mathrm{N}$ & 17. Transpoier $1 \mathrm{Ack} o y$ \\
& Printed/Typed Name
\end{tabular}

18. Transporter 2 Acknowledgement of Receipt of Materials Crta

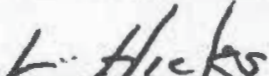
Printed/Typed Name

19. Discrepancy Indication Space

20. Facility Owner or Operator: Certification of recoipl of hazardous materials çvered by this manifest except as noted in Item 19. 


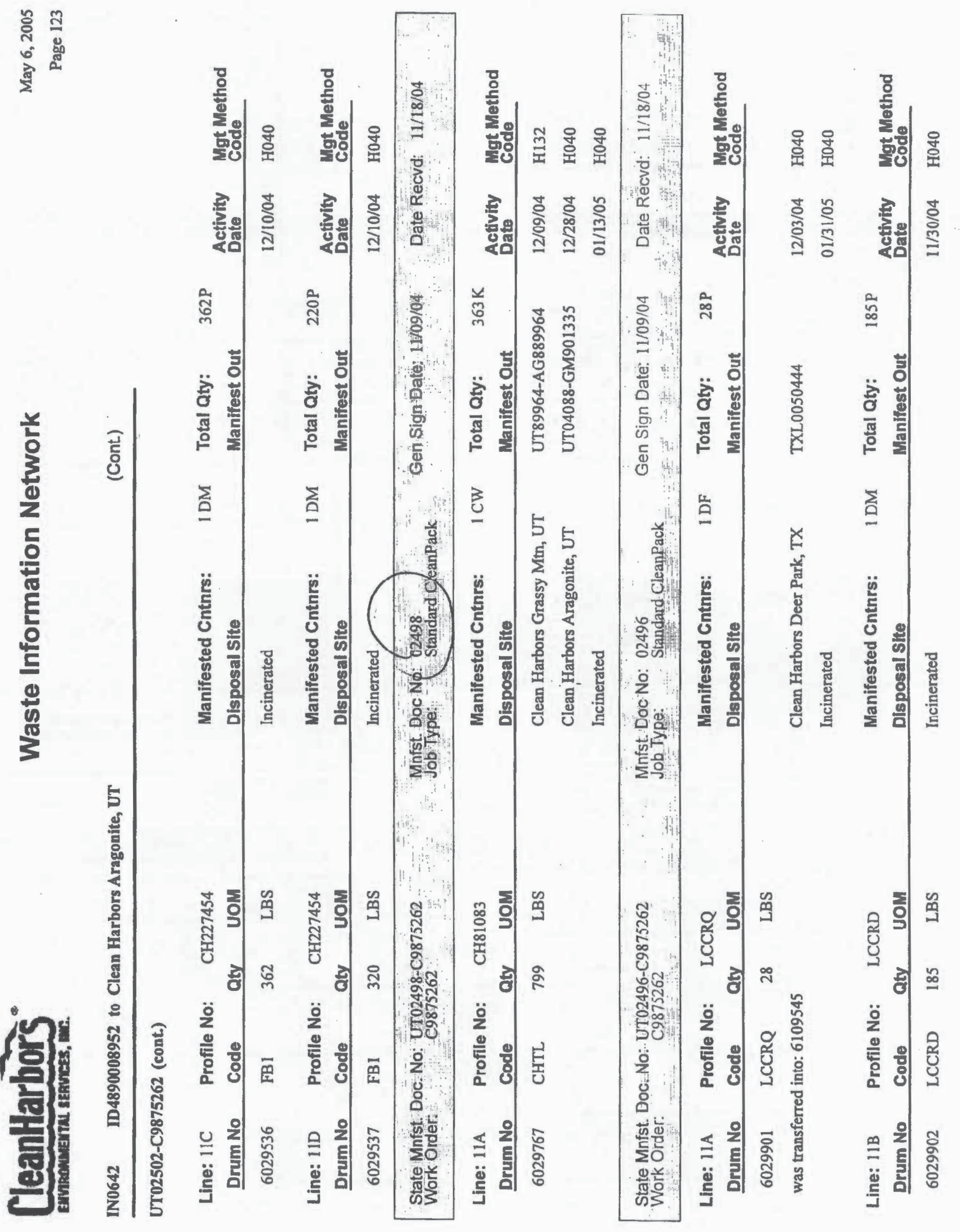


Manifest No. Recv. Date 1002346-C9796039p2 06/15/04 $1002375-0981255 \quad 07 / 28 / 04$ 1002370-C9811256P! 07/28/04 1502370-C981/256P2 07/28/04 $1002376-\mathrm{C} 8811256 \mathrm{PI}$ 07/28/04 $1003372-60811256 \mathrm{PI} \quad 07 / 28104$ ID02371-Cy811256P! 07/28/04 1002368-C981126411 07/28/04 ID02380-Co811256P! 07/28/44 1002381-C9811256P 1 07/25/04 [D02377-C9911256P! 07/28/04 1D02369-C9811256Pl $07 / 28104$ ID02378-C9811256P1 07/28/04 ID02379.C9811256P! 07/28/04 ID02367-C9811264P1 07/28/04 $1002367 . \mathrm{C} 981126482 \quad 07 / 28 / 04$ $1002367.09811264 \mathrm{P3}$ 07/28/04 $1002367-\mathrm{Cg} 11264 \mathrm{PA}$ 07/28/04 $1002395-\mathrm{C} 9811256 \mathrm{P}$. 0728104 1D02392-C9811264P1 07/28/04 $1002374-C 9811256 \% 1 \quad 07 / 28 / 04$

1002373.C9811256P] 07/28/04 $1002373-6981125682 \quad 07 / 28 / 04$ $1002373-\mathrm{C} 9811256 \mathrm{P3} \quad 07 / 28 / 24$ 1002373-Co811256P4 $\quad 07 / 28104$ [D02373-C2811256!5 07/28/04 1002373-Co84125696 07/28/04 $1002373-C 9811256 \quad 07 / 2804$ [D02373-C9841253 07/28/04 IDO2403-C9829700 08/19/04 $1002409-C 9829752 \quad 08 / 17 / 04$ 1D02408-C982975? 08/19/04 1002407-C9829752.1 08/10104 1002407-59829752-2 $08 / 19 / 04$ $1002400-C 9829752 \quad 08 / 19 / 04$ $1002405-C 9829752 \quad 08 / 19 / 04$ $1002399 \cdot C 9829753 \quad 08 / 19 / 104$ 1002402-C9829735 08/19/04 1002406-C982975z 08/19/04 1002401-C9829752-1 08/19704 102401-C9829752-? 08/19/04 $1002401-69829752-3 \quad 08 / 19 / 04$

\begin{tabular}{|c|c|}
\hline & \\
\hline & \\
\hline & \\
\hline & \\
\hline & \\
\hline & \\
\hline & $0 / 13 / 04$ \\
\hline & \\
\hline 75 & \\
\hline & \\
\hline 30 & \\
\hline 80 & 104 \\
\hline & is \\
\hline & is \\
\hline $57181-1$ & \\
\hline $18181 \mathrm{P3}$ & $10 / 14 / 0$ \\
\hline$[002451-\cos 57181-2$ & $10 / 12 / 0$ \\
\hline & $10 / 12 / 0$ \\
\hline & $10 / 13 / 0$ \\
\hline & \\
\hline & \\
\hline
\end{tabular}

$1002457-60857181 \quad 10 / 13 / 04$ $1002463-09857181 \quad 10 / 33 / 04$ $1002867-0957181 \quad 10 / 12 / 04$ 1002462-C9857181-1 10/13/04 $1002462-C 9857181.2 \quad 10 / 13 / 04$ $1002451-0995718 ! \quad 1013 / 04$ 1002452-C9457181PG: 10/12/04 1002452-C9857181P5 16/12/04 $1002452-09857181 \quad 10 / 12 / 04$ uro2501-Co875262 11/18/04 Uro2502-C8875262 11/18/04 UT02498.C9875262 1/1/18/04 บ702496-C9875262 11/18704 UT02496-C9875262-2 13/1804 UT02496-C9875262.3 $11 / 18 / 04$ Uro2496-C9975262-4 $11 / 18 / 04$ 1002504-98875262 11/18/04 $1002503-09875262 \quad 11 / 18 / 04$ $1002495-C 9875262 \quad 11 / 18104$ 1002495-C9875262-2 $\quad 11 / 18104$ 1002499-Co875262-1. 11/1804

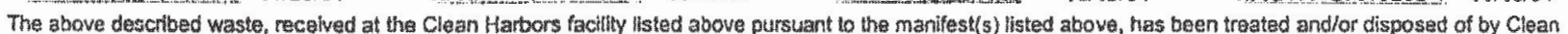
Harbors; or another ficensed facilly aporoved by Clean Harbors, in accorcance with applicable faderal and state laws and reoulations. Any waste recaiveo by Clean

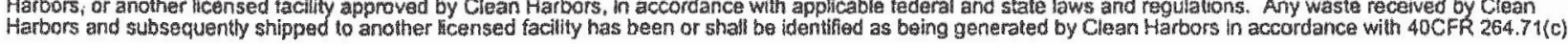

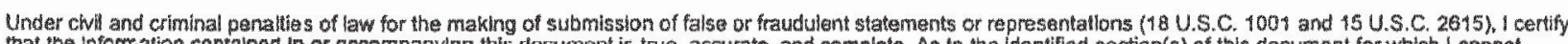
that the infomiation contained in or accompanying this document is true, accurate, and compleste. As lo the identified section(s) of this documant for which 1 cannot personally verly truth and accuracy, I certify as the company ofiticial having supervisory responsibilty for the persons who, acting under my direct instructions, miade the verification that this intomation is true, accurate, and compisete.

signed: Laul Hello

Date: $5 / 6 / 2005$

Title: Serior Tracking Manager 


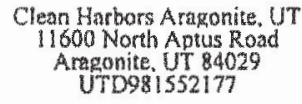

\begin{tabular}{|c|c|}
\hline Manifest No. & Recv. Date \\
\hline $1002499<09875262=2$ & $11 / 18 / 04$ \\
\hline $1002505-C 9875262$ & $11 / 18 / 04$ \\
\hline $1002506 . C 9875262.1$ & $11 / 18 / 04$ \\
\hline $1002500-C 9875266-1$ & $18 / 1804$ \\
\hline $1002500-C 0875266-2$ & $11 / 18 / 04$ \\
\hline $1002500-09875266-3$ & $11 / 18 / 04$ \\
\hline $1002507-C 9875262$ & $11 / 18 / 04$ \\
\hline $1002524-F C 889749$ & $12 / 13 / 04$ \\
\hline DDO2525-EC889749 & $12 / 13 / 04$ \\
\hline $1002514-C 9891796$ & $12 / 22 / 04$ \\
\hline $1002516-C 8891796$ & $12 / 22 / 04$ \\
\hline $1002519-09891796$ & $12 / 22 / 04$ \\
\hline $1002518-69891796$ & $12 / 22 / 04$ \\
\hline (D)2520-C0891796-! & $12 / 22 / 04$ \\
\hline $1002520-C 9891796-2$ & $12 / 22 / 04$ \\
\hline $1002521<9891796=1$ & $12 / 22 / 04$ \\
\hline $1002521-09891706-2$ & $12 / 22 / 04$ \\
\hline $1002322-09891796$ & $12 / 22 / 04$ \\
\hline $102585-C 9891796-2$ & $12 / 22 / 04$ \\
\hline DDO2515-C9891796-3 & $12 / 22 / 04$ \\
\hline $515=0989$ & $12 / 2$ \\
\hline
\end{tabular}

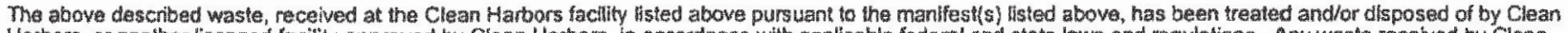
Harbors, or anolher licensed faciliv aporoved by Clean Hartars, in accordance with epolicable federal and state laws and regulatuns. Ang waste recened by Clean Harbors and subsequently shipped to another icensed facility has been or shall be identified as being generated by Clean Harbors in accordance with socFin $264.71(\mathrm{c})$

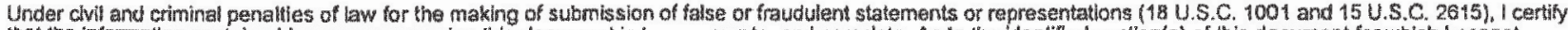

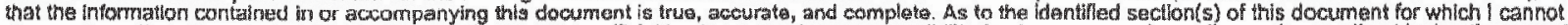
personally werty truth and accuracy, / certivy as the company official having supervisory responsibility for the pertsons who, actino under my direct instructions, made the verification that this infomation is true, atcurate, and complets.

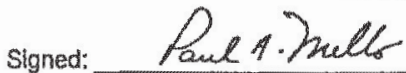

Date: $5 / 6 / 2005$

THe: Senhor Tracking Manager 



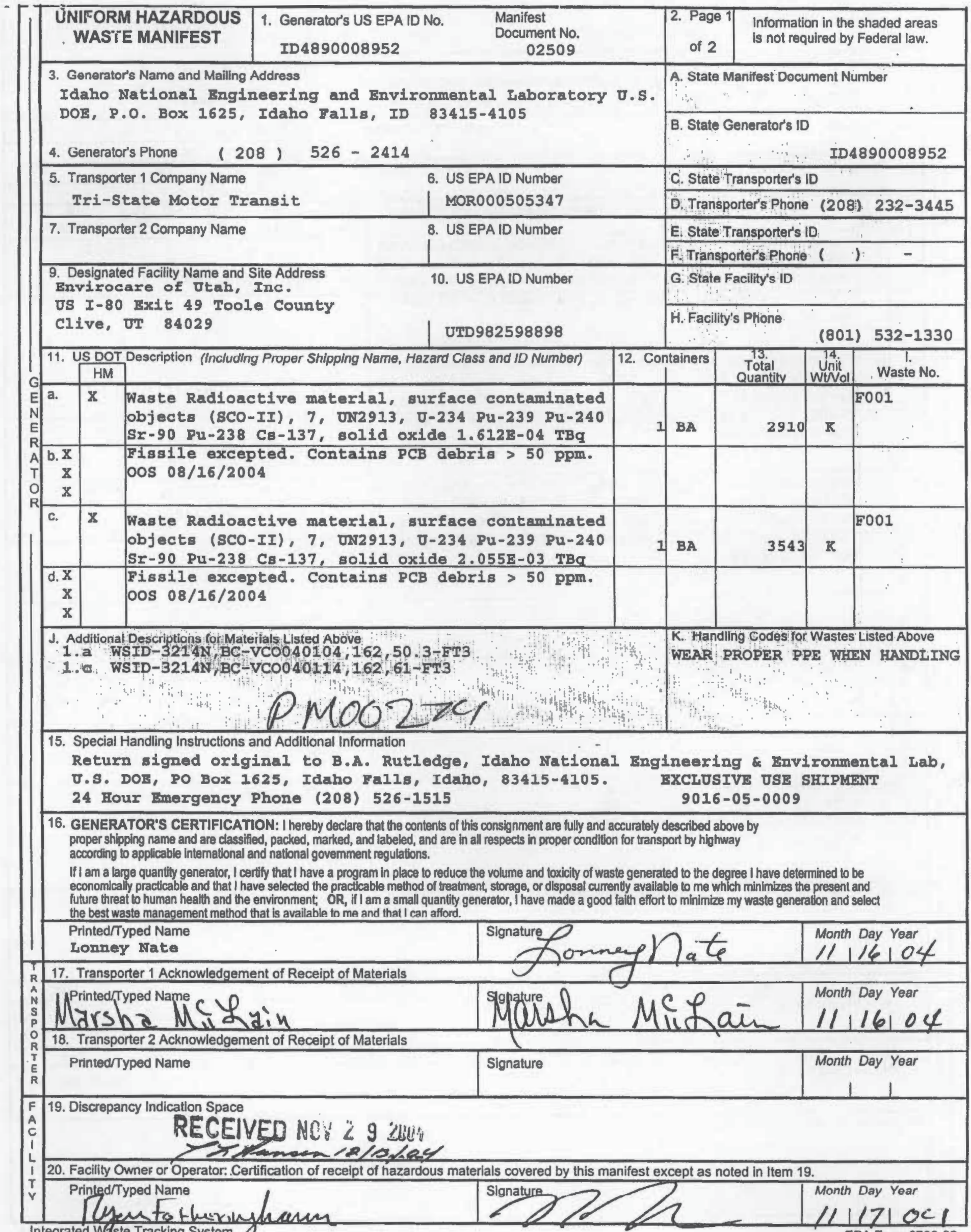




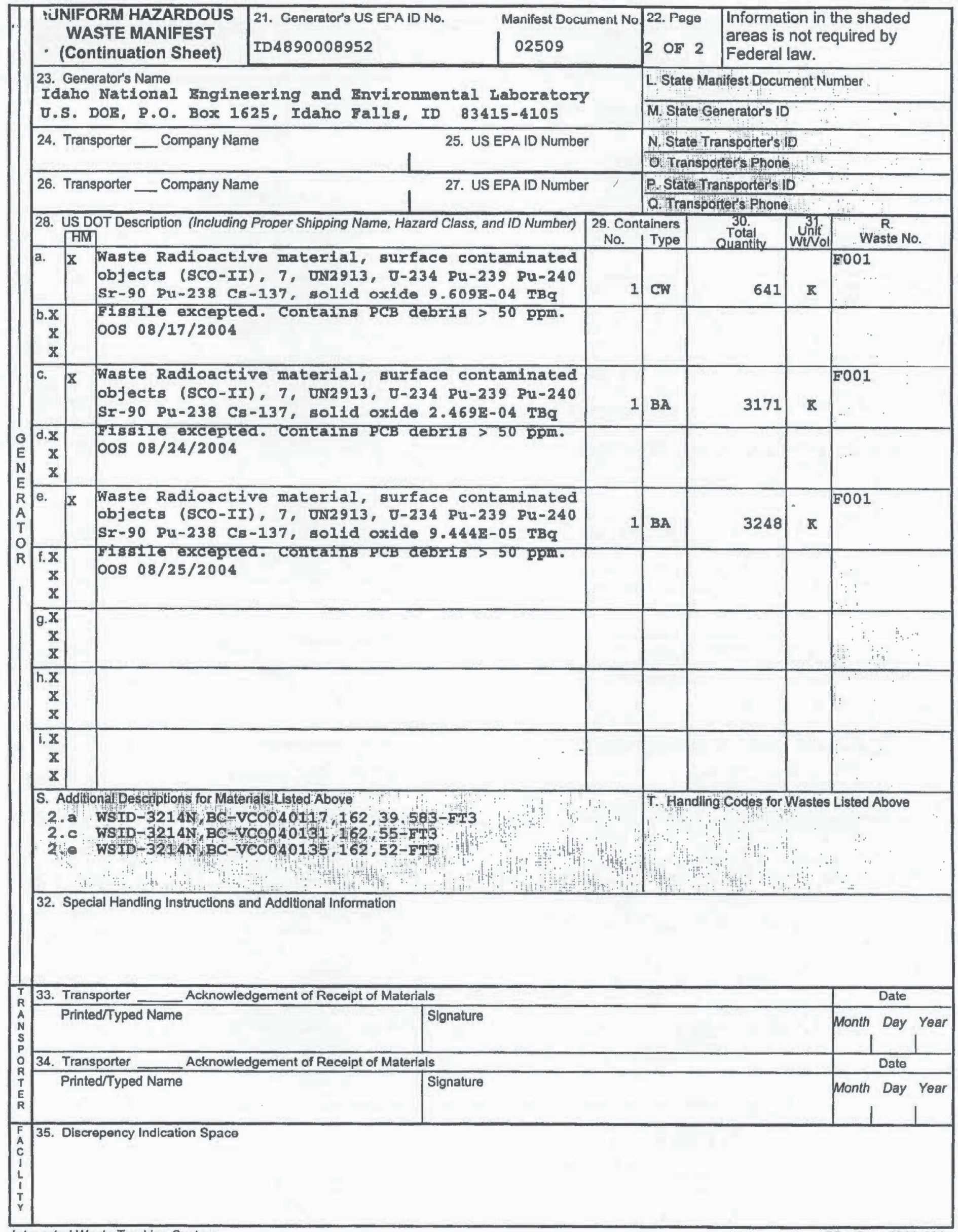




\section{ENVIROCARE}

OF UTAK, INC.

\section{THE SAFE ALTERNATIVE}

3 mi. s. $\operatorname{tax}, 49,1.90$

Clive, Utah $2 A 02958$

ID; UTต825988.

\section{CERTIFICATE OF DISPOSAL}

This Certificat acknowledger that the following manifested shipments:

$\frac{\text { Shipment }}{0016-05-0009} \frac{\text { Manifest }}{02509} \quad \frac{\text { Date(s) of Disposal }}{01 / 11 / 2005} \quad \frac{\text { Cu/fH }}{257.683} \quad \frac{\text { Process }}{\text { Landill }} \quad \frac{\text { Disposal Location }}{\text { Mlxed Wasto }}$

Representing 257.883 Cubic remt of waste of at listed Disposal Feility landill. Disposal is subject to

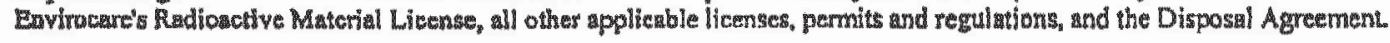

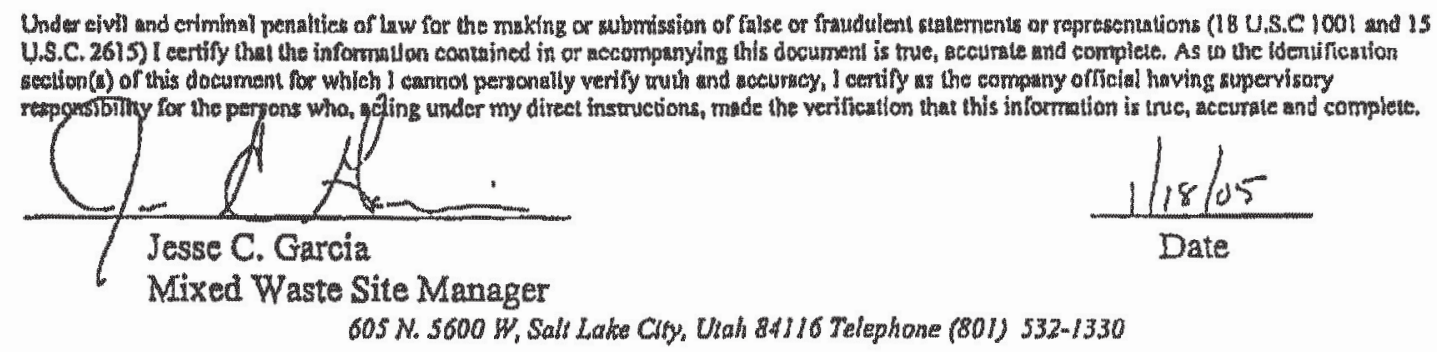





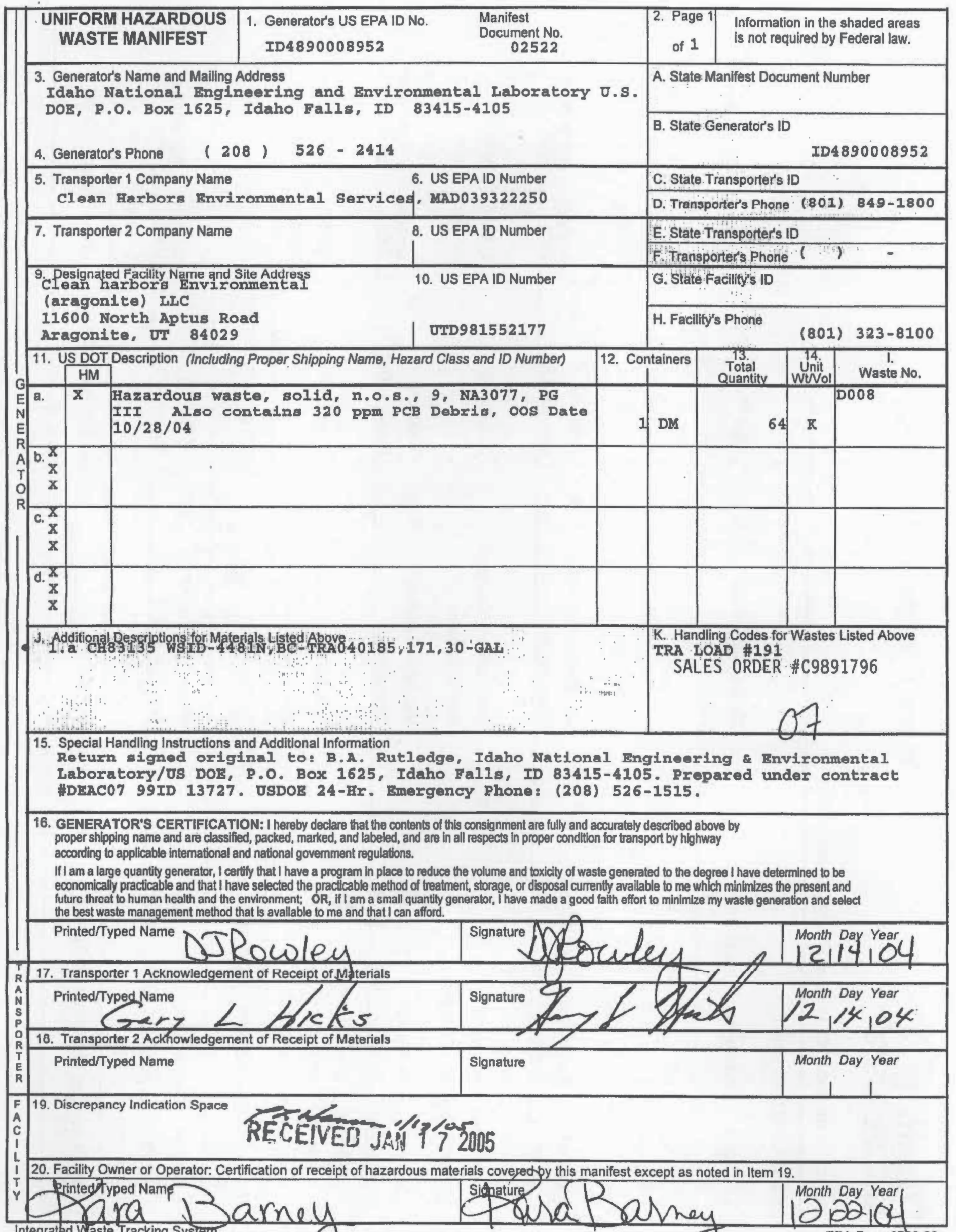




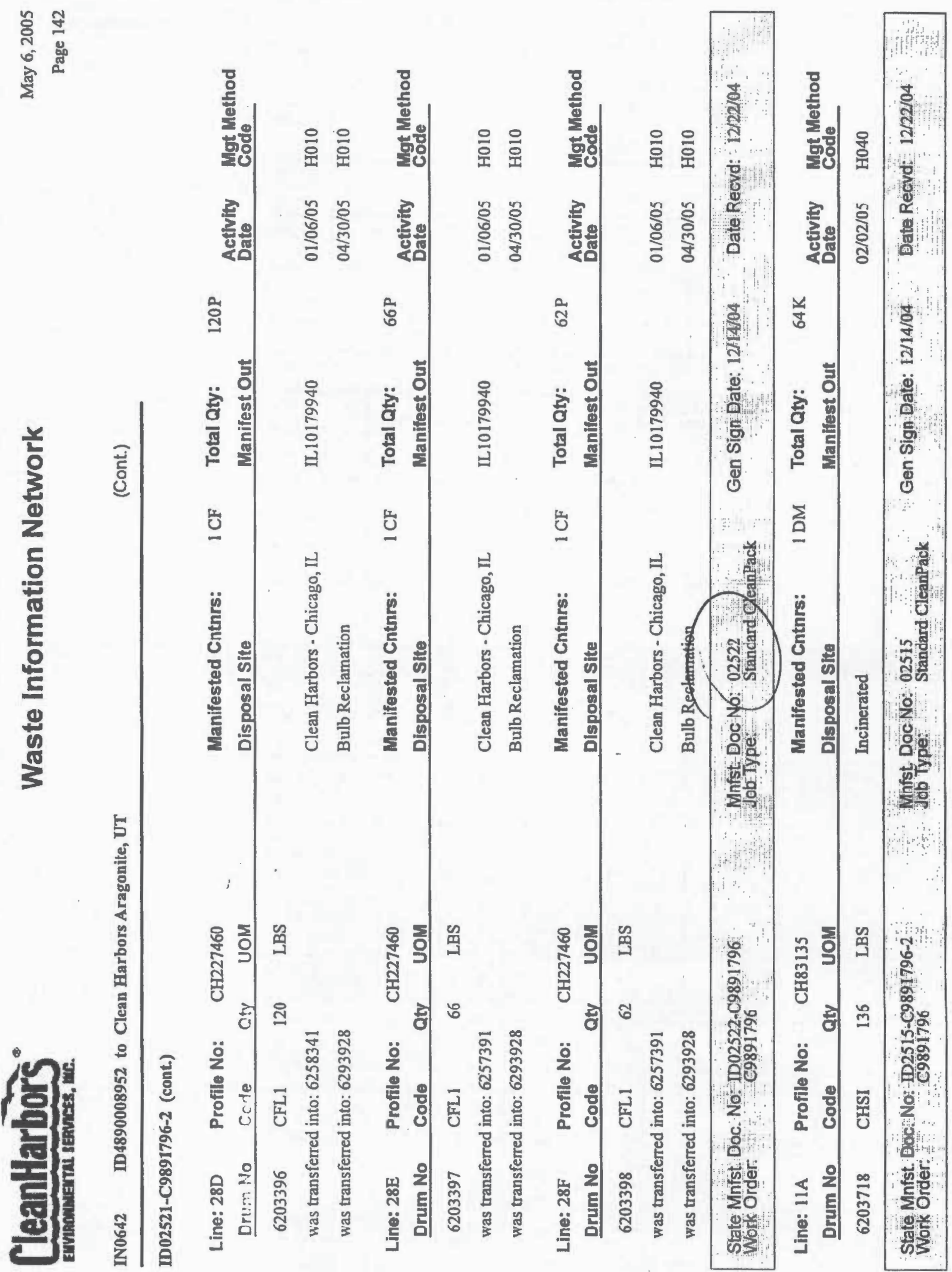




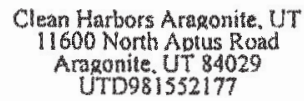
Manlfest No. Recv. Date
Manifest No.
Recv. Date
Manifest No.
Recv. Date
Manifest No.
Recv. Date

1002499-C9875262-2 11/18/04

$1002505-C 9375262 \quad$ 11/18/04

1002506-C9875262-1 11/18/04

1002500-C9875266-! 11/18/04

ID02500-C8875266-2 11/18/04

1002500-C9875260-3 11/18/04

$1002507.09875262 \quad 11 / 18 / 04$

$1002524+\mathrm{FC} 839749 \quad 12 / 13 / 04$

ID02525-FC $889749 \quad 12 / 13 / 04$

1002514 C9891796 12/22/04

$1002516-\mathrm{C} 9891796 \quad 12 / 22 / 04$

1002519.C9821796 12/22/04

1D02518-Cos91796 12/22/04

1002520-C9891796-1 12/22/04

1002520-C9891796-2 12/22/04

ID02521-C98917\%6-1 12/22/04

1002521-C9891796-? 12/22/04

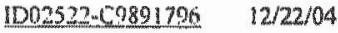

102515-C9891796-2 12/22/04

1002515-C9891796-3 12/22/04

$1002515-C 9891796 \quad 12 / 22 / 04$

The abowe described waste, received at the Clean Harbors facilly listed above pursuant to the mantiest(s) ilsted above, has been treated and/or disposed of by Clakn Harbors, or another licensed facility approved by Claen Harbors, in accordance with applicable federal and stake laws and regulations. Any waste received by Clearn Harbors and subsequently shipped to another licensed faclity has been or shall be kdentified as being generated by Clean Harbors in accordance with $40 \mathrm{CF}$. 264.71 ( $\mathrm{Cl}$.

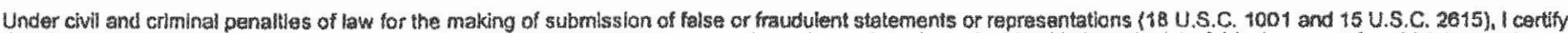
that the information contained in or eccompanying this document is true, accurats, and complefe. As to the identified section(s) of this document for which i cannol personally varify truth and accuracy, 1 certify as tree company ofticial having supervisory resporisiblity for the persons who, acting under my direct inatruetions, mado the verification that this information is brue, accurate, and completes.

Signed:

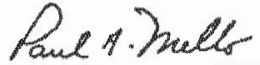

Date:

$5 / 6 / 2005$

Title:

Senior Tracking Manager 



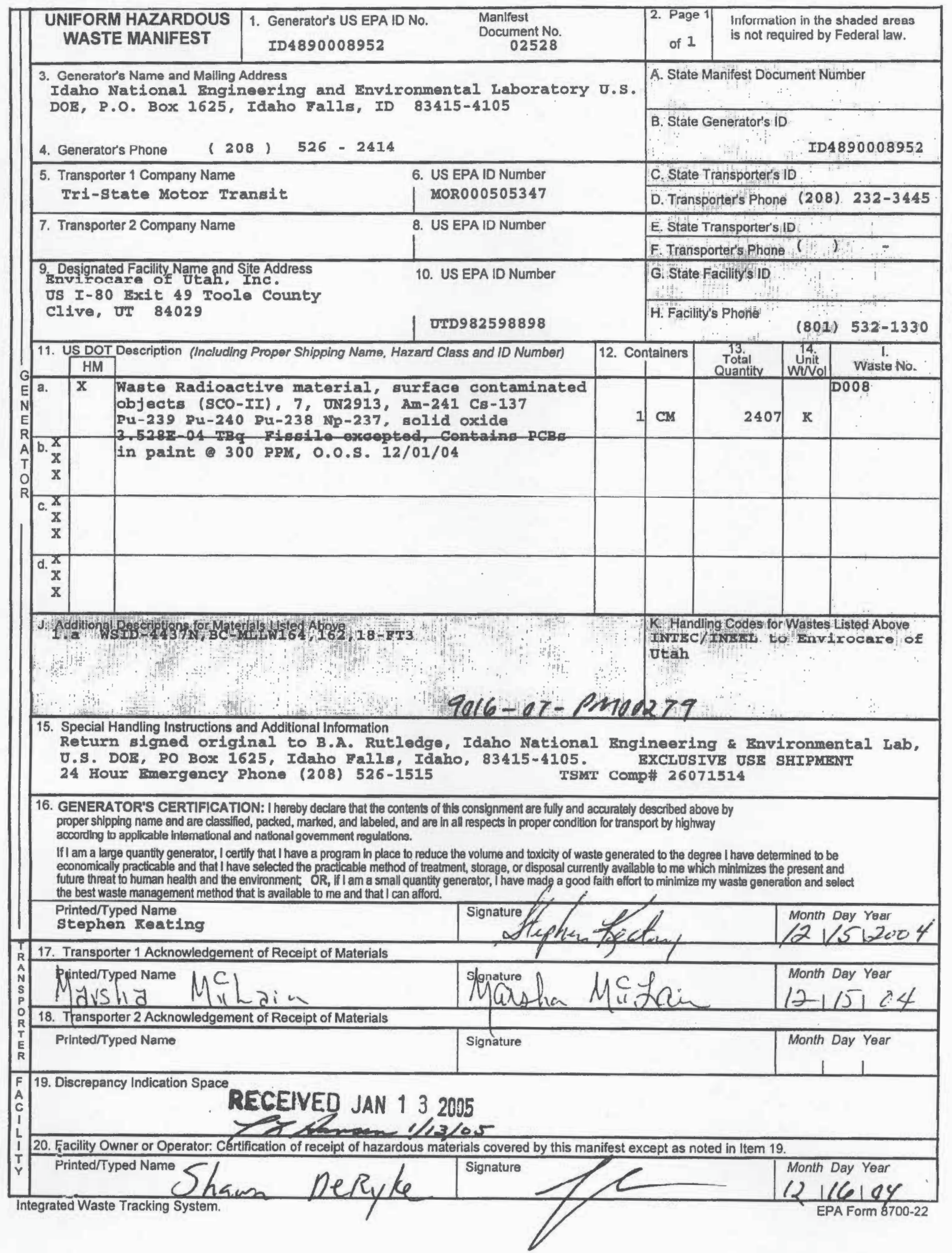

